\title{
A New World Post COVID-19: Lessons for Business, the Finance Industry and Policy Makers
}

Book

Published Version

Creative Commons: Attribution 4.0 (CC-BY)

Open Access

Billio, M. and Varotto, S. ORCID: https://orcid.org/0000-00015328-5327, eds. (2020) A New World Post COVID-19: Lessons for Business, the Finance Industry and Policy Makers. Innovation in Business, Economics \& Finance, 1. Edizioni $\mathrm{Ca}^{\prime}$ Foscari, Venice, Italy, pp375. ISBN 9788869694424 doi: https://doi.org/10.30687/978-88-6969-442-4 Available at https://centaur.reading.ac.uk/92077/

It is advisable to refer to the publisher's version if you intend to cite from the work. See Guidance on citing.

Identification Number/DOI: https://doi.org/10.30687/978-88-6969-442-4 <https://doi.org/10.30687/978-88-6969-442-4>

Publisher: Edizioni Ca' Foscari

All outputs in CentAUR are protected by Intellectual Property Rights law, including copyright law. Copyright and IPR is retained by the creators or other copyright holders. Terms and conditions for use of this material are defined in the End User Agreement. 


\section{CentAUR}

Central Archive at the University of Reading

Reading's research outputs online 
Innovation in Business,

Economics \& Finance 1

\section{A New World \\ Post COVID-19}

Lessons for Business,

the Finance Industry

and Policy Makers

edited by Monica Billio and Simone Varotto

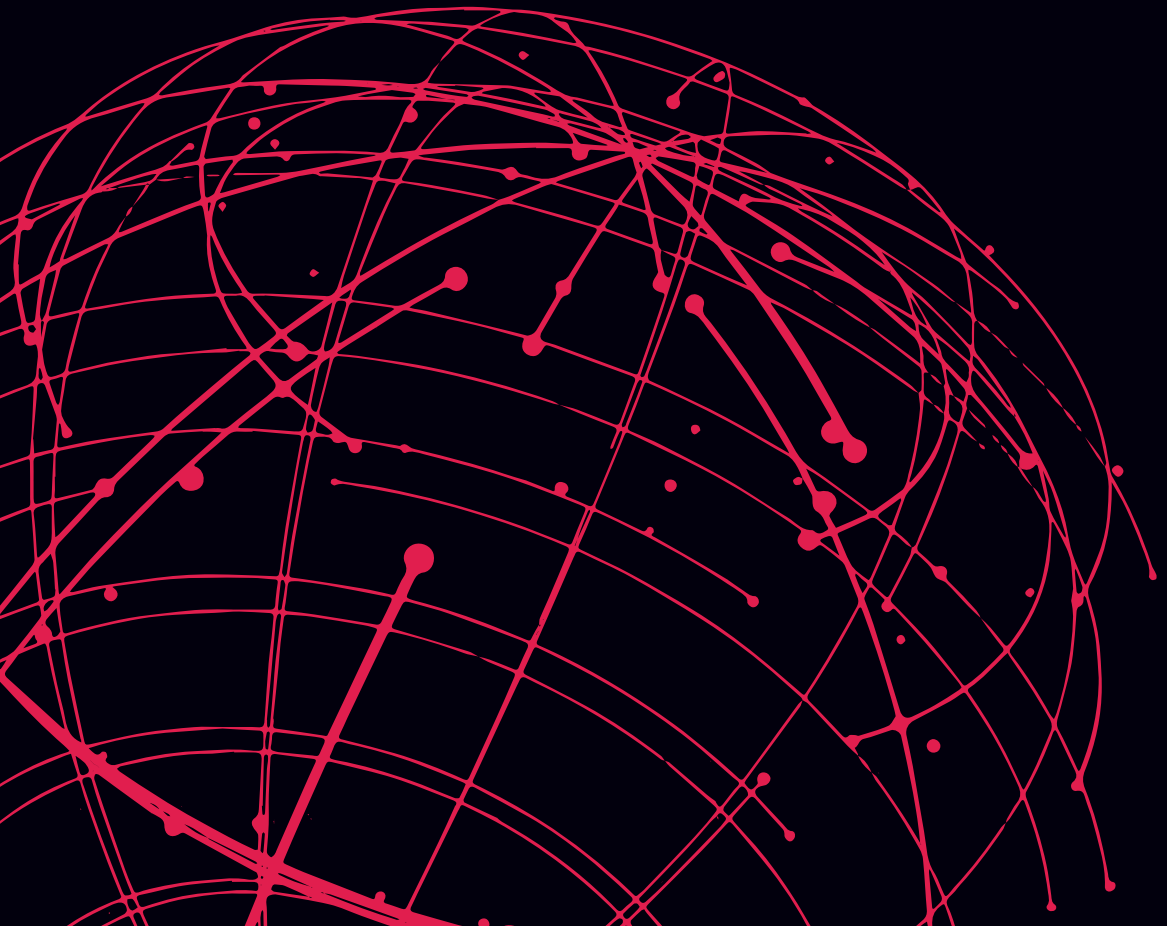

Edizioni

Ca'Foscari 
A New World Post COVID-19

\section{Innovation in Business, Economics \& Finance}

Series coordinated by

Carlo Bagnoli

1

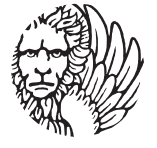

Edizioni

Ca'Foscari 


\section{Innovation in Business, Economics \& Finance}

\section{General Editor}

Carlo Bagnoli (Università Ca' Foscari Venezia, Italia)

\section{Advisory Board}

Carlo Bagnoli (Università Ca' Foscari Venezia, Italia)

Giorgio Bertinetti (Università Ca' Foscari Venezia, Italia)

Monica Billio (Università Ca' Foscari Venezia, Italia)

Alfonso Dufour (University of Reading, UK)

Steven Ongena (University of Zurich, Switzerland)

Loriana Pelizzon (Università Ca' Foscari Venezia, Italia)

Marti G. Subrahmanyam (Stern Business School, New York University, US)

Simone Varotto (ICMA Centre, Henley Business School, University of Reading, UK)

URL http://edizionicafoscari.unive.it/it/edizioni4/collane/innovation-in-business-economics-amp-finance/ 


\section{A New World Post COVID-19 \\ Lessons for Business, the Finance Industry and Policy Makers}

edited by Monica Billio and Simone Varotto

Venezia

Edizioni Ca' Foscari - Digital Publishing 2020 
A New World Post COVID-19. Lessons for Business, the Finance Industry and Policy Makers Monica Billio, Simone Varotto (edited by)

(c) 2020 Monica Billio, Simone Varotto for the text (c) 2020 Edizioni Ca' Foscari - Digital Publishing for the present edition

\section{(ㄷ)(1)}

Quest'opera è distribuita con Licenza Creative Commons Attribuzione 4.0 Internazionale This work is licensed under a Creative Commons Attribution 4.0 International License

\section{OPDEN}

Qualunque parte di questa pubblicazione può essere riprodotta, memorizzata in un sistema di recupero dati o trasmessa in qualsiasi forma o con qualsiasi mezzo, elettronico o meccanico, senza autorizzazione, a condizione che se ne citi la fonte. Any part of this publication may be reproduced, stored in a retrieval system, or transmitted in any form or by any means without permission provided that the source is fully credited.

Edizioni Ca' Foscari - Digital Publishing

Fondazione Università Ca' Foscari Venezia

Dorsoduro 3246|30123 Venezia

http://edizionicafoscari.unive.it/

ecf@unive.it

1st edition July 2020

ISBN 978-88-6969-442-4 [ebook]

Certificazione scientifica delle Opere pubblicate da Edizioni Ca' Foscari - Digital Publishing: il volume pubblicato ha ottenuto il parere favorevole da parte di valutatori esperti della materia. La valutazione è stata condotta in aderenza ai criteri scientifici ed editoriali di Edizioni Ca' Foscari.

Scientific certification of the works published by Edizioni Ca' Foscari - Digital Publishing: the volume has received a favourable opinion by subject-matter experts. The evaluations were conducted in adherence to the scientific and editorial criteria established by Edizioni Ca' Foscari.

The book has been published in collaboration with the University of Reading, the Henley Business School and the ICMA Centre

\section{University of Reading}

A New World Post COVID-19. Lessons for Business, the Finance Industry and Policy Makers / Monica Billio, Simone Varotto (edited by) - 1. ed. - Venezia: Edizioni Ca' Foscari - Digital Publishing, 2020. - 374 pp.; 23 cm. - (Innovation in Business, Economics \& Finance; 1 ). 


\section{Acknowledgements}

The editors would like to thank Charles Sutcliffe for his continuous encouragement from the early stages of this project, and Adrian Bell and Carol Padgett for their support. We wish to thank all contributing authors for sharing their expertise, and the following colleagues for providing constructive feedback and suggestions for improvements to the authors: Nikolaos Antypas, Nick Bardsley, Adrian Bell, Alfonso Dufour, Kecheng Liu, Gianluca Mattarocci, Peter Scott, Carl Singleton, Charles Sutcliffe and Alexander Wagner. We thank Massimiliano Vianello and Mariateresa Sala of Edizioni Ca' Foscari for the invaluable help and professional advice during the production of this volume. We are grateful to the ICMA Centre for financial support which has made it possible to present this volume in a freely accessible format through Gold Open Access. A special thank you to Leonardo Varotto for his help with the conceptual design of the front cover. 



\section{Table of Contents}

\section{Introduction}

Monica Billio, Simone Varotto

PART 1. HISTORICAL PERSPECTIVE

The Global Financial Crisis and the COVID-19 Pandemic Antonio Moreno, Steven Ongena,

Alexia Ventula Veghazy, Alexander F. Wagner

What Can the Black Death Tell Us About the Global Economic Consequences of a Pandemic?

Adrian R. Bell, Helen Lacey, Andrew Prescott

PART 2. FISCAL AND MONETARY POLICY

Recovering from the Economic Impact of COVID-19

Who Should Pick Up the Bill for the British Lockdown?

Peter Scott

The European Repo Market, ECB Intervention and the COVID-19 Crisis

Monica Billio, Michela Costola, Francesco Mazzari, Loriana Pelizzon

COVID-19 and Fiscal Policy in the Euro Area

Filippo Busetto, Alfonso Dufour, Simone Varotto 
PART 3. BANKING, RISK AND REGULATION

The Effects of the COVID-19 Pandemic Through the Lens of the CDS Spreads

Alin Marius Andrieș, Steven Ongena, Nicu Sprincean

Market Risk Measurement

Preliminary Lessons from the COVID-19 Crisis

Emese Lazar, Ning Zhang

PART 4. FINANCIAL MARKETS

COVID-19 and the Stock Market

Stefano Ramelli, Alexander F. Wagner

Stock Performance When Facing the Unexpected

Alfonso Dufour

The COVID-19 Challenge to European Financial Markets Lessons from Italy

Nicola Borri

Portfolio Effects of Cryptocurrencies During the COVID-19 Crisis

María de la O. González, Francisco Jareño, Frank S. Skinner

PART 5. COMMODITIES AND REAL ESTATE MARKETS

Will COVID-19 Change Oil Markets Forever?

Yelena Kalyuzhnova, Julian Lee

Real Estate and the Effects of the COVID-19 Pandemic in Europe

Gianluca Mattarocci, Simone Roberti

PART 6. BUSINESS PERFORMANCE, FUNDING AND GROWTH

Private Equity \& Venture Capital

Riding the COVID-19 Crisis

Keith Arundale, Colin Mason 
Mergers and Acquisitions in the Years of COVID

Slowing Down Before Accelerating Yet Again

Nikolaos Antypas

On the Impact of COVID-19-Related Uncertainty

Marta Castellini, Michael Donadelli, Ivan Gufler

PART 7. PENSIONS AND INSURANCE

The Implications of the COVID-19 Pandemic for Pensions

Charles Sutcliffe

Insurance Risk Management During Pandemics

Michalis Ioannides

PART 8. CLIMATE CHANGE

Pandemics, Climate and Public Finance

How to Strengthen Socio-Economic Resilience

across Policy Domains

Stefano Battiston, Monica Billio, Irene Monasterolo

Avoiding a Great Depression in the Era of Climate Change Nicholas Bardsley

PART 9. LABOUR MARKET

COVID-19 Pandemic and Gender Inequality in the Labour Market in the UK

Giovanni Razzu

India's Lockdown and the Great Exodus

Some Observations

Arup Daripa

291

Human Skills \& the AI COVID Challenge

Naeema Pasha

COVID-19 and Its Impacts on Talent Mobility in China

Mikkel Rønnow Mouritzen, Shahamak Rezaei, Yipeng Liu 
PART 10. AI AND BIG DATA

Artificial Intelligence and Data Analytics in Digital Business Transformation Before, During and Post COVID-19

Kecheng Liu, Hua Guo

Reshaping the Future

Unlocking the Potential of Alternative Data

for the Post-COVID-19 World

Hung-Yi Chen

PART 11. TRAVEL, TOURISM AND ENTERTAINMENT

Travel and Tourism

At the Frontline of COVID-19

Adrian Palmer

European Football After COVID-19

J. James Reade, Carl Singleton

PART 12. POLITICS: PROTECTIONISM AND POPULISM

Why Collaboration Needs to Win Over Protectionism

Benjamin Laker

The Political Implications of COVID-19

What Now for Populism?

Daphne Halikiopoulou 
With gratitude, to all essential workers and to all those who behave responsibly to prevent another wave 



\title{
Introduction
}

\author{
Monica Billio \\ Università Ca' Foscari Venezia, Italia \\ Simone Varotto \\ ICMA Centre, Henley Business School, University of Reading, UK
}

Pandemics are disruptive events that have profound consequences for society and the economy. This volume aims to present an analysis of the economic impact of COVID-19 and its likely consequences for our future. This is achieved by drawing from the expertise of authors who specialise in a wide range of fields including fiscal and monetary policy, banking, financial markets, pensions and insurance, artificial intelligence and big data, climate change, labour market, travel, tourism and politics, among others. We asked contributing authors to write their chapters for a non-technical audience so that their message could reach beyond academia and professional economists to policy makers and the wider society. The material in this volume draws from the latest research and provides a wealth of ideas for further investigations and opportunities for reflection. This also makes it an ideal learning tool for economics and finance students wishing to gain a deeper understanding of how COVID-19 could influence their disciplines.

The volume begins by taking a historical perspective. Moreno, Ongena, Ventula Veghazy and Wagner explore the linkages between the Great Recession of 2008-09 and the current pandemic. They argue that the ways in which the former crisis was fought may have a bearing on the severity of the outcomes of the current crisis. Governments that piled up debt to bail out banks in their country may have diverted resources away from critical sectors including public health ser- 
vices. This in turn may have curtailed the ability of those countries to contain the spread of the virus and offer adequate health treatment to the sick. Similarly, job losses following the Great Recession, especially among young people (e.g. in Italy and Spain) may have created a greater incentive for younger generations to live at home with their parents. Such proximity between younger and older people, with the latter more vulnerable to the infection, may have led to higher mortality rates during the pandemic. Finally, forbearing bank supervisors that have allowed banks to keep in their balance sheet 'zombie' firms following the last crisis may have created the pre-conditions for government funding to fall in the 'wrong hands' of failing companies, rather than healthy ones, during the current crisis.

Historical comparisons are further stretched back by Bell, Lacey and Prescott who look at the lessons from the Black Death of 134851, which may still be relevant today. They argue that restricting freedom of movement, especially if protracted in time, can generate resentment and lead to social unrest and political turmoil. Events in fourteenth century England suggest that governments need to act quickly to address social injustice when social tension is high because of a pandemic. History also teaches us that psychological reactions of crisis-affected masses may lead to nationalistic tendencies. This is further explored by Halikiopoulou who focuses on the rise of populism in Europe. The author distinguishes between countries already dominated by populist movements and those where populists are in opposition parties. A pandemic, and the resulting economic crisis, may create an opportunity for populists in opposition to gain more support from the voters that are worst affected by the economic downturn. A likely consequence of 'my-country-first' policies, which can find quick appeal in periods of economic and health crises, is protectionism. Laker identifies clear signs of protectionist trends emerging from the pandemic and warns that these can have disproportionate consequences for developing economies as they are more dependent on imports for critical medical supplies and their population's basic needs.

The UK experience during the First and Second World Wars as well as the Great Recession is examined by Scott to shed light on the fiscal implications of COVID-19 and the likely consequences for British taxpayers. He argues that the austerity measures that could follow fiscal expansion during the current pandemic would be misguided. Past events suggest that fiscal austerity may have the unintended consequence of slowing economic growth and generating mass unemployment, while a less fiscally conservative approach would lead to a stronger and sustainable recovery.

Busetto, Dufour and Varotto extend the fiscal policy analysis to continental Europe. They show that pre-existing debt levels influence governments' ability to sustain their pandemic-hit economies. Ger- 
many's relatively low debt-to-GDP ratio has helped it to implement a 'fiscal bazooka' to protect its economy without paying the price of a substantially higher cost of borrowing. Italy, on the other hand, with a more contained fiscal expansion, is expected to experience a more punitive increase of its borrowing costs. This, in turn, would have a further negative impact on its already anaemic growth prospects.

Financing costs in European countries are also explored by Billio, Costola, Mazzari and Pelizzon who look at the repo market. Specifically, they focus on the effect on repo rates of monetary policy announcements made by the European Central Bank (ECB) during the pandemic. They find that countries in Europe's periphery, e.g. Italy and Spain, may be highly dependent on the ECB support to keep their repo rates in line with those of other countries. An announcement made by the ECB that it would not intervene to support countries with higher sovereign risk was sufficient to generate a substantial divergence of their repo rates from those of low risk countries. A subsequent ECB announcement which clarified that the Central Bank would indeed support weaker economies caused an immediate realignment of the repo rates. This highlights the critical role that monetary policy can have to contain the effect of the pandemic on financial markets.

The connection between sovereign risk and bank risk has become more evident since the European sovereign debt crisis. Andries, Ongena and Sprincean observe that such connection and feedback loop have become stronger during the pandemic but are not as important as they were during the sovereign crisis. This is partly the result of stricter bank regulation that has made banks better able to withstand periods of instability. Lazar and Zhang examine in detail some aspects of the new bank rules and conclude that they might lead to banks overestimating risk and keeping higher than needed equity capital levels, which are sub-optimal.

Stock markets reacted strongly to the spread of COVID-19. Ramelli and Wagner analyse the stock performance across 90 countries in different phases of the crisis: incubation, outbreak, fever and recovery. They find highly levered companies to be the ones with a more volatile behaviour, which confirms the role of debt in amplifying economic shocks and uncertainty. Worryingly, corporate debt levels have increased since the start of the pandemic, which may contribute to further market instability in case of future outbreaks of the virus. This has reawakened the debate about whether corporations should still be incentivised to pile up debt through the tax deductibility of interest payments. ${ }^{1}$ The authors also perform an industry analysis that

1 See Financial Times article "Should We End the Tax Deductibility of Business Interest Payments?". 22 July 2020. https://www.ft.com/content/426c1465-9561-4300$8 d 3 e-2430 e 4124 c 93$. 
reveals how energy firms, banks, consumer services and the transportation sector were the worst affected by the crisis. Dufour breaks down these effects at the country level for the US and the UK and observes similar patterns. Banks are badly affected as loan defaults are expected to rise and low interest rates compress banks' profit margins. Regulatory restrictions on banks' dividend payouts have put further downward pressure on bank stocks. Energy firms and, particularly, oil companies have suffered from the largest contraction in demand ever recorded. Kalyuzhnova and Lee explain that this, combined with persistent excess supply, produced a 'perfect storm' for the industry. Furthermore, demand may not go back to pre-pandemic levels for some time. This may be caused by lower oil consumption resulting from, among other factors, changes in people's attitude towards air travel and companies embracing more extensively working-from-home practices and virtual meetings instead of international corporate travels. An obvious casualty of travel restrictions following COVID-19 lockdowns worldwide is tourism. Palmer considers the short-term and long-term consequences of the pandemic on consumer behaviour. He argues that lifting restrictions will not automatically reset the clock back to pre-pandemic times. The lockdowns are likely to make tourists more prudent when planning their holidays, at least in the short term. But in the long run the sector is likely to recover thanks to its capacity to reinvent itself as it did repeatedly in the past.

Travel restrictions have also had profound consequences for the real estate sector. In addition, Mattarocci and Roberti argue that the residential and commercial real estate markets in Europe were also impacted by site-visit limitations, the lower disposable income of householders and falling revenues of commercial tenants. The authors suggest that householders may seek bigger dwellings in the future to be able to work from home more comfortably. The preferred relocation areas for households and offices could be outside city centres because of their greater affordability and their lower infection risk as they are less densely populated.

The insurance industry was also affected by the current pandemic. However, Ioannides explains that insurers and reinsurers are well capitalised to absorb the shock of this crisis, even though their losses so far have been substantial at US \$200 billion. Sutcliffe argues that the increased elderly mortality rates because of COVID-19 may benefit life insurers and defined benefit pension funds, but only in the short run unless there are further and extensive infection waves. He concludes that those who moved out of their defined benefit pensions or cashed in their defined contribution pensions during the pandemic, when asset prices were depressed, are losers from this crisis.

An obvious question for institutional investors and individuals is how to structure an investment portfolio in such a way that makes it resilient to pandemic risk. González, Jareño and Skinner explore this 
question by investigating the risk reduction that may result by diversifying portfolios into cryptocurrencies. They conclude that some cryptocurrencies (Ethereum and Bfinance) have the potential to control risk, while others (Bitcoin, Litecoin and Tezos) are less effective in this respect. However, risk reduction comes at the cost of lower risk adjusted returns.

Social distancing has limited our ability to see family and friends and also to participate in leisure activities. Football fans across Europe have been prevented from attending live matches and the football industry has suffered financially as a result. Reade and Singleton point out that football's decision makers should rethink the allocation of resources within the industry to help it recover. Greater investment in women football, a small role for agents and perhaps state intervention could all contribute to resolving football's current and more long-standing issues.

Borri takes a close look at Italy, the first country to witness high infection rates in Europe. From a careful analysis of the measures taken in the country, which varied across cities and regions, he concludes that the Italian experience can be a useful case study for policy makers to assess the costs and benefits associated with different approaches to tackling future waves. Donadelli, Gufler and Castellini argue that COVID-19 containment measures were introduced with delay and were badly communicated by the Italian government. The resulting uncertainty had the strongest effect on the construction, education, manufacturing and hospitality sectors and may slow down their recovery phase.

Arundale and Mason examine the coronavirus crisis from the perspective of private equity (PE) and venture capital firms. Their assessment is that the inevitable short-term contraction in this industry's activity is likely to revert to pre-pandemic levels in the notso-distant future. The undervaluation of public companies may generate good opportunities for PE firms. However, start-ups may struggle to find funding in the current economic environment unless governments support their growth. Antypas predicts that PEs as well as hedge funds will be big players in the mergers and acquisitions market over the next few months. Before the pandemic, these firms had accumulated a lot of 'dry powder', that is capital available for investments. Furthermore, their long-term investment horizon makes them particularly attractive to distress firms.

The drastic reduction in air travel and road congestion in cities around the world has undoubtedly had a positive impact on the environment with lower levels of pollution and $\mathrm{CO}_{2}$ emissions. Battiston, Billio and Monasterolo review the fiscal and monetary policies in Europe and challenge their short-term objective of taking the economy back to 'business as usual'. Instead, the authors suggest that the adoption of longer term objectives aiming to an alignment with 
the EU Green Deal and the EU corporate taxation policies would be more beneficial and as cost-effective. Indeed, the European Central Bank has recently taken a pro-environmental stance that is in line with the authors' proposed policy response. ${ }^{2}$ Bardsley also proposes that central banks should support an environmentally friendly recovery. But, he points out that this should not be done through bond purchases in the secondary market, which are "regressive and strategically blind". Instead, he favours an open monetisation of public sector borrowing and discusses different ways in which this could be implemented.

Unemployment has risen dramatically during the pandemic. Raz$\mathrm{zu}$ examines the pandemic consequences for the labour market in the UK with a focus on gender inequality. His analysis of recent studies and the data available so far reveals that unemployment has increased more for low paid jobs and in sectors such as retail, accommodation and food services where women are more likely to be over-represented. He also finds that, because of school closures, women are more likely than men to devote additional time to childcare and household work, which may have a substantial impact on their career prospects. The gender pay gap may also have increased during the current crisis and the government's suspension of the requirement for large firms to publish the gender pay differentials among their employees has not helped bring more equality to the UK labour market.

A form of labour market inequality that has had a dramatic impact in India concerns seasonal workers. Daripa reports that 120 million villagers were made unemployed overnight when the Indian government sanctioned a total lockdown on March 24, 2020. These workers were left without any support and 9 weeks after the lockdown the vast majority of them could still not benefit from government sponsored food rations under India's Public Distribution System. The author argues that the lack of political representation of these workers has left their voice unheard when it comes to government policy.

Mouritzen, Rezaei and Liu focus on how the coronavirus influenced the flow of international talent and specifically examine the experience of European researchers in China. Cross-country mobility of researchers can increase scientific productivity with ultimate benefits for the economy. The authors show preliminary evidence that a large proportion of European researchers that were based in China before the pandemic has now left the country and is not planning to return or is uncertain about that possibility, which is a concern.

2 See "Lagarde Puts Green Policy Top of Agenda in ECB Bond Buying". The Financial Times, 8 July 2020. https://www.ft.com/content/f776ea60-2b84-4b72-9765$2 \mathrm{c} \odot 84 \mathrm{bff} 6 \mathrm{e} 32$. 
COVID-19 has also accelerated the adoption of digital technology and artificial intelligence (AI) in the corporate world. Pasha explores what this means in terms of the skillset that employees need to develop to thrive in the new working environment. Adaptability emerges as a key quality for personal success. Liu and Guo further analyse the business transformation that AI, big data and data analytics are producing in the business world. They also discuss ethical and cybersecurity implications. Finally, Chen looks at how alternative data sources can be used to support decision-making especially in critical times like those faced during the current pandemic. Therefore, unlocking the potential of new data sources can be key to make our society better equipped to face future crises. 

Part 1

Historical Perspective 



\title{
The Global Financial Crisis and the COVID-19 Pandemic
}

\author{
Antonio Moreno \\ Universidad de Navarra, España \\ Steven Ongena \\ University of Zurich, Switzerland; Swiss Finance Institute; KU Leuven and CEPR \\ Alexia Ventula Veghazy \\ European Central Bank \\ Alexander F. Wagner \\ University of Zurich, Switzerland; Swiss Finance Institute; European Corporate Governance \\ Institute; CEPR
}

\begin{abstract}
We sketch possible linkages between features of the 2008-2009 financial crisis and outcomes of the 2020 COVID-19 pandemic. We start from three features of the financial crisis, i.e. (1) costly bank bailouts, (2) constrained SME credit, and (3) strict bank regulation. We then discuss their intermediate outcomes in terms of: (1) sovereign debt accumulation and possible cuts in public health spending, (2) the slowing of economic growth and labour mobility; and (3) bank zombie lending, to arrive at the COVID-19 pandemic severity in terms of infection and death rates and the difficulties in designing and implementing economic support policies.
\end{abstract}

Keywords Financial crisis. COVID-19 pandemic. Bank default. Local credit. Zombie lending.

Summary 1 Costly Bank Bailouts. - 2 Constrained SME Credit. - 3 Strict Bank Regulation. - 4 Testing Strategy: Preliminary Exploration.

We aim to sketch possible linkages between features of the 2008-09 financial crisis and outcomes of the 2020 COVID-19 pandemic. We do not aspire to theoretically and/or empirically establish such links in this chapter, but rather seek to point out a few possible channels. Our hope is that future re- 
search (including our own, i.e. we are pursuing cross-country and within-country testing) can reject or confirm some of the conjectures regarding the impact of the 2008-09 financial crisis on the unfolding health and economic outcomes of the 2020 COVID-19 pandemic. Empirical testing for sure can occur comparing countries, but also across localities, banks, and firms.

We will focus on three features of the financial crisis, i.e. bank bailouts that were often costly, SME credit which became more constrained, and bank regulation that became stricter. We will then discuss their intermediate outcomes in terms of the accumulation of sovereign debt and possible cuts in public health spending, the slowing of economic growth and labour mobility, and bank zombie lending, to arrive at the COVID-19 pandemic severity in terms of infection and death rates and difficulties in designing and implementing economic support policies.

Figure 1 below provides a small roadmap to the rest of the discussion.

\begin{tabular}{|l|l|l|}
\hline \multicolumn{3}{|c|}{ 2008-2009 Global Financial Crisis } \\
\hline Costly bank bailouts & Constrained SME credit & Stricter bank regulation \\
\hline $\begin{array}{l}\text { Sovereign debt } \\
\text { accumulation }\end{array}$ & $\begin{array}{l}\text { Lack of local economic } \\
\text { growth }\end{array}$ & Bank zombie lending \\
\hline $\begin{array}{l}\text { Funding cuts in public } \\
\text { health sector and } \\
\text { crowding at retiree homes }\end{array}$ & $\begin{array}{l}\text { Young employees cannot or } \\
\text { do not leave parental home } \\
\text { or town }\end{array}$ & $\begin{array}{l}\text { Many zombie firms clog } \\
\text { product markets }\end{array}$ \\
\hline \multicolumn{3}{|l|}{} \\
\hline \multicolumn{2}{|l|}{ Higher COVID-19 infection and death rates } & $\begin{array}{l}\text { Difficulty designing and } \\
\text { implementing economic } \\
\text { support policies }\end{array}$ \\
\hline
\end{tabular}

Figure 1 The channels through which the Global Financial Crisis affected the COVID-19 Pandemic Outcomes

Figure 1 links elements of the financial crisis in 2008-09, through their impact on public health and economic outcomes since then, on characteristics of the COVID-19 pandemic in 2020. Financial elements are in red, public health elements are in blue, and economic elements are in green.

The rest of the paper proceeds as follows. Section I discusses the costly bank bailouts, Section II the constrained SME credit, and Section III the strict bank regulation. Section IV concludes by discussing a few possible empirical testing strategies and offers preliminary findings. 


\section{Costly Bank Bailouts}

Bank bailouts are complex phenomena. ${ }^{1}$ In Berger, Nistor, Ongena and Tsyplakov (2020) we note that bank bailouts are not the 'one-shot' events commonly described in the literature. Bank bailouts are instead dynamic processes in which regulators 'catch' financially distressed banks; 'restrict' their activities over time; and 'release' the banks from restrictions at sufficiently healthy capital ratios. Even more important than their complexity is their potential cost to the taxpayers. Both capital injections and debt guarantee bailouts led to governmental outlays that resulted in further governmental debt buildups in many countries in Europe. While it is true that the picture is dynamic and complex, as a significant portion of the capital injections were later recouped and most debt guarantees never led to any claims, the UK government for example probably 'borrowed' around $£ 150$ billion (and was exposed for ten times that amount) according to its own National Audit Office. ${ }^{2}$ This amount represented around $10 \%$ of general government gross debt (which stood at $£ 1,821.3$ billion at the end of the financial year ending March 2019, equivalent to $85.2 \%$ of gross domestic product). As a matter of relevant comparison, that $£ 150$ billion is higher than the yearly budget of the National Health Service (NHS) by a dozen or so billions. ${ }^{3}$

The linkage from one government budget item to another one is never straightforward, as demands are many and money is fungible. At the same time also in the case of the NHS it is hard to overlook an actual decrease in its budget in 2009 after 50 years of year-on-year growth and the slower growth thereafter.

In any case, the financial crisis led to costly bailouts, not only increasing sovereign debt but also putting pressure on other governmental spending, including those in the public health space, making dealing with any pandemic more challenging. Think about the impact of lower funding prior to 2020 on the functioning or even existence of pandemic coordination units, the number of hospital beds including intensive care units, staff and their specialisation, etc. However,

1 Berger and Roman (2020) provide an excellent kaleidoscopic review of bank bailouts as these occurred around the world.

2 On December 15, 2010 in its Second Report on the financial crisis, the National Audit Office reported that the "scale of the support currently provided to the banks has fallen from its peak of $£ 955$ billion to $£ 512$ billion as at 1 December 2010 . However, the amount of cash currently borrowed by the Government to support UK banks has risen by $€ 7$ billion since December 2009 to a total of $£ 124$ billion” (https://www.nao.org. uk/report/maintaining-the-financial-stability-of-uk-banks-update-on-thesupport-schemes/).

3 See for example the websites of the Institute for Fiscal Studies and the UK Economic and Social Research Council on Health Spending: https://www.ifs.org.uk/tools_ and_resources/fiscal_facts/public_spending_survey/health_spending. 
not only hospital care but also elderly care may have been affected, leading to lower quality care for the elderly in more packed facilities, attended by fewer quality staff with fewer medical on-site facilities again making the pandemic outcomes potentially worse.

In addition, the further build-up of governmental debt due to the bailouts may have made it more difficult to set up very large and/or the appropriate economic assistance packages when needed (due to an actual or implied government budget constraint). ${ }^{4}$

\section{Constrained SME Credit}

The financial crisis led to a worsening of access to credit for households and corporations alike. Especially SMEs in periphery countries (such as Greece, Ireland, Italy, Portugal and Spain) were negatively affected. Banks, for example, ended up closing branches in those countries, which in Bonfim, Nogueira and Ongena (2020) we show to involve losses for (small) firms locally.

A lack of local credit access led to increasing local unemployment and worse economic conditions. Take Spain. With a real estate boom underway, once past the mandatory school age, many youngsters had directly entered the labour force to work in the well-paying real estate construction sector. Once the crisis hit, these youngsters found themselves quickly out of jobs and out of money, but strong family networks kept them off the street by bringing them back to live with their parents or other older relatives. And later, after a few years, when conditions in Spain improved, this lost generation may have found it challenging to find a job far away from their home town, maybe also not wanting to move too far away from their now aged parents or relatives.

Overall, the financial crisis may have made living at home or in the hometown for 20-to-30-year olds in countries like Spain and Italy (which was already prevalent) more common. In addition, this livingin-close-proximity of older and younger people due to the financial crisis may have made COVID-19 infections more likely and deadly as younger people often carry the virus asymptomatically while especially older adults seem more likely to succumb to it.

4 In Andrieș, Ongena and Sprincean (2020) we assess the impact of the pandemic in Europe on sovereign CDS spreads using an event study methodology. We show that a higher number of cases and deaths and public health containment responses during the pandemic significantly increase the uncertainty among investors in European government bonds. 


\section{Strict Bank Regulation}

Finally, higher capital requirements and loan loss provisioning introduced after the financial crisis may have led banks to wait longer to recognise potential loan losses. In Bonfim, Cerqueiro, Degryse and Ongena (2020), for example, we argue how in spite of growing regulatory pressure applied in the opposite direction in most developed economies, 'zombie lending' remains a widespread practice by banks (see also Acharya et al. 2019). We then exploit a series of large-scale on-site inspections made on the credit portfolios of several Portuguese banks to show how these inspections affect banks' future lending decisions making an inspected bank 20\% less likely to refinance zombie firms, immediately spurring their default. Overall, we document that banks seemingly reduce zombie lending because the incentives to hold these loans disappear only once they are forced to recognise losses.

This forced recognition of losses, and in general, the willingness by supervisors to force banks to recognise and restructure, may matter a great deal, both for subsequent economic growth and also for the possibilities for an optimal pandemic economic policy response. In Gropp, Ongena, Saadi and Rocholl (2020), for example, we show that during the recent crisis in the US regions with higher levels of supervisory forbearance on distressed banks, there was less restructuring in the real sector: fewer establishments, firms, and jobs were lost if more distressed banks remained in business. We find that in these regions the banking sector is less healthy for several years after the crisis, manifested in lower capital, and higher non-performing assets ratios. But consistent with the cleansing hypothesis, regions with less supervisory forbearance during the crisis experienced a better productivity growth path after the crisis with more establishment entries, job creation, and employment, wages, patents, and output growth. Therefore, it seems to be a matter of short-term gain, long-term pain, with both zombie firms and zombie banks depressing economic activity for a long time after a financial crisis has been unspooling.

If zombie firms (and zombie banks) are so difficult to get rid of, their presence for sure also makes the implementation of government lending programmes to help firms through the early and mid-stages of the pandemic compromised from the very start. This is because money ends up in the 'wrong hands' and banks are all too happy to have a deep-pocketed co-underwriter, i.e. the government, of the set of zombie firms they have continued to service. 


\section{$4 \quad$ Testing Strategy: Preliminary Exploration}

There are several levels at which the impact of the financial crisis on the unfolding of the COVID-19 pandemic can be assessed. At the country level, correlations can be assessed of the measures of the severity of the financial crisis in terms of the loss in output growth, increase in sovereign debt or subsequent build-down in the public health sector and the (pre-lockdown) severity of the pandemic in terms of infections and death rates. At the local level, in Spain for example, one can assess how measures of changes in health care expenditures (after minus before the financial crisis) are related to financial crisis measures. In addition, we can study how measures of changes in living in close proximity (after versus before the crisis) are predicted by financial crisis measures. Based on these assessments, one can then see how predicted values of these two sets explain the COVID-19 pandemic measures, controlling for the level of healthcare and the level of living in proximity.

We present here some preliminary analysis for the Spanish case, which provides motivation for further formal work (which we pursue ourselves). We focus first on the relation between foreclosures, which capture the severity of the financial crisis across provinces, and changes in public health expenditures. Using data from the Spanish Property Registrar, we identify the number of per-capita foreclosures across the 50 provinces ('Provincias') in $2012 .{ }^{5}$ That year is the second trough of the Spanish double dip recession and is associated with the deepest phase of the sovereign debt crisis, which ended in an important bailout for Spanish banks. Public bailouts in Spain reached 60 billion EUR, around 6\% of GDP. We correlate three foreclosure measures with the percent changes in per-capita public health expenditures across provinces relative to 2009, the year with highest per-capita public health expenditure prior to crisis-driven cuts. Data for health care expenditures were collected from the Spanish Health Ministry at the regional level. ${ }^{6}$ This expenditure data from the 17 regions ('Comunidades Autónomas') was then distributed across provinces proportionately to the province population. The average province drop in public health expenditures relative to 2009 was $8 \%, 12 \%, 12 \%$ and $6 \%$ in 2012, 2013, 2014 and 2015, respectively. Table 1 shows the results for three measures: foreclosure initiatives, materialised foreclosures, and settlements between the household and the bank aimed to give back the property with no further payments ('dación en pago').

5 Foreclosures data from the Property Registrar was downloaded from: https:// www.registradores.org/actualidad/portal-estadistico-registral/estadisticas-de-propiedad.

6 Public health expenditures was obtained from: https://www.mscbs.gob.es/estadEstudios/estadisticas/sisInfSanSNS/pdf/egspGastoReal.pdf. 
Antonio Moreno, Steven Ongena, Alexia Ventula Veghazy, Alexander F. Wagner The Global Financial Crisis and the COVID-19 Pandemic

Table 1 Correlations between per-capita foreclosure measures per province in 2012 and changes in per-capita health expenditures per province with respect to 2009

\begin{tabular}{cccc}
\hline & $\begin{array}{c}\text { Initiations } \\
\text { of foreclosures } \\
\text { procedures }\end{array}$ & $\begin{array}{c}\text { Foreclosure } \\
\text { procedures } \\
\text { materialized }\end{array}$ & $\begin{array}{c}\text { Settlements } \\
\text { between } \\
\text { household and bank }\end{array}$ \\
\hline $2013-2009$ & $-0.32^{\star *}$ & $-0.30^{\star \star}$ & $-0.30^{\star \star}$ \\
\hline $2014-2009$ & $-0.30^{\star \star}$ & $-0.26^{\star \star}$ & $-0.29^{\star \star}$ \\
\hline $2015-2009$ & $-0.26^{\star}$ & $-0.24^{\star}$ & -0.19 \\
\hline $2016-2009$ & $-0.25^{\star}$ & $-0.24^{\star}$ & -0.22 \\
\hline $2017-2009$ & -0.18 & -0.19 & -0.15 \\
\hline $2018-2009$ & -0.13 & -0.15 & -0.12 \\
\hline
\end{tabular}

Measures of foreclosures are: initiations of foreclosures procedures, foreclosure procedures materialized, and settlements between household and bank to give back the property with no further payments. One and two stars imply statistical significance at the $10 \%$ and $5 \%$ confidence levels, respectively.

Results in table 1 suggest that provinces with a higher intensity of foreclosures due to the financial crisis experienced significantly negative changes in health care expenditures in 2013, 2014, 2015 and 2016. There may be a number of mechanisms at work behind these correlations, such as the need to shift public expenditures to other items, such as unemployment benefits. Additionally, lower tax collection during those years, the need to reduce fiscal deficits during those years and an overall higher fiscal burden seem to have taken a toll precisely in provinces heavily hit by the financial crisis. We also note that these negative correlations are pervasive throughout the sample, including the latest year, 2018, though their size and statistical significance naturally decrease over time.

The severity of the Spanish financial crisis had a relevant impact in terms of the unemployment rate, which reached $26 \%$ in 2013. The real estate bubble of the 1990s and 2000's burst in 2009, when construction abruptly came to a halt and many young low-skilled workers were laid off. Unemployment was particularly high among young workers, reaching above $50 \%$ of active young population. The response of these workers came in different forms. While some moved to other countries, returning home was definitely an option for many of them. If, consequently, household sizes increase and older children are staying in the same home, this could have had an impact in the transmission of the COVID-19.

To assess the relation between the Spanish financial crisis and the potential changing patterns of co-residence in Spanish households, we retrieve yearly province-level census data from IPUMS from 2009 to 2018: family size, age of the eldest child, and the age spread between the eldest and youngest child. We then correlate 
changes in these co-residence measures - also with 2009 being the base year - and the 2012 foreclosure measures.

Table 2 shows the results. Strikingly, each correlation in the table starting in 2014 is positive, implying that households in provinces that were harder-hit by the financial crisis, experienced either higher growth or a lower decrease in the household size in the following years. Not all correlations are significant. Interestingly, significance is generally higher for later years, indicating that perhaps there is a lag by which the co-residence effects are borne out. The strongest results are obtained for the age of the eldest child. While with these data it is not possible to distinguish whether these descendants return home after being laid off or stay at home after the financial crisis, both channels are consistent with our results and could potentially contribute to an increased likelihood of disease contagion during the pandemic. Overall, the findings are consistent with the hypothesis stated above, at least at the unconditional level (i.e. not controlling for other relevant factors).

Table 2 Correlations between per-capita foreclosure measures per province in 2012 and changes in co-residence census measures across households

\begin{tabular}{|c|c|c|c|c|}
\hline & Foreclosure measure & Family size & Age eldest child & Age spread children \\
\hline \multirow[t]{3}{*}{ 2013-2009 } & initiations & -0.21 & -0.09 & -0.15 \\
\hline & materializations & 0.15 & 0.10 & 0.03 \\
\hline & settlements & -0.05 & 0.02 & -0.08 \\
\hline \multirow[t]{3}{*}{ 2014-2009 } & initiations & 0.14 & 0.15 & 0.14 \\
\hline & materializations & 0.22 & 0.12 & 0.05 \\
\hline & settlements & $0.25^{\star}$ & $0.28^{\star \star}$ & $0.24^{\star}$ \\
\hline \multirow[t]{3}{*}{ 2015-2009 } & initiations & $0.34^{\star \star \star}$ & $0.39^{\star \star \star}$ & $0.25^{\star}$ \\
\hline & materializations & 0.16 & 0.16 & 0.10 \\
\hline & settlements & 0.21 & 0.15 & 0.14 \\
\hline \multirow[t]{3}{*}{ 2016-2009 } & initiations & 0.20 & $0.28^{\star \star}$ & $0.23^{\star}$ \\
\hline & materializations & $0.29^{\star \star}$ & $0.34^{\star \star \star}$ & $0.25^{\star}$ \\
\hline & settlements & 0.15 & 0.23 & 0.20 \\
\hline \multirow[t]{3}{*}{$2017-2009$} & initiations & 0.09 & 0.17 & 0.18 \\
\hline & materializations & $0.27^{\star \star}$ & 0.21 & 0.20 \\
\hline & settlements & 0.18 & $0.25^{\star}$ & 0.21 \\
\hline \multirow[t]{3}{*}{ 2018-2009 } & initiations & 0.18 & $0.24^{\star}$ & 0.16 \\
\hline & materializations & $0.28^{\star \star}$ & $0.24^{\star}$ & $0.24^{\star}$ \\
\hline & settlements & 0.22 & $0.29^{\star \star}$ & 0.18 \\
\hline
\end{tabular}

Measures of foreclosures are: initiations of foreclosures procedures, foreclosure procedures materialised, and settlements between household and bank to give back the property with no further payments. Measures of co-residence are: changes in family size, changes in the age of the eldest child at home, and changes in the age spread between the eldest and youngest child. One, two and three stars imply statistical significance at the $10 \%, 5 \%$ and $1 \%$ confidence levels, respectively. 
As a third descriptive exercise, we explore the relation between the financial crisis and the use of nursing homes for the elderly, commonly known in Spain as elderly residences. Elderly residences have been at the centre of the COVID-19 impact in Spain. In particular, and while official data are not available at the time of the writing of the article, it is widely believed that more than half of the deceased died in elderly residences. ${ }^{7}$ We measure the usage intensity of elderly residences with two different ratios provided by the IMSERSO (Spanish Institute for Elderly and Social Services) in 2018, the latest year available. ${ }^{8}$ The first one is the ratio between users of elderly residences in a given province and the province population. The second one is the ratio of users of elderly residences in a given province and their total capacity. The residences considered here are only those under public funding.

Table 3 shows the correlations between the two residence ratios and the changes in public expenditures in health services with respect to 2009. The correlations are negative in most cases, implying that provinces that reduced their per capita public health expenditures by a larger amount were also those with a more intensive usage of the elderly residences under public funding in 2018. These correlations become larger and more significant for the 2014-2009 year interval. Thus, provinces with more crowded elderly residences were also the ones that experienced more serious public health expenditure cuts. This finding points at potential trouble for these provinces in the wake of the COVID-19 pandemic, as their response may be hindered by both overcrowded residences and less public health resources.

7 See, for instance, the June 6th, 2020 newspaper interview with the President of the Elderly Residence Association in Spain: https://www.elmundo.es/espana/2020/06/๑ 7/5edbeec9fdddff5e298b457f.html.

8 See https://www.imserso.es/imserso_01/documentacion/estadisticas/ssppmm_ esp/index.htm. 
Antonio Moreno, Steven Ongena, Alexia Ventula Veghazy, Alexander F. Wagner The Global Financial Crisis and the COVID-19 Pandemic

Table 3 Correlations between elderly residence ratios of intensive usage in 2018 and changes in per-capita health expenditures per province with respect to 2009

\begin{tabular}{lcc}
\hline & $\begin{array}{c}\text { Residence users divided } \\
\text { by province population }\end{array}$ & $\begin{array}{c}\text { Residence users divided } \\
\text { by residence positions } \\
\text { in the province }\end{array}$ \\
\hline $2013-2009$ & 0.08 & 0.06 \\
\hline $2014-2009$ & $-0.33^{\star \star}$ & $-0.33^{\star \star}$ \\
\hline $2015-2009$ & -0.02 & -0.13 \\
\hline $2016-2009$ & -0.14 & $-0.25^{\star}$ \\
\hline $2017-2009$ & -0.12 & -0.19 \\
\hline $2018-2009$ & -0.13 & -0.16 \\
\hline
\end{tabular}

Measures of residence ratios are: residence users divided by province population, and residence users divided by residence positions in the province. The residences considered are those under public funding. One and two stars imply statistical significance at the $10 \%$ and $5 \%$ confidence levels, respectively.

In future work, we aim to test more formally the links among the four dimensions considered in this chapter: severity of the financial crisis, changes in health expenditures, changes in household co-residence and overcrowding of elderly residences. The preliminary results presented here at least suggest the possibility that provinces more affected by the financial crisis suffered higher public health expenditure cuts, a higher increase in household co-residence as a response to the crisis as well as more crowded elderly residences ex-post. This combination of factors might have exacerbated the consequences of COVID-19 in these provinces.

Overall the main question that will need to be addressed is "How to better manage systemic risks - from cyber attacks and pandemics to financial crises and climate change - in a globalized world" (Goldin, Mariathasan 2014). Fighting the fires of one realisation of such a global systemic risk, i.e. the financial crisis, may have lead to consequences for how another realisation one decade later, i.e. the COVID-19 pandemic, is having its impact and is being handled. The whole picture calls for more creative thinking, acting and resource allocation at all levels and by all agents (government, households and firms) to enhance system resiliency, in accordance with the costs and benefits involved. But in the end, and not simplifying too much, global systemic risks likely also call for a sure-footed global 'systemic' approach. 


\section{Bibliography}

Acharya, V.V.; Eisert, T.; Eufinger, C.; Hirsch, C.W. (2019). "Whatever it Takes: The Real Effects of Unconventional Monetary Policy". Review of Financial Studies, 32, 3366-411. https://doi.org/10.1093/rfs/hhz005.

Andrieș, A.M.; Ongena, S.; Sprincean, N. (2020). The COVID-19 Pandemic and Sovereign Bond Risk. Iasi: Alexandru loan Cuza University of lasi. https:// dx.doi.org/10.2139/ssrn.3605155.

Berger, A.N.; Nistor, S.; Ongena, S.; Tsyplakov, S. (2020). Catch, Restrict, and Release: The Real Story of Bank Bailouts. Zurich: University of Zurich. https://dx.doi.org/10.2139/ssrn.3611480.

Berger, A.N.; Roman, R. (2020). TARP and Other Bank Bailouts and Bail-ins Around the World. New York: Elsevier. https://doi.org/10.1016/C2017$\odot-\odot \odot 528-1$.

Bonfim, D.; Cerqueiro, G.; Degryse, H.; Ongena, S. (2020). On-site Inspecting Zombie Lending. Lisboa: Banco de Portugal. https://dx.doi.org/10.2139/ ssrn. 3530574.

Bonfim, D.; Nogueira, G.; Ongena, S. (2020). "Sorry, We're Closed”. Bank Branch Closures, Loan Pricing and Information Asymmetries. Lisboa: Banco de Portugal.

Goldin, I.; Mariathasan, M. (2014). The Butterfly Defect: How Globalization Creates Systemic Risks, and What to Do about It. New York: Princeton University Press. https://doi.org/10.1515/9781400850204.

Gropp, R.; Ongena, S.; Saadi, V.; Rocholl, J. (2020). The Cleansing Effect of Banking Crises. Halle: IHW. 



\title{
What Can the Black Death Tell Us About the Global Economic Consequences of a Pandemic?
}

Adrian R. Bell

Henley Business School, University of Reading, UK

Helen Lacey

University of Oxford, UK

Andrew Prescott

University of Glasgow, UK

\begin{abstract}
The COVID-19 pandemic and global lockdown have led to academics and media outlets looking for historical parallels to draw lessons from. Whilst great care needs to be taken when trying to relate events many centuries apart, this chapter reviews the Black Death (1348-1351) and particularly focuses upon its economic impact on England. We will contextualise the pandemic and illustrate both the immediate and longer term outcomes of this devastating event. Whilst we can direct the reader to implications for our current situation, we will also discuss the many differences of these two global events.
\end{abstract}

Keywords Pandemic. Black Death. Economic History. Recovery.

Summary 1 The Economic Shock of Pandemics. - 2 'Anger, Antagonism, Creativity'. -3 Lessons for Today. 


\section{The Economic Shock of Pandemics}

Concerns over the spread of the novel coronavirus in March 2020 translated into an immediate economic slowdown. Stock markets were hit: the UK's FTSE 100 seeing its worst days of trading for many years (This is Money 2020) ${ }^{1}$ and additionally the Dow Jones and S\&P500 in the US. Money had to go somewhere and the price of gold - seen as a stable commodity during extreme events - reached a seven-year high. ${ }^{2}$

The real economic impacts became more evident as globally we saw a country by country lockdown of normal activities. In the UK this translated into a Government bailout of a scale never previously seen or imagined. ${ }^{3}$ Soon economists were predicting a 'Greatest recession', as governments struggled with their exit plans and attempting to reconcile levels of debt never seen in peacetime, alongside the prospect of mass unemployment - perhaps at levels that would take economies back to the 1980 s (or worse). ${ }^{4}$

Whilst it was perhaps immediately clear (to economic commentators rather than governments) that the COVID-19 pandemic and associated lockdowns were going to have a long term downwards effect on the world economy, it became more and more tricky to link events to historical pandemics. The main differentiating factor is the ability of current governments to lockdown their citizens for long periods of time, a feat that would have been beyond the means of medieval rulers (who, in any case, would have had fewer qualms about sending out the labourers to work during a pandemic).

So whilst acknowledging the challenges, a look back at history can help us consider the economic effects of public health emergencies and how best to manage them. In doing so, however, it is important to remember that past pandemics were far more deadly than coronavirus, which has a relatively low death rate (Parker 2020). Without modern medicine and institutions like the World Health Organization, past populations were more vulnerable. It is estimated that

\footnotetext{
This is an expanded version of an original article in the Conversation by the same authors (Bell, Lacey, Prescott 2020).

We would like to thank the editors of this volume for helpful comments and also Annabel Bligh for originally encouraging and commissioning the article for the Conversation (https://theconversation.com/what-can-the-black-death-tell-us-aboutthe-global-economic-consequences-of-a-pandemic-132793).

1 https://www.thisismoney.co.uk/wmoney/markets/article-8055045/FTSE-LIVEShares-deep-red-market-panic-continues.html.

2 https://www.bbc.co.uk/news/business-51612520.

3 https://www.henley.ac.uk/news/2020/when-is-a-bailout-not-a-bailout.

4 https://www.project-syndicate.org/commentary/coronavirus-greatergreat-depression-by-nouriel-roubini-2020-03.
} 
the Justinian plague of 541 AD killed 25 million and the Spanish flu of 1918 around 50 million. ${ }^{5}$

By far the worst death rate in history was inflicted by the Black Death. Caused by several forms of bubonic plague, it lasted from 1346 to 1353, killing anywhere between 75 million and 200 million people worldwide and perhaps one half of the population of England (Benedictow 2005). As we will describe, the economic consequences were also profound.

\section{2 'Anger, Antagonism, Creativity'}

It might sound counter-factual - and this should not minimise the contemporary psychological and emotional turmoil caused by the Black Death - but the majority of those who survived went on to enjoy improved standards of living. Prior to the Black Death, England had suffered from severe overpopulation.

Following the pandemic, the shortage of manpower led to a rise in the daily wages of labourers, as they were able to market themselves to the highest bidder. The diets of labourers also improved and included more meat, fresh fish, white bread and ale (Dyer 1989, 158-60). Although landlords struggled to find tenants for their lands, changes in forms of tenure improved estate incomes and reduced their demands. But the period after the Black Death was also, according to economic historian Christopher Dyer (2005, 429), a time of "agitation, excitement, anger, antagonism and creativity".

Across Europe, the reaction of many governments was to try to hold back the tide of supply-and-demand economics (Cohn 2007). In France, King John II passed detailed regulations for northern France controlling work practices, wages and prices. Similar regulations had been enacted in southern France in 1348. In Spain, legislation in Castile stipulated that lords could specify the place and time of work of rural labourers, while in Aragon, work was made obligatory for all except the ill, the old and children under 12. Italian city states also attempted to control wages and prices. The most well-known labour legislation is however the various ordinances and statutes passed by the English government from 1349.

The 'problem of labour' became a preoccupation of English parliaments and governments. Between 1349 and 1430, one third of the 77 parliaments which met passed legislation attempting to control wages, terms of service and prices (Given-Wilson 2000, 85). An initial Ordinance of Labourers in 1349 specified that every man or woman, free or unfree, aged sixty years or younger without income from land or

5 https://www.rwjf.org/en/blog/2013/12/the_five_deadliesto.html. 
trade must work for whoever required their labour. Wages were set at the levels that had been customary in 1346 and anyone receiving excessive wages forfeited the excess sum to the king. Victuallers were also obliged to sell their wares for 'reasonable' prices (Poos 1983, 29).

These provisions were elaborated and enshrined in statute in 1351. ${ }^{6}$ The 1351 Statute of Labourers incorporated a table of set wage rates for specific occupations. It stipulated that servants were obliged to serve for entire years, and not by the day (Poos 1983, 30). Subsequent legislation expanded and refined the national pay scales, with even pay rates for stipendiary chaplains being controlled in 1362. Enforcement was also progressively tightened. In 1361, monetary fines for breaches of labour legislation were replaced by branding of the letter $\mathrm{F}$ for Falsity on the forehead (although there is no evidence this punishment was ever inflicted [Cohn 2007, 476]). A 1388 statute required letters of authorisation for any worker travelling away from home (Bennett 2010, 12).

This was the first time an English government had attempted to micromanage the economy. However, the aim of the government in the 14th century was not to promote economic growth but rather to maintain the existing social order. In a world where social ranks were seen as God-given, governments thought there was a moral imperative to restrict excessive consumption or accumulation of wealth by those classes not entitled to it. These concerns also led to sumptuary legislation which for example specified which social groups could wear what type of clothes with poorer people "allowed to wear only blanket and russet wool" (Sponsier 1992, 275). Legislation such as this sought to preserve society as it was before the pandemic - just as furloughing sought to deep freeze the economy in 2020, only the medieval legislation was not temporary.

But this attempt to regulate the market did not work. Enforcement of the labour legislation led to evasion and protests. In the longer term, real wages rose as the population level stagnated with recurrent outbreaks of the plague. Landlords struggled to come to terms with the changes in the land market as a result of the loss in population. There was large-scale migration after the Black Death as people took advantage of opportunities to move to better land or pursue trade in the towns. Most landlords were forced to offer more attractive deals to ensure tenants farmed their lands. However, any suggestion that women benefitted, even temporarily, from the situation through increased job opportunities and incomes, seems to be a myth. Research has shown that women lost out by accepting permanent contracts and the perceived security they offered, despite the fact that casual work was better remunerated (Humphries, Weisdorf 2015).

6 https://sourcebooks.fordham.edu/seth/statute-labourers.asp. 
The failure of the government's attempts to control the labour market is vividly illustrated in legal records. In Surrey, William Cothull found John Egger wandering and able to work. Cothull offered to employ Egger as a ploughman for a year. Egger refused, so Cothull had Egger arrested and put in the stocks until he agreed to work for him (Bennett 2010, 17). Others were more successful in evading the legislation. A common trick was to claim that you already worked for someone else: when Peter de Semere offered work to William atte Merre of Merrow in February 1350, William claimed he was unable to work for Peter because he was already a serf of the prior and convent of St Mary at Boxgrove on the priory's manor of Merrow, and the justices found in William's favour (Horrox 1994, 317). Others simply disappeared. John Carter a 'common labourer' took an oath before the constables of Apley in Lincolnshire in June 1373 to work in that village the following summer and autumn but vanished a week later (Poos 1983, 31).

The inequities of the labour legislation led to resistance. In 1350, two constables in the village of Preston in Suffolk tried to force Richard Digg, a common labourer, to work for various men in the village. The vicar objected and demanded to know by what authority Digg could be ordered to work. The vicar excommunicated the constables and, encouraged by the vicar, Digg refused to serve and instead earned his own living as a wage labourer (Bennett 2010, 22-3).

The idea that labourers might not work according to the customary patterns and could earn their own living as wage labourers offended many. Wage labourers were often portrayed as idle and feckless, wasting their time in taverns and gaming (itself a sign that they had more disposable income). William Langland in his great moral poem Piers Plowman contrasted the honest virtuous figure of the ploughman with the wage labourers who were portrayed as rootless wasters unwilling to do an honest day's work, akin to fraudulent beggars (Dyer 2000). These themes were taken up by the gentry and merchants in parliament who complained about workers refusing to accept the statutory levels of pay and leaving before the end of their service:

For fear of such flights, the commons now dare not challenge or offend their servants, but give them whatever they wish to ask, in spite of the statutes and ordinances to the contrary - and this chiefly through fear they will be received elsewhere. (Dobson 1981, 73)

A new middle class of men (almost always men) emerged. These were people who were not born into the landed gentry but were able to make enough surplus wealth to purchase plots of land. Clement Paston (of the Norfolk family who bequeathed the famous medieval letter collection) took advantage of the Black Death to accumulate substantial landholding in the vicinity of Paston. It is possible that Clem- 
ent started life as a peasant bondsman, but he accumulated enough wealth to have his son educated in the law and in two generations the family rose rapidly through the ranks of the gentry. ${ }^{7}$ Recent research has shown that property ownership opened up to market speculation (Bell, Brooks, Killick 2019a) and this market allowed investors to speculate and profit (Bell, Brooks, Killick 2019b).

Meanwhile, England was still at war with France and required large armies for its campaigns overseas. This had to be paid for, and in England led to more taxes on a diminished population. The parliament of a young Richard II came up with the innovative idea of punitive poll taxes in 1377, 1379 and 1380, leading directly to social unrest in the form of the Peasants' Revolt of $1381 .^{8}$ This revolt, the largest ever seen in England, came as a direct consequence of the recurring outbreaks of plague and government attempts to tighten control over the economy and pursue its international ambitions. When the rebels met the King at Mile End, they demanded that serfdom should be abolished and that all land should be held at a rent of four pence an acre. They also requested that the laws controlling when and for whom men and women should work should be abolished and that nobody should be forced to work against their will and without a written agreement (Dobson 1981, 161).

\section{Lessons for Today}

While the plague that caused the Black Death was very different to the COVID-19 pandemic, there are some important lessons here for future economic growth. First, governments must take great care to manage the economic fallout. Maintaining the status quo for vested interests can spark unrest and political volatility. Second, restricting freedom of movement can cause a violent reaction. We have already seen the tensions around lockdown as a result of COVID-19. At the time of writing, it is unclear how far further restrictions will be necessary, but it is worth noting that there were five further outbreaks of bubonic plague in Britain between 1360 and 1390 and these recurrences, combined with resentment against the restrictions on the labour market, contributed significantly to the tensions which led to the revolt in 1381.

In the wake of the Black Death schemes for government borrowing collapsed amidst accusations of corruption and misconduct. As an alternative, Edward III prioritised overseas trade and implement-

7 https://www.oxforddnb.com/view/10.1093/ref:odnb/9780198614128.001.0001/ odnb-9780198614128-e-52791; jsessionid=99CFE47439CC 7396B9551FEF55548ABB.

8 https://www.1381.online. 
ed reforms to the wool markets (wool was England's most import export in the period). The government broke up the old cartels that had dominated the trade and these reforms were successful in generating a level of profit that was unsurpassed for the rest of the Middle Ages (Ormrod 2011, 369). As Boris Johnson conducts negotiations over the Brexit deal he would do well to bear in mind the importance of boosting overseas trade.

The pandemic of bubonic plague in the 14th century brought to the fore anxieties about social change and inequality. Attempts by the magnates and gentry over a period of decades to control these changes led to large-scale social unrest. Today, the slow reaction of governments to the disproportionate effects of the COVID-19 virus on BAME populations has fostered the unprecedented international protests by the Black Lives Matter movement following the killing of George Floyd. The 14th-century experience reinforces the need for government to act swiftly to address issues of social injustice at a time when pandemics have heightened social and cultural anxieties.

Plus, we should not underestimate the knee-jerk, psychological reaction. The Black Death saw an increase in xenophobic and antisemitic attacks. ${ }^{9}$ It unleashed waves of persecution: against beggars and priests in Narbonne, Carcassonne and Grasse; pilgrims in Catalonia; Catalans in Sicily; and most infamously Jews across German-speaking regions of Central Europe, through the Rhineland and thence into Spain, France and the Low Countries (Cohn 2018, 48-53). In England, resentment at the role of merchants from the Low Countries in the wool trade led to xenophobic massacres of Flemings during the 1381 revolt. Fear and suspicion of non-natives changed trading patterns.

There will be winners and losers economically as the current public health emergency plays out. In the context of the Black Death, elites attempted to entrench their power, but population change in the long term forced some rebalancing to the benefit of labourers, both in terms of wages and mobility and in opening up the market for land (the major source of wealth at the time) to new investors. Population decline also encouraged immigration, albeit to take up low skilled or low-paid jobs. All are lessons that reinforce the need for measured, carefully researched responses from current governments. 


\section{Bibliography}

Bell, A.R.; Brooks, C.; Killick, H. (2019a). "A Reappraisal of the Freehold Property Market in Late Medieval England". Continuity and Change, 34(3), 287313. http://doi.org/10.1017/S0268416019000316.

Bell, A.R.; Brooks, C.; Killick, H. (2019b). "Medieval Property Investors, ca. 13001500”. Enterprise \& Society, 20(3), 575-612. http://doi.org/10.1017/ eso.2018.92.

Bell, A.R.; Lacey, H.; Prescott, A. (2020). "What Can the Black Death Tell Us About the Global Economic Consequences of a Pandemic?". The Conversation, 3 March. https://bit.ly/31TfgGA.

Bennett, J.M. (2010). “Compulsory Service in Late Medieval England". Past and Present, 209(1), 7-51. http://doi.org/10.1093/pastj/gtq032.

Benedictow, O. (2005). "The Black Death: The Greatest Catastrophe Ever". History Today, 55(3). https://www.historytoday.com/archive/blackdeath-greatest-catastrophe-ever.

Cohn, Jr., S.K. (2007). "After the Black Death: Labour Legislation and Attitudes Towards Labour in Late-Medieval Western Europe". Economic History Review, 60(3), 457-85. http://doi.org/10.1111/j.1468-0289.2006.00368.x.

Cohn, Jr., S.K. (2018). Epidemics: Hate and Compassion from the Plague of Athens to AIDS. Oxford: Oxford University Press. http://doi.org/10.1093/ oso/9780198819660.001.0001.

Dobson, R.B. (ed.) (1981). The Peasants'Revolt of 1381.2nd ed. London: Macmillan.

Dyer, C. (1989). Standards of Living in the Later Middle Ages: Social Change in Europe c. 1200-1500. Cambridge: Cambridge University Press.

Dyer, C. (2000). "Work Ethics in the Fourteenth Century". Bothwell, J.; Goldberg, P.J.P.; Ormrod, W.M. (eds), The Problem of Labour in Fourteenth-Century England. York: York Medieval Press, 21-42.

Dyer, C. (2005). "Villeins, Bondmen, Neifs, and Serfs: New Serfdom in England, c. 1200-1600". Freedman P.; Bourin, M. (eds), Forms of Servitude in Northern and Central Europe: Decline, Resistance, and Expansion. Turnhout: Brepols Publishers, 419-36. https://doi.org/10.1484/M.TCNE-EB.3.4153.

Given-Wilson, C. (2000). "The Problem of Labour in the Context of English Government c. 1350-1450". Bothwell, J.; Goldberg, P.J.P.; Ormrod, W.M. (eds), The Problem of Labour in Fourteenth-Century England. York: York Medieval Press, 85-100.

Horrox, R. (1994). The Black Death. Manchester: Manchester University Press.

Humphries, J.; Weisdorf, J. (2015). "The Wages of Women in England, 12601850". The Journal of Economic History, 75(2), 405-47. https://doi. org/10.1017/S๑022050715000662.

Ormrod, W.M (2011). Edward III. New Haven (CT): Yale University Press.

Parker, E. (2020). "Coronavirus Outbreak: A New Mapping Tool that Lets You Scroll Through Timeline". The Conversation, 11 February. https://theconversation.com/coronavirus-outbreak-a-new-mappingtool-that-lets-you-scroll-through-timeline-131422.

Poos, L.R. (1983). "The Social Context of Statute of Labourers Enforcement". Law and History Review, 1(1), 27-52. https://doi.org/10.2307/744001.

Sponsier, C. (1992). "Narrating the Social Order: Medieval Clothing Laws". CLIO, 21(3), 265-83. 
Part 2

Fiscal and Monetary Policy 



\title{
Recovering from the Economic Impact of COVID-19 \\ Who Should Pick Up the Bill for the British Lockdown?
}

\section{Peter Scott}

Henley Business School, University of Reading, UK

\begin{abstract}
This chapter examines what lessons can be learned from three previous crises that created public debt mountains of similar magnitude to the pandemic: the First World War, Second World War, and Credit Crunch. In all three cases the Treasury pressed for drastic spending cuts, to maintain confidence in sterling and the City. However, in the one case where the Treasury's advice was rejected, there was a substantially stronger recovery. The Treasury has similarly lobbied for austerity measures to deal with the COVID-19 government debt, again raising the spectre of slow growth and mass unemployment.
\end{abstract}

Keywords COVID-19. Austerity. Economic recovery. Treasury. Bank of England. Recovery policy.

Summary 1 Introduction. -2 The First Crisis: 1914-31. - 3 The Second Crisis: 193951. - 4 The Third Crisis: 2008-15. - 5 Lessons for the Pandemic. 


\section{Introduction}

Aside from its terrible human toll (which will have enduring impacts), the economic costs of the coronavirus pandemic will be catastrophic, both in the short and longer term. Can Britain learn anything from three previous episodes of international crises that massively increased its national debt, while destabilising the domestic and world economies: the First and Second World Wars and the Credit Crunch?

In some respects, the coronavirus pandemic is different from these crises - it inflicts no significant damage on physical infrastructure; it has not skewed industrial output towards a 'war economy', and - unlike the Credit Crunch - it has not laid bare more fundamental instabilities and insolvencies among key sectors and firms. However, in common with these crises, it will hugely inflate government debt, while generating further costs of economic reconstruction, to save businesses that are fundamentally solvent, but have been driven to the brink of collapse by the lock-down. Britain will also face a major expansion in unemployment and other welfare costs, at least in the short and medium term.

The previous crises are illuminating in showing the solutions that British policy-makers have repeatedly advocated. Influential voices (particularly the Treasury, Bank of England, and leading bankers and City figures) repeatedly advocated placing much of the burden of adjustment on lower income groups, via policies of savage deflation and public expenditure cuts. In only one case did politicians reject this advice, in the special circumstances of an electorate who had learned the lessons of the government response to the First World War aftermath and took the opportunity of the 1945 election to vote in a radical government, committed to social reconstruction and the welfare state.

\section{The First Crisis: 1914-31}

The First World War was both an unprecedented humanitarian disaster and a huge negative shock to the international economy. Both belligerents and neutral countries greatly expanded their industrial production, especially for staple commodities such as coal, iron and steel, and textiles (which formed the core of Britain's industrial base), creating a problem of massive excess capacity following the Armistice (Scott 2007, 74-85). Until the final months of war, it had been assumed that the outcome would probably be a stalemate, with a strong Germany possibly switching from a fighting war to an eco-

Thanks are due to Paloma Fernandez Perez, Daniel Raff, Andrew Smith, and Simone Varotto, for comments on earlier drafts. Any errors are mine. 
nomic conflict with Britain (Cline 2017, 157-81). This challenge was to be addressed by policies of industrial reconstruction and job creation - partly via a massive building programme of 'homes for heroes' (state-subsidised municipal housing). However, the Treasury and Bank of England were strongly opposed to this strategy, which ran counter to their own plans for savage deflation, to bring the pound back to its pre-war gold standard parity and restore the City to its status as the world's main financial centre (Peden 2000, 125).

Germany's sudden military collapse in autumn 1918 enabled the Treasury and Bank of England to implement their deflationary strategy (Garside 1998, 27-9). This contrasted with the policies of most major European nations, including Germany, France, and Italy, which, to varying degrees, relied on inflationary policies to reduce their debt's real value. Adopting such a solution in Britain would have made a resumption of Bank of England co-ordination of the international gold standard impossible, while shattering ambitions for a resumption of the City's status as the world's leading financial center (that, in any case, proved illusory). It would have also adversely impacted the middle classes - the bedrock of Conservative electoral support - by drastically reducing the value of their fixed-interest stocks (Daunton 2002, 64-6). Sparing the middle-classes by focusing on paying off the debt nevertheless enraged the very constituency that the policy was designed to protect, as it entailed high taxation (by pre-1914 standards). The standard rate of income tax rose from 5.8\% in 1913-14 to an interwar peak of 30\% during the 1918-19/1921-22 tax years (Daunton 2002, 883-9). Top rates were much higher, but a failure to address growing tax avoidance/evasion allowed the super-rich to dodge a growing proportion of their taxes (Scott, forthcoming).

Returning to gold at pre-war parity ( $€ 1=\$ 4.86$ ) required substantial price falls to counter war-time inflation. However, the government's deflationary policy mainly acted to increase unemployment rather than reduce prices. Nevertheless, in April 1925 the Chancellor, Winston Churchill, took Britain back to gold at its old parity (which proved to be substantially over-valued). As John Maynard Keynes famously noted, what he estimated to be a $10 \%$ sterling overvaluation meant that:

whenever we sell anything abroad, either the foreign buyer has to pay 10 per cent more in his money or we have to accept 10 per cent less in our money. That is to say, we have to reduce our sterling prices, for coal or iron or shipping freights... by 10 per cent in order to be on a competitive level, unless prices rise elsewhere. (Keynes 1970, 23; emphasis in original)

Britain was a negative outlier in terms of its poor economic growth during the 1920s, largely as a result of deflationary policy - which 
continued after 1925 in order to defend its over-valued exchange rate (Eichengreen 2004, 322-3). Ultimately the policy was not sustainable; a loss of international confidence in sterling triggered a political crisis in the summer of 1931 and one of the first acts of the new Conservative-led 'National' government was to take Britain off the gold standard. Contrary to the Treasury and Bank of England's dire predictions, the value of the pound did not collapse, but settled at a more internationally competitive rate, which assisted Britain in achieving one of the strongest recoveries from the 1929-32 depression. However, despite a surge in economic growth and employment, the staple industries (principally coal, iron and steel, and textiles) were slow to recover from a decade of being priced out of international markets, creating what proved to be a permanent north-south divide in British prosperity.

\section{The Second Crisis: 1939-51}

The Second World War saw a much wider mobilisation of domestic resources than the First, in a conflict where, for a time, Britain stood alone. At its peak, almost all working-age adults, including civilians, were subject to some sort of conscription and, thanks to the Luftwaffe, many urban residents faced a real threat of death or injury. Government accepted the imperative to keep food and other necessities both affordable and available, via a system of rationing, price controls, and subsidies. These policies sharply reduced living standards for the upper and middle classes, while improving the nutrition of many manual workers' families. Rationing did not remove disparities in living standards - the affluent retained their better housing, could still dine at smart restaurants where food was unrationed, and enjoyed better food at home by using the ration coupons of their domestic servants. However, the system was based on equality of sacrifice and "fair shares" for all, according to needs, rather than wants (Roodhouse 2013, 2-6).

Contrary to some popular accounts, there was no consensus within the war-time government that post-war economic policy should prioritise domestic reconstruction and Keynesian full-employment policy. An influential coalition of Bank of England and Treasury officials advocated an economic policy based on prioritising the restoration of sterling's credit-worthiness - in the face of Britain's huge war debts - through another round of severe deflation. Keynes criticised this group for prioritising international "obligations" over the war-time commitment to build a fairer society - which would amount to a repetition of the 1920s gold standard debacle - though his direct influence was ended with his untimely death in April 1946 (Newton 2004, 262-3).

However, the deflationary lobby failed to appreciate the drastic change in popular opinion, reflecting the levelling tendency in socie- 
ty brought about by the collective nature of the war effort. Most senior politicians recognised the impracticalities of the Bank of England's 'sterling first' policy, while the remainder had their dreams shattered by Labour's landslide 1945 election victory. Clement Atlee's 1945-51 Labour governments used a continuation of rationing and other wartime direct controls to create a comprehensive welfare state and nationalise what Labour saw as key areas of the economy, while avoiding any deflationary plunge into recession. Moreover, they achieved substantial economic growth, with GDP rising at a respectable $2.5 \%$ per annum from 1946-51. The October 1951 election saw the return of a Conservative government, which increasingly followed Treasury and Bank of England advice to prioritise a strong and stable pound and an early re-opening of the City, over wider domestic economic and social reconstruction. Nevertheless, many of the gains of the Attlee era, including the NHS, the welfare state, and a commitment to full employment, persisted.

\section{The Third Crisis: $2008-15$}

The Credit Crunch was a very different type of economic shock than the two world wars, in part a financial crisis (on a scale never seen before), but also a crisis of the global economic system. From the 1980s, governments had increasingly ceded their regulatory functions to markets, private sector institutions, and central banks, on the basis of a philosophy that markets could fix any problems they could create, if set free from the heavy hand of the state. However, the events of autumn 2008 shattered this myth, as the spike in equities, house prices, and securities based on home mortgages suddenly burst, threatening to bring down the international financial system.

The subsequent fall in house and equity prices over 2008-09 wiped out $\$ 1.5$ trillion of British household wealth, equivalent to $50 \%$ of GDP (according to an IMF estimate), with $10 \%$ of home-owners facing negative equity (Tooze 2019, 156). Internationally, trillions of pounds of taxpayers' money was mobilised by the world's leading industrial nations, to save banks from their own mistakes and mismanagement. The new reality produced a rapid, if short-lived, ideological volteface, with many of the people who had hitherto been the strongest advocates of market-based solutions making ever-more desperate pleas for massive government bailouts. As former Federal Reserve chairman Alan Greenspan admitted, "I made a mistake in presuming that the self-interest of organisations, specifically banks and others, was such that they were best capable of protecting their own shareholders" (Beattie, Politi 2008).

Across the developed world, eye-wateringly expensive bank bailouts were mobilised, via loans, recapitalisations, asset purchases, and 
state-backed guarantees. These were reinforced by similarly huge government economic stimulus packages to prevent a global economic meltdown. Gordon Brown's plan to recapitalise Britain's ailing clearing banks, while taking equity stakes in them, is generally regarded as one of the most successful bank bailouts (though the Labour governments of which he had been Chancellor, then PM, must shoulder substantial responsibility for earlier failures to introduce stronger regulation) (Tooze 2019, 190-2). Meanwhile Britain's clearing banks were remarkably unrepentant. For example, RBS - the world's largest bank on the eve of the crisis, based on its 2008 balance sheet - insisted on honouring $£ 1$ billion of bonus contracts, despite just having been saved from bankruptcy by an enormous injection of taxpayers' money (Tooze 2019, 292). Then, once the crisis was averted, the banks aggressively lobbied for a quick return to business as usual.

As in 1919 and 1945, the Treasury lobbied for prioritising deficit reduction over maintaining living standards (Tooze 2019, 349). The 6th May 2010 general election failed to produce a Parliamentary majority, with the Tories gaining the most seats and the Liberals holding the balance of power. However, negotiations soon revealed the Liberals' top team to be dominated by economic liberals, having much more in common with the Tories than with Labour. They thus signed up to a Conservative programme of 'austerity', in stark contrast to their manifesto pledges. This was a very different brand of austerity than that employed by the 1945-51 Labour governments, based around 'fair shares' and equality of sacrifice. Instead, austerity was disproportionately targeted on lower income groups, cutting welfare benefits and raising regressive taxes, particularly VAT. The rich were much less impacted, largely due to their ability to avoid or evade taxation and make capital gains through borrowing at historically low interest rates to purchase houses or other scarce real assets, which rose in value owing to the volume of cash chasing them (Moore 2016).

One major element of the Tory-Liberal austerity was a further rolling back of the welfare state. From September 2009 to July 2016 over one million public sector jobs were cut or transferred to the private sector (outstripping the earlier cuts by the Thatcher or Major governments) (Tooze 2019, 350). This included substantial cuts in police numbers (followed, several years later, by an epidemic of gun and knife fatalities), while the NHS was progressively starved of resources (relative to its sector-specific inflation rate), leaving it ill-equipped to cope with a major flu epidemic, let alone the worst pandemic for a century. There were also deep cuts in welfare benefits. The 2012 Welfare Reform Act replaced unemployment-related and income benefits by Universal Credit. Despite some positive features (such as rationalising the benefits system), it required claimants to wait over a month before receiving their first payment. As many had little or no savings, waiting five or six weeks without money often led to be- 
ing evicted from their homes and/or amassing huge debts to 'payday lenders', charging extortionate interest rates. This plunged substantial numbers of families into the type of deep absolute poverty not seen in Britain since the 1930s, including several cases of death by starvation for vulnerable people refused benefits (Butler 2020).

\section{Lessons for the Pandemic}

The pandemic is creating a debt burden of similar magnitude to these earlier crises. Britain's budget deficit is likely to approach $£ 350$ million by the end of 2020, while the national debt is expected to rise to over $100 \%$ of GDP (Warner 2020). However, this time there is particularly widespread support for an expansionary solution, from a broad range of the political spectrum. Influential commentators have pointed out that debt is not as big a problem as the 'Treasury view' suggests. Major trading nations typically borrow in their own currency, from their own people - though the debtors and creditors are not one and the same. Government debt is disproportionately owned by the rich, but less so than was the case in 1920 or 1945, owing to the rise of institutional investors that view government debt as a safe, if low yielding, asset.

Adam Tooze and others have suggested that a wealth tax and/or a move against corporate and personal tax evasion would more fairly realign debt holders and payers, thereby avoiding the recent pattern of lower income groups being the main losers from crises and recessions. Moreover, these policies would avoid deflation and thus stimulate growth, in turn reducing the aggregate burden of the debt. Another round of Quantitative Easing would assist growth and the debt burden, while also further lowering interest rates and internalising the debtor-creditor relationship (the state owes debts to itself). 'Printing money' is potentially inflationary, but given the strong deflationary momentum of a 'depression' (even a threatened one) inflationary pressures are severely muted (Tooze 2020). While Britain's debts from the crisis appear staggering, they are unremarkable compared to the other G7 nations (which have typically introduced larger stimulus/support packages) and Britain has the advantage of 'safe haven' appeal to investors facing turbulent international conditions. ${ }^{1}$

In addition to the obvious moral case for equitably spreading the costs of a catastrophe that has impacted all sections of society, there is also a strong economic case. As Table 1 shows, while the deflation-

1 "The Guardian View on Government Debt: Sensible, not Spendthrift". The Guardian, 14 May 2020, 2. https://www.theguardian.com/commentisfree/2020/may/14/theguardian-view-on-government-debt-sensible-not-spendthrift. 
ary solutions pushed by the Treasury and Bank of England after the First World War and the Credit Crunch may have been beneficial for the City of London and the banking and financial sectors, this came at the cost of very slow aggregate growth. In contrast, the more expansionary and broadly-based policies pursued by the Attlee Labour governments achieved significantly higher growth, without preventing them from pursuing other priorities, such as physical reconstruction and founding the modern welfare state.

Table 1 Average GDP growth per annum during the first five, and ten, years following the three crises

\begin{tabular}{lccc}
\hline \multicolumn{4}{c}{ Average GDP growth for recovery } \\
\hline Crisis & Starting year & $\mathbf{5}$ years & 10 years \\
\hline First World War & 1919 & -0.71 & 0.79 \\
\hline Second World War & 1946 & 2.45 & 2.92 \\
\hline Credit Cruch & 2009 & 1.94 & 1.86 \\
\hline
\end{tabular}

Source: Williamson, S.H. (2020). "Annualized Growth Rate of Various Historical Economic Series". MeasuringWorth. https://www.measuringworth.com/ calculators/growth/index.php (UK GDP growth index)

Many eminent contemporary economists, notably J.M. Keynes in the first two crises and - during the Credit Crunch - Paul Krugman, were deeply critical of policy prescriptions that would both generate mass unemployment and reduce growth (Keynes 1931; Tooze 2019, 372). In 2020 there are particularly strong reasons for choosing an expansionary strategy, aimed at boosting growth by creating the necessary conditions for the recovery of businesses hit by the crisis. First, this crisis is different from the three discussed above in that there is no 'fundamental disequilibrium' in the economy from inflationary pressures, speculative euphoria, world overproduction, or physical capital destruction. The problem is mainly one of hugely enlarged government debt, which could be addressed by long-term funding, taking advantage of extraordinarily low interest rates. As long as economic growth out-paces the interest rate on government bonds, the real burden of the debt will fall over time, even if it is never paid-off (Hounsel 2020). The government could also follow Gordon Brown's precedent in insisting that loans to ailing businesses should include an equity stake for the government. In addition to reducing firms' debt problems, this would also effectively compel shareholders to make a contribution to their companies' financial support.

Secondly, there is plenty of scope for raising tax rates for the rich. In 1970 the top $0.1 \%$ and top 1\% of personal incomes had income shares of 0.73 and $4.83 \%$ of all post-tax personal income. How- 
ever, tax cuts during the 1980s and 1990s, together with growing tax avoidance (facilitated by the abolition of capital export controls), boosted their respective incomes shares to 3.5 and $10.3 \%$ by 2000 , while the twenty first century has seen further pre- and post-tax income share gains for these groups (Atkinson 2007, 104-5). Even a partial reversal of their tax cuts and tax evasion loopholes could greatly increase the income tax take, especially if accompanied by effective measures against tax avoidance/evasion. There is also good reason to think that initiatives to tackle endemic personal tax avoidance/evasion would command stronger international support than in the preCOVID-19 era. Most other major nations face similar imperatives to increase the tax take. British governments have played no small role in covertly supporting the tax avoidance industry, as part of a broader strategy to support the City of London. If the UK showed that it was finally serious about addressing tax avoidance/evasion, it might find strong support among other European nations.

Higher taxes for top incomes are also likely to be more politically acceptable in the wake of the pandemic. Government has taken on responsibilities to maintain the incomes of a substantial proportion of the population, together with interventions in the lives of British citizens on a scale unprecedented in peacetime. This has produced a 'levelling tendency' reminiscent of the Second World War. For example, the iron curtain that had separated the NHS and the private hospital sector was suddenly torn down in March 2020, effectively requisitioning (by agreement) all private hospital capacity (Neville, Plimmer 2020). A more tacit, but possibly more important, trend has been the re-evaluation of the societal 'worth' of occupations which, despite being skilled, have become relatively less well-paid since the 1980s, especially the nursing and other 'caring' professions. While during Teresa May's administration her Chancellor, Philip Hammond, could brusquely sweep aside calls to remove the austerity-induced cap on public sector pay by stating that public-sector workers were already 'overpaid' (Walker 2017), television coverage of NHS and other carers working long shifts at real risk to their lives (largely owing to shortages of vital equipment) gave the public a more realistic view of their calling. NHS and other care workers have emerged as the heroes of this conflict, as evidenced by an outpouring of popular support, ranging from the Thursday night clapping ritual to street art.

While both May and, especially, Hammond, were arch fiscal conservatives, Boris Johnson's interventionism during the COVID-19 emergency and his longer-term record as London mayor paints a more complex picture of a politician who is at least prepared to consider other options if the political climate is conducive. With the possible exception of Winston Churchill's war-time government, Conservativeled administrations have typically preferred the "Night Watchman state" model, of intervention only to reset the market mechanism, 
rather than the Bismarckian "developmental state" (Bresser-Pereira 2016). However, it is at least plausible that this might be up for reevaluation, especially if the public and academics show their support for an expansionary route out of this crisis rather than another sacrifice of British economic growth and living standards to meet the narrow interests of the City and the banks.

However, while the Bank of England appears to be broadly supportive of an expansionary policy, the Treasury has reverted to type. Coronavirus debts threaten to become "the battering ram for a new campaign of austerity" (Tooze 2020). A leaked 5th March 2020 Treasury assessment proposed a package of tax increases and spending cuts (including a two-year public sector pay freeze) - equivalent to a $5 \%$ increase in the basic rate of income tax - to "enhance credibility and boost investor confidence", despite there being no signs of investors losing confidence in Britain. ${ }^{2}$ Even the normally conservative Daily Telegraph was appalled, publishing an article beginning, "There is a special place in Purgatory for Her Majesty's Treasury... Its COVID-19 blueprint for fiscal retrenchment borders on macroeconomic insanity [...] The thinking is a throwback to the inflexible 'Treasury View'", that so exasperated John Maynard Keynes (Evans-Pritchard 2020).

One of the most important lessons from all four crises is that the Treasury is past its sell-by date; indeed it was already past it in 1920. A particularly valuable administrative innovation would be to replace the Treasury with an economics ministry, with a remit giving equal weigh to economic growth and the Treasury's traditional finance functions. However, any real change would require a wholesale cull of senior staff, replacing the Treasury mandarins with professional economists. Only then will the British economy finally be able to break free from the Treasury's dead hand.

2 "Treasury says virus to cost $£ 300$ bn as it warns of tax rises and pay freeze: confidential analysis of economic impact lays out options for the Chancellor to cover extraordinary expense of lockdown". Daily Telegraph, 13 May 2020, 1. https://www.pressreader.com/uk/the-daily-telegraph/20200513/281479278596293. 


\section{Bibliography}

Atkinson, A.B. (2007). "The Distribution of Top Incomes in the United Kingdom, 1908-2000". Atkinson, A.B.; Piketty, T. (eds), Top Incomes Over the Twentieth Century. Oxford: Oxford University Press, 82-140.

Beattie, A.; Politi, J. (2008). “I Made a Mistake,' Admits Greenspan”. Financial Times online, 23 October 2008. https://www.ft.com/content/ aee9e3a2-a11f-11dd-82fd-000077b07658.

Butler, P. (2020). "Disabled Man Starved to Death After DWP Stopped His Benefits". Guardian online, 28 January. https://www.theguardian.com/ society/2020/jan/28/disabled-man-starved-to-death-afterdwp-stopped-his-benefits.

Cline, P. (2017). "Winding Down the War Economy: British Plans for Peacetime Recovery, 1916-19". Burk, K., War and the State. The Transformation of British Government 1914-1919. London: Routledge, 157-81. https://doi. org/10.4324/9781315779720.

Daunton, M.J. (2002). Just Taxes. The Politics of Taxation in Britain, 1914-1979. Cambridge: Cambridge University Press.

Eichengreen, B. (2004). "The British Economy Between the Wars". Floud, R.; Johnson, P., The Cambridge Economic History of Modern Britain. Cambridge: Cambridge University Press, 314-43. https://doi.org/10.1017/ CHOL9780521820370.013.

Evans-Pritchard, A. (2020). "The Treasury is Wrong: We Don't Need Hairshirt Austerity”. Daily Telegraph, 13 May. https://search.proquest.com/ news/docview/2402189566/2AC7EB9B63494E3DPQ/2?account id $=13460$.

Garside, W.R. (1998). "The Economic Legacy of Conflict: Britain in the Aftermath of the First World War”. Berghoff, H.; von Friedeburg, R. (eds), Change and Inertia. Britain under the Impact of the Great War. Bodenheim: Philo, 25-36.

Hounsel, H. (2020). "Who Pays for This". Collaborative Fund Blog, Apr 17, 2020. https://www.collaborativefund.com/blog/who-pays-for-this/.

Keynes, J.M. (1931). Essays in Persuasion. London: Papamoa Press.

Keynes, J.M. (1970). “The Economic Consequences of Mr Churchill”, abbreviated reprinted version, 27-43, in Pollard, S., The Gold Standard and Employment Policies between the Wars. London: Methuen.

Moore, J. (2016). “An RBS Scandal: Haven't We Already Seen This Movie?”. Independent online, 17 February 2016. https://www.independent.co.uk/ news/business/comment/an-rbs-scandal-haven-t-we-alreadyseen-this-movie-a6878531.html.

Neville, S.; Plimmer, G. (2020). "NHS Enlists All English Private Hospitals to Treat Coronavirus". FT.com website, 21 March. https://www.ft.com/content/ c9a9be78-6b7b-11ea-89df-41bea055720b.

Newton, S. (2004). "Keynesianism, Sterling Convertibility, and British Reconstruction 1940-1952”. Michie, R.; Williamson, P. (eds), The British Government and the City of London in the Twentieth Century. Cambridge: Cambridge University Press, 257-75.

Peden, G.C. (2000). The Treasury and British Public Policy 1906-1959. Oxford: Oxford University Press.

Roodhouse, M. (2013). Black Market Britain, 1939-1955. Oxford: Oxford University Press. 
Scott, P. (2007). Triumph of the South: A Regional Economic History of Britain During the Early Twentieth Century. Aldershot: Ashgate.

Scott, P. (forthcoming). "A Fiscal Constitutional Crisis: Tax Avoidance and Evasion in Inter-war Britain". English Historical Review.

Tooze, A. (2019). Crashed. How a Decade of Financial Crises Changed the World. London: Penguin.

Tooze, A. (2020). "Should We be Scared of the Coronavirus Debt Mountain?". Guardian online, 27 April. https://bit.ly/2DYFGwB.

Walker, P. (2017). "Philip Hammond Urges Caution Over Moves to Lift Publicsector Pay Cap". Guardian online, 16 July. https://bit.ly/3fGPDga.

Warner, J. (2020). "No Way Out, as Covid's Incoming Tide of Debt Sweeps All Before It". Sunday Telegraph, 7 June. https://bit.ly/2DTM6gq. 


\title{
The European Repo Market, ECB Intervention and the COVID-19 Crisis
}

\author{
Monica Billio \\ Università Ca' Foscari Venezia, Italia \\ Michela Costola \\ Università Ca' Foscari Venezia, Italia \\ Francesco Mazzari \\ Università Ca' Foscari Venezia, Italia \\ Loriana Pelizzon \\ Leibniz Institute for Financial Research SAFE, Frankfurt, Deutschland; \\ Università Ca' Foscari Venezia, Italia
}

\begin{abstract}
During the COVID-19 crisis, the combined effect of ECB communications, concerns on sovereigns' stability, illiquidity and market expectations led to a flight to quality. This produced a sell-off of peripheral sovereign bonds that drove the repo rates of core and peripheral countries out-of-sync. Two ECB announcements affected the repo market, namely (i) the Press Conference of the ECB Governing Council on March 12, 2020 and (ii) the announcement of a $€ 750$ billion Pandemic Emergency Purchase Program (PEPP). These two announcements had heterogeneous effects in the European repo market which we shall investigate.
\end{abstract}

Keywords COVID-19 crisis. ECB announcements. European repo market. Repo specialness. Flight-to-quality.

Summary 1 Introduction. - 2 The European Repo Market in the Last Decade. - 3 The European Repo Market During the COVID-19 Crisis. - 4 Conclusions.

Innovation in Business, Economics \& Finance 1

ISBN [ebook] 978-88-6969-442-4 


\section{Introduction}

The outbreak of the COVID-19 pandemic and the unprecedented lockdowns imposed by European member states in March 2020 marked the beginning of a crisis in the repurchase agreements (namely 'repo') market. As a result, repo rates of European core countries (i.e. Germany, France, the Netherlands and Belgium) and peripheral countries (i.e. Spain, Italy, Greece, Ireland and Portugal) went out-ofsync. ${ }^{1}$ The events during this period not only shed light on the role of illiquidity and ECB announcements in this market, but also on the tight nexus between the repo and the secondary bond cash market. The repo market plays an essential role in banks' liquidity and collateral management as well as in the transmission of monetary policy (Cœuré 2017). Therefore, changes in monetary policy may impact on the repo rate and the wider financial system.

This paper investigates how monetary policy announcements by the ECB and specifically its quantitative easing announcements affected European repo rates during the COVID-19 crisis. This is a time when many firms needed access to the repo market in order to manage intraday liquidity and collaterals. In particular, we highlight how flight-to-quality impacted the repo market during the pandemic and how the repo market is strongly influenced by ECB monetary announcements.

\section{The European Repo Market in the Last Decade}

The market for repos consists of secured, over-collateralised, shortterm, two-leg money market transactions in which the cash-taker simultaneously sells a security at the current spot price and enters into a forward agreement to buy the security back at a pre-specified price. The difference between the selling and purchasing price of the security is the repo rate. Repo contracts are either driven by the need for funding (i.e. General Collateral - GC transactions) or the need for a specific collateral (i.e. Special Collateral - SC transactions). In GC transactions, the exchanged collateral is unspecified and can be chosen amongst a basket of deliverable securities. However, in SC transactions, the collateral to be exchanged is specified. This is why special repos are entered into at a lower rate than general collateral repos because collat-

1 In the European Union, peripheral countries are characterised by high debt-to-GDPratios, lower employment levels and lower GDP per capita ratios (Kinsella 2012). Clustering between the core and the periphery was especially highlighted during the 2010-12 sovereign debt crisis. Peripheral countries were the Member States that have been hit the most by the crisis. In this paper, the peripheral countries that are analysed are Italy and Spain and the core countries are Germany, France, the Netherlands and Belgium. 
eral scarcity may be envisaged as a dividend for the cash-taker, i.e. a convenience yield for holding the collateral rather than the cash. The collateral traded on such transactions is said to be 'on special', so that its repo rate is lower than the corresponding GC repo rate. With the Deposit Facility Rate (DFR), the rate at which the Central Bank remunerates reserves, being lower than zero, we have also started to observe negative repo rates. This implies that the buyer (who is lending cash) effectively pays an interest to the seller, who is borrowing cash (ICMA 2013) or, put differently, the lender pays a fee to borrow the collateral.

In the European market, repo agreements are mostly entered into three dealer-to-dealer electronic trading platforms: Eurex Repo, BrokerTec and MTS (mostly for the Italian market), which link to several central clearing counterparties (CCPs), such as LCH.Clearnet LTD, LCH.Clearnet SA and Cassa di Compensazione e Garanzia (CC\&G) for the Italian market (Mancini, Ranaldo, Wrampelmeyer 2015). Eurex Repo $\mathrm{GmbH}$ is the leading platform for GC transactions and relies on Eurex Clearing AG (Deutsche Boerse Group) as CCP and on Clearstream for collateral management and settlement. This platform uses mainly two baskets to manage transactions: the GCP ECB basket and the ECB EXTended basket. BrokerTec is the largest platform for SC transactions and is operated by ICAP plc. MTS is part of MTS Group whose majority stake is owned by the London Stock Exchange (Mancini, Ranaldo, Wrampelmeyer 2015).

Repo contracts are said to be over-collateralised as a haircut is applied to each operation in order to account for credit and liquidity risk. The collateral value is given by the difference between the market value of the traded collateral and the market value of the portion of collateral used as haircut. The securities for which the lowest haircut is applied are central government bonds. However, sovereign risk in the euro area varies widely between core and peripheral countries. For this reason, the rate at which an investor is willing to lend cash in exchange for a collateral differs according to the sovereign risk of the collateral.

This aspect is well represented in figure 1 which shows the RepoFunds Rate (RFR) indexes for Belgium, France, Germany, Italy, the Netherlands and Spain as well as the average repo rate for the Eurozone [fig. 1]. RFRs are based on the average of both general and special collateral transactions settled on the three aforementioned platforms where the collaterals accepted are all government bonds.

As it is shows, in January 2010, there was almost no difference in the RFR indexes for all the countries considered, i.e. the market was not charging different rates for transactions based on the German Bund or the Italian BTP. However, starting with the Greek sovereign crisis, repo rates began to diverge. The figure reports that the RFR indexes for Germany and the Netherlands are the lowest from that date onwards, indicating that German and Netherlands government bonds represent the safest collateral traded in the market. By 
Monica Billio, Michela Costola, Francesco Mazzari, Loriana Pelizzon The European Repo Market, ECB Intervention and the COVID-19 Crisis

contrast, the RFR index for Italy is riskiest collateral among the analysed countries in most of the sample period (with Spain occasionally taking the lead).

More generally, figure 1 gives a historical representation of the effects of the ECB's Balance Sheet Policies (BSPs) announcements on the repo market since the sovereign debt crisis (outliers are trimmed). ${ }^{2}$

Figure 1 RFRs from 2010 and some major announcements

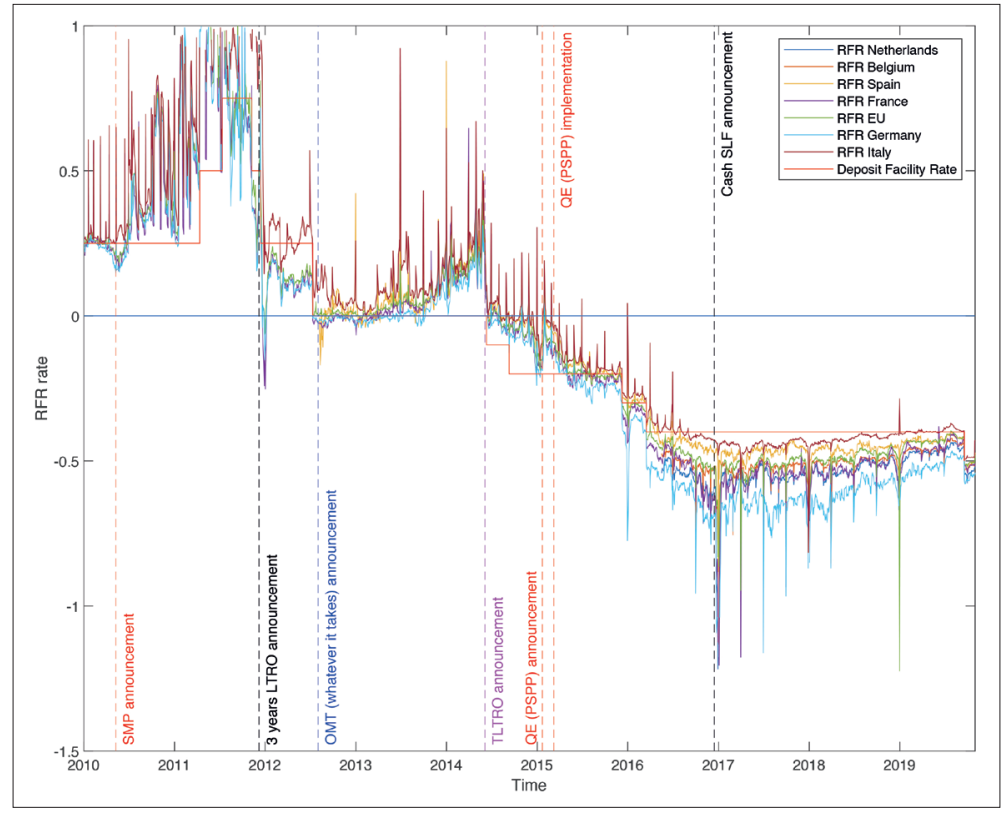

This figure shows the average daily repo rates for six European countries (Belgium, France, Germany, the Netherlands, Italy and Spain) as well as the average repo rates for the Euro, the deposit Facility Rate offered by the ECB and five event lines. The five event lines represent: (1) SMP announcement on May 10, 2010; (2) Announcement of the 3 years Longer Term Refinancing Operations on December 8, 2011; (3) Outright Monetary Transactions (i.e. OMT) announcement on August 2, 2012; (4) Targeted Longer Term Refinancing Operations (TLTRO) on June 5, 2014; (5) Cash Security Lending Facility announcement on December 8, 2016. Repo Funds Rate data has been downloaded from http://www.repofundsrate.com/ for the Netherlands, Belgium, Spain, France, the European Union, Germany and Italy. The RFR Netherlands and RFR Belgium time series start from May 16, 2016. Data on RFR Spain starts from August 6, 2012. The Deposit Facility Rate time series has been downloaded from the ECB's Statistical Data Warehouse.

2 For a detailed description of the evolution of the repo market during the sovereign crisis of 2010-12 see Corradin, Maddaloni 2019. 
The pattern of the repo market is quite striking in the period after the QE announcement, i.e. after 2015. The implementation of a buyand-hold Public Sector Purchase Program (PSPP) led (mostly) National Central Banks to buy central government bonds in the secondary cash market, in turn reducing the availability of collateral for repo transactions. The $\mathrm{QE}$ produced the strongest effects on repo rates of the safest countries due to their superior funding conditions, increasing scarcity until even GC rates were pushed below zero. Furthermore, two regulatory factors contributed to increase the scarcity of High Quality Liquid Assets (HQLA) at reporting dates. Firstly, the implementation of the Basel III non-risk-weighted capital requirements, such as the leverage ratio, strengthened window dressing in banks' balance sheets, increasing the scarcity of the safest collateral in these dates. Secondly, accounting practices and the implementation of the European market infrastructure regulation (EMIR) created an opposite shock for the demand and supply of repo transactions in the periods in which these contracts were needed the most (Ranaldo, Schaffner, Vasios 2019). For these reasons, core countries' RFRs are affected by quarterly negative spikes, as the scarcity of HQLA is the highest in these periods. Interestingly, the effect on peripheral countries is the opposite. As one can see from figure 2, RFR Italy reached record-high levels on the same dates, due to the intrinsic risk of the collateral [fig. 2]. The average European effect has been negative overall.

This effect has been exacerbated through time, as highlighted in figure 2 . The figure shows that the joint effect of the scarcity channel activated by the implementation of unconventional monetary policies and the enforcement of non-risk-weighted capital requirements in the Basel III framework inverted the usual relationship between repo rates and the DFR. This might be surprising given that at the DFR the ECB remunerates the excess reserves of banks, preventing transactions in the money market to be concluded at a lower interest rate. However, as Arata et al. (2020) demonstrate, Basle III prevents banks that have access to the ECB to arbitrage away transactions concluded in the repo market at a lower interest rate than the DFR. Even if core countries' repo rates adjusted to the 50 basis point cut of the DFR on September 18, 2019, scarcity and market segmentation affected their levels by pushing them below it.

\section{The European Repo Market During the COVID-19 Crisis}

How does the European repo market react to the COVID-19 crisis? In this section we highlight the role of policy announcements, concerns on sovereigns' stability, scarcity and market expectations on the economic outcomes of the health crisis in the repo market tur- 
Figure 2 RFRs in 2019 and 2020

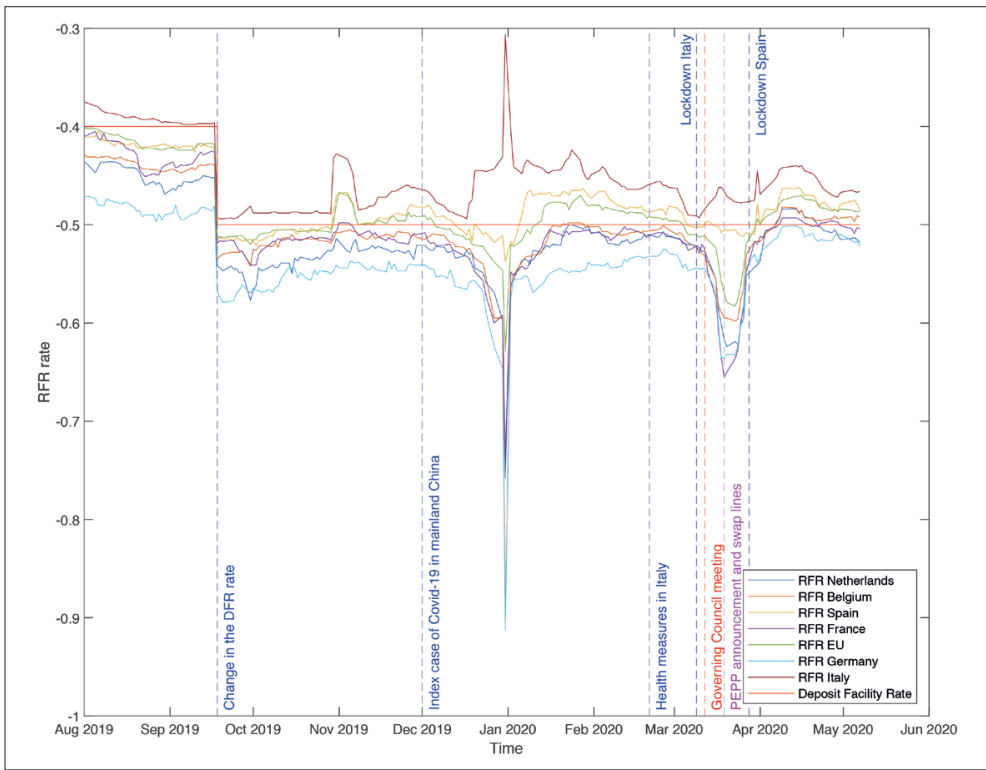

This figure reports the RepoFunds Rates (RFRs) between August 2019 and May 2020 The blue dashed event line represents the change in the Deposit Facility Rate (DFR) occurred on September 19, 2019. RFR data has been downloaded from http://www. repofundsrate.com/ for the Netherlands, Belgium, Spain, France, the European Union, Germany and Italy. The DFR time series has been downloaded from the ECB's Statistical Data Warehouse.

moil of March 2020. The unfolding and resolution of the tensions developed mostly in a few weeks.

Three events characterised the evolution of the crisis: (i) the lockdown in Italy at the end of February and first half of March, 2020; (ii) the Press Conference of the ECB Governing Council on March, 12 2020, and; (iii) the announcement of a $€ 750$ billion Pandemic Emergency Purchase Program (PEPP) on March 18, 2020. Figures 2 and 3 depict the three events and the heterogeneous consequences of the announcements in the repo market. In figure 3, the sample of countries analysed is restricted to two core countries, namely France and Germany, and two peripheral countries, namely Italy and Spain, to better focus on the dynamic between the core and the periphery [fig. 3]. 
Figure 3 RFRs during the COVID-19 crisis

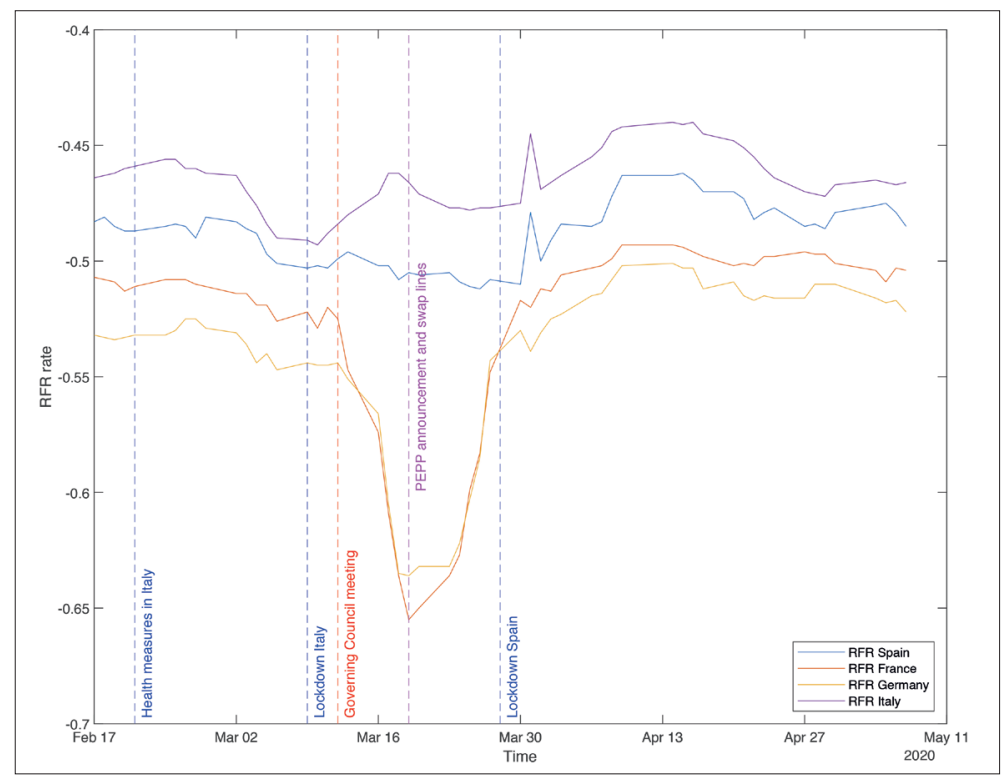

This figure shows the RFRs during the COVID-19 crisis for two core countries (Germany and France) and two peripheral countries (Spain and Italy). The figure also reports six event lines that represent: (1) Enforcement of health measures in Italy on February 21, 2020; (2) Beginning of the lockdown in Italy on March 9, 2020; (3) Meeting of the ECB Governing Council on March 12, 2020; (4) Activation of swap lines between the Bank of Canada, the Bank of England, the Bank of Japan, the European Central Bank, the Federal Reserve, and the Swiss National Bank on March 18, 2020; (5) Announcement of the Pandemic Emergency Purchase Program on March 18, 2020; (6) Beginning of the Lockdown in Spain on March 28, 2020. RepoFunds Rate data has been downloaded from http://www.repofundsrate.com/ for Spain, France, Germany and Italy.

Figure 2 shows that the six countries considered in our analysis entered the COVID-19 crisis with different repo rates. The RFRs of Italy and Spain and the average Repo-Funds Rate of the Eurozone were above the DFR, whereas the average RFRs of core countries were below the DFR. The difference between the Italian RFR and the German RFR indexes was equal to about 7 basis points, which was impacted a lot by the COVID-19 crisis. By March 17, this difference more than doubled and reached 17 basis points as the Italian RFR increased and the German and French RFRs significantly decreased.

The figures review the differential effects of the policy announcement on the repo market. Italy and Spain are the two countries most severely hit by the coronavirus, societally as well as economically. Figure 3 already shows a large increase of the Italian repo rates af- 
ter the national lockdown was imposed, but the Italian RFR, on the one hand, and the German and French RFRs, on the other, started to significantly diverge after the first policy announcement. Figure 3 details that repo rates signalled early warnings of distress in the first half of March. Indeed, as the consequences of the pandemic materialised in Italy, concerns regarding the future economic and political measures that the country would have to implement started mounting. As a result, a sell-off of securities started in this period (ICMA 2020), making RFRs to trend downwards. However, this effect was not limited to core countries. Although March 2020 was characterised by a general appreciation of repo rates, the actual distress started after the first policy announcement on March 12, 2020. This event marked the beginning of a downwards adjustment of core countries' repo rates, making them persistently move out-of-sync with respect to the peripheral ones.

On March 12, the meeting of the ECB Governing Council deliberated measures aimed at addressing the increasing distress in financial markets as the health crisis was spreading in Western Europe. In particular, the Council adopted a dovish monetary policy stance focused on liquidity injections via additional (Targeted) Longer-TermRefinancing-Operations. Additionally, it eased collateral eligibility criteria for securities pledged in Open Market Operations (OMOs). Moreover, to support the private sector, the Council decided to expand the existing Private Sector Purchase Programs, up until the effects of the crisis would diminish. Such measures were different from the ones taken by other Central Banks. For instance, the Federal Reserve cut interest rates by 150 basis points between March 3, 2020 and March 15, 2020. On March 15, 2020, in contrast to the first attempts of a quantitative tightening in 2019, the Fed opted for the implementation of a new QE to support the smooth functioning of the market and the effective transmission of monetary policy. Nonetheless, the dovish stance of the ECB Governing Council, a looming economic downturn and the ECB President's statement that closing spreads between member states' funding costs is not an ECB objective, failed to alleviate market tensions. Rather, the announcement re-awaked concerns on the financial stability of sovereigns, raising questions on the ability of peripheral countries struggling to tackle the coronavirus (like Italy) to cope with increased debt issuance. Consequently, the statement by the ECB President resulted in a flight to quality assets, which gave rise to a sell-off of the riskiest securities. In addition, spreads widened in the cash market and core repo rates collapsed to unprecedented levels in times when reporting obligations were not binding. In fact, the effects produced were moderate with respect to 2019-year end effects (ICMA 2020), but persistent and clustered between core and peripheral countries. Indeed, RFRs based on the safest collateral, plummeted to record lows, as 
those treasuries were valued more with respect to the ones of other Eurozone states.

Another aspect highlighted by figure 3 is that the French RFR reached a negative peak at -65.5 basis points, which is even lower than the one of Germany which stood at -63.6 basis points. This is surprising as Germany is almost invariably the preferred safe haven in the sample period as shown in figures 1 and 2. However, the effect might be due to the fact that, in the European Union, the bulk of dollar-denominated transactions is carried out by French banks. By pledging collateral against liquidity, the amount of French sovereign bonds outstanding decreased, hence increasing their scarcity and decreasing their repo rate. In general, in the whole sample represented in figure 2, one can see that rates collapsed, and scarcity increased for several countries. But the impact on RFR Italy and RFR Spain was heterogeneous. Indeed, while the Spanish repo rate mildly cheapened during the week after the announcement, RFR Italy significantly appreciated in the same period. The level of uncertainty for Italian sovereigns was such that the Repo Funds Rate moved outof-sync with respect to the sample of countries analysed. For these reasons, there is evidence that the joint effect of sovereign conditions and the severity of the virus played a major role in driving repo rates, as the effects on Italy and Spain were significantly different. The worsening of the health conditions in the latter country did not generate effects akin to the ones produced in the former. However, the response of Spanish RFR may be affected by the second policy announcement described below. As it became clear that the spread of COVID-19 was not only regional and that the number of cases was increasing in all Western Europe, the tensions on the first policy announcement compounded up until the second policy event on March 18, 2020, when the ECB Governing Council decided to implement a $€ 750$ Billion Pandemic Emergency Purchase Program (PEPP). Indeed, the announcement marked the nadir of the crisis as it restored market confidence into the stability of distressed sovereigns and alleviated pressures in the secondary bond cash market. For these reasons, the sell-off of risky assets ended and the negative trend and the volatility of repo rates in the previous days bounced back, up to normal levels. In addition, after the announcement, French rates increased to usual levels. However, it seems that the effect is mainly due to the activation of swap lines: arrangements to provide foreign currency liquidity to domestic commercial banks via agreements between Central Banks. As in Open Market Operations, Central Banks require the financial institutions to pledge HQLA as collateral in exchange for the currency. These measures are designed to tackle market stress and to alleviate illiquidity in dollar funding markets. In this period, the Bank of Canada, the Bank of England, the Bank of Japan, the European Central Bank, the Federal Reserve, and the Swiss National 
Bank agreed upon the implementation of standing US dollar liquidity swap lines [fig. 3]. The last spike, which occurred in March 2020, marked the beginning of the last week prior to the first quarter-end, which is affected by reporting dates as previously explained. Then, the unfolding of the crisis drastically revealed the effect of the ECB communication policy on the sovereign bond cash market and, in turn, on the repo market.

\section{Conclusions}

The crisis that resulted from the outbreak of the coronavirus in Western Europe did not only shed light on scarcity issues in the repo market but also on the tight nexus between funding and secondary bond cash markets. It especially highlighted the impact ECB announcements may have. Even though scarcity and market expectations on the economic outcomes of the health crisis may have significantly affected repo rates, there is evidence that the tensions originated from policy announcements may have fuelled the turmoil of March 2020. Instead of alleviating market tensions, the economic outlook and the statement of the ECB President during the Q\&A emphasising that the "ECB is not there to close spreads" reawakened concerns regarding the ability of peripheral countries struggling to tackle the virus to cope with increased debt issuance. The resulting flight to quality mostly affected core countries. There is also evidence that illiquidity in the dollar funding market may have further risen scarcity for the countries more involved in foreign currency transactions, such as France. Instead, the peripheral countries hit by the pandemic, e.g. Italy, were most negatively affected. As a result, their repo rates moved persistently out-of-sync with respect to the core countries. On the contrary, the announcement of expansionary monetary policies, the PEPP, significantly contributed to calm markets down, to restore confidence and its normal activity, and the swap lines restored the German bund as the most demanded collateral.

The repo market has a pivotal role in preserving the liquidity of the money market. The COVID-19 crisis created significant liquidity needs largely for non-financial firms. While demand for repos increased substantially during the height of the crisis in February/March due to flight to quality, dealers' capacity to intermediate that demand was relatively constrained. This limited the ability of many firms to access the repo market which was badly needed to manage intraday liquidity and collaterals. Our analysis highlights the dependence of the repo market on central bank interventions in times of stress. 


\section{Bibliography}

Arrata, W.; Nguyen, B.; Rahmouni-Rousseau, I.; Vari., M., (2020). "The Scarcity Effect of Qe on Repo Rates: Evidence from the Euro Area". Journal of Financial Economics. https://doi.org/10.1016/j.jfineco.2020.04.009.

Briciu, L.; Lisi, G. (2015). An Event-Study Analysis of ECB Balance Sheet Policies Since October 2008. European Commission publications, Economic Brief 001, July 2015. http://dx. doi.org/10.2765/844347.

Cœuré, B. (2017). "Asset Purchases, Financial Regulation and Repo Market Activity". Speech by Benoît Cœuré, Member of the Executive Board of the ECB, at the ERCC General Meeting, Brussels, 14 November, 2017.

Corradin, S.; Maddaloni, A. (2019). "The Importance of Being Special: Repo Markets During the Crisis". Journal of Financial Economics, 137(2), 392-429. https://doi.org/10.1016/j.jfineco.2020.02.006.

ICMA (2013). Frequently Asked Questions on Repo. International Capital Market Association.

ICMA European Repo and Collateral Council (ERCC) (2020). The European Repo Market and the COVID-19 Crisis. International Capital Market Association.

Kinsella, S. (2012). "Conventions and the European Periphery". Journal of Balkan and Near Eastern Studies. https://dx.doi.org/10.2139/ssrn.2155577.

Mancini, L.; Ranaldo, A.; Wrampelmeyer, J. (2015). "The Euro Interbank Repo Market". The Review of Financial Studies, 29(7), 1747-79. https://doi. org/10.1093/rfs/hhv056.

Ranaldo, A.; Schaffner, P.; Vasios, M. (2019). "Regulatory Effects on Short-Term Interest Rates". Bank of England Working Paper No. 801. https://dx.doi. org/10.2139/ssrn.3397082. 



\title{
COVID-19 and Fiscal Policy in the Euro Area
}

Filippo Busetto

ICMA Centre, Henley Business School, University of Reading, UK; European Central Bank

Alfonso Dufour

ICMA Centre, Henley Business School, University of Reading, UK

Simone Varotto

ICMA Centre, Henley Business School, University of Reading, UK

\begin{abstract}
In this chapter we document fiscal policy developments in the main euro area economies over the last two decades and highlight the dramatic changes triggered by the COVID-19 pandemic. We analyse how euro area yield curves respond to COVID-19 related expectations of fiscal expansion. We show how fiscal constraints may affect interest rates. Upward pressure on national yields from higher debt levels could compromise fiscal and financial stability in the long-term.
\end{abstract}

Keywords Fiscal Policy. Debt. COVID-19. Interest Rates. Sovereign Yields.

Summary 1 Introduction. - 2 Fiscal Policy in the Euro Area. - 3 Interest Rate Dynamics Before and During the COVID-19 Crisis. - 4 Conclusion.

\section{Introduction}

The coronavirus pandemic has completely reshaped the current macroeconomic conditions and the economic outlook. According to the European Commission, euro area GDP is expected to shrink, on average, by $7.7 \%$ in 2020 . This contraction is far deeper than what was experienced during the Great Financial Crisis of 2008-09. Furthermore, the average contraction rate masks 
marked cross-country heterogeneity, with countries hardest hit by the recession, such as Italy, Spain and France, facing a projected decrease in output of $9.2 \%, 9.4 \%$ and $8.4 \%$, respectively. ${ }^{1}$ Euro area countries have tackled the crisis with an unprecedented fiscal response. This will increase government budget deficits by several percentage points and will heavily affect the Debt-to-GDP ratios over the medium term. ${ }^{2}$

In this chapter, we show that this fiscal expansion comes at a time when governments face substantially different financial constraints across the euro area. Germany, which was the most fiscally conservative country leading up to the crisis, has plenty of financial resources to respond to the economic downturn. Instead, other countries, such as Italy and Spain, did not manage to reduce their outstanding debt in the last decade, which limits their ability to respond to the crisis. ${ }^{3}$ We also analyse several euro area yield curves during the pandemic and explain how they may be linked, at least in part, to expectations of increased budget deficits.

The effects of fiscal policy on the macroeconomy and on interest rates have been widely studied in the past. ${ }^{4}$ One of the main economic channels linking government bond supply and interest rates is duration risk, as described in Vayanos and Vila (2009). A number of

This paper should not be reported as representing the views of the European Central Bank. The views expressed are those of the Authors and do not necessarily reflect those of the ECB.

1 Data from European Commission's spring 2020 forecast can be found at https:// ec.europa.eu/info/business-economy-euro/economic-performance-and-forecasts/economic-forecasts/spring-2020-economic-forecast-deep-and-unevenrecession-uncertain-recovery_it.

2 Examples of newspaper on expected fiscal expansions are: "Germany Tears Up Fiscal Rule Book to Counter Coronavirus Pandemic". Financial Times, 21 March 2020; "Italy Boosts Aid Package as Europe Battles Coronavirus Outbreak". Financial Times, 10 March 2020; "France to Extend Crisis Jobs Scheme for Up to Two Years". Financial Times, 8 June 2020.

3 This was also reported in the international press. For example: "Spain's Tight Budget Puts Squeeze on Coronavirus Response". Financial Times, 24 June 2020.

4 For example, Corsetti et al. (2013) find that strained public finances might affect macroeconomic stability by a sovereign-risk channel, which raises funding costs in the private sector. Bonam and Lukkezen (2019) show that, when government debt is risky, increased deficits raise interest rates and crowd out consumption. Blanchard (2019) argues that in the US, as long as interest rates are below growth rates, debt rollovers may have no fiscal cost. Hatchondo, Roch and Martinez (2012) study how economies pay a significant default premium in absence of fiscal rules. Laubach (2009) estimates how debt and deficits affect long-term forward rates in the US. Ghosh et al. (2013) estimate for several countries a debt limit, which serves as an upper threshold for government debt that would cause a sovereign default if surpassed. Other relevant work on fiscal policy and interest rates is for example: Reinhart, Sack, Heaton 2000; Cimadomo, Claeys, Poplawski-Ribeiro 2016; Arellano et al. 2013; Bi 2012; Jaramillo, Weber 2013; Kumar, Baldacci 2010; Falagiarda, Gregori 2015. 
empirical papers has found a positive relationship between different measures of bond supply and sovereign yields. ${ }^{5}$ Other related empirical work has estimated the impact of asset-purchase programmes (Quantitative Easing) in US and in Europe, which lowered interest rates by effectively decreasing bond supply in the market through bond purchases. ${ }^{6}$

The chapter is structured as follows: section 2 discusses fiscal policy developments in the euro area. Section 3 illustrates yield curve movements before and during the pandemic period and describes the relationship between sovereign yields and fiscal policy. Section 4 concludes.

\section{Fiscal Policy in the Euro Area}

The fiscal position of the main euro area (EA) countries has been quite heterogenous in the last fifteen years. In figure 1, we show how budget deficits and Debt-to-GDP have evolved for Italy, Spain, France and Germany [fig. 1]. All countries responded to the Great Financial Crisis with a fiscal expansion, which deteriorated budget deficits and increased Debt-to-GDP ratios between 2008 and 2011. The situation stabilised in the last few years, with Italy, Spain and France running very similar budget deficits - below 3\% - from 2016 onwards. The most fiscally conservative country was Germany, which ran a budget surplus from 2013 to 2019. This surplus contributed to a significant reduction of German Debt-to GDP which shrank by 20 percentage points in the last decade. France and Spain currently display very similar levels of outstanding debt, while Italy is by far the country showing the worst Debt-to-GDP ratio which reached about 140\% in Q4 2019.

With such a high Debt-to-GDP ratio, Italy may soon show signs of "fiscal fatigue" (Ghosh et al. 2013). Specifically, government debt can be ultimately repaid in two ways: either with a nominal GDP growth rate higher than nominal sovereign yields (i.e. a positive GDP growthinterest rate differential) or by running primary surpluses that will compensate the interest payments on debt. However, high levels of debt would need a substantial primary surplus in order to cope with mounting interest payments and reduce the outstanding amount of

5 See, for example, Greenwood, Vayanos 2014; Billio et al. 2020; Krishnamurthy, Vissing-Jorgensen 2012; Greenwood, Hanson, Vayanos 2015.

6 Some of the papers tackling this effect are for example: D'Amico, King 2013; Gagnon et al. 2011; Krishnamurthy, Vissing-Jorgensen 2011; Altavilla, Carboni, Motto 2015; Blattner, Joyce 2016; De Santis, Holm-Hadulla 2017; Li, Wei 2013; Joslin, Priebsch, Singleton 2014; Eser et al. 2019; Lemke, Werner 2020. 
Filippo Busetto, Alfonso Dufour, Simone Varotto COVID-19 and Fiscal Policy in the Euro Area

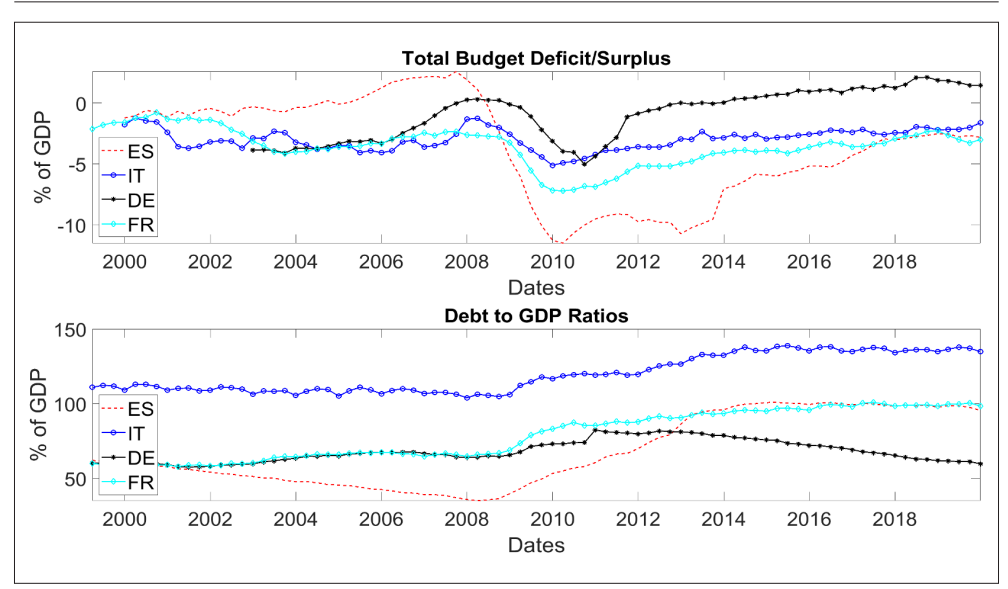

Figure 1 Time series of budget deficit and Debt-to-GDP ratios for the four main EA economies. The upper panel shows the time-series of budget deficit/surplus for Spain (ES), Italy (IT), France (FR) and Germany (DE) from January 2006 to December 2019. The bottom panel shows Debt-to-GDP ratios. Source: ECB

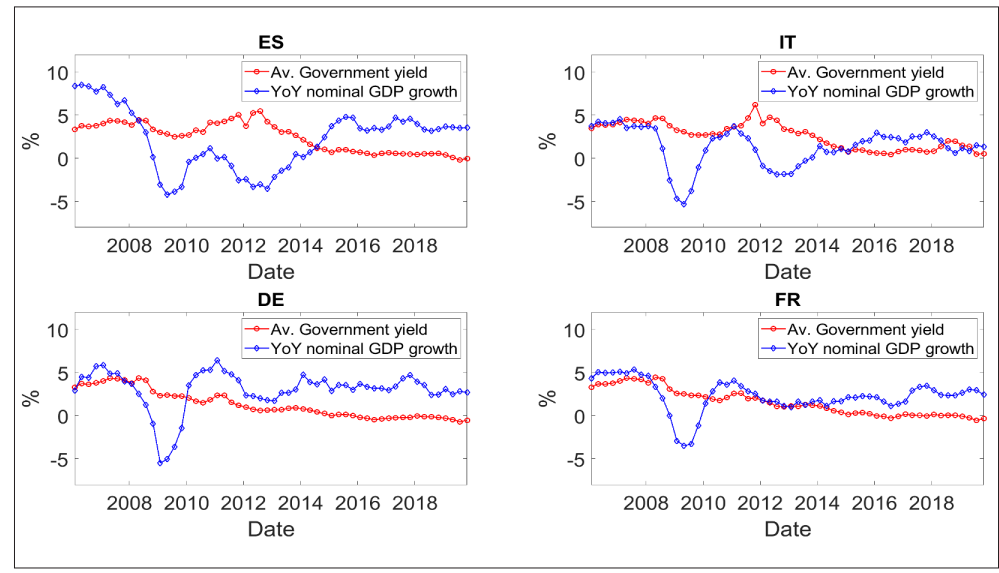

Figure 2 Interest rates and nominal GDP growth rates for Spain, Italy, Germany and France. The figure shows average nominal interest rates and year-on-year nominal GDP growth rates for the largest euro area economies, Spain (ES), Italy (IT), Germany (DE), France (FR). The average interest rates are calculated as the mean of 1,5 , and 10 year zero-coupon bonds. Source: ECB 


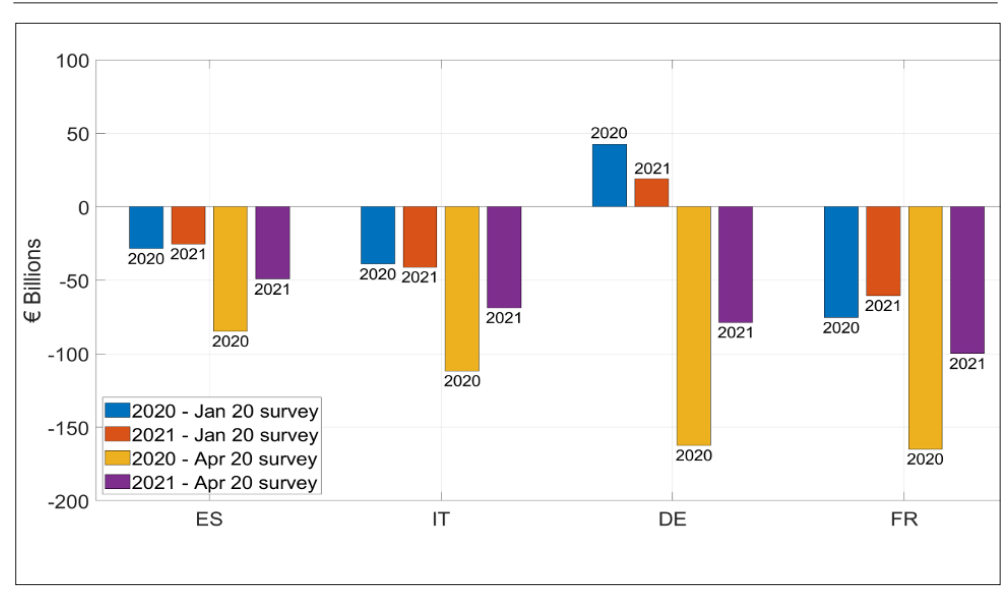

Figure 3 Budget deficit forecasts for 2020 and 2021 surveyed before and during the COVID-19 Pandemic. This figure shows budget deficit survey forecasts for 2020 and 2021 obtained in January 2020 and in April 2020.

Source: Consensus Economics

debt. ${ }^{7}$ Fiscal fatigue materialises whenever a government's ability of increasing the primary balance cannot keep up with the rising debt. The current low level of interest rates may attenuate this problem if it persists in the future and is not reversed by a surge in sovereign risk.

In figure 2 we show the relationship between interest rates and GDP growth for the four countries [fig. 2]. Countries that show a positive GDP-interest rate differential over time would stabilise debt even by not running budget surpluses, as the nominal growth rate of the economy would be higher than the nominal borrowing rates to finance that growth. In the figure, all countries had a negative differential during the financial crisis, while it became positive in the subsequent period. However, Italy and Spain had the worst differential across the entire sample. The Italian differential was positive only for a few years around 2016 and, compounded with the high level of debt, suggests a problematic fiscal position for the country.

Entering into 2020, Germany had clearly the highest fiscal flexibility and financial resources to face a macroeconomic downturn, in contrast with all the other countries that would have struggled to find resources in case of a deep recession. Then, in response to the COVID-19 pandemic, euro area countries planned a substantial fiscal expansion in 2020 and 2021 to counter the economic damage stemming from nationwide shutdowns. Market expectations of budg-

7 The Government could increase the surplus by raising taxes or by cutting non-interest expenditures. 
et deficits have deteriorated consistently since the start of the crisis. In figure 3 we show how survey forecasts for government budgets changed from January to April 2020 [fig. 3]. Germany is the country in which the forecast for current and next year budget deficit changed the most in absolute terms. Indeed, the country's budget forecast changed from an expected surplus to a sizable deficit both in 2020 and in 2021. Moreover, all countries' forecasts worsened, as all euro area economies planned a substantial increase in government spending to boost their economies. These forecasts signal that investors expect sizable budget deficits going forward, which will substantially increase future Debt-to-GDP ratios.

In figure 4 we also show the time-series of the cross-sectional volatility of budget deficit survey forecasts [fig.4]. This variable could be interpreted as a measure of uncertainty regarding the overall size of current and future fiscal policy interventions. The spike in the last data point (April 2020) is unprecedented and is bigger in magnitude than spikes recorded during both the Great Financial Crisis and sovereign debt crisis. Thus, this figure really shows how uncertain market participants were about the magnitude of the fiscal policy response by euro area countries to the pandemic. Indeed, neither the size of such programmes nor to what extent this fiscal expansion would have been covered by European schemes, such as the European Stability Mechanism or the Recovery Fund, were clear. This expected fiscal stimulus will then have to be financed by higher issuance of sovereign debt, which could put upward pressure on sovereign yields, as investors might request a higher premium to absorb this higher supply of bonds. Quite likely, the impact on sovereign yields will vary across countries, with larger yield increases in countries with higher outstanding debt and sovereign credit risk.

\section{Interest Rate Dynamics Before and During the COVID-19 Crisis}

Sovereign bond market yields reflect current and expected macroeconomic conditions. Euro area interest rates have shown signs of stress during the pandemic period. Between February and May 2020, as shown in figure 5, the euro area GDP-weighted yield curve has detached itself from the Bund and Overnight Index Swap (OIS) curves, which are often used as euro area reference curves [fig. 5]. The OIS is a benchmark risk-free rate and the Bund is the German government bond curve. The bottom-left side of the figure shows average yield curves in the months preceding the COVID-19 pandemic, when the three curves were in a tighter range. The crisis caused a relatively small shift in the level of the euro area curve across all maturities. In order to put things into perspective, we compare the current 


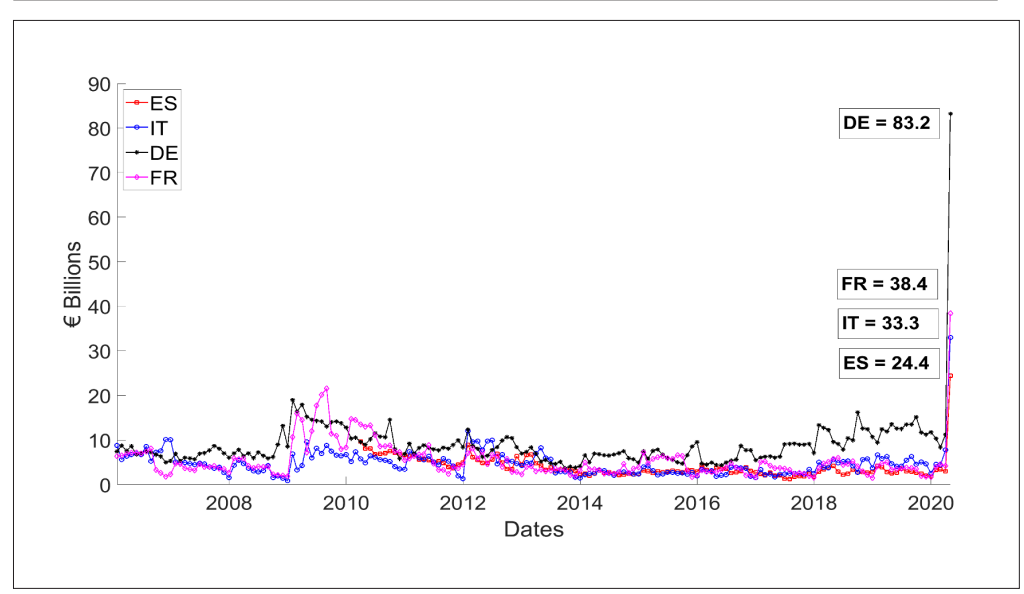

Figure 4 Standard deviation of budget deficit forecasts. This figure shows cross-sectional dispersions of budget deficit survey forecasts for annual budget surplus/d eficit from 2007 to 2020 . The forecasts are for the same year overall budget balance. Source: Consensus Economics

bond market dynamics with the market dynamics before and during the Sovereign Debt Crisis, as shown in the graphs at the top of figure 5. The three curves were priced almost equally in the period preceding the Sovereign Crisis. However, during the worst part of the downturn, when investors were unsure about the solvency of some peripheral countries, a shift in the level of the euro area curve suggests a complete repricing across all maturities of the yield curve.

Even though the size of yield movements has been smaller during the COVID-19 pandemic than during the Sovereign Crisis, the transmission mechanism of these higher perceived risks has had a similar impact on the level and shape of the euro area curve. In figure 6, we show the time-series of these three curves at the 10-year maturity [fig. 6]. During the past 15 years, the 10-year euro area yield has been very close to the Bund and OIS 10-year rates during tranquil times (before the financial crisis and after the end of the Sovereign Crisis), while it detached in times of market stress. The bottom panel of the figure shows interest rate movements for the same 10-year yields in the period surrounding the Pandemic. The spread between the euro area yield and the Bund/OIS rate increased abruptly between the end of February and mid-March, when it was unclear what kind of monetary policy support the European Central Bank would provide. Then, on March 18, 2020 the ECB announced the Pandemic Emergency Purchase Program (PEPP). The PEPP was announced as an asset purchase program worth $€ 750$ billion, to be initially undertaken by the ECB until the end of 2020. After the announcement, yield spreads retraced back from their previous maximum. 


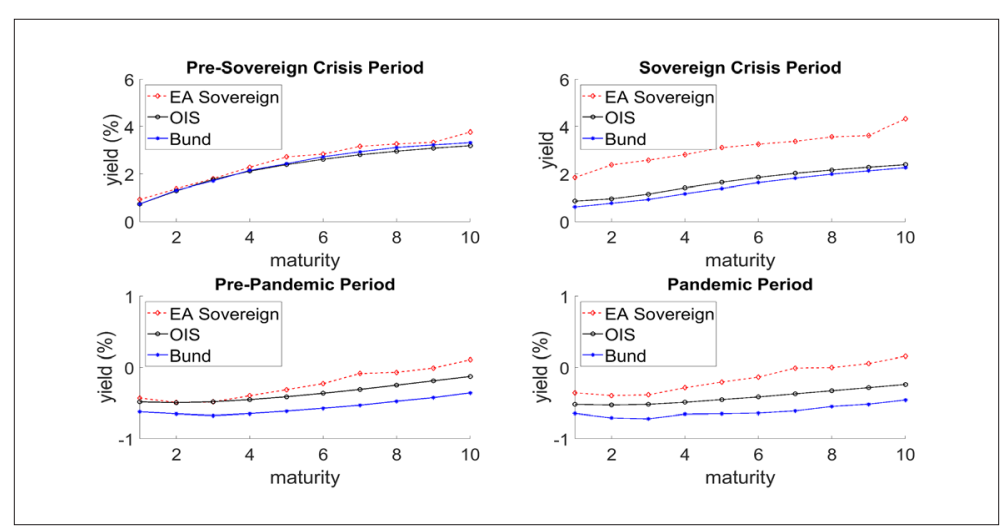

Figure 5 Average OIS, Bund and EA yields before and during the Sovereign Crisis and the COVID-19 Pandemic. This figure shows average OIS, Bund and Euro Area yield curves before and during the COVID-19 Pandemic and the Sovereign Crisis. The Pre-crisis periods are June 2010-December 2010 for the Sovereign Crisis and September 2019-January 2020 for COVID-19. The crisis periods are June 2011-December 2011 for the Sovereign Crisis and February 2020-April 2020 for the COVID-19 Pandemic. The Euro Area yield curve is calculated by a GDP-weighted average of national sovereign yields. Source: Refinitiv, ECB

However, the spread between the euro area 10-year yield and the Bund/OIS yields remained wider than before the crisis. Estimating the upward pressure of a fiscal expansion on interest rates during the COVID-19 crisis is not an easy task. Euro area interest rates have probably been driven by several different factors during this period. Further, the PEPP announcement and implementation contributed to a significant reduction of euro area yields. We tackle this issue by employing a simple linear model, and by comparing the estimated yield impact of a fiscal expansion with yield spreads movements during the period preceding the PEPP announcement. Specifically, we focus on the period between the start of February and March 18th. This is when macroeconomic and fiscal policies had their full impact on yields, which was softened afterwards by the ECB's monetary policy intervention. We calculate the potential impact of a fiscal expansion as follows. First, we run a linear regression model to study the relationship between 10-year country-level yield spreads over the OIS rate and expected budget deficits relative to GDP. The sample period ends in December 2019, so as to exclude any data points from the current crisis. Second, we use the estimated coefficients from the model and multiply them by the expected fiscal expansion due to the COVID-19 crisis. This is calculated as the difference between the budget deficit forecasts taken in April 2020 and the same forecasts obtained in January 2020. Figure 7 reports the results of this exercise in basis points [fig. 7]. The estimated impact greatly varies across countries. We estimate that Italy and Spain would have had 


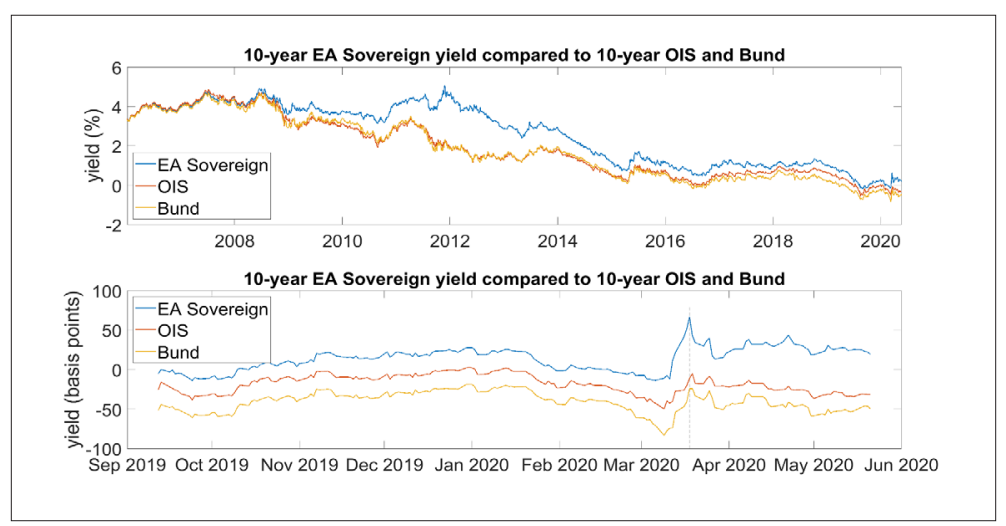

Figure 6 Time series of the OIS, Bund and euro area average 10 year yields. The upper panel of this figure shows time-series of OIS, Bund and euro area yields from January 2006 to May 2020. The bottom panel shows the same time-series from November 2019 to May 2020. The vertical dashed line in the bottom panel indicates the date the ECB announced the Pandemic Emergency Purchase Program (PEPP). The euro area 10-year yield is calculated by a GDP-weighted average of national sovereign yields. Source: Refinitiv, ECB

the most sizable yield increases, with 160 and 90 basis points, respectively. Germany and France show a much smaller impact instead, with magnitudes of around 40 basis points for both. The main takeaway from the exercise is that the estimated yield change would be non-negligible especially for peripheral countries.

How does this empirical evidence square with actual yields observed in the market? As mentioned before, we want to focus on the period preceding the PEPP announcement to reduce the confounding effect of the ECB's monetary policy on yields. We can use this preannouncement period as a benchmark for yield changes that would happen, at least partially, without a clear monetary policy support. Figure 8 shows 10 -year country-level yield spreads over the OIS from February to May 2020 [fig. 8]. Countries with the highest estimated impact from our model also had the greatest yield movements in this period. Examining the period from the beginning of February to the 18th of March, yield spreads increased by about 125 basis points for Italy, 75 basis points for Spain, 30 basis points for France and remained unchanged for Germany. Except for Germany, the magnitudes are not so far off from our estimated impacts.

Indeed, German Bunds were largely unaffected by the crisis, with yields remaining stable during this period. So, the expected large fiscal expansion in Germany did not have any effect on German yields, which is at odds with what observed in other countries. However, in our model we do not control other factors that might have driven yields during the pandemic, such as flight-to-safety effects. Spe- 


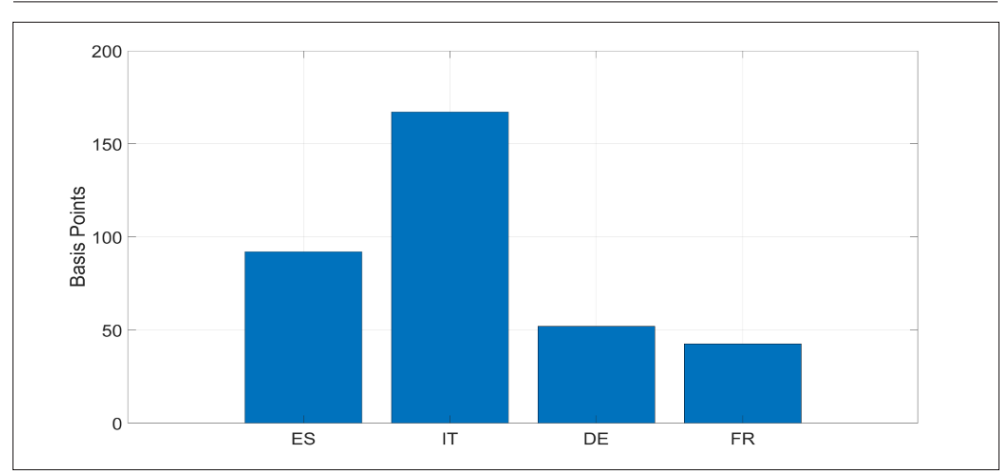

Figure 7 Estimated impact of budget deficit shocks during the pandemic on yield spreads. This figure shows the estimated impact in basis points on euro area yield spreads of a shock on expected country-leve budget deficits. The magnitudes are obtained as follows: 10-year country-level yield spreads over OIS are linearly projected onto expected budget deficit forecasts. Regression residuals are assumed to follow an $\mathrm{AR}(1)$ process. Further, the coefficients obtained by the regression are multiplied by a fiscal shock, which is calculated by looking at the difference between budget deficit forecasts obtained in December 2019 (prepandemic) and in April 2020 (pandemic period). Source: ECB, Consensus Economics, Author's calculations

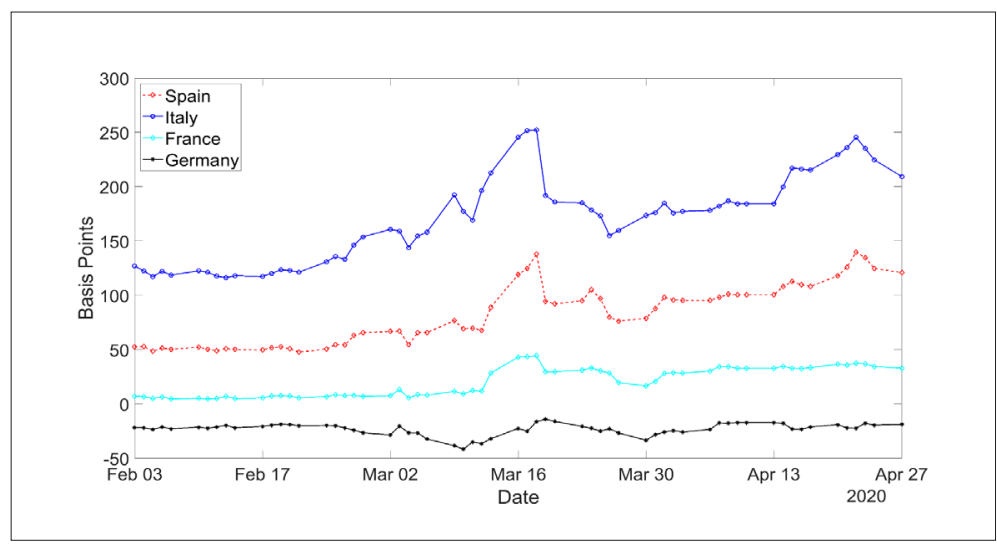

Figure 8 Country-level spreads over OIS between February and April 2020 This figure shows time-series of 10-year country-level yield over the 10-year OIS rate. Source: Refinitiv, ECB

cifically, the German Bund is widely considered a safe-haven asset. As a result its yield could experience downward pressure in times of high risk aversion. Thus, it is possible that the expected bond supply expansion by the German government was compensated by a higher demand for Bunds during the pandemic. 


\section{Conclusion}

In this chapter, we describe the fiscal adjustments made by the main Euro area countries following the onset of the COVID-19 pandemic. Such countries planned a robust expansionary fiscal response after nationwide shutdowns caused a massive economic downturn. We consider the effect of deteriorating expectations of budget deficits on government bond yields during the pandemic period. From a policymaking perspective, it is important to assess how fiscal constraints during expansionary fiscal interventions might affect interest rates, as upward pressure on national yields from higher debt might compromise fiscal and financial stability in the long-term.

\section{Bibliography}

Altavilla, C.; Carboni, G.; Motto, R. (2015). "Asset Purchase Programmes and Financial Markets: Lessons from the Euro Area”. ECB Working Paper No. 1864. https://www.ecb.europa.eu/pub/pdf/scpwps/ecbwp1864.en.pdf.

Arellano, C.; Bai, Y.; Kehoe, P.; Ramanarayanan, A. (2013). "Credibility and the Maturity of Government Debt”. Federal Reserve Bank of Minneapolis, Manuscript. https://drive.google.com/file/d/1FRgVimNlqrKJBjSYTimX-KfTVMCADPUF/view.

Bi, H. (2012). "Sovereign Default Risk Premia, Fiscal Limits, and Fiscal Policy". European Economic Review, 56(3), 389-410. https://doi.org/10.1016/j. euroecorev.2011.11.001.

Billio, M.; Busetto, F.; Dufour, A.; Varotto, S. (2020). "Bond Supply Expectations and the Term Structure of Interest Rates". Working Paper. https://ssrn. com/abstract=3631320.

Blanchard, O. (2019). "Public Debt and Low Interest Rates". American Economic Review, 109(4), 1197-229.

Blattner, T.S.; Joyce, M.A. (2016). "Net Debt Supply Shocks in the Euro Area and the Implications for QE". ECB Working Paper No. 1957. https://www.ecb. europa.eu/pub/pdf/scpwps/ecbwp1957.en.pdf.

Bonam, D.; Lukkezen, J. (2019). "Fiscal and Monetary Policy Coordination, Macro economic Stability, and Sovereign Risk Premia". Journal of Money, Credit and Banking, 51(2-3), 581-616. https://doi.org/10.1111/jmcb.12577.

Cimadomo, J.; Claeys, P.; Poplawski-Ribeiro, M. (2016). "How Do Experts Forecast Sovereign Spreads?”. European Economic Review, 87, 216-35. https:// doi.org/10.1016/j.euroecorev.2016.03.๑०2.

Corsetti, G.; Kuester, K.; Meier, A.; Müller, G.J. (2013). "Sovereign Risk, Fiscal Policy, and Macroeconomic Stability". The Economic Journal, 123(566), F99F132. https://doi.org/10.1111/ecoj.12013.

D’Amico, S.; King, T.B. (2013). "Flow and Stock Effects of Large-Scale Treasury Purchases: Evidence on the Importance of Local Supply". Journal of Financial Economics, 108(2), 425-48. https://doi.org/10.1016/j.jfineco.2012.11.007.

De Santis, R.A.; Holm-Hadulla, F. (2017). "Flow Effects of Central Bank Asset Purchases on Euro Area Sovereign Bond Yields: Evidence from a Natural 
Experiment". ECB Working Paper No. 2052. https://www.ecb.europa. eu/pub/pdf/scpwps/ecb.wp2052.en.pdf.

Eser, F.; Lemke, W.; Nyholm, K.; Radde, S.; Vladu, L.A. (2019). "Tracing the Impact of the ECB's Asset Purchase Programme on the Yield Curve". ECB Working Paper Series No. 2293. https://www.ecb.europa.eu/pub/pdf/scpwps/ecb.wp2293 41f7613883.en.pdf.

Falagiarda, M.; Gregori, W.D. (2015). "The Impact of Fiscal Policy Announcements by the Italian Government on the Sovereign Spread: A Comparative Analysis". European Journal of Political Economy, 39, 288-304. https:// doi.org/10.1016/j.ejpoleco.2015.07.002.

Gagnon, J.; Raskin, M.; Remache, J.; Sack, B. et al. (2011). "The Financial Market Effects of the Federal Reserve's Large-Scale Asset Purchases". International Journal of Central Banking, 7(1), 3-43. https://www.ijcb.org/ journal/ijcb11q1a1.pdf.

Ghosh, A.R.; Kim, J.I.; Mendoza, E.G.; Ostry, J.D.; Qureshi, M.S. (2013). "Fiscal Fatigue, Fiscal Space and Debt Sustainability in Advanced Economies". The Economic Journal, 123(566), 4-30. https://doi.org/10.1111/ ecoj.12010.

Greenwood, R.; Hanson, S.; Vayanos, D. (2015). "Forward Guidance in the Yield Curve: Short Rates Versus Bond Supply”. NBER Working Paper No. 21750. http://www.nber.org/papers/w21750.

Greenwood, R.; Vayanos, D. (2014). "Bond Supply and Excess Bond Returns". Review of Financial Studies, 27(3), 663-713. https://doi.org/10.1093/ rfs/hht133.

Hatchondo, J.C.; Roch, M.F.; Martinez, L. (2012). "Fiscal Rules and the Sovereign Default Premium". IMF Working Paper No. 12/30. https://bit. ly/2Cd3PPr.

Jaramillo, L.; Weber, A. (2013). "Bond Yields in Emerging Economies: It Matters What State You are in". Emerging Markets Review, 17, 169-85. https://doi. org/10.1016/j.ememar.2013.09.003.

Joslin, S.; Priebsch, M.; Singleton, K.J. (2014). "Risk Premiums in Dynamic Term Structure Models with Unspanned Macro Risks". Journal of Finance, 69(3), 1197-233. https://doi.org/10.1111/jofi.12131.

Krishnamurthy, A.; Vissing-Jorgensen, A. (2011). "The Effects of Quantitative Easing on Interest Rates: Channels and Implications for Policy". Brooking Papers of Economic Activity. https://www.brookings.edu/bpea-articles/the-effects-of-quantitative-easing-on-interestrates-channels-and-implications-for-policy/.

Krishnamurthy, A.; Vissing-Jorgensen, A. (2012). "The Aggregate Demand for Treasury Debt”. Journal of Political Economy, 120(2), 233-67. http://www. jstor.org/stable/10.1086/666526.

Kumar, M.M.S.; Baldacci, M.E. (2010). "Fiscal Deficits, Public Debt, and Sovereign Bond Yields". IMF Working Paper No.10/184. https://bit. ly/2DKkE4Z.

Laubach, T. (2009). "New Evidence on the Interest Rate Effects of Budget Deficits and Debt". Journal of the European Economic Association, 7(4), 858-85. https://www.jstor.org/stable/40282791.

Lemke, W.; Werner, T. (2020). "Dissecting Long-Term Bund Yields in the Runup to the ECB Public Sector Purchase Programme". Journal of Banking \& Finance, 111, 105682. https://doi.org/10.1016/j.jbankfin.2019.105682. 
Filippo Busetto, Alfonso Dufour, Simone Varotto COVID-19 and Fiscal Policy in the Euro Area

Li, C.; Wei, M. (2013). "Term Structure Modeling with Supply Factors and the Federal Reserve Large-Scale Asset Purchase Programs". International Journal of Central Banking, 9(1), 3-39. https://econpapers.repec.org/ReP Ec:ijc:ijcjou:y:2013:q:1:a:1.

Reinhart, V.; Sack, B.; Heaton, J. (2000). "The Economic Consequences of Disappearing Government Debt". Brookings Papers on Economic Activity, 2, 163220. www.jstor.org/stable/2667358.

Vayanos, D.; Vila, J.-L. (2009). "A Preferred-Habitat Model of the Term Structure of Interest Rates". NBER Working Paper No. 15487. http://www. nber. org/papers/w15487. 

Part 3

Banking, Risk and Regulation 



\title{
The Effects of the COVID-19 Pandemic Through the Lens of the CDS Spreads
}

\author{
Alin Marius Andrieș \\ "Alexandru Ioan Cuza" University of Iași; Institute for Economic Forecasting; Romanian \\ Academy, Romania
}

Steven Ongena

University of Zurich; Swiss Finance Institute; KU Leuven and CEPR

Nicu Sprincean

"Alexandru loan Cuza" University of Iași, Romania

\begin{abstract}
In this paper we are analysing the impact of the general lockdown measures imposed in Italy in the context of the COVID-19 pandemic on European banks' CDS spreads. Compared to the impact of the COVID-19 pandemic on sovereign risk, we find little evidence of increased bank risk following the event. However, investors' reaction was clearly negative in longer time frames. In addition, we quantify the feedback loop between sovereign and bank risk and document an increased interconnectedness between sovereigns and banks during the current health crisis, however with a smaller magnitude comparing to the sovereign debt crisis. Banks are now more resilient to shocks, being a direct consequence of the post-crisis regulatory framework.
\end{abstract}

Keywords COVID-19 pandemic. Bank risk. Country risk. Spillover effects.

Summary 1 Introduction. -2 Related literature. -3 Methodological aspects. -4 Results and discussion. -5 Conclusion.

Innovation in Business, Economics \& Finance 1

ISBN [ebook] 978-88-6969-442-4 


\section{Introduction}

The outbreak of the novel coronavirus, i.e. the SARS-CoV-2 and the disease it causes, i.e. the COVID-19, is a rare disaster that has affected the world economy in an unprecedented way. The severity of this global health crisis, which was declared a pandemic by the World Health Organization (WHO) on March 11, 2020, has been compared with that of the Great Influenza (Spanish Flu) from 1918-19 with up to 50 million worldwide fatalities (Boissay, Rungcharoenkitkul, 2020). At the time of writing, the total number of confirmed cases with COVID-19 is almost nine millions, whereas the global death toll is near 500,000 according to Johns Hopkins University.

Against the backdrop of highly globalised economies and integrated cross-border supply chains, the lockdown measures imposed in the majority of countries and the containment measures adopted to limit the spread of the virus have brought the global economy to a sudden stop, making this crisis truly different. Eichenbaum, Rebelo and Trabandt (2020) note that pandemics depress the real economy through a reduction in both supply and demand. As a consequence, governments around the world have stepped in with a mix of health, fiscal, monetary, macroprudential, microprudential and market-based stimuli in order to help households and businesses to have a quick recovery. ${ }^{1}$ However, in the short run, these measures tend to boost the risk aversion of investors in government bonds, who are worried about the reduced fiscal capacity of countries that are too indebted (Andries, Ongena, Sprincean 2020).

We extend the analysis on European sovereign CDS spreads conducted in Andrieș, Ongena, Sprincean (2020) to European banks' CDS spreads, focusing on the sovereign-banks feedback loop during the global financial crisis from 2007-09, sovereign debt crisis in Europe (2010-13), and the current health crisis. We find that investors' reaction to the general lockdown measures imposed in Italy on March 9, 2020, which corresponds to the arrival of the pandemic in Europe, quantified through the abnormal performance of European banks' CDS spreads, is less pronounced than in the case of sovereign CDS spreads. However, on a longer time frame their concern increases. Our findings suggest that the spillover effects from sov-

1 See the IMF Policy Tracker (https://www.imf.org/en/Topics/imf-and-covid19/ Policy-Responses-to-COVID-19) and the Global Policy Tracker from the Harvard Business School (https://www.hbs.edu/covid-19-business-impact/Insights/Economic-and-Financial-Impacts/Global-Policy-Tracker). From March to May 2020, the largest fiscal stimulus in Europe as a percent of 2018 GDP was implemented by Italy (25.15\%), followed by Denmark (11.94\%), Belgium (11.40\%) and Switzerland (10.75\%). On average, the fiscal announcements as a share of GDP for developed economies (6.66\%) are twice as high as those announced by developing countries (3.64\%). 
ereigns to banks and vice versa, amplified following the COVID-19 shock. But their magnitude is smaller compared to other recent crisis episodes. This is the result of the solid position of the banks and their improved capacity to absorb losses due to stricter capital and liquidity regulation following the financial crisis of 2007-09.

\section{Related Literature}

European banks present specific features that substantially differentiate them from the US ones. If the latter recovered to the pre-crisis profitability level by 2013, the European banks still struggle to reach that level. This aspect is primarily explained by three factors (Carletti et al. 2020): (i) the European sovereign debt crisis which impacted severely especially the banks in peripheral countries (the GIIPS countries, i.e. Greece, Italy, Ireland, Portugal and Spain); (ii) the high level of non-performing loans: in the US, early government intervention helped banks to clear their balance sheets; and (iii) the macroeconomic environment: strong fiscal stimulus in the US compared to a sober approach (austerity measures) in Europe. Moreover, Europe's financial structure has become strongly bank-based, making it more prone to systemic risk (Langfield, Pagano 2016).

The nexus between the risk profile of banks and countries has been addressed in various studies, and is mainly attributed to four channels that interact with each other: (i) the sovereign exposure channel; (ii) the safety net channel; (iii) the collateral channel; and (iv) the sovereign downgrade channel (BIS 2011; De Bruyckere et al. 2013; Dell'Ariccia et al. 2018). Banks hold in their balance sheets a significant amount of public debt, averaging 30\% in developed markets and 45\% in emerging markets (Arslanalp, Tsuda 2014). According to Basel Accords, banks have to maintain capital buffers with regulatory risk weights that depend on their asset exposures. However, European banks do not hold capital against their European debt exposures, i.e. they have zero-risk weight (Keddad, Schalck 2020). As a consequence, European banks are undercapitalized if a negative shock hits countries and sovereign risk increases (Kirschenmann, Korte, Steffen 2019). In empirical analyses sovereign risk is found to influence banks' risk, especially in the context of the global financial crisis and sovereign debt crisis in Europe (Alter, Schüler 2012; De Bruyckere et al. 2013; Gibson, Hall, Tavlas 2016; Keddad, Schalck 2020).

The second transmission channel, the safety net channel, reflects the explicit and implicit guarantees provided by governments and central banks, especially for too-big-to-fail financial institutions, to support financial stability. When the fiscal position of countries worsens, the value of public guarantees to the banking system reduces, resulting in spillover effects from sovereign to bank risk (Alter, 
Schüler 2012; Bertay, Demirgüç-Kunt, Huizinga 2013; Avino, Cotter 2014). In the same vein, banking crises activate backstops, guarantees and other resolution policies that affect public finance sustainability, resulting in spillover effects from bank to sovereign risk ( $\mathrm{Yu}$, 2017; Dell'Ariccia et al. 2018).

The third transmission channel is the collateral channel that operates against the backdrop of the reduced value of collateral that banks hold in the form of sovereign debt, affecting borrowing costs of banks in the interbank market, private repo markets and other types of transactions (BIS 2011; Correa et al. 2012; De Bruyckere et al. 2013). Finally, the last channel deals with sovereign rating downgrades that can affect banks' borrowing capacity, leading to the downgrade of domestic banks. These channels have been investigated, among others, by Arezki, Candelon, Sy (2011) and Gibson, Hall, Tavlas (2016). The latter (2016) document that during the sovereign debt crisis in Europe the decline in commercial banks' equity prices reflected direct and indirect linkages with the sovereigns. Dell'Ariccia et al. (2018) also mention the macroeconomic channel, i.e. the three-sided relationship between banks and government sector and real economic activity.

\section{Methodological Aspects}

We extend the analysis of Andrieș, Ongena, Sprincean (2020) to the European banking sector, investigating the impact of the COVID-19 pandemic on banks' CDS spreads. Similarly to Andrieș, Ongena, Sprincean (2020), we employ an event study methodology to assess the reaction of investors in bank bonds to: (1) general lockdown measures imposed in Italy on March 9, 2020; (2) the pandemic intensity (the country specific day when the number of cases totalled 100 , the growth rate climbed to 30 cases a day, and the death rate surpassed 10); (3) and some dates related to the stringency of the containment measures, such as restrictions on internal movement and general workplace closing. Further, we measure spillover effects from sovereigns to banks and vice versa during three crisis periods: (i) the global financial crisis of 2007-09; (ii) the euro area debt crisis of 2010-13; and (iii) the current health crisis, comparing their magnitude across and within groups. We follow the approach of Billio et al. (2012) and analyse the interdependencies between sovereigns and banks through Granger-causality networks. For banks from the same countries, we construct equally-weighted CDS indices. We use the 5-years CDS contracts denominated in Euro with modified-modified restructuring, written on senior obligations. The source of the data is Thomson Reuters DataStream. 


\section{Results and Discussion}

Figure 1 exhibits the evolution of sovereign CDS spreads and banks' equally-weighted CDS indices for four European countries that have been heavily affected by the pandemic (Italy, Germany, France and Spain), over the January 1-April 20, 2020 period [fig. 1]. The vertical lines from each graph represent our main event date, i.e. March 9, 2020. We can note that, with the exception of Germany, all sovereign CDS quotes increased following the announcement of general lockdown measures imposed in Italy. The same is true for banks' CDS spreads, including German banks. Thus, investors reacted to this announcement by requiring higher premia to invest in bonds issued by these European sovereigns or by the banks headquartered in these countries.

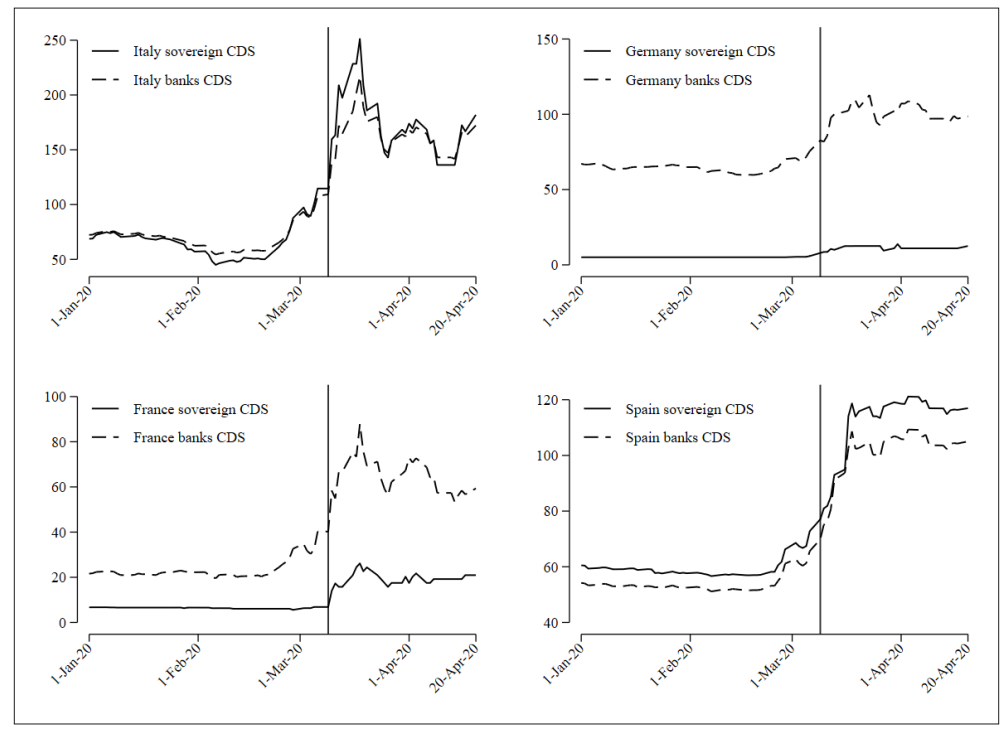

Figure 1 The evolution of sovereign CDS spreads and banks' CDS spreads (equally-weighted indices) for Italy, Germany, France and Spain from January 1, 2020 to April 20, 2020 (in basis points).

Note: the vertical lines represent March 9, 2020

Next, we present the findings from the event study with March 9, 2020 as the main event date table $1 .^{2}$ The event study is conducted over the event windows: $[0 ; 0],[-1 ; 1],[-5 ; 5]$, and $[0 ; 30]$ days. Thus, we analyse the market reaction for short and longer time frames. The results show little evidence in favour of a negative reaction of inves-

2 See Table A1 from the Annexes with the list of the banks used in our analysis. 
tors in bonds issued by European banks on the event day, quantified through an increase in cumulative average abnormal change (CAAC) ${ }^{3}$ of CDS spreads by 94.22 basis points only. Only one test out of four (generalised sign test) shows statistical significance of CAACs on the event day. The findings for sovereign CDS spreads, however, indicate a clear negative effect on March 9, 2020 of 503.85 basis points boost in CAAC. Thus, the market reaction is more pronounced in the case of sovereign risk than bank risk. However, the harmful effect of containment measures to curtail the spread of the virus is present for banks over longer periods, especially for $[-5 ; 5]$ days event window with an increase in CAAC by 4787.67 basis points, being highly statistically significant.

In terms of pandemic intensity, unreported results show that the highest risk from investors' in both sovereign and bank bonds is associated with a rapid increase in daily confirmed cases (i.e. 30 cases a day), whereas the general restrictions on internal movement worry more investors in bank bonds than those in sovereign bonds. Nonetheless, according to investors in European sovereign debt the economic channel of non-pharmaceutical interventions ${ }^{4}$ dominates that of coordination where people purposely reduce their consumption and labour supply to reduce the spread of the virus and the risks associated with the pandemic (Correia, Luck, Verner 2020).

3 Cumulative average abnormal change for CDS spreads is the analogue of cumulative average abnormal return (CAAR) from equity prices. We compute the change in CDS spreads as the natural logarithm of CDS quote at time $t$ over CDS quote at time $t-1$. In event studies, the abnormal return (AR) is the difference between the actual and the expected return, the latter being calculated based on specific models. The AR can be averaged across all firms in the sample to get the average abnormal return (AAR) for each $t$. In the end, one can sum the AARs over specific time intervals to get the cumulative average abnormal return, which can capture the aggregate effect of the abnormal returns.

4 Strategies carried out by people and communities to limit the spread of the virus, besides vaccination and medical treatment (pharmaceutical interventions), such as social distancing and public hygiene. 
Alin Marius Andries, Stevan Ongena, Nicu Sprincean The Effects of the COVID-19 Pandemic Through the Lens of the CDS Spreads

Table 1 Banks' CDS spreads reaction to the general quarantine measures imposed in Italy

\begin{tabular}{lcccc}
\hline \multicolumn{5}{c}{ CDS CAACs 9 March 2020 (b.p.) } \\
\hline Event window & {$[0 ; 0]$} & {$[-1 ; 1]$} & {$[-5 ; 5]$} & {$[0 ; 30]$} \\
\hline \multicolumn{5}{c}{} \\
\hline 29 European banks & 94.22 & 2176.44 & 4787.67 & 3853.68 \\
\hline Significance tests & & & & \\
\hline Adjusted-Patell test & 1.07 & $8.13^{\star \star \star}$ & $10.09^{\star \star \star}$ & $12.87^{\star \star \star}$ \\
\hline BMP test & 1.33 & $7.10^{\star \star \star}$ & $8.40^{\star \star \star}$ & $8.74^{\star \star \star}$ \\
\hline Generalised sign test & $-2.87^{\star \star \star}$ & $3.46^{\star \star}$ & $3.84^{\star \star \star}$ & $4.21^{\star \star \star}$ \\
\hline GRANK test & -0.57 & $2.36^{\star \star}$ & $2.61^{\star \star}$ & $2.83^{\star \star \star}$ \\
\hline
\end{tabular}

Note: this table exhibits the cumulative average abnormal changes (CAACs) in basis points of European banks' CDS spreads considering the following event windows: [0; $0],[-1 ; 1],[-5 ; 5]$, and $[0 ; 30]$ days. The event refers to March 9, 2020. The estimation window is 250 days and the model employed to compute the expected change is the market model with DataStream Banks Europe 5Y CDS index as the market index (see Andrieș, Ongena, Sprincean 2020 for details). The table also reports the statistics of the tests used to assess the significance of CAACs: two parametric tests (Adjusted Patell and BMP tests) and two non-parametric tests (Generalised sign and GRANK tests). ${ }^{\star \star}$ and ${ }^{\star \star \star}$ denote statistical significance at the $5 \%$ and $1 \%$ level, respectively.

Further, we quantify the dynamic interconnectedness between sovereigns and banks in a Granger-causality framework. Considering our data, changes in sovereigns' CDS quotes can Granger-cause changes in banks' CDS spreads if information contained in the past values of sovereigns' CDS and in the past values of banks' CDS is better at predicting the value of banks' change in CDS than the information based only on the past values of banks' change in CDS (for details, see Andriess et al. 2020). Following Billio et al. (2012) we compute the Dynamic Causality Index (DCI) which is based on Granger-causality relationships. An increase in the Dynamic Causality Index is associated with enhanced spillover effects between sovereign and bank risk.

Being constrained by the availability of data, our analysis starts on November 10, 2008. From figure 2, which depicts the evolution of the DCI index over time, we can note three spikes: two during the sovereign debt crisis, and one during the current health crisis [fig. 2]. The highest magnitude of the Dynamic Causality Index is reached during the European sovereign debt crisis indicating an increased feedback loop between sovereign and bank risk. The DCI is constantly raising during the global financial crisis. However we do not capture the Lehman Brothers event. Contrary to the Great Recession and sovereign debt crisis episodes, now banks are more resilient to shocks, being better equipped with capital and liquidity buffers and have lower incentives of excessive risk-taking as a direct consequence of the post-crisis regulatory environment. However, due to disruptions in 


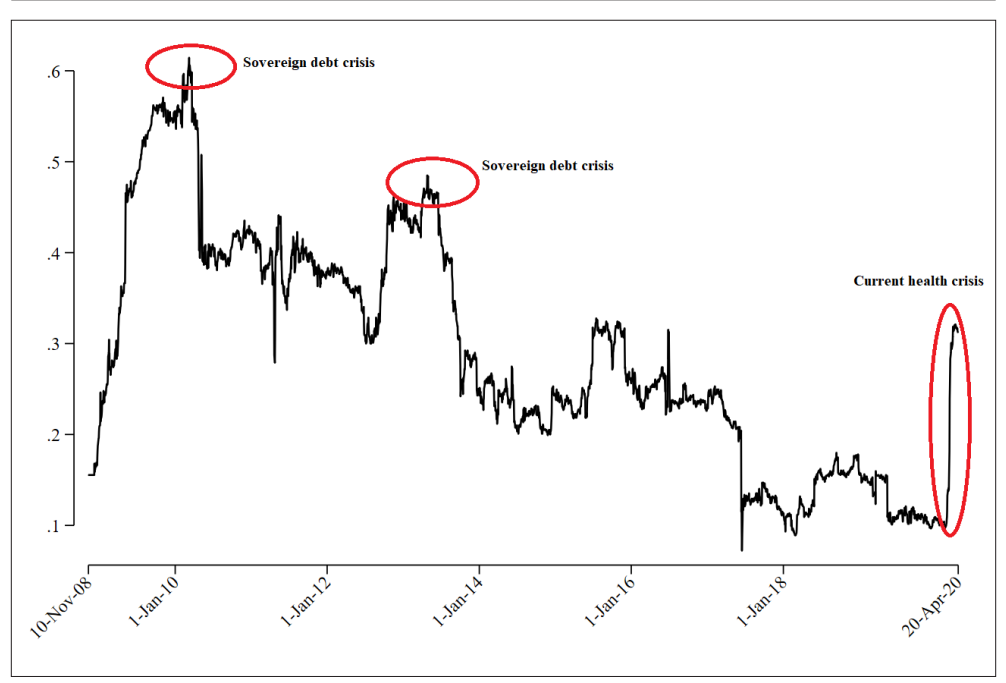

Figure 2 The evolution of Dynamic Causality Index over the November 10, 2008-April 20, 2020 period

the global supply chains and reduction in demand caused by the lockdown measures, banks could rapidly face a surge in non-performing loans amplified by the default of firms, notably small and medium-sized enterprises that depend on bank funding as their primary source of borrowing. ${ }^{5}$ Carletti et al. (2020) point-out four challenges that banks' business models will face in the post-COVID-19 era: (i) a prolonged period of low interest rates; (ii) increased credit risk; (iii) digitalisation; and (iv) stricter bank regulations.

Based on pairwise Granger-causality relationships between sovereigns and banks one can construct the Granger-causality network, being defined as a set of nodes (sovereigns and banks) connected by edges. If changes in sovereign i's CDS spreads Granger-cause changes in bankj's CDS quote, than these two nodes will be connected by a straight line with the arrow coming from sovereign $i$. Otherwise, there will be no connection. The arrow can also come from bank $j$ to sovereign $i$ if changes in bankj's CDS spreads Granger-cause changes in sovereign $i$ 's CDS quote. Unreported results show that linkages within groups (sovereign-sovereign and bank-bank) are more pronounced than linkages across groups (sovereign-bank and bank-

5 The main macroprudential measures adopted at the European level to mitigate the negative effects of COVID-19 pandemic and avoid a credit crunch consist of relaxation of regulatory capital buffers, such as capital conservation buffer, countercyclical capital buffer, and systemic risk buffer. For more details, see the database from the ESRB: https://www.esrb.europa.eu/home/coronavirus/html/index.en.html. 
sovereign), and the Italian banks are the most exposed to shocks that propagate through the network.

\section{Conclusion}

The COVID-19 pandemic is a rare disaster that has affected the global economy in an unprecedented way. Governments around the world have stepped in by making use of health, fiscal, microprudential, macroprudential, monetary, or marked-based measures in order to mitigate the negative effects of the health crisis and to avoid a credit crunch in the banking sector. We analyze the impact of the general lockdown measures imposed in Italy in the context of the COVID-19 pandemic on European banks' CDS spreads. Compared to sovereign risk, we find little evidence of increased bank risk following the event, which also corresponds to the commencement of the pandemic in Europe. However, investors' reaction was clearly negative in longer time frames. In addition, we quantify the feedback loop between sovereign and bank risk and document an increased interconnectedness between sovereigns and banks during the current health crisis, but with a smaller magnitude as compared to the sovereign debt crisis in Europe. Banks are now more resilient to shocks, being better equipped with capital and liquidity buffers and have lower incentives to excessive risk-taking as a direct consequence of the post-crisis regulatory framework.

\section{Bibliography}

Alter, A.; Schüler, Y.S. (2012). "Credit Spread Interdependencies of European States and Banks During the Financial Crisis". Journal of Banking \& Finance, 36(12), 3444-68. https://doi.org/10.1016/j.jbankfin.2012.๑8.๑๑2.

Andrieș, A.M.; Ongena, S.; Sprincean, N. (2020). "The COVID-19 Pandemic and Sovereign Bond Risk". Swiss Finance Institute Research Paper No. 20-42. https://dx.doi.org/10.2139/ssrn.3605155.

Andrieș, A.M.; Ongena, S.; Sprincean, N.; Tunaru, R. (2020). "Risk Spillovers and Interconnectedness between Systemically Important Institutions". Swiss Finance Institute Research Paper No. 20-40. https://dx.doi. org/10.2139/ssrn.3597962.

Arezki, M.R.; Candelon, B.; Sy, M.A.N. (2011). "Sovereign Rating News and Financial Markets Spillovers: Evidence from the European Debt Crisis". IMF Working Paper, No. 11-68. http://dx.doi.org/10.5089/9781455227112.001.

Arslanalp, S.; Tsuda, T. (2014). "Tracking Global Demand for Advanced Economy Sovereign Debt”. IMF Economic Review, 64, 430-64. https://doi. org/10.1057/imfer.2014.20.

Avino, D.; Cotter, J. (2014). "Sovereign and Bank CDS Spreads: Two Sides of the Same Coin?". Journal of International Financial Markets, Institutions and Money, 32, 72-85. https://doi.org/10.1016/j.intfin.2014.05.007. 
BIS (Bank for International Settlements) (2011). "The Impact of Sovereign Credit Risk on Bank Funding Conditions”. CGFS Papers No. 43.

Bertay, A.C.; Demirgüç-Kunt, A.; Huizinga, H. (2013). "Do We Need Big Banks? Evidence on Performance, Strategy and Market Discipline". Journal of Financial Intermediation, 22, 532-58. https://doi.org/10.1016/j. jfi.2013.02.002.

Billio, M.; Getmansky, M.; Lo, A.W.; Pelizzon, L. (2012). "Econometric Measures of Connectedness and Systemic Risk in the Finance and Insurance Sectors". Journal of Financial Economics, Market Institutions, Financial Market Risks and Financial Crisis, 104, 535-59. https://doi.org/10.1016/j.jfineco.2011.12.010.

Boissay, F.; Rungcharoenkitkul, P. (2020). "Macroeconomic Effects of Covid-19: an Early Review”. BIS Bulletin No. 7.

Carletti, E.; Claessens, S.; Fatas, A.; Vives, X. (2020). "The Bank Business Model in the Post-Covid-19 World". The Future of Banking 2, CEPR Press.

Correa, R.; Sapriza, H.; Zlate, A. (2012). "Liquidity Shocks, Dollar Funding Costs, and the Bank Lending Channel During the European Sovereign Crisis". Federal Reserve System International Finance Discussion Papers 1059. https:// www.federalreserve.gov/PubS/ifdp/2012/1059/ifdp1059.pdf.

Correia, S.; Luck, S.; Verner, E. (2020). "Pandemics Depress the Economy, Public Health Interventions Do Not: Evidence from the 1918 Flu". https://papers.ssrn.com/sol3/papers.cfm?abstract_id=3561560.

De Bruyckere, V.; Gerhardt, M.; Schepens, G.; VanderVennet, R. (2013). "Bank/Sovereign Risk Spillovers in the European Debt Crisis". Journal of Banking \& Finance, 37, 4793-809. https://doi.org/10.1016/j.jbankfin.2013.08.012.

Dell'Ariccia, G.; Ferreira, C.; Jenkinson, N.; Laeven, L.; Martin, A.; Minoiu, C.; Popov, A. (2018). "Managing the Sovereign-Bank Nexus". Departmental Paper No. 18/16, IMF. http://dx.doi.org/10.5089/9781484359624.087.

Eichenbaum, M. S.; Rebelo, S.; Trabandt, M. (2020). "The Macroeconomics of Epidemics". National NBER Working Paper No. 26882.

Gibson, H.D.; Hall, S.G.; Tavlas, G.S. (2016). "How the Euro-Area Sovereign-debt Crisis Led to a Collapse in Bank Equity Prices". Journal of Financial Stability, 26, 266-75. https://doi.org/10.1016/j.jfs.2016.07.010.

Keddad, B., Schalck, C. (2020). "Evaluating Sovereign Risk Spillovers on Domestic Banks During the European Debt Crisis". Economic Modelling, 88, 356-75. https://doi.org/10.1016/j.econmod.2019.09.047.

Kirschenmann, K.; Korte, J.; Steffen, S. (2019). "A Zero-Risk Weight Channel of Sovereign Risk Spillovers". https://ssrn.com/abstract=2395097.

Langfield, S.; Pagano, M. (2016). "Bank Bias in Europe: Effects on Systemic Risk and Growth”. Economic Policy, 31, 51-106. https://doi.org/10.1093/ epolic/eivo19.

Yu, S. (2017). "Sovereign and Bank Interdependencies-Evidence from the CDS Market". Research in International Business and Finance, 39, 68-84. https://doi.org/10.1016/j.ribaf.2016.07.033. 


\section{Table A1}

List of the banks used in the analysis

\begin{tabular}{|c|c|c|}
\hline Nr. crt. & Name of the bank & Country of origin \\
\hline 1 & ERSTE GROUP BANK AG & Austria \\
\hline 2 & BAWAG PSK & Austria \\
\hline 3 & DANSKE BANK A/S & Denmark \\
\hline 4 & BNP PARIBAS SA & France \\
\hline 5 & SOCIETE GENERALE & France \\
\hline 6 & CREDIT AGRICOLE SA & France \\
\hline 7 & DEUTSCHE BANK AG & Germany \\
\hline 8 & BAYERISCHE LANDESBANK & Germany \\
\hline 9 & COMMERZBANKAG & Germany \\
\hline 10 & LANDESBANK BADEN-WÜRTTEMBERG & Germany \\
\hline 11 & IKB DEUTSCHE INDUSTRIEBANK AG & Germany \\
\hline 12 & $\begin{array}{l}\text { LANDESBANK HESSEN-THÜRINGEN } \\
\text { GIROZENTRALE }\end{array}$ & Germany \\
\hline 13 & ALLIED IRISH BANKS & Ireland \\
\hline 14 & UNICREDITO ITALIANO SPA & Italy \\
\hline 15 & MEDIOBANCA SPA & Italy \\
\hline 16 & BANCO COMERCIAL PORTUGUES SA & Portugal \\
\hline 17 & BANKINTER SA & Spain \\
\hline 18 & BANCO DE SABADELL & Spain \\
\hline 19 & BBV ARGENTARIA SA & Spain \\
\hline 20 & CAJA DE AHORROS DEL MEDITERRÁNEO & Spain \\
\hline 21 & SVENSKA HANDELSBANKEN AB & Sweden \\
\hline 22 & SWEDBANKAB & Sweden \\
\hline 23 & SKANDINAVISKA ENSKILDA BANKEN AB & Sweden \\
\hline 24 & CREDIT SUISSE GROUP & Switzerland \\
\hline 25 & UBS AG & Switzerland \\
\hline 26 & LLOYDS BANK & United Kingdom \\
\hline 27 & BARCLAYS BANK PLC & United Kingdom \\
\hline 28 & THE RBS GROUP PLC & United Kingdom \\
\hline 29 & HSBC BANK PLC & United Kingdom \\
\hline
\end{tabular}





\title{
Market Risk Measurement Preliminary Lessons from the COVID-19 Crisis
}

Emese Lazar

ICMA Centre, Henley Business School, University of Reading, UK

Ning Zhang

ICMA Centre, Henley Business School, University of Reading, UK

\begin{abstract}
This chapter presents a preliminary analysis on how some market risk measures dramatically increased during the COVID-19 pandemic, with measures computed over longer horizons experiencing more pronounced effects. We provide examples when regulatory market risk measurement proved to be suboptimal, overestimating risk. A further issue was the large number of Value-at-Risk 'exceptions' during the first few months of the crisis, which normally leads to overinflated bank capital requirements. The current regulatory framework should address these problems by suggesting improvements to the calculation of risk measures and/or by modifying the rules which determine capital requirements to make them appropriate and realistic in crisis situations.
\end{abstract}

Keywords Marketrisk. Measurement. Value-at-Risk. Expected Shortfall. Regulation. Basel.

Summary 1 Introduction. - 2 Overview of the Market Risk Regulation Before the Crisis. - 3 Market Risk Measurement Over the First Five Months of the Crisis. - 4 Challenges to the Regulatory Framework. - 5 Looking Ahead. - 6 Conclusions.

Innovation in Business, Economics \& Finance 1

ISBN [ebook] 978-88-6969-442-4 


\section{Introduction}

The coronavirus pandemic has been one of the most devastating global crises since the Second World War. It has had far-reaching consequences that affected all countries to varying degrees. The most tragic impact has been the loss of lives, but also job losses, the lack of healthcare access and the effects on mental health etc. have been devastating. The outcome of the pandemic in the financial sector has been a financial crisis, named the COVID-19 crisis. Ramelli and Wagner (2020; forthcoming) compare stock performances by industry as early effects of the crisis, and identify the Energy sector as being the worst hit whilst Telecom, Pharma \& Biotech reaping the largest gains. Acharya and Steffen (2020) highlight how stock performance depended on liquidity as stocks with high liquidity performed better. Aldasoro et al. (2020) raise concerns about the long-terms prospects of banks, as the banking sector has been more severely hit than most sectors, and argue that the consequences are comparable with the outcomes of the 2008 global financial crisis.

Here we investigate how financial risks increased and how the crisis affected financial institutions, with a focus on market risk measurement, and we discuss the challenges faced by regulators. We examine the first five months of the crisis, analysing the effects of equity market index risk factors, and to some extent commodity risk factors, as these are the risk dimensions most affected by the COVID-19 crisis. Other risk factors indicated serious levels of market stress. Examples include government bond yields, which reached historical lows, and volatility risk factors, such as the CBOE VIX index, which had its largest shocks, both positive and negative and reached its highest value ever of 82.69 in March 2020, as illustrated in figure 1 [fig. 1]. At the time of writing the crisis is still affecting the economies worldwide as well as the day-to-day lives of millions.

\section{Overview of the Market Risk Regulation Before the Crisis}

Market risk refers to the risk of losses arising from adverse movements in market prices of assets. From a regulatory perspective, the Basel Committee on Banking Supervision (1996) first introduced market risk capital reserves against unexpected asset price movements in the trading books of banks. Since then, Value-at-Risk (VaR) has become the dominating measure of market risk, which financial institutions and regulators use to make risk-informed decisions and to calculate market risk capital requirements. VaR is defined as the potential loss one may face over a given time horizon with a pre-defined confidence level. For example, if the $99 \%$ 10-day VaR is $\$ 1$ million, there is $99 \%$ chance that the losses will not exceed $\$ 1$ million over the next 10 trading days. 


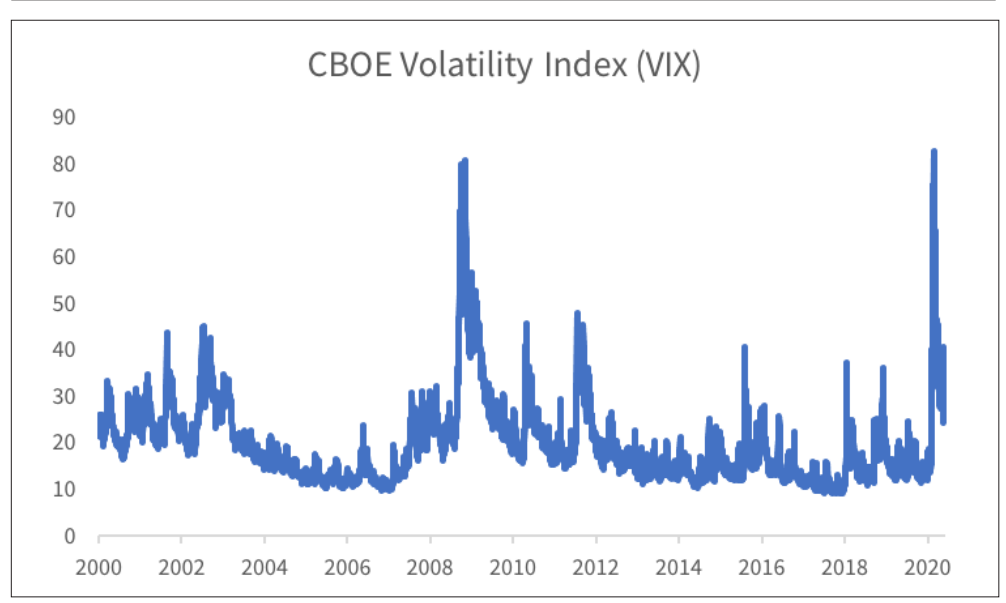

Figure 1 CBOE volatility index from 2000-01-23 to 2020-06-23

In the aftermath of the 2008 global financial crisis, the flaws of market risk regulation have become evident. For instance, the VaR-based risk assessment has been found to underestimate the risks in turbulent markets. To address these problems, the Basel Committee on Banking Supervision (2019) published revisions to its global regulatory standards that include a move from Value-at-Risk to Expected Shortfall (ES). ES measures the average loss beyond the VaR threshold in the tail of the loss distribution, producing more accurate gauges of tail risk. The typical confidence level is $99 \%$ for VaR and $97.5 \%$ for ES, corresponding to the $1 \%$ and $2.5 \%$ worst-case losses, respectively. Moreover, considering the liquidity of various assets, varying time horizons are used to evaluate financial risks, i.e. 10 days for large cap equities, 20 days for small cap, and up to 120 days for some risk categories. However, the latest regulations stipulate that these risk calculations are based on overlapping 10-day returns and we discuss this procedure in our risk assessments.

Figure 2 shows the 10-day 97.5\% ES ${ }^{1}$ calculated using the most widely accepted risk model in the industry, Historical Simulation (denoted by HS in the following), based on the S\&P 500 index returns (2000-06-26/2020-06-23), and plots it along the index [fig. 2]. Within one week during March 2020, the index was hit by a shock of around $-19 \%$ cumulative return. As the figure shows, during the global finan-

1 Throughout this chapter, ES is expressed in returns, of which the value is nonnegative; a rolling window scheme is used to estimate ES with a window length of 250 trading days. 


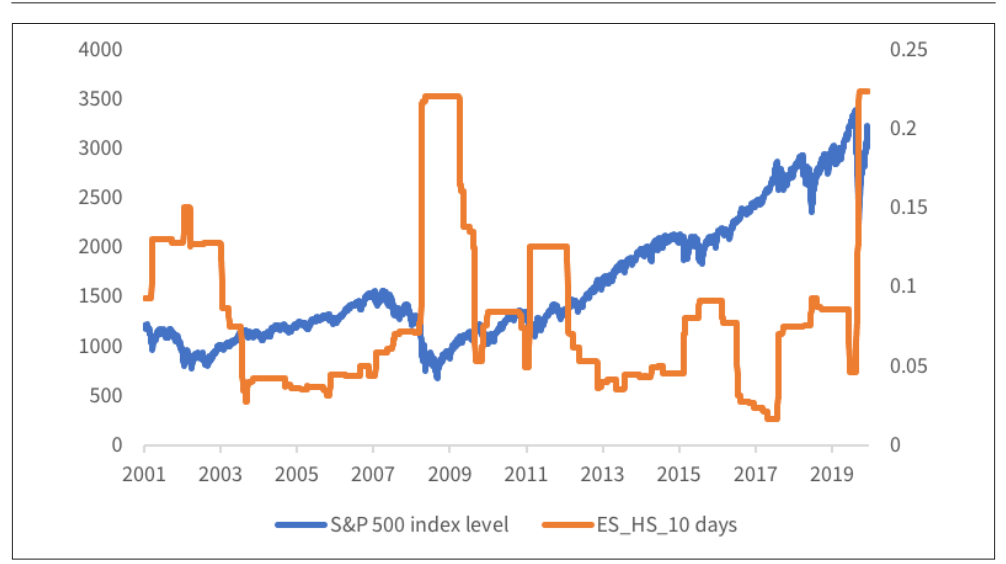

Figure 2 10-day Historical Simulation ES at 97.5\%, based on S\&P 500 index returns from 2000-06-26 to 2020-06-23

cial crisis between mid 2007 and early 2009, as well as during the sovereign debt crisis which peaked between 2010 and 2012, the risk measure, ES, peaked. The same can be seen during the crisis wrought by the coronavirus pandemic, with ES reaching a level comparable with the ES during the financial crisis, as also discussed in CapelleBlancard and Desroziers (2020). It is to be noticed that the ES during the crisis increased to multiple times the level before the crisis.

Though the first cases of COVID-19 date back to December 2019, the lockdown in China occurred on January 23, 2020. Following this, the virus spread quickly over other parts of the globe and a global pandemic was declared by the WHO on March 11, 2020. ${ }^{2}$ On seeing the widespread effects of the coronavirus outbreak on the economy and the banks, prudential authorities as well as local jurisdictions decided to delay the implementation of the latest version of market risk regulatory framework (Basel Committee on Banking Supervision 2019), called the Fundamental Review of the Trading Book (FRTB), until January 2023. This gives regulators time to consider suitable changes to market risk measurement and management in the new Basel framework, if required. It also gives financial institutions breathing space to reevaluate their market risk estimation methodologies as well as the steps needed to be taken to reduce risk exposures to an acceptable level. Also, risk estimates such as VaR and ES depend

2 More information about how this global event unfolded and a detailed timeline can be found in https://www.who.int/news-room/detail/27-๑4-2020-who-timeline--covid-19. 
on the modelling framework, and in the following we examine this dependence in more detail.

\section{Market Risk Measurement Over the First Five Months of the Crisis}

For regulatory purposes and for internal risk assessment of institutions, the estimation of VaR and ES measures over a given time period is of interest, since market risk capital calculations are based on risk assessments. Here we focus on the estimation of ES as it is a central element of the recent regulations. To illustrate the dramatic increase in risk witnessed in the first half of $2020,{ }^{3}$ figure 3 presents the level of $97.5 \%$ ES risk over 10 days, for two assets: FTSE 100 index returns as well as Europe Brent Crude Oil Spot returns, based on two methods: Historical Simulation, computed using overlapping 10-day returns, as well as the well-known $\operatorname{GARCH}(1,1) \bmod$ el that assumes normally distributed returns. For the GARCH model, the $h$-day ES is calculated based on the daily ES estimates, written as $h$-day ES $=1$-day ES $\mathrm{x} \sqrt{h}$, which is called the 'square root of time' rule [fig. 3].

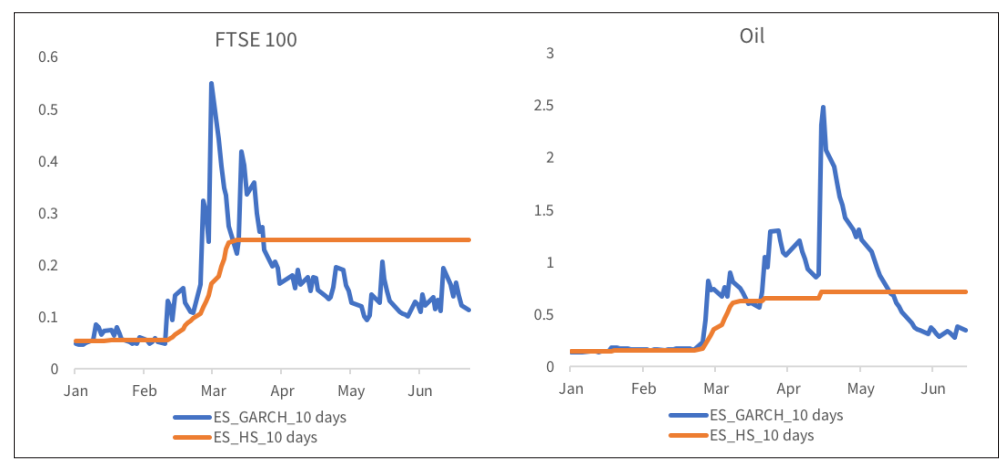

Figure 310 -day HS ES and GARCH ES at $97.5 \%$ for FTSE 100 and oil returns

The first thing to notice from figure 3 is that the general level of ES risk computed using HS increases dramatically during March 2020, by a multiplier of more than 4 for the FTSE index, and by a multiplier of more than 5 for the risk computed from oil returns. Also, the ES stays at this level until the end of the sample period, unaffected by the

3 Similarly, Ibikunle and Rzayev (2020) show a substantial increase of a cross-sectional average volatility for 110 European stocks from 24 Jan. to 24 March in their figure 1. 
events during this period. If these values are used for capital calculation, the required capital would also increase multiple times, with many financial institutions not being able to meet these increased capital requirements. ${ }^{4}$ To address this, banks across the world are allowed to temporarily suspend the new capital calculation method against the radically increased risk, as discussed by Borio and Restoy (2020). Moreover, the GARCH model does a good job in terms of the speed of reaction to large negative returns, but it leads to risk estimates increasing dramatically, by a multiplier of more than 10 , as can be seen in figure 3 for the FTSE returns, which would give capital requirements that are impossible to meet, reaching levels of more than 10 times the pre-crisis levels. Followed by this initial sharp rise in risk, the risk level estimated by GARCH decreases back within a month, and in the second part of the sample period it is below the risk level estimated by the HS method.

For oil returns, the risk estimate obtained by GARCH displays a large variation. After the initial sharp rise in risk at the beginning of March, on April 20 the market experienced its deepest fall in the price of a barrel of West Texas Intermediate (WTI), the benchmark for US oil, even leading to negative prices for this commodity - caused by an abrupt drop in demand. This aroused investors' fears and created a turbulent oil market, as evidenced by the predictions of GARCH ES of oil returns, with the ES risk reaching levels more than 15 times higher than the level in January 2020. This shows the high dependence of GARCH risk estimates on returns; although the model is quick to react to events, due to the high level of risk estimates it is less suitable to be used for capital calculations. These risk estimates highlight the severity of the COVID-19 financial crisis, especially after the coronavirus pandemic was declared in March 2020.

To illustrate the effects of the COVID-19 crisis on the global financial markets, we consider the market indices S\&P 500 (spx), FTSE 100 (ftse), DAX (dax), Nikkei 225 (nky), and Shanghai Composite (sse), as well as several commodities including Europe Brent Crude Oil Spot prices (oil), Henry Hub Natural Gas Spot Prices (gas), London PM fix gold prices (gold), Copper Jul 20 futures contract (copper), as well as the Sugar \#11 Oct 20 futures contract (sugar), from January 2019 to June 2020. Figure 4 shows the multipliers for Historical Simulation ES, calculated as the ratio of the average ES over the last five trading days of the sample period, ending with June 23, 2020, and the average ES over the first five trading days starting with January 23, 2020 [fig. 4]. We use three different time horizons (1

4 More measures are taken by governments and banks to alleviate the adverse financial and economic effects of the COVID-19 crisis, as suggested by Basel Committee on Banking Supervision (2020). 


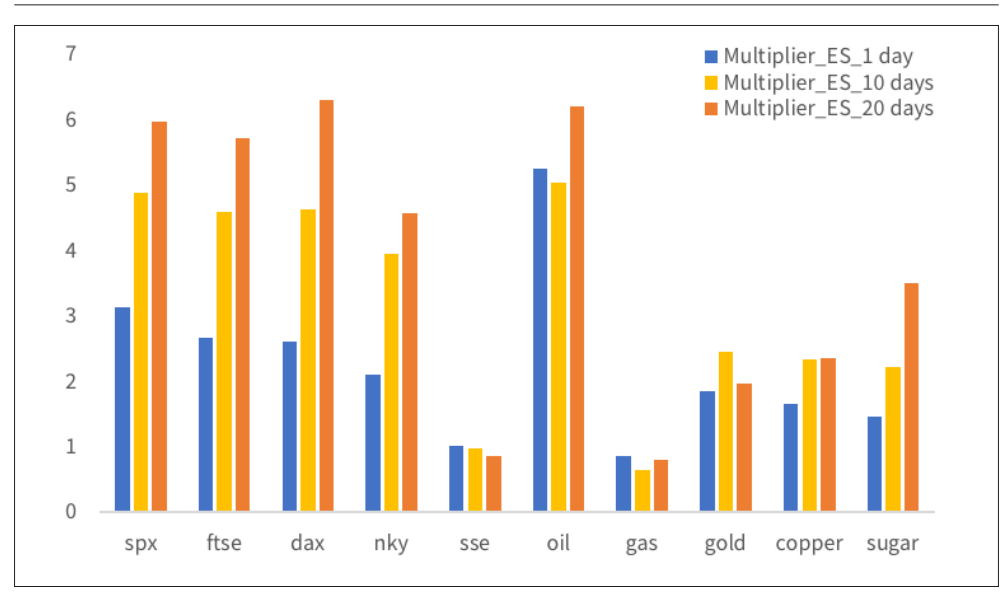

Figure 4 Multipliers for HS ES at $97.5 \%$ over 1,10 and 20 days across various assets,
calculated as the ratio of the average ES over the last five trading days of the sample period divided by the average ES over the first five trading days of our sample

day, 10 days and 20 days) to compute the risk estimates and the multipliers. For some assets the multipliers take large values: index returns and oil returns, most noticeably. For the S\&P 500, FTSE, DAX and Nikkei 225 index returns, the increase in the risk level shows a similar pattern: the risk increased by 3 to 6 times, depending on the risk horizon. For the Shanghai Composite index, the value of the multiplier is less than one, showing that this index didn't display an increase in the level of ES risk estimates. The gas market seems unaffected as well in terms of risk estimates. The other commodities considered - gold, copper and sugar - show an increase in the risk level by about twofold, whilst the risk estimates obtained from oil returns increased dramatically during the crisis.

It is interesting to note the dependency of the multiplier on the risk horizon: for most assets considered, the multiplier for the 1-day risk horizon is smaller than the multiplier for the 10-day horizon, and the multiplier for the 20-day horizon is the largest. If the 'square root of time' rule was valid, then these multipliers should have been at the same level, regardless of the time horizon. However, this is not the case, which highlights that longer horizon risks were affected by the COVID-19 crisis more than short horizon risks, with some of the risk estimates going up sixfold over the sample period. This pattern is not followed by all asset classes, but it seems to be a typical behaviour of risk estimates for the majority of assets considered here. 


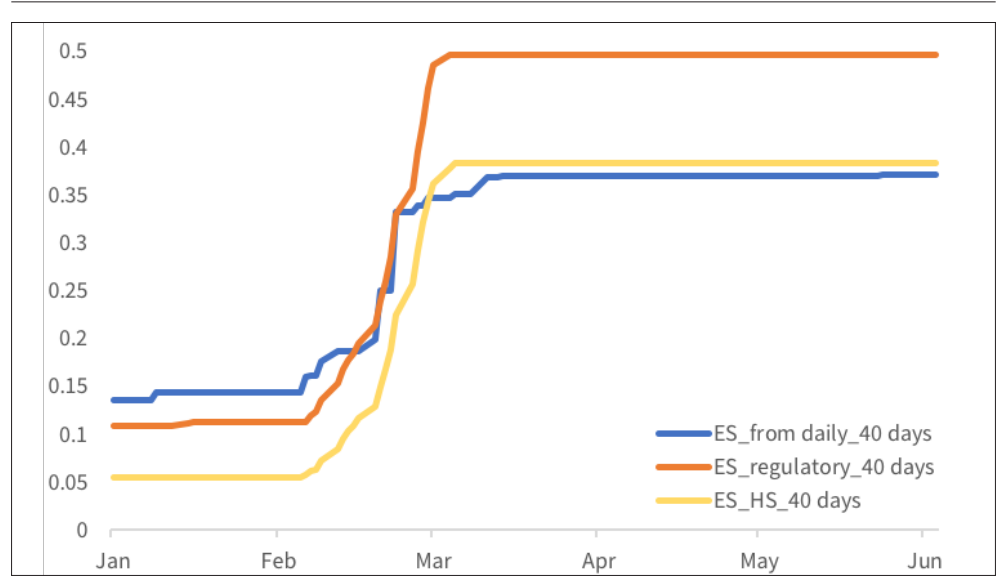

Figure 5 Comparison of three approaches to compute 97.5\% HS ES over 40 trading days, based on FTSE 100

\section{Challenges to the Regulatory Framework}

In the following we consider the current Basel framework for market risk calculations, with a focus on the risk horizons considered in these assessments. As specified by the regulation, different risk horizons are applied to different categories of risk factors, ranging from 10 days for the most liquid asset classes and up to 120 days for some risk factor categories. Under the current framework, these calculations are based on 10-day ES assessments, and then the 'square root of time' rule is used to compute risk over longer horizons, written as $h$-day ES $=10$-day ES $\mathrm{x} \sqrt{h / 10}$. The question we are asking here is whether this approximation was proved to be correct or not during the recent crisis.

Figure 5 investigates three different approaches to estimate ES of an individual asset, ${ }^{5}$ the FTSE 100 index, over h days: 1 ) in the first approach, the $h$-day ES is calculated based on the daily ES using the 'square root of time' rule, so $h$-day ES $=1$-day ES $\mathrm{x} \sqrt{h} ; 2$ ) in the second approach, we follow the FRTB recommendations and calculate the h-day ES from the 10-day ES estimates (computed from overlapping observations) as $h$-day ES $=10$-day ES $\mathrm{x} \sqrt{h / 10}$, hereafter referred to as the regulatory ES; 3 ) in the third approach we directly use the $h$-day overlapping observations to get $h$-day ES [fig. 5]. We focus on the calculation of 40 -day ES $(h=40)$ at $97.5 \%$ level, considering the above

5 For simplicity, we illustrate the calculation of ES where only one risk factor is considered. 


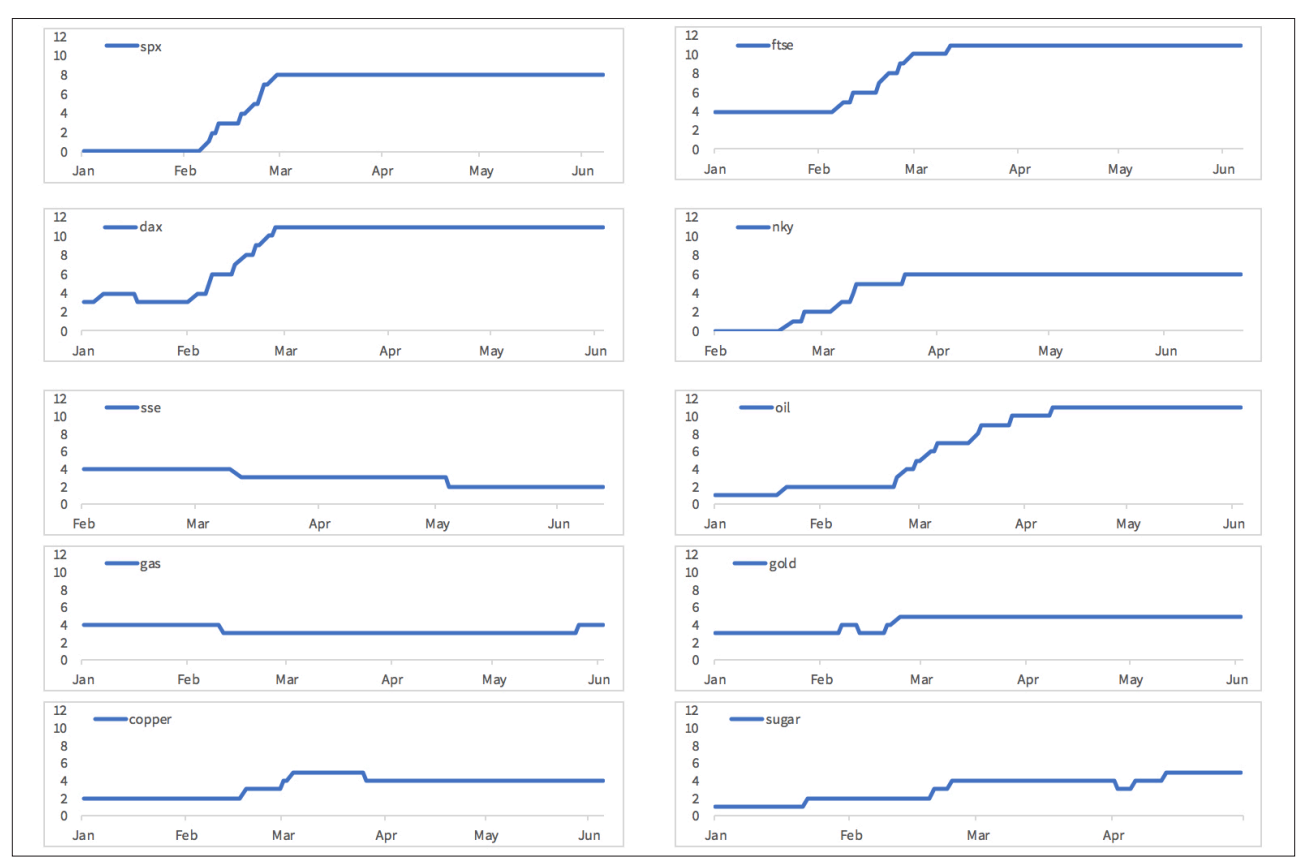

Figure 6 Time-varying number of VaR exceptions (the daily returns being below the negative of the daily HS VaR at 99\%) over a 250 trading day backtesting period

three approaches with the estimates displayed in figure 5. It is to be noted that the regulatory ES (as shown using a red line) overestimates the actual risk (as shown by the yellow line), whilst the approach based on the simple 'square root of time' rule computed from daily ES estimates (as shown by the blue line) gives a better fit. This pattern, which we noticed for other asset classes and for other risk horizons as well, suggests that regulatory capital might overestimate risk in such cases.

Whilst market risk measurement has moved from VaR to ES, backtesting ES is a debating area and the current regulation stipulates VaR backtesting only. As such, the focus is on counting the number of daily VaR exceptions (cases when the daily return is below the negative of daily VaR estimate) over a period of 250 days. Coloured zones are considered, with the green zone applying if the number of exceptions is less than or equal with 5, amber zone when the number of exceptions is more than 10, and yellow zone in between. Different zones carry different levels of multipliers applied for capital calculations.

In figure 6, over a five-month period in early 2020, we show the total number of exceptions of HS VaR, with a backtesting period of 250 trading days specified in the regulatory framework [fig. 6]. Nev- 
ertheless, the major indices (except for the Shanghai Composite index, sse) and oil experienced a steep increase in the number of exceptions between March and April 2020 (with the FTSE, DAX and oil risk estimates in the amber zone), indicating that the Historical Simulation method is unable to accommodate for the extreme market events of early 2020. This shows a weakness of the HS method, and raises a point that needs to be addressed by regulators and financial institutions, namely to improve on the current market risk models.

\section{Looking Ahead}

As the previous sections highlight, some of the challenges in terms of market risk measurement, as a result of the COVID-19 crisis, faced by the regulatory bodies, local jurisdictions, and financial institutions can be summarised as:

1. as a result of the increased values of risk measures, obtained using regulatory calculations, the level of capital requirements rose dramatically, which is a challenge because such high capital needs are very hard to meet; as such, improvements should be made to the risk and capital calculations that would lead to more realistic capital requirements;

2. risk assessments depend on the models used; and the estimated risks can display large variations as a result of this; this model dependence needs to be addressed;

3. risk estimates obtained over longer horizons seem to be affected more by the crisis, as compared to risk estimates obtained over shorter horizons, which is a pattern shown by the majority of assets considered in this study. This highlights that the suitability of the 'square root of time' rule, which is currently stipulated by the regulation, needs more investigation;

4. a typical pattern we found is that market risk calculation based on the current regulatory framework overestimates the actual risk, which leads to the question of how the currently stipulated risk calculations can be improved;

5. the large number of VaR breaches over the first 5 months of the COVID-19 crisis is worrisome; these can be addressed via improved risk calculations, or via improvements in the regulatory framework (e.g. the number of exceptions allowed). 


\section{Conclusions}

As seen above, the events of early 2020 have had devastating consequences globally including serious financial outcomes. In terms of market risks, we found that in general the effects of the COVID-19 crisis were more pronounced for longer horizons. It is vital for financial institutions to do their best to prepare for such events, and for regulators to encourage banks to set aside enough capital for future crises. So, it is important to have an appropriate modelling framework that is able to quickly and appropriately respond to crisis events, whilst leading to realistic and suitable bank capital requirements.

\section{Bibliography}

Acharya, V.V.; Steffen, S. (2020). "The Risk of Being a Fallen Angel and the Corporate Dash for Cash in the Midst of COVID". CEPR COVID Economics, 10. http://pages.stern.nyu.edu/ sternfin/vacharya/public_html/ pdfs/dash-for-cash.pdf.

Aldasoro, I.; Fender, I.; Hardy, B.; Tarashev, N. (2020). "Effects of Covid-19 on the Banking Sector: The Market's Assessment". BIS Bulletin, 12, 7 May. https://www.bis.org/publ/bisbull12.pdf.

Basel Committee on Banking Supervision (1996). Amendments to the Capital Accord to in Corporate Market Risks. Report, January. Bank for International Settlements. http://www.bis.org/publ/bcbs24.pdf.

Basel Committee on Banking Supervision (2019). Minimum Capital Requirements for Market Risk. February. Bank for International Settlements. http://www.bis.org/bcbs/publ/d457.pdf.

Basel Committee on Banking Supervision (2020). Measures to Reflect the Impact of Covid-19. Report, April. Bank for International Settlements. https://www.bis.org/bcbs/publ/d498.pdf.

Borio, C.; Restoy, F. (2020). "Reflections on Regulatory Responses to the Covid-19 Pandemic". FSI Briefs 1, 15 April. https://www. bis.org/fsi/fsibriefs1.htm.

Capelle-Blancard, G.; Desroziers, A. (2020). "The Stock Market and the Economy: Insights from the COVID-19 Crisis". VoxEU, 19 June. https://voxeu.org/article/stock-market-and-economy-insights-covid19-crisis.

Ibikunle, G.; Rzayev, K. (2020). "Grey Rhinos in Financial Markets and Venue Selection: the Case of COVID-19". https://dx.doi.org/10.2139/ssrn.3586410.

Ramelli, S.; Wagner, A.F. (2020). "What the Stock Market Tells Us About the Consequences of COVID-19”. Baldwin, R.; Weder di Mauro, B. (eds), Mitigating the COVID Economic Crisis: Act Fast and Do Whatever. London: CEPR Press, 63-70. https://voxeu.org/content/mitigating-covid-economiccrisis-act-fast-and-do-whatever-it-takes.

Ramelli, S.; Wagner, A.F. (forthcoming). "Feverish Stock Price Reactions to COVID-19". Review of Corporate Finance Studies. 



\section{Part 4}

Financial Markets 



\title{
COVID-19 and the Stock Market
}

\author{
Stefano Ramelli \\ University of Zurich, Switzerland \\ Alexander F. Wagner \\ University of Zurich, Switzerland; Swiss Finance Institute; European Corporate \\ Governance Institute; CEPR
}

\begin{abstract}
When disaster strikes, the weak suffer mightily, the strong only slightly. That is the lesson from stock market reactions to COVID-19. Strong firms had a robust financial position, advanced environmental and social performance, and were not severely exposed to social distancing and lockdowns. Firms with significant international exposure suffered more, at least at first. The ultimate effects of policy interventions, including those by central banks, have yet to be revealed. The market recovery in the second quarter of 2020 is like a patient recovering from COVID-19: hopeful but still uncertain. Managers and policymakers should project the future with great caution.
\end{abstract}

Keywords Stock markets. Tail risk. Industry sectors. COVID-19.

Summary 1 Introduction. - 2 Overall Stock Returns Over Time. -3 What Makes Firms Resilient Against Tail Risks? Learnings from COVID-19. - 4 Policy Interventions and Stock Price Reactions. - 5 What is Behind the Exuberant Second Quarter of 2020? 6 Implications for Business and Public Policy.

\section{Introduction}

The outbreak of COVID-19 took the world economy by surprise. The topic "infectious diseases" was ranked number 10 in terms of impact in the World Economic Forum's Global Risk Report 2020, published on January 15, 2020, but was considered quite unlikely. Only a few weeks later, attention shifted dramatically. On March 11, the World Health Organization characterised COVID-19 as a pandemic. While in the second quarter of 2020 in many 
countries - except notably in the US, Brazil, and some other countries - case and death growth rates had slowed down or reversed, at the end of June 2020, uncertainty is again rising as countries such as China experience new outbreaks and are again considering severe lockdowns. Especially in light of the possibility of a second pandemic wave, it is useful to look back and consider what can be learned from financial market responses to the first wave.

As a tool supporting decisions about public policy interventions but also private sector choices, asset price changes can be extremely valuable. In essence, asset markets provide ongoing, high-stakes surveys regarding future expected outcomes. For corporate decisionmakers, it is especially important to learn from COVID-19 about what makes firms resilient when a tail risk is realised.

Although the focus currently is on COVID-19, it should be stressed that tail risks do exist in various domains. The lessons learnt from this pandemic are likely to be valuable also in the context of other tail risks, for instance those related to climate change or cybersecurity.

This paper begins by reviewing the worldwide stock-market development in section 2 . Section 3 summarises which firms were most affected by the crisis. Section 4 reviews the stock-market based evidence on policy interventions. While virtually all research so far deals with the crisis period of the first quarter of 2020, section 5 provides insights on the recovery phase in the second quarter. Section 6 concludes.

\section{Overall Stock Returns Over Time}

This section documents some facts about the global stock market performance. It is important to distinguish different phases of the crisis. We follow Ramelli and Wagner (forthcoming) for details of the timing and expand the timeline of that study with newer data. Specifically, we organise our primary analysis along four periods: Incubation (Thursday, January 2 through Friday, January 17)1, Outbreak (Monday, January 20 through Friday, February 21)², Fever (Monday, February 24 through Friday, March 20) ${ }^{3}$, and Recovery (Monday, March

We thank an anonymous reviewer for constructive comments.

1 On December 31, 2019, cases of pneumonia detected in Wuhan, China, were first reported to the WHO. On January 1, 2020, Chinese health authorities closed the Huanan Seafood Wholesale Market after it was discovered that wild animals sold there may be the source of the virus.

2 On January 20, Chinese health authorities confirmed human-to-human transmission of the Coronavirus, and the WHO issued the first situation report on the outbreak.

3 On February 23, Italy placed almost 50,000 people under strict lockdown in Lombardy, one of the country's most productive regions. 
23 through June 8). ${ }^{4}$ Obviously, further updates may require the addition of a Relapse phase and other periods.

We retrieve daily stock prices for common shares from the Compustat North America and Compustat Global databases (from Wharton Research Data Services, WRDS). We adjust prices for dividends and stock splits, and we keep only common stocks listed on major stock exchanges in countries covered by the MSCI EQWI index (including both developed and developing countries). ${ }^{5}$ We convert all prices in USD, and we drop firms with less than USD10 million of market capitalisation as of December 31, 2019. We end up with a sample of around 31,200 firms headquartered in 90 different countries.

Figure 1a plots equally-weighted stock returns in USD across countries with at least 50 firms, while figure $1 \mathrm{~b}$ plots the value-weighted ones. ${ }^{6}$ (Figures in local currency are available on request.) Several simple facts emerge. First, most countries saw their average firm decline in value over the almost two quarters under consideration (black bars). Second, the average firm performed best in Poland, Turkey, and Saudi Arabia, and worst in Mexico, South Africa, and Brazil. The best value-weighted performance occurred in Saudi Arabia, Denmark, and China; the worst in South Africa, Greece, and Brazil. Third, every single country experienced negative (positive) equaland value-weighted average returns in the Fever (Recovery) periods [figs. 1a-b].

4 On Monday, March 23, the US Federal Reserve Board (Fed) announced a comprehensive bond purchase program (see § 4). The highest point that the S\&P500 reached in June was obtained on June 8, so we stop this period then.

5 We defined major stock exchanges as in Chaieb, Langlois, Scaillet 2020.

6 We consider both equal- and value-weighted figures because of the recent tendency, at least in some countries, of a pronounced concentration of market values among a few companies. 
Stefano Ramelli, Alexander F. Wagner

COVID-19 and the Stock Market
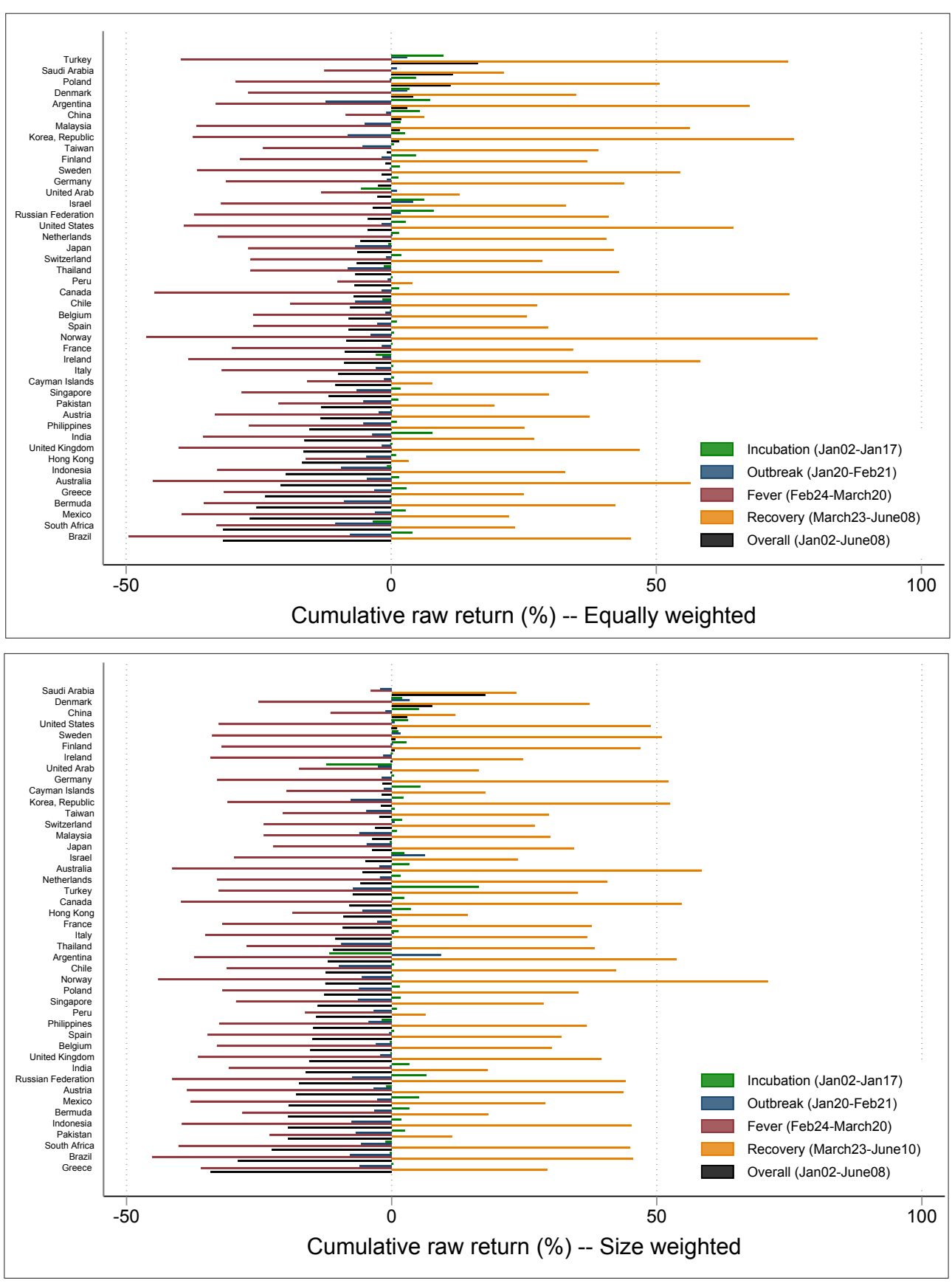

Figures 1a-1b Cumulative returns across the world from January 2 through June 8, 2020 


\section{$3 \quad$ What Makes Firms Resilient Against Tail Risks? Learnings from COVID-19}

Figures 1a and 1b confirm that COVID-19 had a tremendous effect on stock markets. While those figures highlight the average performance, COVID-19 has differentially affected the valuations of companies in the first quarter of 2020.

First, consider industry effects. In Ramelli and Wagner (forthcoming), we show that, in the US, telecom services, food and staples retailing, and utilities performed relatively well. Energy, consumer services, and transportation were among the biggest losers. As an ominous sign that the crisis was at least potentially wide-reaching, in the Fever period consumer services were among the biggest losers, and food and staples retailers were among the strongest winners (again, relatively speaking). The between-industry differences observed in the Fever period intuitively reflect different degrees of disruption in firms' operations caused by social distancing and lockdown measures. ${ }^{7}$ As shown in figure 2, similar considerations also emerge when looking at the between-industry performance in our international sample of firms [fig. 2].

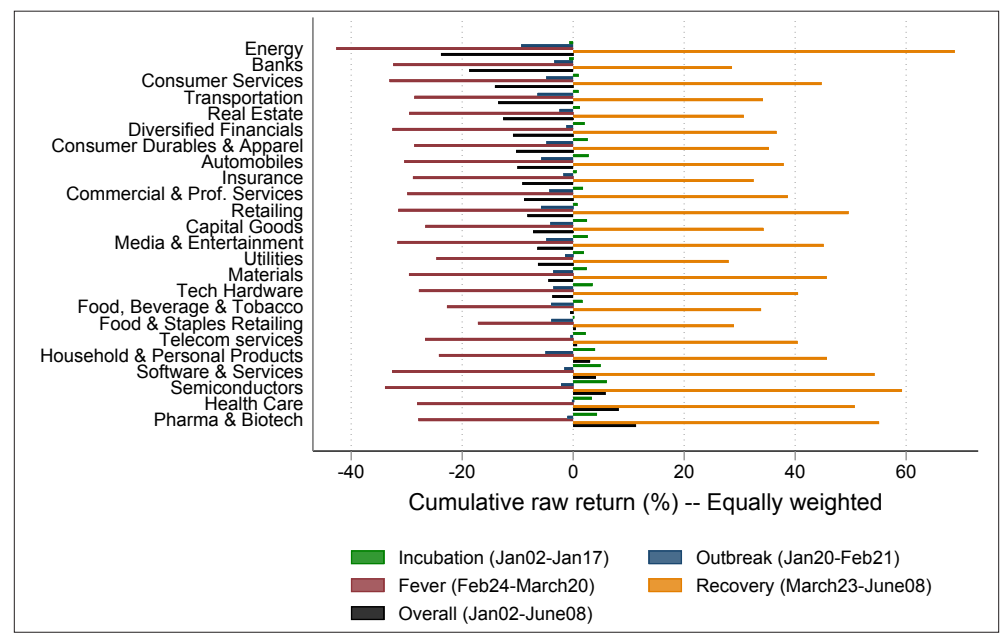

Figure 2 Stock returns by industry, international sample

7 Several measures of the extent to which job activities in different sectors can be carried out from home and without human interaction in physical proximity are now available (Dingel, Neiman 2020; Hensvik, Le Barbanchon, Rathelot 2020; Koren, Pető 2020). See Pagano, Wagner, Zechner 2020 for an analysis. 
Second, especially in the Fever phase concerns about corporate debt (leverage) and corporate liquidity (cash holdings) started to play an important role (Ramelli, Wagner forthcoming). Figure 3 illustrates this result in the international sample, focusing on the return effects of being in the top quartiles of leverage or cash holdings [fig. 3]. Within the same industry and controlling for standard firm characteristics (size, book-to-market, and profitability), highly-indebted firms suffered severely in the Fever period; high-cash firms performed relatively better. Intuitively, high-cash firms are more likely able to survive and to preserve or expand their physical and human capital. ${ }^{8}$ Additionally, from a systemic perspective, the surge in the value of cash also suggests that as the crisis unfolded investors became increasingly concerned about a tightening of firms' access to external finance. The policy measures taken by central banks seek to address this concern; indeed, in the Recovery period, the effects of cash and leverage reversed. See sections 4 and 5 for more on this topic.

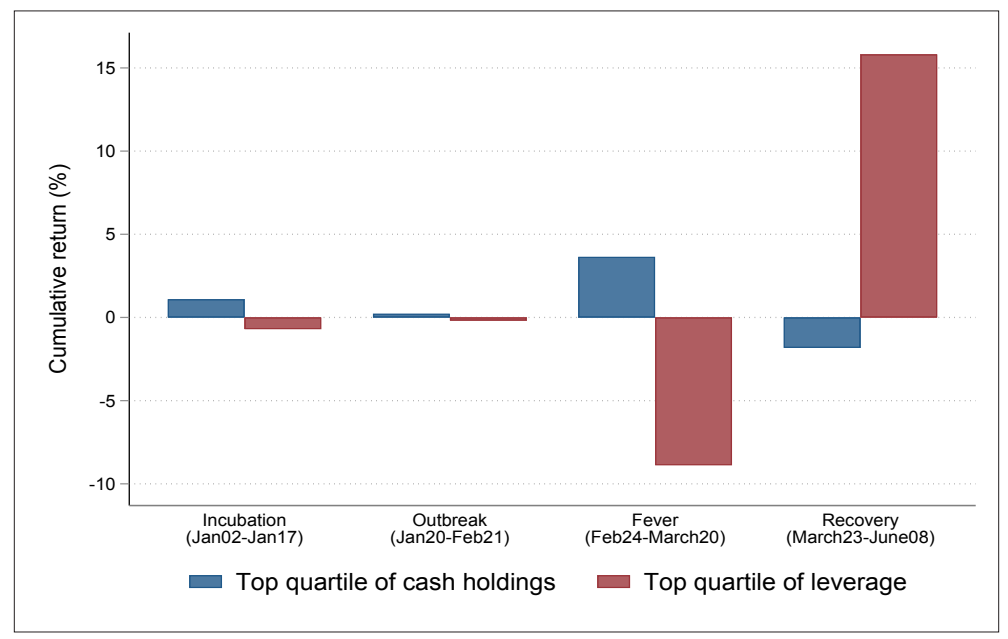

Figure 3 Relative cumulative performance of firms in the top quartile of cash holdings in percent of assets and in the top quartile of leverage, international sample

Third, the role of international trade has received surprisingly little attention. In Ramelli and Wagner (forthcoming), we document that US firms with more export or supply chain exposure to China experienced substantially lower cumulative abnormal returns during the Outbreak period, and to a lesser extent in the Incubation period. et al. (2020) report similar results in international data. 
More generally, internationally-oriented companies did poorly over these periods. Interestingly, when China seemed to get COVID-19 under control, whereas the situation in Europe and the US worsened, the effects reversed. This suggests that a second wave hitting specific countries might again see a drop in the value of firms relatively more exposed to those particular countries.

Fourth, besides 'hard' factors such as the degree of exposure to lockdown measures, financial strength, and reliance on international trade, some 'softer' factors may play an important role. For example, Albuquerque et al. (2020) and Garel and Petit-Romec (2020) document that stocks of firms with high environmental and social (ES) ratings fared better during the market turmoil. Li et al. (2020) show that stocks of firms with a strong corporate culture did better.

One natural question raised by these results is which investors valued which aspects and why. Our early-stage work in Glossner et al. (2020) suggests that institutional investors overall focused on hard measures of financial resilience and did not noticeably increase their stakes in high-ES firms (suggesting that retail investors may have been responsible for the strong performance of these companies).

\section{Policy Interventions and Stock Price Reactions}

Some interventions, such as lockdowns or stay-at-home orders, were directly aimed at containing the spread of the virus. The financial market responses to such interventions have been investigated in a number of studies. The first-order effect is negative for business according to some studies, at least in the short term, though these interventions do reduce infection and death rates (Barrot, Grassi, Sauvagnat 2020). However, because stock returns do respond to daily unanticipated changes in COVID-19 cases (Alfaro et al. 2020), such interventions can also have indirect beneficial effects for businesses (Ashraf 2020; Chen et al. 2020). Further research is needed to clarify the conditions under which interventions are (perceived as) harmful or beneficial to the value of firms.

There were important and novel interventions by central banks. ${ }^{9}$ For example, on Monday, March 23 the US Federal Reserve Board (Fed) announced two new facilities - the "Primary Market Corporate Credit Facility" and the "Secondary Market Corporate Credit Facility" - to support credit to large corporations at least up to the end of

9 The initial intervention by the US Federal Reserve Board to cut interest rates was met with a negative stock market response. Presumably, it was interpreted as a signal that the situation was about to get worse. 
Q3 2020. ${ }^{10}$ On April 9, the Fed expanded those programs. ${ }^{11}$ Considering short-term corporate bond reactions, D'Amico, Kurakula and Lee et al. (2020), Haddad, Moreira and Muir (2020) and Nozawa and Qiu (2020) find evidence in line with the notion that the Fed's actions enhanced overall economic prospects and thus reduced default risk of borrowers. ${ }^{12}$ In Ramelli and Wagner (forthcoming), we find differentiated effects of the March 23 announcement. Stocks with high leverage and low cash-holdings initially benefited, but after ten days, the effect had reversed. Investors' concerns about corporate leverage and liquidity seem to have diminished somewhat after April 9, when the Fed announced a significant expansion of its programs. One difficulty in assessing the impacts of these measures is that there was also news about the spread of COVID-19, which would work against the potential positive effects of the Fed's intervention. The future will reveal the long-term effects of these interventions. ${ }^{13}$

There were also fiscal policy interventions. For example, Ashraf (2020) finds a neutral effect of income and debt relief support to households, whereas K.J. Heyden and T. Heyden (2020) find that the announcement of country-specific fiscal policy measures has negative effects on stock returns. Future research should investigate under which conditions such programs may have positive effects, and how different firms were affected by these various types of interventions. ${ }^{14}$

Finally, appropriate political communication is likely to have played a major role. ${ }^{15}$ Uncertainty plays a key role in the market response (Gormsen, Koijen 2020; Landier, Thesmar 2020). Political credibility and clear communication are key to reduce uncertainty on both the pandemic and the policy responses, and hence, in turn, to also support the proper functioning of financial markets.

10 https://www.federalreserve.gov/newsevents/pressreleases/monetary20200323b.htm.

11 https://www.federalreserve.gov/newsevents/pressreleases/monetary20200409a.htm.

12 Brunnermeier and Krishnamurthy (2020) provide a theoretical analysis.

13 Although large central banks' interventions in the corporate debt and equity markets can certainly help listed corporations accessing external capital, they may also have unintended effects in terms of pricing distortion. See, for instance, Barbon, Gianinazzi 2019

14 For example, as described in Wagner, Zeckhauser, and Ziegler (2020), various provisions of the Tax Cuts and Jobs Act that had been relevant to stock price responses at the implementation of that Act were rolled back or altered by the CARES Act.

15 Coibion, Gorodnichenko and Weber (2020) provide survey evidence that household beliefs and spending plans do not appear to be affected much by policy responses. Interestingly, Hanspal, Weber and Wohlfart (2020) show that the stock market crash severely affected expectations of households, for example, regarding retirement age. Thus, tangible, realised losses do appear to shift household expectations. It will be interesting to see whether these expectations reverse as well as the market in the second quarter. 


\section{What is Behind the Exuberant Second Quarter of 2020?}

The first quarter of 2020 saw extreme uncertainty and steep stock market declines. The real economy entered a state of emergency, unemployment soared in many countries, corporate earnings proved dismal, and double-digit percentage GDP drops never seen before occurred. Yet, in the Recovery period the stock market rose virtually everywhere.

Large stock price reversals were common across firms, as figure 4 illustrates. This figure is a binned scatter plot. We sort all 29,465 international firms for which data is available into 100 equal-sized bins of cumulative returns in the Fever period. The vertical axis plots the average cumulative returns in the Recovery period within each bin. The stock returns in the Recovery period strongly negatively correlate to those in the Fever period. Interestingly, companies that had small negative or even positive returns did not on average experience such a reversal [fig. 4].

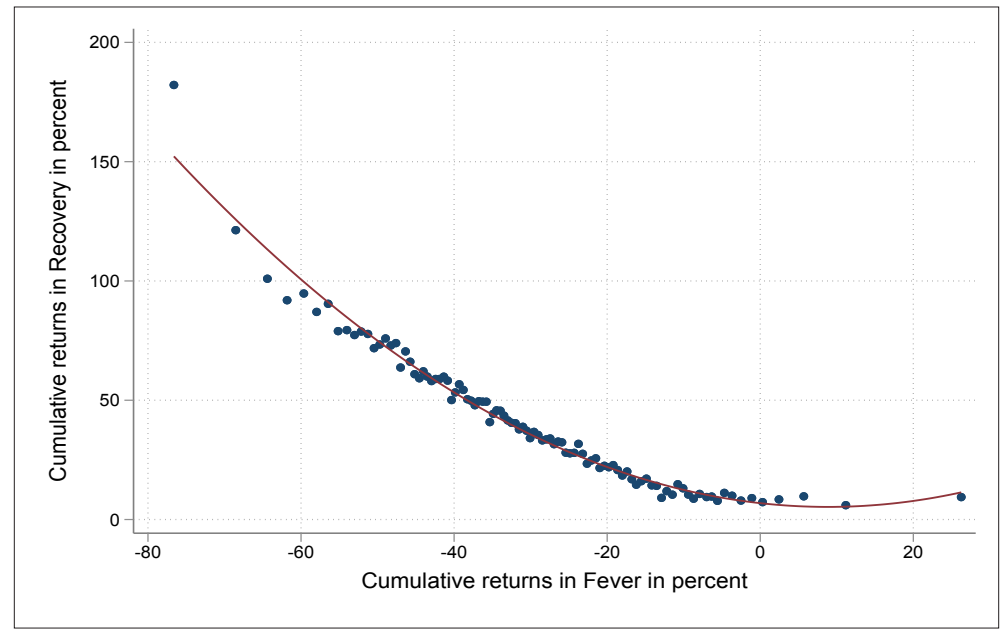

Figure 4 Returns in Fever and the Recovery Periods

How should one interpret the extraordinary market performance in the second quarter and the pattern in figure 4? This question will surely spur substantial future research. In the following, we suggest a few possible explanations which might be worth further investigating (and which may not be mutually exclusive).

First, suppose that investors genuinely expected the worst to be over, and hence inferred that valuations at the end of the second quarter should be back to their pre-crisis levels (or slightly higher, 
as investors also need to earn their cost of capital). Simple arithmetic then yields a shape consistent with the one plotted in figure $4 .{ }^{16}$ Intuitively, a stock that falls by $50 \%$ has to rise by $100 \%$ to get back to the initial level, whereas a stock that falls by $10 \%$ only has to rise by $11.1 \%$. Notice that for this Recovery Arithmetic to be a candidate explanation, investors would need to see both expected future cash flows and uncertainty at similar levels as in the pre-crisis period. While it is plausible that discount factors substantially declined during the second quarter, general macroeconomic forecasts remain dismal in many countries.

Second, figure 4 shows that the few firms that had been winners in the Fever period and had exhibited positive returns do not, in fact, on average show negative returns in the Recovery period (as they would under the Recovery Arithmetic). This finding may reflect sustained and structural changes in the economy and in how we live and work, which give especially certain technology companies enormous advantages.

Third, the medium-term stock price reaction to the Fed's intervention announcements may drive the returns. In other words, the Fed is providing enormous liquidity and is indirectly supporting also firms that did not suffer that much in the Fever period. (There is no official distinction by industry in the Fed's bond purchase programs, for example.) This would also imply that there is distortion in market prices away from fundamentals.

Fourth, the Recovery returns may be driven by individual investors, who may have 'bought the dip' gambling on the rebound of stock prices perhaps amplified by a prolonged intervention of the Fed into capital markets. ${ }^{17}$

In work in progress, we are seeking to distinguish these explanations, in particular with the goal of determining the relative importance of fundamentals versus liquidity provided by central banks in driving assets prices.

16 Consider a stock with an annual cost of equity of $\mathrm{k} \%$. Suppose for simplicity that the stock pays no dividend. Roughly, we would expect a price appreciation for that stock for the first two quarters of $0.5 * \mathrm{k} \%$. Suppose the stock price change in the first quarter (or in the Fever period, assuming things were flat before) was f\% (where for most stocks, $\mathrm{f}<0$ ). Then, to get to the expected price target by the end of $\mathrm{Q} 2$, the stock price change in the Recovery period would need to be $\mathrm{r}=(1+0.5 * \mathrm{k}) /(1+\mathrm{f})$. Plotting this relationship with $\mathrm{r}$ on the vertical axis and $\mathrm{f}$ on the horizontal axis yields a non-linear relationship such as figure 4 .

17 In Glossner et al. (2020) we find that investors on "Robinhood" (a low-cost platform increasingly popular among retail investors) tended to increase holdings in high-leverage and low-cash holdings during the first quarter of 2020. Thus, these investors targeted companies that suffered heavily in the Fever period; conversely, they may, therefore, have done very well in the Recovery period. 


\section{Implications for Business and Public Policy}

It is far too early to declare that an end is in sight for the COVID-19 pandemic. While the stock market, as a forward-looking device, has been sending positive signals through the steep rise in the second quarter of 2020, valuations remain tenuous. A resurgence of uncertainty may lead to another round of sharp drops in equity markets. Thus, it is not clear whether the second quarter was indeed a sustainable recovery, or just a temporary phase before a heavy relapse or perhaps even a devastating collapse.

Regardless, for corporate decision-makers and policy-makers, some lessons of the first quarter 2020 are already clear. A powerful driver of corporate resilience - which, in turn, helps also to secure jobs and sustain the broader economy - has been a sufficiently strong financial position before the pandemic hit. Worryingly, the COVID-19 crisis is leading to a substantial increase in both corporate and public debt, which will potentially exacerbate the existing fragilities of the financial markets. A critical policy objective will be to find new ways to reduce these fragilities.

\section{Bibliography}

Albuquerque, R.A.; Koskinen, Y.; Yang, S.; Zhang, C. (2020). "Resiliency of Environmental and Social Stocks: An Analysis of the Exogenous COVID-19 Market Crash". European Corporate Governance Institute - Finance Working Paper No. 676/2020. https://dx.doi.org/10.2139/ssrn.3583611.

Alfaro, L.; Chari, A.; Greenland, A.N.; Schott, P.K. (2020). "Aggregate and FirmLevel Stock Returns During Pandemics, in Real Time”. NBER Working Paper No 26950. https://www.nber.org/papers/w26950.

Ashraf, B.N. (2020). "Economic Impact of Government Interventions During the COVID-19 Pandemic: International Evidence from Financial Markets". Journal of Behavioral and Experimental Finance, 27, 100371. https://doi. org/10.1016/j.jbef.2020.100371.

Barbon, A.; Gianinazzi, V. (2019). "Quantitative Easing and Equity Prices: Evidence from the ETF Program of the Bank of Japan”. Review of Asset Pricing Studies, 9, 210-55. https://doi.org/10.1093/rapstu/raz००8.

Barrot, J-N.; Grassi, B.; Sauvagnat, J. (2020). "Estimating the Costs and Benefits of Mandated Business Closures in a Pandemic". CEPR Discussion Paper No. DP14757.

Brunnermeier, M.; Krishnamurthy, A. (2020). "Corporate Debt Overhang and Credit Policy”. Brookings Papers on Economic Activity June 25, 2020. https://www.brookings.edu/wp-content/uploads/2020/०6/Brunnermeier-Krishnamurthy-conference-draft.pdf.

Chaieb, I.; Langlois, H.; Scaillet, O. (2020). "Factors and Risk Premia in Individual International Stock Returns". Swiss Finance Institute Research Paper No. 18-04. https://dx.doi.org/10.2139/ssrn.3103752. 
Chen, C.; Dasgupta, S.; Huynh, T.D.; Xia, Y. (2020). "Were Stay-at-Home Orders During Covid-19 Harmful for Business? - The Market's View". https:// cepr.org/content/covid-economics-vetted-and-real-timepapers-๑.

Coibion, O.; Gorodnichenko, Y.; Weber, M. (2020). "Does Policy Communication during COVID Work?". https://cepr.org/content/covid-economicsvetted-and-real-time-papers- $\odot$.

D'Amico, S.; Kurakula, V.; Lee, S. (2020). "Impacts of the Fed Corporate Credit Facilities through the Lenses of ETFs and CDX". Federal Reserve Bank of Chicago, Working paper 2020-14. https://doi.org/10.21033/wp-2020-14.

Ding, W.; Levine, R.; Lin, C.; Xie, W. (2020). "Corporate Immunity to the COVID-19 Pandemic". Working paper. http://dx.doi.org/10.2139/ssrn.3578585.

Dingel, J.I.; Neiman, B. (2020). "How Many Jobs Can be Done at Home?". Becker Friedman Institute, White Paper. https://bfi.uchicago.edu/wp-content/uploads/BFI_White-Paper_Dingel_Neiman_3.2020.pdf.

Fahlenbrach, R.; Rageth, K.; Stulz, R.M. (2020). "How Valuable is Financial Flexibility when Revenue Stops? Evidence from the COVID-19 Crisis". NBER Working Paper No. 27106. https://www.nber.org/papers/w27106.

Garel, A.; Petit-Romec, A. (2020). "Investor Rewards to Environmental Responsibility: Evidence from the COVID-19 Crisis". https://cepr.org/content/ covid-economics-vetted-and-real-time-papers- $\odot$.

Glossner, S.; Matos, P.; Ramelli, S.; Wagner, A.F. (2020). "Where Do Institutional Investors Seek Shelter When Disaster Strikes? Evidence from COVID-19". https://papers.ssrn.com/sol3/papers.cfm?abstract_ id $=3655271$.

Gormsen, N.J.; Koijen, R.S.J. (2020). "Coronavirus: Impact on Stock Prices and Growth Expectations”. NBER Working Paper No. 27387. https://www. nber.org/papers/w27387.

Haddad, V.; Moreira, A.; Muir, T. (2020). When Selling Becomes Viral: Disruptions in Debt Markets in the COVID-19 Crisis and the Fed's Response". NBER Working Paper No. 27168. https://www.nber.org/papers/w27168.

Hanspal, T.; Weber, A.; Wohlfart, J. (2020). "Exposure to the Covid-19 Stock Market Crash and Its Effect on Household Expectations". SAFE Working Paper No. 279. https://dx.doi.org/10.2139/ssrn.3577217.

Hensvik, L.; Le Barbanchon, T.; Rathelot, R. (2020). "Which Jobs Are Done from Home? Evidence from the American Time Use Survey". IZA Discussion Paper No. 13138. https://www.iza.org/publications/dp/13138.

Heyden, K.J.; Heyden, T. (2020). "Market Reactions to the Arrival and Containment of COVID-19: An Event Study". Working paper. https://dx.doi. org/10.2139/ssrn.3587497.

Koren, M.; Petö, R. (2020). "Business Disruptions from Social Distancing". https://arxiv.org/abs/2003.13983v1.

Landier, A.; Thesmar, D. (2020). "Earnings Expectations in the COVID Crisis". NBER Working Paper No. 27160. https://www.nber.org/papers/ W27160.

Li, K.; Liu, X.; Mai, F.; Zhang, T. (2020). "The Role of Corporate Culture in Bad Times: Evidence from the COVID-19 Pandemic”. Working paper. https:// dx.doi.org/10.2139/ssrn.3632395. 
Nozawa, Y.; Qiu, Y. (2020). “The Corporate Bond Market Reaction to Quantitative Easing During the COVID-19 Pandemic". Working paper. https:// dx.doi.org/10.2139/ssrn.3579346.

Pagano, M.; Wagner, C.; Zechner, J. (2020). "Disaster Resilience and Asset Prices". CSEF Working Paper No. 563. http://www.csef.it/WP/wp563.pdf.

Ramelli, S.; Wagner, A.F. (forthcoming). "Feverish Stock Price Reactions to COVID-19". Review of Corporate Finance Studies.

Wagner, A.F.; Zeckhauser, R.J.; Ziegler, A. (2020). "The Tax Cuts and Jobs Act: Which Firms Won? Which Lost?”. HKS Working Paper No. RWP20-018. https://www.hks.harvard.edu/publications/tax-cuts-and-jobsact-which-firms-won-which-lost\#citation.

World Economic Forum (2020). "The Global Risks Report 2020". January 15. https://www.weforum.org/reports/the-global-risks-report-2020. 



\title{
Stock Performance \\ When Facing the Unexpected
}

Alfonso Dufour

ICMA Centre, Henley Business School, University of Reading, UK

\begin{abstract}
The COVID-19 crisis has had enormous costs. The effects on financial markets were exacerbated by panic, fear of the unknown, fear of the end of the world as we knew it. This panic obfuscated our ability to make rational predictions on future cash flows and asset values. Overall though, our economic system is bouncing back. We can learn from this experience and build more flexible models which can help us to better manage severe systemic risks.
\end{abstract}

Keywords COVID-19. Equity market performance. CAPM. Beta. Volatility.

Summary 1 Introduction. -2 The Perfect Storm: Panic and Uncertainty. -3 The Timeline of the COVID-19 Pandemic. - 4 The Effects of the COVID-19 Crisis on Equity Markets. 5 Industry Groups. -6 The Prediction of Financial Models (CAPM Beta). - 7Conclusions.

\section{Introduction}

This crisis has had huge costs in terms of human lives lost, great physical and psychological suffering caused either directly by the disease or indirectly by the drastic measures adopted to contain the spread of the virus. This pandemic will have enduring consequences on the world population, the economy, our societies, the environment, and the financial systems. Notwithstanding the enormity of the physical and psychological pain caused by the virus, in this chapter 1 only reflect on the effects of the COVID-19 pandemic on the equity markets. Financial markets, more generally, provide an essential price discovery function. They aggregate demand and supply for assets and prod- 
ucts and help us discover the value of these assets and products so that we can properly allocate resources to particular projects, sectors/industries and enterprises.

\section{The Perfect Storm: Panic and Uncertainty}

To assess the level of panic in the equity markets due to the COVID-19 pandemic we can refer to two major volatility indices: the VIX (CBOE Volatilty Index) in the US and the Vstoxx (Euro Stoxx 50 Volatility Index) in Europe. These are the indices for the level of volatility implied from option contracts on major equity indices, the S\&P 500 and the Euro Stoxx 50 in the US and Europe, respectively. The VIX and the Vstoxx are often referred to as fear gauges capturing the level of uncertainty in financial markets. Over the last 20 years, these indices had two major peaks which reflect episodes of extremely high levels of uncertainty in the financial markets. The first peak was in October 2008 during the credit crisis, and the second was in March 2020 when the Western world went into lockdown.

In mid-March 2020, the announcement of drastic restrictive measures by US authorities precipitated the crisis. Market participants realised that the COVID-19 pandemic was not going to be confined to Asia. It had already started showing the first signs of potentially devastating effects on Western economies and the lockdown increased the likelihood of the most catastrophic scenarios. As the graphs in figure 1 show, the US markets became even more fearful of the effects of the pandemic on equity values than what they were at the time of the credit crisis [fig. 1]. Perhaps this is because the pandemic severely affected New York, the main US financial centre. In Europe instead, financial markets reflected a relatively greater level of uncertainty during the financial crises. The pandemic created havoc in Italy and Spain sparing, at first, Europe's main financial centres such as London, Frankfurt, and Paris. With so much fear and uncertainty markets do not function well in discovering asset prices.

\section{The Timeline of the COVID-19 Pandemic}

So, how and when did it all begin? A new mysterious virus was first reported by Chinese authorities to the World Health Organisation (WHO) on December 31, 2019, although now scientists believe the virus was already circulating in China since November 2019. Despite the drastic containment measures taken by the Chinese authorities to try to limit the contagion, unfortunately the virus spread to other countries in South East Asia. The virus was showing unexpected strength and high infection rates which could yield high mortality rates. By the end 

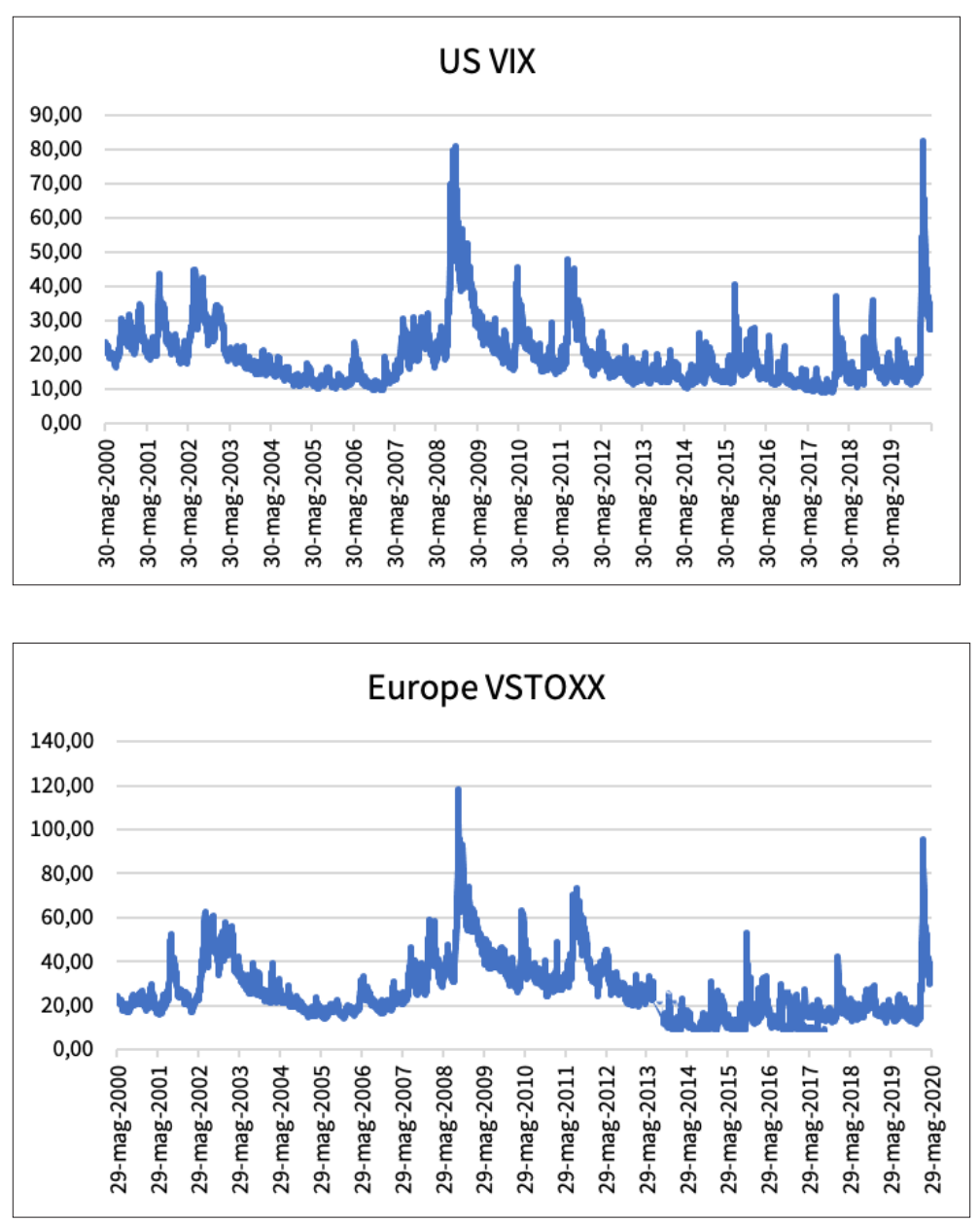

Figure 1 The volatility indices. This figure presents the time series for the daily values of the VIX and the VSTOXX indices from 29 May 2000 to 30 May 2020. The data were downloaded from the Thompson Reuters Eikon platform 
of January, the virus had spread to 18 countries outside China. On January 30, 2020, the WHO officially declared the status of International Health Emergency. This declaration triggered a series of health procedures and travel restrictions across the world. On February 11, 2020, the WHO named the new coronavirus as COVID-19. On March 11,2020 , the WHO declared the outbreak of a global pandemic. ${ }^{1}$

The first western country to enter into a national lockdown was Italy on March 10, 2020. On March 13, 2020, President Trump declared a national emergency initiating a series of government response procedures. ${ }^{2}$ In the following days, a number of other European countries adopted restrictive measures and on March 23, 2020 the UK also entered into a national lockdown. ${ }^{3}$ In the US, the first "stay at home" order was issued by California on March 19, 2020. ${ }^{4}$ Although a US-wide lockdown was never implemented, most states adopted restrictive measures. $^{5}$

\section{The Effects of the COVID-19 Crisis on Equity Markets}

The Italian, UK and US stock markets started a rapid decline on February 20, 2020 when the new virus was rapidly spreading across Europe and the US [fig. 2]. The Italian equity market suffered the steepest fall and reached the lowest level on March 12, 2020 [fig. 3]. In less than a month, the Italian equity market fell by more than $41 \%$. It took a bit longer for the US and the UK markets to reach their lowest level. This came on the March 23 when the FTSE 100 Index closed down by almost 200 points for the day.

1 The timeline of the pandemic is based on a report by the World Health Organisation detailing its response to the COVID-19 crisis. The report is available at https:// www.who.int/news-room/detail/29-06-2020-covidtimeline.

2 See for example, https://edition.cnn.com/2020/03/13/politics/states-coronavirus-fema/index.html.

3 On March 9, 2020, the Italian prime minister Giuseppe Conte signed a decree for the implementation of a national lockdown starting from March 10, 2020. Detailed information on the measures implemented by governments in response to the pandemic is provided by Oxford University's COVID-19 Government Response Tracker, which is available at https://www.bsg.ox.ac.uk/covidtracker.

4 See the Executive Order N-33-20 issued by California at https://www.gov.ca.gov/ wp-content/uploads/2020/03/3.19.20-attested-EO-N-33-20-COVID-19-HEALTH-ORDER.pdf

5 A list of the states implementing 'stay at home' orders is available at https://www. nbcnews.com/health/health-news/here-are-stay-home-orders-across-countryn1168736. 


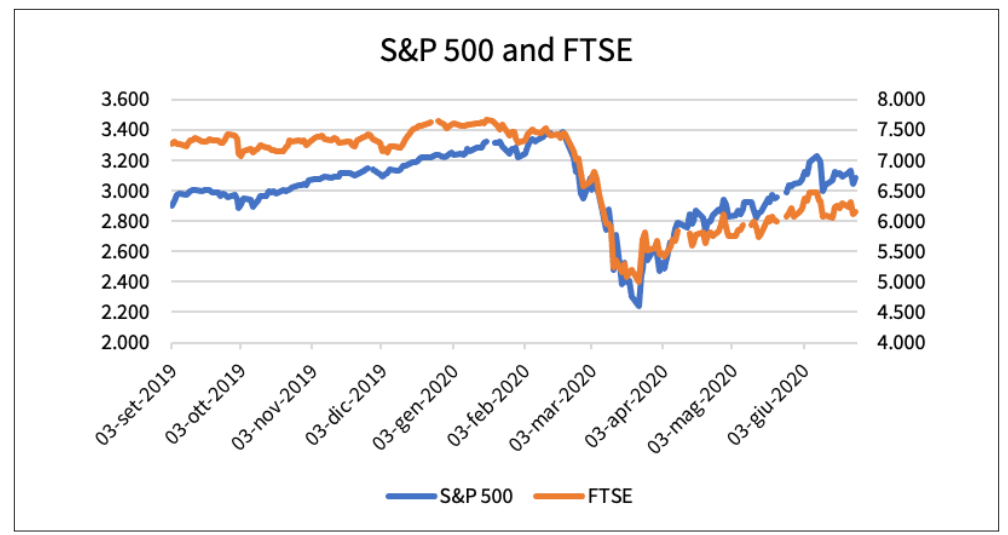

Figure 2 The scale for the S\&P 500 Index is indicated on the left-hand side and the scale for the FTSE 100 index is indicated on the right-hand side. The sample covers the period from September 3, 2019 to June 25, 2020. The data was downloaded from the Thompson Reuters Eikon platform

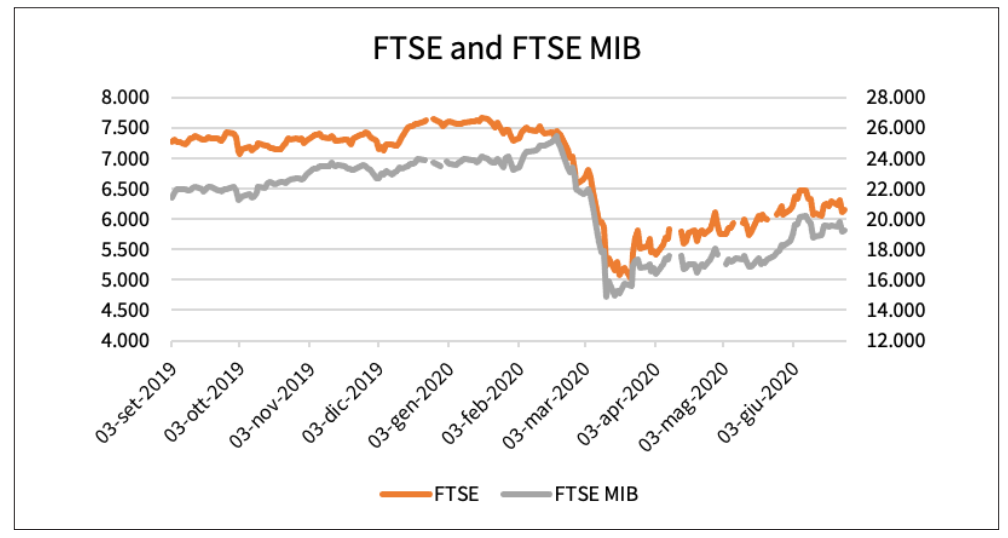

Figure 3 The scale for the FTSE 100 Index is indicated on the left-hand side and the scale for the FTSE MIB index is indicated on the right-hand side. The sample covers the period from September 3, 2019 to June 25, 2020. The data was downloaded from the Thompson Reuters Eikon platform

Over the period from February 19 to March 23, 2020, the UK FTSE 100 index lost about 33\% and the S\&P 500 index about 34\% of their values, respectively. The worst daily price change for the UK equity market was recorded on March 12 when the FTSE 100 Index lost $10.87 \%$ in a single day. This is the largest single-day drop recorded over the last 20 years (since May 30,2000). Table 1 shows the distinct phases of the COVID-19 crisis so far and summarises the changes in the values of the benchmark Italian, UK and US equity indices. 
Table 1 Equity price changes during the COVID-19 crisis

\begin{tabular}{lcccccc}
\hline Country & $\begin{array}{c}\text { Decline } \\
\text { phase }\end{array}$ & $\begin{array}{c}\text { Index } \\
\text { change } \\
(\%)\end{array}$ & $\begin{array}{c}\text { Recovery } \\
\text { phase }\end{array}$ & $\begin{array}{c}\text { Index } \\
\text { change } \\
(\%)\end{array}$ & $\begin{array}{c}\text { Covid-19 } \\
\text { crisis and } \\
\text { recovery } \\
\text { period }\end{array}$ & $\begin{array}{c}\text { Index } \\
\text { change } \\
(\%)\end{array}$ \\
\hline Italy & $\begin{array}{c}\text { Feb 19- } \\
\text { Mar 12, 2020 }\end{array}$ & -41.54 & $\begin{array}{c}\text { Mar 12- } \\
\text { Jun 8, 2020 }\end{array}$ & 30.02 & $\begin{array}{c}\text { Feb 19- } \\
\text { Jun 8, 2020 }\end{array}$ & -20.59 \\
\hline UK & $\begin{array}{c}\text { Feb 19- } \\
\text { Mar 23, 2020 }\end{array}$ & -33.03 & $\begin{array}{c}\text { Mar 23- } \\
\text { Jun 8, 2020 }\end{array}$ & 29.61 & $\begin{array}{c}\text { Feb 19- } \\
\text { Jun 8, 2020 }\end{array}$ & -13.20 \\
\hline USA & Feb 19- & -33.92 & Mar 23- & 44.47 & Feb 19- & -4.54 \\
& Mar 23, 2020 & & Jun 8, 2020 & & Jun 8, 2020 & \\
\hline
\end{tabular}

The equity indices used for Italy, UK and USA are FTSE MIB, FTSE 100 and S\&P 500, respectively. Returns were computed using daily data which was downloaded from the Thompson Reuters Eikon platform.

\section{$5 \quad$ Industry Groups}

The performance of the various industry groups during the decline and recovery phases of the crisis is summarised in tables 2 and 3 below. The industry returns are value-weighted and thus they will be driven by the performance of the largest companies in each sector. In the UK, the transportation industry was the most affected (-63\%). With the lockdown in place, aeroplanes were grounded, international travel stopped almost completely, and most people were housebound. More surprisingly, the media and entertainment industry (WPP, Pearson, etc.) was the second worst performing industry during the decline phase. With many businesses halted by health and safety restrictions, advertising budgets froze, and fairs and exhibitions were cancelled; this hit the UK media industry, which relies almost exclusively on ad revenue. However, in the US the increased demand for news and home entertainment helped online American media companies (Google, Facebook, Walt Disney, etc.) to recover more rapidly than other industries.

Industries providing core and essential services or those that were able to adapt quickly to flexible/distance working conditions suffered lower declines and recovered very quickly (for example, e-commerce, technology, software services). In the US, the retailing (Amazon, Ebay, Dollar General) and technology industries managed to weather the COVID-19 storm better than other industries posting double digit increases in aggregate industry values. 
Alfonso Dufour

Stock Performance when Facing the Unexpected

Table 2 The performance of the FTSE 100 index components by industry groups over the COVID-19 crisis from December 2019 to June 2020

\begin{tabular}{|c|c|c|c|c|c|c|}
\hline \multirow[b]{2}{*}{ FTSE 100 - Industry Groups } & \multicolumn{2}{|c|}{ Decline } & \multicolumn{2}{|c|}{ Recovery } & \multicolumn{2}{|c|}{ Overall } \\
\hline & $\begin{array}{c}1 \text { Jan } \\
-27 \operatorname{Mar} 20(\%)\end{array}$ & Rank & $\begin{array}{l}27 \text { Mar } \\
-26 \text { Jun } 20(\%)\end{array}$ & Rank & $\begin{array}{c}27 \text { Dec } 19 \\
-26 \text { Jun } 20(\%)\end{array}$ & Rank \\
\hline Banks (5) & $-28.11 \%$ & 16 & $-16.74 \%$ & 22 & $-40.86 \%$ & 20 \\
\hline Capital Goods (9) & $-24.95 \%$ & 14 & $9.81 \%$ & 9 & $-19.16 \%$ & 12 \\
\hline $\begin{array}{l}\text { Commercial \& Professional } \\
\text { Services (5) }\end{array}$ & $-8.05 \%$ & 4 & $10.89 \%$ & 8 & $0.72 \%$ & 5 \\
\hline Consumer Durables \& Apparel (5) & $-30.55 \%$ & 18 & $9.11 \%$ & 10 & $-24.02 \%$ & 17 \\
\hline Consumer Services (5) & $-30.87 \%$ & 19 & $5.08 \%$ & 15 & $-28.00 \%$ & 18 \\
\hline Diversified Financials (8) & $-20.28 \%$ & 10 & $11.65 \%$ & 7 & $-11.47 \%$ & 10 \\
\hline Energy (3) & $-35.76 \%$ & 20 & $-7.16 \%$ & 21 & $-41.59 \%$ & 21 \\
\hline Food \& Staples Retailing (3) & $-8.83 \%$ & 5 & $-1.60 \%$ & 19 & $-10.23 \%$ & 9 \\
\hline Food, Beverage \& Tobacco (5) & $-18.77 \%$ & 7 & $6.59 \%$ & 13 & $-14.05 \%$ & 11 \\
\hline $\begin{array}{l}\text { Health Care Equipment \& } \\
\text { Services (1) }\end{array}$ & $-23.47 \%$ & 12 & $6.13 \%$ & 14 & $-20.82 \%$ & 13 \\
\hline Household \& Personal Products (2) & $-6.15 \%$ & 2 & $13.56 \%$ & 6 & $5.63 \%$ & 2 \\
\hline Insurance (6) & $-24.54 \%$ & 13 & $3.07 \%$ & 16 & $-22.50 \%$ & 15 \\
\hline Materials (14) & $-25.54 \%$ & 15 & $23.04 \%$ & 2 & $-8.78 \%$ & 8 \\
\hline Media \& Entertainment (6) & $-38.76 \%$ & 21 & $6.75 \%$ & 12 & $-35.42 \%$ & 19 \\
\hline $\begin{array}{l}\text { Pharmaceuticals, Biotechnology } \\
\text { \& Life Sciences ( } 3 \text { ) }\end{array}$ & $-12.26 \%$ & 6 & $16.83 \%$ & 4 & $0.74 \%$ & 4 \\
\hline Real Estate (3) & $-28.81 \%$ & 17 & $7.35 \%$ & 11 & $-22.27 \%$ & 14 \\
\hline Retailing (5) & $-19.49 \%$ & 8 & $31.95 \%$ & 1 & $7.00 \%$ & 1 \\
\hline Software \& Services (3) & $-19.53 \%$ & 9 & $17.07 \%$ & 3 & $-7.06 \%$ & 7 \\
\hline $\begin{array}{l}\text { Technology Hardware } \\
\text { \& Equipment (1) }\end{array}$ & $-6.76 \%$ & 3 & $14.65 \%$ & 5 & $5.50 \%$ & 3 \\
\hline Telecommunication Services (2) & $-21.00 \%$ & 11 & $-0.92 \%$ & 18 & $-23.47 \%$ & 16 \\
\hline Transportation (1) & $-62.96 \%$ & 22 & $-1.90 \%$ & 20 & $-63.72 \%$ & 22 \\
\hline Utilities (5) & $-1.92 \%$ & 1 & $2.46 \%$ & 17 & $-0.78 \%$ & 6 \\
\hline
\end{tabular}

The table presents cumulative returns for the various industry groups. These are percentage changes in the aggregate value (market capitalisation) of each industry group. The lowest rank is given to the best performing industry group during each phase. The best 5 performing industries are coloured in green and the worst 5 in red. The data was downloaded from the Thompson Reuters Eikon platform. 
Alfonso Dufour

Stock Performance when Facing the Unexpected

Table 4 The performance of the S\&P 500 index components by industry groups over the COVID-19 crisis from December 2019 to June 2020

\begin{tabular}{|c|c|c|c|c|c|c|}
\hline \multirow[b]{2}{*}{ S\&P 500 - Industry Groups } & \multicolumn{2}{|l|}{ Decline } & \multicolumn{2}{|c|}{ Recovery } & \multicolumn{2}{|l|}{ Overall } \\
\hline & $\begin{array}{c}1 \text { Jan } 20 \\
-27 \operatorname{Mar} 20(\%)\end{array}$ & Rank & $\begin{array}{c}27 \text { Mar } \\
-26 \text { Jun } 20(\%)\end{array}$ & Rank & $\begin{array}{c}27 \text { Dec } 19 \\
-26 \text { Jun } 20(\%)\end{array}$ & Rank \\
\hline Automobiles \& Components (4) & $-40.92 \%$ & 23 & $19.74 \%$ & 8 & $-29.66 \%$ & 22 \\
\hline Banks (18) & $-36.59 \%$ & 22 & $4.43 \%$ & 23 & $-34.05 \%$ & 23 \\
\hline Capital Goods (48) & $-25.28 \%$ & 18 & $8.63 \%$ & 18 & $-19.33 \%$ & 20 \\
\hline $\begin{array}{l}\text { Commercial \& Professional } \\
\text { Services (10) }\end{array}$ & $-16.69 \%$ & 12 & $16.55 \%$ & 10 & $-2.54 \%$ & 7 \\
\hline $\begin{array}{l}\text { Consumer Durables \& Apparel } \\
\text { (18) }\end{array}$ & $-27.58 \%$ & 19 & $17.97 \%$ & 9 & $-14.38 \%$ & 17 \\
\hline Consumer Services (15) & $-31.48 \%$ & 21 & $8.29 \%$ & 19 & $-26.14 \%$ & 21 \\
\hline Diversified Financials (26) & $-21.56 \%$ & 15 & $10.47 \%$ & 15 & $-13.64 \%$ & 16 \\
\hline Energy (26) & $-48.69 \%$ & 24 & $22.92 \%$ & 5 & $-37.03 \%$ & 24 \\
\hline Food \& Staples Retailing (5) & $-9.27 \%$ & 3 & $6.07 \%$ & 21 & $-4.19 \%$ & 9 \\
\hline Food, Beverage \& Tobacco (21) & $-17.37 \%$ & 13 & $7.96 \%$ & 20 & $-10.68 \%$ & 14 \\
\hline $\begin{array}{l}\text { Health Care Equipment \& } \\
\text { Services (38) }\end{array}$ & $-16.68 \%$ & 11 & $13.76 \%$ & 12 & $-5.39 \%$ & 10 \\
\hline Household \&Personal Products (7) & $-12.57 \%$ & 6 & $10.81 \%$ & 14 & $-3.19 \%$ & 8 \\
\hline Insurance (22) & $-28.04 \%$ & 20 & $12.01 \%$ & 13 & $-19.09 \%$ & 19 \\
\hline Materials (28) & $-25.13 \%$ & 17 & $20.32 \%$ & 7 & $-9.83 \%$ & 12 \\
\hline Media \& Entertainment (22) & $-15.69 \%$ & 10 & $24.63 \%$ & 3 & $3.64 \%$ & 5 \\
\hline $\begin{array}{l}\text { Pharmaceuticals, Biotechnology } \\
\text { \& Life Sciences (24) }\end{array}$ & $-12.36 \%$ & 5 & $14.57 \%$ & 11 & $0.04 \%$ & 6 \\
\hline Real Estate (31) & $-19.15 \%$ & 14 & $9.89 \%$ & 17 & $-10.38 \%$ & 13 \\
\hline Retailing (24) & $-7.63 \%$ & 2 & $34.48 \%$ & 1 & $23.31 \%$ & 1 \\
\hline $\begin{array}{l}\text { Semiconductors \& } \\
\text { Semiconductor Equipment (16) }\end{array}$ & $-12.03 \%$ & 4 & $22.04 \%$ & 6 & $6.62 \%$ & 4 \\
\hline Software \& Services (35) & $-7.08 \%$ & 1 & $23.14 \%$ & 4 & $13.73 \%$ & 3 \\
\hline $\begin{array}{l}\text { Technology Hardware \& } \\
\text { Equipment (20) }\end{array}$ & $-14.27 \%$ & 9 & $32.43 \%$ & 2 & $14.56 \%$ & 2 \\
\hline Telecommunication Services (4) & $-13.90 \%$ & 7 & $5.28 \%$ & 22 & $-9.18 \%$ & 11 \\
\hline Transportation (15) & $-23.11 \%$ & 16 & $10.26 \%$ & 16 & $-15.92 \%$ & 18 \\
\hline Utilities (28) & $-14.25 \%$ & 8 & $0.64 \%$ & 24 & $-13.07 \%$ & 15 \\
\hline
\end{tabular}

The table presents cumulative returns for the various industry groups. These are percentage changes in the aggregate value (market capitalisation) of each industry group. The lowest rank is given to the best performing industry group during each phase. The best 5 performing industries are coloured in green and the worst 5 in red. The data was downloaded from the Thompson Reuters Eikon platform. 
The share prices of US and European banks have been falling significantly since the beginning of the COVID-19 crisis as investors have been fearing that the disruption to business caused by the lockdown may increase default rates on bank loans, while continuing monetary stimulus may keep interest rates low, thus hurting banks' margins and profitability. In addition, regulators have urged banks to freeze dividend payments to shareholders and strengthen their core capital so that they would be able to absorb larger than expected losses in their loan portfolios.

Another industry hit hard by the pandemic has been the energy industry. The travel restrictions and the lockdown created a sharp fall in the demand for oil. Such a deep and sudden negative demand shock combined with a relatively sticky supply created the perfect storm with devastating effects on oil prices. The negative pressure on oil prices was amplified by the delays in finding an agreement among oil-producing countries on the appropriate, joint response to dwindling energy demand. Thus, the excess oil supply led to increases in oil inventories and a sharp fall in oil prices. All available storage was full and sellers had to pay buyers to take oil off their hands. Oil was cheap but the cost of storage had surged. On Monday April 20, 2020, the light crude oil contract trading on the New York Mercantile exchange reached a minimum of about negative $\$ 40$ per barrel. This created a problem. Traditionally, financial models assume that asset prices do not go below the zero level. Thus, how do we price an asset with negative prices? Financial markets had to scramble and implement ad-hoc models to allow commodity prices to reach negative values. ${ }^{6}$

\section{The Prediction of Financial Models (CAPM Beta)}

Usually, our financial models would suggest taking refuge in defensive stocks during downturns and then shifting to more aggressive stocks during the rebound. Stocks would be classified using the beta coefficient of the Capital Asset Pricing Model (CAPM) which indicates how correlated and sensitive a particular stock is to movements in the whole financial market. Low beta stocks (with beta less than 1) are often called defensive stocks. They have more stable performance and relatively lower volatility. Whereas, high beta stocks (with beta greater than 1) are called aggressive stocks. These are riskier but can potentially deliver higher returns. How did so-called

6 See the note released by the CME on April 8, 2020 at https://www.cmegroup.com/ content/dam/cmegroup/notices/clearing/2020/04/Chadv20-152.pdf. Eventually, on 22 April 2020, CME Clearing adopted the Bachelier Option Pricing Model (https://

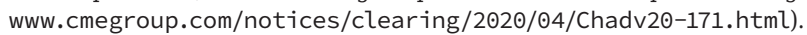


defensive stocks perform during the declining phase of the pandemic? Did the market behave as expected supporting financial theories or instead provided further evidence of the limitations of existing financial models and thus calling for new theories to be developed?

I used industry CAPM beta coefficients computed by Aswath Damodaran in January 2020 for US stocks and related them to cumulative stock returns during the two main phases of the COVID-19 pandemic. ${ }^{7}$ Figure 4 shows scatter plots relating cumulative returns for the stocks included in the S\&P 500 index with their industry beta during the decline and recovery phases of the COVID-19 pandemic [fig. 4]. The scatter plots also show the trend line which summarises the relationships between cumulative returns and CAPM betas.

The CAPM model worked very well during the recovery phase when high beta stocks clearly bounced back more rapidly than low beta stocks posting high cumulative returns. This evidence seems consistent with the more rigorous work conducted by Savor and Wilson (2014) which shows how on days with macroeconomic announcements there is a strong positive relation between average returns and stock betas as predicted by the CAPM model. On other days though, the same relationship does not hold. Hence, our financial models seem to work well during the recovery phase of the crisis as well as on announcement days because, as Savor and Wilson (2014) note, in these days there is "a clear link between macroeconomic risk and asset returns". When traders are driven by panic and fear instead, our traditional models based on long-term expectations and rational behaviour break down. The return-risk relationship observed during the decline phase is almost flat. Thus, the intuition of investing in defensive stocks might have just marginally limited investment losses. This preliminary evidence seems to support Lopez de Prado (2019)'s call for the development of more flexible models which are optimal under different regimes and market conditions.

7 The CAPM beta data is available at http://people.stern.nyu.edu/adamodar/New_ Home_Page/datacurrent.html. The cumulative returns were computed using data downloaded from the Thompson Reuters Eikon platform. 

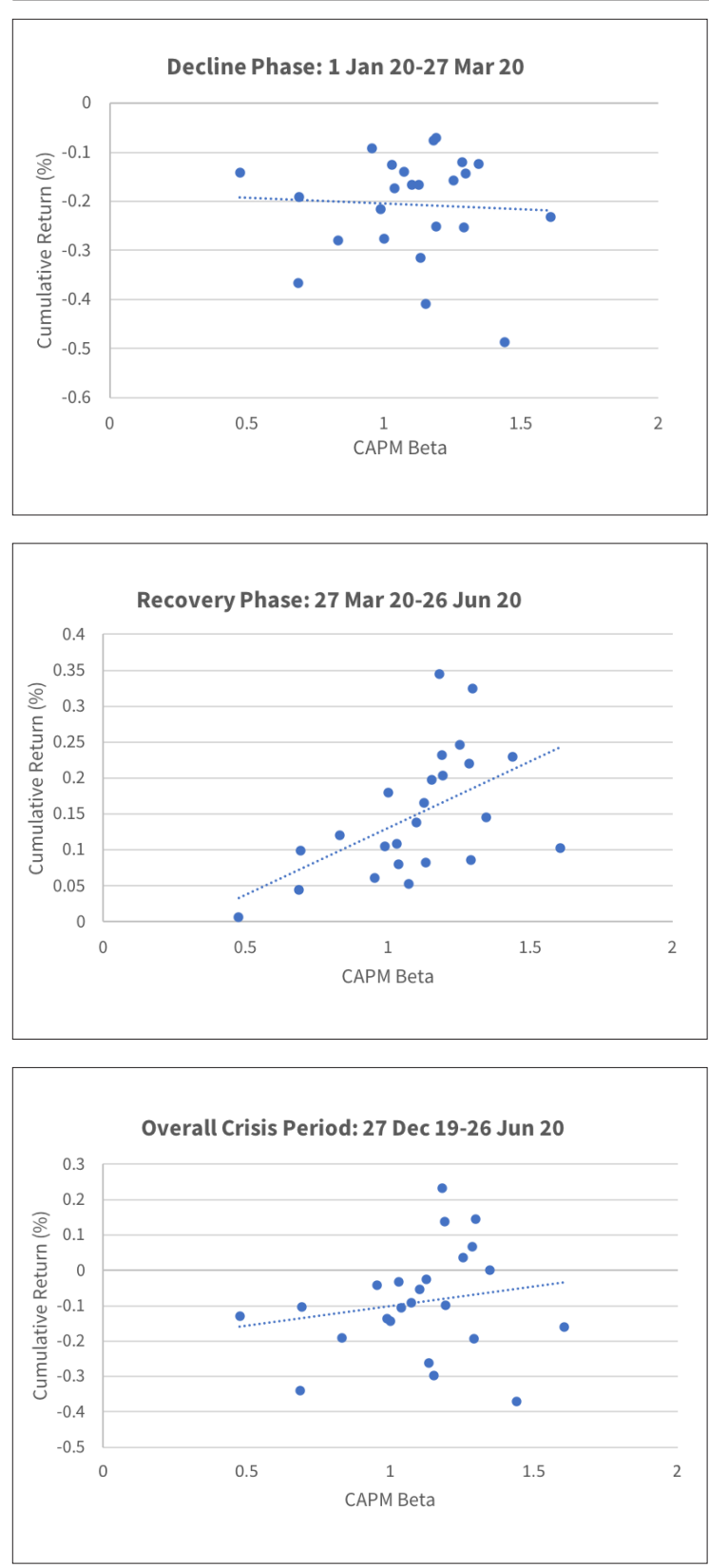

Figure 4 Cumulative stock returns (\%) versus CAPM industry beta coefficients for the S\&P 500 Index stock components. A dotted trend line is shown. Cumulative returns were computed using stock data downloaded from the Thompson Reuters Eikon platform. The CAPM industry beta coefficients were estimated by Aswath Damodaran for January 2020 


\section{Conclusions}

This pandemic has destabilised our financial markets and severely affected our economies. Governments have now committed enormous resources to help the economy recover. Financial markets and financial infrastructures will have to play their part. It is time to start reflecting on the lessons from the pandemic. We are now in a world with potentially negative prices and with negative interest rates. We are very interconnected and therefore vulnerable to factors which may lead to systemic crises (credit and liquidity shortages, pandemics, cybersecurity attacks, etc.). Given the extreme scenarios created by the pandemic, it is important to gather relevant data and reflect on whether our models are still fit for purpose. If not, we should use the evidence to guide the development of new theories and models. These theories and models should help us better rationalise the effects of these crises on asset values and prevent reaching extreme levels of uncertainty which may have contributed to escalating the crisis. At the outburst of the pandemic, the priority of governments and regulators correctly focused on adopting all measures necessary to save human lives. Perhaps for future pandemic scenarios we should more promptly implement measures to mitigate the impact of the pandemic on our businesses and financial markets hence preventing reaching such an extreme level of uncertainty about firm and asset values.

Clearly, we are not out of the woods yet with respect to COVID-19. The disease is still spreading around the world and a second wave is still likely if a vaccine is not developed before the next flu season. The economic engine of the Western world was temporarily switched off to "stop the virus and save the NHS" as we were saying in the UK. It is now the time to switch on the economic accelerator and take the opportunity to learn from the crisis and set the foundations for creating an even stronger, more resilient, and more equitable financial system.

\section{Bibliography}

López de Prado, M. (2019). "Tactical Investment Algorithms". Working paper. http://dx.doi.org/10.2139/ssrn.3459866.

Savor, P.; Wilson, M. (2014). "Asset Pricing: A Tale of Two Days". Journal of Financial Economics, 113, 171-201. http://dx.doi.org/10.1016/j.jfineco.2014.04.005. 


\title{
The COVID-19 Challenge to European Financial Markets Lessons from Italy
}

Nicola Borri

LUISS Guido Carli, Roma, Italia

\begin{abstract}
The COVID-19 pandemic has sickened more than 10 million people around the world and killed at least 500,000. In this chapter, we focus on the experience of Italy, which is the first country hit by the virus in Europe. While the lockdown measures appear to have successfully contained the virus, the economic consequences have been very severe. Policy makers should study the Italian experience to evaluate the cost-benefit effectiveness of different policies in containing the pandemic.
\end{abstract}

Keywords COVID-19. Italy. Pandemic. Lockdown. ECB.

Summary 1 Introduction. -2 The Evolution of the Health Crisis in Italy. -3 The Government Response to the Pandemic. 4 The Economic Effects of the Pandemic. 5 Conclusions.

\section{Introduction}

As a result of the COVID-19 pandemic, nearly 3 billion people worldwide have been under lockdowns put in place by governments to stop the virus, with severe consequences for workers, firms, and public finances. The pandemic is also expected to have long-run effects on the economy and individuals' wellbeing which cannot be fully assessed yet.

The diffusion of the pandemic, according to data and evidence currently available, was very fast. The starting point is usually traced back to Wuhan (China), at the end of 2019, when dozens of cases from an unknown virus were registered. In January 2020, Japan and South Korea confirmed the 
first cases outside mainland China, and towards the end of February 2020 infections surged in South Korea and Italy. Since then, most countries in the world have been affected, although with different intensities, in part depending on the type and timing of social distancing measures in place.

In this chapter, we focus on the experience of Italy, which is the first country hit by the virus in Europe. We believe the example of Italy is of particular interest for at least three reasons. First, Italy is considered approximately 2-3 weeks ahead of other advanced economies in the state of the pandemic. Second, Italy put in place one of the stricter lockdown policies, practically halting a large fraction of the economic activities and the movement of people not only across the country, but also within cities and towns. Therefore, Italy is an interesting case study to evaluate the effectiveness of different policies in fighting the pandemic and their economic and social costs. Third, because Italy is one of the advanced countries with the most fragile government finances, and with a stagnant economy for at least a decade, the COVID-19 shock could spark an economic crisis which could potentially propagate to the Eurozone and beyond.

The rest of the chapter is organised as follows. Section 2 describes the evolution of the health crisis in Italy. Section 3 presents the government response to the health emergency. Section 4 describes the economic effects of the pandemic in Italy. Finally, in Section 5 we present our conclusions.

\section{The Evolution of the Health Crisis in Italy}

After four months since the outbreak of the pandemic, the situation in Italy is finally stabilising, but the death toll is dramatic. The number of active cases is declining, as is the number of daily deaths due to COVID-19, which is approaching zero. Figure 1, using official data from the Italian Protezione Civile, shows a breakdown of the evolution of the pandemic in Italy into active cases (roughly 16 thousand at the end of June), deaths (roughly 35 thousand at the end of June) and recovered cases (roughly 200 thousand at the end of June) [fig. 1]. The figure shows that the number of active cases reached a peak at the end of April 2020, and then slowly declined as the number of recovered cases increased. Differently from other countries, like the US, where the diffusion of the pandemic resumed to grow after a first stabilisation, current data for Italy do not show any resurgence of the virus.

Figure 2 considers alternative measures of the state of the pandemic, and in particular the number of patients hospitalized or in quarantine [fig. 2].

One of the lessons from the Italian experience with the pandemic is that congestion of hospitals, and in particular of intensive care units 
Nicola Borri

The COVID-19 Challenge to European Financial Markets. Lessons from Italy

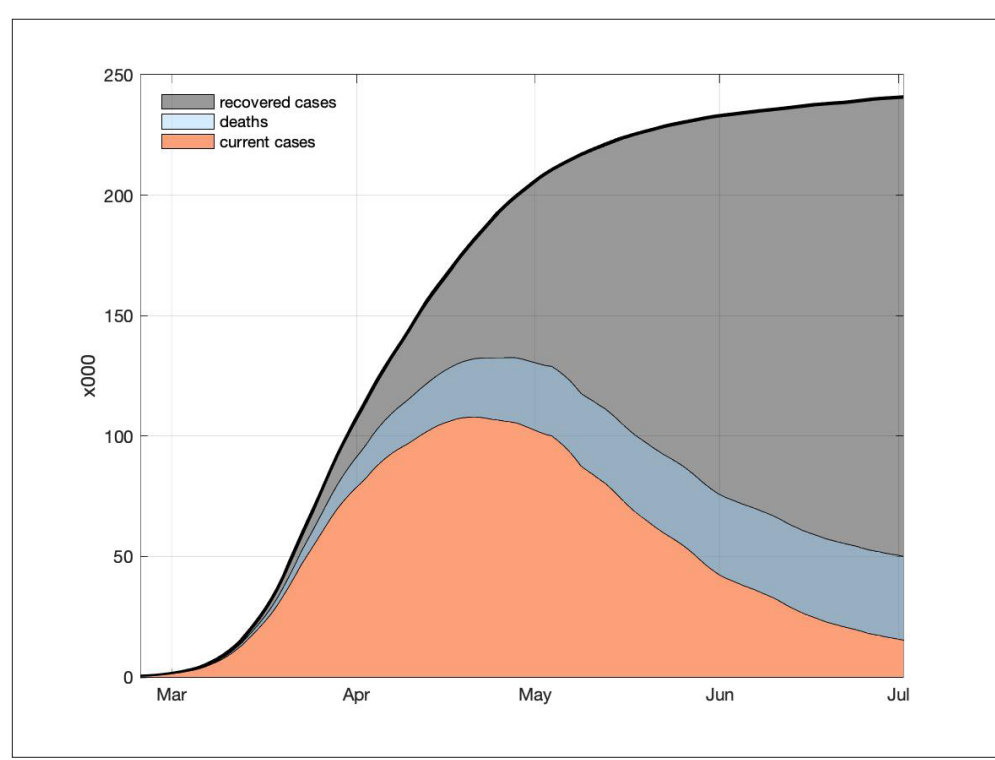

Figure 1 The Evolution of the COVID-19 Pandemic in Italy. Notes: the figure shows the evolution of the COVID-19 pandemic in Italy. The black solid line corresponds to the cumulated number of cases; the orangeshaded are active cases; the blue-shaded area are COVID-19 deaths; the gray-shaded area indicates recovered

cases. Data are from Protezione Civile and available at: https://github.com/pcm-dpc/COVID-19

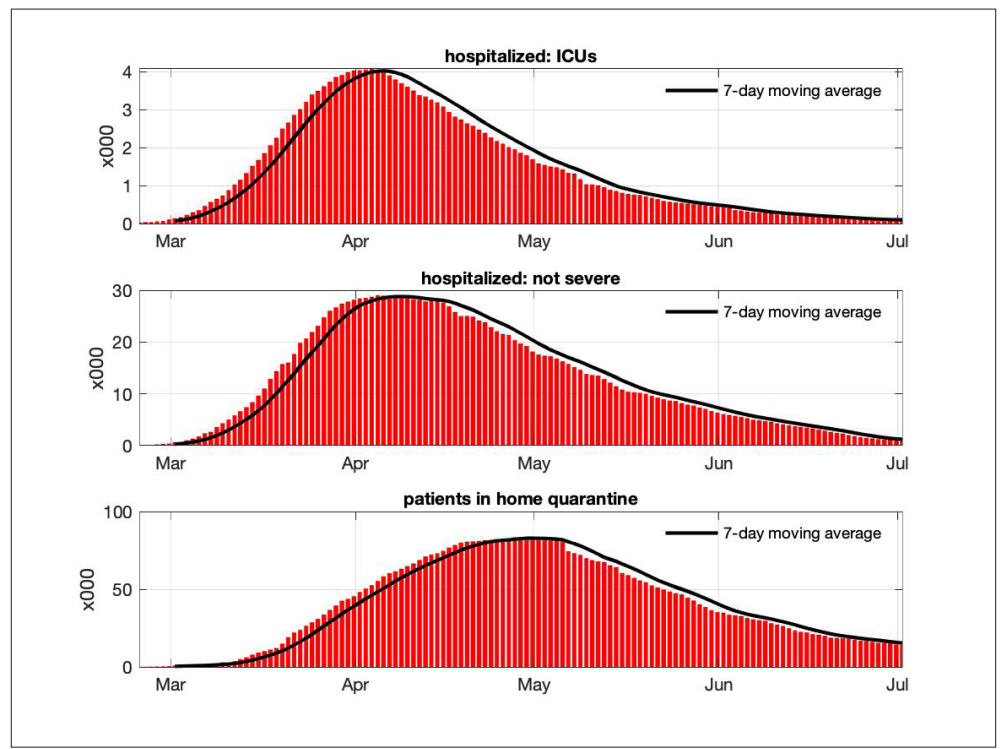

Figure 2 Patients Hospitalized and in Quarantine. Notes: the figure plots the evolution of the patients hospitalized in ICUs (top panel); hospitalized, but in less severe conditions (middle panel); and in quarantine at home (bottom panel). The black solid lines correspond to the 7-day moving average. Data are from Protezione Civile and available at: https://github.com/pcm-dpc/COVID-19 
(ICUs), should be avoided at all costs. In fact, given the exponential path of the uncontrolled pandemic, hospitals are likely to work at capacity, unable to cure all COVID-19 patients, and forced to postpone non-essential treatment to non COVID-19 patients with health consequences that are difficult to predict. The current data show that both the number of patients in ICUs, and the number of hospitalized patients in less severe conditions, are currently steadily declining (see the top and middle panels of figure 2). Specifically, the number of patients in ICUs reached a maximum value of approximately 4,000 in April, at the peak of the pandemic. As the diffusion of the pandemic was particularly severe in the North of the country, ICUs in these regions worked at full capacity, and this might have increased the true death toll (e.g. Bonanno, Galletta, Puca 2020; Galeotti, Surico 2020). Finally, the bottom panel of figure 2 shows the evolution of the patients in quarantine at home which has also been steadily declining. Although these are patients with less severe symptoms, they risk infecting their relatives and/or anyone living in their homes.

The diffusion of the pandemic in Italy has been very heterogenous across the Italian regions. Specifically, the pandemic was concentrated in the North of the country, and in particular in Lombardia, Piemonte, Veneto and Emilia Romagna. These regions account for approximately $40 \%$ of the Italian gross domestic product (GDP) and are populated by a large number of firms with interactions with firms scattered around the world. This could have been at the origin of the first contagion with the COVID-19 virus. Figure 3 shows the number of current active cases, along the number of cases at the beginning of three different phases of the lockdown (described in the next section), at the province level (note that these numbers are not divided by population) [fig. 3]. A quick look at the figure immediately reveals the strong geographic component of the pandemic and indicates that the lockdown was successful in containing the spreading of the virus throughout the country.

It is important to notice that the heterogeneity in the diffusion of the pandemic does not depend on, for example, differences in the frequency of testing. For example, we observe similar heterogeneity in the evolution of the COVID-19 deaths across Italian regions. Figure 4 shows that approximately $65 \%$ of the total COVID-19 deaths occurred in five regions: Lombardia, Piemonte, Emilia Romagna, Veneto and Liguria [fig. 4]. 
Nicola Borri

The COVID-19 Challenge to European Financial Markets. Lessons from Italy

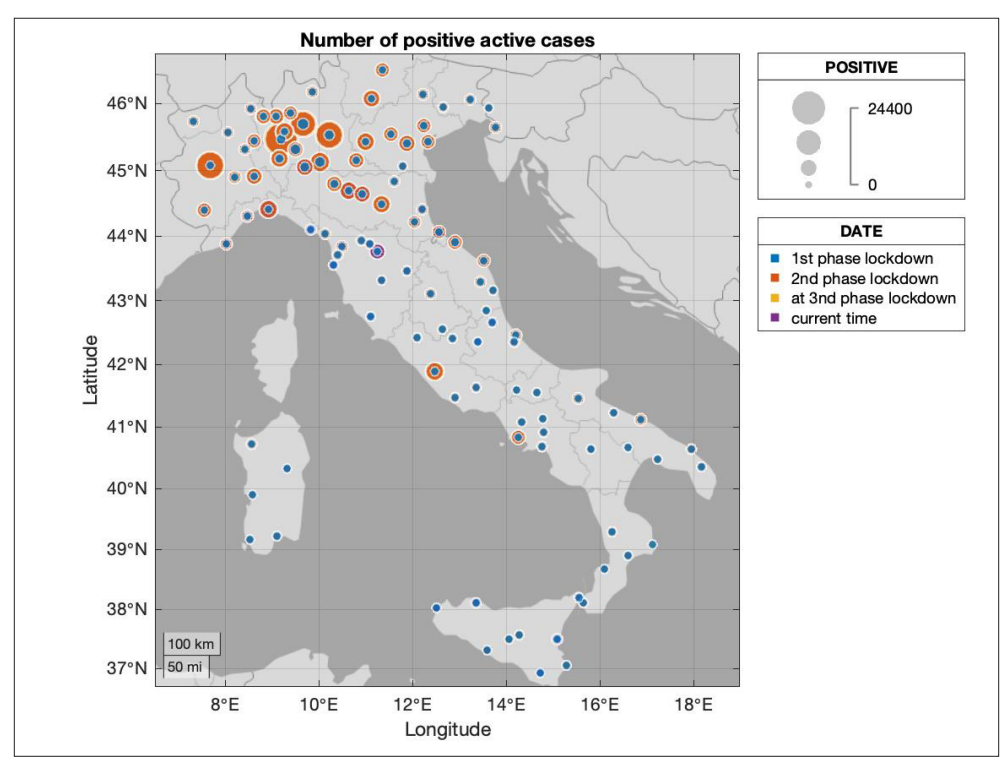

Figure 3 Number of COVID-19 Positives. Notes: The figure plots the total number of active COVID-19 cases at the province level. The size of the circles increases with the number of active cases. The colors correspond to different dates: first phase of national lockdown (blue, March 9, 2020); second phase of national lockdown (orange, May 4, 2020); third phase of national lockdown (yellow, June 15, 2020); current time (violet, June 30 , 2020). Data are from Protezione Civile and available at: https://github.com/pcm-dpc/COVID-19

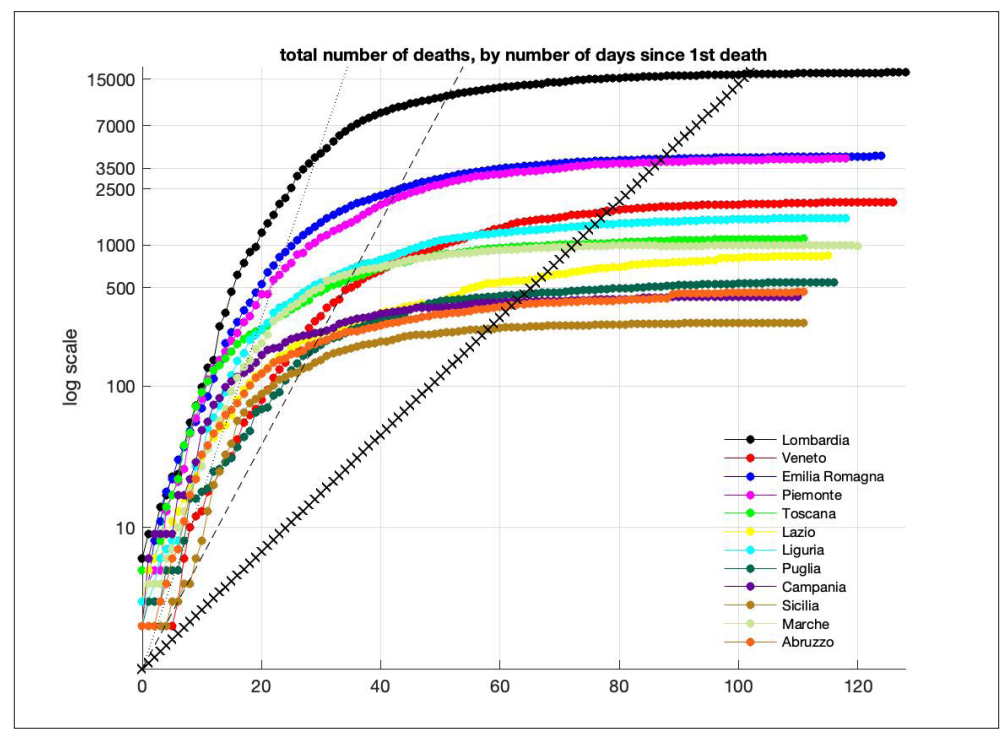

Figure 4 Evolution COVID-19 Deaths at Regional Level. Notes: The figure plots the evolution of the COVID-19 deaths for a sample of Italian regions. For each region, the values on the horizontal axis correspond to the number of days since the first COVID-19 death. The $y$-axis is in log-scale, the $y$-ticks correspond to numbers in levels. The straight lines from the origin correspond to daily growth rates of, respectively, $10 \%, 20 \%$, and 33\%. Data are from Protezione Civile and available at: https://github.com/pcm-dpc/COVID-19 


\section{The Government Response to the Pandemic}

In this section we consider the response of the Italian government to the health emergency, while in the next section we additionally consider the government response to the economic crisis.

The response of the Italian government to the pandemic has been a strict lockdown. We can roughly distinguish three phases of the lockdown. The first phase started on March 9 in all regions and implied the closing of schools, some economic activities (for example, restaurants, hospitality and non-food retail sectors), and the restriction of movement of people not only across regions, but also within regions and municipalities. In addition, on March 23 all non-essential economic activities were also shut down, affecting approximately $51 \%$ of firms and $55 \%$ of workers. The lockdown of economic activities, because of the heterogeneity in the geographical distribution of essential activities, determined differences in the fraction of inactive workers across different provinces [fig. 5].

Borri, Drago, Sobbrio (2020) used exactly this policy induced heterogeneity in the fraction of inactive workers to evaluate the effectiveness of the economic lockdown. Table 1 summarises their results. Specifically, while the estimated effect of the share of inactive workers goes in the right direction and is associated to a reduction in the number of COVID-19 infected patients, the estimates are not statistically significant. Borri, Drago, Sobbrio (2020) argue that their results, rather than evidence against the effectiveness of the lockdown, highlight the importance of good quality granular data, for example at the municipal level, and/or accounting for mobility patterns.

Table 1 Effect of the economic Lockdown

\begin{tabular}{lccc}
\hline & \multicolumn{2}{c}{ COVID-19 positive cases (province level) } \\
\hline & All provinces & $\begin{array}{c}\text { Provinces } \\
\text { in North }\end{array}$ & $\begin{array}{c}\text { Provinces above median } \\
\text { at lockdown }\end{array}$ \\
\hline$\Delta$ inactive post-lockdown & -139.977 & -356.936 & -305.268 \\
\hline & $(87.030)$ & $(218.068)$ & $(229.712)$ \\
\hline Obs. & 3640 & 1540 & 1540 \\
\hline FE province level & YES & YES & YES \\
\hline FE region-day & YES & YES & YES \\
\hline $\begin{array}{l}\text { Unconditional mean } \\
\text { dependent variable }\end{array}$ & 796.8 & 1496 & 1556 \\
\hline
\end{tabular}

Notes: robust standard errors clustered at provincial level. Regression includes five lags of dependent variable. The table report the estimates of a panel estimation model for the COVID-19 positive cases (at the province level) on the share of inactive workers as a consequence of the lockdown. The estimations always include a fixed effect at the province level; a fixed effect at the region-day level. The table is from Borri et al. 2020. 


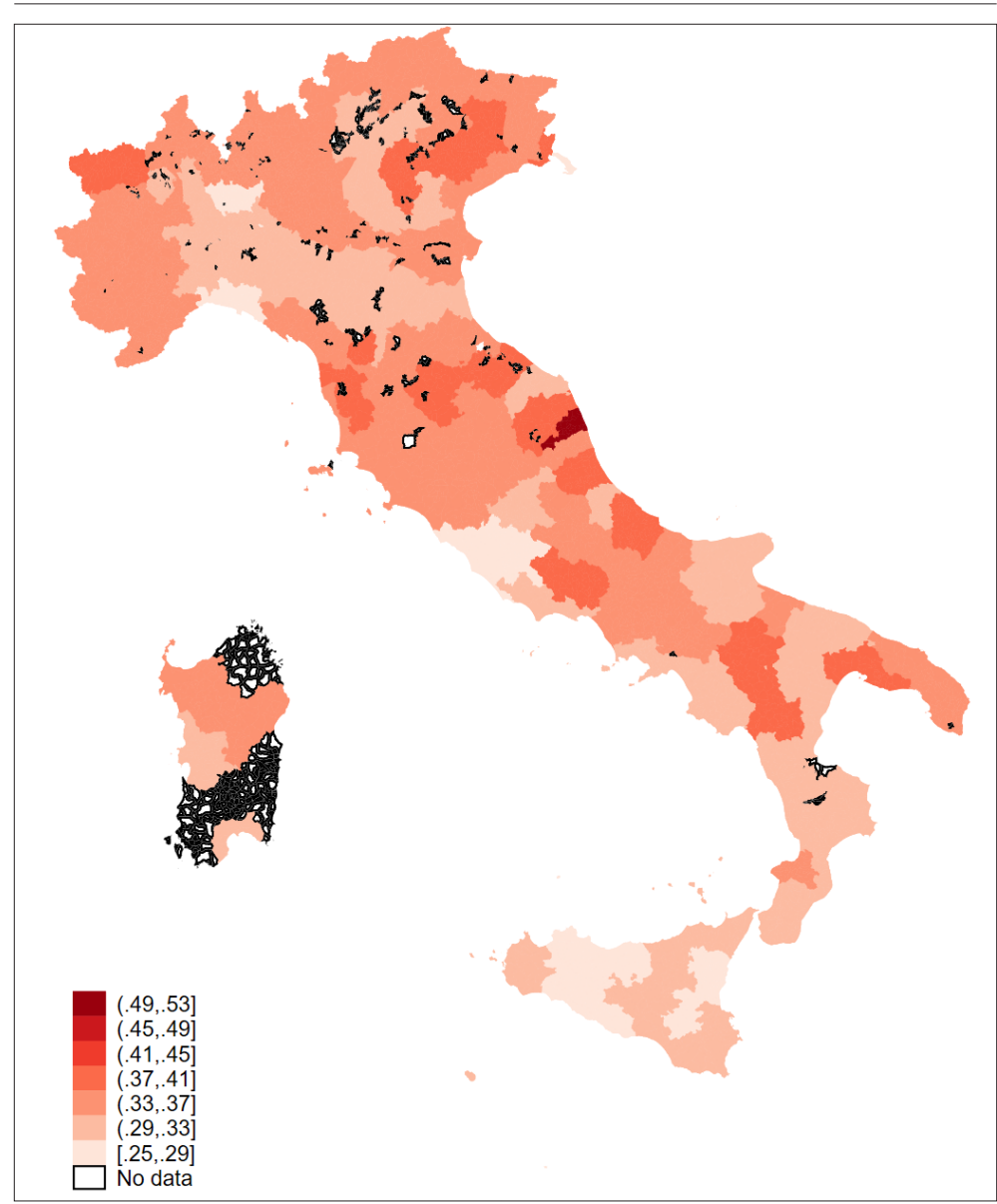

Figure 5 Share of Inactive Workers. Notes: The figure represents the share of inactive workers as a consequence of the first phase of the economic lockdown. Dark (lighter) colours correspond to a higher (lower) fraction of inactive workers. The figure is from Borri et al. 2020

The second and third phases correspond to the relaxation of the lockdown. Specifically, the second phase started on May 4, with the reopening of economic activities, and the relaxation of the restrictions to the movement within regions. Finally, the third phase started on June 15, and implied the relaxation of most lockdown measures. However, all schools remained closed and the use of masks in public places is currently mandatory. It is too early to be able to evaluate the risks and/or effects associated to the relaxation of the lockdown measures in the second and third phases in Italy. 


\section{The Economic Effects of the Pandemic}

While the lockdown, decided by the Italian government, has been so far effective at containing the pandemic, its economic effects have been very severe. Italian GDP is expected to drop by approximately 10\% in 2020 (Bloomberg). This historically large drop in GDP depends on the expected decrease in consumption (-11.8\%), investment (-15.4\%), and industrial production (-14.5\%). Government deficit is expected to be large and equal to $12.2 \%$ and, correspondingly, public debt is expected to reach $150 \%$ of GDP. The large increase in public debt depends on both the increase in public spending put in place to limit the negative effects of the pandemic (i.e. unemployment benefits, credit guarantees to firms, healthcare investments, etc.), and the sharp reduction in tax revenues because of the lower output. The fiscal response by the Italian government has been so far limited and constrained by the large public debt. The approved measures, worth around 1\% of GDP, are associated to emergency financing of the health system; employment and income support; tax deferrals and utility bills; and support of credit supply. Most analysts also expect a quick recovery in 2021, after the end of the lockdown. For example, for 2021, they expect an increase in GDP of approximately 5.6\%. However, there is substantial uncertainty around all these estimates, as well as over the likelihood that a second COVID-19 wave could hit advanced economies in the Fall/Winter of 2020.

Because of the large public debt and low economic growth before the COVID-19 shock, Italy is particularly exposed to the recent crisis. In addition, the fragile public finances limit the resources that the government could inject in the economy, thus increasing the risk of a deep recession. In fact, Italy is expected to be one of the economies most severely hit in the Eurozone. The response of equity markets, which are forward looking, confirms the difficult economic Italian outlook. Figure 6 shows the evolution of three equity indices, normalised to 1 on January 1, 2020 [fig. 6]. The equity indices correspond to the S\&P500 for US equity markets, the Eurostoxx50 for Eurozone equity markets, and the FTSE MIB for the Italian equity market (data are from Bloomberg). The figure shows that while the initial drop in the equity market in Italy and the rest of the Eurozone was similar, the recovery has been weaker in Italy. In fact, equity markets dropped, first, by roughly $35 \%$ in Italy and the rest of the Eurozone, and by $30 \%$ in the US. The intervention by the major central banks, which announced large asset purchase programmes like the Pandemic Emergency Purchase Program (PEPP) by the European Central Bank (ECB), helped to put a floor to the fall in equity markets. However, while the US equity market has gained back almost all of the lost ground, the Eurozone market and, especially, the Italian market, are still approximately $15 \%$ lower than their values at the beginning of the year. 


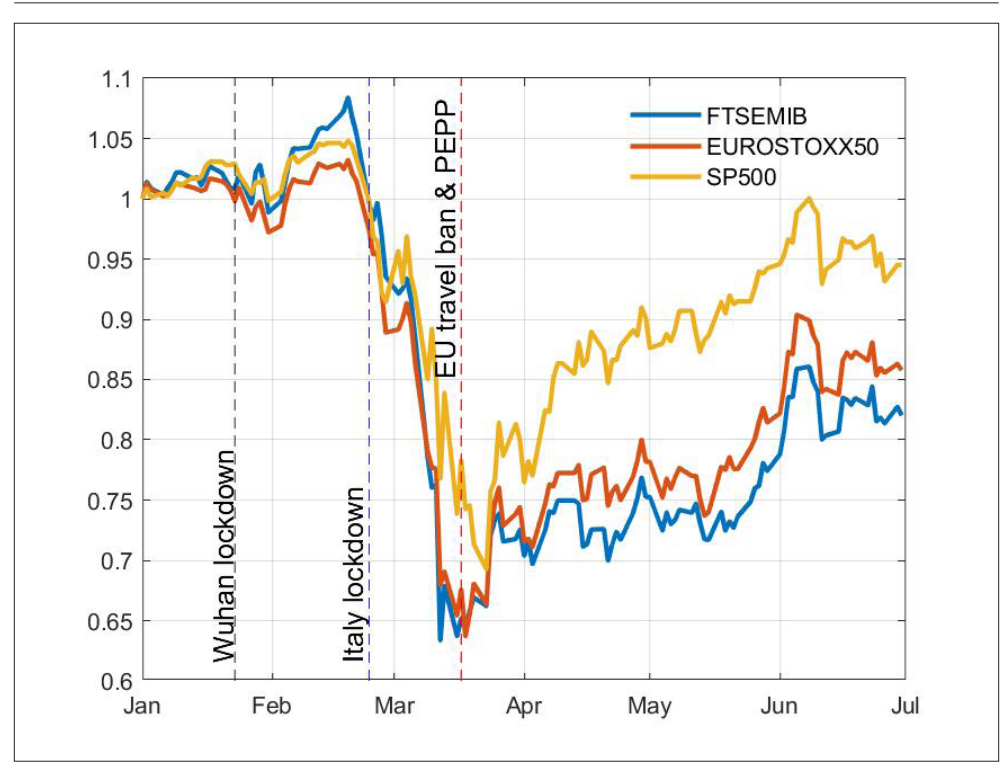

Figure 6 Equity Markets around the Great Lockdown. Notes: the figure shows the evolution of the prices of the S\&P500 (solid yellow line), Eurostoxx50 (solid red line), and FTSE MIB (solid blue line) indices. All series are normalised to 1 on January 1, 2020. The vertical lines correspond to the Wuhan lockdown, the first lockdown in Italy limited to some regions in the North, and the announcement of the ECB PEPP programme. Data are from Bloomberg

Because investors and policy makers expect a large increase in public debt, and a significant fall in output and tax revenues, they also worry about the possible default of one, or more, members of the Eurozone, overwhelmed by a striking crisis and thus compelled to stop servicing their debt. Figure 7 shows the evolution of government bond yields for Italy, Spain and Portugal (the data are from Bloomberg) [fig. 7]. As we have seen for equity markets, also for government bonds we first see a sharp increase in yields (and, thus, a sharp drop in prices). For example, the yield on the 10-year Italian government bond increased from 150 to more than 250 basis points. We observe a similar increase in yields also for Spain and Portugal which, however, had lower yields before the COVID-19 shock. Even so, it appears that the intervention by the ECB, with the announcement of the PEPP asset purchase programme, was able to avoid the risk of a sovereign debt crisis.

Bonaccolto, Borri, Consiglio (2020) find also evidence of an increase in the redenomination risk for France and Italy since the beginning of January 2020, i.e. the risk that one, or both, of these two countries abandon the Euro for a new, undervalued, currency. However, they also find that this risk is historically lower than after political shocks, like the recent election in Italy of an anti-euro government. 


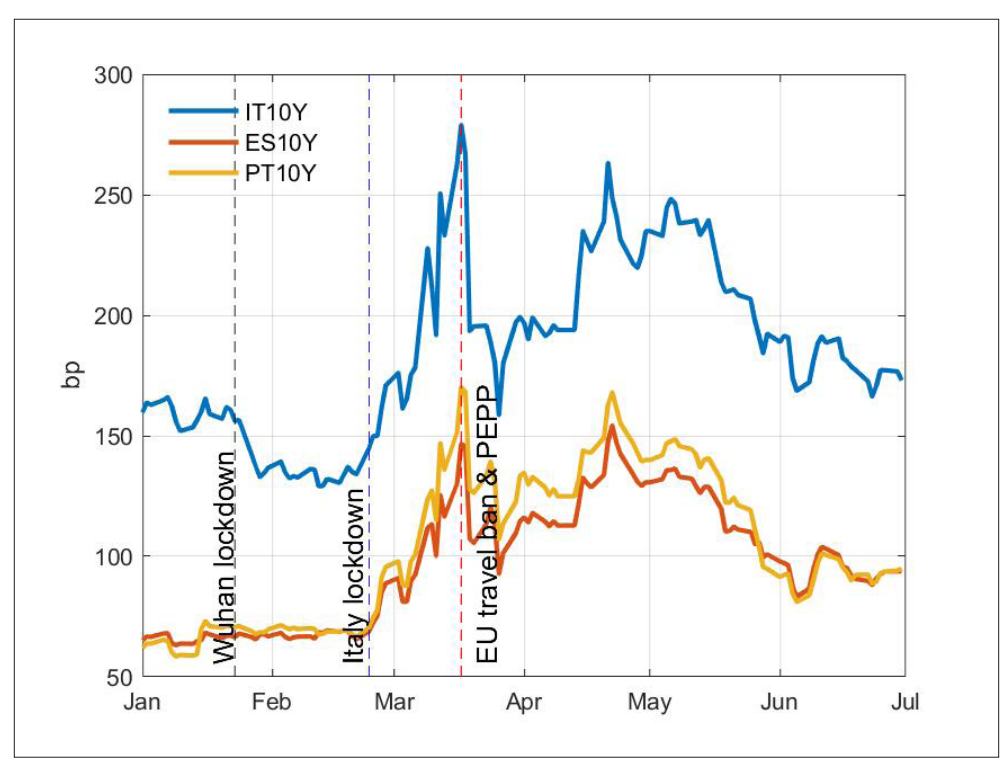

Figure 7 Government Bond Yields around the Great Lockdown. Notes: the figure shows the evolution of the yields of the Italian (solid blue line), Spanish (solid red line), and Portuguese (solid yellow line) 10-year benchmark government bonds. The vertical lines correspond to the Wuhan lockdown, the first lockdown in Italy limited to some regions in the North, and the announcement of the ECB PEPP programme. Yields are reported in basis points. Data are from Bloomberg

\section{Conclusions}

Italy is one of the first advanced economies hit by the COVID-19 pandemic. After approximately four months, the health crisis has stabilised, and the pandemic appears to be under control. However, there is still a lot of uncertainty around the possibility that a second wave could hit the country in the next Fall.

One of the lessons from the Italian experience is that strict lockdown measures are necessary to stop the pandemic and avoid that the virus spreads across regions. In addition, large scale testing is crucial to identify positive cases with no or small symptoms. In fact, within Italy, we observe very different outcomes for two neighbouring regions, Lombardia and Veneto. Although these two regions were the first to be hit by the COVID-19, they subsequently experienced very different evolutions of the pandemic, with Lombardia suffering many more deaths. While the Veneto region started early with a large testing programme which was effective at identifying positive cases, the Lombardia region started a large testing programme only at a later date. Finally, the strict restriction to the movement of people within the country is likely to be one of the reasons for the virus not to spread to, for example, the South of the country. 
While the lockdown measures appear to have successfully contained the virus, the economic consequences have been very severe. The economic situation is very fragile, and critically supported by international institutions, like the ECB, which has been able to avoid the risk of a sovereign debt crisis. This experience confirms the need for a risk-sharing mechanism in the Eurozone. So far, the actions of the ECB have filled this hole in the design of the European institutions. However, for the future, it is crucial to think of new, and permanent, instruments that guarantee some forms of risk-sharing.

In this light, an objective cost-benefit analysis of lockdown measures is crucial for at least three reasons. First, to guide and inform policy makers in their decisions regarding a safe and effective relaxation of the lockdown measures after the end of the medical emergency. Second, to guide and inform policy makers in the design of the social distancing measures that are likely to be in place up until a vaccine against COVID-19 has been found or that should immediately become effective in the event of a second 'wave' of the pandemic. Third, to understand the overall cost-effectiveness of the different lockdown measures in the containment and/or prevention of future pandemics. In fact, because different "nonpharmaceutical interventions" (NPIs) differ from each other in terms of their economic and psychological cost, it is crucial "to identify the interventions that most reduce transmission at the lowest economic and psychological cost" (Haushofer, Metcalf 2020).

This type of analysis remains, however, a daunting task, as it hinges upon the evaluation of a causal effect of these measures on the spread of the pandemic, or the economy (see, for example, GoodmanBacon, Marcus, 2020). While challenging, the heterogeneity in the introduction of these measures in Italy - both at the geographical and the temporal level - and the availability of detailed data on mobility and deaths at the city level provide researchers with a unique quasi-experimental pre-test/post-test design to elicit the causal effects of the lockdown. 


\section{Bibliography}

Bonaccolto, G.; Borri, N.; Consiglio, A. (2020). "Breakup and Default Risks in the Great Lockdown”. Working Paper. https://dx.doi.org/10.2139/ ssrn.3487453.

Bonanno, P.; Galletta, S.; Puca, M. (2020). "Estimating the Severity of Covid-19: Evidence from the Italian Epicenter". Working Paper. https://dx.doi. org/10.2139/ssrn.3567093.

Borri, N.; Drago, F.; Sobbrio, F. (2020). “Lockdown dell'economia, un primo bilancio". Lavoce, 20 April. https://www.lavoce.info/archives/65771/ lockdown-delleconomia-un-primo-bilancio/.

Galeotti, A.; Surico, P. (2020). "A User Guide to COVID-19”. VoxEU. https:// voxeu.org/article/user-guide-covid-19.

Goodman-Bacon, A.; Marcus, J. (2020). "Using Difference-in-Difference to Identify Causal Effects of COVID-19 Policies”. Working Paper. https://doi. org/10.18148/srm/2020.v14i2.7723.

Haushofer, J.; Metcalf, J. (2020). "Which Interventions Work Best in a Pandemic?”. Science, 368(6495), 1063-5. http://doi.org/10.1126/science. abb6144. 


\title{
Portfolio Effects of Cryptocurrencies During the COVID-19 Crisis
}

\author{
María de la O. González \\ University of Castilla-La Mancha, Spain \\ Francisco Jareño \\ University of Castilla-La Mancha, Spain \\ Frank S. Skinner \\ Brunel University London, UK
}

\begin{abstract}
We investigate the performance of optimised three asset portfolios comprised of stocks, bonds and a cryptocurrency or gold for the period immediately before and during the COVID-19 financial crisis. We compare the performance of these portfolios with a two-asset cash portfolio comprised of stocks and bonds. Cryptocurrencies have the potential to control risk as most portfolios that include cryptocurrencies consistently experienced risk no greater than 50 basis points above the risk experienced by cash portfolios. However, there is no free lunch. While three asset portfolios can control risk, they also have a lower return per unit of risk.
\end{abstract}

Keywords Portfolio Optimization. Bitcoin. Cryptocurrency. Altcoin. Gold.

Summary 1 Introduction.-2Cryptocurrencies.-3InvestmentPotential ofCryptocurrencies. -4 Conclusions. 


\section{Introduction}

On May 22, 2010, Laszlo Hanyecz reported that he bought two medium sized pizzas from Papa John's for 10,000 Bitcoins. ${ }^{1}$ Ten years later, the price of a Bitcoin closed at $\$ 9,238$ suggesting that this transaction would then be worth more than $\$ 92$ million. Such a huge rise in value attracts speculative interest leading to the introduction of very many competing products and consequently to the development of a whole new asset class we now call 'cryptocurrencies'. Nowadays, there are some 2,700+ cryptocurrencies with an overall market value of more than $\$ 250$ billion.

As this market is in its infancy, many questions arise regarding the purpose, value, and use of cryptocurrencies. The academic literature notes the issues with governance and the association of cryptocurrencies with criminality (Corbet et al. 2019), while much of the literature examines the diversification, safe haven and hedging properties of cryptocurrencies using a variety of econometric techniques. ${ }^{2}$ From this literature we understand that cryptocurrencies work best as safe havens and for portfolio diversification and less so for hedging strategies. González, Jareño and Skinner (2020) examine the statistical connectedness between Bitcoin and other popular cryptocurrencies finding substantial amounts of co-movements in the long and short run amongst the top ten largest cryptocurrencies. This chapter contributes by examining the role cryptocurrencies can play as an asset class added to traditional portfolios. More specifically, we examine the role cryptocurrencies can play in moderating the risk or enhancing the return of traditional cash portfolios comprised of stocks and bonds during the run up to and after the heart of the COVID-19 inspired financial crisis.

To accomplish this task, we first describe nine different cryptocurrencies. We then review the performance of cryptocurrencies from February 5, 2018 to May 15, 2020 thereby incorporating the COVID-19 crisis. Recognising that the COVID-19 crisis presents an opportunity to discover if cryptocurrencies can play a role of either improving investment performance or controlling risk or both, we form portfolios of stocks and bonds as of January 1, 2019. We then measure the actual return and risk experiences of this portfolio and compare them to the actual return and risk once a cryptocurrency such as Bitcoin is added to the cash portfolio. We do this for the top nine cryptocurrencies, namely Bitcoin, Ethereum, Ripple, Bcash, Tether, Litecoin, Eos, Bfinance and Tezos. We also incorporate Gold into our

1 See https://bitcointalk.org/index.php?topic=137.msg1195\#msg1195.

2 Bouri et al. (2017), Shahzad et. al. (2020), and Baur and Hoang (forthcoming) are examples. 
analysis for comparison purposes. After discussing our results, we then draw conclusions.

\section{Cryptocurrencies}

As a class, cryptocurrencies perform all the basic functions of a currency, including representing a store of value, a medium of exchange and a common denominator to measure value of goods and services. In contrast to traditional currencies, cryptocurrencies are not issued by a central bank and so do not derive their value as being backed by the resources of the issuing authority's credit. Instead, the value is supported by technology that makes it impossible to create unauthorised units of a given cryptocurrency. For some cryptocurrencies, supply is determined by miners, traders who solve complex mathematical problems to earn new cryptocurrency coins. The interaction between the demand and supply of a given cryptocurrency determines its value. All cryptocurrencies are convertible into traditional currencies on cryptocurrency exchanges at rates determined by open and transparent transactions. While the above is common to most types of cryptocurrencies, each one has a different price as the technical structure of each cryptocurrency is different. Therefore, our first task is to describe Bitcoin and outline how each of the remaining cryptocurrencies in our sample is different.

\subsection{The Main Type of Cryptocurrencies}

Table 1 reports the nine cryptocurrencies we examine in this chapter. On May 15, 2020, Bitcoin, with a market capitalisation of nearly $\$ 175$ billion and with a 24 -hour trading volume of more than $\$ 50$ billion, dominates the rest of our sample in terms of size and liquidity. Meanwhile, Tezos has the smallest market capitalisation and the least liquidity with a market capitalisation of under $\$ 2$ billion and a 24-hour trading volume of approximately $\$ 120$ million.

Table 1 This table reports the market capitalisation as a measure of the size and 24-hour trading volume and circulating supply as indicators of liquidity of nine top cryptocurrencies as on May 15, 2020

\begin{tabular}{llllll}
\hline Name & Ticker & $\begin{array}{c}\text { Market Cap } \\
\text { (Billions) }\end{array}$ & Price & $\begin{array}{c}\text { Volume } \\
\text { (24h-Billions) }\end{array}$ & Circulating Supply \\
\hline Bitcoin & BTC & $\$ 174.72$ & $\$ 9,507.28$ & $\$ 50.24$ & $18,378,018$ BTC \\
\hline Ethereum & ETH & $\$ 22.09$ & $\$ 199.13$ & $\$ 17.94$ & $110,938,751$ ETH \\
\hline Tether & USDT & $\$ 8.83$ & $\$ 1.00$ & $\$ 56.06$ & $8,798,069,379$ USDT \\
\hline Ripple & XRP & $\$ 8.82$ & $\$ 0.20$ & $\$ 2.07$ & $44,112,853,111$ XRP \\
\hline
\end{tabular}


María de la O. González, Francisco Jareño, Frank S. Skinner Portfolio Effects of Cryptocurrencies During the COVID-19 Crisis

\begin{tabular}{lccccc}
\hline Name & Ticker & $\begin{array}{c}\text { Market Cap } \\
\text { (Billions) }\end{array}$ & Price & $\begin{array}{c}\text { Volume } \\
\text { (24h-Billions) }\end{array}$ & Circulating Supply \\
\hline Bcash & BCH & $\$ 4.38$ & $\$ 237.94$ & $\$ 3.33$ & $18,407,919$ BCH \\
\hline Litecoin & LTC & $\$ 2.80$ & $\$ 43.21$ & $\$ 4.51$ & $64,735,081 \mathrm{LTC}$ \\
\hline Binance Coin & BNB & $\$ 2.50$ & $\$ 16.07$ & $\$ 0.35$ & $155,536,713 \mathrm{BNB}$ \\
\hline EOS & EOS & $\$ 2.39$ & $\$ 2.59$ & $\$ 4.19$ & $922,646,994 \mathrm{EOS}$ \\
\hline Tezos & XTZ & $\$ 1.78$ & $\$ 2.51$ & $\$ 0.12$ & $710,520,732 \mathrm{XTZ}$ \\
\hline Total & M/A & $\$ 228.32$ & N/A & $\$ 138.80$ & N/A \\
\hline
\end{tabular}

Bitcoin is a digital currency. It is the original popular cryptocurrency and holds the market lead in size and acceptance for retail transactions. For example, Amazon accepts bitcoins as payment for gift cards. Since the development of Bitcoin there has been an explosion in the number of alternative coins (hereafter altcoins) that seek ways to improve on Bitcoin. Successful innovations include increasing the range of applications, increasing the volume, speed and reducing the cost of transactions and improving the security and governance of altcoin operating systems.

Ethereum moved beyond being a digital currency by allowing users to develop their own applications such as online betting and ticket sales via an open source platform. These decentralised applications also reduce the likelihood of being hacked by operating on decentralised networks instead of centralised servers. Like Ethereum, EOS uses a decentralised operating system and allows users to create their own commercial sized applications. However, EOS is also designed to alleviate the scalability issues of Bitcoin and Ethereum by being capable of handling millions of transactions per second without transaction fees. While Tezos is also an Ethereum style decentralised system, it distinguishes itself by improving the security and governance of the system. Tezos rewards coin holders for verifying transactions and contracts thereby reducing the likelihood of malicious attacks. Governance is improved by empowering coin holders to vote on proposed updates to the network.

Bcash and Litecoin are direct competitors of Bitcoin by making some technical adjustments to the block chain technology that drives cryptocurrency transactions thereby allowing for more transactions to be processed faster. Ripple is designed to aid financial institutions to settle global transactions more efficiently and more cheaply. For example, Ripple can settle up to 200 times more transactions a second than Bitcoin. Potentially, Ripple can replace the SWIFT system currently used by financial institutions as the facilitator of cross-border transactions between currencies. Ripple can handle millions of transactions per second, settles transactions in seconds (rather than days for SWIFT) with a transaction cost of less than $\$ 0.01$.

Other altcoins seek to compete with Bitcoin by offering services to coin holders. Bfinance, while having its own coin, is a Tokyo 
based cryptocurrency exchange designed to facilitate trading between cryptocurrency pairs. Like any other exchange, Bfinace offers limit, market, and stop limit orders as well as listing and delisting facilities. It has also proved to be a valuable venue for initial coin offerings for new cryptocurrencies. Meanwhile, Tether is a type of stable coin - meaning that the value of the coin is benchmarked against another asset. In the case of Tether, the value of one unit is calibrated to be one US dollar. Originally, this was accomplished by being convertible to US dollars on a one to one basis. Since then, however, Tether has been backed by a variety of assets and in practice the value can fluctuate from one dollar.

\section{Investment Potential of Cryptocurrencies}

Our choice of beginning and ending dates for our study is dictated by the need to cover the heart of the COVID-19 crisis and the need to maximise the number of cryptocurrencies we can examine. We first selected the top 10 Cryptocurrencies ranked by market capitalisation from investing.com only to discover that Bitcoin SV did not started trading until November 2018. As this will give us too few data points to reliably measure performance, we decided to drop Bitcoin SV. The next most recently issued altcoin, Tezos, was issued on February 5, 2018 giving us 220 daily observations to measure starting values we need to measure investment performance quarterly from January 1, 2019. Accordingly, we collect daily stock, bond, gold and cryptocurrency prices from February 5, 2018 to May 15, 2020.

Daily cryptocurrency information is from investing.com. To represent the stock, bond and gold markets we collect the Wiltshire 5000 total return index, the Wiltshire global bond total return index and gold prices from the Federal Reserve Database FRED. The Wiltshire 5000 is a market weighted index of more than 3,000 US stocks that is intended to be a very broad indicator of US stock performance. Similarly, the Wiltshire Global Bond index has a very broad coverage of all types of taxable US dollar denominated bonds that reflects the actual holdings by US institutional investors. Finally, gold prices are the London daily 15:00 price fixing.

Figures 1a to 1e report daily returns of cryptocurrencies and figures $2 \mathrm{a}$ and $2 \mathrm{~b}$ report the daily returns of stocks, bonds and gold from February 5, 2018 to May 15, 2020. Figure 1 clearly shows that cryptocurrencies can suffer catastrophic daily loses [figs.1a-e]. Notice that the daily (not annualized) gains and losses range from plus and minus $40 \%$ prior to the COVID-19 period whereas the corresponding range in figure 2 is a much more modest plus or minus 3\%. Figure 2 clearly illustrates that uncertainty related to COVID-19 began to be incorporated into the cash markets about the third week of February 
2020 [fig. 2]. During this heightened period of uncertainty, unannualized daily stock returns were sometimes greater than $5 \%$ and losses were greater than 10\%. On COVID-19 day March 12, 2020, most cryptocurrencies lost approximately one half of their value whereas equity lost a little more than $10 \%$. Despite a strong rebound, the following day a further catastrophic loss was experienced on Monday March 16 where most cryptocurrencies lost 10\% of their value and equities $13 \%$. Given these wild gyrations in the financial markets, it is interesting to determine if we can moderate the risk of investing in cash assets by adding a cryptocurrency to a cash portfolio.
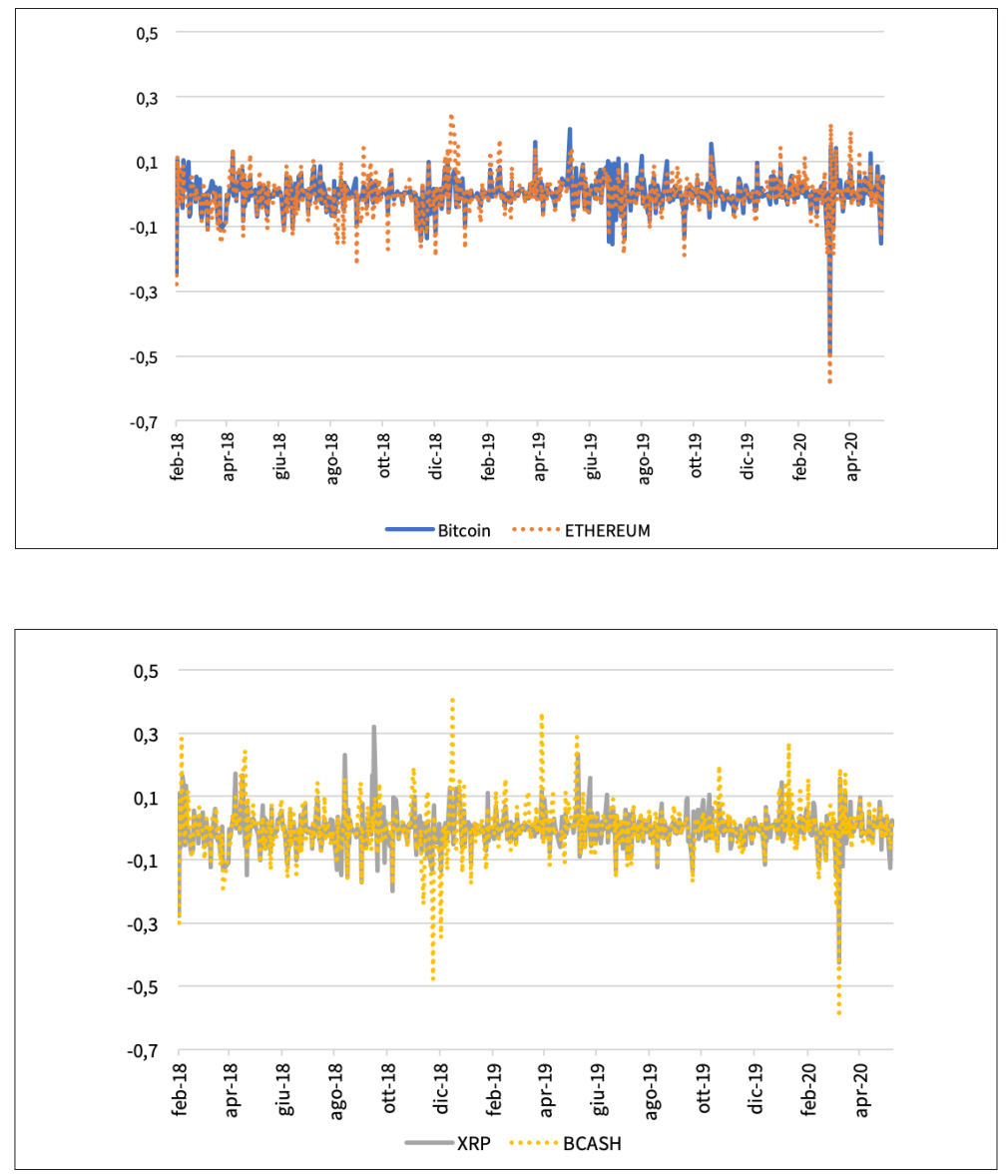
María de la O. González, Francisco Jareño, Frank S. Skinner Portfolio Effects of Cryptocurrencies During the COVID-19 Crisis
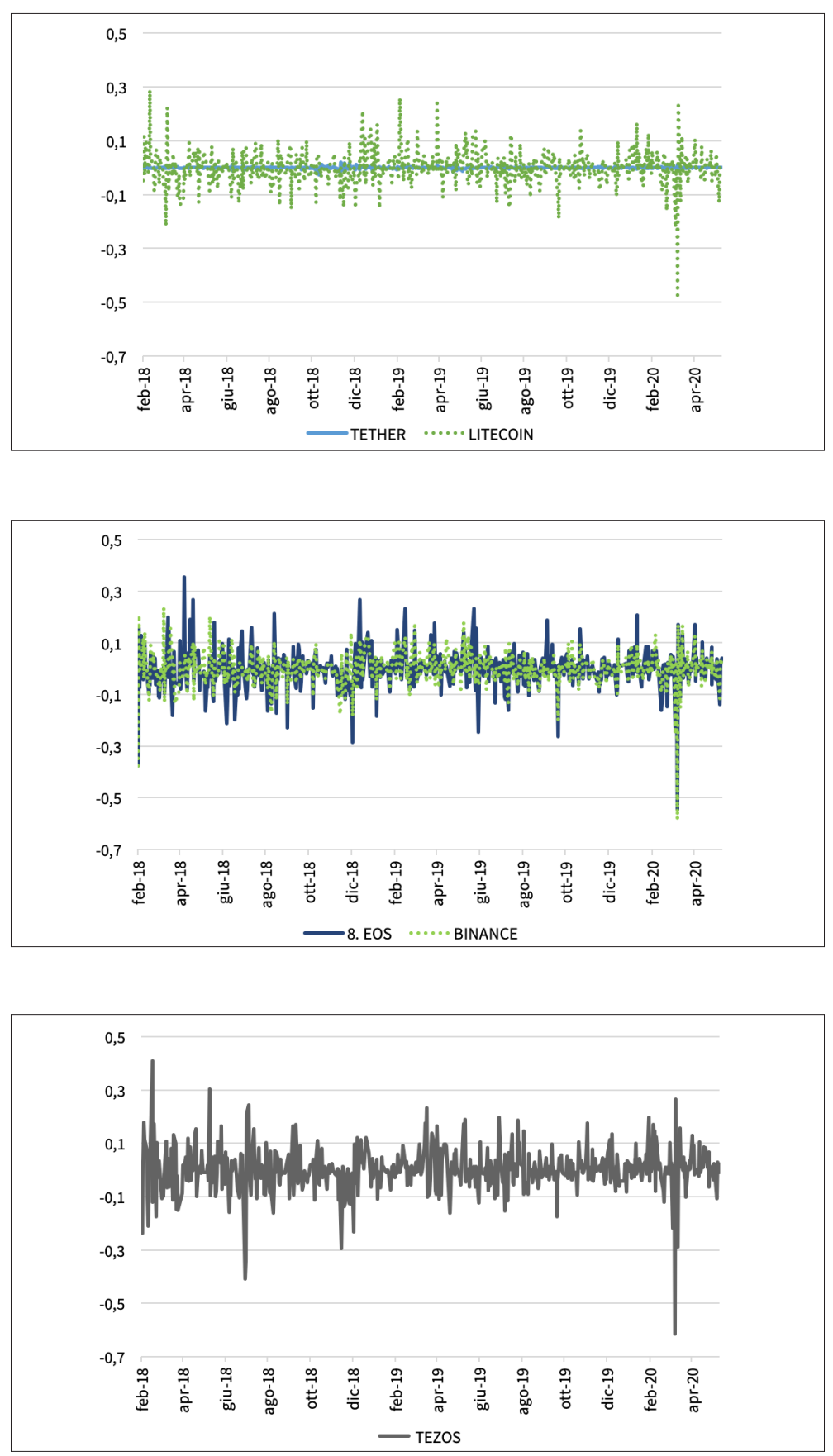

Figures 1a-e Cryptocurrency Daily Returns. February 5, 2018 to May 15, 2020 


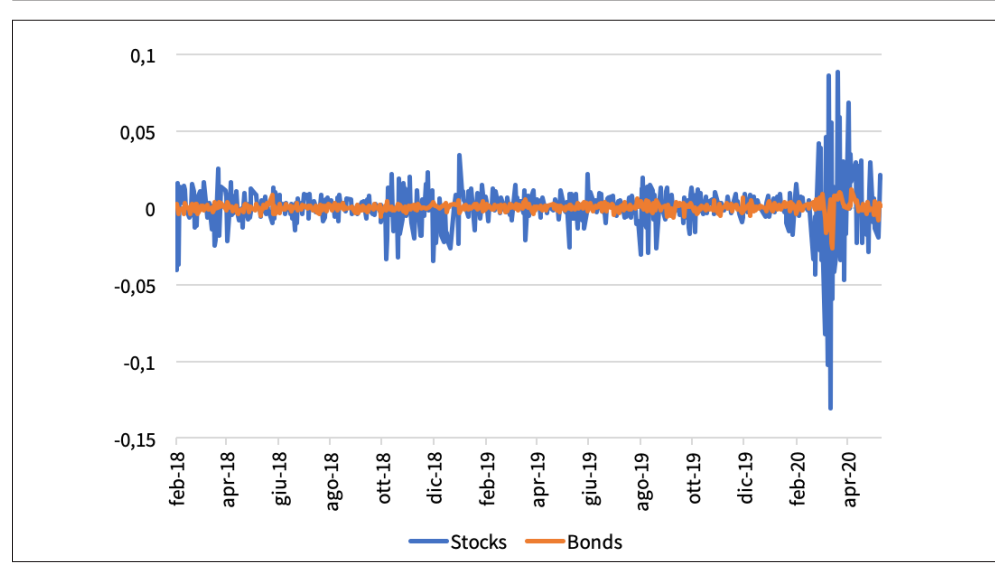

Figure 2a Stock and Bond Daily Returns. February 5, 2018 to May 15, 2020

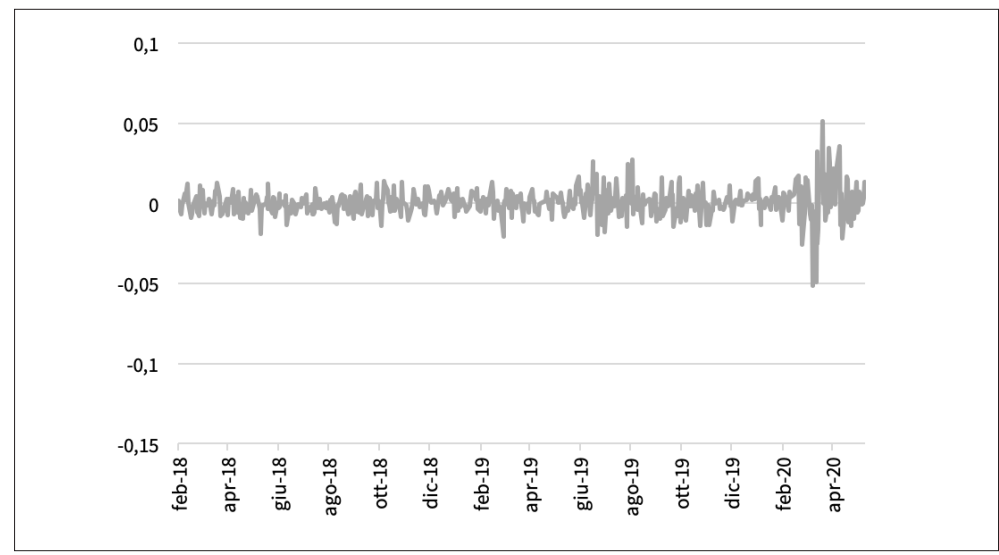

Figure 2b Gold Daily Returns. February 5, 2018 to May 15, 2020

Our testing strategy is as follows. We first measure expected returns and risk as inputs to determine what portion of each asset should be included in a three-asset portfolio comprising of stocks, bonds and an alternative asset such as gold or a cryptocurrency. Using these inputs, we set a target risk level and then optimise by changing the portions invested in each of the three component assets to obtain the highest possible return given the target risk level on January 1, 2019. This optimisation is accomplished via the solver function in Excel. Using these optimised portions, we then measure the return, the risk (portfolio standard deviation) and the ratio of return to risk (hereafter Sharpe ratio) three months later on March 31, 2019 and 
compare these actual values to what was promised initially. We then repeat by rebalancing our initial portfolio using updated risk measures - the variances and covariances amongst included assets in the portfolio - on March 31 2019, but retain the initial target returns and portfolio target standard deviation and then measure the second quarterly returns, risk and the Sharpe ratio on June 30, 2019. We continue rebalancing the portfolio at the beginning of each quarter to compare to the actual performance at the end of the quarter until March 31, 2020. To capture the rapid bounce back after March 31, 2020 we rebalance the portfolio on March 31 and measure the performance of this portfolio seven weeks later May 15, 2020.

We use the five-year average, from January 1, 2014 to December 31,2018 , to calculate the expected value for the mean returns of stocks, bonds and gold. We use the annualised daily averages over the 220 daily observations from February 5, 2018 to December 31, 2018 to calculate expected values for the variances and covariances for all assets. However, the five year (or part thereof) return of the nine cryptocurrency returns were incredible and using a similar five-year average would result in portfolios dominated by cryptocurrencies. This would defeat the purpose of this study as we wish to examine how cash portfolios can be improved by including cryptocurrencies as an additional rather than a substitute asset class in the portfolio. Therefore, we arbitrarily chose $4 \%$ as the target return, which is part way between the average target return for stocks, bonds and gold at $8,3.5$ and $0.5 \%$ respectively. ${ }^{3}$

Once chosen, the starting values will be used to form a portfolio with a controlled level of risk by minimising risk to a chosen level. We chose an overall portfolio standard deviation of $9.9 \%$ as the target risk. This is the average five-year standard deviation for the Wilshire 5000 index up to December 31, 2018, the idea being that investors are willing to invest some portion of their wealth in cryptocurrencies, provided that this does not result in an expected major increase in risk. Using our chosen expected values, we now optimise portfolios by finding the portions invested in each asset that in combination obtains the highest possible portfolio expected return based on the expected values, consistent with an overall portfolio standard deviation of $9.9 \% .{ }^{4}$ Short selling is not allowed so the minimum investment in any given asset is zero.

3 We experimented with a range of values for the target cryptocurrency target return from $0.5 \%$ to $5 \%$. Using lower values resulted in very little investment in cryptocurrencies whereas using a value greater than $4 \%$ lead to portfolios with more than $50 \%$ invested in cryptocurrencies. As shown in table 2 , the use of a $4 \%$ target return allowed is to form portfolios with a significant, but not dominant investment in cryptocurrencies.

4 We initially set the investment in Equity as 100\% and zero for the remaining assets and then optimise. 
María de la O. González, Francisco Jareño, Frank S. Skinner Portfolio Effects of Cryptocurrencies During the COVID-19 Crisis

Table 2 This table reports the initial percentage allocations, expected returns, variances and covariances from Q1 the first quarter of 2019 to Q6 the second part quarter of 2020 ending on May 15 based on information prior to the date portfolios are formed. All figures are in percent

\begin{tabular}{|c|c|c|c|c|c|c|c|c|c|c|c|}
\hline Q1 & Cash & Gold & Bitcoin & Ethereum & Ripple & Bcash & Tether & Litecoin & Eos & Bfinance & Tezos \\
\hline Equity & 60.3 & 58.4 & 44.4 & 36.5 & 57.4 & 59.2 & 58.4 & 23.8 & 33.7 & 54.2 & 59.4 \\
\hline Bonds & 39.7 & 21.4 & 47.2 & 56.4 & 40.7 & 39.2 & 21.7 & 67.4 & 60.4 & 42.6 & 39.2 \\
\hline Alternative & 0.0 & 20.2 & 8.3 & 7.0 & 1.9 & 1.6 & 19.9 & 8.8 & 5.9 & 3.2 & 1.4 \\
\hline \multicolumn{12}{|l|}{ Q2 } \\
\hline Equity & 62.4 & 60.6 & 43.8 & 45.4 & 34.8 & 60.6 & 60.6 & 26.1 & 35.1 & 52.2 & 29.2 \\
\hline Bonds & 37.6 & 20.3 & 46.6 & 48.4 & 57.9 & 37.5 & 20.6 & 65.2 & 58.7 & 43.4 & 64.7 \\
\hline Alternative & 0.0 & 19.1 & 9.6 & 6.2 & 7.3 & 1.9 & 18.8 & 8.7 & 6.1 & 4.4 & 6.1 \\
\hline \multicolumn{12}{|l|}{ Q3 } \\
\hline Equity & 65.1 & 63.4 & 49.7 & 27.1 & 65.1 & 64.3 & 63.3 & 29.6 & 35.1 & 53.9 & 59.2 \\
\hline Bonds & 34.9 & 18.8 & 41.6 & 64.0 & 34.9 & 34.2 & 19.2 & 61.8 & 58.4 & 41.4 & 37.7 \\
\hline Alternative & 0.0 & 17.8 & 8.7 & 8.9 & 0.0 & 1.6 & 17.5 & 8.6 & 6.5 & 4.8 & 3.0 \\
\hline \multicolumn{12}{|l|}{ Q4 } \\
\hline Equity & 65.8 & 64.3 & 55.3 & 29.4 & 65.8 & 64.7 & 64.0 & 30.0 & 36.0 & 53.9 & 48.3 \\
\hline Bonds & 34.2 & 18.1 & 37.5 & 61.7 & 34.2 & 33.6 & 18.9 & 61.3 & 57.4 & 41.0 & 46.7 \\
\hline Alternative & 0.0 & 17.5 & 7.3 & 8.9 & 0.0 & 1.8 & 17.1 & 8.7 & 6.6 & 5.0 & 5.0 \\
\hline \multicolumn{12}{|l|}{ Q5 } \\
\hline Equity & 68.6 & 67.4 & 57.9 & 31.9 & 68.6 & 67.4 & 67.0 & 31.8 & 37.0 & 51.3 & 48.6 \\
\hline Bonds & 31.4 & 16.5 & 34.7 & 58.8 & 31.4 & 30.8 & 17.3 & 59.1 & 55.9 & 42.5 & 46.0 \\
\hline Alternative & 0.0 & 16.1 & 7.4 & 9.3 & 0.0 & 1.8 & 15.7 & 9.1 & 7.0 & 6.3 & 5.4 \\
\hline \multicolumn{12}{|l|}{ Q6 (Part) } \\
\hline Equity & 40.6 & 32.9 & 20.9 & 40.6 & 40.6 & 30.9 & 40.6 & 40.6 & 40.6 & 40.6 & 40.6 \\
\hline Bonds & 59.4 & 36.3 & 70.6 & 59.4 & 59.4 & 65.3 & 30.1 & 59.4 & 59.4 & 59.4 & 59.4 \\
\hline Alternative & 0.0 & 30.8 & 8.5 & 0.0 & 0.0 & 3.9 & 29.3 & 0.0 & 0.0 & 0.0 & 0.0 \\
\hline
\end{tabular}

The initial allocations are reported in table 2. Based on the expected returns, variances and covariances, these allocations are optimal as they give the highest possible returns given the target of holding the overall standard deviation of the portfolio to $9.9 \%$. The portion invested in Gold and Cryptocurrencies do vary substantially. For example, the initial allocation for the first quarter has $20.2 \%$ invested in gold and $1.4 \%$ invested in Tezos. It is interesting to note that only Gold and Tether regularly enter the rebalanced portfolios with allocations of between 15 to $30 \%$. All other cryptocurrencies have allocations of less than 10\%. Also, for the part quarter from April 1 to May 15, when the markets bounced back from the heart of the COVID-19 crisis, six cryptocurrencies do not even enter the rebalanced portfolios as, clearly based on past data, they were 'too risky'. Including them would results in a rebalanced portfolio with a standard deviation greater than $9.9 \%$. 
María de la O. González, Francisco Jareño, Frank S. Skinner Portfolio Effects of Cryptocurrencies During the COVID-19 Crisis

Table 3 This table reports the mean, standard deviation SD and Sharpe ratio quarterly from Q1 the first quarter of 2019 to the end of the part second quarter of 2020 on May 15,2020 . The means and standard deviations are annualised percent rates

\begin{tabular}{|c|c|c|c|c|c|c|c|c|c|c|c|}
\hline Q1 & Cash & Gold & Bitcoin & Ethereum & Ripple & Bcash & Tether & Litecoin & Eos & Bfinance & Tezos \\
\hline Mean & 39.6 & 36.5 & 36.0 & 31.7 & 37.2 & 39.8 & 35.4 & 50.4 & 41.2 & 41.2 & 42.9 \\
\hline SD & 7.8 & 7.9 & 9.9 & 7.4 & 7.6 & 7.9 & 7.9 & 8.8 & 7.4 & 7.4 & 8.2 \\
\hline Sharpe & 5.1 & 4.6 & 3.6 & 4.3 & 4.9 & 5.0 & 4.5 & 5.7 & 5.6 & 5.6 & 5.3 \\
\hline \multicolumn{12}{|l|}{ Q2 } \\
\hline Mean & 18.0 & 22.4 & 58.2 & 36.7 & 27.7 & 26.0 & 13.8 & 45.1 & 27.9 & 32.5 & 18.8 \\
\hline SD & 7.1 & 7.2 & 7.7 & 6.7 & 7.8 & 6.7 & 7.4 & 9.0 & 7.6 & 6.7 & 7.7 \\
\hline Sharpe & 2.5 & 3.1 & 7.5 & 5.5 & 3.5 & 3.9 & 1.9 & 5.0 & 3.7 & 4.8 & 2.5 \\
\hline \multicolumn{12}{|l|}{ Q3 } \\
\hline Mean & 4.0 & 4.7 & -9.0 & -11.6 & 4.0 & -0.1 & 3.3 & -18.9 & -12.3 & -9.5 & 3.2 \\
\hline SD & 9.9 & 9.8 & 10.2 & 9.0 & 9.9 & 9.9 & 9.7 & 9.1 & 8.7 & 9.4 & 10.0 \\
\hline Sharpe & 0.4 & 0.5 & -0.9 & -1.3 & 0.4 & 0.0 & 0.3 & -2.1 & -1.4 & -1.0 & 0.3 \\
\hline \multicolumn{12}{|l|}{ Q4 } \\
\hline Mean & 22.2 & 22.3 & 14.7 & -0.9 & 22.2 & 20.5 & 21.5 & -0.5 & 8.8 & 15.6 & 25.7 \\
\hline SD & 6.1 & 5.8 & 6.6 & 5.6 & 6.1 & 6.1 & 5.9 & 6.3 & 5.5 & 6.0 & 6.0 \\
\hline Sharpe & 3.7 & 3.8 & 2.2 & -0.2 & 3.7 & 3.4 & 3.6 & -0.1 & 1.6 & 2.6 & 4.3 \\
\hline \multicolumn{12}{|l|}{ Q5 } \\
\hline Mean & -64.0 & -59.9 & -57.2 & -27.1 & -64.0 & -62.4 & -63.1 & -30.0 & -37.6 & -49.4 & -40.4 \\
\hline SD & 39.6 & 41.1 & 39.4 & 30.5 & 39.6 & 40.5 & 38.4 & 29.1 & 29.4 & 36.8 & 35.7 \\
\hline Sharpe & -1.6 & -1.5 & -1.5 & -0.9 & -1.6 & -1.5 & -1.6 & -1.0 & -1.3 & -1.3 & -1.1 \\
\hline \multicolumn{12}{|l|}{$\begin{array}{l}\text { Q6 } \\
\text { (Part) }\end{array}$} \\
\hline Mean & 55.6 & 77.1 & 72.3 & 55.6 & 55.6 & 54.2 & 48.8 & 55.6 & 55.6 & 55.6 & 55.6 \\
\hline SD & 16.3 & 15.1 & 12.4 & 16.3 & 16.3 & 13.4 & 15.8 & 16.3 & 16.3 & 16.3 & 16.3 \\
\hline Sharpe & 3.4 & 5.1 & 5.8 & 3.4 & 3.4 & 4.1 & 3.1 & 3.4 & 3.4 & 3.4 & 3.4 \\
\hline
\end{tabular}

Table 3 reports the mean, standard deviation and the Sharpe ratios for the twelve portfolios formed quarterly between January 1, 2019 and May 15, 2020. Recalling that all portfolios were calibrated to have an expected standard deviation of $9.9 \%$, we can see that the actual risk experienced by these portfolios were sometimes far higher than expected based on the prior data. For all of 2019, the cash portfolio realised a standard deviation that was the same as expected or lower, but from January 1 to May 15, 2020, the cash portfolio had a much higher realised standard deviation clearly reflecting the heightened risk associated with COVID-19.

First, looking at the 2019 calendar year, with few exceptions, the risk of a cash portfolio is not materially increased by the inclusion of a third asset. In fact, there are only four out of a possible 36 instances where risk increased by more than 100 basis points and eight of 36 instances where risk increased by more than 50 basis points over the cash portfolio. Meanwhile, in nearly half, 17 of 36 instances, risk 
is less, sometimes by substantial amounts, than the risk experienced by the cash portfolio. Bitcoin seems to create the most excess risk, followed by Litecoin and Tezos. In contrast, Bcash and Tether consistently realise risk no great than 50 basis points than that experienced by cash portfolios and Ethereum and Bfinance consistently have a realised risk lower than the risk of the cash portfolio.

For the COVID-19 period from January 1, 2020 to March 31, 2020, we find that including a cryptocurrency asset increases risk only in the case of Bcash, whereas the remaining cryptocurrencies reduced risk sometimes by substantial amounts. The worst performing asset was gold as inclusion of gold resulted in a 150 basis point increase in risk while the corresponding figure for Bcash was 90 basis points. It is difficult to draw any conclusions regarding the bounce back period as it includes only seven weeks of information and six of the nine cryptocurrencies do not even enter the portfolios as they were too risky based on data from the COVID-19 period. However, we do observe that the three cryptocurrencies that did enter the portfolios all have a lower risk than the cash portfolio. ${ }^{5}$

Finally, we examine the trade-off between risk and return by examining the Sharpe ratio where the higher the ratio the greater the reward for taking risk. Here we see that in 21 out of a possible 36 instances inclusion of a cryptocurrency results in a lower Sharpe ratio. For the COVID-19 period, the Sharpe ratio is always higher or the same as the cash portfolio and all ratios are negative.

\section{Conclusions}

We conclude that cryptocurrencies have the potential to control risk as most cryptocurrencies consistently experienced risk no higher than 50 basis points of the risk experienced by cash portfolios comprised of stocks and bonds. However, some cryptocurrencies appear to control risk less well than others. In particular, Bitcoin appears to be the least stable followed by Litecoin and Tezos. On the other hand, two cryptocurrencies, Ethereum and Bfinance combined with cash assets result in portfolios that have a realised risk that is less than

5 It is interesting to speculate whether an investment in gold or a cryptocurrency would form a hedge during the heart of the COVID-19 financial crisis from Thursday March 12 to Monday March 16, 2020. We note that except for Gold and Tether, all cryptocurrencies moved in the same direction during these three working days as the stock market experienced losses on Thursday and Monday and an increase on Friday. This suggests that during this critical period most cryptocurrencies could form a hedge had the investor short sold the corresponding cryptocurrency. To confirm this, a study of hedge portfolios formed of long bonds and stocks with a short position in the candidate cryptocurrency designed to minimise portfolio variance needs to be conducted - a task beyond the scope of this chapter. 
the risk of the corresponding cash portfolio. However, there is no free lunch because clearly, while risk can be controlled, it comes at the expense of a lower Sharpe ratio suggesting that the reward for taking on the risk is higher when we ignore cryptocurrencies in forming portfolios. More specifically, the two cryptocurrencies that best control risk, Ethereum and Bfinance, also often have Sharpe ratios that were lower than the corresponding Sharpe ratio for cash portfolio.

These results add to the literature by finding that while cryptocurrencies can control the risk of well diversified cash portfolios, not all cryptocurrencies are able to do this during the run up to and during the COVID-19 financial crisis. Our findings implies that investors seeking to control the risk of well diversified cash portfolios should consider altcoins, particularly Bfinance and Tether, rather than Bitcoins but all the while realising that a reduction in risk is likely to be accompanied by a lower return. In contrast, the literature mostly concentrates on Bitcoin finding some evidence that bitcoins can effectively diversify cash portfolios in the case of extreme events (Bouri et al. 2017) but gold appears to have more stable diversification properties than Bitcoin (Shahzad et. al. 2020). In contrast, we find Gold did not control risk well during the height of the COVID-19 financial crisis and there were better performing altcoins than Bitcoin. Perhaps the variation in diversification effectiveness can be traced to the structure of an altcoin. Altcoins designed to attract the interest of professional investors by incorporating the altcoin to the trading on an exchange - Bfinance - or tied to another asset - Tether or provide ancillary services - Ethereum lead to more rational trading and less speculation resulting in more effective diversification than other alternatives.

\section{Bibliography}

Baur, G.; Hoang, L. (forthcoming). "A Crypto Safe Haven Against Bitcoin”. Financial Research Letters. https://doi.org/10.1016/j.frl.2020.101431.

Bouri, E.; Molnár, P.; Azzi, G.; Roubaud, D.; Hagfor, L. (2017). "On the Hedage and Safe Haven Properties of Bitcoin: is It Really More Than a Diversifier?". Financial Research Letters, 20, 192-8. http://dx.doi.org/10.1016/j. frl.2016.09.025.

Corbet, S.; Lucey, B.; Urquhart, A.; Yarovaya, L. (2019). "Cryptocurrencies as a Financial Asset: A Systematic Analysis". International Review of Financial Analysis, 62, 182-99. http://dx.doi.org/10.1016/j.irfa.2018.09.๑०3.

González, M.; Jareño, F.; Skinner, F. (2020). "Nonlinear Autoregressive Distributed Lag Approach: An Application on the Connectedness between Bitcoin Returns and the Other Ten Most Relevant Cryptocurrency Returns". Mathematics, 8(5), 810. https://doi.org/10.3390/math8050810.

Shahzad, S.; Bouri, E.; Roubaud, D.; Kristoufek, L. (2020). "Safe Haven, Hedge and Diversification for G7 Stock Markets: Gold Versus Bitcoin”. Economic Modeling, 87, 212-24. https://doi.org/10.1016/j.econmod.2019.07.023. 



\section{Part 5}

Commodities and Real Estate Markets 



\title{
Will COVID-19 Change Oil Markets Forever?
}

\author{
Yelena Kalyuzhnova \\ Henley Business School, University of Reading, UK \\ Julian Lee \\ Bloomberg
}

\begin{abstract}
The oil market is experiencing unprecedented dislocations in 2020. The industry is trying to cope with the biggest slump in demand ever recorded, as governments around the world try to tackle the COVID-19 pandemic. Will oil demand return to a prepandemic 'normal', or will the outbreak hasten a peak in oil demand? Will patterns of oil consumption change and, if so, what pressures will that place on an industry already struggling to adapt to growing environmental concerns and a demand for carbon-free energy? The paper will explore the options.
\end{abstract}

Keywords Oil prices. Oil markets. Energy demand. Energy supply. OPEC.

Summary 1 Introduction. - 2 The effect of the COVID-19-Pandemic on Oil Markets. 3 The Effect of the COVID-19-Pandemic on Transportation. - 4 Conclusion.

\section{Introduction}

Economic and social upheavals always affect oil markets and the COVID-19 pandemic is no exception. Short-term disruption to the consumption of fuels and plastics derived from oil is inevitable, as the spread of the disease disrupts economic activity and trade, while the response of governments worldwide sees large parts of the global population subjected to some form of curtailment of movement. The rapid contraction in economic activity, the collapse of trade, and the dramatic increase in the unemployment rate are all without precedent. So, too, is the collapse in oil demand and the subsequent cut 
in supply, both voluntary and in response to economic forces (Fernandes 2020). The main objective of this chapter is to explore how the COVID-19 pandemic might affect oil demand in both the short and long term and the implications that has for the oil industry.

Difficult though these short-term dislocations are to overcome, the more fundamental question is what will be the long-run consequences of the pandemic for the oil market. Will the fear that has been instilled in populations required to shelter at home for weeks on end and keep their distance from fellow human beings dissipate quickly as restrictions are eased, or will it result in fundamental and longlasting changes in behaviour that will impact global demand for fuels? Will the experience of a long period of remote working and virtual meetings change the behaviour of companies and their staff, or will it reinforce the importance of face-to-face contact and international business travel?

\section{The Effect of the COVID-19-Pandemic on Oil Markets}

Some experts are suggesting that "the COVID-19 crisis accelerates what was already shaping up to be one of the industry's most transformative moments" (Barbosa et al. 2020). Focusing on the pressure placed on the industry, it is useful to look at the broader environment. The long megacycles of shifting demand and supply tend to have wide swings. Without doubt, the combination of demand disruption due to the pandemic as well as excess supply created a deep crisis for the industry. Almost a fifth of global demand for oil is expected to disappear during the second quarter of 2020 and it is not expected to return to pre-pandemic levels before the end of 2021. All three of the major forecasting agencies - The International Energy Agency (IEA), the Organization of Petroleum Exporting Countries (OPEC) and the US Energy Information Administration (EIA) - now agree that the world faces its biggest-ever slump in oil consumption, after governments imposed movement restrictions on billions of people to combat the coronavirus. "The scale of the demand hit means that despite producers implementing unprecedented output cuts, stockpiles will soar this year" (Lee 2020b). This unprecedented stockbuild will create an overhang that will suppress prices even as demand recovers, until it is drawn down and inventories return to more normal levels. The forecasts of the IEA indicate that the world will consume about 1.7 billion barrels less oil in the second quarter of 2020 than it did during the same period of 2019. Over the whole of 2020 and 2021, the volume of lost demand compared with pre-pandemic forecasts balloons to about 5.4 billion barrels, equivalent to the entire proven oil reserves of Mexico [fig. 1]. In addition, the decades-long upward movement in crude oil demand has been undermined by a repeated pattern of declining 
oil-intensity of GDP (oil consumption/GDP) followed by a brief and incomplete recovery in which intensity did not return to its pre-decline levels (Fagan 2020). The oil intensity of the global economy been declining since the 1980s and 1990s mainly in non-OECD countries as well as in some OECD countries.

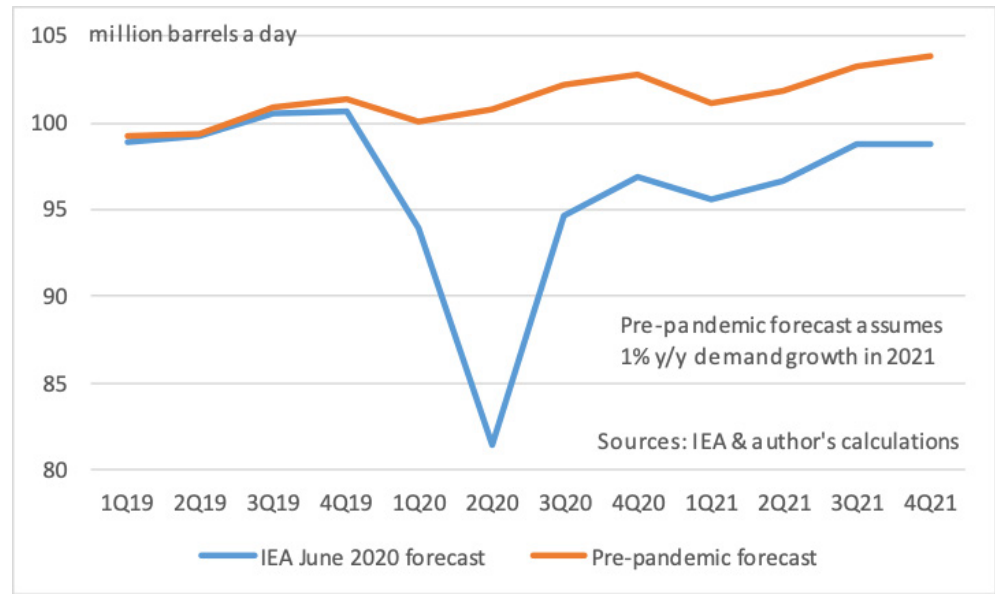

Figure 1 The effect of the COVID-19 pandemic on world oil demand

The unprecedented collapse in oil demand has required a similarly unique response from oil producers, who simply could not keep pumping at pre-pandemic rates without filling all the available storage capacity for crude and refined products. Storage tanks at key hubs like Rotterdam, Singapore and Saldanha Bay were filling fast and any available space had already been contracted. The industry was forced to turn to the more expensive option of storing oil in tankers at sea. Oil analytics firm Vortexa Ltd estimates that the volume of crude oil in floating storage soared to more than 180 million barrels, over three times its average level in 2019, as oil demand tumbled [fig. 2]. That will start to draw oil out of stockpiles, but the overhang is huge. The volume of crude oil stored in tankers rose to more than 200 million barrels by June 19, according to data from analytics firm Vortexa supplied via Bloomberg (Bloomberg 2020). That is four times as much as at the same time in 2019 (Lee 2020e). 


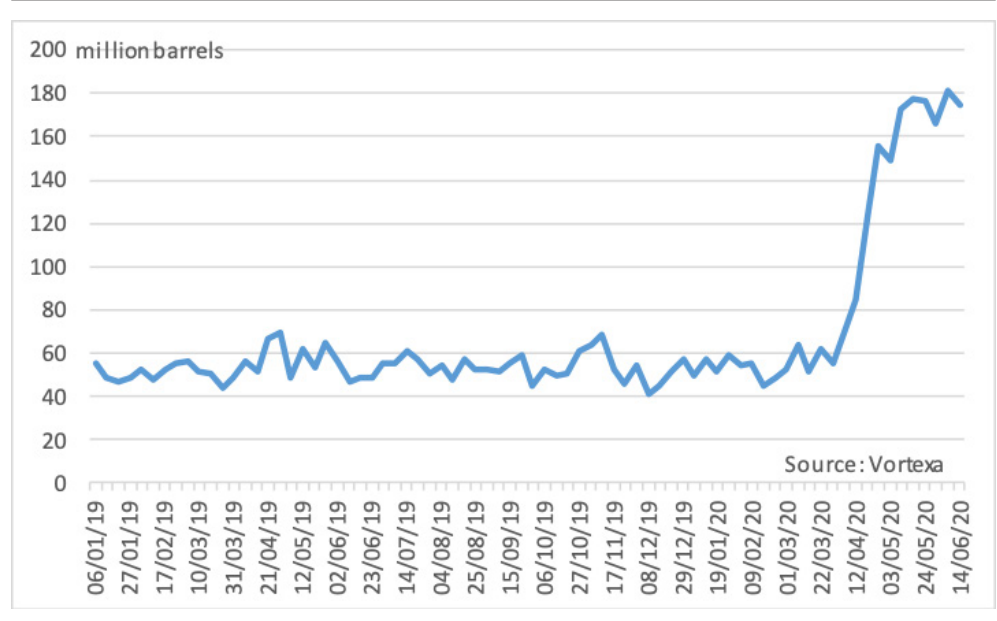

Figure 2 Crude stored on tankers at sea soared as oil demand collapsed

In April 2020 the world oil price made history. US West Texas Intermediate (WTI) crude turned negative for the first time in the 160-year history of the oil industry, as holders of contracts for future delivery sought to unload them before they expired and they had to take delivery of physical barrels [fig. 3].

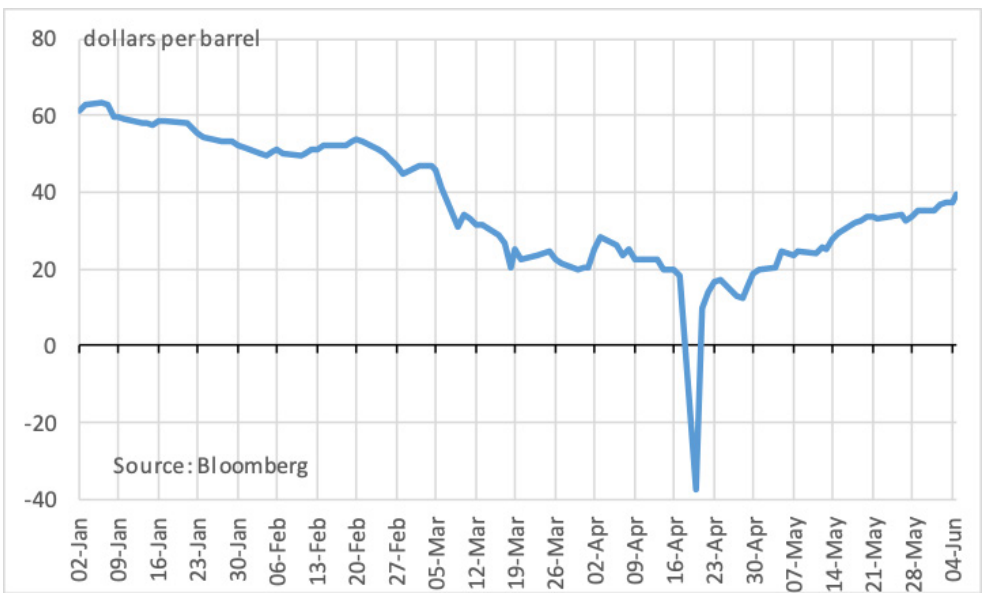

Figure 3 West texas intermediate crude price in early 2020 
The normal buyers of such contracts faced difficulties of their own, with almost no available storage capacity at the contract's delivery point of Cushing, Oklahoma. "Dismissing the historic move in the May contract for West Texas Intermediate crude as 'more of a financial thing than an oil situation,' as U.S. President Donald Trump did, misses the point" (Lee 2020a). Although the negative oil price was a peculiarity of the WTI contract, it was also a wake-up call to oil producers in America that they had to get serious about reducing their own supply, rather than simply waiting for others to make the cuts that would rebalance supply and demand and allow them to keep pumping.

Global financial markets have been hit severely by the oil price collapse. Two serious shocks, the collapse of oil prices two months after the onset of the COVID-19 epidemic in Wuhan city as well as after the unexpected decision of Saudi authorities to offer record price discounts of as much as $\$ 13$ against regional benchmarks to their main customers, sent worldwide stock markets into free fall (Sharif, Aloui, Yarovaya 2020).

Despite record output cuts of almost 10 million barrels a day agreed by the members of OPEC and a group of allied oil producers, combined with unprecedented reductions in supply from producers in the US, Canada and other countries outside the so-called OPEC+ group, inventories have continued to build. US commercial crude stockpiles hit a record high in June, surpassing the previous peak set in 2017 [fig. 4].

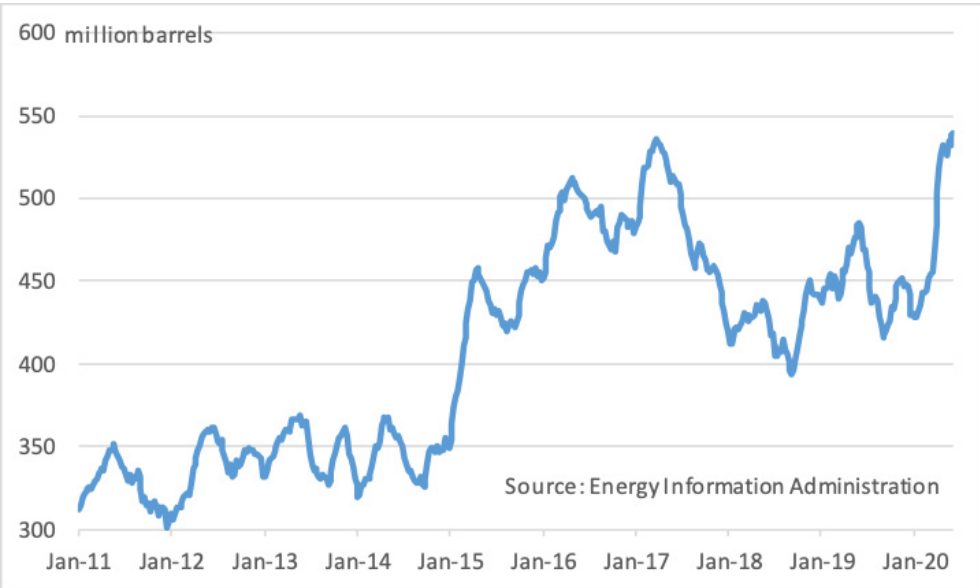

Figure 4 US commercial crude stockpiles hit a new high in June 2020

In the short term, the only way to stabilise the oil market was to meet the biggest ever collapse in demand with the largest reduction in supply. The 23 members of the OPEC+ group of countries, which joins the 
OPEC members with ten non-OPEC countries, including Russia, Mexico, Kazakhstan and Azerbaijan, met by video conference in April and eventually agreed to reduce their collective oil production by an initial 9.7 million barrels a day in May and June 2020 and to taper those cuts in two steps, with output restrictions that would last until April 2022.

Oil producing countries outside this group were reluctant to make formal commitments to cut output, but many said that their industries would cut production in response to market forces, with the Canadian oil sands and the US shale oil sectors seen to be particularly vulnerable to the downturn. High operating costs and long routes to markets made operations in Canada's Alberta Province vulnerable, while the constant need to drill new wells to offset steep decline rates at US shale wells put that sector at risk.

The reluctance to cut production and close wells is understandable. Most of the costs of producing oil are already sunk by the time crude starts flowing out of the ground; the operating costs of keeping a well flowing are usually only a small fraction of the total cost and oil prices have to fall to very low levels indeed to stop covering cash operating costs. Furthermore, shutting a well is not cost-free. Getting them pumping again can be even more expensive. The decision to shut the well will involve a number of factors such as the cost and technical challenges of restoring the wells back to pre-curtailed volumes (Adams-Heard, Wethe, Crowley 2020).

US oil production had fallen by 2 million barrels a day by midJune from a peak of 13.1 million barrels a day in mid-March, before the pandemic caused oil prices to tumble, according to preliminary weekly data from the EIA. The number of rigs drilling for oil in the US has slumped to its lowest level since June 2009, figures from Baker Hughes show; a drop of $72 \%$ in the space of 14 weeks [fig. 5].

Output cuts are doing their job, with forecasts from the IEA (IEA 2020) and others indicating that demand will be running ahead of supply in the second half of 2020, as countries begin to recover from the worst effects of the lockdowns imposed to combat the COVID-19 pandemic and production rates remain curtailed.

While production cuts have helped to balance oil supply and demand on a day-to-day basis, the global oil industry still faces a daunting task. The most recent forecast from the IEA shows demand growth recovering more slowly than the group previously thought. "Global demand will still be below pre-pandemic levels by the end of 2021, never mind this year" (Lee 2020d). 


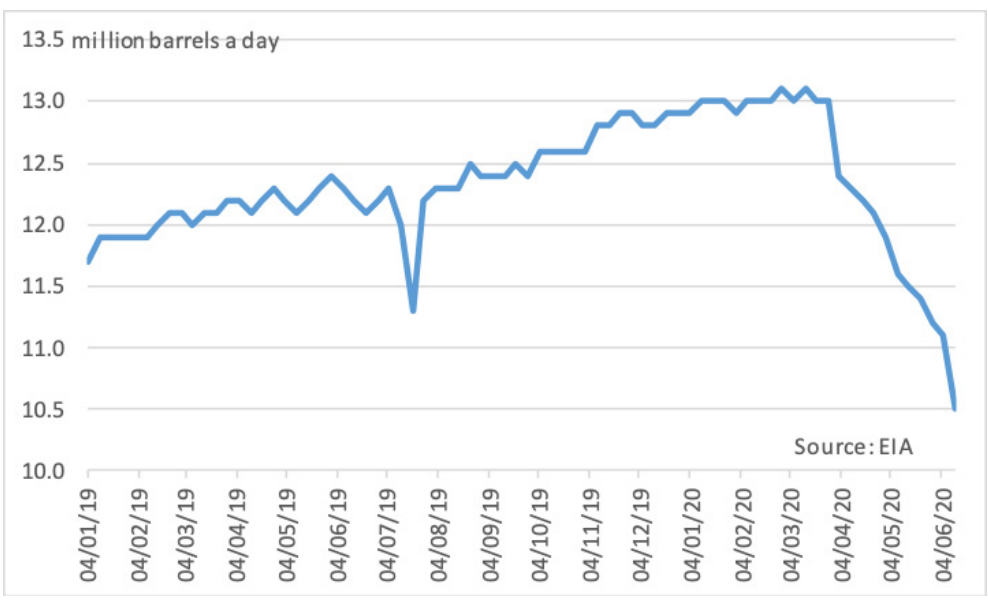

Figure 5 Domestic US crude production has tumbled

\section{The Effect of the COVID-19-Pandemic on Transportation}

The COVID-19 pandemic has severely impacted travel, by road, rail, sea and air. As the pandemic spread, individual behavioural changes took place, partly the result of individual choices and partly in response to government-imposed restrictions on movement and economic activity. Working from home became the normal practice for those who could do so, commuting to work virtually ceased, public gatherings were banned and international travel severely curtailed. People stopped driving, flying, or travelling on public transport.

Data from FlightRadar24, which tracks both commercial and noncommercial air traffic, show that by mid-June, even though the number of commercial flights worldwide had doubled since the depth of the pandemic, it was still down by about $60 \%$ from the pre-virus level (Reed 2020) [fig. 6].

One of the biggest questions that remains unanswered is to what extent travel behaviour will return to its pre-COVID-19 normal once restrictions are lifted. Congestion on Chinese city streets rebounded quickly after lockdowns were eased and congestion even surpassed pre-lockdown levels, as people chose to use private cars to get to work rather than crowded transit systems. But high-frequency journey-time data from TomTom Traffic Index show that the return of congestion is not uniform [fig. 7].

The congestion data show that roads are still much emptier in the evenings and during the middle of the day during the weeks and that traffic levels remain well below pre-pandemic levels during weekends. In other parts of the world, where lockdowns are only gradu- 


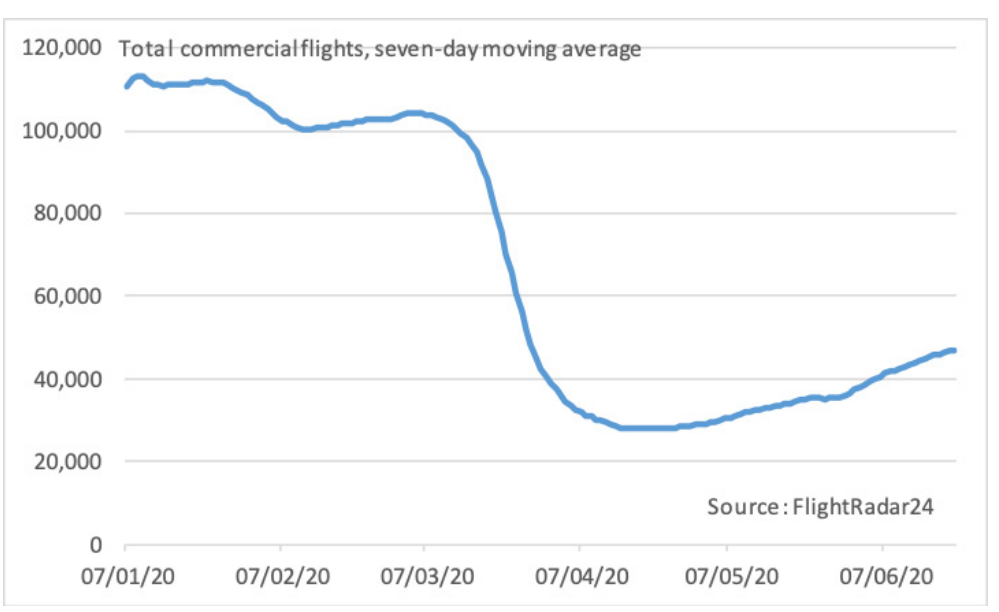

Figure 6 Commercial flights are recovering, but remain 60\% below pre-COVID-19 levels

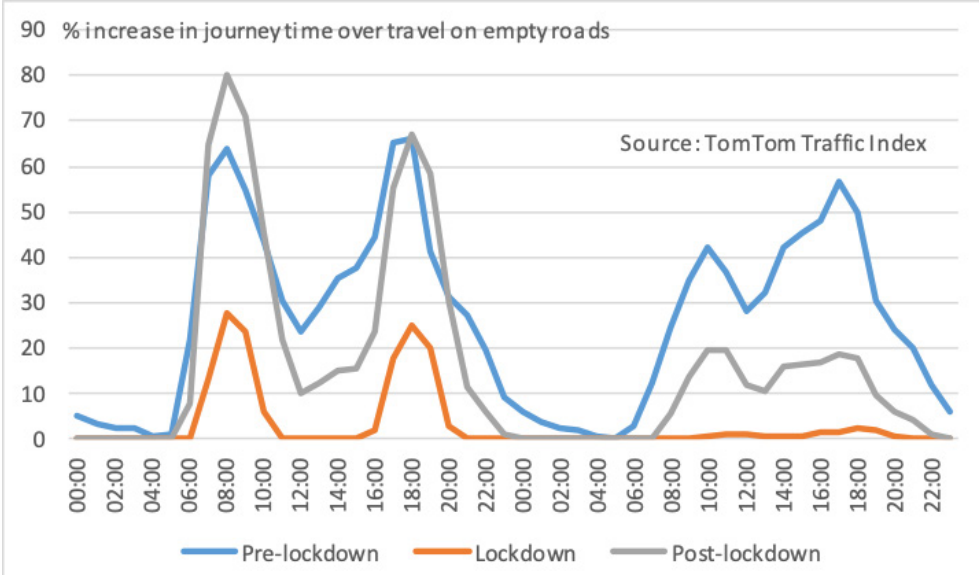

Figure 7 Congestion has returned to Beijing streets during commuting hours, but not outside them The chart shows average congestion for working days (left) and weekends (right)

ally being eased, similar patterns are emerging. These may change as a greater range of economic activities are permitted and leisure travel in particular can be expected to increase as more leisure opportunities become available.

Whether the loss of oil demand is a brief anomaly, as it was during the financial crisis of 2008-09, or reflects a structural change in consumption remains to be seen. It is too early yet to determine whether the pandemic will alter fundamentally people's attitudes to- 
wards air travel, or commuting to work, or whether it will lead companies to reassess working-from-home opportunities for their staff, or international corporate travel to attend meetings and events. UBS Group Chief Operating Officer Sabine Keller-Busse said that as many as a third of its employees could work remotely on a permanent basis (Halftermeyer, Lacqua 2020).

Bloomberg economists Jamie Rush, Maeva Cousin and David Powell see a rapid economic recovery in Europe running out of steam. The big questions here are how quickly the rebound will be and how much social distancing will be an obstacle for this (Rush et al. 2020).

By mid-June of 2020, Ben Luckock, co-head of oil trading at Trafigura Group told Bloomberg News that demand for crude was already back to $90 \%$ of normal levels as countries emerge from pandemic-related lockdowns, but that returning to normal could prove difficult. He believes that 5\% (of the remaining 10\%) will be recovered in a few months, although he expressed his worries that complete recovery to pre-crisis levels may be difficult. There are many obstacles for this and some 'new normal' patterns like working-from-home as well as reduced air travels (Blas 2020).

\section{Conclusion}

If long term oil demand settles at a level some 5\% lower than the pre-COVID-19 trajectory, the implications for the oil sector will be significant. Investment in the oil projects needed to provide the production capacity in the coming decade are not being made. Oil companies from the supermajors like ExxonMobil and Royal Dutch Shell to the small operators in the US shale patch have all slashed their budgets. Shell has cut its dividend for the first time since the Second World War (Hurst 2020).

The combination of lower oil demand and green post-COVID-19 stimulus packages could transform the energy landscape. Germany has committed 130 billion euros ( $\$ 145$ billion) to pandemic recovery, with about $30 \%$ to be spent on activities that will cut emissions. That compares with about $15 \%$ of the stimulus money injected into the global economy during the 2008-09 financial crisis that went to green initiatives (Rathi, 2020).

Goldman Sachs analysts see spending on renewable power overtaking oil and gas drilling for the first time in 2021. Clean energy affords a \$16 trillion investment opportunity through 2030 Renewables policies including biofuels which will account for about a quarter of all energy spending next year. This is up from about 15\% in 2014, driven in part by diverging costs of capital, as borrowing rates have risen to as high as $20 \%$ for hydrocarbon projects compared with as little as 3\% for clean energy (Murtaugh 2020). 
The current disequilibrium in global energy markets is a signal that the post-COVID-19 new energy normal would be characterised by a more uncertain future for the oil and gas industry. To a certain extent, the COVID-19 Pandemic has and will reshape of our energy future. The oil and gas industry will experience short and long term impacts from the crisis to which it will have to adjust, with the potential for future oil demand to be significantly reduced from pre-pandemic forecasts.

\section{Bibliography}

Adams-Heard, R.; Wethe, D.; Crowley, K. (2020). "Turning Oil Wells Back on Is Trickier Than Shutting Them Off”. Bloomberg, May 8. https://bloom. bg/3jBXA8R.

Barbosa, F.; Nyquist, S.; Yanosek, K.; Bresciani, G.; Graham, P. (2020). "Oil and Gas After COVID-19: The Day of Reckoning or a New Age of Opportunity?". McKinsey \& Company, May 15. https://mck.co/30PEvHQ.

Blas, J. (2020). "Commodity Trader Trafigura Says Oil Demand Back to $90 \%$ of Normal”. Bloomberg, June 17.

Blas, J.; El Wardany, S.; Smith, G. (2020). "Oil Price War Ends With Historic OPEC+ Deal to Slash Output”. Bloomberg, April 13. https://bloom.bg/30N7bBf.

Bloomberg (2020). "Crude Oil in Floating Storage 300\% Higher Than Year Ago: Vortexa”. Bloomberg, June 22.

Fagan, M. (2020). "Up the Down Staircase: What History Teaches Us about Oil Demand after a Crisis”. USAEE Working Paper No. 20-440. May 4. http:// dx.doi.org/10.2139/ssrn.3592443.

Fernandes, N. (2020). "Economic Effects of Coronavirus Outbreak (COVID-19) on the World Economy". https://dx.doi.org/10.2139/ssrn.3557504.

Globaldata (2020). "COVID-19 Pandemic Has Considerably Disrupted Oil and Gas Supply Chains, Says GlobalData”. https://bit.ly/20VaS2c.

Halftermeyer, M.; Lacqua, F. (2020). "UBS Says One-Third of Staff Could Permanently Work Remotely". Bloomberg, June 22. https://bloom.bg/30JXkMj.

Hurst, L. (2020). "Shell Cuts Dividend for First Time Since Second World War". Bloomberg, April 30. https://bloom.bg/2WS70TI.

IEA (International Energy Agency) (2020). "Oil Market Report”, June 16. https://www.iea.org/reports/oil-market-report-april-2020.

Lee, J. (2020a). “Negative Oil Prices Were a Warning, Not an Anomaly”. Bloomberg, April 26. https://bloom.bg/2D5oRj2.

Lee, J. (2020b). "Pandemic Punches 1.7-Billion-Barrel Hole in Global Oil Demand". Bloomberg, May 15. https://bloom.bg/30KkRN3.

Lee, J. (2020c). “Oil Demand Isn't Roaring Back Yet”. Bloomberg, June 14. https://bloom.bg/39q8Yjj.

Lee, J. (2020d). "Oil Demand Recovery Set to Be Slower for Longer”. Bloomberg, June 18. https://bloom.bg/2ZVU9Sq.

Lee, J. (2020e). "Buyer Beware: Oil Stockpiles Are Enormous”. Bloomberg, June 21. https://bloom.bg/39rGpCo.

Murtaugh, D. (2020). “Goldman Sees \$16 Trillion Opening as Renewables Pass Oil and Gas". Bloomberg, June 16. https://bloom.bg/2CAyxm4.

Rathi, A. (2020). "Germany Leads World on Climate-Friendly Stimulus: Green Insight”. Bloomberg, June 16. https://bloom.bg/301kDCp. 
Reed, D. (2020). "Airlines Can't Shrink Fast Enough To Keep Up With The Unprecedented Collapse In Global Travel Demand". Forbes, March 26. https://bit.ly/2Bt1zTT.

Rush, J.; Cousin, M.; Powell, D. (2020). "EURO-AREA INSIGHT: Economic Forecasts for a Post-Covid Europe”. Bloomberg, June 17.

Sharif, A.; Aloui, C.; Yarovaya, L. (2020). "COVID-19 Pandemic, Oil Prices, Stock Market, Geopolitical Risk and Policy Uncertainty Nexus in the Us Economy: Fresh Evidence from the Wavelet-Based Approach". International Review of Financial Analysis, 101496. https://doi.org/10.1016/j.irfa.2020.101496.

WoodMackenzie (2020). "Coronavirus Oil and Gas Supply Chain Risks are Hidden in Your Backyard”. https://bit.ly/2CBTOMd. 



\title{
Real Estate and the Effects of the COVID-19 Pandemic in Europe
}

\author{
Gianluca Mattarocci \\ Università degli Studi di Roma «Tor Vergata», Italia \\ Simone Roberti \\ Colliers International, Italia
}

\begin{abstract}
The real estate industry was severely affected by the COVID-19 in both the residential and the commercial sectors due to travel and site-visit limitations, rent sustainability issues and a decrease of or higher uncertainty about disposable income. During the lockdown, houses became more important and were analysed in depth. It can be assumed that a new demand could emerge after this crisis making households looking for more comfortable houses since this asset will increase its importance for living and working. Similarly, the commercial real estate sector will change due to lower rent sustainability. However, the main expected change is related to the building type and the standards requested by tenants in the new economic environment.
\end{abstract}

Keywords Real Estate. Residential. Commercial. Pandemic. COVID-19.

Summary 1 Introduction. - 2 Residential Real Estate. - 3 Commercial Real Estate. 3.1 Office Market. - 3.2 Retail. - 3.3 Industrial and Logistic Real Estate. - 3.4 Hospitality. -4 Conclusion.

\section{Introduction}

After the SARS in 2003, the literature started to study the economic impact of similar diseases by considering not only the social cost of the deaths related to the infection but also the negative effects of government policies that aimed to reduce infection and protect lives (Keogh-Brown et al. 2010). Theoretical 
models applied to Europe tried to test the impact of a pandemic similar to the Spanish influenza in 1918-19. Results showed sector and country differences but assumed a short-term effect that would last a few quarters (Jonung, Roeger 2006). The coronavirus disease has unique features with respect to previous pandemics because it is the first time that we are experiencing such an event in a globalised and interconnected world. Preliminary analysis of the data available to date shows that, during the lockdown period, consumption behaviour changed significantly with negative effects on some sectors (food and beverage, hospitality, etc.) and positive effects on others (e-commerce, healthcare, etc.) (Backer et al. 2020). These effects will be long lasting because companies will require several months to recover from the losses suffered during the lockdown and customers will require time in order to adapt themselves to the new economic environment.

The real estate sector was severely affected by the pandemic since commercial tenants had lower revenues for paying rents during the lockdown period and households had lower income to pay rents or mortgages. Moreover, there is a change in the perception of the efficient use of space that may have an impact on the demand for existing and new real estate assets (Taltavull 2020). This chapter analyses the real estate market by considering separately residential (section 2) and commercial (section 3) real estate. The focus will be on European real estate markets and the analysis will consider the different approaches adopted by policy makers for managing the pandemic and the lockdown period.

\section{Residential Real Estate}

The analysis of household residence in Europe shows significant differences among countries [fig. 1].

On average, more than $70 \%$ of citizens own their house (with or without an outstanding mortgage). But the percentage is significantly lower in some North and Central European countries (e.g. Switzerland, Germany, and Austria) and higher in some East European countries (e.g. Croatia, Bulgaria, Romania, and Slovakia) where less than $20 \%$ of citizens are renters.

Looking at the type of dwelling, on average less than $50 \%$ of Europeans are living in a flat but this percentage is significantly higher in the main cities compared to the countryside [fig. 2].

Countries like Switzerland, Latvia and Spain have more than 60\% of citizens living in a flat while other North European countries (like Ireland, UK and Netherlands) have more than $80 \%$ of citizens living in detached and semi-detached or terraced houses.

The lockdown experience showed some limitations of the existing housing stock. People that experienced 'smart working' often 


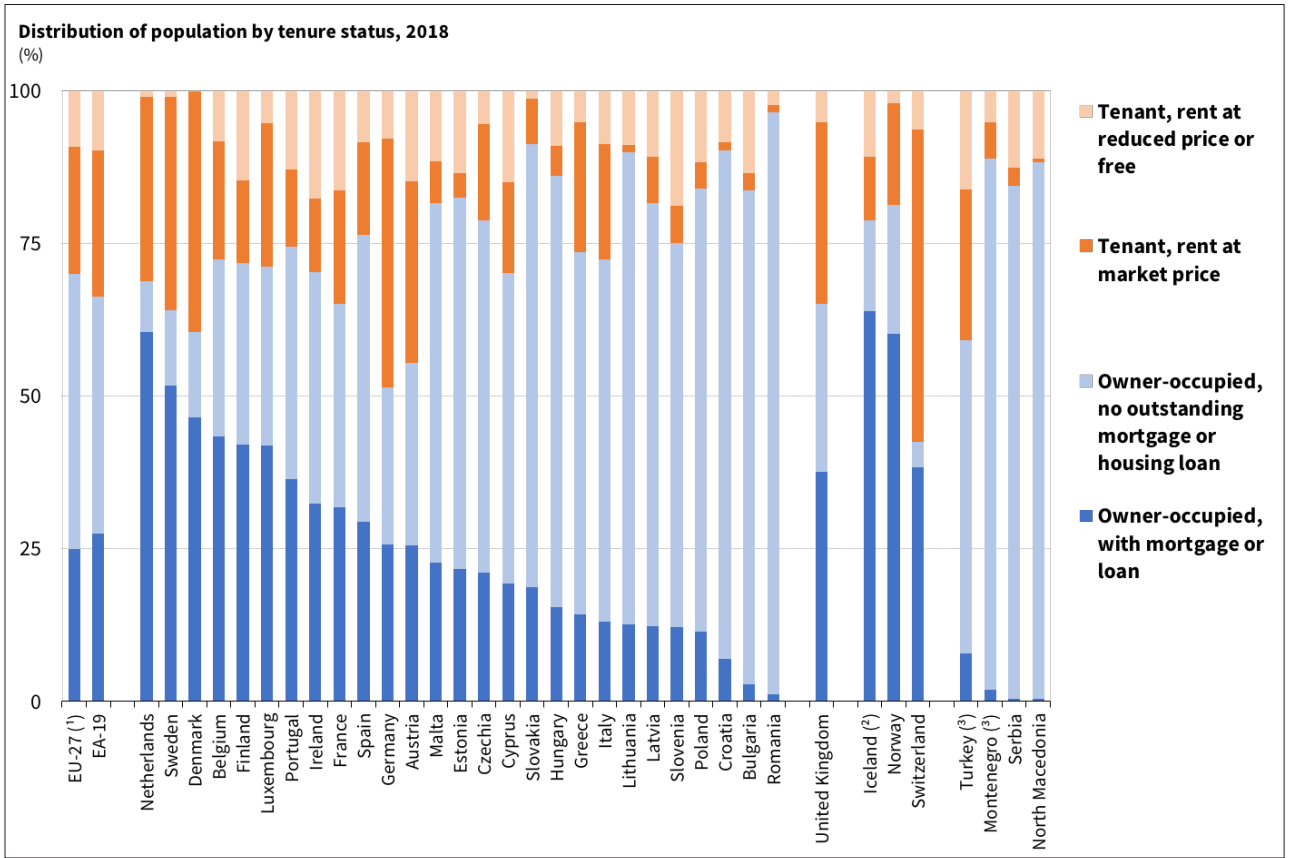

Figure 1 Population distribution by tenure status in 2019. Source: Eurostat data processed by the Authors

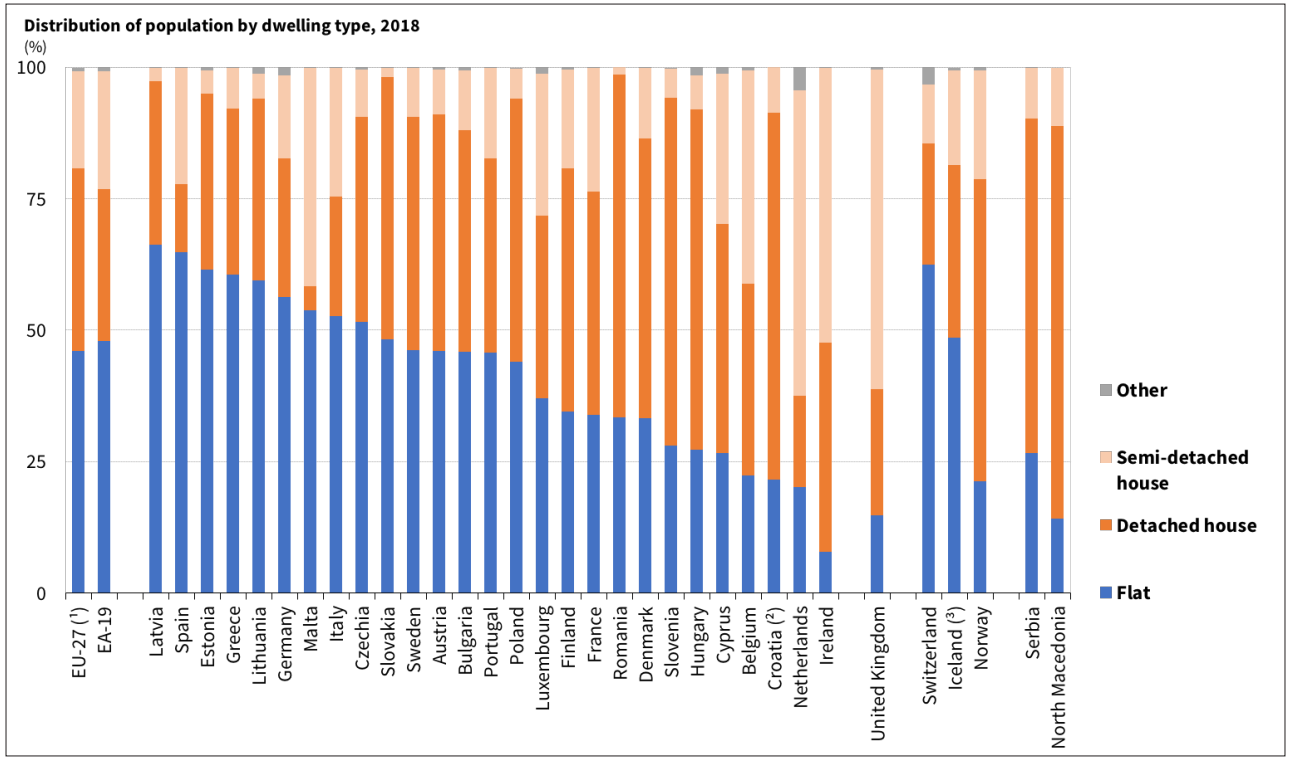

Figure 2 Population distribution by dwelling type in 2019. Source: Eurostat data processed by the Authors 
suffered from the lack of space necessary for working from home. A dedicated table and comfortable seat for working appeared to be necessary. The entrance of the flat was eliminated in some developments and now could be repurposed, as a 'decontamination room'. Therefore, demand is expected to change in the near future with an increase of the average size of houses. Families with children, in particular, will look for independent real estate units (detached and semi-detached houses) with gardens and terrace that may make living at home more enjoyable. Households that expect to work from home (even only for few days per week) may have an incentive to buy outside downtown areas where prices per square meter are generally lower, making it possible to buy a bigger house.

However, the pandemic had a negative effect on the disposable income of individuals that were obliged to stop working during 'phase one' of the lockdown, or are facing higher redundancy risk or salary cuts (Mann 2020). Moreover, the economic crisis and the credit conditions are getting worse in the short term which may reduce the number of transactions in the real estate market.

\section{Commercial Real Estate}

\subsection{Office Market}

The office market has slowly been changing in the last years with an increase of flexible spaces and a more intensive use of desks (i.e. less dedicated desks), causing a decline in the square metre per employee. The main driver was cost reduction. Therefore, companies changed the style and the layout of offices and landlords had to adapt to the new requirements of the market with a switch from the model of small, independent rooms to open spaces, with a lot of common areas, to minimise the consumption of space per employee [fig. 3].

The demand for office space in the last years gave more importance to ancillary services (conference rooms, canteens, fitness centres, and so on) that could represent a benefit for the employees and increase job satisfaction and corporate loyalty (Cushman \& Wakefield 2020).

During the COVID-19 emergency many firms were obliged to increase the use of smart working solutions in order to reduce the risk of infection for their employees and avoid stopping their business during the lockdown. Data showed a huge increase in home working and, independently of the country selected, from $60 \%$ to $70 \%$ of the European companies used smart working solutions for the months of April and May (JLL 2020).

The social distancing rules have changed the layout of the office, increasing the space necessary for each employee. The impact of this change could be disruptive for the industry because companies will be obliged to reduce people that will be in the office at the same time by 
Gianluca Mattarocci, Simone Roberti Real Estate and the Effects of the COVID-19 Pandemic in Europe

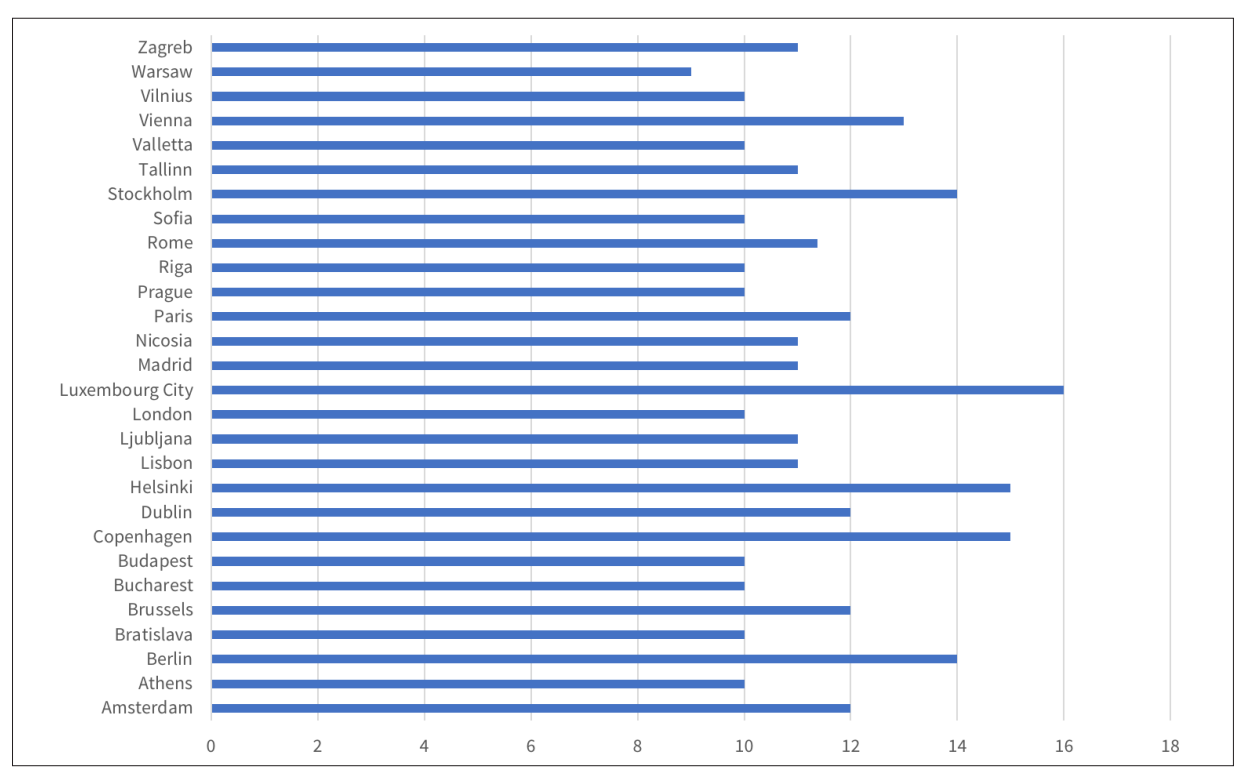

Figure 3 Average office square metres per employee in the main European cities in 2019. Source: Cushman \& Wakefield data processed by the Authors

applying rotation and smart working. Otherwise, they will be obliged to leave the current buildings and move to new and bigger ones. Moreover, companies may be encouraged to avoid downtown buildings (or towers) and may prefer to look for secondary office areas where bigger buildings are more affordable. This could become a new trend if employees start moving out of urban areas and prefer to drive to their office. In some markets, shared workspace companies, like Regus or WeWork, have grown significantly (e.g. Greater Paris). They offer an alternative model for big corporations that may opt to rent desks in coworking spaces located in the suburbs near to residential areas where employees live. This may be more cost effective than investing new money in developing owned corporate real estate (Knight Frank 2019).

\subsection{Retail}

The retail sector has been experiencing a significant change in the last decade. This was characterised by a crisis of the commercial centres not located in prime areas and a decrease in the volume of the new investments in some of the major locations in Europe. A comparison between commercial retail property investment and consumer online spending shows that countries with higher rates of their population 


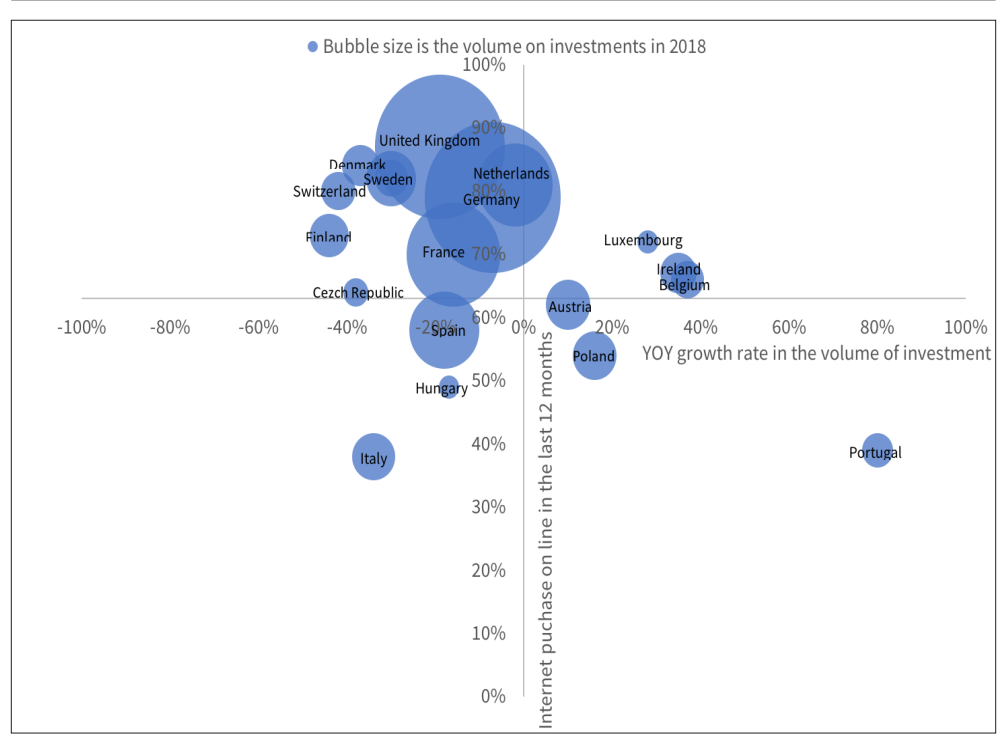

Figure 4 European retail volume vs Online spending. Source: RCA and Eurostat data processed by the Authors

spending online have weaker retail property investment volumes. The ongoing shift away from bricks-and-mortar retail in some areas has a direct impact on commercial property market trends (RCA 2019) [fig. 4].

The COVID-19 and the lockdown measures have had an effect on almost all retail activities causing a significant decrease of annual income and impacting on the sustainability of rents paid to landlords. Groceries and supermarkets were the only businesses that saw an increase in monthly revenues following the lockdown. The real estate market showed some interest in developing such businesses in areas previously not served (Savills 2020).

During the lockdown, consumers' behaviour has changed and some changes are expected to last: an increased importance of food and drinks expenditure for home consumption (in supermarkets) and the use of e-commerce solutions. Restaurants and bar are expected to suffer in the short and medium-term until the contagion control measures will be permanently removed. This is because the smart working (or more precisely home working) and travel restrictions affect negatively the demand. Moreover, social distancing measures reduce the number of customers that can be served at the same time. The forced experience of using e-commerce during the lockdown period to buy goods may represent a disruptive event for the economy, with more customers developing a preference for the internet channel. 


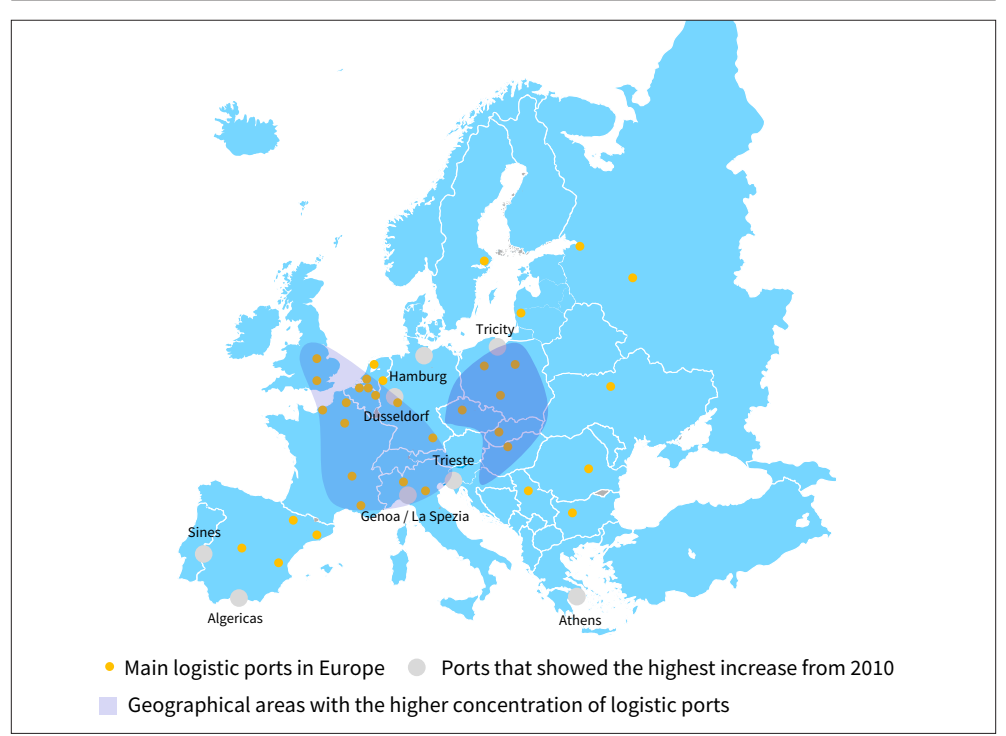

Figure 5 European Logistic and Industrial Hubs. Source: Colliers International, 2015

\subsection{Industrial and Logistic Real Estate}

Industrial and logistic real estate in Europe showed an increase in the volume of take-ups in areas with a good connectivity by ship, plane, or train that represented the main market for new investments (Mattarocci, Pekdemir 2017) [fig. 5].

In 2019, the main global gateways were located in Benelux, Germany and UK (the so called 'blue banana'). But there are new markets that are growing as critical supply chain links and regional hubs outside of this area in Northern, Eastern and Southern Europe (Cushman \& Wakefield 2020).

During COVID-19 the industrial and logistic sector suffered an increase in time to delivery, a reduction of the number of connections and several constraints applied by each country to reduce commerce for inessential goods. Immediately after the end of the lockdown, the time necessary for re-activating businesses was significantly longer for companies with few logistic nodes for acquiring inputs and delivering goods (Deloitte 2020). The pandemic showed the limits of excessively globalised supply chains, which turned out not to be sufficiently resilient (Hohenstein et al. 2015). It also pointed out the need of a new strategy for procurement and sales that would reduce dependence on international trade in order to avoid the risk of similar supply chain disruptions in the future (Choi, Rogers, Vakil 2020). 


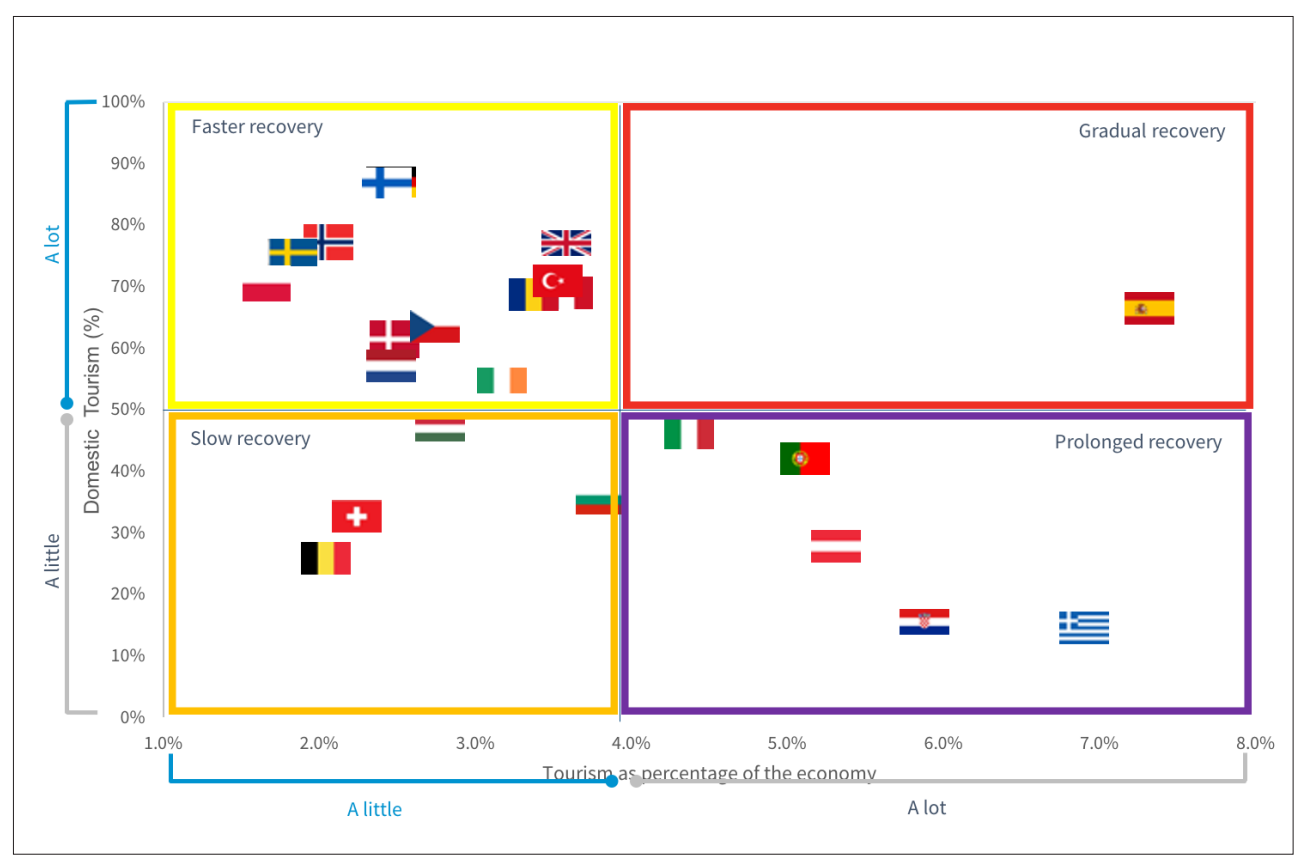

Figure 6 The expected impact of the COVID-19 on leisure hotels. Notes: Faster recovery: countries that depend to a larger degree on domestic tourists and tourism represent a limited part of the economy; Gradual recovery: countries that can still count on domestic tourism and less reliant on international tourism; Prolonged recovery: countries largely depending on international travellers; Slow recovery: countries where tourism play a small role in the economy. Source: Colliers International, 2020

Moreover, consumer behaviour has changed due to the experience of e-commerce during the lockdown period and the opportunities related to home delivery. For some countries, the growth of e-commerce is expected to change radically the logistic and the industrial markets with an expected growth in the demand of "last mile" warehouses near the main cities (Prologis 2020).

\subsection{Hospitality}

The hospitality sector was the first to be directly affected by the COVID-19 with hotels, both leisure and business, closing even before the enforcement of the lockdown measures. Therefore, it is currently one of the sectors that is suffering the most from the pandemic and the social distancing rules (Fernandes 2020).

Many hotels registered cancellation not only during the lockdown period but also for the following summer holidays. The negative effect is related to a lack of confidence of travellers regarding safety 


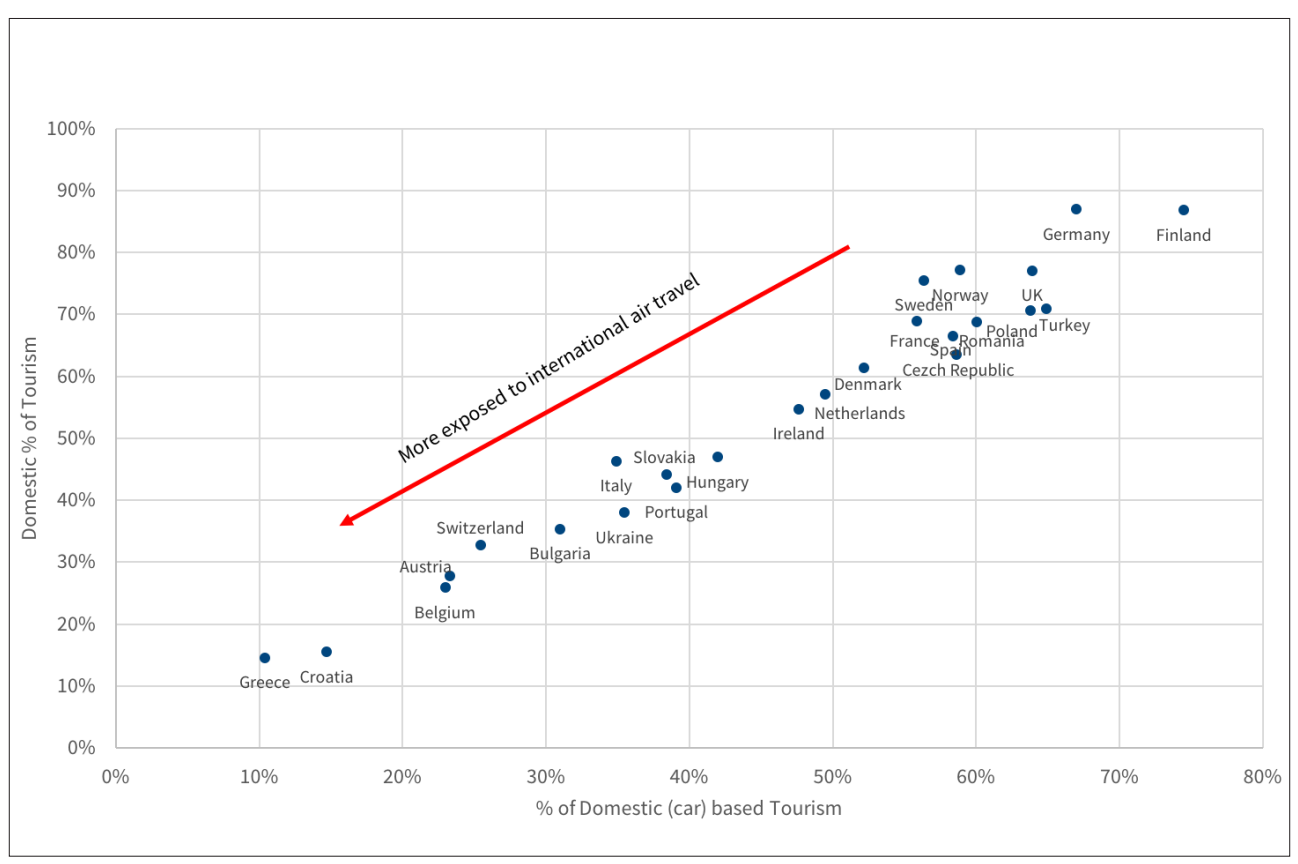

Figure 7 Importance of domestic land (car) based travel. Source: Colliers International, 2020

and hygiene as well as the decrease of disposable income that may oblige individuals to avoid unnecessary expenses. The impact on the sector is expected to vary across countries also in relation to the incidence of domestic versus foreign tourism [fig. 6].

An analysis of EU shows that the speed of the recovery for the hospitality industry will vary across countries. The majority of countries (13) expect to recover quickly because the size of their tourism sector is small and mainly driven by domestic demand. In contrast, other countries will recover slowly since the demand is mainly driven by foreigners (Belgium, Bulgaria, Hungary, Switzerland) or because the tourism sector is one of the most important sectors of the economy (Spain). The worst scenario is for countries that were targeting mainly foreign tourism (Croatia, Greece, Italy, Latvia, Portugal). But among these countries there could be significant differences. For some of them the recovery could be faster due to a change in the habits of their citizens that in the past preferred to go on holiday abroad (e.g. Italy) or due to the financial support offered by their governments to the tourism industry (Colliers 2020). 


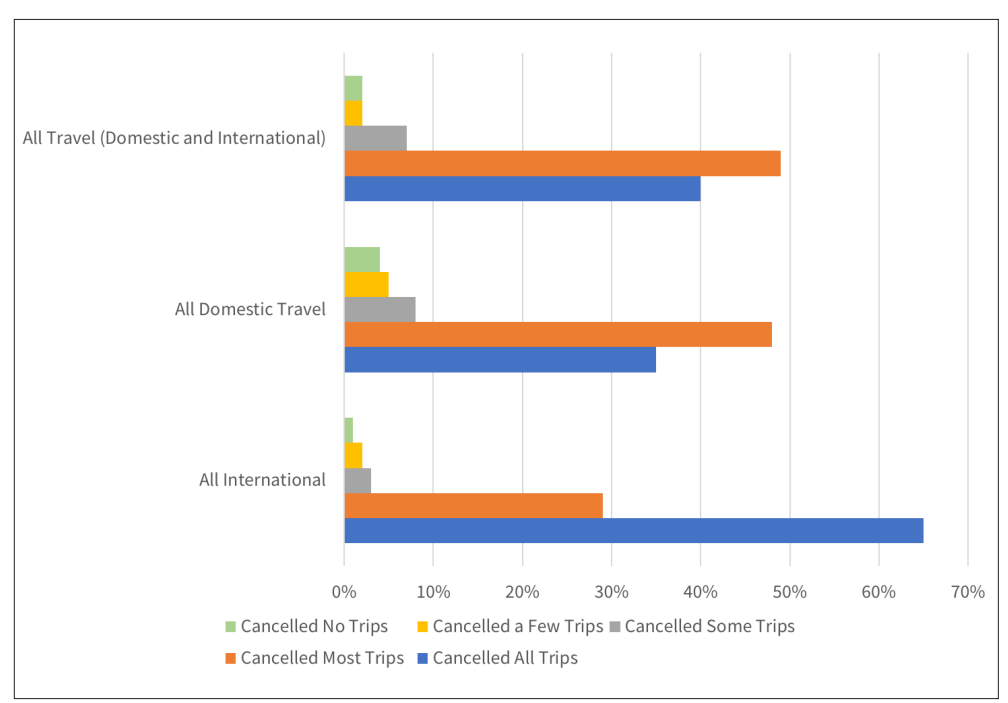

Figure 8 The Impact of the COVID-19 on the companies' business travel policy. Source: GTBA data processed by the authors

Another relevant issue is the main type of transport used by tourists (plane/boat or car), which varies significantly across countries [fig. 7]. As international air travel is curtailed, markets more prone to demand from international air travel are most exposed to a sharp downturn. Markets that can function on domestic car-based travel are probably the most resilient.

Looking at the hotel typology, business ones were also significantly affected by the pandemic. This is because companies have changed radically their travel policies due to government restrictions on citizen mobility, issues related to the safety of their employees, and the reduced profit margins available [fig. 8].

The effect on the hospitality sector is expected to last because almost all the companies were obliged to switch to online meetings during the last months and it may represent an opportunity for businesses to reduce travel costs in the coming years. The impact is expected to be higher for the one-day journeys.

A forecast about the effects of the COVID-19 on the hospitality industry could be made by starting from comparable disruptive events in the past [fig. 9].

A forecast of the hotel occupancy rate dynamics after the COVID-19 could be done by considering the SARS outbreak in Asia in the 2003. The hotel statistics in the main urban areas in China show that after just two months from the discovery of the disease the hotel mar- 
Gianluca Mattarocci, Simone Roberti

Real Estate and the Effects of the COVID-19 Pandemic in Europe

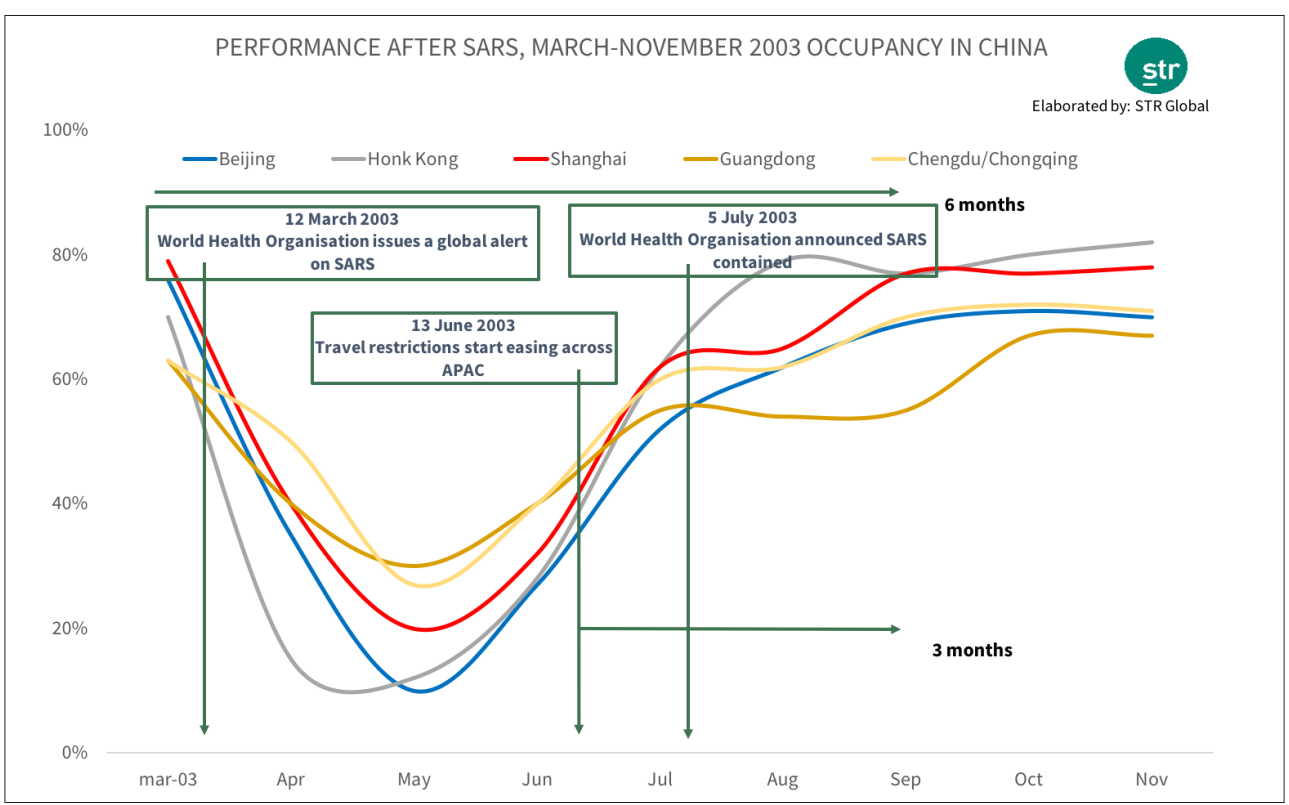

EUROPE, REVPAR AND GOPPAR INDEXED TO 2007, EUR, CONSTANT CURRENCY

-GOPPAR Index $\quad$ RevPAR Index

Elaborated by: STR Global

120

110

100

90

80

7 years

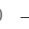

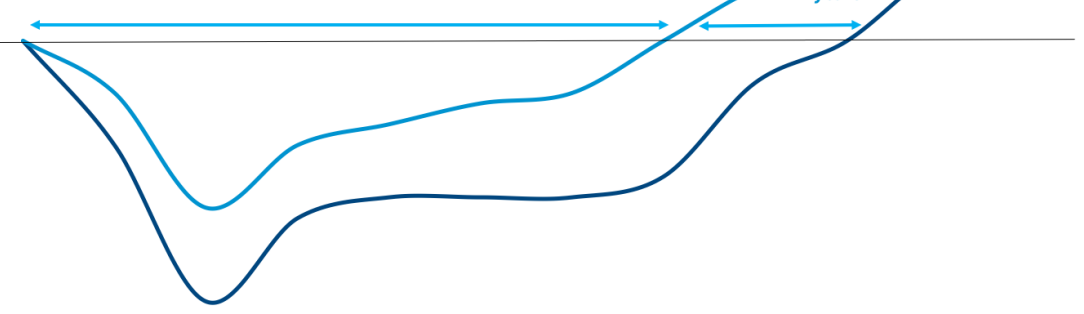

$\begin{array}{lllllllllll}2007 & 2008 & 2009 & 2010 & 2011 & 2012 & 2013 & 2014 & 2015 & 2016 & 2017\end{array}$

Figure 9a-b Effects of comparable disruptive events on the Hospitality Industry. Source: Colliers International, 2020 
ket collapsed in term of occupancy and fell below $10 \%$ of capacity. When the country was able to control the pandemic, travel restrictions were removed allowing the hospitality industry to recover the standard occupancy rates in only three months.

The main difference between the current pandemic and SARS is that now the economy is expected to slow down significantly due to the lockdown period, with a loss in average disposable income. The more comparable event in the last decades in term of economic impact on the hotel industry is the last financial crisis. More than seven years were required to recover the average revenue per available room recorded in 2007, and two more years to recover the gross operating profits per available room. Moreover, the impact on the hospitality sector will be different across countries depending on the length and severity of local travel restrictions and quarantine rules (Voth 2020).

\section{Conclusion}

The economic slowdown related to the COVID-19 pandemic is not expected to last in the long term. The real estate market will likely be one of the key drivers of economic growth in the recovery phase. However, the pandemic will change the standards requested for both residential and commercial assets. The expected change is not only related to the rent or the price per square meter but also to a new demand composition. This will oblige the landlords to adapt their supply to this new market and offer assets in line with the requests of the tenants.

This process of adaptation will take several years and will not be the same across countries and real estate sectors. The resulting transformation of the real estate market will create new opportunities and accelerate ongoing trends. 


\section{Bibliography}

Backer, S.R.; Farrokhnia, R.A.; Meyer, S.; Pagel, M.; Yannelis, C. (2020). "How Does Household Spending Respond to an Epidemic? Consumption During the 2020 COVID-19 Pandemic". NBER Working Paper No. 26949. https:// www.nber.org/papers/w26949.ack.

Choi, T.Y.; Rogers, D.; Vakil, B. (2020). "Coronavirus is a Wake-Up Call for Supply Chain Management”. Harvard working paper. https://hbr.org/2020/03/coronavirus-is-a-wake-up-call-for-supply-chain-management.

Colliers International (2015). From First Mile to Last Mile: Global Industrial \& Logistics Trends. https://bit.ly/20sMzIt.

Colliers International (2020). The Impact of COVID-19 on the Italian Hotel Market.https://www2.colliers.com/en-it/news/coronavirus-hotel.

Deloitte (2020). COVID-19: Managing Supply Chain Risk and Disruption. https://bit.ly/2Cxdgcq.

Cushman \& Wakefield (2020). The Changing Face of Distribution. The Shape of Things to Come. https://issuu.com/cushwake_be/docs/.

Fernandes, N. (2020). "Economic Effects of Coronavirus Outbreak (COVID-19) on the World Economy". IESE Business School Working Paper. http:// dx.doi.org/10.2139/ssrn.3557504.

GTBA (Global Business Travel Association) (2020). Coronavirus Poll Results April 2020. https://www.gbta.org/research-tools/covid-19-member-polls.

Hohenstein, N.O.; Feisel, E.; Hartmann, E.; Giunipero, L. (2015). "Research on the Phenomenon of Supply Chain Resilience: A Systematic Review and Paths for Further Investigation". International Journal of Physical Distribution \& Logistics Management, 45(1/2), 90-117. https://doi.org/10.1108/ ijpdlm-05-2013-0128.

JLL (Jones Lang LaSalle) (2020). Global Findings on Workplace Re-Entry During COVID-19. https://bit.ly/3j5oy8A.

Jonung, L.; Roeger, W. (2006). The Macroeconomic Effects of a Pandemic in Europe: A Model-Based Assessment. European Commission, Directorate General for Economic and Financial Affairs. Economic Papers No. 251. https://bit.ly/2ZssVmg.

Keogh-Brown, M.R.; Smith, R.D.; Edmunds, J.W.; Beutels, P. (2010). "The Macroeconomic Impact of Pandemic Influenza: Estimates from Models of the United Kingdom, France, Belgium and the Netherlands". European Journal of Health Economics, 11, 543-54. https://doi.org/10.1007/s10198๑०९-๑210-1.

Knight Frank (2019). French Property Market-Review 2019\& Outlook 2020. https://bit.ly/3eysc7k.

Mann, C.L. (2020). "Real and Financial Lenses to Assess the Economic Consequences of COVID-19". Baldwin, R.; Weder di Mauro, B. (eds), Economics in the time of COVID-19. London: CEPR Press, 81-5. https://voxeu.org/content/economics-time-covid-19.

Mattarocci, G.; Pekdemir, D. (2017). Logistic Real Estate Investment and REITs in Europe. Houndmills: Palgrave MacMillan. https://doi.org/10.1007/9783-319-69206-7.

Prologis (2020). "Accelerated Retail Evolution Could Bolster Demand for WellLocated Logistics Space". June. https://bit.ly/3hyGhna. 
Gianluca Mattarocci, Simone Roberti Real Estate and the Effects of the COVID-19 Pandemic in Europe

RCA (2019). Europe Capital Trends. https://www.rcanalytics.com/ect2019-overview/.

Savills (2020). "Market in Minutes: European Retail Sale and Leaseback". Savills, 4 June. https://bit.ly/3fZ3M8u.

STR (2020). COVID-19 Hotel Performance Update. https://str.com/data-insights-blog/coronavirus-hotel-industry-data-news.

Taltavull, P. (2020), “Editorial”. Journal of European Real Estate Research, 13(1), 1-3. https://doi.org/10.1108/JERER-05-2020-055.

Voth, J. (2020). "Trade and Travel in the Time of Epidemics". Baldwin, R.; Weder di Mauro, B. (eds), Economics in the Time of COVID-19. London: CEPR Press, 93-6. https://voxeu.org/content/economics-time-covid-19. 


\section{Part 6}

Business Performance, Funding and Growth 



\title{
Private Equity \& Venture Capital Riding the COVID-19 Crisis
}

Keith Arundale

ICMA Centre, Henley Business School, University of Reading, UK

Colin Mason

Adam Smith Business School, University of Glasgow, UK

\begin{abstract}
Private equity has successfully weathered economic crises in the past and appears to be well-placed to manage the current coronavirus crisis. Whilst both fundraising and investments will be significantly reduced from pre-pandemic levels for some time these are expected to recover and resume the historic overall growth trend. Private equity firms may find opportunities through taking undervalued public companies private and in restructuring under-performing businesses. However, start-ups may find seed and early stage finance hard to access. Government support measures need to meet the characteristics and needs of high growth enterprises.
\end{abstract}

Keywords Coronavirus. Fund raising. High growth enterprises. Investment. Pandemic. Private equity. Start-ups. Venture capital.

Summary 1 Introduction. - 2 Trends in the Pandemic Period. - 2.1 Fund Raising. 2.2 Investment Trends. - 3 Opportunities for Private Equity Firms. - 4 Impact on Start-ups. -5 Government Intervention. -6 Prospects.

\section{Introduction}

Private equity is medium- to long-term finance that is invested by professional fund managers in unquoted companies in return for equity stakes in those companies (Arundale 2007; Gilligan, Wright 2014). It includes equity finance for established businesses often provided to assist management teams to buy out businesses from their existing owners (management buyouts - MBOs) or 
growth capital for later stage expansion and early stage finance, otherwise known as venture capital (VC), to help companies grow quickly and scale successfully.

Private equity-backed enterprises make a significant contribution to the global economy in terms of greater innovation, increased productivity, enhanced competitiveness and, in the longer term, increased employment opportunities (Frontier Economics 2013). Venture capital has financed many so-called 'unicorns' (privately held start-up companies valued at over $\$ 1$ billion). For example, $82 \%$ of the 190 European start-ups that have achieved unicorn status are venture capital-backed (EuropeanStartups.co 2020). With its long-term investment horizons, with funds typically having lives of 10 years or more, private equity is usually less susceptible to the ups and downs of economic cycles. The asset class successfully weathered the 2008 financial crash, despite debt finance used to leverage deals being in short supply, and with far fewer failures than had been predicted by some observers. Private equity maintained its relatively stable, longterm overall returns of 13\% to 14\% pa. (BVCA 2010, 2019) which make the asset class attractive to institutional investors and so provides essential funding for high growth enterprises. The question is whether this historic resilience will be apparent with the COVID-19 pandemic.

Many private equity and VC funds are constituted as limited partnerships (Gilligan, Wright 2014) whereby investors, such as pension funds, banks, insurance companies, family offices, sovereign wealth funds and endowment funds (the limited partners or LPs), commit capital to funds which are managed by fund managers (the general partners or GPs). In 2019 alone over $\$ 600$ billion of private equity funds were raised globally, with accumulated funds of around \$1.5 trillion now awaiting investment (Preqin 2020a).

In previous economic crises, fundraising for both private equity and VC funds initially declined but then recovered, eventually hitting new peaks as shown in table 1. Both fundraising for private equity and VC funds declined following the dot-com and global financial crises periods but then quickly recovered. It is too early to tell whether fundraising has been impacted severely by COVID-19 in 2020 to date. Certainly, both the number of funds and amount raised in Q1 2020 has fallen by $32 \%$ and $29 \%$, respectively for private equity as a whole, compared to Q4 2019 but this is not unusual with the relatively slower fundraising that always occurs at this time of year. The amount of capital raised by venture capital funds actually increased in Q1 2020 by some 44\% from the previous quarter, although this has declined significantly in Q2 to date with a steep decline in the number of funds closed (Preqin 2020b). As at April 2020 there were 3,620 private equity funds in the market globally seeking to raise some $\$ 933$ billion for their investment funds (Preqin 2020a). 
Keith Arundale, Colin Mason Private Equity \& Venture Capital. Riding the COVID-19 Crisis

Table 1 Funds raised during previous financial crises (data supplied to authors by Preqin)

\begin{tabular}{|c|c|c|c|c|}
\hline & $\begin{array}{c}\text { Private equity } \\
\text { (buyout) }\end{array}$ & & $\begin{array}{c}\text { Venture } \\
\text { capital }\end{array}$ & \\
\hline $\begin{array}{l}\text { Year of final } \\
\text { close }\end{array}$ & No of funds & $\begin{array}{c}\text { Aggregate } \\
\text { capital } \\
\text { raised (\$bn) }\end{array}$ & No of funds & $\begin{array}{c}\text { Aggregate } \\
\text { capital } \\
\text { raised (\$bn) }\end{array}$ \\
\hline \multicolumn{5}{|l|}{ Dot com era } \\
\hline 1999 & 225 & 92.9 & 293 & 42.2 \\
\hline 2000 & 285 & 130.4 & 488 & 76.4 \\
\hline 2001 & 256 & 91.0 & 359 & 43.5 \\
\hline \multicolumn{5}{|c|}{ Global financial crisis } \\
\hline 2007 & 659 & 366.2 & 424 & 46.5 \\
\hline 2008 & 655 & 357.5 & 445 & 52.7 \\
\hline 2009 & 447 & 185.5 & 360 & 26.9 \\
\hline \multicolumn{5}{|c|}{ Pre-coronavirus pandemic } \\
\hline 2018 & 833 & 537.9 & 1,105 & 108.5 \\
\hline 2019 & 733 & 548.8 & 872 & 95.7 \\
\hline 2020 Q1 & 211 & 102.6 & 225 & 37.7 \\
\hline
\end{tabular}

\section{Trends in the Pandemic Period}

\subsection{Fund Raising}

Whilst LPs remain committed to private equity the amount of their commitments is likely to fall as a result of recent stock market falls which may lead to some rebalancing of asset allocations to private equity and other asset classes (Real Deals 2020b). This is partly for technical reasons - the 'denominator effect': if the value of their other types of investments go down then they will become over-allocated to private equity, prompting them to pull back on investing both directly and indirectly, via funds, in private equity and venture capital (Mason 2020). Buyouts will compete with growth and venture capital for investors' preferred fund type. There has been a trend in recent years of limited partner investors targeting fewer fund managers with larger commitments in order to focus their GP relationships whilst maintaining their overall allocations to the private equity asset class; this is likely to continue into and beyond the current pandemic. Co-investment, where LPs invest in portfolio companies alongside their commitments through a GP managed fund, may decline as LPs focus on their existing co-investments and shy away from new single company investments. LPs may also be called upon to commit additional capital to shore up existing companies in GPs' 
portfolios. For GP firms seeking to raise capital additional to their usual fund structures there has been a trend of GPs selling minority equity stakes in their firms as an alternative to seeking a public listing; there are now fund of firms vehicles dedicated to building portfolios of GP minority stakes. Teams trying to raise a fund for the first time may find the fund raising process takes longer than usual, possibly extending over two years, due to limitations on travel and fewer opportunities to develop face-to-face relationships in what is very much a people business. Where LPs were already well into due diligence on prospective funds prior to the pandemic lockdown this is likely to continue to completion. Whilst LPs may have put new investment activity on hold, a recent survey of LPs has noted that they remain "cautiously optimistic" that activity will pick up once the coronavirus pandemic abates (Houlihan Lokey 2020).

\subsection{Investment Trends}

On the investment side, in 2019 funds invested $\$ 393$ billion in management buyouts (MBOs), down 20\% from a record high in 2018, and $\$ 224$ billion in VC deals, down 17\% from the prior year (Preqin 2020c). Whilst a number of mega deals helped to prop up the value of buyouts in Q1 2020, the overall downward trend in 2019 is likely to continue further into 2020 with GPs focusing their efforts on safeguarding existing portfolio companies, reserving more finance for follow-on rounds and spending less time on sourcing new deals - at least initially in the pandemic. Buyout investments in Asia particularly declined significantly by value in Q1 2020 although the number of deals held up; possibly due to GPs not completing the larger deals due to the COVID-19 crisis. VC deals fared worse in Q1 2020 both in terms of the decline in number of deals completed and the overall value of deals with Greater China, the initial location of coronavirus, suffering the most with a 60\% year on year decrease between Q1 2019 and Q1 2020 in the aggregate levels of equity investment (Brown, Rocha 2020). Encouragingly, deals in Asia have picked up again in Q2 2020 with a 21\% increase in aggregate deal value and a $6 \%$ increase in the number of deals compared to Q1 2020, reflecting that VC is now emerging from the earlier onset of the pandemic in Asia (Preqin 2020b).

Many GPs have been cancelling deals in the pandemic, or at least delaying them, because of the uncertainty whether, in the absence of a vaccine, there may be a second spike in cases which will result in another global lockdown that will close businesses again (Real Deals 2020d). There is evidence that GPs have been dropping out of auctions and investment committees are taking much longer to sign off on even relatively small deals (Real Deals 2020a). It has also been reported that some VCs have withdrawn from investments after sign- 
ing term sheets and sending letters of intent (Beauhurst 2020a). GPs are revising the scenario analyses of portfolio companies, building in much longer holding periods to exit and downgrading valuations. BVCA members reported that they expect to significantly mark down portfolio valuations, by an average of some 20\% (BVCA 2020a). Later-stage start-ups are expected to be hit the hardest as they reflect the decline in public markets. Where deals are still being pursued due diligence procedures on management and staff need to be complemented with questions on furlough arrangements, termination clauses, regulatory, data protection and employment law issues with regard to requiring employees to take COVID-19 tests (Real Deals 2020e). Due diligence on rent and leasing agreements will need to assess where rent has not been paid. Some VCs have been carrying on with due diligence remotely via video conferencing such as Zoom and DingTalk. It is unlikely that digital platforms will completely replace face-to-face relationship development between private equity and VC investors and management teams but they are likely to continue to be used post-pandemic and may well help facilitate more cost-effective interface with start-ups and other companies which are located away from the investment hubs (Financial Times 2020c).

For their part, private equity and VC portfolio companies have been cancelling, or at least postponing, their capital spend, concentrating on stocking levels, reviewing supply chains where these are being challenged, renegotiating rent and leasing agreements, furloughing staff and overall cutting costs where possible and, above all, preserving cash. Firms with only a short runway of cash of, say, less than 6 months are particularly vulnerable. Early communication with banks and other lenders is required to arrange interest payment holidays, relaxation of amortisation payments and suspension of loan covenants. Other companies will need capital in order to exploit COVID-19 opportunities, to pivot their business models and take advantage of sectorial trends.

Governments have introduced new schemes to assist businesses impacted by the pandemic. For example, in the UK these include the Coronavirus Business Interruption Loan Scheme (CBILS) whereby the government provides an $80 \%$ guarantee on each loan offered by selected lenders through the state-owned British Business Bank. However, CBILS does not support unprofitable companies and there is also evidence that some banks in the UK and Europe have been rejecting applications from PE-owned companies because of the financial engineering from use of debt in buyouts that makes them non-compliant with EU state-aid rules (Financial Times 2020a). Then there is the Future Fund which provides convertible loans of between $£ 125$ thousand and $£ 5$ million provided this is matched by private investment and the recipient companies have raised $£ 250$ thousand of equity investment in past 5 years from third parties. Also private eq- 
uity firms should themselves have the resources in terms of finance and expertise to help support and turnaround viable companies.

\section{Opportunities for Private Equity Firms}

Private equity often benefits from a crisis and change. Accordingly there will be opportunities for PE firms to take public companies private at lower valuations, buy up underperforming corporate subsidiaries, engage in bolt-ons and carve-outs and profit from 'special situations' (distressed assets, rescues and restructurings) as long as there are no severely underfunded pension schemes involved. Some, mainly US private equity groups, are taking a bullish view and are aggressively striking deals during the crisis to take advantage of lower valuations (Financial Times 2020f). Some VCs have resumed investing, focusing on companies which are seeking new opportunities in the crisis with in-demand services and sectors. Exits, essential for PE funds to show returns to their LP investors and to generate carried interest for the GPs, are likely to be delayed with longer holding periods. Investec's annual GP trends survey reveals that some $83 \%$ of GPs do not expect to make an exit in the next 12 months (Bain \& Co 2020). Whilst M\&A activity may be somewhat reduced for private equity firms, opportunities for exits may come from some of the large technology companies, such as Alphabet, Amazon, Apple, Facebook and Microsoft, which have been energetically pursuing deals following recent stock market falls (Financial Times 2020b). However, this is raising concern that "a few powerful firms are set to gain more clout", prompting governments in various countries to consider tightening their rules on foreign takeovers (Mason 2020); indeed a number of European countries have already announced stricter screening measures on foreign investment following new guidance issued by the European Commission (Real Deals 2020c). On a positive note, there has been a recent resurgence of interest in IPOs (Financial Times 2020e).

Private equity firms are increasingly focused on specific industry sectors. To the extent that changes can be made to the sector strategies set out in private placement memoranda and limited partnership agreements and the expertise of the individual investment executives, firms may need to rebalance their portfolios away from the hardest hit sectors such as hospitality and travel. Those firms focused on the tech sectors, including digital healthcare, fintech, cybersecurity, artificial intelligence, edtech, gaming and more traditional pharma, medical devices and e-commerce should be better able to weather, and even benefit from, the current crisis. For example, investors are actively targeting health-tech start-ups from those involved with remote-healthcare apps to those developing new drugs targeting cor- 
onavirus (Financial Times 2020d); VC-backed health-tech deal values are rising in the COVID-19 environment (Preqin 2020b).

\section{$4 \quad$ Impact on Start-ups}

Whilst the pandemic is clearly impacting on private equity firms and their portfolio companies, many of which will have been subject to a management buyout or a take private transaction in the past, it is perhaps the effect on start-ups and VC financing that the pandemic is having the greatest effect. There is a clear consensus that this economic crisis will result in a decline in VC (Mason 2020). As evidence of this the Plexal Start-Up Tracker ${ }^{1}$ monitors start-ups and fastgrowth businesses in the UK that have attracted equity or venture debt funding and publishes statistics each week on investments by value and number of deals. For the period from March 23 to June 17 2020, when the country was in the lockdown, the tracker revealed that there was a $48 \%$ decrease in the value of start-up investment and a 34\% decrease in deal numbers compared to the same period in 2019. As noted above, VCs are backing existing portfolio companies and focusing their new deals on the more established later stage companies. It is likely that there will be a decline in VC investing over the remainder of 2020 and possibly beyond for three reasons: (1) portfolio companies in sectors impacted most severely by the crisis are finding it difficult to increase revenues and scale, (2) VCs are finding it much harder to raise new funds and (3) opportunities to exit from investments are relatively scarce (Mason 2020). The situation is particularly concerning for start-ups seeking their first round of VC finance when they have little or no cash buffer to cope with their lack of revenues. Funding for UK start-ups raising for the first time fell by 83\% between March 23 and May 17 compared to the same period in 2019 (Sifted 2020c). These companies will likely fail, go into hibernation or continue to bootstrap. A survey of 250 growth businesses in the UK seeking investment reported that 9 out of 10 will close within the next 12 months if their current investment plans, disrupted by the coronavirus crisis, fail to materialise (Save Our StartUps 2020).

There is evidence that some business angel investors, who usually precede VCs in the "funding escalator" (Mason, Botelho, Harrison 2016) and who are the dominant source of early stage equity capital, are continuing to invest in start-ups during this pandemic. A survey of angel investors and early stage VCs in May 2020 by Activate our Angels ${ }^{2}$ revealed that $67 \%$ of the 223 respondents were still in-

1 https://www.plexal.com/startup-tracker.

2 https://www.activateourangels.com. 
vesting during the lockdown (51\% investing in new deals and $16 \%$ in their existing portfolios); they are getting deals done at reduced valuations. However this optimistic view is qualified by other surveys and commentary which suggest that business angels might be seeking to conserve cash to support their existing investments (Mason 2020). The on-going support by angels appears to vary by country and type of angel investor, with occasional (or 'tourist') angels having largely disappeared (Sifted 2020d). With many VCs now focusing on their existing portfolios to the detriment of new investments, angels will need to fund their scale up businesses for longer. The negative impact of the current crisis on angel investing could be similar to that experienced in the post dot-com era and the global financial crisis (Sohl, Lien, Chen 2020).

Equity crowdfunding platforms, such as Crowdcube and Seedrs, have experienced a drop in investment activity of around $20 \%$ since lockdown (Sifted 2020a). Crowdfunding is an important component of the funding escalator, often preceding or complementing angel investment and acting as an additional "proof of concept" and marketability for VC investors.

Table 2 Summary of issues and opportunities for private equity and venture capital

\begin{tabular}{lll}
\hline Investors (LPs) & PE firms & VC \\
\hline $\begin{array}{l}\text { Reduced allocations to PE asset } \\
\text { class }\end{array}$ & Deals postponed or cancelled & Favoured sectors \\
\hline Longer fund raising process & $\begin{array}{l}\text { Extended due diligence for deals } \\
\text { in progress }\end{array}$ & Reduced valuations \\
\hline Extensions to fund terms & Longer holding periods & Non-existent exits \\
\hline $\begin{array}{l}\text { Difficulties in raising first-time } \\
\text { funds }\end{array}$ & Stricter rules on foreign acquirers & Reduced finance for start-ups \\
\hline $\begin{array}{l}\text { Additional commitments } \\
\text { to support portfolio companies }\end{array}$ & $\begin{array}{l}\text { Opportunities with take privates } \\
\text { and distressed assets }\end{array}$ & $\begin{array}{l}\text { New government support } \\
\text { schemes - but not for start-ups }\end{array}$ \\
\hline $\begin{array}{l}\text { Wall of funds raised not invested } \\
\text { from prior years }\end{array}$ & & $\begin{array}{l}\text { Continued support from business } \\
\text { angels }\end{array}$ \\
\hline
\end{tabular}

\section{Government Intervention}

Governments have introduced a wide variety of support measures for the small business sector in the coronavirus pandemic to help them preserve cash, providing loan finance, both directly and by providing guarantees to banks, subsidising employee costs, and allowing the deferral of tax, business rates and social security payments. However, these schemes will have limited benefits for high-growth enterprises. For example, the UK's CBILS scheme referred to above, which provides financial support in the form of guaranteed bank loans to small- 
er businesses across the UK that are losing revenue and seeing their cashflow disrupted as a result of the COVID-19 outbreak, requires businesses to meet the lending criteria of banks in order to qualify. However, many would not meet this requirement as they might not have sufficient trading record or, typical of VC backed companies, may currently be loss making and hence unable to service a bank loan. A new loan guarantee scheme for companies not able to access CBILS has been advocated. Support to enable firms to furlough staff provides few benefits to new and small firms as staff are not permitted to work if they are furloughed and companies must continue to trade in order to survive. The Future Fund which provides convertible loans of between $£ 125$ thousand and $£ 5$ million that is matched by private investment is only available to businesses that have received $£ 250,000$ of external investment in the previous 5 years. Moreover, the investment by private investors is not eligible for relief under the EIS, SEIS and VCT schemes (BVCA 2020b) and so is unattractive to business angels (SeedLegals 2020). In addition, if companies choose to repay the loan and not convert to equity they are required to pay back double what they borrowed, plus interest (Beauhurst 2020b); this onerous constraint should be reviewed (Sifted 2020b).

\section{Prospects}

The decline in both private equity and venture capital investment in terms of the amount invested and the number of deals that we are seeing in this current coronavirus crisis will impact on the speed and strength of the economic recovery. Many deals will be follow-on rounds as investors seek to strengthen the financial runway of their portfolio companies. As noted above there are opportunities for private equity firms to take undervalued public companies private and to restructure underperforming businesses. The lack of venture capital will mean that recent start-ups will close resulting in the loss of businesses that might otherwise have flourished and preventing companies that have traction to develop and scale. It is likely that seed investing will suffer the most, making it difficult for start-up businesses to get off the ground. This has serious implications as when current furloughing arrangements cease a larger number of redundancies are likely to occur; finance for redundant employees looking to start their own businesses will be in short supply. This needs urgent government review along with a revitalisation of local government supported training programmes to reskill workers and to provide business planning and finance raising advice. Whilst the majority of such businesses will be SMEs with fewer than 10 employees and little potential or ambition for growth, some may develop into the high-growth enterprises that are the bedrock of private equity and 
entrepreneurial finance investment and which drive innovation, employment creation and productivity growth. Amendments or additions to current government financial support schemes are required which are aimed particularly at start-up businesses and which better suit the characteristics and needs of high growth potential enterprises.

Fund managers will need to be openly transparent with their institutional investors with frequent communication on capital calls, delays in distributions and plans to mitigate the impact of COVID-19. They will also need to continue spending more time in supporting their portfolio companies in helping them to adjust to the new environment, seek new opportunities arising from the pandemic, pivot business models and manage cash.

To conclude on a positive note, private equity has successfully weathered economic shocks before and the signs are that it is well prepared to do so again despite the immediate cutback in activity. Many successful companies are founded in recessions - WhatsApp, Instagram, Uber, Pinterest, Slack and Square were all founded in the aftermath of the 2008 global financial crisis. This is reflected in fund returns with some of the best performing vintages established in periods of economic crisis.

\section{Bibliography}

Arundale, K. (2007). Raising Venture Capital Finance in Europe. London: Kogan Page. Bain \& Co (2020). "How European Private Equity is Taking Coronavirus' First Punch". Bain \& Company, 3 June. https://bit.ly/32CrwLO.

Beauhurst (2020a). "The Effect of Coronavirus on UK investment: Q1 2020". Beauhurst, 2 April. https://about.beauhurst.com/blog/effect-ofcoronavirus-uk-investment-q1-2020.

Beauhurst (2020b). COVID-19 Business Impact: Understanding the Impact of COVID-19 on Ambitious UK Businesses. London: Beauhurst.

Brown, R.; Rocha, A. (2020). "Entrepreneurial Uncertainty During the Covid-19 Crisis: Mapping the Temporal Dynamics of Entrepreneurial Finance". University of St Andrews Working Papers in Entrepreneurial Finance, WP № 20 008, 2nd Quarter 2020. https://www.st-andrews.ac.uk/business/ rbf/workingpapers/RBF20_008.pdf.

BVCA (The British Private Equity \& Venture Capital Association) (2010). Private Equity and Venture Capital Performance Measurement Survey 2009. London: BVCA. https://bit.ly/2WCSWOh.

BVCA (2019). Private Equity and Venture Capital Performance Measurement Survey 2018. London: BVCA. https://bit.ly/3eFT8lK.

BVCA (2020a). BVCA Feedback on Impact of COVID-19 on the UK Private Equity and Venture Capital Industry. 4th report. 9 April. https://bit.ly/2CSFUES.

BVCA (2020b). BVCA Feed back on Impact of COVID-19 on the UK Private Equity and Venture Capital Industry. 5th report. 23 April. https://bit.ly/2E18pRA. 
Keith Arundale, Colin Mason Private Equity \& Venture Capital. Riding the COVID-19 Crisis

EuropeanStartups.co (2020). "Europe's Startup Ecosystem Navigating the COVID-19 Crisis”. Launch report, 22 April. https://europeanstartups.co/ reports/launch-report-european-startups.

Financial Times (2020a). "'Video is Fine': Venture Capitalists Find the Benefits in Digital Due Diligence". Financial Times, 3 June. https://www.ft.com/ content/202f6034-9190-4b08-bf6d-f69ebcf4bb22.

Financial Times (2020b). "Private Equity Companies Miss Out on Bailout Loans". Financial Times, 19 May. https://www.ft.com/content/46641ba1fd7d-4718-8f17-262881bf31ef.

Financial Times (2020c). "Private Equity Steps in Where Others Fear to Tread During Pandemic". Financial Times, 18 June. https://www.ft.com/ content/912929f7-7366-45d0-90ce-4467b9fec7fo.

Financial Times (2020d). "Big Tech Goes on Pandemic M\&A Spree Despite Political Backlash". Financial Times, 28 May. https://www.ft.com/ content/04a62a26-42aa-4ad9-839e-05d762466fbe.

Financial Times (2020e) "Lex Letter from London: The Tech IPO Comeback". Financial Times, 17 June. https://www.ft.com/content/13f7523c$8 d 1 c-443 d-b d 9 c-c 2 a 45 c c 810 d 8$.

Financial Times (2020f). "How Covid-19 is Attracting Investors to Us Health Ventures". Financial Times, 15 June. https://on.ft.com/32BO2Gp.

Frontier Economics (2013). Exploring the Impact of Private Equity on Economic Growth in Europe: A Report Prepared for the EVCA. May 2013. Brussels: Frontier Economics Europe. https://www.investeurope.eu/media/1110/ frontier_economics_report.pdf.

Gilligan, J.; Wright, M. (2014). Private Equity Demystified. An Explanatory Guide. 3rd ed. London: ICAEW Corporate Finance Faculty. https://bit.ly/32CUNGb.

Houlihan Lokey (2020). COVID-19: Private Equity Fundraising Outlook. Los Angeles: Houlihan Lokey, Private Funds Group. http://cdn.hl .com/pdf/2020/ covid-19-private-equity-fundraising-outlook-04-2020.pdf.

Mason, C. (2020). The Coronavirus Economic Crisis: Its Impact on Venture Capital and High Growth Enterprises. European Commission Joint Research Centre. Luxembourg: Publications Office of the European Union. http://dx. doi. org/10.2760/408017.

Mason, C.; Botelho, T.; Harrison, R. (2016). "The Transformation of the Business Angel Market: Evidence and Research Implications". Venture Capital: An International Journal of Entrepreneurial Finance, 18(4), 321-44. https://doi. org/10.1080/13691066.2016.1229470.

Preqin (2020a). Preqin Quarterly Update: Private Equity \& Venture Capital Q1 2020. https://www.preqin.com.

Preqin (2020b). The Impact of COVID-19 on the Venture Capital Industry. 0100 Conferences Virtual, June 2020.

Real Deals (2020a). Real Deals Magazine, 457, 19 March.

Real Deals (2020b). Real Deals Magazine, 459, 16 April.

Real Deals (2020c). Real Deals Magazine, 460, 30 April.

Real Deals (2020d). Real Deals Magazine, 461, 14 May.

Real Deals (2020e). Real Deals Magazine, 462, 28 May.

Save Our StartUps (2020). 9th April. https://bit.ly/2E4x73D.

SeedLegals (2020). "The Government's Future Fund Won't Help UK Startups". SeedLegals, 21 April. https://seedlegals.com/resources/the-governments-future-fund-wont-help-uk-startups. 
Sifted (2020a). "Crowdfunding Platforms Grapple with Slowdown". Sifted, 2 April. https://sifted.eu/articles/crowdfunding-coronavirus.

Sifted (2020b). "How to Apply to the Future Fund". Sifted, 19 May. https:// sifted.eu/articles/future-fund-how-to-apply.

Sifted (2020c). "Funding for Seed-stage Uk Start-ups Drops Over 50\%". Sifted, 21 May. https://sifted.eu/articles/first-time-founders-funding.

Sifted (2020d). "What's Happened to the Angels?". Sifted, 21 May. https:// sifted.eu/articles/angel-investing-startups-europe-covid.

Sohl, J.; Lien, W.-C.; Chen, J. (2020). "The Angel Market and COVID-19: Building Bridges or Piers". UNH Center for Venture Research, Paul College of Business and Economics. 


\title{
Mergers and Acquisitions in the Years of COVID Slowing Down Before Accelerating Yet Again
}

Nikolaos Antypas

ICMA Centre, Henley Business School, University of Reading, UK

\begin{abstract}
Mergers and acquisitions (M\&As) have been less frequent during crises. The COVID-19 pandemic has resulted in a global economic shock and a surge in uncertainty, depressing M\&A activity to record low levels. The unpromising economic prospects, the persisting high valuations, and potential liquidity crunches will restrict acquisitions for the foreseeable future. Companies with large cash balances may perform opportunistic acquisitions when asset prices drop to attractive levels. Acquisition activity can be further affected by government actions, especially if governments discourage acquisitions to promote market competition.
\end{abstract}

Keywords Mergers. Acquisitions. Growth. Corporate investments. Investment banking.

Summary 1 Introduction. - 2 M\&A Activity. - 3 Valuation Multiples and Premia. 4 Liquidity, Cash Reserves and Dry Powder. -5 Concluding remarks, the Future of M\&As and the Role of Regulators.

\section{Introduction}

Mergers and Acquisitions (M\&As) have been an integral part of the corporate success story for the last few decades. Acquiring firms have been absorbing other companies with the aim of improving their offering, enhance their market share, or enter new markets. At the same time, companies have been divesting assets and company segments in an effort to shift their activity focus (Mavis et al. 2016). Selling or target firms have been divesting full 
or partial ownership of their assets, usually in exchange for hefty returns, i.e. 'premia', ${ }^{1}$ or for a chance to save their business from a wide array of challenges, such as financial constraints, obsolescence, and productivity inefficiencies (see e.g. Hopkins 1991). A sizeable industry serving both sides of the transaction has mushroomed over the years, providing auxiliary services such as due diligence, financing, even match-making between buyers and sellers. ${ }^{2}$ While M\&A activity almost never stops, it follows a wave-like pattern over the years, with peaks and troughs in the number and total value of deals. The troughs usually coincide with economic shocks related to surges in market uncertainty, economic slowdown, and liquidity crunches.

The current COVID-19 pandemic posits an unprecedented shock to the modern, global economy. While an accurate prediction on the economic damage is impossible at the time of writing (June 2020), the OECD expects the impact to be the worst during peace-time for at least the last 100 years (Giles 2020). As a result, M\&A activity has also taken a hit. In this chapter, we will look at several aspects of M\&As and the ways the current pandemic has affected them. When appropriate, we will extrapolate from past experience and try to predict the implications for prospective acquirers and the overall M\&A industry for the foreseeable future.

\section{M\&A Activity}

The number of deals and aggregate deal value per annum fluctuate over time. In 2019, the global M\&A market saw 49,849 deals totalling a value of $\$ 3.70$ trillion, which is markedly higher than 2009 , when the market saw 40,710 deals totalling $\$ 2.19$ trillion (IMAA 2020). In 2007-08, all major economies were affected by the Global Financial Crisis and, as a result, the number of transactions plummeted. The US market, which usually yields most of the global deal activity, experienced a severe drop in deal making as well. Figure 1 shows the annual M\&A activity in deal numbers and total value for the US [fig. 1]. Both activity metrics follow the pattern of waves that span over several years; activity usually plummets at the onset of an economic shock, which introduces uncertainty for corporate performance and, therefore, unfavourable economic prospects for acquisitions. Three distinct waves can be identified in figure 1: the "DotCom" wave in the late 1990, a consolidation wave in the mid-2000s,

1 For a review of acquisition premia, see Laamanen 2007; Alexandridis et al. 2013; Nielsen, Melicher 1973.

2 For a review of investment banks and deal auxiliary services, see Chemmanur, Ertugrul, Krishnan 2019; Golubov, Petmezas, Travlos 2012; McLaughlin 1992. 
and a mega-deal wave in the 2010s, where the total deal value surpassed the previous wave, but deal number did not recover (see e.g. Alexandridis, Antypas, Travlos 2017).

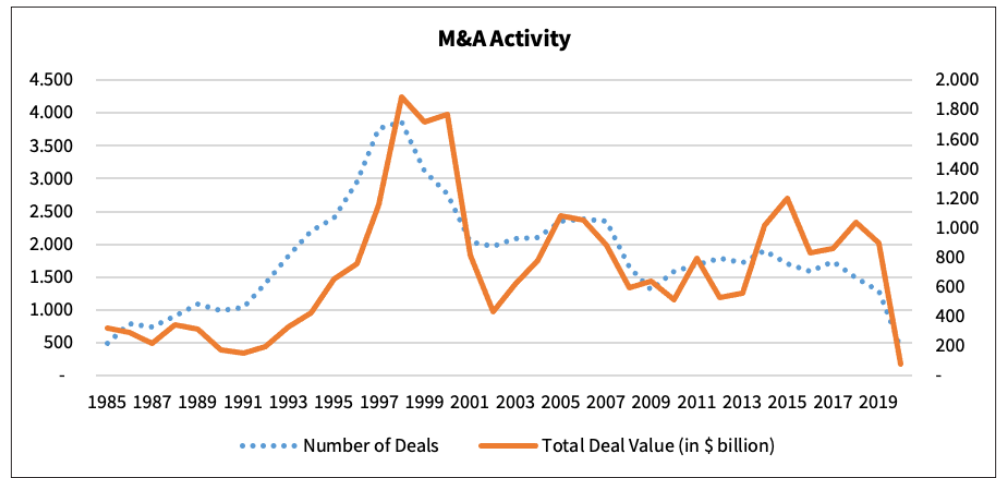

Figure 1 Deal activity by year. The deals include transactions by US-based acquirer and deal value of at least $\$ 1$ million. The following types of transactions have been excluded: Minority Stake Purchases, Privatizations, Leveraged Buyouts, Repurchases, Recapitalizations, Self-Tenders, Exchange Offers, Acquisitions of Remaining Interest. Source of data: Securities Data Company (SDC) by Refinitiv

The economic uncertainty introduced by COVID-19 has resulted in the near total suspension of deal-making in 2020. The decrease in activity, as presented in figure 1, shows an unprecedentedly low level of deals, although the 2020 data reflect only the activity during JanuaryJune. In order to have a fair understanding of the COVID-19 impact on deals during early 2020 , I have created a month-by-month comparative analysis. In figures 2-3, we see the number and total value of deals, respectively, during the first few months of 2020 and the average of the same months over the years 1985-2019 [figs. 2-3]. The M\&A activity started deteriorating in February, when COVID-19 was developing into a pandemic and capturing an increasing portion of the news headlines. Since then, most US-listed companies have announced a major hit to their first-quarter earnings due to the sudden drop in economic activity across most sectors, especially in transportation, consumer products, and hospitality services (see e.g. Morris 2020). The broad economic effect of the pandemic has cast doubts, not only on the shortterm prospects for the economy, but also on the duration of the recession. As the crisis persists, transaction metrics are expected to remain depressed.

Corporate executives have acknowledged the unpredictable duration and impact of the pandemic, which has forced them to revise their acquisition plans. According to a small-scale survey, more than $50 \%$ of prospective acquirers have either withdrawn from deal negotiations or postponed their acquisition plans, while about $23 \%$ expect to con- 


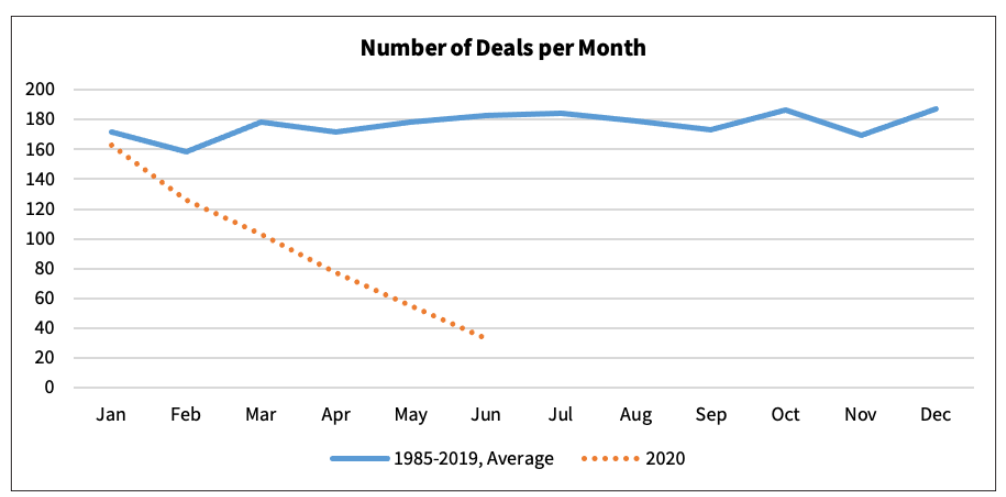

Figure 2 Number of Deals per Month. The deals include transactions by US-based acquirer and deal value of at least \$1 million. The following types of transactions have been excluded: Minority Stake Purchases, Privatizations, Leveraged Buyouts, Repurchases, Recapitalisations, Self-Tenders, Exchange Offers, Acquisitions of Remaining Interest. Source of data: SDC by Refinitiv

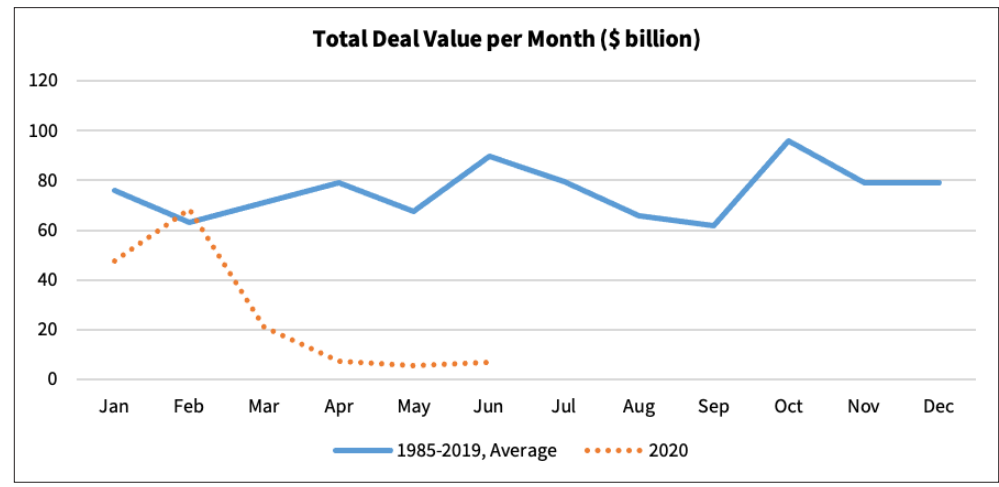

Figure 3 Total Deal Value per Month. The deals include transactions by US-based acquirer and deal value of at least $\$ 1$ million. The following types of transactions have been excluded: Minority Stake Purchases, Privatizations, Leveraged Buyouts, Repurchases, Recapitalisations, Self-Tenders, Exchange Offers, Acquisitions of Remaining Interest. Source of data: SDC by Refinitiv

tinue their investments in the second half of 2020 (Herndon, Bender 2020). Their plans should be contingent to two main factors. First, a potential second wave of infections may lead state governments to enforce a second lockdown, unless an effective and readily available treatment has been introduced by then. Second, consumption may not recover to pre-pandemic levels, since the increase in unemployment and bankruptcies may have resulted in a permanent loss of income for a critical proportion of the population. Therefore, prospective acquirers may have to postpone their plans once again and wait for market prospects to improve before continuing with their investments. 
It is important to note that regardless of the changes in the aggregate level of M\&A activity, companies may still conduct acquisitions while the pandemic persists. Their decision will have to factor in the economic and strategic prospects of the deal, the absolute and relative cost of the acquisition, capital availability, and potential regulatory concerns. We will be looking into these factors in the following sections.

\section{Valuation Multiples and Premia}

One of the most important features of a deal is the price. Acquirer and target shareholders have to come to an agreement on a fair price for the target firm's shares, as well as the appropriate consideration structure, i.e. cash, stock, or a mix of the two. It is common for acquirers to pay a 'premium' for a target's shares. In general, the premium is an amount paid on top of the target's fair equity value. In the case of publicly listed targets, the premium is defined as the percentage by which the target market capitalisation implied by the offer price exceeds the target's recent market capitalisation. Historically, the average premium has been around $20-30 \%{ }^{3}$ The premium serves as an enticement to target shareholders, who would otherwise have little incentive to sell their shares at current market prices. The premium can also be viewed as the target firm's share of the future synergistic gains that are expected to be achieved by the new, combined entity. If the premium is low, the acquirer's shareholders may enjoy a larger share of the future synergies; while if it is too high the acquirer's shareholders may receive only a small part of the synergies, or they may lose part of their current value. Therefore, it is apparent that the pricing exercise is a key step in designing an acquisition, and is the single most important aspect that can 'make or break' a deal.

The complexity of pricing has been further complicated during the pandemic. In previous economic and financial crises the market has reflected the decrease in economic prospects in security prices. The lower expected revenue and higher probability of insolvency have led to a decrease in stock prices, even for individual stocks with relatively good prospects. However, in 2020 the stock market in most western countries has substantially recovered after a quick and sharp correction, while the economic prospects of the respective countries have deteriorated. Although it may be too early to identify the causes of the market-economy disconnection, the prevalent explanation is complex and involves the following factors:

3 The premium figure is calculated based on SDC data for deals with US acquirers that are valued at more than $\$ 1$ million. 
1. the reported willingness of central banks to provide unlimited support to the economy (Lewis 2020),

2. optimism for the discovery of an effective vaccination within the next 12 months (Gallagher 2020),

3. the gradual re-starting of economic activity in countries with imposed lockdowns (BBC 2020).

Regardless of the causes for the market-economy disconnection, stock prices do not reflect the cash flow potential of the underlying businesses. As can be seen in [fig. 4], US stock prices have remained near an all-time high, after a sharp, short-lived correction. In order to understand the stock market optimism and the disconnection between the market and the economy, we will look into the price-toearnings (P/E) ratio for the S\&P 500 index. For shares, the P/E ratio shows the amount investors are willing to pay today in order to have a claim on one unit of earnings. The aggregate index P/E ratio can be interpreted as being based on investor expectations for future earnings growth; a high P/E ratio can indicate either high growth expectations or overvaluation, while a low $\mathrm{P} / \mathrm{E}$ ratio indicates uncertainty about future growth or undervaluation.

Figure 5 shows the S\&P 500 P/E ratio since 1985. The recent P/E ratio is no lower than for the past 20 years [fig. 5]. Despite the $13.3 \%{ }^{4}$ US unemployment rate and the 45 million new unemployment claims in the US between February and June, ${ }^{5}$ the market seems to have maintained unreasonably high expectations regarding future earnings growth. We can refine this conclusion after adjusting the P/E ratio for inflation and long-run earnings. The refined measure, labelled "Shiller P/E ratio" after Robert Shiller, provides a smoothed measure of valuation. ${ }^{6}$ Figure 6 shows the S\&P 500 Shiller P/E ratio since 1985 [fig. 6]. The interpretation of this new measure suggests that valuations have been near the highest levels since the outbreak of the "DotCom bubble" in the late 1990s. Most surprisingly, if we ignore the period of irrational valuations of the late 1990s and go further back in time, the current S\&P 500 Shiller P/E ratio is near its highest level since the retro-fitted estimation of the index for back to 1872. This is indicative of the market-economy disconnection, and the optimism portrayed in the markets despite the dreadful recession ahead of us.

Prospective acquirers attempting to take control of a public target should be willing to pay a premium on top of the aforementioned historically high prices, while the prospects of revenue and earn-

4 For more details, see http://www.bls.gov.

5 For more details, see https://www.dol.gov.

6 For more details on the calculation and interpretation of Shiller's P/E ratio, see https://www.multpl.com/shiller-pe. 


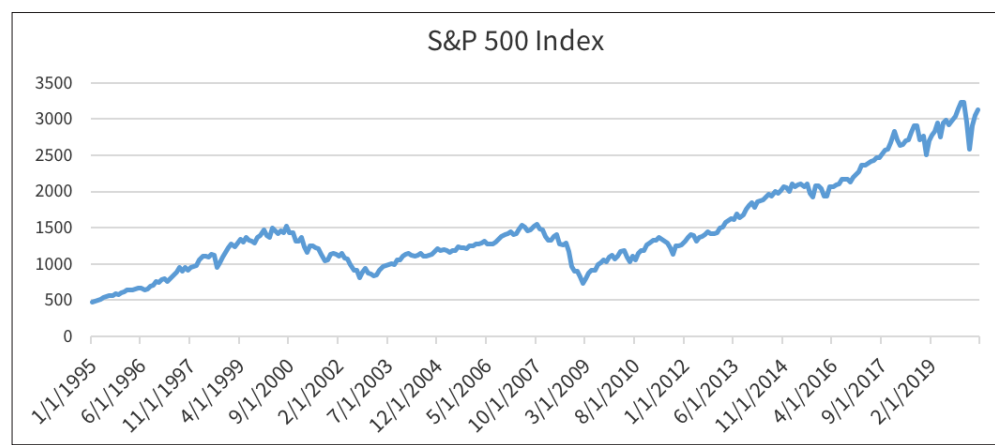

Figure 4 S\&P 500 Index. Source of data: EIKON by Refinitiv

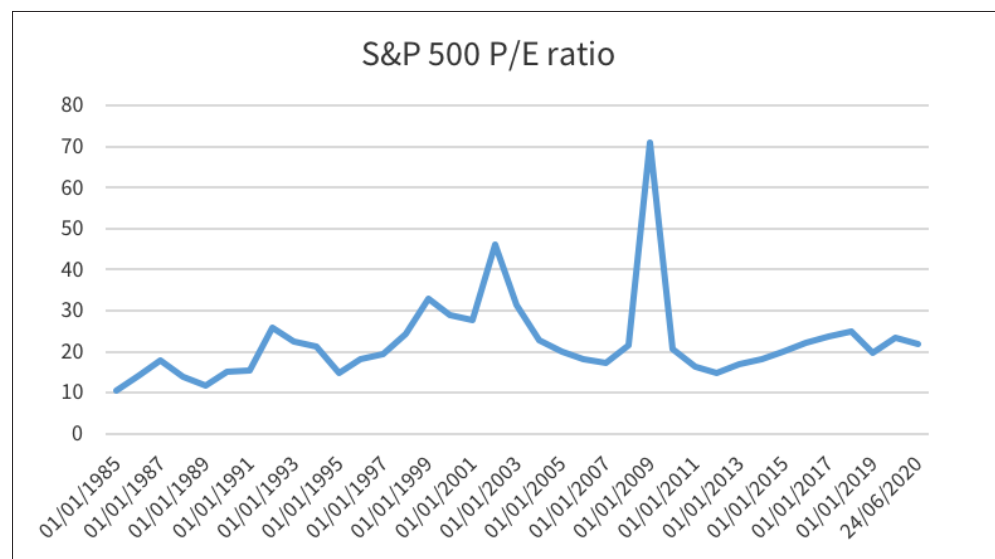

Figure 5 S\&P 500 P/E ratio. Source of data: https://www.multpl.com/

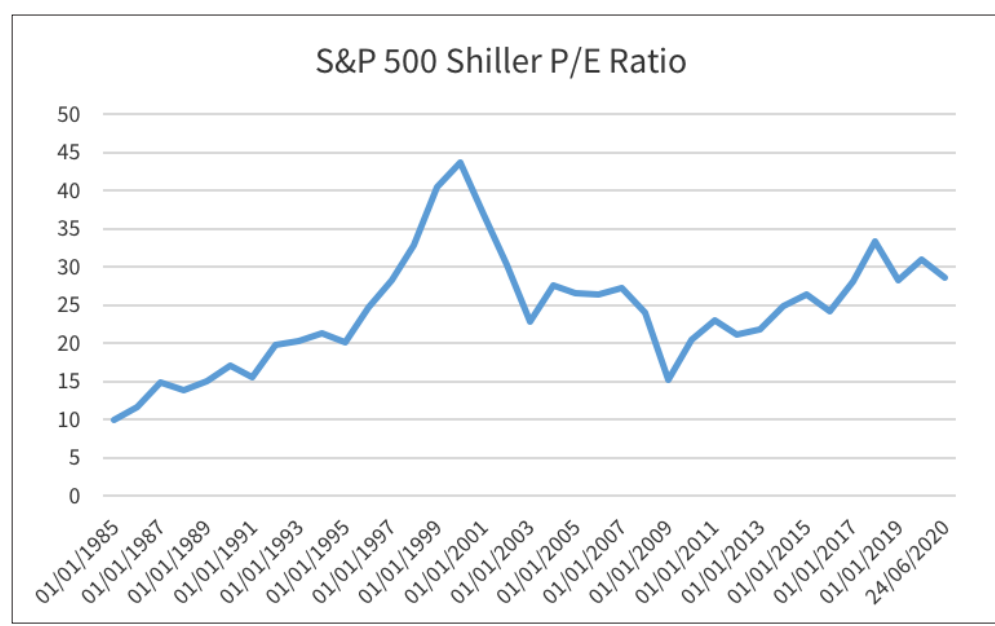

Figure 6 S\&P 500 Shiller P/E ratio. Source of data: https://www.multpl.com/ 
ings growth are uncertain for the foreseeable future. Cautious acquirers usually avoid the risk of overpaying for assets, and the high stock market valuations may hamper M\&A activity during the pandemic. An exception to this expectation can be the consolidation of ailing sectors, such as transportation and hospitality, where companies may need to join forces in order to survive. In these cases, we may see more mergers of equals instead of acquisitions.

Nevertheless, some deal activity may also continue in the least affected sectors, especially deals with stock swap consideration, since there is evidence suggesting that the absolute level of valuation may be less important than the relative valuation between the acquirer and the target (see e.g. Rhodes-Kropf, Viswanathan 2004). Specifically, acquirers that are overvalued relative to their targets will still pursue the acquisition in order to take advantage of the beneficial overvaluation. The window of opportunity for such acquisitions is unknown, since the disconnection between the securities market and the economy may be reduced at any time. In any case, due to the high uncertainty in the securities market, we may see the application of strict price collars, that define the exchange rate of acquirer and target shares within and outside pre-agreed price ranges. ${ }^{7}$

\section{$4 \quad$ Liquidity, Cash Reserves and Dry Powder}

The poor short- and mid-term prospects for the economy may be less of a deterrent for aspiring acquirers with sufficient liquidity. Robust cash reserves fulfil a double role during the pandemic. First, they support the operations of the companies during the recession. Since the duration of the downturn cannot be forecast with reasonable accuracy, the large reserves place these cash-rich firms at the advantage of maintaining operational capacity and being ready to capture the recovering demand. Second, the excess cash reserves can be used as consideration for M\&As in case raising capital in the securities markets is too slow for a time-sensitive investment opportunity, or the market uncertainty results in low demand for equity and debt issuance.

Large companies have been amassing cash for the better part of the last decade, waiting for the opportunity to buy undervalued assets of strategic importance to their business (Rocco 2019). In table 1 , we can see the cash balance in absolute terms, and as a percentage of total assets for the largest 10 US companies in 2008 and 2019. The reason we compare these two years is because they preceded years of major economic shocks. We also see the net cash position for each firm, which is calculated by subtracting debt from cash. One

7 For a review of price collars, see Officer 2004. 
takeaway from table 1 is that many of the top 10 cash-holding firms, as a group, have stronger positions in 2019 (\$754 billion) compared to 2008 (\$323 billion) even after accounting for inflation. This can be partially attributed to the companies that were in the list in 2008 having even larger cash balances in 2019. Another key insight, taken from untabulated information, is that the top cash-holders of 2008 proceeded to perform a series of strategic acquisitions in the aftermath of the crisis. We expect that this will be the case for the postCOVID-19 era as well, especially since cash balances have grown more than ever before.

Table 1 Top 10 cash-holding companies in 2008 and 2019. Financial and utility companies have been excluded from the list due to dissimilarities in accounting standards and regulatory treatment. Source of data: Compustat by Capital IQ

\begin{tabular}{|c|c|c|c|c|}
\hline \multirow[t]{2}{*}{2008} & \multirow[t]{2}{*}{ Company name } & Cash & Cash over & Net Cash \\
\hline & & (in 2019 \$bn) & Total Assets & (in 2019 \$bn) \\
\hline 1 & GENERAL ELECTRIC CO & 59.59 & $6 \%$ & -332.41 \\
\hline 2 & EXXON MOBIL CORP & 38.01 & $14 \%$ & 29.67 \\
\hline 3 & FORD MOTOR CO & 37.23 & $14 \%$ & -70.3 \\
\hline 4 & BERKSHIRE HATHAWAY & 35.19 & $11 \%$ & -3.95 \\
\hline 5 & CISCO SYSTEMS INC & 31.16 & $45 \%$ & 23.57 \\
\hline 6 & APPLE INC & 29.09 & $62 \%$ & 29.09 \\
\hline 7 & PFIZER INC & 28.18 & $21 \%$ & 18.73 \\
\hline 8 & MICROSOFT CORP & 28.1 & $33 \%$ & 28.1 \\
\hline 9 & ALPHABET INC & 18.82 & $50 \%$ & 18.82 \\
\hline \multirow[t]{3}{*}{10} & WYETH & 17.27 & $33 \%$ & 4.42 \\
\hline & Sum & 322.64 & & -254.26 \\
\hline & Average & 32.26 & $29 \%$ & -25.43 \\
\hline \multirow[t]{2}{*}{2019} & Company name & Cash & Cash over & Net Cash \\
\hline & & (in 2019 \$bn) & Total Assets & (in 2019 \$bn) \\
\hline 1 & BERKSHIRE HATHAWAY & 135.22 & $17 \%$ & 36.39 \\
\hline 2 & MICROSOFT CORP & 133.82 & $47 \%$ & 54.71 \\
\hline 3 & ALPHABET INC & 119.68 & $43 \%$ & 104.91 \\
\hline 4 & APPLE INC & 100.58 & $30 \%$ & 8.77 \\
\hline 5 & AMAZON.COM INC & 55.3 & $25 \%$ & -7.91 \\
\hline 6 & FACEBOOKINC & 54.86 & $41 \%$ & 44.92 \\
\hline 7 & ORACLE CORP & 43.06 & $37 \%$ & -27.67 \\
\hline 8 & ABBVIE INC & 39.92 & $45 \%$ & -23.3 \\
\hline 9 & GENERAL ELECTRIC CO & 36.92 & $14 \%$ & -33.48 \\
\hline \multirow[t]{3}{*}{10} & FORD MOTOR CO & 34.65 & $13 \%$ & -67.76 \\
\hline & Sum & 754.01 & & 89.58 \\
\hline & Average & 75.40 & $31 \%$ & 8.96 \\
\hline
\end{tabular}


A considerable portion of the M\&A activity during the next few months may originate from professional investors such as Private Equity (PE) and Hedge Funds (HF). The capital available for investments, i.e. 'dry powder', was at a record of \$2.5 trillion in 2019 (Espinoza, Platt 2019). PE companies rely on their ability to pinpoint the firms with strong cash-flow statements, as well as growth and cost-cutting potential. A market fall may trigger a buying spree from professional investors. It is important to note that both PE and HF companies have a unique advantage compared to other investment management firms: their investment horizon is significantly longer than the average investor, and spans more than the few years the pandemic is expected to directly affect the markets. The average investment horizon for PE companies is about seven years, while some HFs invest with horizons of decades. As a result, we may see professional investors wait patiently for short-term liquidity crunches to occur, rendering them irresistible partners to distressed firms.

The overall outlook in terms of capital availability can be favourable for some acquirers, regardless of the downturn in aggregate economic output. An additional contributing factor is the persisting and historically low interest rates. The Federal Reserve, the Bank of England, and the European Central Bank have declared that they will allow benchmark interest rates to remain at low, even negative levels, for the foreseeable future in order to support their respective economies (Financial Times 2020). As a result, corporations with healthy cash flows and sustainable leverage levels could take advantage of the favourable debt market, and fund their M\&A plans with inexpensive debt capital.

\section{Concluding remarks, the Future of M\&As and the Role of Regulators}

Since the beginning of the 20th century, the US economy has experienced at least seven M\&A waves, i.e. wave-like patterns of M\&A activity levels. There are various theoretical explanations for the formation of waves (see e.g. Maksimovic, Phillips, Yang 2013; Goel, Thakor 2010), and the most widely accepted framework is the neoclassical theory (see e.g. Ahern, Harford 2014), which is based on the field of neoclassical economics. The neoclassical theory of acquisitions is that the market for corporate control reacts to an industry-wide shock, such as the introduction of ground-breaking technology, or a sudden decrease in supply of raw materials. When industry-specific shocks coincide and, most importantly, capital availability is high, a marketwide M\&A wave is formed (Harford 2005). If all these conditions are fulfilled, we could be soon see the onset of a new merger wave.

Regulators should be aware that the form of economic stimulus they provide, and the criteria they attach to the help they offer, may 
contribute to a rise in deal activity and the creation of an M\&A wave. For instance, if companies are offered debt in order to survive the economic slowdown in the short-run, they may face accelerated insolvency issues when they need to pay back the loans, unless economic activity recovers materially or state support is prolonged until recovery. This predicament will increase the acquisitions of distressed firms by more liquid acquirers. Instead, if companies are incentivised to cut costs and downsize, which would be a politically charged policy, more companies would divest their assets and focus on their core business segments. The policies to be announced and implemented may yet be the most significant factor determining M\&A activity during and after the crisis.

The contribution of the state is significant, even if a merger wave does not materialise in the near future. As has been mentioned earlier, the cash balances of some companies have stayed strong for a few years, and these companies have increased their relative 'buying' power relative to companies that are struggling during the recession. As a result, we may observe sector-specific market consolidation led by industry leaders with large cash reserves, spare debt capacity, or high stock valuations, e.g., price-to-earnings ratios. There have been discussions among regulators about preventing a consolidation wave during the pandemic, especially banning acquisitions by firms that have received state funding, so that markets remain competitive (Fontanella-Khan, Fedor 2020). The government institutions responsible for maintaining market competition, such as the Federal Trade Commission (FTC) in the US and the Competition and Markets Authority (CMA) in the UK, may face intense pressure to forbid deals that could save target companies from insolvency, so that markets remain competitive.

At every turn of the economy, the market for corporate control has followed suit in an attempt to decrease efficiencies and empower corporations to thrive. The current pandemic is poised to become one of the sharpest turns in modern economic history and, thus, the M\&A activity during and after this crisis should reflect the proportions of such a novel shock. Companies with good access to capital are expected to benefit most from this turmoil, while companies that have already been struggling will become inexpensive targets when security markets adjust to match their share price with their poor economic prospects. Finally, regulators will have to balance their efforts between saving existing corporate structures via allowing consolidation, and maintaining market competition at healthy levels. Whatever lies ahead, we will most certainly look back to these times for instruction in extremity, same as we do with the Global Financial Crisis and previous major crises. 


\section{Bibligraphy}

Ahern, K.R.; Harford, J. (2014). "The Importance of Industry Links in Merger Waves". The Journal of Finance, 69(2), 527-76. https://doi.org/10.1111/ jofi.12122.

Alexandridis, G.; Antypas, N.; Travlos, N. (2017). "Value Creation from M\&As: New Evidence". Journal of Corporate Finance, 45, 632-50. https://doi. org/10.1016/j.jcorpfin.2017.05.010.

Alexandridis, G.: Fuller, K.P.; Terhaar, L.; Travlos, N.G. (2013). “Deal Size, Acquisition Premia and Shareholder Gains". Journal of Corporate Finance, 20, 1-13. https://doi.org/10.1016/j.jcorpfin.2012.10.006.

BBC (2020). "Coronavirus: How Lockdown is Being Lifted Across Europe". BBC, 2 July. https://www.bbc.co.uk/news/explainers-52575313.

Chemmanur, T.J.; Ertugrul, M.; Krishnan, K. (2019). "Is It the Investment Bank or the Investment Banker? A Study of the Role of Investment Banker Human Capital in Acquisitions". Journal of Financial and Quantitative Analysis, 54(2), 587-627. https://doi.org/10.1017/S002210901800073X.

Espinoza, J. (2019). "Private Equity Races to Spend Record \$2.5tn Cash Pile". Financial Times, 27 June. https://www.ft.com/content/2f7776569854-11e9-9573-ee5cbb98ed36.

Financial Times (2020). "Negative Interest Rates are a Tool, not a Gift, Viewed". Financial Times, 26 June. https://www.ft.com/content/319b2a3a-9a9811 ea-8b5b-63f7c5c86bef.

Fontanella-Khan, J.; Fedor, L. (2020). "Warren and Ocasio-Cortez Propose M\&A ban during crisis". Financial Times, 27 June 2020. https://www.ft.com/ content/35442f52-2230-4867-96fe-2975532a1098.

Gallagher, J. (2020). “Coronavirus Vaccine: When Will We Have One?”. BBC, 20 June. https://www.bbc.co.uk/news/health-51665497.

Giles, C. (2020). "OECD Warns of Deepest Economic Scars in Peacetime for a Century". Financial Times, 15 June. https://www.ft.com/content/498b43bf4813-40f8-9953-022e@d7820b5.

Goel, A.M.; Thakor, A.V. (2010). "Do Envious CEOs Cause Merger Waves?”. The Review of Financial Studies, 23(2), 487-517. https://doi.org/10.1093/ rfs/hhpe88.

Golubov, A.; Petmezas, D.; Travlos, N.G. (2012). "When It Pays to Pay Your Investment Banker: New Evidence on the Role of Financial Advisors in M\&As". The Journal of Finance, 67(1), 271-311. https://doi.org/10.1111/j.15406261.2011.01712.x.

Harford, J. (2005). "What Drives Merger Waves?". Journal of Financial Economics, 77(3), 529-60. https://doi.org/10.1016/j.jfineco.2004.05.004.

Herndon, M.; Bender, J. (2020). "What M\&A Looks Like During the Pandemic". Harvard Business Review, 10 June. https://hbr.org/2020/06/what-malooks-like-during-the-pandemic?

Hopkins, H.D. (1991). "Acquisition and Divestiture as a Response to Competitive Position and Market Structure". Journal of Management Studies, 28(6), 665-77. https://doi.org/10.1111/j.1467-6486.1991.tb๑0985.x.

IMAA, Institute for Mergers, Acquisitions and Alliances (2020). "M\&A Statistics", viewed 26 June. https://imaa-institute.org/mergers-and-acquisitions-statistics/. 
Laamanen, T. (2007). "On the Role of Acquisition Premium in Acquisition Research". Strategic Management Journal, 28(13), 1359-69. https://doi. org/10.1002/smj.639.

Lewis, L. (2020). “Will Central Banks Serve Up Fresh Stimulus?”. Financial Times, 20 June. https://www.ft.com/content/22822338-5a08-4169-9197$3 f 70702518 \mathrm{~d} 1$.

Maksimovic, V.; Phillips, G.; Yang, L. (2013). "Private and Public Merger Waves". The Journal of Finance, 68(5), 2177-217. https://doi.org/10.1111/ jofi. 12055.

Mavis, C.; McNamee, N.; Petmezas, D.; Travlos, N.G. (2016). "Selling to Buy: Asset Sales and Method of Payment in M\&As". University of Surrey working paper.

McLaughlin, R.M. (1992). "Does the Form of Compensation Matter? Investment Banker Fee Contracts in Tender Offers". Journal of Financial Economics, 32(2), 223-60.

Morris, S. (2020). "Investment Banks Braced for Pandemic Earnings Wipeout". Financial Times, 10 June. https://www.ft.com/content/43dcabdd68af-4d9c-83a4-46a74265d4a1.

Nielsen, J.F.; Melicher, R.W. (1973). "A Financial Analysis of Acquisition and Merger Premiums". Journal of Financial and Quantitative Analysis, 8(2), 13948. https://doi.org/10.2307/2330006.

Officer, M.S. (2004). "Collars and Renegotiation in Mergers and Acquisitions". The Journal of Finance, 59(6), 2719-43. https://doi.org/10.1111/ j.1540-6261.2004.00714.x.

Rhodes-Kropf, M.; Viswanathan, S. (2004). "Market Valuation and Merger Waves". The Journal of Finance, 59(6), 2685-718. https://doi.org/10.1111/ j.1540-6261.2004.00713.x.

Rocco, M. (2019). "US Corporate Cash Pile Shrinks as Spending Climbs After Tax Cuts". Financial Times, 25 June. https://www.ft.com/ content/81ff6034-8b91-11e9-a1c1-51bf8f989972. 



\title{
On the Impact of COVID-19-Related Uncertainty
}

\author{
Marta Castellini \\ Università degli Studi di Brescia, Italia; Fondazione Eni Enrico Mattei, Milano, Italia \\ Michael Donadelli \\ Università degli Studi di Brescia, Italia \\ Ivan Gufler \\ Università Ca' Foscari Venezia, Italia
}

\begin{abstract}
COVID-19 has generated a substantial increase in the level of economic policy uncertainty (EPU) around the World. Recent empirical investigations suggest that the COVID-19 has played a key role in amplifying the overall level of political uncertainty. In Italy, where anti-COVID-19 measures were implemented with some delay and were badly communicated, EPU rose dramatically. We examine the implications of rising COVID-19-related uncertainty for company revenues, gross operating margin and employment in 16 different Italian sectors. Our findings indicate construction, education, manufacturing activities and hospitality as the most hit sectors, with an average short-term drop in company revenues of around $4 \%$ in annual terms and a recovery time of almost two years. Thus, COVID-19-related uncertainty is found to be a significant business cycle driver.
\end{abstract}

Keywords Political uncertainty. COVID-19. Non-macro-related uncertainty. Ambiguity. Revenues. Employment.

Summary 1 Introduction. - 2 Empirical Analysis. - 3 Concluding remarks.

Innovation in Business, Economics \& Finance 1

ISBN [ebook] 978-88-6969-442-4 


\section{Introduction}

Undeniably, the set of social-distancing measures adopted in the majority of advanced economies hit by the COVID-19 pandemic since the beginning of February 2020 led to a severe drop in the global aggregate demand. According to current knowledge, it is also very likely that the COVID-19 virus will continue to spread around the world in coming months and that the high degree of uncertainty surrounding its diffusion will certainly generate further drops in market demand, especially in some economic sectors. Not surprisingly, estimates of the International Monetary Fund (IMF) indicate a cross-country average drop in real GDP among the G7 countries of almost 9.5\% for 2020.

Table 1 IMF Real GDP growth estimates for 2020 (Source: IMF)

\begin{tabular}{lcccccc}
\hline Canada & France & Germany & Italy & Japan & UK & US \\
\hline$-8.40 \%$ & $-12.50 \%$ & $-7.80 \%$ & $-12.80 \%$ & $-5.80 \%$ & $-10.20 \%$ & $-8.00 \%$ \\
\hline Notes: this table depicts the IMF Real GDP growth estimates for 2020 in the G7. \\
Source: IMF World Economic Outlook (June 2020) \\
\hline
\end{tabular}

With a total number of cases (deaths) of almost $240,000(35,000)$, Italy has been one of the advanced economies most severely hit by the COVID-19 virus. This has forced the government to implement more stringent social distancing measures than in other countries. Differently from other contexts, Italy took some time to implement such measures. Indeed, the first measure was adopted 23 days after the first 100 confirmed cases of COVID-19 were reported, amplifying thus the risk of infection. France, Germany and the US reacted instead after 12, 8 and 15 days, respectively. Needless to say that, in facing a pandemic emergency, timely policies are fundamental to support the economy in case of an imminent slowdown. This initial delay in implementing the social-distancing rules and the subsequently stricter COVID-19-related measures (such as lockdown and forced stop of industrial production), together with a fragile fiscal and political structure, are responsible for the estimated $12.80 \%$ drop in the Italian real GDP [tab. 1]. More probably, this figure is also the result of the high level of uncertainty induced by both the delay and the lack of clarity in the measures adopted and implemented by the Italian government. In particular, the vagueness of policy communication had sizable adverse effects on business and consumer confidence, leading to a further drop in private consumption and investment. 
Of course, some sectors have been more affected than others. ${ }^{1}$ More importantly and, most likely for some sectors, the COVID19-induced crisis will last longer than the virus itself. Not surprisingly - due to current and future, national and international, travel restrictions for people - the most suffering sector is (and will be) "hospitality and tourism". For instance, Prometeia (2020) has estimated a post-COVID-19 scenario characterized by a drop in added value in "accommodation and food service activities" of around 30\%, which is more than twice compared to other sectors such as "manufacturing" and "construction". It is clear that in Italy, where the overall impact of tourism on GDP is around 13\%, the return to preCOVID-19 aggregate macroeconomic conditions is going to be quite slow. The "transportation and storage" and "art, leisure and entertainment" sectors are also expected to suffer more than others (Prometeia, 2020).

Some direct economic measures to stimulate these sectors have been adopted and will be soon implemented by the Italian government. However, whether or not these economic incentives will be enough to mitigate the devastating economic impact of COVID-19 still remains an open issue. In the current scenario, the effectiveness of such incentives depends on many factors. One of them is the political uncertainty that has recently rocketed in both Italy and Europe [fig. 1]. Indeed, in March 2020 the level of EPU rose by 110\% in Europe (70\% in Italy). As already shown in Bernanke (1985) and Baker et al. (2016), among others, political-related uncertainty could make consumers and entrepreneurs more cautious, discouraging both current and future consumption, as well as investments. In addition, the adverse effects of political uncertainty on production and labour market conditions have been shown to be more severe during bad times and when the economy is at the Zero Lower Bound (Caggiano et al., 2017a, b). Due to its recessionary effects, the rising of EPU would call for a cut in the central bank policy rate (CBPR). However, when rates are close to zero, there is no room for conventional monetary policies and the loss of their effectiveness makes EPU shocks more harmful. Of course, unconventional monetary policies might help, but (sometimes) at the cost of rising perceived policy uncertainty.

1 Further discussion could be also devoted to the relation between a company's technological automation level and the impact of containment policies on the firm's performance during the pandemic. The less employees of a firm are required to work within restricted physical limits, more it is likely that such firms are not subjected to mandatory cessation of production. If such perspectives had also been considered when deciding the industrial lockdown, maybe some firms could have continued production even during the pandemic. In other words, the fostering of automation in industrial production processes could be a potential solution to avoid production shut down during a potential new pandemic wave. 


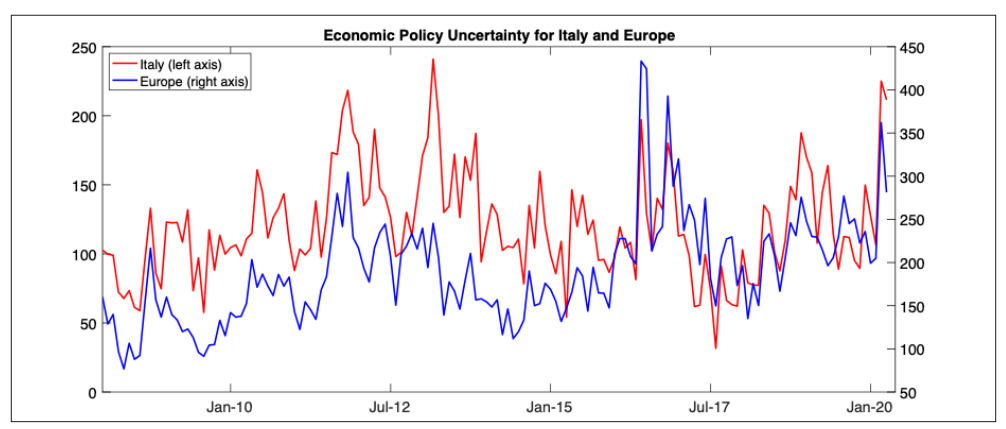

Figure 1 The Evolution of Political Uncertainty in Italy and Europe. Notes: this figure depicts the dynamics of the Economic Policy Uncertainty Index for Italy (left axis, red line) and Europe (right axis, blue line). Data at monthly frequency have been retrieved from https://www.policyuncertainty.com/. Sample: 2008:M1-2020:M4

The effects of political uncertainty on the real economy are well known. However, the recent and still ongoing pandemic comes with unprecedented EPU levels, in particular in the US as well as globally [fig. 2]. According to Baker, Bloom, Davis (2020) this is due to the fact that the COVID-19 has boosted several aspects of uncertainty: (i) uncertainty related to the disease (e.g. degree of infectiousness, lethality and mortality rate, capacity and efficiency of the health system, timing and development of vaccines); (ii) uncertainty induced by social distancing measures (e.g. duration and stringency of the implemented measures, probability of further lockdowns, implementation of new mitigation and containment strategies) and (iii) economic-related uncertainty (e.g. policy effectiveness, recovery timing, the number of firms at risk of default). COVID-19 induced uncertainty is not strictly related to macroeconomic policy issues, but it also includes health and science-related topics, ${ }^{2}$ which have been shown to be significant business cycle drivers (Donadelli, Gerotto 2019). This is also confirmed by the rise observed in the World Pandemic-related uncertainty index over the past three months [fig. 3].

2 The efficiency of the health system and the ability of the scientific community to provide quick feedbacks to the policymakers played a key role in the evolution of the pandemics. The complex cooperation between local health systems, governments and the World Health Organization (WHO) is responsible for increasing COVID-19 related uncertainty. Furthermore, it is important to underline that further investigations must be done regarding the relationship between the past public (as well as private) funding assigned to both the health system and scientific research and the country's 'COVID-19 performance'. 


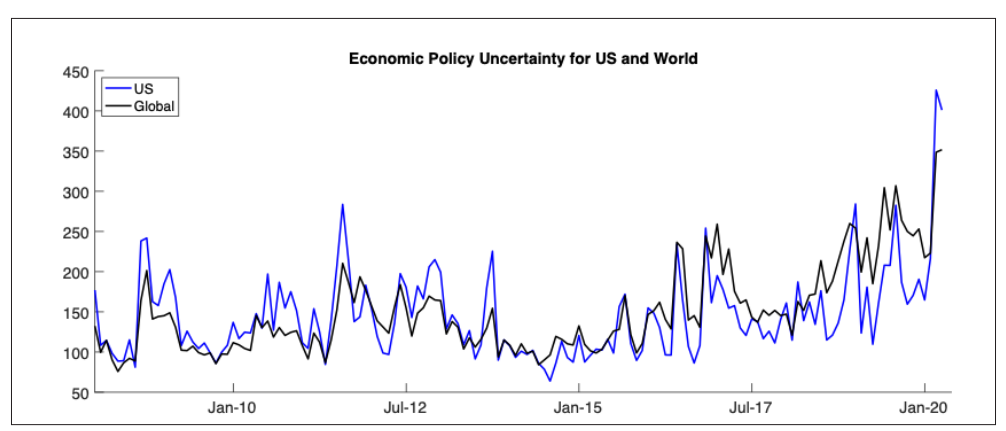

Figure 2 The Evolution of Political Uncertainty in the US and in the World. Notes: this figure depicts the dynamics of the Economic Policy Uncertainty Index for the US (blue line) and World (black line). Data at monthly frequency have been retrieved from https://www. policyuncertainty.com/. Sample: 2008:M1-2020:M4

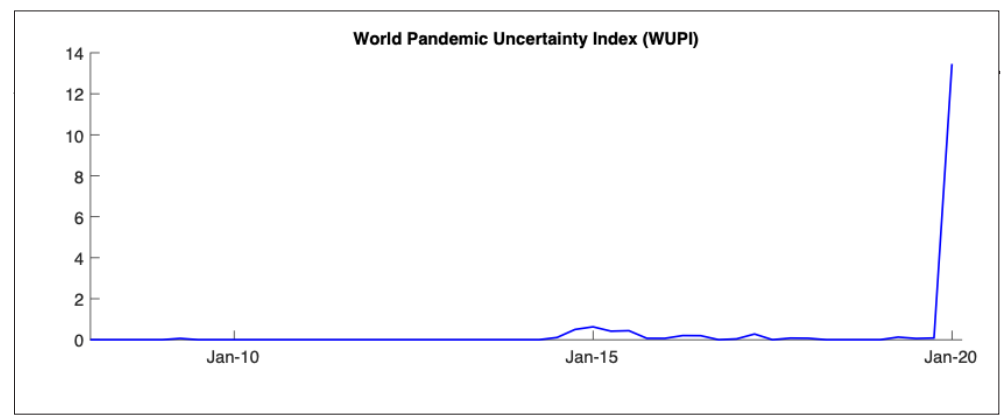

Figure 3 The Evolution of Pandemic-Related Uncertainty in the World. Notes: this figure depicts the dynamics of the World Pandemic Uncertainty Index (WUPI). Source: FRED. Sample: 2008:Q1-2020:Q1

In this respect, the implementation and the subsequent communication of efficient strategic economic-sectoral plans will help to mitigate part of this uncertainty, allowing the Italian economy, and in particular those sectors that have never recovered from past crises, to breathe again. In a country like Italy, already weakened by previous economic crises (i.e. the subprime and the sovereign debt crises) and constrained by the extremely high level of public debt, solving the COVID-19 induced uncertainty has to be considered a priority. The absence of a national industrial policy able to solve, at least partially, the uncertainty generated by this health emergency, amplified by weak and confused government economic measures, as well as by litigious EU economic policy makers, can be lethal especially for sectors such as (i) hospitality and tourism, (ii) transport and storage, and (iii) art, leisure and entertainment.

In this chapter, we assess the macroeconomic implications of COVID-19 induced uncertainty on company revenues, gross operating margin and employment in 16 different Italian sectors by means of a stand- 
ard VAR analysis. Our results confirm COVID-19 induced uncertainty to be detrimental for the majority of Italian sectors, with significant drops in revenues and gross operating margin. 'Construction', 'education', 'manufacturing activities', 'professional, scientific and technical activities' and 'hospitality' are among the most seriously affected sectors.

\section{Empirical Analysis}

\section{Data and methodology}

From ISTAT we retrieve revenues, gross operating margins and employment data for Italian businesses across 16 ATECO sectors. ${ }^{3}$ Unfortunately, the aggregated company data available in the ISTAT database are recorded with annual frequency. Standard linear interpolations are performed to obtain quarterly figures with the aim to match the quarterly frequency of our uncertainty measure. As measure of political uncertainty, we employ the EPU index of Bloom, Baker and Davis. ${ }^{4}$ All data run from 2008:Q1 to 2017:Q1.

During the subprime crisis, ${ }^{5}$ EPU for Italy settled at 97.93 . The average Italian EPU after the lockdown (March and April 2020) was 218.32, more than twice compared to the great financial crisis era of 2007-09. Prometeia (2020) shows that the impact of COVID-19 is not symmetric across sectors. Thus, following these estimates and, in the spirit of Baker et al. (2020) and Caggiano, Castelnuovo, Figueres (2020), we reparametrize our calculations accordingly. Specifically, we calibrate the magnitude of the uncertainty shock due to COVID-19 to be 2.3 times higher than during the subprime crisis in all sectors, except for 'hospitality' and 'art, leisure and entertainment', for which a factor of 3 and 2.8 is used, respectively. Our choice of rescaling the size of EPU shocks in all sectors is motivated by the fact that political uncertainty will last for several months. In addition, we believe that the ongoing and future social distancing measures (including several travel restrictions) in addition to the anxiety and general bad mood induced by COVID-19 will certainly have stronger recessionary effects on tourism and leisure activities. For this reason, we applied an even higher factor for the 'hospitality' and 'art, leisure and entertainment' sectors.

In the spirit of Baker et al. (2020) and Caggiano, Castelnuovo, Figueres (2020), we estimate the impact of COVID-19 by means of

3 ATECO is the coding system used by the National Institute for Statistics (ISTAT) to clasO sify national economic activities. It complies with the European nomenclature, Nace Rev. 2.

4 See https://www.policyuncertainty.com/.

5 Note that this occurred from October to December 2008. 
standard bivariate VAR models. We thus ask: what is the effect of an EPU shock in the 16 ATECO sectors, once the greater magnitude of EPU induced by COVID-19 is accounted for?

Evaluating and understanding the impact of COVID-19 pandemic on the economy is rather challenging. News-based uncertainty metrics do not capture direct effects of COVID-19 (such as lockdowns or other social distancing measures and infection dynamics or other healthrelated issues) and our analysis focuses on COVID-19 induced-uncertainty shock only. Actually, even though there are similarities between the subprime crisis and the COVID-19 one, especially in terms of increased economic-policy uncertainty, we have no knowledge yet about the persistence of this crisis given the risk of further waves of contagions. In addition, EPU hardly takes into account likely drops in future productivity due to social distancing measures and the reduction of investments. In other words, our approach is not capturing all the dimensions of uncertainty induced by the COVID-19. In this respect, one could expect stronger impact than those observed in our analysis. ${ }^{6}$

\section{Results}

Figure 4 shows the impulse response of COVID-19 induced uncertainty on company revenues [fig. 4]. The overall impact of COVID-19 on total revenues is negative in most sectors. The most affected sectors are 'construction', 'education', 'manufacturing activities', 'business support services' and 'hospitality', which also show the longest recovery time (i.e. almost 18 months). Note that the daily activity of these sectors has been interrupted from 21 March 2020 to mid-May 2020 by the Italian government due to social distancing measures. It is worth noting that in the majority of sectors heavily hit by the COVID-19 growth has shown a negative trend over the period 2008:Q1-2017:Q1. The COVID-19 is thus worsening a pre-existing critical economic outlook, in particular in those sectors that have never fully recovered from the 2007-09 financial crisis and the sovereign debt crisis. In general, the short-run drop vanishes within 12 quarters in most sectors. In other words, only after three years these sectors are supposed to return to their long-term equilibrium production and employment levels.

Exceptions are the 'electricity and gas supply' and 'health and social care' sectors, which show a positive response following a COVID-19 induced uncertainty shock. However, the positive effect is statistically significant only in the "electricity and gas supply" sector from two quarters after the shock. 

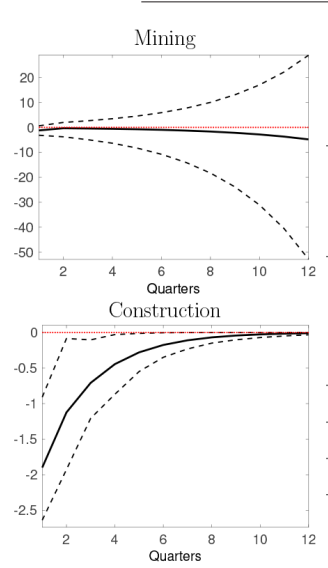

Telecommunications

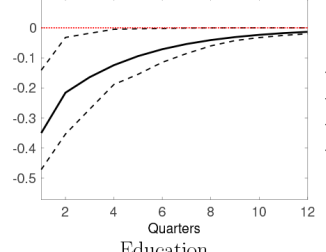

Education
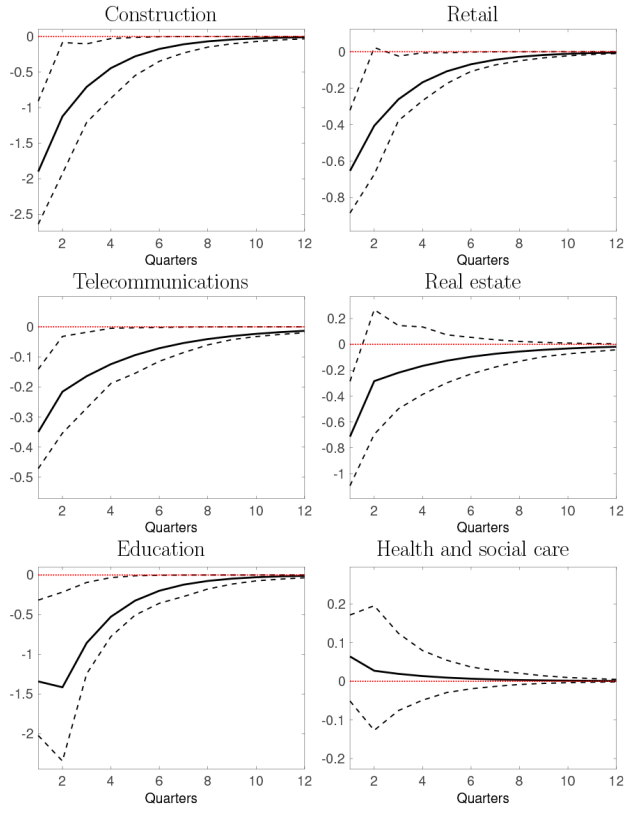

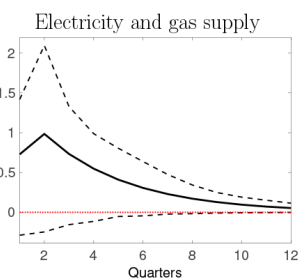

Transport and storage

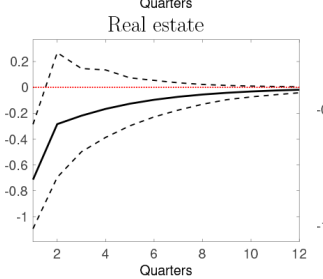

Figure 4 COVID-related uncertainty impact on company revenues (\% deviations from mean). Notes: this figure depicts impulse responses (expressed as deviations from long-term mean) of company revenues (in different economic sector) to a COVID-19-related uncertainty shock. For each sector the impulse response function is estimated from a bivariate-VAR where COVID-related uncertainty is ordered first. Black solid lines and dashed black ones: point estimates and $68 \%$ percent confidence bands. Data on company revenues are from the ISTAT. Sample: 2008:Q1-2017:Q1

Estimates on gross operating margin are presented in figure 5 and show a very similar pattern compared to revenues [fig. 5]. Once again, the sectors most adversely affected by the COVID-19 are 'construction', 'education', 'manufacturing activities', 'business support services' and 'hospitality'. Dynamics in figure 5 indicate also that in these sectors the effects of the pandemic will last for almost two years. Differently from aggregate revenues, the impact on the gross operating margin is found to be larger in magnitude. For instance, 'construction', 'hospitality' and 'art, leisure and entertainment' drop by more than $3 \%$. 

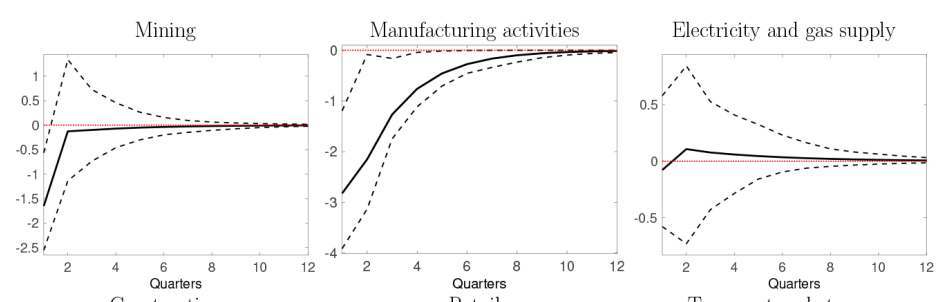

Water and multiutilities

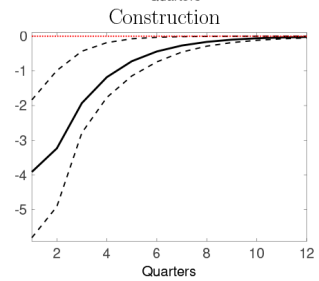
Retail

Transport and storage
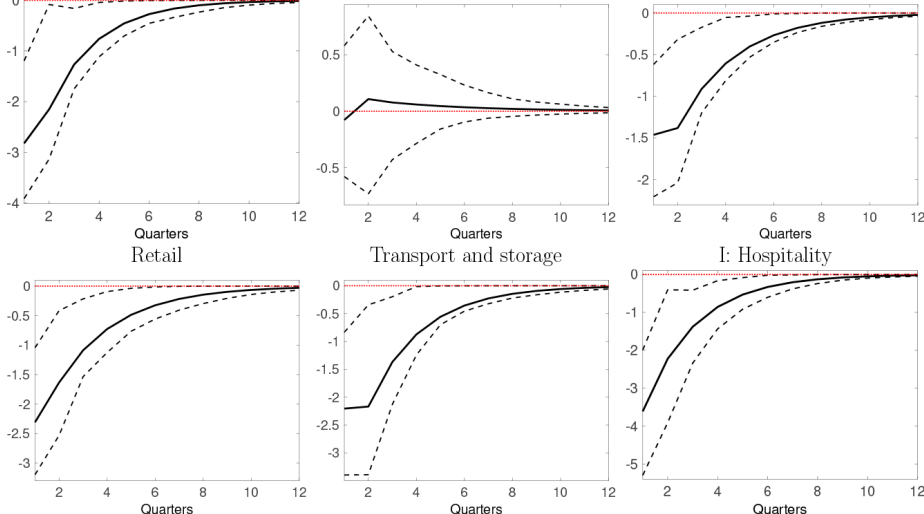

I: Hospitality

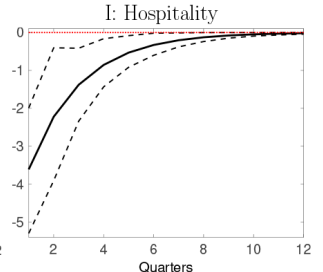

Telecommunication
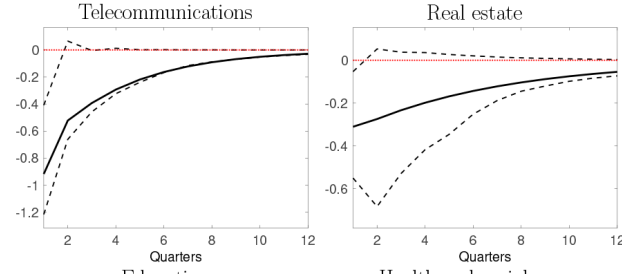

Business support services

Travel and rental services
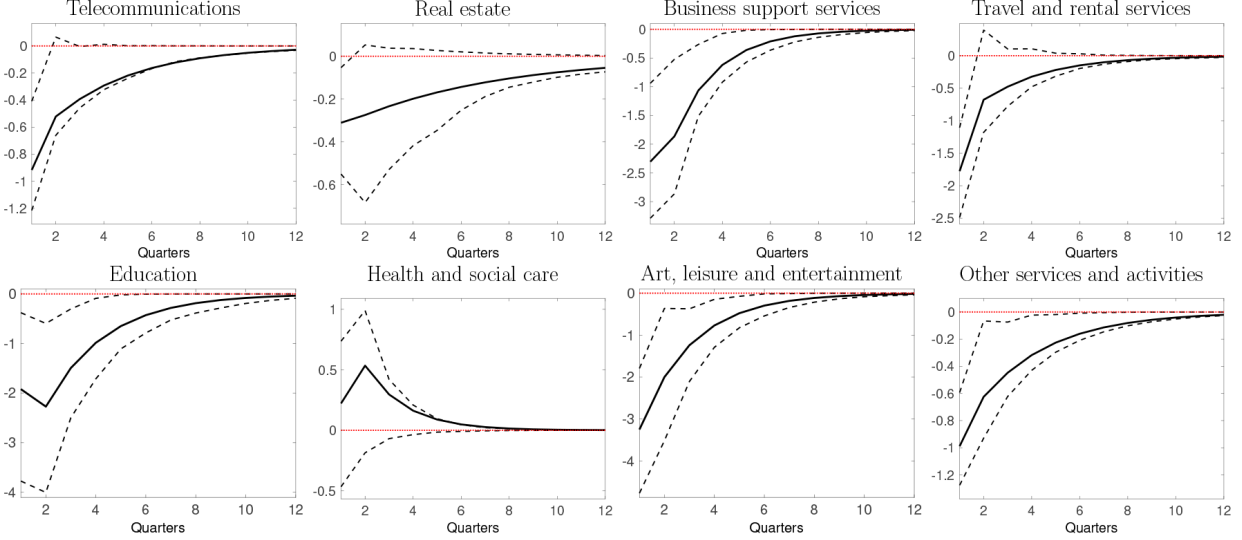

Other services and activities

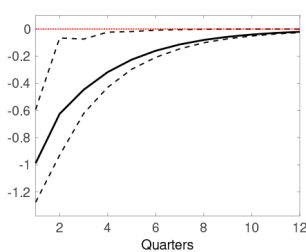

Figure 5 COVID-related uncertainty impact on employment (\% deviations from mean). Notes: this figure depicts impulse responses (expressed as deviations from long-term mean) of company gross operating margin (in different economic sectors) to a COVID-19-related uncertainty shock. For each sector the impulse response function is estimated from a bivariate-VAR where COVID-related uncertainty is ordered first. Black solid lines and dashed black ones: Point estimates and $68 \%$ percent confidence bands. Data on company revenues are from the ISTAT. Sample: 2008:Q1-2017:Q1

Lastly, we present and discuss the estimated COVID-19 impact on the number of employed workers in each sector [fig. 6]. Estimates are generally less significant with respect to the previous cases. Nevertheless, similar conclusions can be drawn. 'Business support services' show the highest (negative) impact on employment, with a drop of $-0.5 \%$ after one quarter and a full recovery not earlier than three years, followed by 'education' with almost $-0.5 \%$ after six months. A key difference with respect to responses on revenues and gross operating margin regards the recovery time. Due to certain rigidities in the labour market, the effects of COVID-19 induced uncertainty 
Marta Castellini, Michael Donadelli, Ivan Gufler

On the Impact of COVID-19-Related Uncertainty
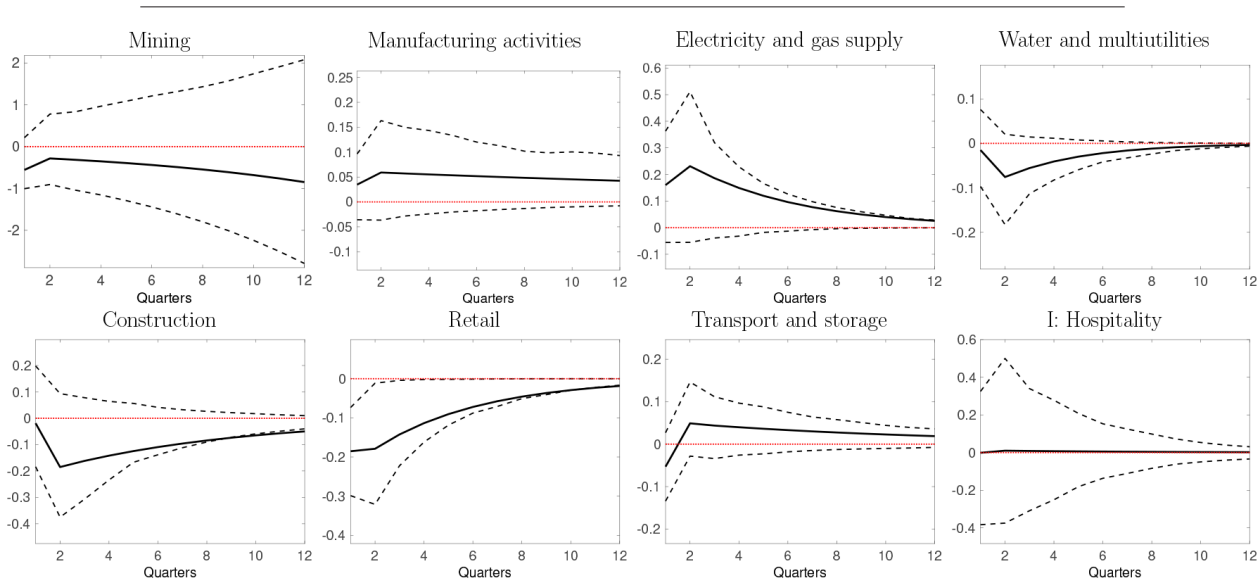

Transport and storage

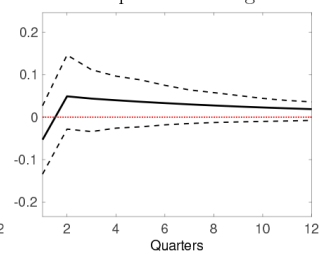

I: Hospitality

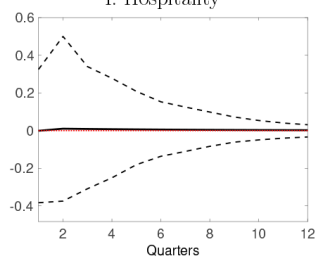

Telecommunications
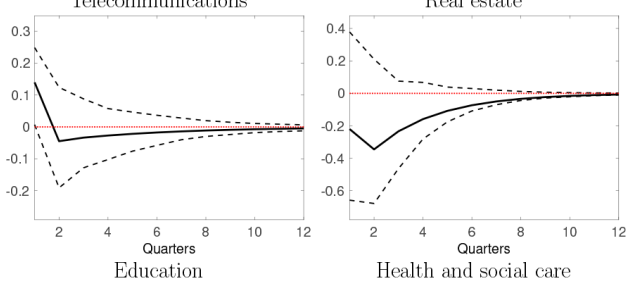

Business support services

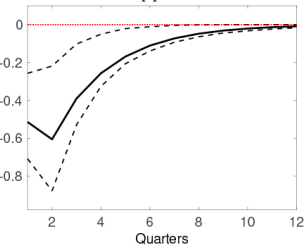

Travel and rental services

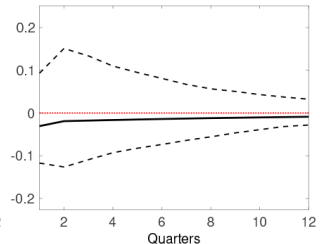

Art, leisure and entertainment

Other services and activities
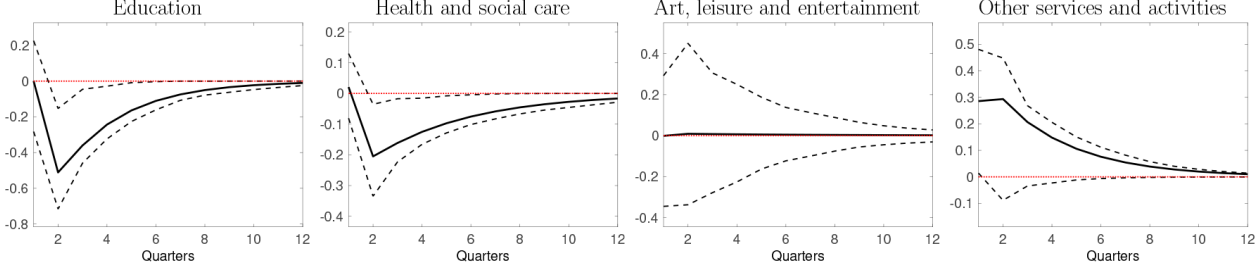

Figure 6 COVID-related uncertainty impact on employment (\% deviations from mean). Notes: this figure depicts impulse responses (expressed as deviations from long-term mean) of company employment (in different economic sectors) to a COVID-19-related uncertainty shock. For each sector the impulse response function is estimated from a bivariate-VAR where COVID-related uncertainty is ordered first. Black solid lines and dashed black ones: point estimates and $68 \%$ percent confidence bands. Data on company employment level are from the ISTAT. Sample: 2008:Q1-2017:Q1

shocks on employment are more persistent. It is important to underline that - at the end of 2019, before the virus spread - Italy was one of the EU countries with the highest unemployment rate $(9.9 \% \mathrm{com}-$ pared to an EU average of 6.7\%). ${ }^{7}$ The slowdown of the economy induced by COVID-19 is undoubtedly worsening a pre-existing Italian economic scenario. With regard to 'hospitality', it is noteworthy that employment levels follow a seasonal trend and most of the workers in

7 Source: Word Bank data, Total Unemployment (\% of total labor force). 
Marta Castellini, Michael Donadelli, Ivan Gufler On the Impact of COVID-19-Related Uncertainty

this sector are hired during the tourist season (i.e. from May to October). The consequences on employment are thus likely to be worse than those estimated in figure 6.

Finally, table 2 shows the cumulative impact of COVID-19 at 6, 12 and 18 months after the EPU shock. On average, the impact on revenues after 18 months is $-2.1 \%$. Estimates on GOM depicts a more dramatic framework among Italian sectors. The average cumulative impact equals $-3.4 \%$ after 6 months, $-4.5 \%$ after 12 and $-5 \%$ after 18 . Clearly, many Italian sectors are not going to recover quickly from this pandemic.

Table 2 Cumulative impact of COVID-19 (\% deviations from the mean)

\begin{tabular}{|c|c|c|c|c|c|c|c|c|c|}
\hline $\begin{array}{l}\text { Moths } \\
\text { after } \\
\text { the } \\
\text { shock }\end{array}$ & & Mining & $\begin{array}{l}\text { Manfactu- } \\
\text { ring } \\
\text { activities }\end{array}$ & $\begin{array}{l}\text { Electricity } \\
\text { and gas } \\
\text { supply }\end{array}$ & $\begin{array}{l}\text { Water } \\
\text { and } \\
\text { multi- } \\
\text { utilities }\end{array}$ & $\begin{array}{l}\text { Construc- } \\
\text { tion }\end{array}$ & Retail & $\begin{array}{c}\text { Transport } \\
\text { and storage }\end{array}$ & Hospitality \\
\hline \multirow[t]{3}{*}{6} & Rev & -1.549 & -1.532 & 1.713 & -1.574 & -3.024 & -1.059 & -1.478 & -1.403 \\
\hline & GOM & -1.777 & -4.973 & 0.030 & -2.847 & -7.148 & -3.943 & -4.374 & -5.832 \\
\hline & $\mathrm{E}$ & -0.836 & 0.094 & 0.391 & -0.091 & -0.204 & -0.364 & -0.004 & 0.009 \\
\hline \multirow[t]{3}{*}{12} & Rev & -2.569 & -2.147 & 2.994 & -2.286 & -4.177 & -1.488 & -2.059 & -2.010 \\
\hline & GOM & -1.945 & -7.000 & 0.167 & -4.365 & -10.260 & -5.759 & -6.614 & -8.065 \\
\hline & E & -1.501 & 0.206 & 0.727 & -0.187 & -0.508 & -0.620 & 0.079 & 0.025 \\
\hline \multirow[t]{3}{*}{18} & Rev & -4.303 & -2.441 & 3.710 & -2.541 & -4.633 & -1.665 & -2.274 & -2.313 \\
\hline & GOM & -2.031 & -7.729 & 0.248 & -5.036 & -11.423 & -6.572 & -7.527 & -8.924 \\
\hline & $E$ & -2.331 & 0.311 & 0.943 & -0.239 & -0.741 & -0.783 & 0.149 & 0.036 \\
\hline $\begin{array}{l}\text { Moths } \\
\text { after } \\
\text { the } \\
\text { shock }\end{array}$ & & $\begin{array}{l}\text { Telecom- } \\
\text { munica- } \\
\text { tions }\end{array}$ & $\begin{array}{c}\text { Real } \\
\text { estate }\end{array}$ & $\begin{array}{l}\text { Business } \\
\text { support } \\
\text { services }\end{array}$ & $\begin{array}{l}\text { Travel } \\
\text { and } \\
\text { rental } \\
\text { services }\end{array}$ & Education & $\begin{array}{l}\text { Health } \\
\text { and } \\
\text { social } \\
\text { care }\end{array}$ & $\begin{array}{l}\text { Art, leisure } \\
\text { and enter- } \\
\text { tainment }\end{array}$ & $\begin{array}{c}\text { Other } \\
\text { services } \\
\text { and } \\
\text { activities }\end{array}$ \\
\hline \multirow[t]{3}{*}{6} & Rev & -0.566 & -0.998 & -2.103 & -0.315 & -2.758 & 0.091 & -1.263 & -1.549 \\
\hline & GOM & -1.438 & -0.585 & -4.169 & -2.454 & -4.194 & 0.756 & -5.249 & -1.614 \\
\hline & $E$ & 0.095 & -0.565 & -1.120 & -0.050 & -0.511 & -0.184 & 0.008 & 0.579 \\
\hline \multirow[t]{3}{*}{12} & Rev & -0.854 & -1.383 & -2.983 & -0.295 & -4.140 & 0.124 & -1.809 & -2.569 \\
\hline & GOM & -2.124 & -1.018 & -5.853 & -3.253 & -6.673 & 1.214 & -7.259 & -2.379 \\
\hline & $E$ & 0.035 & -0.957 & -1.768 & -0.084 & -1.114 & -0.471 & 0.022 & 0.934 \\
\hline \multirow[t]{3}{*}{18} & Rev & -1.019 & -1.605 & -3.325 & -0.284 & -4.662 & 0.140 & -2.081 & -4.303 \\
\hline & GOM & -2.505 & -1.330 & -6.423 & -3.621 & -7.751 & 1.351 & -8.032 & -2.765 \\
\hline & Emp & -0.005 & -1.138 & -2.047 & -0.113 & -1.388 & -0.643 & 0.033 & 1.116 \\
\hline
\end{tabular}

Notes: this table depicts the cumulative impulse responses of company revenues (Rev), gross operating margin (GOM), and employment (E) in different economic sectors to a COVID-19-related uncertainty shock after 6,12 and 18 months. For each sector the impulse response function is estimated on the basis of a bivariate-VAR where COVID-related uncertainty (i.e, EPU) is ordered first. Data on company revenues, gross operating margins and employment level are from the ISTAT. Sample: 2008:Q1-2017:Q1 


\section{Concluding Remarks}

Since March 2020, the rising number of confirmed COVID-19 cases around the World has made it necessary to implement a series of social distancing measures (including lockdowns) aimed at slowing down the rate of infection. Naturally, these measures have generated a direct effect on the real economic activity. In particular, a rapid drop in production and subsequently in employment levels. Even before the virus was detected in Italy, the country was in a thorny economic situation. In fact, it was one of the last EU countries in terms of economic growth performance and among the first for level of unemployment and public debt. Certainly, for Italy the economic effects related to COVID-19 could be more harmful than for other countries.

Measuring the true impact of COVID-19 may be challenging. What is sure is that this newly declared pandemic has generated an unprecedented level of uncertainty. Even if not strictly related to economics or politics, such uncertainty seems to be induced by topics associated (on average) with bad news that are well known to be detrimental for production.

The lack of clarity in managing the pandemic and the absence of immediate, efficient and concrete government actions ${ }^{8}$ failed in restoring market confidence and resolving uncertainty. This will lead to more severe adverse effects on the real economy. Intuitively, unclear policies and measures make consumers and businesses more averse to ambiguity. Consequently, investments and hiring are postponed to obtain additional information on future outcomes (Baker, Bloom, Davis 2016). More importantly, COVID-19 induced uncertainty seems to be responsible for a delay in economic recovery. More severe and long-lasting negative effects have been found in particular in the 'construction', 'education', 'manufacturing activities', 'business support services' and 'hospitality' sectors.

COVID-19 hit 208 countries worldwide representing thus a global shock. In order to mitigate its adverse effects, any government should implement policies aimed at reducing the overall level of domestic political uncertainty and slowing down contagions while boosting the economy. This with the ultimate goals of recovering more quickly.

8 In the case of Italy, it is also important to underline the significant delay of national government in establishing a scientific-economic committee. The scientific health committee was formally set up in early February 2020, whereas the economic one was established only in April 2020. First lockdown measures started in early March 2020 whereas industrial shutdown was declared from mid-March 2020. Since containment policies aimed to protect population health also affect economy, the government should have defined earlier and more concisely the economic compensation policies. By immediately identifying the optimal mix between containment policies and economic compensation this would have reduced the overall uncertainty induced by the COVID-19 pandemic as well as its negative impact on economy. 
Indeed, uncertainty related to this pandemic may represent the trigger of a deep change in the current paradigm of economic development. The need of a different approach to the economic growth has been widely recognised over the last 10 years. The tackling of climate change, inequality and hunger are at the centre of the world debate from many years and still local governments lack of concrete actions in their policy strategies. This 'new world' re-designed by the pandemic represents the perfect field to put finally such strategies into actions.

Close cooperation between EU members represents a fundamental element for the success of any economic, as well as health, policy identified by each country. In the last years, European Union played a central role in boosting innovation in green technologies sector for instance, but such specific interventions are not enough now to address the economic challenge drawn by the COVID-19 virus. The institutional role of EU and its economic policy in response to ongoing COVID-19 induced crises are crucial for the economic recovery of the continent.

Italy has been in need of a consistent industrial policy for many years. The labour market was subject to different reforms but all of them were constrained by the high level of political uncertainty. Digitalisation and sustainability topics were key elements of several electoral programmes but they remained so even after the elected government settled. The current pandemic has emphasised the effect of policymakers' behaviour to postpone such interventions, which instead firms necessitated even before the COVID-19 diffusion. Italian policymakers identified short-term solutions to support the economy during the pandemics, and contain the virus diffusion at the same time, by selecting specific industrial sectors to exclude from the mandatory cessation of production and providing economic compensation measures to the others. In a medium term perspective, it is very unlikely that this solution to be optimal for the national economy. In addition to the traditional economic policies aimed at fostering the growth of an economy after a shock like this one, policymakers are called to identify specific interventions aimed at supporting firms' innovation so that production to continue even during a second potential wave of pandemic (i.e. supporting automation of industrial process, home automation, digitalisation, implementation of smart working system....). ${ }^{9}$ The success of such instruments is conditioned by the presence of a high level of efficiency in public insti-

9 With reference to the Italian case and the economic measures to be adopted for those sectors affected the most by this pandemic, the different entrepreneurial perspectives at regional level must be taken into account. As also during the pandemic, the governors of the regions will play a central role on this aspect. Since the Italian firms' environment is characterised by a significant level of family-owned SME, a specific dialogue with each trade association must be open to understand the different entrepreneurs' perspectives. 
tutions, infrastructures and national health care system. Thus, economic reforms must focus also on these aspects.

With reference to the health system in particular, we underline the importance of a close cooperation and coordination between private and public health institutions, as well as of the role played by academic research. Regulations regarding the former must be redefined learning from the experience of the last months of pandemics (by increasing the employees in the sector, the compliance of the health structures to operational and safety standards in line with the pandemic critical issues and the level of technological endowment...), so that the uncertainty related to the pandemic is reduced. In addition to that, public funding strategies for these sectors must be reorganised with a specific attention to their contribution in responding to the emergency. Reducing the uncertainty in public funding in these two sectors could increase their qualitative performance and outputs, which in turn can be considered as a key element to prevent or manage the next pandemic wave.

\section{Bibliography}

Baker, S.R.; Bloom, N.; Davis, S.J. (2016). "Measuring Economic Policy Uncertainty". The Quarterly Journal of Economics, 131(4), 1593-636. https:// doi.org/10.1093/qje/qjw024.

Baker, S.R.; Bloom, N.; Davis, S.J.; Terry, S. (2020). "Covid-Induced Economic Uncertainty”. NBER Working Paper no. 26983. https://www.nber.org/ papers/w26983.

Bernanke, B.S. (1983). "Irreversibility, Uncertainty, and Cyclical Investment”. The Quarterly Journal of Economics, 98(1), 85-106. https://doi. org/10.2307/1885568.

Caggiano, G.; Castelnuovo, E.; Figueres, J.M. (2017). "Economic Policy Uncertainty and Unemployment in the United States: A Nonlinear Approach". Economics Letters, 151, 31-4. https://doi.org/10.1016/j.econlet.2016.12.002.

Caggiano, G.; Castelnuovo, E.; Kima, R. (2020). "The Global Effects of Covid19-Induced Uncertainty". Bank of Finland Research Discussion Paper No. 11/2020. https://ssrn.com/abstract=3623226.

Caggiano, G.; Castelnuovo, E.; Pellegrino, G. (2017). "Estimating the Real Effects of Uncertainty Shocks at the Zero Lower Bound". European Economics Review, 100, 257-72. https://doi.org/10.1016/j.euroecorev.2017.08.008.

Donadelli, M.; Gerotto, L. (2019). "Non-Macro-Based Google Searches, Uncertainty, and Real Economic Activity". Research in International Business and Finance, 48, 111-42. https://doi.org/10.1016/j.ribaf.2018.12.007.

Prometeia (2020). Italy in the Global Economy. Prometeia Brief, April 2020 - no. 20/3. https://rb.gy/lqasfw. 


\section{Part 7}

Pensions and Insurance 



\title{
The Implications of the COVID-19 Pandemic for Pensions
}

\section{Charles Sutcliffe}

The ICMA Centre, Henley Business School, University of Reading, UK

\begin{abstract}
COVID-19 and the lockdowns have had a big global economic effect, as well as increasing mortality. We examine the effects of COVID-19 and the resulting relaxations of pension regulations on pension schemes. Those who transfer their pension or withdraw cash from their pension pot while asset prices are depressed by COVID-19 are losers; as are members of defined benefit schemes with a deficit whose employer fails due to COVID-19. The increased mortality from COVID-19 will have a minimal effect on pensions. If economies recover to pre-COVID-19 levels, the long run effects on pensions should be small.
\end{abstract}

Keywords Pensions. COVID-19. Coronavirus. Longevity. Mortality. Lockdown. Pension contributions. Pension transfers. Pension scams. Pension withdrawals. State pensions.

Summary 1 Introduction. - 2 Types of Pension Scheme. - 3 Longevity. - 4 State Pensions. - 5 Asset Values. - 6 Discount Rate. - 7 Companies. - 8 Members. - 9 Regulation. - 10 Conclusions.

\section{Introduction}

The COVID-19 pandemic and the associated lockdown has had big negative effects on national economies - sharply reduced gross national product (GNP), depressed share prices, considerably increased unemployment, forced firms into liquidation, reduced interest rates, lowered government tax revenues, and caused very large amounts of government spending. The economic consequences of COVID-19 have affected pension schemes in a variety of ways. In addition, COVID-19 has led to the death of hundreds of thousands of people globally, which also has implications for pension schemes and annuity providers.

Innovation in Business, Economics \& Finance 1

ISBN [ebook] 978-88-6969-442-4 


\section{Types of Pension Scheme}

There are two main types of pension scheme - defined benefit (DB) and defined contribution (DC) (Sutcliffe 2016). DB schemes are offered by employers (sponsors), and promise to pay a pension calculated using either a member's final or average salary, and the number of years of membership of the scheme (accrued years). Both the employer and members make contributions which are a percentage of the member's salary. This money is then invested in a pooled manner by the DB scheme to provide the cash to pay the promised pensions. Every year (or every three years in the UK) each DB scheme undergoes an actuarial valuation when the assets are compared with the present value of the scheme's liabilities, i.e. the promised pensions. This may lead to a change in both the member and employer contribution rates, although the ultimate responsibility for meeting the pensions promise lies with the employer.

DC schemes receive contributions from both the members and their employer, and this money is paid into segregated pots of money, each 'owned' by the member concerned. Members can usually choose how their pot of money is invested (although the vast majority do not), and when they retire they choose what to do with the final value of their pot of money - buy an annuity, take it in cash, or go into drawdown (i.e. invest the money and make withdraws as required).

The relative importance of DB and DC schemes in terms of assets and accrued liabilities differs between countries, as shown in table 1.

Table 1 asset split between DB and DC occupational schemes and total assets in 2019 (Willis Towers Watson 2020b)

\begin{tabular}{lcccccc}
\hline & Japan & Canada & Netherlands & UK & US & Australia \\
\hline DB & $95 \%$ & $95 \%$ & $94 \%$ & $82 \%$ & $39 \%$ & $14 \%$ \\
\hline DC & $5 \%$ & $5 \%$ & $6 \%$ & $18 \%$ & $61 \%$ & $86 \%$ \\
\hline Assets US\$ bn. & 3,386 & 1,924 & 1,690 & 3,451 & 29,196 & 2,077 \\
\hline
\end{tabular}

\section{Longevity}

By 17th June 2020 there were 8,006,427 confirmed cases of COVID-19 globally, including 436,899 deaths, reported to the World Health Organization (WHO 2020). The death of many members and pensioners from COVID-19 has reduced the liabilities of DB pension schemes, as the deceased will not receive any pension payments. The death of a pensioner terminates their pension, leaving only a spouse's pension, which is usually half the full pension. The death of an active member results in a death-in-service payment, which is generally a lot less 
than the actuarial value of the pension they would otherwise have received. Similarly insurance companies, who sell annuities mainly to former members of DC schemes, will also benefit. The death of an annuitant terminates the annuity payments, although survivor benefits (e.g. spouses) may continue at a much reduced rate. The size of these beneficial effects of COVID-19 for DB pension schemes and insurance companies is unclear. There may be repeat waves of $\mathrm{CO}$ VID-19 infection, and increased deaths from other causes indirectly caused by COVID-19, e.g. the temporary withdrawal of treatment for some medical conditions, people not seeking medical treatment due to the fear of contracting COVID-19, the damage caused by COVID-19 to the health of those who have recovered shortening their longevity, etc. Cairns et al (2020) modelled the likely effects of COVID-19 on UK longevity, and concluded that the main effect is to advance the date of death by a few years, e.g. people who would otherwise have died at age 85 , are dying at the age of 80 (40\% of deaths from COVID-19 in the UK were aged over 85). The implication of this model is that the beneficial effect of COVID-19 for DB schemes and annuity providers from the elevated death rate is small; and makes little difference to the funding of DB schemes and the price of annuities. In short, UK mortality has been declining over time, but COVID-19 has increased it to its level in 2008.

\section{State Pensions}

State pension schemes often have unique and complicated designs. Many state pensions, e.g. the UK, are pay-as-you-go with contributions by current employers and employees used to pay current pensions. Other state pensions are funded, and invest the contributions to pay the promised state pensions at a later date, e.g. China. COVID-19 has affected state pensions in a variety of ways.

Following COVID-19, the Finnish government temporarily reduced the employers' state pension contribution rate by $2.6 \%$ until the end of 2020, and will finance this using a reserve fund. The reduction in contributions will be recouped from employers by increasing their contribution rate for 2022-25. COVID-19 may lead to reductions in US Social Security benefits, as they are based on the US average wage index. Biggs (2020) has forecast that COVID-19 will automatically reduce US Social Security expenditure. He has estimated that, if this index drops by 15\% in 2020, Social Security benefits for those aged 60 in 2020 will be around 13\% per year lower when they retire. This will lower the cost of US Social Security and extend the date when it runs out of money to beyond 2034 (OASDI Trustees 2020). However, the large increase in the US unemployment rate from 3.5\% in February 2020 to $14.7 \%$ in April 2020 has reduced total Social Se- 
curity contributions paid by employees and employers (US Bureau of Labor Statistics 2020). There has also been a small increase in Social Security payments, due to unemployed workers retiring early. These effects may bring the date of exhaustion of the Social Security fund forward to 2029 (Gladstone, Akabas 2020).

The very large cost of COVID-19 to governments, in terms of supporting individuals and companies, and the drop in tax revenues from the reduction in economic activity may have a negative effect on the level of state pensions as governments seek to offset the costs of COVID-19. Since 2011 the UK has had a "triple lock" on annual increases in the state pension; which must rise by at least the highest of inflation, average earnings growth and 2.5\%. The Social Market Foundation has estimated that removing $2.5 \%$ to leave a "double lock" would save the government $£ 4$ billion per year (Corfe 2020).

Since over eight million UK workers have been furloughed on $80 \%$ of their wages, average earnings are forecast by the Office for Budget Responsibility (OBR 2020) to drop by 7.3\% in 2020. So state pensions will rise by the guaranteed minimum of $2.5 \%$. For 2021, after the furlough has ended, average earnings should rise by $7 / 93=8 \%$, while the OBR has forecast they will increase by $18.3 \%$. If this OBR forecast is correct state pensions will also rise by $18 \%$, unless the rules are changed.

Some governments have set aside a specific revenue stream, e.g. North Sea oil, to create a sovereign wealth fund to provide for state pensions (e.g. Norway, Chile, Ireland, France, China). Governments seeking to fund their COVID-19 expenditure and loss of revenue may draw money from their sovereign wealth fund. Norway has a $\$ 1,000$ billion sovereign welfare fund (the Government Pension Fund Global, GPFG) which receives government revenues from North Sea oil. Due to the pressures on government finances caused by COVID-19, the 2020 Norwegian budget has been amended, and instead of paying $\$ 0.4$ billion into the GPFG, the Norwegian government will withdraw $\$ 38$ billion from the fund. Further withdrawals from the GPFG may be needed in subsequent years. In France, as well as suspending major pension reform due to COVID-19, the French Pension Reserve Fund (FRR) will pay at least an additional $€ 13$ billion to help finance state pensions.

\section{Asset Values}

COVID-19 and the associated economic disruption has led to dramatic falls in stock markets around the world. From 12th February 2020 to 23rd March 2020 the FTSE 100 and S\&P 500 indices both fell by $34 \%$, although they then rose. As DB and DC pension funds hold large amounts of equities, this caused big reductions in the value of the 
assets available to pay pensions. During the first quarter of 2020 the value of US DB pension assets dropped by $14.9 \%$, and the value of UK DB pension assets dropped by 19.7\% (Evestment 2020). For DB schemes this led to a deterioration in their funding ratios (i.e assets/liabilities); while the pension pots of DC scheme members became smaller.

If $\mathrm{DB}$ schemes have a deficit they need to eliminate it over a number of years, usually by additional contributions. Higher contribution rates will put extra financial pressure on employers, leading them to reduce their dividends, investment, and other discretionary expenditure. There may also be an increase in the contribution rate for members, reducing their disposable income and incentivising them to leave the pension scheme and become deferred pensioners. For DC members the drop in asset values has reduced the expected size of their pension pot at retirement, which may mean they need to work longer before they can afford to retire.

The drop in equity prices caused by COVID-19 may be a short term phenomenon having little long term effect, with DB scheme funding and the value of DC pension pots recovering to their pre-COVID-19 levels. However, even if this happens, there will be losers. In some countries active members of DC schemes are allowed to withdraw money from their pension pot before they retire. Those members who transfer out of a DB scheme, or who cash in part of their DC pension pot before asset values recover, will be losers. To prevent this the Canadian government has placed a temporary ban on pension transfers and the purchase of annuities (Government of Canada 2020). In the UK DB scheme members can transfer their accumulated benefits to a DC scheme and, if they are over the age of 55, withdraw some or all of the money in their new DC pension pot. Transferring out of a DB scheme when asset values are depressed results in a low valuation of the member's accumulated pension benefits (the cash equivalent transfer value) that are transferred to the DC scheme, and therefore a poor deal for the member.

Australia has allowed unemployed members to remove $\$ 20,000$ from their pension pot, leading to a sharp increase in withdrawals. The US CARES Act 2020 allows DC scheme members to withdraw up to $\$ 100,000$ from their pot without penalty (Anzalone 2020), and 30\% of US DC scheme members have withdrawn money from their pension pots since the COVID-19 pandemic (Berger 2020). Iceland has allowed withdrawals from pensions of up to $€ 75,000$, regardless of age. While helping to deal with the immediate pressures of COVID-19 on household budgets, withdrawals reduce the size of pension pots available to finance retirement. It also means members are liquidating their pension assets when values are low. 


\section{Discount Rate}

COVID-19 has resulted in cuts in interest rates to exceptionally low levels, e.g. the Bank of England rate went from $0.75 \%$ on 11th March 2020 to only $0.10 \%$ on March 19, 2020. Cuts in interest rates reduce the discount rate used to compute the present value of DB scheme liabilities, leading to larger liabilities and reductions in scheme funding ratios. This may result in higher pension contributions being required from employers and members, and members leaving or declining to join DB schemes due to the higher cost.

Most DB scheme members in the UK and US are in the public sector (e.g. civil servants, armed forces, police, teachers, NHS, fire fighters). Almost all these UK schemes are unfunded, and contributions are set using the forecast rate of UK economic growth to discount the liabilities. It is widely forecast than COVID-19 will result in a substantial drop in long-term economic growth rates, with negative growth in the short run. This will increase the liabilities of unfunded public sector schemes, requiring higher contributions by public sector employers and scheme members.

\section{Companies}

By June 9, 20208.9 million workers in the UK had been furloughed (i.e. supported by the government not to work), and 2.5 million selfemployed workers were also being supported by the government (BBC 2020). A further 2.1 million were claiming unemployment benefits in April 2020 (ONS 2020). The UK pensions regulator has allowed employers to defer making their agreed deficit repair contributions to restore the funding of their DB schemes for three months or longer, on condition they do not pay any dividends during the deferment period and receive agreement from their trustees. This offer has been taken up by more than $10 \%$ of UK DB schemes. UK schemes are also free to alter the employer's contribution rate for DB and DC schemes, provided the scheme rules are followed; and Deloitte and the Financial Times have substantially reduced their DC contribution rates on a temporary basis. Only 15\% of UK DB schemes plan to make up for these temporary reductions in contributions by making additional contributions in the future (Willis Towers Watson 2020a). Most UK DB schemes are cash flow negative, so suspending employer contributions may increase the sale of assets at depressed prices. Cuts in dividends will also reduce the income received by pension funds on their equity holdings, e.g. Royal Dutch Shell has cancelled its $£ 2$ billion dividend. Given the financial pressures on employers, the UK pensions regulator will not pursue employers who are late in making their pension contributions; although 
it will pursue employers who do not pass on the member contributions deducted from salaries.

Due to the financial pressures on employers from COVID-19, employers in the Netherlands have been allowed to delay making their contributions to DB schemes, as have those in Bulgaria; while German employers have been allowed to delay making DB deficit repair contributions until 2021. Finland has also allowed employers to suspend contributions by themselves and their employees to occupational schemes for up to three months, and US employers have reduced or suspended their contributions to DC schemes (Mitchell 2020). In order to reduce their workforce due to the economic effects of COVID-19 on their revenue, some companies may offer early retirement on more generous terms. Providing these enhanced terms will deplete the funding of DB schemes.

The lockdown and associated drop in income will result in corporate failures. For those firms with DB pension schemes, this may mean their DB scheme has a deficit, and is unable to meet its pensions promise. In some counties such schemes enter a government authorised compensation scheme such as the Pension Protection Fund in the UK, and the Pension Benefit Guarantee Corporation in the US. COVID-19 will put pressure on the finances of these compensation schemes, and this will probably lead to an increase in the levies they impose on DB schemes.

\section{Members}

Most of those made unemployed by COVID-19 will probably become deferred pensioners, or perhaps transfer their pension to another scheme. Oku (2020) has estimated this will increase the number of dormant pensions in the UK by $32 \%$, and the deferred pensioners may lose track of these pensions. Older people who are made unemployed may decide to retire and start collecting their DB pension, or cash in their DC pension pot, while still looking for work. This will reduce the size of their annual DB or DC pension because they will be retired for longer. For those who continue to be employed, pressure on household finances and the possibility of higher contribution rates has meant that three million UK members of DC schemes have reduced or stopped their contributions, which will reduce the size of their pension pots at retirement. Similarly in the US, $47 \%$ of DC scheme members have lowered or stopped their contributions (Berger 2020).

The UK pension freedoms of 2015 brought the UK into line with other counties by allowing DC pensioners to invest their pension pot themselves, rather than buy an annuity with a guaranteed income when they retired. These pensioners in drawdown have suffered a sharp drop in their wealth as a result of the drop in asset values cau- 
sed by COVID-19. By giving members much more choice over their pensions, pension freedoms have permitted an increase in pension scams, and COVID-19 has led to a big increase in such scams. In May 2020 Canada Life (2020) found that since the COVID-19 outbreak began pension scams in the UK have risen by about $40 \%$, with one million people being targeted. This has reduced the pension assets of the victims, making them more likely to experience poverty in retirement. Many other counties have also warned against pension scams in connection with COVID-19.

COVID-19 may lead to runaway inflation (Amundi 2020). In the UK all DB pensions are required to be indexed to inflation up to $2.5 \%$, and some annuities are also inflation indexed. To the extent that DB pensions and annuities are subject to limited price indexation, since asset prices tend to increase with inflation, DB schemes should be protected or even gain. But pensioners will be losers, as their pensions will rise by less than inflation, reducing the real value of their pension for the rest of their retirement.

\section{Regulation}

The response of pension regulators has differed across countries in terms of suspending employer and member contributions, allowing members to access their pension assets, and the relaxation of other regulations. The US CARES Act has suspended the requirement for DC pensioners over the age of 72 to make minimum withdrawals from their pension pot. The UK has relaxed its insolvency laws and now restricts the right of creditors to recover debts, which reduces the ability of DB schemes and the Pension Protection Fund to pursue employers for unpaid pension contributions. Due to fears that foreign investment by Icelandic pension funds would devalue the krona, the central bank asked them to refrain from making foreign investments from March 2020 until September 2020. Regulators who have suspended rules (e.g. employer contributions, member pension withdrawals, insolvency), extended deadlines (e.g. actuarial valuations, reports to the pension regulator) and tolerated rule breaches, as well as placed restrictions on some activities (e.g. paying dividends, discouraging transfers from DB schemes), must decide when and how to restore the rules and their enforcement to pre-COVID-19 levels.

\section{Conclusions}

While COVID-19 has clearly had a negative short run effect on pensions, most of these negative effects should largely disappear in the long run, depending on the speed and extent to which the economy, 
asset prices and interest rates recover to pre-COVID-19 levels. Those who transferred out of a DB scheme, or who cashed in their DC pot during the period when asset prices were depressed, are losers. Employers who fail as a result of COVID-19 may have underfunded DB schemes, and the pension compensation schemes usually replace most, but not all, of the promised pension. Therefore the members (but not the pensioners, as they are usually fully compensated) of these DB schemes will also be losers, as will victims of the increased level of pensions fraud stemming from COVID-19. Pensions regulators face difficult decisions about when to end their forbearance, and require employers to revert to pre-COVID-19 regulations and contributions. They will also need to address the time scale over which employers are required to make their deferred contributions. Unless there is an upsurge in deaths from COVID-19, the benefit to DB pensions and annuity providers from the temporary increase in elderly mortality will have little short term effect on DB pension schemes, and no long term effect.

\section{Bibliography}

Amundi (2020). "Inflation: Persistent Headwinds but a Possible Inflationary Cocktail". Amundi, 9 June. https://bit.ly/39qYFvF.

Anzalone, J. (2020). "Retirement Plan Provisions in the Coronavirus Stimulus Bill". River and Mercantile Solutions, 29 March. https://bit.ly/2D3uFts.

BBC (2020). "More Than One in Four UK Workers Now Furloughed". BBC, 9th June. https://www.bbc.co.uk/news/business-52977098.

Berger, S. (2020). "3 in 10 Americans Withdrew Money from Retirement Savings Amid the Coronavirus Pandemic - and the Majority Spent it on Groceries". MagnifyMoney, 13 May. https://www.magnifymoney.com/blog/ news/early-withdrawal-coronavirus/.

Biggs, A.G. (2020). "How the Coronavirus Could Permanently Cut Near-Retirees' Social Security Benefits". PRC WP2020-6, April. https://repository.upenn.edu/prc_papers/675/.

Cairns, A.; Blake, D.; Kessler, A.; Kessler, M. (2020). "The Impact of COVID-19 on Future Higher-Age Mortality". The Pensions Institute. https://openaccess.city.ac.uk/id/eprint/24218/.

Canada Life (2020). "5.2 million UK Adults Either a Victim or Know Someone Who Has Fallen Victim to a Scam Since the Outbreak of Covid-19". Canada Life, 29 May. https://bit.ly/39nGgjh.

Corfe, S. (2020). "Intergenerational Fairness in the Coronavirus Economy". Social Market Foundation Briefing Paper, 14 April. https://www.smf.co.uk/ publications/intergenerational-fairness-coronavirus/.

Evestment (2020). US and UK Public Plan Asset Allocation: Opportunities for Asset Managers in the Public DB Space. April. https://bit.ly/3eRqz4Y.

Gladstone, N.; Akabas, S. (2020). "COVID-19 May Deplete Social Security Trust Funds This Decade". Bipartisan Policy Centre Report, 22 April. https:// bit.ly/2Br4L2j. 
Government of Canada (2020). "OSFI Actions to Address Issues Stemming from COVID-19”. 27 March. https://www.osfi-bsif.gc.ca/Eng/pp-rr/pparra/Pages/Pen20200327_let.aspx

Mitchell, O.S. (2020). "Building Better Retirement Systems in the Wake of the Global Pandemic". PRC WP2020-08, June. https://repository.upenn. edu/prc_papers/677/.

OASDI Trustees (2020). The 2020 Annual Report of the Board of Trustees of the Federal Old-Age and Survivors Insurance and Federal Disability Insurance Trust Funds. US Government Publishing Office. https://www.ssa.gov/ OACT/TR/2020/index.html.

OBR, Office for Budget Responsibility (2020). Commentary on the OBR Coronavirus Reference Portfolio. https://obr.uk/?s=earningst.

Oku, R. (2020). "Number of Dormant Pensions Set to Exceed 20m in 2020 Owing to Coronavirus". PensionBee, 3 June. https://www.pensionbee.com/ press/dormant-pensions-to-exceed-20m-in-2020.

ONS, Office for National Statistics (2020). "Claimant Count: K02000001 UK: People: SA: Thousands". 19 May. https://bit.ly/2WVjla1.

Sutcliffe, C.M.S. (2016). Finance and Occupational Pensions: Theories and International Evidence. London: Palgrave Macmillan. http://doi. org/10.1057/978-1-349-94863-5.

US Bureau of Labor Statistics (2020). "Labor Force Statistics from the Current Population Survey". https://data.bls.gov/timeseries/ LNS140000000.

WHO, World Health Organization (2020). WHO Coronavirus Disease (COVID-19) Dashboard. https://covid19.who.int/?gclid=EAIaIQobChMI_q_ T94re6QIVRevtCh10YwOwEAAYASAAEgJNIPD_BwE.

Willis Towers Watson (2020a). "Survey: Only 1-in-7 UK DB Schemes Say Additional Cash is the Answer". Willis Towers Watson, 20 May. https://bit. ly/2ZW8XAt.

Willis Towers Watson (2020b). "Global pension Assets Study 2020”. February. https://bit.ly/3eWZcq4. 


\title{
Insurance Risk Management During Pandemics
}

\section{Michalis loannides}

Director of Credit and Market Risk, Europe, Canada Life Group; ICMA Centre, Henley

Business School, University of Reading, UK

\begin{abstract}
The insurance sector plays a key role in absorbing systemic risks under normal conditions and its role is particularly important in taking losses following a pandemic or natural catastrophe. Strong risk management and contingency planning frameworks have ensured that insurers and reinsurers are well capitalised to withstand the economic shock of a pandemic. An estimate of the current impact of the coronavirus puts losses at more than US $\$ 200$ billion, half of which is attributed to general insurance business, and the other half is attributed to losses due to volatile investment markets.
\end{abstract}

Keywords Solvency 2. Pandemics. Solvency ratio. Credit default risk. Market risks. Business interruption risk.

Summary 1 Introduction. - 2 A First Glance on the Impact of Pandemics on the Wider Economy. - 3 The Role of Insurance and the Impact of the Pandemic Crisis on the Sector. - 3.1 Business Interruption (BI) Cover. - 3.2 Variability in Investment Returns. 3.3 Sensitivity of Solvency Capital to Key Risk Drivers. - 4 Conclusions.

\section{Introduction}

Risk management in insurance companies requires careful contingency planning. The plans incorporate the actions that management would take following well predefined stress and scenario tests upon the realisation of very low probability events. Insurance groups have been well prepared for this crisis with strong capital positions. Still, the current pandemic raises many questions regarding the sector's product offerings and investment portfolio mix.

Innovation in Business, Economics \& Finance 1

ISBN [ebook] 978-88-6969-442-4 
Section 2 of this chapter briefly reviews the impact of past crises on economic output. Section 3 discusses the role of insurance and the impact of the current crisis on the sector.

\section{A First Glance on the Impact of Pandemics on the Wider Economy}

Severe acute respiratory syndrome coronavirus 2 (SARS-CoV-2) will reclassify ${ }^{1}$ the emergence of infectious diseases amongst the key top risks, in terms of impact and likelihood of occurrence, that should be anticipated in financial institutions' business planning. Given the right conditions, COVID-19, the name of the disease caused by the highly virulent pathogen SARS-CoV-2, unexpectedly spread across borders to disrupt the longest run of world economic growth on record, to devastate communities, cities and continents posing unprecedented health and financial stability challenges.

This event is not the first pandemic event in history. Pandemics are amongst the deadliest events in human history. Events such as the 1918-19 'Spanish Flu' and the medieval 1347-51 bubonic plague known as 'Black Death' tortured the world causing pronounced increases in excess mortality. ${ }^{2}$ DeWitte (2014) reports that Black Death is estimated to have killed $30 \%$ to $50 \%$ of the European population at that time. In addition to widespread increases in mortality and morbidity, pandemics can cause fiscal deficits in the short-term and can be the primary cause for long-term pronounced negative shocks to economic growth. Table 1 presents a non-exhaustive list of these events over the last century, and details the significant blow to life and to the economy that these have delivered in the past.

1 Infectious diseases were kept consistently outside the World Economic Forum's (WEF) top five risks. The WEF, in its 2020 Global Risks Report, classified infectious diseases amongst the top 10 risks in terms of impact, but assigned a lower probability of realisation than the average probability assigned to other risks (http://www3.weforum.org/docs/WEF_Global_Risk_Report_2020.pdf).

2 Excess mortality is a term used in epidemiology and public health to refer to the number of deaths above the level expected under normal conditions. The World Health Organisation define 'excess mortality' as the "mortality above what would be expected based on the non-crisis mortality rate in the population of interest. Excess mortality is thus mortality that is attributable to the crisis conditions. It can be expressed as a rate (the difference between observed and non-crisis mortality rates), or as a total number of excess deaths" (https://www.who.int/hac/about/definitions/en/). 
Table 1 Notable pandemics and epidemics and the impact on human life and the economy. Adapted mainly from Madhav et al. 2018 and other sources as stated in the table

\begin{tabular}{|c|c|c|c|}
\hline $\begin{array}{l}\text { Starting } \\
\text { Year }\end{array}$ & Event & Estimated mortality & $\begin{array}{l}\text { Estimated economic } \\
\text { impact }\end{array}$ \\
\hline 1918 & 'Spanish Flu' & $\begin{array}{l}\text { 20mn-100mn deaths } \\
\text { (Johnson, Mueller 2002) }\end{array}$ & $\begin{array}{l}\text { GDP loss of } 11 \% \text { in the US, } \\
17 \% \text { in the UK and } 15 \% \\
\text { in Canada (McKibbin, } \\
\text { Sidorenko 2006) }\end{array}$ \\
\hline 1957 & 'Asian flu' & $\begin{array}{l}0.7 \mathrm{mn}-1.5 \mathrm{mn} \text { deaths } \\
\text { (Viboud et al. 2016) }\end{array}$ & $\begin{array}{l}\text { GDP loss of } 3 \% \text { in the US, } \\
\text { UK, Canada, and Japan } \\
\text { (McKibbin, Sidorenko 2006) }\end{array}$ \\
\hline 1968 & 'Hong Kong Flu' & $\begin{array}{l}1 \mathrm{mn} \text { deaths (Mathews } \\
\text { et al. 2009) }\end{array}$ & $\begin{array}{l}\text { US } \$ 23 b n \text { to US } \$ 26 b n \text { direct } \\
\text { and indirect costs in the US } \\
\text { (Kavet } 1977 \text { ) }\end{array}$ \\
\hline 1981 & HIV/AIDS & $36.7 \mathrm{mn}$ death & $\begin{array}{l}2 \%-4 \% \text { annual loss in GDP } \\
\text { growth in Africa }\end{array}$ \\
\hline 2003 & SARS & $\begin{array}{l}744 \text { deaths across } 37 \\
\text { countries (Wang, Jolly 2004) }\end{array}$ & $\begin{array}{l}\text { Overall economic loss } \\
\text { of US } \$ 50 \mathrm{bn} \text { (FT 2009) }\end{array}$ \\
\hline 2009 & 'Swine Flu' & $\begin{array}{l}\text { 151.7k to } 575.5 k \text { deaths } \\
\text { (Dawood et. 2012) }\end{array}$ & GDP loss of US $\$ 1 b n$ \\
\hline 2013 & Ebola outbreak & $\begin{array}{l}11,323 \text { deaths } \\
\text { Mainly West Africa }\end{array}$ & $\begin{array}{l}\text { US } \$ 2.8 \mathrm{bn} \text { for Guinea, Liberia } \\
\text { and Sierra Leone } \\
\text { (World Bank 2014) }\end{array}$ \\
\hline 2015 & Zika virus outbreak & $\begin{array}{l}2,656 \text { reported cases } \\
\text { of microcephaly (WHO 2017) } \\
\text { across } 76 \text { countries }\end{array}$ & $\begin{array}{l}\text { US } \$ 7 b n \text { to US } \$ 18 \text { bn loss } \\
\text { in Latin America and the } \\
\text { Caribbean (UNDP 2017) }\end{array}$ \\
\hline
\end{tabular}

The coronavirus pandemic is savaging the world economy. By the end of Q2 2020, the "global economy is in its most precarious position since the global financial crisis", ${ }^{3}$ and was entering the deepest and possibly the shortest recession in living memory. That view is reflected in the IMF's recent update on the growth of the world economy. The IMF forecasts a contraction of $-4.9 \%$ in world GDP, a change of $-1.9 \%$ from its previous update in April. At the end of 2019, world GDP is reported at c. US $\$ 142$ trillion in purchasing power parity terms (i.e. international dollars). The IMF's estimate would imply a staggering contraction of c. $-\$ 6.95$ trillion from the 2019 year-end figure in purchasing power parity terms.

At the time of writing (end of May-mid June 2020), the latest economic data point to a rapid slowdown to economic activity resulting

3 Quote from Laurence Boone's, OECD Chief Economist, article "Tackling the Fallout from the Coronavirus", published at https://oecdecoscope.blog/2020/03/०2/tackling-the-fallout-from-the-coronavirus/. 
in widespread business closures, near-universal event cancellations, remote working, and a general disruption of supply chains. Some of these key risks can be covered privately through insurance.

\section{The Role of Insurance and the Impact of the Pandemic Crisis on the Sector}

The insurance sector plays a key role in absorbing systemic risks under normal conditions, and its role is particularly important in taking losses following a pandemic or natural catastrophe caused by an earthquake or extreme weather event. Insurers and reinsurers act as financial intermediaries to provide effective risk transfer of financial and biometric risks, natural catastrophes and man-made disasters and pandemic risks. Reinsurers provide cover to life insurers against adverse mortality experience and stand to incur losses as big as the economic losses inflicted by natural catastrophes. Traditional retrocession and risk pooling methods provide the mechanisms for effective risk transfer and accumulation of capital.

For example, the Swiss Re Institute (2020) reports that in 2019, insurance provided cover for US $\$ 60$ billion of the US $\$ 146$ billion of economic losses inflicted by disasters. This cover is lower than in each of the previous two years due to the absence of severe hurricanes in the US, and is below the annual average of US $\$ 75$ billion over the previous 10 years.

SCOR, the French reinsurance group, limits its exposure to natural catastrophes to $10 \%$ of its eligible own funds ${ }^{4}$ (i.e. €980 million) and $20 \%$ for pandemic risks (i.e. $€ 1.970$ billion). SCOR monitors its key risk drivers and extreme scenario exposures against predefined risk tolerance limits. Table 2 provides SCOR's expected loss in extreme scenarios calibrated to the 1-in-200 year single events. The cost of a pandemic event is estimated just under $€ 1.5$ billion.

4 Eligible own funds as the name implies are the insurers/reinsurers' own capital that are available to absorb losses. Pursuant to Article 88 of the Solvency 2 Directive (EU Directive 2009/138/EC), own funds are composed of the excess of assets over liabilities and subordinated liabilities. Own funds items are classed into three tiers. 
Michalis Ioannides

Insurance Risk Management During Pandemics

Table 2 Controlling risk appetite. Lessons from SCOR. Source: Company disclosure ${ }^{5}$

\begin{tabular}{lcc}
\hline & in $€ \mathbf{m n}$ & Risk Capacity ${ }^{*}$ in $€ \mathbf{m n}$ \\
\hline North Atlantic Hurricane & 660 & 980 \\
\hline U.S Earthquake & 460 & 980 \\
\hline EU Wind & 670 & 980 \\
\hline Japanese Earthquake & 250 & 980 \\
\hline Terrorist Attach & 230 & 980 \\
\hline Pandemic & 1,470 & 1,970 \\
\hline * The exposure amount by risk that SCOR is willing to accept in pursuit of its \\
business objectives.
\end{tabular}

Pandemics could also have serious consequences for insurers. The economic loss caused in 2003 by the SARS epidemic is estimated at c. US $\$ 50$ billion and was mostly attributed to decreased travel and consumer spending. It is conceivable that all the shocks in table 2 could eventually materialise someday, but it is highly unlikely that all these single events will occur in the same year.

Today, the current impact of the coronavirus is being felt on both sides of insurers' balance sheets. Lloyd's of London projects total industry losses ${ }^{6}$ amounting to more than US $\$ 200$ billion, half of which is attributed to general insurance business, and the other half is due to losses from volatile investment markets. The lines of general insurance business that are likely to generate a larger proportion of the overall insured losses are event-cancellation cover, and US, UK and European business interruption cover. Other lines such as Contingency, Director and Officers, employment practices liability, general liability, mortgage, marine aviation, trade credit and surety and workers compensation will contribute less to the total insured losses. Other lines of business such as motor classes provide a positive offset to the bottom-line earnings along with an expected reduction in expense ratios.

Figure 1 illustrates the industry's largest reported losses realised in Q1 2020 in the EMEA region [fig. 1]. Munich Re's and Allianz Group's losses are associated mostly with general insurance business lines, but are mixed with losses realised due to natural catastrophes. No material COVID-19 claims impact (either mortality or critical illness) emerged in the first quarter of 2020.

5 Kessler 2019. Presentation to investors.

6 See https://www.ft.com/content/51d32286-5264-4c93-80c3-3d@b@fd4558a. 


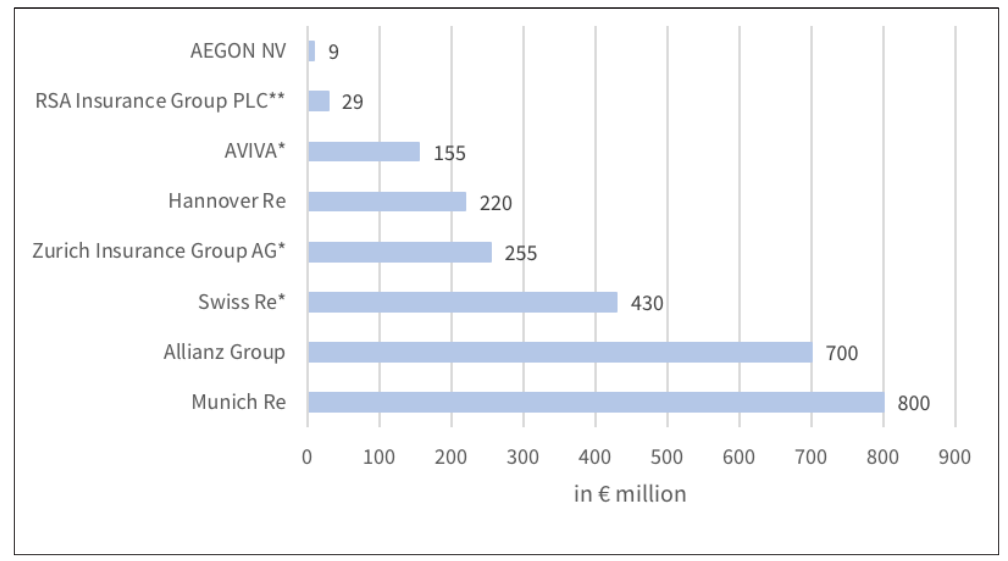

Figure 1 Q1 of 2020 pandemic losses reported by selective European insurance groups. The figure illustrates that in Q1 Munich Re and Allianz Group reported the largest losses associated with the pandemic and natural catastrophes. Loss estimates reflect the actual figures reported in the interim reporting figures of the selected insurance groups: * denotes a conversion of the loss in $€$ using the average exchange rate over Q1, ${ }^{\star \star}$ denotes only travel insurance and disability insurance claims

\subsection{Business Interruption (BI) Cover}

BI cover protects a business against economic losses due to property damage inflicted during periods of suspended operation. Most businesses carry BI insurance as part of their property insurance. In most cases, contagious diseases do not constitute property damage, especially when passed from person to person. Most of the BI cover provides cover against flood, fire and other physical damage to buildings. Only a minority of insurance policies have extensions that provide cover for infectious diseases. For example, in 2003, Mandarin Oriental hotels in Hong Kong, Malaysia, Singapore and Thailand suffered economic losses due to cancellations and reduced restaurant sales stemming from the SARS outbreak. Mandarin Oriental International Ltd recovered US \$16 million from its insurers to pay for such business interruption losses. ${ }^{7}$

Following the aftermath of the SARS epidemic, insurers sought to re-design the type of insurance cover offered by adding exclusions for bacterial or viral infections to their coverage. Most insurers applied ISO standard wordings to exclude business interruption claims caused by an infectious disease. However, displeased policyholders, especially small businesses, argue that these new additions are subject to interpretation. In particular, they argue that policy wording such as the "inarchive at https://www.sec.gov/Archives/edgar/vprr/๑401/04010312.pdf. 
ability to use the office due to restrictions imposed by a public authority during the period of insurance following an occurrence of notifiable human disease" implies that cover is provided for the current crisis.

An industry wide solution is required, and concessions need to be made. This is a key controversial area and the UK's financial regulator $^{8}$ is seeking answers to the question "should insurers remain liable?" at the High Court in late July. This involves 17 disputed policy wordings offered by eight insurance groups. This existential battle for some UK businesses has a global audience, given that European, US and Asian insurers are also facing the same issue.

\subsection{Variability in Investment Returns}

The sharp downturn in economic activity resulting from the COVID-19 outbreak has put significant pressure on insurer's profitability in the near term, as already reflected in insurers' equity prices. Figure 2 illustrates the sharp change in risk appetite which caused a panic 'sell-off' across all major stock market benchmarks [fig. 2]. The shares of insurance groups in most jurisdictions have also fallen. At the end of Q2 2020, the sector's performance, approximated by the fall in the MSCI Global Insurance Index, experienced a drop of c. 22\%. During the Great Financial Crisis (GFC), the sector experienced a dramatic fall of c. 53\%, underperforming the broader equity indices, as illustrated in panel 1 of figure 2 .

Falling equity prices (panel 1) were accompanied by widening corporate spreads (panel 2), which were marginally offset by declines in government yields, as illustrated in figure 3. This further exacerbated the under performance of the insurance sector, relative to broader stock market indices. Insurance companies' portfolios are heavily invested in long-term sovereign and corporate bonds, and the market's reaction anticipated potential mark-to-market losses on the investment portfolios of insurers. Large falls in the market prices of corporate bonds are linked to the widening of credit spreads [fig. 2, panel 2]. These losses are largely offset by gains on government bond portfolios due to the negative change in government yields [fig. 3, panels 1 and 2].

Over Q1 2020, the dislocation in financial markets was more pronounced in the sub-investment grade corporate bond markets. Figure 2 , panel 2, illustrates the widening of the credit spreads across four different credit indices over three different periods. The change to the Barclays high yield credit spreads reached levels not seen since the 2007 GFC, although they fell short of touching the GFC peaks. This index along with the widening of spreads in investment grade iBOXX indices indicate pronounced levels of credit risk. These are 
associated with the weakening credit quality of borrowers in vulnerable corporate sectors (i.e. the retail, travel, transportation, leisure and gambling, hotels and oil and gas sectors), some of which operate with significantly higher liquidity requirements, maturity mismatches and leverage. Further weakening of the corporate sector for the above reasons could significantly increase the credit downgrade and default losses experienced by insurance groups.

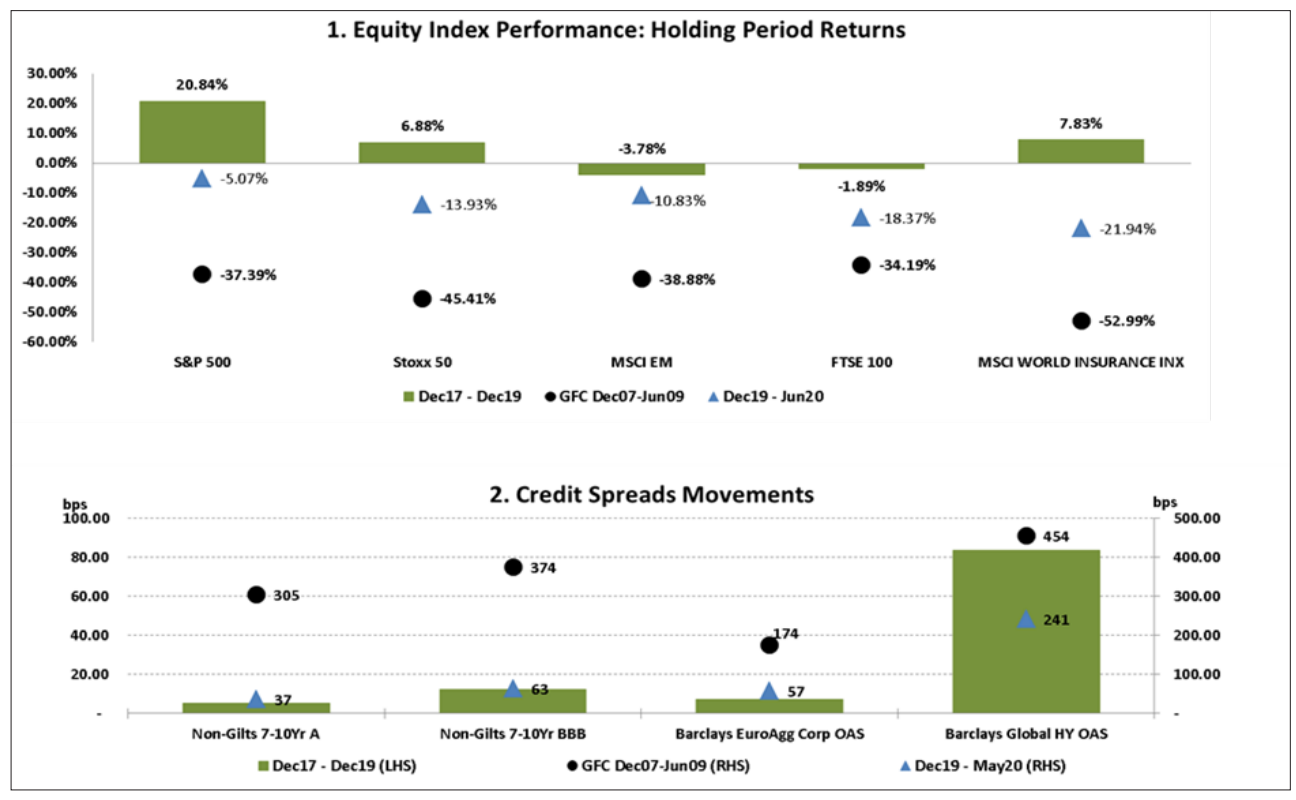

Figure 2 Equity and bond market performance over selected periods. Source: Author's calculations, Bloomberg, IHS Markit. Panel 2 includes the UK Non-Gilts iBOXX 7-10 Year indices that include bonds rated $A$ and $B B B$ with terms to maturity between 7 to 10 . The quotes spread is the change of the OAS (option adjusted spreads) over the stated period

\subsection{Sensitivity of Solvency Capital to Key Risk Drivers}

Declines in interest rates are not necessarily associated with strong solvency ${ }^{9}$ positions. Life insurance groups' balance sheets are generally more sensitive to declines in short-term interest rates. That sensitivity is associated with the long-dated nature of policy holder annuity

9 In Europe, the Solvency 2 directive requires insurance and reinsurance groups to have enough capital buffers in place over one year to be able to survive with at least a $99.5 \%$ probability (i.e. having assets in excess of its liabilities in one year's time) and then being able to fully de-risk its balance sheet. In Switzerland, the aim of the Swiss solvency test (SST) is similar. The required capital is calibrated at the 99th percentile. The solvency ratio is defined as the ratio of eligible own funds to the required solvency capital. 
liabilities, and with investment guarantees embedded in the investment products that are usually wrapped by life insurance contracts.

Life insurance companies usually seek long duration assets, in order to match the long-term duration of their annuity liabilities, and in effect minimise any duration gaps in their asset and liability management processes. This active management is required due to the biometric nature of their liabilities. Life insurance companies are exposed to changes in life expectancy, which in turn affects the duration of the insurers' annuity liabilities. If this change in duration is left unmanaged, it will affect the company's earnings and solvency capital position. Therefore, insurers engage actively in managing duration gaps by ensuring that cash flows from their fixed income portfolio match the annuity liability outgoings, either through lengthening the maturity of their asset portfolio, and/or engaging in hedging activity.

Insurance groups also maintain a high-quality asset portfolio, primarily consisting of government bonds, corporate bonds (average credit quality of A) with limited exposure to sub-investment grade bonds (i.e. average $2 \%$, but varies between $0 \%$ to $8 \%$ ), and to the most vulnerable corporate sectors impacted by the coronavirus pandemic. The fixed income portfolios also include portfolios of privately rated assets (i.e. up to $30 \%$ to $40 \%$ of the overall portfolio) made up of commercial real estate loans secured by property assets, equity release mortgages, infrastructure loans and loans extended to housing associations and universities.

Panels 3 and 4 of figure 3 illustrate the solvency ratio as at the year-end 2019 and the change to the solvency ratio of major European insurance groups recorded over Q1 2020, respectively. For instance, AXA's solvency ratio was $182 \%$ on March 31, 2020; down 16\% points on its year-end 2019 position. The negative change in AXA's solvency ratio, as for most groups, is mainly driven by unfavourable market conditions, primarily higher corporate and sovereign spreads and lower interest rates. Thus far, the COVID-19 crisis and the volatility market environment have depleted earnings and reduced solvency capital within each group's acceptable ranges. Q1 losses were offset by positive operating returns for the quarter.

Given that events are still unfolding, credit risk remains a pronounced exposure for European insurers. Groups with holdings of direct property and commercial real estate loans have provided rent concessions to tenants in response to the 'Great Lockdown' and in accordance with the authorities' guidance. Depending on the duration of this lockdown, these rent concessions could create short-term cash flow mismatches that could lead to bigger concerns in terms of liquidity, asset-liability management and capital. If this is prolonged, insurance groups will experience further downgrades and defaults in their fixed income portfolios associated with non-financial businesses operating in the most vulnerable sectors of the economy. 
Michalis loannides Insurance Risk Management During Pandemics

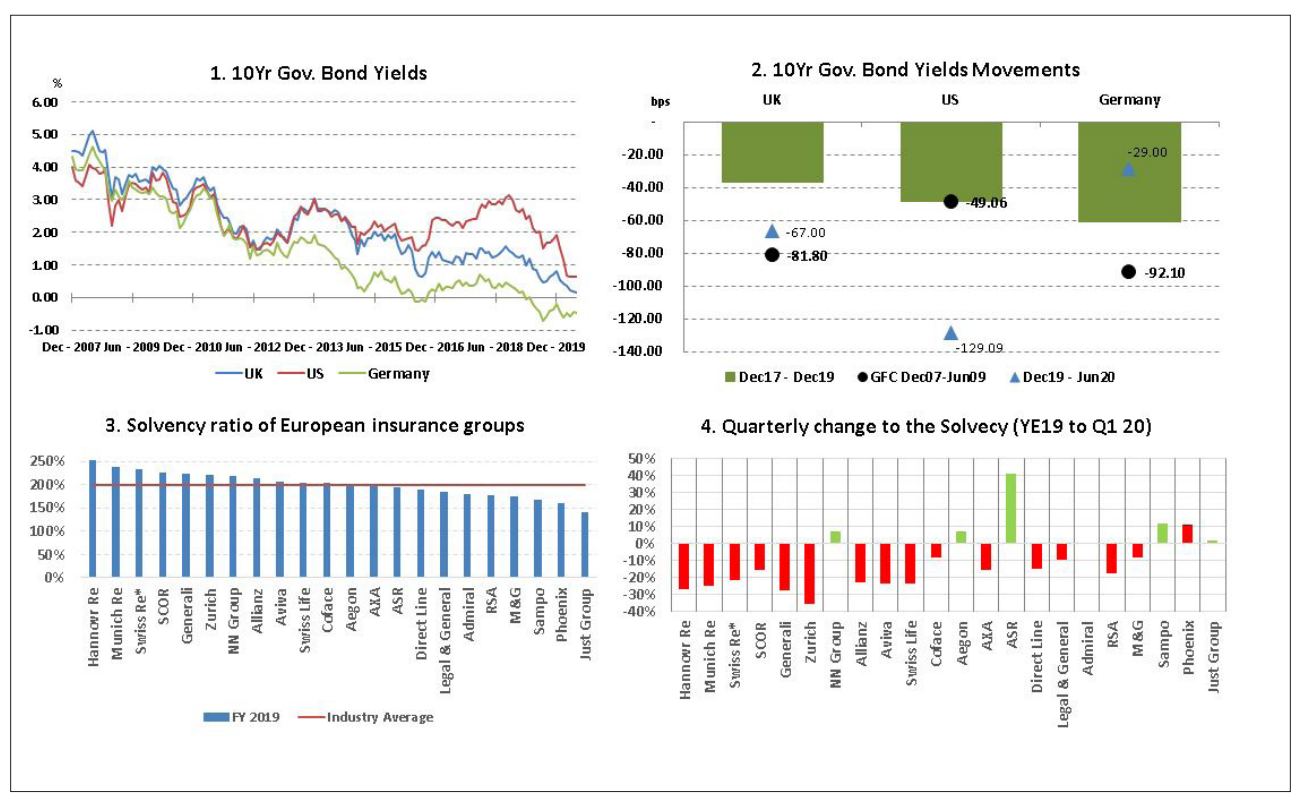

Figure 3 Long-term rates and solvency of selected European groups. The figure illustrates the levels and changes to the 10-year government nominal rates and to the solvency levels as reported in the year-end 2019 audited financial disclosures of each insurance group. Almost all European groups are on a Solvency 2 basis. Only Swiss insurance groups, Zurich, Swiss Re and Swiss Life are on a Swiss Solvency Test (SST) basis. Note: Swiss Re's (denoted with *) quarterly change to its solvency ratio (panel 4) is an estimate, and not an actual disclosed figure. Swiss Re noted in its recent quarterly announcement that the Solvency ratio for Q1 2020 is comfortably above $200 \%$

The impact of current defaults remains below the 2009 peak level. ${ }^{10}$ AXA has disclosed that its solvency sensitivity is $-6 \%$ points to a credit rating migration that assumes a full letter downgrade (i.e. three notches) to $20 \%$ of its corporate bonds (including privately rated debt). This is not an unlikely scenario given the IMF's current outlook on the world economy, as discussed in section 2.

\section{Conclusions}

Thus far insurance groups have comfortably covered their losses caused by the current pandemic. The duration of the lockdown impacts the speed of the economic recovery, which in turn determines

10 As per Moody's most recent default report. This forecasts an increase in sub-investment grade bond default rates from the current level of $4 \%$ to $10.4 \%$ by the end of 2020 . 
the extent of the impact on the grown of the economy and on the insurance sector. Further vulnerabilities in the corporate sector could lead to further falls in financial markets. This would adversely impact earnings and could marginally reduce the solvency position of large life insurance groups. Impairments and revaluations due to credit rating migrations would further impact investment income, creating liquidity concerns and asset and liability mismatches. The key focus is disciplined asset-liability management, through duration extension and increased use of traditional retrocession. Life annuity writers could see an increase in their liabilities over the next five years, driven by a slow down in life expectancy improvements.

In the non-life segment, there is uncertainty around the underwriting performance of the property and casualty business. Few groups have withdrawn their earnings guidance partly due to the potential for further COVID-19 relation claims, as well as the lower investment yield environment. The current High Court case on business interruption claims adds litigation and reputational risks to the repertoire of risks that concern insurers.

Coming out of this crisis, insurance groups will need to re-design specific product lines to align more closely with policyholders' needs and meet regulators' expectations. Regulators will also be focused on the adequacy of the industry's solvency capital, the appropriateness of their regulatory frameworks and on the effectiveness of the industry's current risk management frameworks.

Finally, in a post COVID-19 world, governments could play a more active role in providing pandemic insurance. The US insurance industry is supporting new legislation that would allow federal states to share pandemic losses with the industry. This would not be unprecedented, as the Terrorisms Risk Insurance Act (TRIA), which was introduced in response to 9/11, allows for a federal loss sharing programme for certain insured losses resulting from certified act of terrorisms.

\section{Bibliography}

Dawood, F.S. et. al. (2012). "Estimated Global Mortality Associated with the First 12 Months of 2009 Pandemic Influenza A H1N1 Virus Circulation: A Modelling Study". The Lancet Infectious Diseases, 12(9), 687-95. https:// doi.org/10.1016/S1473-3099(12)70121-4.

DeWitte, S.N. (2014). "Mortality Risk and Survival in the Aftermath of the Medieval Black Death”. PLoS ONE, 9(5), e96513. https://doi.org/10.1371/ journal.pone.๑०96513.

FT, Financial Times (2009). "Plan for Pandemic but Avoid Panic". Financial Times. 27 April. https://www.ft.com/content/d115adfe-335e-11de$8 f 1 b-00144 f e a b d c \odot$. 
IMF, June 2020, World Economic Outlook Update. https://www.imf.org/ en/Publications/WEO/Issues/2020/06/24/WEOUpdateJune2020.

Johnson, N.P.A.S.; Mueller, J. (2002). "Updating the Accounts: Global Mortality of the 1918-1920 'Spanish' Influenza Pandemic". Bulletin of the History of Medicine, 76(1), 105-15. https://doi.org/10.1353/bhm.2002.0022.

Kavet, J. (1977). "A Perspective on the Significance of Pandemic Influenza". American Journal of Public Health, 67(11), 1063-70. https://dx.doi. org/10.2105\%2Fajph.67.11.1063.

Kessler, D. (2019). "SCOR Delivers in a World of Extremes". Bank of America Merrill Lynch conference. https://www.scor.com/sites/default/files/ boaml_25-09-2019_final_v2_1.pdf.

Mathews, J.D.; Chesson, J.M.; McCaw, J.M.; McVernon, J. (2009). "Understanding Influenza Transmission, Immunity, and Pandemic Threats". Influenza and Other Respiratory Viruses, 3(4), 143-9. https://doi.org/10.1111/ j.1750-2659.2009.00089.x.

Madhav, N.; Oppenheim, B.; Gallivan, M.; Mulembakani, P.; Rubin, E.; Wolfe, N. (2018). "Pandemics: Risks, Impacts, and Mitigation". Jamison, D.T.; Gelband, H.; Horton, S.; Jha, P.; Laxminarayan, R.; Mock, C.N.; Nugent, R. (eds), Disease Control Priorities: Improving Health and Reducing Poverty. 3rd ed. Washington, DC: World Bank, 315-45. Disease Control Priorities 9. http://dcp-3. org/chapter/2601/pandemics-risks-mitigation-and-costs.

McKibbin, W.J.; Sidorenko, A.A. (2006). "Global Macroeconomic Consequences of Pandemic Influenza". Lowy Institute for International Policy, Sydney, Australia, February 2006. https://bit.ly/2CAzHxT.

Swiss Re Institute (2020). "Sigma 2/2020: Natural Catastrophes in Times of Economic Accumulation and Climate Change". https://www. swissre. com/institute/research/sigma-research/sigma-2020-02.html.

UNDP (United Nations Development Programme) (2017). “A Socio-Economic Impact Assessment of the Zika Virus in Latin America and the Caribbean: With a Focus on Brazil, Colombia, and Suriname". Synthesis report, UNDP, New York.

Viboud, C.; Simonsen, L.; Fuentes, R.; Flores, J.; Miller, M.A.; Chowell, G. (2016). "Global Mortality Impact of the 1957-1959 Influenza Pandemic". Journal of Infectious Diseases, 212(11), 738-45. https://doi.org/10.1093/infdis/jiv534.

Wang, M-D.; Jolly, A.M. (2004). "Changing Virulence of the SARS Virus: The Epidemiological Evidence". Bulletin of the World Health Organization, 82(7), 547-8. https://www.ncbi.nlm.nih.gov/pmc/articles/PMC2622914/ pdf/15500287.pdf. 


\section{Part 8}

Climate Change 



\title{
Pandemics, Climate and Public Finance How to Strengthen Socio-Economic Resilience across Policy Domains
}

\author{
Stefano Battiston \\ Università Ca' Foscari Venezia, Italia; Universität Zürich, Schweiz \\ Monica Billio \\ Università Ca' Foscari Venezia, Italia \\ Irene Monasterolo \\ Vienna University of Economics and Business, Austria; Boston University's Global Development \\ Policy Initiative, US; University of Zurich, Switzerland
}

\begin{abstract}
The outbreak of COVID-19 and the containment measures are having an unprecedented socio-economic impact in the European Union (EU) and elsewhere. The policies introduced so far in the EU countries promote a 'business as usual' economic recovery. This short-term strategy may jeopardise the mid-to-long-term sustainability and financial stability objectives. In contrast, strengthening the socio-economic resilience against future pandemics, as well as other shocks, calls for recovery measures that are fully aligned to the objectives of the EU Green Deal and of the EU corporate taxation policy. Tackling these long-term objectives is not more costly than funding the current short-term measures. Remarkably, it may be the only way to build resilience to future crises.
\end{abstract}

Keywords COVID-19. Climate change. Public debt sustainability. Green Deal. Fiscal inequality. Resilience. Policy complementarity.

Summary 1 Socio-Economic Impact of COVID-19: Is This Time Different? - 2 The Fiscal and Monetary Policy Response. -3 Mind the Gap: Misalignment of Current Policies with the EU Green Deal and EU Tax Policies. - 4 COVID-19 Recovery and Climate Mitigation: A Role for Policy Complementarity? - 5 Doing More and Better Does not Cost More: A Role for Policy Complementarity?

Innovation in Business, Economics \& Finance 1

ISBN [ebook] 978-88-6969-442-4 


\section{Socio-Economic Impact of COVID-19: Is This Time Different?}

Unprecedented socio-economic impact. Yet, are estimates too optimistic? The COVID-19 health crisis is playing a main role in today's policy, business and financial discussion. The COVID-19 epidemics' death and infection toll, and the measures (such as lockdown and social distancing) taken to mitigate it, are expected to drive major fiscal and macroeconomic impacts globally. In April 2020, the International Monetary Fund (IMF) in its World Economic Outlook (IMF 2020) projected the global economy to contract sharply by $-3 \%$ in 2020, much worse than during the 2008-09 financial crisis. Current impact and estimates of future impact are already very large. Yet, the estimates elaborated by the World Bank and the IMF are likely to be optimistic because they are based on the assumption that Gross Value Added of sectors such as tourism, remittance, and export will return to pre-COVID-19 levels by 2021.

Cascading shocks from local to global. The measures introduced to contain the COVID-19 pandemic affected international and domestic demand triggering immediate demand and supply shocks on the local economy. In addition, they can induce cascading effects in the global economy and can be then transmitted to the financial sector with implications on financial stability. The COVID-19-induced economic crisis could lead to a new liquidity crisis and higher cost of debt, affecting public debt sustainability and inequality, in particular in low-income and emerging countries (Gallagher 2020). In turn, inequality contributes to accrue the COVID-19 crisis and its effects on the socio-economic and financial conditions (Ahmed et al. 2020). Further, $\mathrm{FAO}^{1}$ highlighted that the pandemic has increased the risk of food crises in 53 countries (representing 113 million people), many of which are already experiencing acute severe food insecurity. Similar food crises are likely in vulnerable communities already exposed to other crises (e.g. the Desert Locust outbreak in the Horn of Africa), ${ }^{2}$ in Small Islands Developing States that depend on primary exports and tourism, and in countries relying on remittances.

Is this time different? The COVID-19 crisis is the first large and global shock originating in the real economy since WWII and spreading to the financial sector. Specific to this shock is that it has hit, at the same time, both the external and the internal demand sides of many countries for several months. In particular, shocks on tourism demand,

Contributions: all authors contributed to the development of the paper idea and to address the editor's comments. Stefano Battiston and Irene Monasterolo wrote the paper.

1 http://www.fao.org/2019-ncov/q-and-a/impact-on-food-and-agriculture/en/.

2 http://www.fao.org/news/story/en/item/1258877/icode/. 
export prices and remittances affected firms' production, employment, nominal wages and households' income. The shock on internal demand was then amplified by domestic lockdown measures, triggering selfreinforcing supply and demand side dynamics. There has been a loss of social, intellectual and financial capital. For instance, when a substantial number of firms, large and small, default, and production stalls for a few months, an important portion of a country's economic infrastructure may become severely compromised. This is in stark contrast with the estimates of standard economic models where shocks are idiosyncratic and their impact is fully reversible. In contrast, the socioeconomic impact of the COVID-19 shock appears to be persistent and self-reinforcing, as analysed more in detail below.

\section{The Fiscal and Monetary Policy Response}

In this section, we report on the main policy measures introduced by several countries to mitigate the socio-economic impact of the COVID-19 shock, and will focus on fiscal and monetary policies introduced in the EU. This information serves as background for the policy analysis in Section 3.

A wide range of proposals to finance the recovery. It has been recently highlighted that the speed and duration of the COVID-19 economic recovery will depend on the breadth and scope of emergency government funding (Toporowski, Calvert Jump 2020). In this regard, several proposals to finance the COVID-19 recovery have been put forward, including: coronavirus bond $s^{3}$ and a Covid Credit Line ${ }^{4}$ within the European Stability Mechanism (in Bénassy-Quéré et al. 2020); enhanced central banks' purchasing programmes; liquidity lifelines (Brunnermeier et al. 2020) to overcome firms' liquidity shortages; central banks' helicopter money (Couppey-Soubeyran 2020; Galí 2020); and the expansion of the role and scope of international financial institutions such as the European Investment Bank (EIB) in the EU.

Fiscal policies. Governments both in high-income and developing countries have introduced various forms of fiscal policies. These include increased healthcare spending, reduction or deferred payment of some taxes, credit support guarantees to companies, expansion of unemployment benefits and income support, payroll support to the affected sectors (such as tourism) just to name a few. Such measures have contributed to smoothing the negative impacts of the COVID-19 lockdown measures on demand and supply (Monasterolo, Billio, Battiston 2020). The breadth and scope of the measures vary

3 A proposal by Giavazzi, Tabellini 2020.

4 A proposal by Bénassy-Quéré et al. 2020. 
significatively across countries. In low income and emerging countries, the level of government spending ranged from $0.5 \%$ of GDP in Kenya to over $5 \%$ of GDP in the Philippines, dwarfing the financial support provided by development banks (e.g. the World Bank) during the COVID-19 crisis. In contrast, in advanced economies, COVID-19 fiscal spending was the highest in Germany, where it reached $12 \%$ of (2019) GDP, followed by the US (9.1\%), Japan (7\%), the UK (4.5\%) and China (4\%). In the EU, the European Commission (EC) launched:

1. a $€ 540$ billion support to the EU member states via the European Stability Mechanism (ESM) (up to 2\% of 2019 GDP for each euro area country, based on existing precautionary estimates) to finance health related spending;

2. $€ 25$ billion in government guarantees to the European Investment Bank (EIB) to provide up to $€ 200$ billion of financial support to corporations, and a $€ 100$ billion temporary loan-based instrument (SURE) to protect workers and jobs.

3. In addition, €37 billion of the EU Budget (about and $0.3 \%$ of 2019 EU27 GDP) was mobilised to extend the scope of the EU Solidarity Fund to incentivize banks to provide liquidity to small and medium enterprises and mid caps (as a guarantee to the European Investment Fund). Further, it is also aimed to support credit holidays to crisis-affected debtors, and to provide macro-financial assistance to ten countries included in the EU Enlargement and Neighborhood Partnership. ${ }^{5}$

4. The EC also enabled EU member states to compensate companies for the damage directly caused by COVID-19, including measures in sectors such as aviation and tourism. Overall, the national liquidity measures, including schemes approved under temporary, flexible, EU State Aid rules, could lead to support funding up to a total of $€ 2.9$ trillion.

Monetary policies. Given the low interest rate environment, central banks around the world have engaged in asset purchasing programmes, refinancing operations, and foreign exchange operations. For example, the ECB has taken action on several fronts: it has (i) expanded the asset purchase programme of private and public sector securities (Pandemic Emergency Purchase Program, PEPP) to $€ 1.35$ trillion until at least June 2021; (ii) revised the Non-Performing Loans and prudential floor to banks' current minimum capital requirements; (iii) provided more favourable terms and new liquidity facilities within the existing targeted longer-term refinancing operations and a new liquidity facility (PELTRO) of non-targeted Pandemic Emergency Longer-Term Refinancing Operations; (iv) grandfathered

5 https://ec.europa.eu/neighbourhood-enlargement/node_en. 
until September 2021 the eligibility of marketable assets used as collateral in Eurosystem credit operations falling below current minimum credit quality requirements of 'BBB-'; (v) expanded the range of eligible assets under the CSPP, and relaxed collateral standards for Eurosystem refinancing operations (MROs, LTROs, TLTROs) to include Greek sovereign bonds; (vi) allowed institutions ${ }^{6}$ to operate temporarily below the Pillar 2 Guidance (P2G) with regard to the capital conservation buffer and the liquidity coverage ratio (LCR) of the Basel III agreement on bank regulation.

\section{Mind the Gap: Misalignment of Current Policies with the EU Green Deal and EU Tax Policies}

Climate action. The policy measures discussed above could help to mitigate the effects of the lockdown and help the economy to bounce back in the short-term. However, in the long term, they could also negatively impact on the achievement of the global climate targets (i.e. the Paris Agreement aimed to keep the global temperature increase below 2 degrees Celsius with respect to pre-industrial times) and the objectives of the EC Sustainable Finance Action Plan, ${ }^{7}$ aimed to align finance to sustainability. Achieving these objectives is also at the heart of the 2019 EU Green Deal program. ${ }^{8}$ Fiscal measures that provide tax reductions or exemptions to firms that either base their profits on fossil fuels or carbon intensive activities (e.g. fossil fuels extraction, traditional automotive), without any conditionality (e.g. on the decarbonization of their business), contribute to the misalignment of the economies with respect to the climate targets and objectives of the EU Green Deal programme. This, in turn, makes the risk of carbon stranded assets ${ }^{9}$ more material. Indeed, as shown by Battiston et al. (2017), investors' portfolios are largely exposed to carbon stranded assets and, more generally, to Climate Policy Relevant Sectors (CPRS i.e. sectors of economic activity that are affected positively or negatively by a late and sudden transition to a low-carbon economy).

CPRS represent also a large share of the ECB's expansionary monetary policy as already shown in the context of the ECB's CSPP QE (Battiston, Monasterolo 2019). There is a debate on whether the ECB

\footnotetext{
6 https://www.ecb.europa.eu/press/pr/date/2020/html/ecb.pr200312 45417d8643. en.html.

7 https://ec.europa.eu/info/business-economy-euro/banking-and-finance/ sustainable-finance_en.

8 https://ec.europa.eu/info/strategy/priorities-2019-2024/european-greendeal_en.

9 Stranded assets are assets subject to write-downs or devaluations caused by new climate policies (see van der Ploeg, Rezai 2020).
} 
should signal the importance of decarbonizing portfolios to support the EU Green Deal programme. This would contribute to rewarding the firms that demonstrates progress in the low-carbon transition relative to their own sector of economic activity, rather than only penalising all carbon intensive firms.

The misalignment of asset purchases contributes to (i) widen the gap between the COVID-19 recovery and the governments' climate pledges (e.g. the Paris Agreement and the Green Deal programme in the EU), (ii) foster the realisation of carbon stranded assets in the economy, (iii) reverse years of 'signalling' by central banks and financial regulators engaged in supporting climate related financial disclosure, e.g. within the premises of the Network for Greening the Financial System (NGFS) (NGFS 2019). Further, by reducing capital requirements for credit institutions, and by revising the NonPerforming Loans regulation, without conditioning these measures to countercyclical capital accumulation and to the decarbonization of their balance sheets, the recovery measures counteract the regulatory efforts introduced after the 2008 financial crisis aimed to strengthen financial stability.

\section{COVID-19 Recovery and Climate Mitigation: A Role for Policy Complementarity?}

An approach to operationalize EU solidarity in response to the COVID-19 crisis, while exploiting ways to address the impending climate crisis, has been proposed by Monasterolo and Volz (2020). For EU member states with low fiscal space and high debt, financing the COVID-19 response is perceived to have higher priority than the EU's climate targets. The proposal foresees the coordinated issuance of COVID-related bonds by the EC as well as Green Deal bonds by the EIB. The EC issues COVID crisis-conditioned bonds, available for purchase by private and public investors. The bonds proceeds are to be used exclusively for funding an immediate response across the Union to alleviate the socio-economic impact of the pandemic. At the same time, the EIB issues new Green Deal bonds that support projects in the COVID-19 recovery phase via structural investments aligned with the Green Deal carbon neutrality targets. The Green Deal bonds could be used to finance both climate-aligned private investments as well as strategic pan-EU infrastructure investment, at low cost, to support the recovery phase in all member countries. The proposal by Monasterolo and Volz has three interesting features. First, it provides a 'common debt instrument' that does not generate a moral hazard by individual member countries (since it is conditional to the COVID-19 response). Second, it would avoid compromises between using scarce national finances for either the 
COVID-19 response measures or Green Deal investments. This would ease the public debt burden of member states, thus preserving financial stability at the individual country and Eurozone level. Third, it would foster a deeper integration of EU institutions and coherence of EU funding programmes with the Green Deal objectives. This would open the way to a responsible shared management of these funding programmes and objectives among member states and generations.

Deepening fiscal inequality: why it matters for public debt sustainability. An important debate is emerging about the relation between taxation policies and the economic recovery. Many firms that are benefitting from fiscal measures introduced in EU countries belong to holdings or groups which have fiscal residency in countries with very low effective tax rates (such as The Netherlands, Luxembourg, Ireland or Switzerland). ${ }^{10}$ Using a wide range of legal strategies, multinational enterprises are able to shift profits from the country where the revenues are generated to a country with a very low effective tax rate. The problem is well-known and long standing. In the aftermath of the 2009 financial crisis, because of the strain on public finances, an OECD/G20 project called "Base Erosion and Profit Shifting" (BEPS) ${ }^{11}$ was created. "Multinational enterprises exploit gaps and mismatches in the international tax rules to artificially shift profits to low or no tax jurisdictions and avoid paying their fair share of tax". ${ }^{12}$ When these strategies are legal, the practice goes under the name of tax avoidance. The 2016 Panama Papers scandals led to renewed efforts in the EU on combating tax avoidance. Remarkably, the Public-Country-by-Country Reporting (CBCR) directive was rejected by the EU Council thanks to the vote of the member states with low taxation regimes. The directive would have mandated multinational companies to disclose key fiscal financial information of their subsidiaries by country (Garicano 2019).

In the context of the COVID-19 recovery, there is a concern that firms benefitting from public aid in a country in which they generate revenues will avoid taxation by shifting elsewhere their profits. The phenomenon results in an unintended cross-border subsidy and contributes to increasing the inequality between countries. In the EU, this phenomenon is particularly relevant because it works against the EU Cohesion Policy, which represents now the largest item on the EU budget. The aim of the EU Cohesion policy is to narrow the inequality gap by fostering the economic convergence of $\mathrm{EU}$ regions. It is important to notice that all EU countries, including those with

10 For a review of the top ten tax haven see e.g. Zuckman, Wright 2018.

11 https://www.oecd.org/about/impact/combatinginternationaltaxavoidance.htm.

12 Cf. footnote 9 . 
low taxation, benefit from the EU Cohesion Policy. Conversely, even countries that are damaged by this fiscal dumping (e.g. Italy) largely contribute to the funds of the EU Cohesion policy. There is thus a double negative distributive effect.

\section{Doing More and Better Does not Cost More: Policy Complementarity is a Matter of Understanding and Management}

As we have discussed above, the fiscal and monetary policies introduced so far in the EU countries promote a 'business as usual' economic recovery. This is a short-term strategy that may jeopardise the mid-to-long-term environmental sustainability and financial stability objectives. In particular, the fiscal measures introduced so far hamper the climate policy measures and halt the already difficult progress on tax transparency. Indeed, the problem of reconciling taxation fairness, efforts to restart the economy and climate change have been recently explicitly discussed by the EU Commissioner for Economy. ${ }^{13}$

Perhaps, the most important thing to realise is that a short-term approach to the COVID-19 response that does not consider the climate and the taxation issues are more costly and less effective than tackling these issues together. Indeed, we can choose between financing now a carbon intensive economic recovery (i.e. supporting firms unconditionally to their decarbonization efforts) and later a low-carbon transition (thus paying twice), or to finance right away a green economic recovery (thus paying only once), exploiting creative destruction in the Schumpeterian sense. Similarly, governments can choose to give state aid to firms that engage in tax avoidance strategies. In this case, they will face the continued reduced income tax resulting from profit shifting (thus paying twice). Alternatively, they can choose to resolve this taxation policy issue right away and reduce tax income losses in the future (thus paying only once).

To conclude, strengthening the socio-economic resilience against future pandemics, as well as other future shocks, calls for recovery measures that are fully aligned to the objectives of the EU Green Deal and of the EU corporate taxation policy. Tackling these objectives together is more cost effective than addressing the COVID-19 crisis with short-term measures. Remarkably, because of the interconnectedness between climate risk, pandemic risk and financial risk (Monasterolo, Billio, Battiston 2020), this may be actually the only feasible way to build resilience to future crises. 


\section{Bibliography}

Ahmed, F.; Ahmed, N.E.; Pissarides, C.; Stiglitz, J. (2020). "Why Inequality Could Spread COVID-19". The Lancet Public Health, 5(5), e240. https://doi. org/10.1016/s2468-2667(20)30085-2.

Battiston, S.; Monasterolo, I. (2019). "How Could the ECB's Monetary Policy Support the Sustainable Finance Transition?". FINEXUS working paper. https://www.finexus.uzh.ch/en/news/cspp_sustainable_finance.html.

Battiston, S.; Mandel, A.; Monasterolo, I.; Schütze, F.; Visentin, G. (2017). "A Climate Stress-Test of the Financial System". Nature Climate Change, 7(4), 28388. https://doi.org/10.1038/nclimate3255.

Bénassy-Quéré, A.; Boot, A.; Fatás, A.; Fratzscher, M.; Fuest, C.; Giavazzi, F.; Marimon, R.; Martin, P.; Pisani-Ferry, J.; Reichlin, L.; Schoenmaker, D.; Teles, P.: Weder di Mauro, B. (2020). "A Proposal for a Covid Credit Line". VoxEU.org, 21 March. https://voxeu.org/article/proposal-covid-credit-line.

Brunnermeier, M.; Landau, J.P.; Pagano, M.; Reis, R. (2020). "Throwing a COVID-19 Liquidity Life-Line”. VoxEU.org, 19 March. https://voxeu.org/debates/commentaries/throwing-covid-19-liquidity-life-line.

Couppey-Soubeyran, J. (2020). “'Helicopter Money' to Combat Economic Depression in the Wake of the Covid-19 Crisis". Veblen Institut, 2 May. https://bit.ly/38Ze5H1.

Galí, J. (2020). "Helicopter money: The time is now". VoxEU.org, 17 March. https://voxeu.org/article/helicopter-money-time-now.

Gallagher, K. (2020). "Argentina's Creditors Must Face Up to the Coronavirus Challenge". The Financial Times, 20 April. OpEd post in Alphaville. https:// ftalphaville.ft.com/2020/04/17/1587126226000/Argentina-screditors-must-face-up-to-the-coronavirus-challenge/.

Garicano, L. (2019). "Why are European Countries Against Fiscal Transparency?”. EURACTIV, 2 December. https://bit.ly/2Zqpigz.

Giavazzi, F.; Tabellini, G. (2020). "Covid Perpetual Eurobonds: Jointly Guaranteed and Supported by the ECB". VoxEU.org, 24 March. https://voxeu.org/ article/covid-perpetual-eurobonds\#.XnnSSVVDw6o.twitter.

Monasterolo, I.; Billio, M.; Battiston, S. (2020). "The Importance of Compound Risk in the Nexus of COVID-19, Climate Change and Finance". Ca' Foscari University of Venice, Dept. of Economics, Working Paper No. 15/WP/2020. https://econpapers.repec.org/RePEc:ven:wpaper:2020:15.

Monasterolo, I.; Volz, U. (2020). "How to Finance Virus Response in a Sustainable Way? Scale Up Synergies with the Green Deal”. EURACTIV, 7 April. https://bit.ly/2WhLacg.

Toporowski, J.; Calvert Jump, R. (2020). "The COVID-19 Bailout and its Financing Dilemmas". Institute for New Economic Thinking, 30 June. https:// www.ineteconomics.org/perspectives/blog/covid-19-the-financing-dilemmas.

van der Ploeg, F.; Rezai, A. (2020). "The Risk of Policy Tipping and Stranded Carbon Assets". Journal of Environmental Economics and Management, 100, 102258. https://doi.org/10.1016/j.jeem.2019.102258.

Zucman, G.; Wright, T. (2018). "The Exorbitant Tax Privilege”. NBER Working Paper No. 24983. http://www.nber.org/papers/w24983. 



\title{
Avoiding a Great Depression in the Era of Climate Change
}

\author{
Nicholas Bardsley \\ University of Reading, UK
}

\begin{abstract}
If loan issue falls faster than repayments, money becomes increasingly scarce, leading to deflationary pressures and unemployment. Central banks have responded by 'quantitative easing', a regressive form of money printing which buys off the national debt. Such credit could instead finance green infrastructure, health and social care, a basic income, and debt relief. Fiscal policy expansion which is not monetised, in contrast, results in crowding out. Given the ecological crisis caused by greenhouse emissions, the aim ought not to be resumption of business as usual. A social-ecological response to the crisis would deploy a mixture of public credit creation deployed in prioritised sectors, progressive taxation, and direct curbs on greenhouse emissions.
\end{abstract}

Keywords Great Depression. Climate change. Unemployment. Central Bank. Quantitative Easing. Fiscal policy.

Summary 1 Introduction. - 2 Why Fiscal Stimulus cannot be Financed by Bond Issues. - 3 Why Debt Monetisation Should not be Done by QE. - 4 Why We Do not Simply Need 'Recovery' of the Previous Economy. - 5 A Post-COVID Social Ecological Policy Package. -6 Conclusions.

\section{Introduction}

If one asks the general public who creates the money supply, the majority response is invariably the government, via the central bank. This is emphatically not the central bank's understanding, however. As Sir Mervyn King said in 2012, then governor of the Bank of England (hereafter "The Bank"): 
When banks extend loans to their customers, they create money by crediting their customers' accounts [...] a damaged banking system means that today's banks are not creating enough money. We have to do it for them. [...] Insufficient money creation can lead to a contraction of the money supply and a depression. ${ }^{1}$

The governor was talking in the aftermath of the 2008 global financial crisis, and referring to Quantitative Easing (QE), rather than printing notes and coin. In fact, only $3 \%$ of the UK money supply is created as notes and coin in circulation in the modern era, and $97 \%$ is virtual credit, ordinarily supplied as private bank loans. The crisis in the wake of COVID-19 is estimated to be greater than that of 2008, with severe and immediate impact on jobs and GDP.

Whilst much media attention has been focused on the ability of firms and households to service their debts, less attention has been paid to the flow and composition of new loans. The balance between new loans and repayments determines how much money is circulating in the economy. If new lending dries up but the existing loans continue to be serviced, the means of payment present in the economy reduces, since the principal on the loans is destroyed when repaid, under banking rules of account. This dynamic is believed to have been responsible for the Great Depression of the 1930s. People found the depression hard to understand, since the workers, machines and materials were all still perfectly functional. It was as if the ghost in the machine had vanished. Nowadays, central banks are prepared to create credit to compensate.

Credit markets have been strongly affected. UK households repaid a record $€ 7$ billion (net) of bank loans in April, following $€ 3.8$ billion in March with a further $£ 4.6$ billion in May, and real estate transactions, which account for the bulk of UK credit, were just $10 \%$ of their preCOVID count in May (BE 2020). Anticipating contraction The Bank has thus far increased its QE program by an enormous $£ 300$ billion at the time of writing (July 2020), increasing the stock of government bonds it holds to $£ 745$ billion, over $40 \%$ of the UK national debt. In the remainder of this article, I explain why such 'money printing' is the general form that any net 'stimulus' activity has to take, rather than through the government borrowing to spend. I then discuss implications of prospective stimulus activity of the burgeoning climate emergency.

Public understanding of these matters remains weak, not helped by economics texts portraying banks as 'intermediaries' passing money between lenders and borrowers, rather than creating credit. For example, see Williams and Turton (2014, ch. 5), who also state

1 Speech to South Wales Chamber of Commerce, The Millenium Centre, Cardiff, October 23, 2012. 
that QE does not create money. The authors contradict themselves by saying that QE has maintained M4, the broad measure of money supply, when bank lending fell after 2008. The QE part of this contradiction can be resolved if the government pays off the bonds and The Bank retires the funds received. It seems unlikely that this will actually happen however. In the meantime, QE is clearly expanding the money supply.

\section{Why Fiscal Stimulus Cannot be Financed by Bond Issues}

Many commentators apparently believe that government deficits must be financed by selling bonds, and that therefore if the government wants to stimulate the economy by spending more, it must sell more bonds. This overlooks the fact that bonds are purchased using existing money, not new credit. Thus, every pound that goes towards purchasing bonds is a pound that is not being invested elsewhere. Necessarily, no new purchasing power is created, and therefore additional bond issues do not counteract monetary contraction taking place through falling bank loan volume. This is the lesson of Japan's apparent failure to use fiscal policy to boost output following the collapse of its land value bubble in the 1990s. These points are argued convincingly, both theoretically and empirically, by Werner (2005).

For example, the UK's "Green New Deal” group argued for a package including green infrastructure spending financed by bond issues, repeating their call in the wake of COVID-19 (GNDG 2008). The TUC amongst others have also called for government spending to increase "given the low cost of borrowing", seemingly unaware of any crowding-out problem. A common argument is that only government spending can stimulate demand in a recession, as monetary policy to expand bank lending is 'pushing on a string'. It remains the case, however, that new government bonds are not bought with new bank credit. So to the extent that fiscal deficits are financed by bond issues, government borrowing competes for existing (and declining) liquid funds in the hands of pension funds and other investors.

The upshot is clearly that fiscal and monetary policy are not, contrary to what central bankers routinely profess, independent. The viewpoint typical of financial sector actors, including ratings agencies, that governments should not print money to finance expenditures ('monetise the deficit') arguably aligns with the interests of the financial sector to control the supply of money and debt. This interest has recently crystallised into arrangements such as central bank independence and diplomatic agreements such as that in the Maastricht Treaty not to monetise deficits. This situation may help explain why convoluted procedures such as QE are devised to do so 
when necessary. Central bank independence is itself dubious however, when the government appoints the governor and can veto its key decisions, as under the Bank of England Act $1998 .^{2}$

\section{Why Debt Monetisation Should not be Done by QE}

QE involves the central bank buying government bonds and other assets including company bonds, on the 'secondary' market, meaning bonds that have been auctioned by the government previously. For example, it involves buying gilts ${ }^{3}$ held by pension funds, with the latter receiving deposits in their bank accounts in return. Since The Bank is publicly owned, this means the public sector is effectively printing money to buy back its debt ('debt monetisation').

The problems with QE include firstly that it is regressive; because it raises asset prices it benefits owners of bonds and shares, who tend to be well off. Persons with property also benefit through lower interest payments on mortgages, and the effects of this on land values as reflected in house prices. The Bank itself reported that the top 5\% of households by financial assets held $40 \%$ of them, with most households owning little or none. Asset-holding households gained an estimated $£ 600$ billion from $£ 325$ billion of purchases in the first wave of QE (BE 2012). Secondly, QE is strategically blind, since there is no control over where the money that is printed ultimately ends up. Those selling their bonds might use the money to buy more bonds, shares, land, property or related financial products. Mostly these will be trades in existing assets, not generating new goods or services. A third problem is that low interest rates, though they lower debt service costs, discourage bank lending by making it less profitable. Finally, there are adverse effects on pension funds, motivating the abandonment of defined benefit pensions, undermining people's financial security in retirement.

Given its demonstrable ills, QE should not be continued if there are viable alternative forms of monetising deficits. There are at least three. One is that The Bank simply credits government accounts as necessary. Equivalently, the treasury may order The Bank to credit non-government accounts as appropriate for its purchases. Alternatively, The Bank can buy government bonds with new credit. Finally, the government could make loan contracts with banks to finance its deficits. These would result in fresh credit being issued, unlike sales

2 See in particular the extensive "reserve powers" of the Government under the section 19 of the Act: http://www.legislation.gov.uk/ukpga/1998/11/section/19.

3 Gilts (gilt-edged securities) are UK government liabilities offering investors regular payments before maturity. See DMO (nd). 
of bonds in the primary market. The contracts could be made nontradable to prevent them becoming, as bonds are, objects of speculation (Werner 2014). It is worth noting in passing that as an issuer of the currency via The Bank, the government cannot be in a position not to pay debts denominated in sterling. It is therefore strange to suggest, as the current governor of The Bank has, ${ }^{4}$ that the government might somehow run out of cash. The usual objection to monetising a deficit is that it is inflationary. This apparently applies in full to $\mathrm{QE}$, however, so is out of place in a discussion of alternative methods.

Perhaps one reason that The Bank has not pursued open debt monetisation is that it is against the terms of the Maastricht Treaty, the economic cornerstone of the EU project. Should it continue to be politically necessary to avoid open monetisation by The Bank, it is not clear why the option outlined by Werner (2014) would be objectionable.

\section{Why We Do not Simply Need 'Recovery' of the Previous Economy}

In the aftermath of the 2008 financial crisis, environmentalists were hoping to see reduced greenhouse gas (GHG) emissions. They were severely disappointed. Carbon emissions fell only for one year before continuing a relentless upward trajectory (Peters et al. 2019), with policy-makers' attention fixated on the economy.

Similarly, many progressive commentators have been speculating that a different economy might emerge after COVID-19 lockdown. We have to realise that economic 'recovery' conceived only in terms of stimulus instruments (the budgetary measures we have been discussing) means increasing greenhouse emissions again. It was no accident they grew alongside GDP. This is because there is limited substitutability of fossil fuel energy for renewables, given the much higher "power density" of the former (Giampietro, Mayumi 2010). That is, to achieve the same power output to the rest of society, renewable energy infrastructure uses far more land and labour, making fossil fuel use inevitable for most industrial applications. Whilst it seems possible, then, to reactivate the economy by monetised government spending without any structural planning, this is not what should happen given the imperative to reduce global GHG emissions.

Le Quéré et al. (2020) estimate that following the large fall in economic activity by April when economic activity was largely con-

4 Interview with The World Tomorrow, Sky News, June 22 2020. https://news.sky. com/story/coronavirus-governor-says-bank-of-england-saved-britain-fromeffective-insolvency-12012369. 
fined to essentials, if economies operated at their previous intensity by mid-June, there would be a $4 \%$ annual reduction in GHGs. There would be a $7 \%$ fall if certain restrictions remained until the end of the year, comparable to what would be needed to meet the aims of the UN Paris Agreement on climate change.

In the medium term, energy supply constraints following 'peak oil' reinforce these considerations. Conventional crude oil, which has more favourable energetic properties than unconventional hydrocarbons, has been static since around 2006 (Bentley, Mushalik, Wang 2020), suggesting an imminent decline. To simply 'restart' the economy and recover its previous intensity would, it seems, squander much of the remaining higher quality energy resources on inessential consumption.

\section{A Post-COVID Social Ecological Policy Package}

There is limited space here to expound an appropriate response to the ecological crisis. Bardsley (2012) proposed a policy package in detail which I now summarise. To prevent a repeat of the 2009 experience, fossil fuel use needs to be constrained. This could be imposed by capping quantities of coal, oil and gas upstream, that is, requiring fossil fuel companies to purchase emissions permits covering the carbon content of any fuel they sell. An equitable way of doing this is for the emissions rights (permits) to be allocated to the population, either individually (a policy proposal named 'cap and share') or in trust ('cap and dividend'), so that when permits are sold the population acquires the revenue. This would compensate them financially for price increases deriving from energy scarcity, and households with the lowest emissions would benefit the most. See Comhar (2008) for an evaluation applying the E3ME model of Barker (1999), plus Kunkel and Kammen (2011) and Bardsley, Schnepf and Buechs (2017) for illustration of redistributive effects of the policy applied to specific sectors.

Green spending is necessary, financed directly by the central bank or with loan contracts with private banks, and has potential to provide many jobs. This should include extensive thermal insulation upgrades both for commercial and residential property, in addition to development of renewable energy infrastructure. Agroecological and other land management schemes should be developed and deployed to combine enhanced carbon storage in soils and biomass with improved food security. Biochar techniques for example appear promising, if complex.

In a future defined increasingly by resource and ecological limits to growth, extreme inequality will become increasingly abhorrent as the position of the worst off becomes more precarious. A substantial 
land (site) value tax would be a powerful tool for redistribution, and would also help to reduce burgeoning housing costs by eroding speculative gains from landholdings. A shift of the revenue base away from taxes on labour and capital also makes sense to encourage productive activity, and this would not exacerbate GHG emissions given an overall cap. Spending on public health and social care systems, which should be more resource efficient and equitable than private sector counterparts because of the sharing of resources across the population, will also serve to alleviate inequality. Efficiency should not be over-emphasised however, as having excess capacity has proved crucial to the ability of health systems to respond to the crisis.

Debt relief should be introduced if household mortgage debts prove intolerable. This would be problematic if it were to reward irresponsible borrowing, however. A solution could be for each household to receive vouchers which can be exchanged for debt, with the loan issuer exchanging the voucher for central bank money, alleviating bank losses. If the household does not have debt the voucher could instead be exchanged for domestic thermal upgrades or renewable energy bonds. Since this relief scheme would benefit the banks this measure should be conditional, for example on reintroduction of credit controls to give government more power to direct economic activity.

A universal basic income could be partly constituted by the debt relief and carbon revenue elements of the package but could be supplemented as necessary with government spending. This concept could be extended to one of universal basic services encompassing minimum standards of energy and food provision. ${ }^{5}$

It must be admitted that such a program seems very unlikely to happen. However, given the alignment of the current economic system towards ecologically disastrous outcomes, a package that would actually operate in the other direction must inevitably be radical. The objective should be to find the least improbable set of measures that would work to constrain and reduce emissions, whilst maintaining welfare in an increasingly resource-constrained world. Compare it to the UK government's actual response: massive money printing for QE, loan schemes for business, including loans to big business underwritten by the treasury with few conditions attached, a small increase in benefits, temporary income / employment support schemes for those in work, grants for home insulation which benefit property owners, some mortgage relief but no rent relief except for business. There are to be no new controls on GHG emissions. Further infrastructure spending has been announced but it is not yet clear if this

5 I owe this observation to Brian Davey (personal correspondence). 
adds to pre-COVID manifesto commitments. ${ }^{6}$ The regressive nature of QE deserves repeating. BE (2012) estimated that the first wave of QE gave an average transfer of $£ 10,000$ per UK household but reaped only by the richest $50 \%$. It seems the UK is largely helping the better off.

Perhaps the main problem with the package proposed is the difficulty of implementing hard controls on fossil fuel use unilaterally. It might be possible to devise a way of doing this via carbon tariffs. But it would be difficult to drive emissions down year on year, as Le Quéré et al. (2020), along with the mainstream of climate scientists, deem necessary, without international cooperation.

\section{Conclusions}

Printing money to buy back bonds (QE) is regressive and strategically blind. A social ecological stimulus would, in contrast, openly monetise the Public Sector Borrowing Requirement without raising asset prices, and strategically direct credit towards green infrastructure, agroecology, and essential goods and services, including health and social care. Curbing greenhouse emissions is however, inconsistent with maintaining current levels of consumerism, so the overall aim should not be a general upturn in output. The economic response to COVID should rather take place within a framework of hard constraints on greenhouse gas emissions. Suitable policies exist, but plausibly require international cooperation to be implemented. In the absence of such a framework, government spending packages should be targeted, at provision of essential goods and services on a universal basis, development of post-fossil-fuel infrastructure, environmental and agroecological schemes.

6 An overview of government-funded schemes responding to the COVID crisis is given by Deloitte (2020). The overall stimulus effect depends how they are financed, which is not outlined in the document. 


\section{Bibliography}

Bardsley, N. (2012). “Policy Packages”. Davey, B. (ed.) Sharing for Survival. Dublin: FEASTA, ch. 4.

Bardsley, N.; Schnepf, S.V.; Buechs, M. (2017). "Something from Nothing: Estimating Consumption Rates Using Propensity Scores, with Application to Emissions Reduction Policies". PLOS ONE, 12(10), e0185538. http://doi. org/10.1371/journal.pone.0185538.

Barker, T. (1999). “Achieving a 10\% Cut in Europe's Carbon Dioxide Emissions Using Additional Excise Duties". Economic Systems Research, 11, 401-21. https://doi.org/10.1080/09535319900000029.

Bentley, R.; Mushalik, M.; Wang, J. (2020). "The Resource-Limited Plateau in Global Conventional Oil Production: Analysis and Consequences". Biophysical Economics and Sustainability, 5, 10. https://doi.org/10.1007/ s41247-020-00076-1.

BE, Bank of England (2012). "The Distributional Effects of Asset Purchases". Bank of England, 12 July. https://www. bankofengland.co.uk/ news/2012/july/the-distributional-effects-of-asset-purchases-paper.

BE (2020). "Money and Credit - May 2020". Bank of England, 29 June. https://www.bankofengland.co.uk/statistics/money-and-credit/2020/may-2020.

Comhar, Republic of Ireland Sustainable Development Council (2008). A Study in Personal Carbon Allocation: Cap and Share. AEA Energy \& Environment and Cambridge Econometrics. http://www.indiaenvironmentportal. org.in/files/Dec-08-Comhar_Cap_Report.pdf.

Deloitte (2020). "COVID-19 - Government Funding. Summary of Announced Schemes in the UK". Deloitte LLP. Downloaded on 2020-07-06. https:// www2.deloitte.com/uk/en/pages/financial-advisory/articles/ covid19-uk-government-funding-response.html.

Kunkel, C.M.; Kammen, D.M. (2011). "Design and Implementation of Carbon Cap and Dividend Policies”. Energy Policy, 39(1), 477-86. https://doi. org/10.1016/j.enpol.2010.08.046.

Le Quéré, C.; Jackson, R.B.; Jones, M.W. et al. (2020). "Temporary Reduction in Daily Global CO2 Emissions During the COVID-19 Forced Confinement". Nature Climate Change, 10, 647-53. https://doi.org/10.1038/s41558020-0797-x.

Giampietro, M.; Mayumi, K. (2009). The Biofuel Delusion. London: Earthscan.

GNDG, Green New Deal Group (2008). A Green New Deal. London: New Economics Foundation.

Peters, G.P.; Andrew, R.M.; Canadell, J.G. et al. (2019). "Carbon Dioxide Emissions Continue to Grow Amidst Slowly Emerging Climate Policies". Nature Climate Change, 10, 3-6. https://doi.org/10.1038/s41558-019-0659-6.

Werner, R.A. (2005). The New Paradigm in Macroeconomics: Solving the Riddle of Japanese Macroeconomic Performance. Gordonsville: Palgrave Macmillan.

Werner, R.A. (2014). "Enhanced Debt Management: Solving the Eurozone Crisis by Linking Debt Management with Fiscal and Monetary Policy". Journal of International Money and Finance, 49, 443-69. https://doi.org/10.1016/j. jimonfin.2014.06.007.

Williams, T.; Turton, V. (2014). Trading Economics: A Guide to Economic Statistics for Students and Practitioners. Chichester: John Wiley and Sons. 

Part 9

Labour Market 



\title{
COVID-19 Pandemic and Gender Inequality in the Labour Market in the UK
}

Giovanni Razzu

University of Reading, UK

\begin{abstract}
Although the movement towards gender equality in the labour market has slowed in recent decades, a long-term view over the 20th century shows the significant narrowing of the gender employment gap in the UK, a result of the increases in women's labour force participation and employment combined with falling attachment to the labour force among men. It is too early to assess with precision the extent to which these patterns will be affected by the COVID-19 pandemic but emerging evidence and informed speculation do suggest that there will be important distributional consequences. Various studies, produced at an unprecedented rate, are pointing out that the effects of COVID-19 are not felt equally across the population; on the contrary labour market inequalities appear to be growing in some dimensions and there are reasons to believe that they will grow more substantially in the medium term.
\end{abstract}

Keywords Gender. Labour market. COVID-19. Home production. Childcare. Employment. Pay.

Summary 1 Introduction. - 2 Context and Policy Background. -3 The Economic Shocks. - 4 Labour Market Impacts. - 5 Home Production Impacts. - 6 Concluding Remarks.

\section{Introduction}

This chapter aims to assess the existing evidence on the extent to which the COVID-19 pandemic has affected the relative labour market prospects and outcomes of women and men in the UK. We will first introduce the most relevant aspects of the pandemic, underlying the nature and extent of the economic 
shock. This will help us to focus on the impact of the shocks on labour market outcomes, particularly jobs and pay. Given the well-established relationship between the labour market and the division of domestic and unpaid labour, and the clear connection between the latter and the nature of the shock produced by the pandemic, we will also assess the emerging evidence on the gender gaps in household production.

Before proceeding, however, a brief note on the evidence we are able to rely on is needed. Official labour market statistics are derived from the Labour Force Survey (LFS), the largest household survey in the UK. Unfortunately, the LFS is not as timely as we would need in these circumstances to assess the impact of the COVID-19 pandemic on the labour market; the Office for National Statistics (ONS) is therefore making great strides into producing real time labour market data, which is still experimental and, more often than not, does not report the information by gender. For this reason, we complement the data from the ONS with studies that have a specific gender focus, carried out by other organisations and academics, often relying on surveys with much smaller sample sizes and not always representative of the UK population. However, these are fundamental to our understanding of the current impact of the pandemic and, although not rich and comprehensive, they are nevertheless sufficient to establish the key emerging patterns if not orders of magnitude.

\section{Context and Policy Background}

It was January 29, 2020 when the UK's first two patients tested positive for COVID-19, after two Chinese nationals from the same family staying at a hotel in York fell ill. More than a month later, on 5 March, the first victim in the UK was a woman in her 70s, at the Royal Berkshire Hospital in Reading. It is on the 11th of March that the World Health Organisation officially declares a pandemic and the UK Government announces a $£ 12$ billion package of emergency support, while, on March 17, the Chancellor announced a £330 billion package to help businesses furlough staff, saying that "the UK has never in peacetime faced an emergency like this" and that he would abandon "orthodoxy" and "ideology" in response. It is on March 20 that the Government ordered schools, nurseries and pubs to close and on March 23 that the Prime Minister announces a national lockdown, telling people that they may only leave home to exercise once a day, to travel to and from work where absolutely necessary, to shop for essential items and to fulfil any medical or care needs. These were unprecedented measures that the Government introduced to contain the spread of the coronavirus across the country. They have led to businesses being shut down temporarily and extensive restrictions on travel and mobility. 
The two major fiscal measures adopted by the Government to protect employment have been the Coronavirus Job Retention Scheme and the UK Self-employment Income Support Scheme. The former originally allowed firms to furlough workers for up to three months with the Government replacing $80 \%$ of employees' wages, up to a maximum of $£ 2,500$ per month plus the associated Employer National Insurance contributions and pension contributions. This scheme has now been extended until the end of October 2020 but the extent of the wage replacement paid by the Government has been scaled back. The UK Self-employment Income Support Scheme originally allowed self-employed individuals to claim a taxable grant worth $80 \%$ of their trading profits up to a cap of $€ 7,500$ in total for three months. This has also been extended until the end of August but with a reduction in the extent of the Government's contribution to $70 \%$ and a cap of $€ 6,570$ in total.

\section{The Economic Shocks}

The economic effects of these measures combine aspects of so-called supply and demand side shocks. The former are associated with reduction in the economy's ability to produce goods and services and, therefore, with shocks to the supply of labour. For instance, these arise from mortality and morbidity due to the infection and, above all, from the withdrawal of labour due to the social distancing measures put in place. The latter are associated with reduction in consumers' ability to purchases goods and services. For instance, consumers are likely to both increase their demand for health services and, seeking to reduce their risk of exposure to the virus, decrease the demand for products and services that involve close contact with others. ${ }^{1}$ The extent of the initial economic impact arising from the combination of these shocks of course depends on the duration of the outbreak, the public health restrictions imposed to contain the spread of the virus as well as other voluntary social distancing measures that people take to reduce their chances of catching it. At the outset of the lockdown policies in the UK, various estimates of the possible impact ranged from a low of $15 \%$ to a maximum of 35\% reduction in Gross Domestic Product (GDP). ${ }^{2}$ The latest available official figures

1 In the early days of the outbreak, stockpiling behaviour also resulted in a direct demand increase in the retail sector.

2 The Office for Budget Responsibility (OBR) estimated that GDP may fall by as much as 35\% in its "reference" scenario. The National Institute of Economic and Social Research (NIESR) estimated that the fall could be between 15\% and 25\%, and the Organisation for Economic Co-operation and Development (OECD) estimates were at the top end of this range. 
by the ONS report that monthly GDP fell by $20.4 \%$ in April, the biggest monthly fall since the series began in 1997, more than three times larger than the fall of the previous month and almost ten times larger than the steepest pre-COVID-19 fall. In April the economy was around 25\% smaller than in February. Importantly, this affected the whole of the economy, with particularly severe impact on manufacturing and construction. Other notable impacts have been on education, which fell by $18.8 \%$ as a result of school closures; on food and beverage service activities, which fell by $38.8 \%$ as a result of the closure of bars and restaurants and even on health, which fell by $11.4 \%$ as a result of reduced activity in elective operations and fewer accident and emergency visits (ONS 2020a). The extent of this contraction in economic activity is really abnormal, thinking that, in April 2020 , the decline in GDP has been three times greater than the fall experienced during the Great Recession of 2008-09. ${ }^{3}$

The virus and the subsequent economic shocks we have outlined above will have an impact on the world of work across key dimensions: the quantity and quality of jobs and work, including employment and earnings. Importantly, emerging studies have shown that this impact will not be homogeneously felt across the population but will be more pronounced for specific groups who are more vulnerable to adverse labour market outcomes than others. In the following section, we assess this emerging evidence, starting with the employment outcomes.

\section{$4 \quad$ Labour Market Impacts}

Employment adjustment typically follows economic contraction with some delay. In fact, the latest LFS estimates for the period February to April 2020 show that employment, unemployment and inactivity remained mostly unaffected by the impact of the pandemic at that point in time. In order to capture the extent of the impact of the pandemic on the labour market, these more 'traditional' sources of information have limitations. We would also need to look at other information, such as real time information and the intensive margin and the number of hours of work. Indeed, Real time information data from HM Revenue and Customs (HMRC) shows that the number of paid employees fell by 612,000 between March 2020 and May 2020 (ONS 2020b).

3 During the global financial crisis, from the peak in February 2008 to the lowest point of March 2009, a total of 13 months, GDP contracted by $6.9 \%$. Between March 2020 and April 2020, GDP has fallen by $20.4 \%$, equivalent to a fall of approximately $£ 30$ billion in Gross Value Added. 
The Institute for Fiscal Studies (IFS) have assessed the distributional impact of the recession caused by COVID-19. They report that, on the eve of the crisis, around 15\% of employees in the UK worked in a sector that has largely or entirely shut down during the lockdown. These include non-food retail, restaurants and hotels, passenger transport, personal services and arts and leisure services. Women were about one third more likely to work in a sector that was shut down than men: $17 \%$ of female employees were in such sectors, compared to $13 \%$ of male employees (Joyce, Xu 2020). Claudia Hupkau and Barbara Petrongolo (2020) assessed the proportion of working men and women who work in critical sectors, defined according to the UK Government's guidelines on "critical workers" and "businesses that must remain closed", and in sectors that have been explicitly locked down. They report that about $39 \%$ and $46 \%$ of working men and women, respectively, are employed in critical sectors, while $13 \%$ and $19 \%$, respectively, are in locked-down sectors. This leaves $35 \%$ of women and $48 \%$ of men relatively less affected in terms of employment and, therefore, earnings. However, an important characteristic of a job is the percentage of tasks individuals can do from home, so the likelihood of these men and women to avoid loss of employment and earnings is linked to their ability to work from home. AdamsPrassl et al. (2020) show that there is a clear relationship between the percentage of tasks one can do from home and job loss and, in the UK, this relationship has become even steeper as the crisis has unfolded. They also confirm that the percentage of people having lost their jobs varies substantially across the different occupations and industries. We see that both in the US and the UK people working in 'food preparation and serving' and 'personal care and service' are very likely to have lost their job due to the pandemic. On the other side of the spectrum, people working in 'computer and mathematical' occupations or 'architecture and engineering' have been most likely to keep their job. Hukpau and Petrongolo show that women are more likely than men to be in jobs that can be done from home, such as in education as opposed, for instance, to construction. Despite this possibly mitigating factor, in terms of gender equality, the key point remains that because women disproportionately work in retail and hospitality, COVID-19 is likely to have a bigger effect on their employment and earnings. The study from Adams-Prassl et al (2020), which collected two waves of data in the UK and the US from almost 15,000 people, found that a total of $15 \%$ of the UK population have lost their jobs due to the economic impact of coronavirus by mid-April. Moreover, women are four percentage points more likely to have lost their job than men in the UK, with $17 \%$ of women newly unemployed compared to $13 \%$ of men.

The pandemic has also impacted on actual hours worked. Reasons for changes to the intensive margin of employment are similar to those 
mentioned above and include the level and distribution of aggregate economic activity, changes in labour supply arising from health restrictions or other responsibilities such as child care. The survey from Adams-Prassl et al (2020) reports a stark decline in the number of hours worked, with the average change in hours worked (compared to a typical week in February) being 7 hours in the UK. This is confirmed by official statistics from the ONS, which shows that, in the period February to April 2020, the total actual weekly hours worked in the UK decreased by 94.2 million compared to the same period in 2019 , or $8.9 \%$. The 'accommodation and food service activities' sector saw the biggest fall in average actual hours: a decrease of 6.9 hours to 21.2 hours per week (ONS 2020b). We have seen that women are more likely than men to be employed in those activities.

The evidence on the impact of the recessions on the gender gap in earnings is even more limited. The IFS estimates that the largest distributional impact of the recessions associated with the pandemic is by earnings level: those with the lowest earnings are about seven times as likely to work in shut-down sectors as those with the highest earnings. $34 \%$ of employees in the bottom tenth of the earnings distribution work in sectors directly affected by the lockdown, compared to just $5 \%$ of those in the top tenth (Joyce, Xu 2020). Women are substantially overrepresented in the bottom of the earnings distribution. A survey of more than 2,000 working age adults by the national poverty charity Turn2us reports that women's earnings are expected to fall by $€ 309$ (26\%) compared to an 18\% drop (£247) in earnings for men, resulting in a widening of the mean gender pay gap of $€ 62$ a month (Turn2us 2020). A nationally representative survey found that $48 \%$ of mothers and $38 \%$ of fathers, compared with $27 \%$ of non-parents, are worried about making ends meet in the next three months (WBG 2020)

One potential reason for these differences is given by the gender gap in home production and women being more likely than men to spend more time in unpaid activities, such as taking care of children and homeschooling, the latter having been a direct consequence of the school closures imposed by the Government to control the spread of the virus.

\section{Home Production Impacts}

The impact of home production represents possibly the most significant difference between the economic recessions caused by the COVID-19 pandemic and previous recessions, including the most severe ones. This is because of the lockdown measures imposed by the Government, which included the closures of schools from March 23, 2020. This difference is also likely to be the main reason as to why 
the immediate, short-term gender impact of this recession is likely to be different from those of previous recessions, which have typically affected men more than women. ${ }^{4}$

Despite the long-term trends towards increased marketization of household production, whereby some of the unpaid activities usually undertaken by women at home have been acquired in the marketplace, gender gaps in the amount of time spent on unpaid tasks at home have remained stubbornly high even before the lockdown put in place at the end of March 2020. One study by the ONS estimated that women carried out $60 \%$ more unpaid work than men (ONS 2016). The gender division of household work depends on a series of factors, including household composition and number of children. In the UK, almost one-fifth of households with dependent children are single mother households. Some studies have assessed the impact of the lockdown measures on the gender division of household work. One such study by Sevilla and Smith (2020) reports that women have borne the majority of the additional burden of childcare associated with the lockdown measures. More specifically, they report a substantial burden of childcare for families with young children, who are doing the equivalent of a working week of additional childcare, often on top of paid work. The fact that women are less likely to be working than men cannot fully account for their greater burden of childcare. The amount of time women spend on childcare is much less sensitive to their employment than it is for men. Women do a lot of childcare irrespective of whether they are working or not, while men put in a lot more childcare when they are not working compared to when they are. The longer term impact of this, for instance on career progression, cannot be underestimated: mothers' childcare comes more at the expense of their productivity and future career prospects than it does for fathers'. However, the substantial increase in the need to take care of children and home schooling when schools have been closed has resulted in a sizeable increase in childcare done by fathers. Sevilla and Smith (2020) report that fathers who are not working and, to a lesser extent, those who were working from home, have substantially increased the number of hours that they do and assumed an equal (or in some cases greater than equal) share of childcare. This has resulted in a slight reduction in the within-household gender gap from 30.6 percentage points to 27.2 percentage points. The survey from Adams-Prassl et al (2020) also reports that women spend a lot more time on childcare than men.

4 It is important here to emphasise that the finding on men being more affected by recessions than women refer to the short-term, immediate impact of recessions, typically associated with gender industry segregation. When a fuller account of industry and occupational segregation is taken, as well as other factors, such as fiscal austerity measures in the last great recession, women's employment is not less affected than men's (see Razzu, Singleton 2018). 


\section{Concluding Remarks}

COVID-19 is a public health crisis with huge economic and social consequences. Emerging evidence shows that the economic and social impacts are not felt evenly across the population.

Two aspects of the crisis have contributed to making its economic impact peculiar and possibly more severe than previous crisis: the combination of demand and supply side shocks and the nature of the government intervention in terms of lockdown measures and direct closure of economic activities to control the spread of the virus. The latest available data on output shows that GDP contracted by more than $20 \%$ in the month of April. Although this will show later on in statistics on employment and participation, real time experimental data indicate a substantial reduction in the number of paid employees between March and May 2020 and in the hours of work. This impact has been felt across the economy but, given the nature of the lockdown measures, it has affected some sectors more than others, particularly retail, accommodation and food services sectors. Distributional analysis also shows that the impact is most salient at the bottom of the earnings distribution than for high paid jobs. The fact that women are more likely than men to be employed in those sectors, and more likely than men to be at the bottom of the earning distribution, means that their labour market outcomes are more likely to be negatively affected than men's.

The nature of the lockdown measures, including the schools closure, has resulted in a substantial additional burden on child-caring. The impact of this additional burden on gender equality depends on various factors, including household composition, number of children and employment status. The emerging evidence presents two findings. On the one hand, in absolute terms, women have seen a substantial increase in the number of works devoted to household production and childcare. They are also doing a lot more juggling of childcare and work than men are. The impact this is likely to have on women's productivity and therefore their career progression could be very substantial.

On the other hand, given that many men have had their working hours reduced, being furloughed or having lost their jobs since lockdown at the end of March, they have also substantially increased the hours of childcare.

In order to address some of the more pronounced labour market consequences of the crisis, the Government has intervened with two main schemes, supporting the wages of employees and self-employed who have been furloughed. To the extent to which women's labour market outcomes have been affected by the crisis more than men's, these schemes will benefit them relatively more. However, important aspects of the crisis that possibly have significant impact on gender 
equality in the medium term in the labour market have not received necessary government attention. Women are over represented in sectors that have been mostly affected by the lockdown, such as retail, accommodation and food services sectors and it is not clear what long-term impact the lockdown measures will have on the sustainability of many businesses active in those sectors. The UK Government has not yet announced a comprehensive post-COVID economic recovery plan in this respect.

Regarding pay, the Government suspended the legal requirement for all UK firms with more than 250 employees to publish measures of the gender pay gap within their own organisations, which was due annually at the beginning of April. This is unfortunate not just because the emerging evidence suggests the gender pay gap may have increased as a result of the crisis but also because it gives a strong message that gender equality in the labour market is not a priority and can be sacrificed in certain circumstances. The crisis has also started a new dialogue on health, key workers, social care and pay, also epitomised by the Thursday night clapping across the nation. We know these are areas where women's contribution is overwhelming. It would be another missed opportunity if concrete actions on pay and support to these sectors did not follow.

Gender inequality in the labour market is the product of many factors: the issues are complex, manifold and interrelated. Most notably, they are often the result of a structured system of institutions and norms in which gender plays a very important part. This is evident when looking at the role of social attitudes towards gender and employment and the associated impact of motherhood on women's labour market prospects. The pandemic has clearly resulted in an additional burden on childcare; its possible long-term consequences on women's work prospects would need to be addressed. Increasing the amount of child benefit, as proposed by various organisations and academics earlier on in the crisis, is one possible intervention but more can be done to raise awareness and provide practical tools to families on how the distribution of work within the household could be more gender equal, now that many fathers are likely to be at home and are sharing more of the burden than they used to do. Building on this to ensure it becomes engrained would be important. Any discussion, analysis and intervention related to new ways of working represent a great opportunity to address the systemic issue of the relationship between paid and unpaid work in the household. 


\section{Bibliography}

Adams-Prassl, A.; Boneva, T.; Golin, M.; Rauh, C. (2020). "Inequality in the Impact of the Coronavirus Shock: Evidence from Real Time Surveys". IZA Working Paper No. 13183. https://bit.ly/32ARwHv.

Hupkau, C.; Petrongolo, B. (2020). "COVID-19 and Gender Gaps: Latest Evidence and Lessons From the UK". VoxEU.org, 22 April. https://bit. ly/3fKbaVe.

Joyce, R.; Xu, X. (2020). "Sector Shutdowns During the Coronavirus Crisis: which Workers are Most Exposed?". The Institute for Fiscal Studies. https:// www.ifs.org.uk/publications/14791.

NIESR (National Institute of Economic and Social Research) (2020). "Monthly GDP tracker". https://www.niesr.ac.uk/latest-gdp-tracker.

OECD (Organisation for Economic Co-operation and Development) (2020). "Evaluating the Initial Impact of COVID-19 Containment Measures on Economic Activity". https://bit.ly/2ZIkIKX.

OBR (Office for Budget Responsibility) (2020). "Commentary on the OBR Coronavirus Reference Scenario”. https://obr.uk/coronavirus-analysis/.

ONS (Office for National Statistics) (2016). "Women Shoulder the Responsibility of Unpaid Work". https://bit.ly/20E4RXx.

ONS (2020a). "GDP Monthly Estimate, UK: April 2020". https://bit.ly/30x40C6.

ONS (2020b). "Labour Market Overview, UK: June 2020". https://bit. ly/20JqANA.

Razzu, G.; Singleton, C. (2018). "Segregation and Gender Gaps in the United Kingdom's Great Recession and Recovery”. Feminist Economics, 24(4), 3155. https://doi.org/10.1080/13545701.2018.1451907.

Sevilla, A.; Smith, S. (2020). "Childcare During a Global Pandemic: Many Women Left Juggling Work and Childcare, But Men Do their Share When They are not Working". VoxEU.org, 16 June. https://bit.ly/3jq4T38.

Turn2us (2020). "Coronavirus Pandemic Widens the Gender Pay Gap". https://bit.ly/3eKEMRb.

WBG (Women's Budget Group) (2020). "Half of Parents with Young Children 'Struggling to Make Ends Meet'”. https://bit.ly/32xizUe. 


\title{
India's Lockdown and the Great Exodus Some Observations
}

Arup Daripa

Birkbeck, University of London, UK

\begin{abstract}
The pandemic-induced lockdown in India caused a great exodus of millions of seasonal workers from cities, an impact for which the government was completely unprepared. This essay considers the socio-economic setting of the exodus, the potential economic and epidemiological impact, policy suggestions, and evaluation of the policy (non)response of the Indian government. We consider the underlying political economy of policy distortion and suggest ways that might enable incentive compatible corrections.
\end{abstract}

Keywords Internal migration. Lockdown. Informal economy. Public policy distortions. Political economy of policymaking. Incentive compatibility.

Summary 1 Introduction. - 2 "Othering" and Distortion. - 3 Economic Impact. - 4 Policy Proposals. - 5 The Policy Stance of the Government. - 6 Lockdown and Inconsistent Government Policy. - 7 The Selectively Absent Leviathan. - 8 A Ray of Hope?

\section{Introduction}

The threat of COVID-19 assumed ominous proportions in India by mid-March 2020, and even the Government of India, which had so far made few attempts to prepare for the looming crisis, could not brush it aside any longer. In an attempt to contain the spread of the disease, the government announced a total lockdown on March 24, 2020. The announcement came at 8 pm on March 23, with lockdown in effect from midnight. As the incessant churn of life of a billion people across overcrowded metropolises and sprawling semi-urban conurbations of India came to a sudden halt, as transport stalled, shops put down 
their shutters, public places fell silent, and a billion people huddled indoors, a surreal saga unfolded on television screens across the country. In several big cities, roads that were supposed to be empty were in fact teeming with masses carrying children and bundled possessions, waiting at bus and train stations, and, having given up hope of finding transport, embarking on journeys of hundreds of kilometres on foot. These are the seasonal workers of India - a labour force of over 120 million villagers who travel in search of work to urban centres in the fallow seasons. They live in city slums and work mostly in the informal sector in industries such as construction, garment making and small manufacturing, or work as street vendors, rickshaw pullers and domestic help. Once the lockdown was imposed, most of these jobs vanished overnight. The employers themselves faced a cash crunch and stopped paying casual workers. Having little access to the public welfare system (a problem we will come back to later), and in many cases evicted from tenements by landlords concerned about the virus, the workers had little choice but to try to return to their villages. In an article in the Financial Times, the writer and activist Arundhati Roy writes movingly about their plight:

Many driven out by their employers and landlords, millions of impoverished, hungry, thirsty people, young and old, men, women, children, sick people, blind people, disabled people, with nowhere else to go, with no public transport in sight, began a long march home to their villages. They walked for days, towards Badaun, Agra, Azamgarh, Aligarh, Lucknow, Gorakhpur - hundreds of kilometres away. Some died on the way. (Roy 2020)

The great exodus and its human cost raise several economic questions, to which we now turn. How might we think about the economic impact of the exodus? Where in the economy would it show up? What policies might ameliorate the human cost? What role has the government played and what light does that shed on the nature of government policy? If government policy is inadequate, what is the source of the distortion? And, last but not the least, how should social institutions change to address any endemic government failure?

\section{2 "Othering" and Distortion}

But before we talk about such questions, an ontological issue deserves our attention. The seasonal workers come to urban centres from villages across the country - and in most cases they travel across states ${ }^{1}$

1 India is a federal union of 28 states and 8 union territories. 
to seek work. Crossing a state border by an Indian citizen should be an unremarkable event, yet these workers are labelled migrants. Indeed, even those who cross state lines to settle elsewhere, but remain poor, are routinely referred to as migrants. This "othering" through categorisation is unfortunate to say the least and reflects a public attitude that makes for institutional discrimination and insidious biases in public policy. As we discuss economic aspects of the exodus below, this socio-political background is worth keeping in mind. In seeking policy solutions, we need to look for appropriate incentives within this structure. As will become clear later, simply making policy proposals assuming the utopia of a welfare-maximising policymaker is not very useful in the current context.

\section{Economic Impact}

Returning to the questions we posed above, let us first try to decipher the potential economic impact of the exodus. Here it is key to gain an understanding of the setting within which the problem manifests. The Indian economy is large, but mostly informal and most of the over half-a-billion labour force is engaged in relatively unproductive employment. Indeed, this lack of productivity is a crucial reason for the majority of the 1.3 billion population to remain so poor. A staggering $90 \%$ of the employment is in the informal sector including agriculture, and produces a little more than $50 \%$ of the GDP, leaving the formal sector, with $10 \%$ of the labour force, to produce the other half. The productivity gap is obvious.

Even though many of the informal sector workers have basic bank accounts, they lack access to credit or insurance, and are therefore largely financially excluded. The Government of India spends relatively little on health and education, ${ }^{2}$ and in the poorer areas people largely rely on their social networks to provide some support. In this backdrop of endemic poverty and low levels of infrastructure provision, the remittances sent by the seasonal workers play an important role in supporting a large number of households. ${ }^{3}$ Removing these remittances not only hurts the households concerned, but has a multiplier effect on many others in the local economy. In the absence of formal credit or insurance, social networks can take some of the strain when only a few households receive a negative shock. But when

2 Health spending is $1.28 \%$ of GDP and education spending is 3.8\%. To compare, Brazil spends $9.2 \%$ of GDP on health and $6 \%$ on education. The UK spends $9.6 \%$ of GDP on health and $5.5 \%$ on education.

3 See Deshingkar, Akter 2009 for a detailed description of the occupation structure of migrants and their contribution to GDP. 
whole local economies get a macro shock, the networks run out of capacity to cope. Poverty and deprivation rise. Many small businesses go bust permanently. The result is a deep recession in these local economies. And while the removal of the remittances will have an impact on certain areas, it also serves as a weathervane, signalling ill-winds of lockdown for the whole of the informal economy, where many jobs will be lost permanently. This will eventually reduce overall GDP growth estimates. Indeed, the informal sector had already suffered a setback in 2016 from the poorly conceived demonetisation policy, ${ }^{4}$ which drained liquidity from an economic system entirely dependent on cash transactions and had a large and long-term negative impact. Given the long duration of the lockdown, ${ }^{5}$ the total impact on the informal economy is likely to be even greater this time.

The exodus has a negative impact also from an epidemiological point of view. Large numbers travelling to remote locations carry the risk of introducing COVID-19 to previously disease-free areas. These are also precisely the areas without any public health infrastructure, exacerbating the potential downside risk.

\section{Policy Proposals}

What policies might mitigate these problems? In an insightful and wide-ranging work, Debraj Ray and S. Subramanian (2020) have written about the impact of the lockdown. This includes a condensed analysis of policy suggestions made by a variety of commentators. Two broad themes emerge from this. The first is an observation on macroeconomic policy. Given that the contraction in economic activity is driven by a pandemic, both demand and supply sides are hit, and normal channels of monetary policy do not work. On the other hand, fiscal policy stands a much better chance of being effective. If the government were to invest heavily on public infrastructure and create a safe working environment through testing, distancing, and provision of proper equipment, that could indeed have a positive impact on the economy, including the informal economy. Second, and more relevant for our focus on seasonal workers, a consensus has emerged on calling for direct transfers, perhaps the obvious policy in such a crisis. In India, the main channel for transfers is the Public Dis-

4 See Kumar 2018 for a description of the impact of demonetisation on the informal sector. See also Chodorow-Reich et al. 2018 for a theoretical and empirical analysis of demonetisation in a macroeconomic model, which finds strong evidence of the effect of money on output in India and shows why cash matters a great deal in India.

5 The lockdown started on March 24, 2020, and was extended in phases until May 30, 2020. Subsequently, some restrictions were lifted, but a lockdown continues in several areas that have been identified as COVID-19 hotspots. 
tribution System (PDS). Access is through home-state issued ration cards, so that out-of-state workers are excluded from PDS transfers. Expanding the scope of transfers in a crisis requires relaxation of such requirements. Many commentators, including the dream-team of Amartya Sen, Raghuram Rajan and Abhijit Banerjee (2020), have made the case for universal access to the PDS with minimal checks.

Writing in The Wire, Dipa Sinha (2020) discusses a specific policy along these lines. She proposes that the government allocate $10 \mathrm{~kg}$ of grains per head per month, and make the coverage universal, requiring minimal documents simply to keep track of everyone. She estimates that if $20 \%$ of the population were to self-select out, the plan would require 65 million tons of grains over 6 months. The government of India has a large stockpile of 75 million tonnes of grains, with another 30 million tonnes incoming soon, so that the plan is feasible. In our view, apart from the virtue of being simple to implement, the plan has exactly the right incentives. Given universal coverage, the scope for capture by special interests or middlemen is low (and in any case, a second-order concern in a crisis). Further, the long queues that are bound to form to access the rations would serve as an endogenous incentive for the better-off to stay away. The policy therefore targets the needy and goes a long way to solve the problems of hunger and starvation.

\section{The Policy Stance of the Government}

Contrast the proposals with the actual schemes adopted by the government. The policy response has been surprising, mainly because even the most obviously effective suggestions about greater transfers with broader coverage and fewer checks seem to have fallen on deaf ears. The government did announce certain relief measures including transfers of $5 \mathrm{~kg}$ of grains per head per month through the PDS list just after the lockdown started. However, as noted above, seasonal migrants had no access to such transfers. Almost seven weeks later the government announced further measures that expanded coverage for two months to those without a ration card, but then required other documents to grant access. This pathological insistence on identity checking for basic food transfers in a time of crisis - a stance diametrically opposite to the proposals mentioned above - has limited the effectiveness of the policy for migrant workers. A report from the Stranded Workers Action Network (SWAN 2020) notes that as late as early June, over nine weeks since the lockdown started, $80 \%$ of the seasonal migrants have not received any grains under the scheme. A similar apathy characterised the response to millions walking long distances. The government only arranged special trains to carry workers home after six weeks had passed from the imposi- 
tion of the lockdown. Indeed, the government's overall response to the economic crisis brought about by the lockdown amounts to spending only around $1 \%$ of GDP - meagre compared to $9 \%$ in the US, $7 \%$ in Germany and $4.5 \%$ in the UK. ${ }^{6}$ And if we were to use a deflator taking the relative poverty indices into account, the comparative figure would be much more unflattering.

\section{$6 \quad$ Lockdown and Inconsistent Government Policy}

The response raises a more fundamental policy question: is the lockdown itself justified? Recall that starting March 24, the lockdown went on till May 30, and as we write it continues in several areas with only some rules relaxed. There is no question that the lockdown has saved lives by halting the spread of the disease. In an ideal world, the government would supplement the lockdown with appropriately scaled transfers to the poor. But given the actual policy response, the lockdown has itself become an agent of death for the poorest and the most vulnerable, who have little to fall back upon when their daily livelihoods vanish. We do not know precisely how many lives have been saved by the lockdown, but one would hazard a guess that far more lives have been destroyed by it given its prolonged duration.

Numbers aside, it is clear that if saving lives is the objective, the lockdown and the subsequent policy response are not consistent with each other. What explains the sub-optimal policy stance? To understand how such distortions arise, we need to delve into the political economy of policymaking in India.

\section{The Selectively Absent Leviathan}

In their recent intellectual tour de force, The Narrow Corridor, Daron Acemoglu and James A. Robinson (2019) discuss the idea of liberty, and how it requires both a strong state and a strong society. Liberty, they argue, requires not being subject to the capricious will of another. "It requires the capacity to stand eye to eye with your fellow citizens, in a shared awareness that none of you has a power of arbitrary interference over another" (7). Starting from Thomas Hobbes' idea of "Leviathan" as the solution to anarchy, and using examples from history, they show that liberty can be violated both in the absence of a strong state (absent leviathan) and if a strong state were to declare war on its own citizens (despotic leviathan). The plight of

6 See, for example, Jha 2020 and Sibal 2020. Ray and Subramanian 2020 contains a detailed description of policies adopted. 
the seasonal migrants in India clearly demonstrate an absence of liberty. Yet, the Indian state power cannot be properly characterised as either absent or despotic. For India, Acemoglu and Robinson point to the caste system as a powerful cage of norms that fragment society against itself. The consequent inability to monitor the state fuels the absence of liberty even in a participatory democracy. We would argue that this is not the whole story. The plight of the seasonal workers points to a further cause of loss of liberty in India. Even in the absence of caste-based fragmentation, the poorest sections of the society are too distracted by their daily struggle for survival to gel as a unified front with 'voice'. The absence of voice is complete: neither the state nor any structure in society including the press pay them much attention. Thus, the leviathan can be selectively absent.

Let us give a further example to delineate a selectively absent leviathan. A second epidemic - deadlier than COVID-19 - rages in India at this very moment. An entrenched disease, it has been ravaging sufferers for several years now. Yet, many Indians are unaware of it, the press hardly reports on it, and the government devotes some, but by no means sufficient resources to combat it effectively. This is the epidemic of tuberculosis. The World Health Organization's latest report (WHO 2019) estimates that in 2018, 2.7 million Indians contracted the disease, of which 450 thousand died. Absolute numbers as well as the death rate (17\%) far exceed that of COVID-19 so far. What explains the institutional apathy towards the problem? The answer is again linked to poverty. Indeed, tuberculosis is known as a disease of poverty, proliferating in densely inhabited areas such as urban slums. It is therefore the same absence of voice that distorts the government's response to the plight of the seasonal workers as well as that of the victims of tuberculosis. Clearly, these groups would be denied liberty even without a cage of norms.

\section{$8 \quad$ A Ray of Hope?}

Can we envisage a way out of the problem? The National Capital Territory (NCT) of Delhi offers a promising case study. Delhi has a large community of settled 'migrants'. As we discussed before, these are people originating from other states who settle in Delhi but remain poor. Given our previous discussion, it does not come as a surprise that they have historically lacked voice and suffered the absent leviathan. However, with rising numbers, and with a growing recognition that their votes should be cast in a way that brings benefit, their position has gradually changed. Around 2013, a regional political party sensed an opportunity and started putting up members of the community as candidates in a significant number of seats. This helped the migrants leapfrog into a voting bloc, now controlling between $30 \%$ 
and $40 \%$ of the vote, and the party concerned has held sway in Delhi NCT elections since. Indeed, across the political spectrum, anyone in power seeking re-election can no longer ignore migrant welfare issues. To employ another metaphor from Acemoglu and Robinson (2019), by voting as a bloc on development, the settled migrants of Delhi have finally had some success in chaining the leviathan.

For seasonal workers, two entitlements are critical. First, workers who cross state lines should still have access to the Public Distribution System. The government is indeed implementing such a scheme under the banner One Nation One Ration Card, which should be up and running sometime this year. Second, as the Delhi case study shows, to chain the leviathan successfully, the workers also need to participate in India's democracy as an effective bloc. Since voting rights are tied to place of residence, the majority of seasonal workers, working across state lines, are in effect disenfranchised. Even though the group is large - they number somewhere between 120 and 150 million (the government does not have a separate database for seasonal migrants) - their voice is thereby curtailed. Suggestions have been made that they should be allowed postal votes or that individuals should be allowed to carry their vote, enabling exercise of suffrage at the place of work. The government currently has no plans to implement such policies. However, the great exodus has firmly imprinted the worker underclass in the nation's psyche. The political scientist Pratap Bhanu Mehta (2020) writes eloquently about the justice that society owes them. Indeed, if their harrowing stories bring about greater solidarity from social institutions, together they might be able to gain the required rights, escape being subject to the capricious will of others, and have liberty at last. At least we hope so. 


\section{Bibliography}

Acemoglu, D.; Robinson, J.A. (2019). The Narrow Corridor: States, Societies, and the Fate of Liberty. New York: Penguin.

Chodorow-Reich, G.; Gopinath, G.; Mishra, P.; Narayanan, A. (2018). "Cash and the Economy: Evidence from India's Demonetization". NBER Working Paper 25370. http://www.nber.org/papers/w25370.

Deshingkar, P.; Akter, S. (2009). "Migration and Human Development in India". United Nations Development Programme, Human Development Reports Research Paper 2009/13. http://hdr.undp.org/sites/default/files/ hdrp_2009_13.pdf.

Hobbes, T. (1651). Leviathan or The Matter, Forme and Power of a Commonwealth Ecclesiasticall and Civil. London.

Jha, P.S. (2020). "Modi's 'Stimulus Package' is a Gigantic Confidence Trick Played on the People of India". The Wire, 18 May. https://bit.ly/3ePwlE6.

Kumar, A. (2018). "Two Years after Demonetisation, the Nightmare Continues for India's Informal Economy". The Wire, 8 November. https://bit. ly/2CUM1sE.

Mehta, P.B. (2020). "Beyond Solidarity: The Migrant Labour and the Unemployed Will be Demanding their Rights, not Our Mercy". The Indian Express, 18 April. https://bit.ly/2CxKI2J.

Ray, D.; Subramanian, S. (2020). "India's Lockdown: An Interim Report”. 20 May. https://debrajray.com/wp-content/uploads/2020/05/RaySubramanian.pdf.

Roy, A. (2020). "The Pandemic is a Portal". Financial Times, 3 April. https:// www.ft.com/content/10d8f5e8-74eb-11ea-95fe-fcd274e920ca.

Sen, A.; Rajan, R.; Banerjee, A.V. (2020). "Huge Numbers May be Pushed into Dire Poverty or Starvation... We Need to Secure Them". The Indian Express, 17 April. https://bit.ly/39dSbjl.

Sibal, K. (2020). “View: Revival Package Doesn't Help the Poor or Middle Class, Backbone of India's Broken Economy". The Economic Times, 8 June. https://bit.ly/2CMaK25.

Sinha, D. (2020). "Food for All During Lockdown: State Governments Must Universalise PDS". The Wire, 20 April. https://thewire.in/rights/covid19-lockdown-foodsupply-pds.

SWAN (Stranded Workers Action Network) (2020). "To Leave or Not to Leave? Lockdown, Migrant Workers, and Their Journeys Home: A Report". Stranded Workers Action Network, 5 June. http://strandedworkers.in/mdocsposts/to-leave-or-not-to-leave.

WHO (World Health Organization) (2020). Global Tuberculosis Report 2019. October 2019. https://www.who.int/tb/publications/global_report/en/. 



\title{
Human Skills \& the AI COVID Challenge
}

Naeema Pasha

Henley Business School, University of Reading, UK

\begin{abstract}
This chapter examines the impact of both the COVID-19 pandemic and AI on the world of work. Both have created further uncertainty and ambiguity in the labour market landscape. In dealing with high uncertainty, developing both organisational and adaptability skillsets is critical to success, and a dynamic approach may be suitable to enhance skill-building.
\end{abstract}

Keywords Pandemic. Al. Technology. Future of Work. Careers. Skills. Dynamic Capabilities.

Summary 1 Pandemic Economy and Work. - 2 History of Work, Careers and Skills. $-3 \mathrm{Al}$, Came Slow -Then Suddenly. - 4 A Pandemic World of Work. - 5 Skills Building - Adapting for Surviving and Thriving. -6 What Does This Mean Next for Us?

\section{Pandemic Economy and Work}

From the industrial revolution to the present day, the global economy has expanded - albeit with peaks and troughs interspersed throughout - and created transformative innovations from the Ford motor car to the iPhone. However, the troughs are what we humans feel the most. We are still reeling from the last major recession in 2008, as global debt sharply increased, wages remained low and productivity stagnated. Yet, the recession caused by the coronavirus pandemic is different to previous downturns. This COVID-19 recession was not caused by flaws in the global financial system like in 2008, but instead it was the threat of illness and death on a global scale. The rapid and unprecedented worldwide shutdown impacted every human on the plan- 
et, with countless deaths, jobs lost, and livelihoods uprooted. However, the COVID-19 recession has also coincided with the increased worldwide adoption of Artificial Intelligence (AI) and automation, a process that has already streamlined work patterns.

The pandemic has also enabled faster adoption of digital technology. In the familiar world of food retail, we've seen reduced human interaction with consumers turning to online shopping, supermarket scanners and even robot food deliveries. ${ }^{1}$ The pandemic has also caused a shift in healthcare, from the use of robots, to GPs treating patients via WhatsApp video. We have also witnessed the worldwide shift of education from classroom to virtual learning which has allowed - broadly speaking - teaching to continue. Organisations are reconfiguring how 'work' can be done including balancing conflicting ideas that it does not need to happen in offices, against knowing that organisational culture is aided by face-to-face interactions. While we applaud technology for keeping work going, it indicates that more AI integration and automation will be adopted sooner and wider, carrying clear implications for work and workers.

\section{History of Work, Careers and Skills}

Whilst we are seeing the transformation of work, the recent history of work is worth reviewing. From the start to the middle of the last century, in the age of mass manufacturing, workers were recruited for similar skillsets to often work on identical jobs. Job roles were consistent, often not changing in scope over many years (Parsons 1949). During this period, firms operated in hierarchies and managed in tight boundaries. The watchword for this era was steadystate. Later in the 20th Century, flexibility in work grew. Organisations moved towards a more customer-centric operation and as such, systems were faster. Leaders were expected to head up workers with a range of skills and knowledge, which could be applied and re-applied to different scenarios - and so boundaries between jobs, roles and organisations blurred. The watchword thus became boundaryless, coined by Arthur (1994, 295-306). The 21st century saw another shift including upheavals bought by AI, and now COVID-19. Work is more uncertain, but hyperconnected, hypercompetitive and increasingly tech enabled. Companies and workers who display agility in either adapting or taking advantage of digital technology gain success. And so adaptability for this era is our watchword (LeBleu 2020).

1 "Robot Parcel Delivery Starts". BBC News, 31 October 2018. https://www.bbc.com/ news/uk-england-beds-bucks-herts-46045365; "A New Kind Of Business". Starship. https://www.starship.xyz/business/. 


\section{$3 \quad$ Al, Came Slow -Then Suddenly}

Interest in AI is at all time high and has fuelled investment in AI technology. For example, the European Commission's investment in AI has skyrocketed - with a 70\% increase from 2017 to 2020, coming to 11.5 billion. However, even this investment appears small in comparison to the $€ 12.1$ billion investment in North America, and €6.5 billion in Asia (European Commission 2020). But, while AI seems like a new phenomenon, it has existed for over 60 years. The term was coined by a group of scientists who came together in 1956 to explore the deep potential of computers. AI systems developed by early creators looked at mimicking human intelligences - but through a machine (hence the term Artificial Intelligence). The following few years offered some exciting innovations, but AI development slowed, and it really was not until the start of the 21st century with the advent of immense computing power, and crucially, access to vast data, that AI really took off. Like some statistical methodologies such as regression analysis, AI and Machine Learning programmes could observe relationships, classifications and predictions in data, but as AI programmes can work 'unsupervised' and on vast datasets with many variables, the results were unparalleled. As a result, AI innovations have influenced our work and lifestyles, from Facial AI assessing our personality in recruitment, to Conversational AI in our voice assistants such as Alexa who we freely talk to at home but will soon join us in the workplace.

Modern iterations of AI do not need to use the old model of copying humans. Instead, machine learning algorithms learn in an altogether different way to us humans. Some AIs can bypass human skills, for example, a system developed by Google Health was able to find cancerous cells in mammograms more accurately than the radiologists it was tested against. In fact, the system detected $90 \%$ of cancerous cells compared to $78 \%$ by radiologists. AI systems like this can help speed up diagnosis and allow for treatment to start faster (McKinney et al. 2020, 89-94). A question arising from this is the role of doctors. Some suggest that the patient relationship part of a doctor's role is to be amplified - as the machine is giving better data and at a faster rate to patients. But this process raises questions about all our jobs. In the next ten years, we can expect greater AI job integration. Take accountancy, the role of Financial AI will do all the back-breaking work of analysing numbers, and by using Machine Learning with sophisticated Data Science, it will sync with consumer data and predict trends faster. What then does this leave the accountants to do? Possibly do more human tasks such as building customer relationship. However, will companies need many accountants? (World Economic Forum 2916). 'Automation' technology underpins many of the predictions of jobs disappearing (ONS 2019), specifically tech such as Robotic Process Automation (RPAs), where 
'RPAs' will whizz round a system of routine processes and complete tasks that take humans days and weeks to do in days and minutes. And the RPA will complete with fewer inaccuracies.

Although there is no argument that the adoption of AI technologies will create new jobs, it does raise the issue of automation of current jobs and the potential negative impact upon society. In 2017, the Office for National Statistics analysed the jobs of 20 million people in England (ONS 2019) and concluded that 7.4\% are at high risk of being automated. In addition, it highlighted that women, part-time workers and younger people in elementary occupations are most likely to be affected - many doing the jobs RPAs are primed for. A Universal Basic Income (UBI) has been put forward as one possible solution to the loss of jobs and the impact of automation upon the working population. It is claimed that a UBI would allow some security to workers, would contribute to limiting involuntary debt, and lower stress levels. However, the UBI does equate 'work' to 'money' in its simplest terms, negating the social aspects of work including personal value, relationships, a source of self-esteem, citizenship, and role in society (Meyer 2019). It may also increase inequality. UBI, whilst useful, could render the unemployed 'the left behind', creating a social underclass.

\section{A Pandemic World of Work}

The pandemic has made us re-think our work - and many jobs might be done with a mix of home and office work. For those employers looking to keep the traditional office space many will look for technology solutions to minimise spread of disease, such as:

- track and trace software to see who might be sick;

- Wristband sensors to alert workers if they cross set boundaries;

- sensor tracking of small changes in body temperature or voice signatures to see who is ill;

- facial recognition software used to open doors reducing the need to touch surfaces;

- robots emitting UV light to kill viruses.

Ahead of us further technological advances are likely to enable further changes to work. For example, the development of 5G is expected to have an enormous impact on businesses - especially so for a postpandemic economy as it will enable extraordinarily fast networking and connectivity. Workers wanting to maintain a home-based work lifestyle could use Virtual and Mixed Reality devices like Microsoft's HoloLens that would add imaging in video conferencing. 5G will enable faster and clearer connection, creating a far more personal experience. 5G, coupled with growth of AI will fuel development of the 
Internet of Things (IoT) which is expected stimulate the growth of Smart Cities, Smart Healthcare and Smart Work. Current planning on $5 \mathrm{G}+$ IoT adoption is intended to reach more deprived areas and reduce digital differences in access - with many health commentators believing it could even reduce health inequality and even manage pandemic outbreaks better. ${ }^{2}$ The transformative potential of $5 \mathrm{G}$ cannot be underestimated.

By 2025, IDC [2018] estimates that around 1.5 billion 5G connected devices will produce more than 175 zettabytes of data each year. A zettabyte is the equivalent of one trillion gigabytes. This rapid increase in data production through connected $5 \mathrm{G}$ devices is known as the massive Internet of Things (mIoT), which will accelerate the drive to digitalisation. Many of these 5G connected devices will use Edge Computing to deliver super-fast, low latency, AI powered data services directly on the device without needing to access the cloud. $5 \mathrm{G}$ is so much more than just faster $4 \mathrm{G}$. Together with mIoT and 'AI on the Edge', 5G is the gateway to autonomous systems at scale and human-machine collaboration that will make pre-connected human beings look like dinosaurs. (Richard Foster-Fletcher, Digital Strategist, Boundless Podcast) ${ }^{3}$

However, critics of AI voice fears over privacy and cybersecurity with $5 \mathrm{G}$ and IoT having prompted governments to develop a stronger stance on AI governance. The European Union (EU) released guidelines for regulating AI in a white paper, applying to 'high-risk' technologies with high privacy concerns, such as healthcare, transport and surveillance. For example, the impact of certain AI is deemed "high risk" by the EU - such as AI tools used in recruitment, as it may affect workers' rights. They acknowledge that AI has a huge impact on society, and EU citizens must be protected in order to keep trust high. In doing so, the EU has pledged to create an 'ecosystem of trust', ensuring that tech firms comply with EU regulations and allowing citizens to adopt AI technologies with confidence. These governance plans are promised to be embedded into 5G planning - even to the extent of re-evaluating political and country affiliations of network providers.

2 AT\&T Business Editorial Team. "5 Ways 5G Will Transform Healthcare". AT\&T. https://www.business.att.com/learn/updates/how-5g-will-transform-the-healthcare-industry.html.

3 https://boundlesspodcast.co.uk/. 


\section{$5 \quad$ Skills Building - Adapting for Surviving and Thriving}

It is only through understanding the realities of any climate, both internal and external, and adapting effectively, that most creatures survive. We are experiencing a new reality shaped by a major shift that is impacting jobs from both AI and the pandemic, and we need to push our minds further, understanding that we will need a mindset for constant 'adaptability' to build the relevant skills to thrive. Stimulus in skilling from the UK government comes from the UK Office for Artificial Intelligence (OfAI), which has three main aims: ensuring that AI has a positive impact on society, enabling adoption of AI across industries, and upskilling and investment. Key policies include increasing investment in R\&D to $2.4 \%$ of GSP by 2027, investing $£ 406$ million in STEM education, and an additional £64 million for a National Retraining Scheme, enabling lifelong learning in digital and construction industries. In addition, the EU has developed an 'ecosystem of excellence' with small and medium-sized enterprises (SMEs) to boost innovation and the economy. This is an attempt to attract investment in European $\mathrm{AI}$, and in turn stimulate the job market. The EU Commission is also developing a Skills Agenda with the goal to upskill everyone within Europe - with a specific effort on women to enter technology.

Josie Cluer, EY's lead partner on skills and learning, argues for a "skills-led recovery". She says "skills is a key driver of growth, productivity, and the government's levelling up agenda. So the Prime Minister's plan to 'build build build' has to be underpinned by investment in 'skills skills skills'. Organisations too, need to invest in the skills of their people, because the capabilities they need will be different to those pre-COVID. And last, individuals themselves, wherever they are in the labour market, will need to invest in their own skills, for employment and progression". ${ }^{4}$

Essentially at the core of any governmental role on re-skilling is encouraging both organisations and individuals to have a 'learning orientated' mindset. This supports the underlying theory and applications in the dynamic approach to both individual and organisational development. Two 'dynamic' approaches show key skills to survive - and thrive. The first is Dynamic Capabilities, which offers a methodology for organisations to gauge changes and adapt to volatile and complex challenges (Teece 2019) and the second is Career Dynamism (Pasha 2020), which offers a career delivery model that enables people to develop adaptive qualities for career uncertainty. The concept of dynamic capability suggests it is organisational

4 https://www.henley.ac.uk/articles/why-we-need-a-skills-led-recovery. 
adaptive skills that enable "the firm's ability to integrate, build, and reconfigure internal and external competencies to address rapidly changing environments" (Teece, Pisano, Shuen 1997). Dynamic Capabilities methodology suggest AI offers firms competitive advantage through creating efficiencies (such as RPAs, voice assistants, blockchains, and bots) and innovations through 5G and IoT. Career Dynamism showed those people best at managing chaos and uncertainty have demonstrable 'future of work' skills for work that is both uncertain and volatile in nature (Pasha 2020). Abilities such as 'career-resilience' enables people to be both adaptive and pro-active, by demonstrating capabilities such as self-reliance and motivation to learn as well a positive self-concept by truly valuing their personal abilities. Career Dynamism highlights critical qualities such as human skills of creativity, openness and an ability to build positive relationships. These are crucial skills, because robots will undertake routine, data-heavy, mundane and dangerous work, leaving the possibility of unknown new jobs which will unquestionably be focused on such human qualities.

\section{What Might a 'New Normal' Mean for Us?}

No man ever steps in the same river twice, for it's not the same river and he's not the same man.

Heraclitus

We are in a 'new-normal', despite so many things looking similar. We have shared experiment of living and working through COVID-19. At the same time, major activist movements occurred during the pandemic, such as the Black Lives Matter movement, resulting in companies examining their diversity and inclusion culture - asking if they really do offer parity and equality. It is essential, therefore, that AI development is aligned to societal norms. Thus, software used in monitoring employee experience must ensure ethical diversity and inclusion practices, and be mindful of privacy needs of employees. For example, ensuring transparency in extracting building usage data and personal information from wearable tech, such as Fitbits and Apple watches. The role of 'Responsible AI' (Zhu 2019) will increasingly be a core activity that most tech producers are placing into their build strategy. Many firms are now using a multi-stakeholder approach to consider wider implications of AI, to ensure good governance, diversity and social impact. In building more ethical and responsible AI strategies, companies should build AI to align with the 'meaning and purpose' of corporate strategy - and both organisations and individuals will need to consider dynamic capabilities to achieve sustainable growth (Harreld, O’Reilly, Tushman 2007). 
The pandemic has forced huge changes in the world of work, a world that was also starting to experience dramatic change from AI. If we can adapt well and evolve to the changes the pandemic has caused, and adopt AI effectively, firms are likely to see better levels of productivity and growth. And with it, they may see their employees being happier, better skilled and have more adaptability and resilience to withstand future challenges.

\section{Bibliography}

Arthur, M.B. (1994). "The Boundaryless Career: a New Perspective for Organizational Inquiry”. Journal of Organizational Behavior, 295-306. https:// doi.org/10.1002/job.4030150402.

Harreld, J.B.; O’Reilly III, C.A.; Tushman, M.L. (2007). "Dynamic Capabilities at IBM: Driving Strategy into Action”. California Management Review, 49(4), 21 43. https://doi.org/10.2307\%2F41166404.

IDC (International Data Corporation) (2018). "The Digitization of the World From Edge to Core”. Framingham. https://bit.ly/2D31BCw.

European Commission (2020). "White Paper: On Artificial Intelligence - A European Approach To Excellence And Trust”. Brussels. https://bit. ly/2CJJ8ek.

McKinney, S.M.; Sieniek, M.; Godbole, V. et al. (2020). “International Evaluation of an Ai System for Breast Cancer Screening”. Nature, 577, 89-94. https:// doi.org/10.1038/s41586-019-1799-6.

LeBleu, L. (2020). "New Skills For A New World". Forbes. https://bit. ไy/2WUZeIT.

Meyer, H. (2019). "Five Policies to Deal with the Loss of Jobs to Automation (Ubi is not One of Them)". LSE Blogs, 12 April. https://bit.ly/2EhBisR.

Office for National Statistics (2019). "Which Occupations are at Highest Risk of Being Automated?”. ONS, 25 March. https://bit.ly/3hCVFij.

Parsons, T. (1949). Essays In Sociological Theory, Pure And Applied. Glencoe (Illinois): The Free Press.

Pasha, N. (2020). "Responding to Career Uncertainty: Applying a 'Dual-Empathy' Approach to Career Development Using Corporate Strategy Theory”. Journal of the National Institute for Career Education and Counselling, 2020, 44(1), 44-50. https://doi.org/10.20856/jnicec.4407.

Teece, D. (2019). "A Capability Theory of the Firm: an Economics and (Strategic) Management Perspective". New Zealand Economic Papers, 53(1), 1-43.

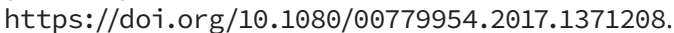

Teece, D.; Pisano, G.; Shuen, A. (1997). "Dynamic Capabilities and Strategic Management". Strategic Management Journal, 18(7), 509-33. https:// doi.org/10.10०2/(SICI) 1097-0266(199708)18:7\%3C509::AIDSMJ882\%3E3.๑.CO;2-Z.

World Economic Forum (2016). "The Future of Jobs: Employment, Skills and Workforce Strategy for the Fourth Industrial Revolution". http://www3. weforum.org/docs/WEF_Future_of_Jobs.pdf.

Zhu, W. (2019). "4 Steps to Developing Responsible Al”. World Economic Forum, 20 June. https://www.weforum.org/agenda/2019/06/4-steps-todeveloping-responsible-ai/. 


\title{
COVID-19 and Its Impacts on Talent Mobility in China
}

\author{
Mikkel Rønnow Mouritzen \\ Roskilde University, Denmark; University of Chinese Academy of Sciences \\ and Sino-Danish Center for Research \& Education, Beijing, China \\ Shahamak Rezaei \\ Roskilde University, Denmark; Sino-Danish Center for Research \& Education, Beijing, China \\ Yipeng Liu \\ Henley Business School, University of Reading, UK
}

\begin{abstract}
COVID-19 has caused countries around the world to close their doors and put strict measures on the mobility of people across geographical boundaries. What will be the impact on highly skilled talent? We address this important question by exploring the experiences of European researchers in China during COVID-19. We do so by utilising the newest unique data gathered in a survey by EURAXESS, which reports that $47 \%$ of the European researchers in China left due to the outbreak. We complement this with archive data, interviews, and COVID-19 regulations to discuss and forecast future scenarios for talent mobility to and from China.
\end{abstract}

Keywords COVID-19. Talent mobility. International researchers. Brain circulation. Travel barriers.

Summary 1 Introduction. - 2 Talent Mobility: Why It Matters. - 3 Talent Mobility on the Rise in EU: China as a Partner or Competitor. - 4 Talent Mobility in China: Traditionally a Brain Drain, But Becoming Competitive. - 5 Data and Methods. - 6 COVID-19 Impact on Cross Border Mobility. - 7 European Talents in China. - 8 Conclusion.

Innovation in Business, Economics \& Finance 1

ISBN [ebook] 978-88-6969-442-4 


\section{Introduction}

In a recent article, Liu, Lee, and Lee (2020) highlight how the COVID-19 pandemic is already having severe effects on both the global economy and global value chains. They emphasise that it is still too soon to draw definite conclusions concerning the consequences of the pandemic. However, they still point out an emerging trend, which shows that global supply chains are decoupling from China because of the pandemic. Moreover, they argue that this is happening in a time when there is a drastic reduction of air travel as well as severe travel restrictions (Liu, J.M. Lee, C. Lee 2020). In this chapter, we continue the discussion of migration and travel restrictions by exploring the effects of the pandemic on talent mobility amongst European researchers in China. Talent attraction policies have become increasingly important globally (OECD 2008). This has opened doors for academics around the world, only to come to a rapid halt because of COVID-19. The transformative issues arising in academia are highlighted in a recent series of articles published in Nature entitled "Science after the pandemic" (Witze 2020). The series explores some of the dramatic changes that have occurred in academia resulting from the COVID-19 outbreak. These issues include topics such as: what will happen to the nature of conferences, travel, and mobility? (Viglione 2020); what is occurring at now empty campuses? (Witze 2020); and how might publications change? (Callaway 2020). But they also deal with the effect on Chinese academia, which otherwise seems to have been on the rise since China became amongst the leading funders of researchers and the leading producer of academic articles (Cyranoski 2020). In this chapter, we will discuss what is happening to foreign researchers in China. We will mainly look indepth at European researcher's experiences and discuss the impact on European and Chinese scientific collaborations.

\section{Talent Mobility: Why It Matters}

Global flows of talent have become an increasingly important element of globalisation (Liu 2019). Whether in the public or private sector, the recruitment of individuals that can make a difference in organisations have become one of the key challenges of the decade (Lee, Rezaei 2019). In an article published before the COVID-19 crisis, Janger and Nowotny (2016) explore academic job choices and the international mobility of talented researchers. They find that in general job choices in academia are driven by factors such as collaboration partners, research funding, and academic freedom rather than personal factors. The literature on talent mobility suggests that the US is the first destination country for researchers and that it attracts 
the most substantial flows of international talent, making it able to reap the innovative rewards that come with global talent (Kerr et al. 2016; European Commission 2017; Kerr 2018). However, other countries have caught up and developed talent attraction schemes of their own (Shachar 2006; Shachar, Hirschl 2013, 2015). These schemes are particularly prominent in academia and often considered beneficial as the mobility of researchers aids in the creation and the diffusion of knowledge, which is of significant importance to knowledge economies (OECD 2008).

\section{Talent Mobility on the Rise in EU: China as a Partner or Competitor}

In an EU context, the introductions of both the Marie SkłodowskaCurie actions programme and Euraxess have aimed to encourage mobility amongst researchers. Here it is argued that:

[t]he main reason to foster geographic mobility lies in the fact that it is related to more intense knowledge flows through international collaboration and, as a consequence, increases scientific productivity which may, in turn, affect economic competitiveness. (European Commission 2017, 10)

These reasons for fostering mobility in order to compete in global research goes beyond the interest of the EU. Concerns revolving around the opportunities as well as risks related to being at the front of the research stage or falling behind are shared by countries such as Brazil, South Korea, India, and China - all countries that have recently been boosting the mobility opportunities for researchers (European Commission 2017).

\section{Talent Mobility in China: Traditionally a Brain Drain, But Becoming Competitive}

As the world's largest transition economy, talent in science and technology is critical to the development of a flourishing knowledge economy for China (Liu, Fang 2019). Since the opening of the Chinese economy and the increased mobility of students as well as researchers, China has suffered from a significant brain drain. The state, universities, and scientific organisations have therefore been part of implementing measures on both a country and local level which aim at attracting first Chinese returnees (Zweig, Kang, Wang 2020) and increasingly also foreign talents (Miao, Wang 2017). These efforts have coincided with the increased quality and the improved ratings of Chi- 
nese universities as well as the development of Sino-Foreign universities (Wang, Chen 2020). Even though these efforts have been successful to a certain extent, the individual talents and researchers seem to remain mobile whether they are Chinese or foreigners (Mouritzen, Rezaei, forthcoming).This reveals an element of vulnerability in the talent flows towards China, so although the country fairs increasingly well in the global competition for human capital, according to the MORE3 survey (European Commission 2017) and OECD publications, China remains a relatively unattractive place for foreign talent (OECD 2013) as seen in the figure below.

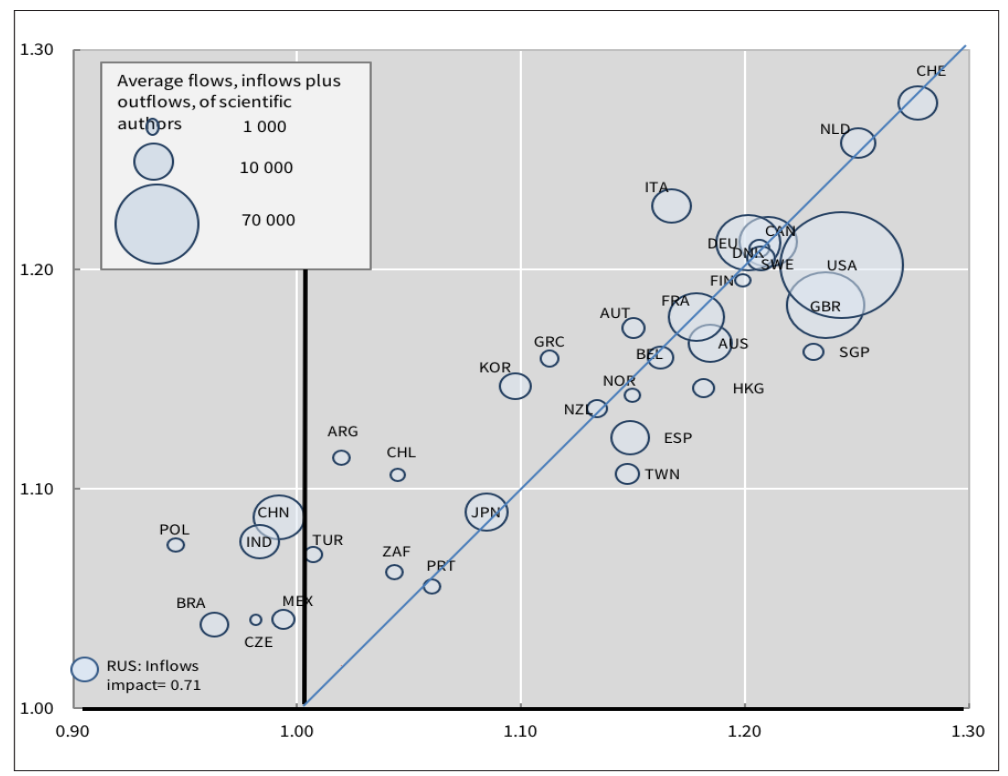

Figure 1 The impact of internationally mobile scientists, inflows versus outflows, 1996-2011 (OECD 2013)

\section{Data and Methods}

While the data revealed significant barriers to Europeans in China that remain relevant, new issues have arisen with the pandemic. In particular, we examined in-depth the 2020 survey conducted by Euraxess that has highlighted the new reality facing European talents in China after COVID-19. The material deriving from Euraxess is included as the organisation has a unique coverage within the community of European researchers in China. We complement the survey data with qualitative interviews collected by one of the authors of this paper during fieldwork in China before the pandemic and through online interviews 
with respondents after the pandemic, although the data collected after the pandemic is based on a smaller sample as many respondents were unavailable for various reasons connected to the pandemic. Finally, we draw upon recently published news and regulations.

\section{COVID-19 Impact on Cross Border Mobility}

As noted, the outbreak of COVID-19 considerably changed the academic reality globally. In China, the inflow of foreign talent has been limited, while the outflow seems to have increased during the pandemic. The challenges emerging because of COVID-19 are already influencing research activities conducted in China, particularly activities done by the group of foreign academics operating there, having forced many researchers to leave the country at least on a temporary basis. Thus, Euraxess China reports that as of March 6, 2020:

When asked if they left China amid the virus outbreak, $47 \%$ of researchers replied positively; among these, 63\% are not planning on returning to China or are uncertain when they will. (EURAXESS 2020)

The impact on foreign talents' cross-border mobility was affected by travel restrictions imposed by the Chinese government since March 28, 2020 (The Foreign and Commonwealth Office 2020b, 2020a), ${ }^{1}$ As stated below:

In view of the rapid spread of COVID-19 across the world, China has decided to temporarily suspend the entry into China by foreign nationals holding visas or residence permits still valid to the time of this announcement, effective from 0 a.m., March 282020. (Ministry of Foreign Affairs the People's Republic of China 2020)

1 As the virus spread across the globe, first moving to Europe only to be overtaken by the Americas, China was no longer the world's hotspot. Therefore, in a grander attempt to combat COVID-19, China implemented a string of restrictions on international travel. These included the suspension of the entry of most foreign nationals - even those who were holding valid visas that were issued before the announcement on March 26, 2020 (China Briefing 2020). Apart from all short-term visas such as transit visas and port visas lasting 72 to 144 hours, the visa restriction includes student visas, work permits, family visas, regular tourist visas, etc. Furthermore, they include such mobility options as the Asia Pacific Economic Cooperation (APEC) Business Travel Card (ABTC), which otherwise allowed individuals to move temporarily between fully participating economies for five years (China Briefing 2020). The few holders of the difficult to obtain green card (China Briefing 2019) are not subjected to restrictions (European Union Chamber of Commerce in China 2020b). It will only be visas issued after March 26, 2020 that will not be affected by the recently imposed restrictions (Ministry of Foreign Affairs the People's Republic of China 2020). 
The restrictions only became additionally significant, as many researchers had already left China to avoid the virus following the COVID-19 outbreak. As foreign holders of most visa types were no longer eligible to enter China, the restrictions have deeply affected international talents operating in China (European Union Chamber of Commerce in China 2020a). As a result, the European Chamber President contacted the Chinese Minister of Foreign Affairs to address the matter and request the easing of the restrictions. According to the European Chamber:

The Ministry of Foreign Affairs' (MFAs') official response recognised and thanked the Chamber for its support in China's fight against COVID-19, and clarified that Chinese green card holders are not subject to the entry restrictions. It also stated that a fasttrack system will be established for foreign nationals who need to return for urgent/necessary purposes, such as trade, science and research or humanitarian reasons. (European Union Chamber of Commerce in China 2020b)

Foreign nationals returning to China for necessary "economic, trade, scientific or technological activities or out of emergency humanitarian needs" will however still need to apply for a visa in order to enter China at the Chinese embassies or consulates abroad and undergo a quarantine period, affecting the travellers for at least 14 days. ${ }^{2}$ Moreover, there have also been severe restrictions on international flights, initiated on March 12, 2020 (Business Traveller 2020; Reuters 2020), so that only 20 international flights could land each day. ${ }^{3}$ By the end of May, it was decided to maintain the restrictions with few exceptions (BBC 2020; Nikkei Asian Review 2020).

2 Travellers will be required to undergo strict testing and individuals will be subjected to a quarantine period of 14 days, although it is possible to enter into a fast-track option available to individuals from countries that have signed fast track agreements with China. However, this requires that the company ensures that the employer remains in a closed circuit or a sealed of environment for 14 days, where a designated driver transports the individual from their home residence to their workplace without this employee having any physical contact with other members of the staff or other parts of society (European Union Chamber of Commerce in China 2020a).

3 The Civil Aviation Administration of China (CAAC) further implemented changes that reduced air travel to and from China, taking affect from March 12, 2020. These changes included a reduction of international flights such that Chinese Airlines could only maintain one route to any country with no more than one flight per week. A similar rule affected foreign airlines that were only allowed to maintain a single route to China and only fly once per week. Moreover, the rules state that each flight must "ensure passenger load factor no higher than 75\%" (CAAC 2020). 


\section{European Talents in China}

The restrictions have particularly affected the foreign community of mobile expats in China, both those who left China at the onset of the pandemic and the ones who stayed behind. Nevertheless, they are only a part of the pandemic's transformational force that we will discuss later, relying on a survey developed and disseminated by Euraxess China where 46 European researchers based in China responded. The survey was an early response to the COVID-19 crisis, and some of the results were published on March 6, 2020 (EURAXESS 2020). Currently, we are working with Euraxess to develop and disseminate new material that will be available at a later stage. While the low numbers challenge the representativeness of the survey, the data is still a reliable indicator of changes affecting talent mobility. When asked "Is the novel coronavirus outbreak and the resulting prevention-and-control measures having any current impact on your work and research activities?", close to $75 \%$ of the respondents replied that it had a medium or high impact on their activities, as illustrated below.

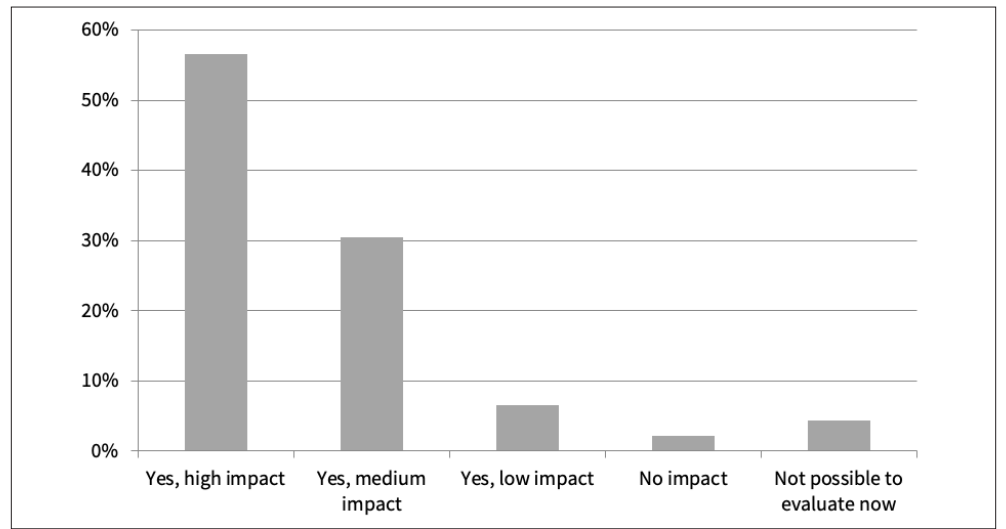

Figure 2 Is the novel coronavirus outbreak and the resulting prevention-and-control measures having any current impact on your work and research activities? With $56 \%$ responding Yes, high impact, $30 \%$ responding

Yes, medium impact, $6 \%$ Yes, low impact, $2 \%$ no impact and $4 \%$ responding not possible to evaluate now

This finding resonates with qualitative interviews conducted amongst researchers based in China. Amongst these respondents, of which many are now living in Europe as they have been blocked from re-entering China, a variety of answers emerged. Researchers who for various reasons decided to stay in China reported that they faced empty campuses and closed laboratories where only they could come and go. While this situation seems to be the new normal which has spread to most of the universities of the world (Witze 2020), the group of researchers stuck outside of China have been affected in slightly differ- 
ent ways with online meetings that at times have to include people based in both the EU and America as well as China. Moreover, most communication seems to have moved online - both the communication between individuals, such as a student and supervisors, but also institutional communication. When asked "Are you and/or your institution introducing or planning on introducing new online tools (such as online classes, webinars, online meetings, and group works) as an alternative to the normal activities?", close to $80 \%$ of the respondents reported that they either had implemented new online tools or were working on implementing new measures.

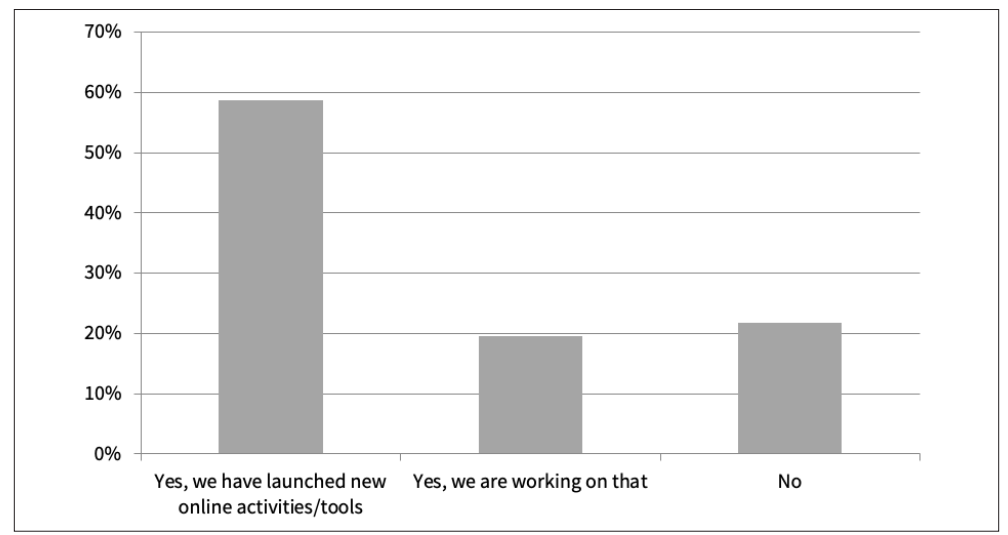

Figure 3 Are you and/or your institution introducing or planning on introducing new online tools (such as online classes, webinars, online meetings, and group works) as an alternative to the norma activities? With $59 \%$ responding that Yes, we have launched new online activities/tools, $20 \%$ responding Yes, we are working on that and $22 \%$ responding no

Like most institutions, Chinese universities have adapted to reality after COVID-19, and while it is still unknown what the exact effects of the pandemic will be on learning as well as migration, it is clear that university institutions across the globe are updating their teaching tools to address a new reality. In particular, the Sino Foreign Universities have reported challenges faced by their cohorts being scattered across the globe and their staff being unable to return to China [tab. 1]. 
Mikkel Rønnow Mouritzen, Shahamak Rezaei, Yipeng Liu COVID-19 and Its Impacts on Talent Mobility in China

Table 1 Challenges and solutions from four Sino Foreign university institutions

\begin{tabular}{lll}
\hline Challenges & $\begin{array}{l}\text { Initiatives that are dealing } \\
\text { with COVID-19 in the short } \\
\text { term }\end{array}$ & $\begin{array}{l}\text { Initiatives that are dealing } \\
\text { with COVID-19 and changes } \\
\text { in the long term }\end{array}$ \\
\hline $\begin{array}{l}\text { Some international staff } \\
\text { and students unable to return } \\
\text { to China. These are advised }\end{array}$ & $\begin{array}{l}\text { Fast transition to online teaching } \\
\text { within the first month of COVID-19 }\end{array}$ & $\begin{array}{l}\text { Planned online teaching ranges } \\
\text { from supporting the teachers } \\
\text { against returning to China. }\end{array}$ \\
& $\begin{array}{l}\text { to filling in full semesters } \\
\text { for international students } \\
\text { and staff blocked by entry barriers. }\end{array}$ \\
& $\begin{array}{l}\text { Most radically seen through } \\
\text { the Sino-Danish Center, which } \\
\text { plans a full-semester online }\end{array}$ \\
\hline
\end{tabular}

Reduction or cancellation

of physical activities, such as:

teaching activities, ceremonies, research activities, and $\mathrm{PhD}$ exchange activities
Online graduation ceremony

and other online events, such as choir contests and introductions to campus life

Reimbursed housing

Flexible semester starts, opening according to Chinese as well as global dynamics

Table based on publicly available information at New York University Shanghai (2020b, 2020a), Nottingham University Ningbo (University of Nottingham Ningbo China 2020b, 2020a), Duke Kunshan University (2020b, 2020a) and Sino-Danish Center (SDC 2020). Moreover, this is a brief collection of the most fundamental and reoccurring challenges related to travel barriers and entry issues. Research that would dive deeper into the actual institutions would reveal other issues and solutions, such as wearing masks on campus and connections between health initiatives in the university and the province.

Just like the challenges faced by the transnational institutions, individual researchers collaborating between China and Europe report that their collaborations have suffered during the pandemic. When asked "In case you are involved in collaborations between China and Europe, have they been affected in some way by the current outbreak?", a third of the respondents answered that it have had an impact, but that the impact is difficult to assess at the early stage, while another third replied that it already either had a medium or highly negative impact on their collaborations. 


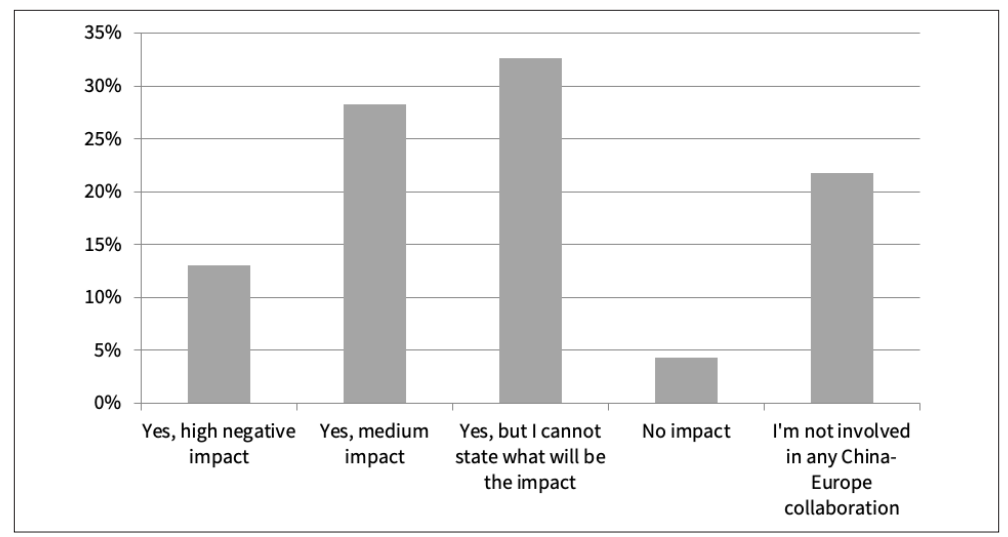

Figure 4 In case you are involved in collaborations between China and Europe, have they been affected in some way by the current outbreak? With $13 \%$ responding Yes, high negative impact, $28 \%$ responding Yes, medium impact, $33 \%$ responding Yes, but I cannot state what will be the impact, $4 \%$ responding No impact and $22 \%$ responding I'm not involved in any China-Europe collaboration

\section{Conclusion}

COVID-19 has abruptly put an end to talent mobility and talent flows. Early data suggests that research, teaching, and mutual collaboration shared by China and Europe will be significantly disadvantaged because of the pandemic. The barriers emerging include both travel restrictions and a significant reduction in the infrastructure that facilitates mobility across borders. This might have even stronger effects in the future by hampering students, researchers, and technicians from either entering a country in the first place or from returning to their country of origin. Moreover, teaching is changing significantly, and particularly transnational institutions are forced to apply online tools that may limit the exposure to other cultures and thereby hinder shared experiences in the time to come. Finally, it seems likely that collaborations across borders will be increasingly difficult to carry out. However, what this difficulty will mean for talent mobility and foreign talents spread out across the globe has yet to reveal itself fully. Therefore, questions relating to COVID-19's impact on talent mobility should be raised and answered based on in-depth empirical research. 


\section{Bibligoraphy}

BBC (2020). "China Eases Foreign Travel Limit After US Threat”. BBC News, 4 June. https://www.bbc.com/news/business-52912517.

Business Traveller (2020). "China Cuts International Flights to Stop Imported Coronavirus Cases". Business Traveller, 26 March. https://www. businesstraveller.com/business-travel/2020/03/27/china-cutsinternational-flights-to-stop-imported-coronavirus-cases/.

CAAC (Civil Aviation Administration of China) (2020). "Notice on Further Reducing International Passenger Flights During the Epidemic Prevention and Control Period". 26 March. http://www.caac.gov.cn/en/XWZX/202003/ t20200326_201748.html.

Callaway, E. (2020). "Will the Pandemic Permanently Alter Scientific Publishing?". Nature, 582, 167-8. http://doi.org/10.1038/d41586-๑2001520-4.

China Briefing (2019). "China Visas Explained: A Reference Guide". China Briefing News, 16 October. https://www.china-briefing.com/news/china-visas-explained/.

China Briefing (2020). "China's Travel Restrictions due to COVID-19: An Explainer". China Briefing News, 17 June. https://www.china-briefing.com/news/ chinas-travel-restrictions-due-to-covid-19-an-explainer/.

Cyranoski, D. (2020). "The Pandemic is Challenging China's Breakneck Race to the Top of Science". Nature, 582, 170-1. http://doi.org/10.1038/ d41586-020-01522-2.

Duke Kunshan University (2020a). "Chancellors welcome staff back to campus". https://dukekunshan.edu.cn/en/chancellors-welcome-staffback-campus.

Duke Kunshan University (2020b). "Coronavirus: Updates on DKU's response”. https://dukekunshan.edu.cn/en/news/special-message-novelcoronavirus.

EURAXESS (2020). "The Impact of COVID-19 on China-Based Researchers". EURAXESS, 6 March. https://euraxess.ec.europa.eu/worldwide/china/impact-covid-19-china-based-researchers.

European Commission (2017). Survey on Researchers outside of Europe. Annex to MORE3 Study: Support Data Collection and Analysis Concerning Mobility Patterns and Career Paths of Researchers. Luxembourg: Publications Office of the European Union. http://doi.org/10.2777/074782.

European Union Chamber of Commerce in China (2020a). "Clarification of Entry Measures for Foreign Employees into Shanghai During the Travel Ban (Normal and Fast track channels)". 23 May. https://bit.ly/2AUsyHP.

European Union Chamber of Commerce in China (2020b). "Progress Made Regarding Return of Foreign Nationals to China". 29 April. https://bit. ly/3gS9hGf.

Janger, J.; Nowotny, K. (2016). “Job Choice in Academia”. Research Policy, 45(8), 1672-83. http://doi.org/10.1016/j.respol.2016.05.001.

Kerr, S.P.; Kerr, W.; Özden, Ç; Parsons, C. (2016). "Global Talent Flows”. Journal of Economic Perspectives, 30(4), 83-106. http://doi.org/10.1257/ jep.30.4.83.

Kerr, W.R. (2018). The Gift of Global Talent: How Migration Shapes Business, Economy \& Society. Stanford: Stanford University Press. http://www.sup.org/ books/title/?id=29770. 
Lee, C.; Rezaei, S. (2019). "Talent Management Strategies in the Public Sector: a Review of Talent Management Schemes in Southeast Asia". Liu 2019, 36495. https://doi.org/10.4337/9781786437105.00027.

Liu, Y. (2019). Research Handbook of International Talent Management. Research Handbook of International Talent Management. Cheltenham (UK): Edward Elgar Publishing. https://doi.org/10.4337/9781786437105.

Liu, Y.; Fang, T. (2019). “China: Talent Management in Transition”. Liu 2019, 396421. https://doi.org/10.4337/9781786437105.00028.

Liu, Y.; Lee, J.M.; Lee, C. (2020). "The Challenges and Opportunities of a Global Health Crisis: the Management and Business Implications of COVID-19 from an Asian Perspective". Asian Business and Management, 19, 277-97. https://doi.org/10.1057/s41291-020-00119-x.

Miao, L.; Wang, H. (2017). International Migration of China, International Migration of China: Status, Policy and Social Responses to the Globalization of Migration. Springer. http://doi.org/10.1007/978-981-10-6074-8.

Ministry of Foreign Affairs the People's Republic of China (2020). "Ministry of Foreign Affairs of the People's Republic of China National Immigration Administration Announcement on the Temporary Suspension of Entry by Foreign Nationals Holding Valid Chinese Visas or Residence Permits". 26 March. https://www.fmprc.gov.cn/mfa_eng/wjbxw/t1761867.shtml.

Mouritzen, M.R.; Rezaei, S. (forthcoming). "Circular Time Travel Through the Belt \& Road Initiative: Is BRI a Mobility Facilitator or Blockage for Sea Turtles and Global Talent Flow?". Asian Journal of Social Science.

Nikkei Asian Review (2020). "Flying to China Still a Challenge as Restrictions Extended". Nikkei Asian Review, 26 May. https://asia.nikkei.com/ Spotlight/Caixin/Flying-to-China-still-a-challenge-as-restrictions-extended.

NYU Shanghai (2020a). "COVID-19 Updates for the NYU Shanghai Community". NYU Shanghai. https://shanghai.nyu.edu/updates-novel-coronavirus (Accessed 2020-06-30).

NYU Shanghai (2020b). "NYU Shanghai Community Stays Connected in a Time of Coronavirus". NYU Shanghai, 28 February. https://bit.ly/2OUVEdu.

OECD (Organisation for Economic Co-operation and Development) (2008). The Global Competition for Talent, The Global Competition for Talent. Paris: OECD Publishing. https://doi.org/10.1787/9789264047754-en.

OECD (2013). Researchers on the move: The impact of brain circulation. Paris: OECD Publishing. https://www.oecd.org/sti/researchers-on-themove-the-impact-of-brain-circulation.pdf.

Reuters (2020). "China Orders Sharp Cuts in Flights In, Out of Country to Curb Coronavirus Risk". Reuters, 26 March. https://reut.rs/32q507F.

SDC, Sino-Danish Center (2020). "SDC Cancels Activities in Beijing". 4 June. https://sdc.university/about/news/1-sdc-cancels-activities-in-beijing/.

Shachar, A. (2006). "The Race for Talent: Highly Skilled Migrants and Competitive Immigration Regimes”. New York University Law Review, 81(1), 148-206. https://bit.ly/2EbYTLj.

Shachar, A.; Hirschl, R. (2013). "Recruiting Super Talent: The New World of Selective Migration Regimes". Indiana Journal of Global Legal Studies, 20(1), 71-107. http://doi.org/10.2979/indjglolegstu.20.1.71. 
Shachar, A.; Hirschl, R. (2015). "On Citizenship, States, and Markets". Goodin, R.E.; Fishkin, J.S. (eds), Political Theory Without Borders: Philosophy. 206233. Wiley Blackwell. http://doi.org/10.1002/9781119110132.ch9.

The Foreign and Commonwealth Office (2020a). "Foreign Travel Advice: China”. https://www.gov.uk/foreign-travel-advice/china.

The Foreign and Commonwealth Office (2020b). "Entry Requirements - China Travel Advice". https://www.gov.uk/foreign-travel-advice/china/entry-requirements.

University of Nottingham Ningbo China (2020a). "Coronavirus: Update for Staff". 12 February. https://bit.ly/3epjEzJ.

University of Nottingham Ningbo China (2020b). "Coronavirus: Update for Students". 12 February. https://bit.ly/2ZoMQCD.

Viglione, G. (2020). "How Scientific Conferences Will Survive the Coronavirus Shock". Nature, 582, 166-7. http://doi.org/10.1038/d41586-02001521-3.

Wang, B.; Chen, J. (2020). "Emotions and Migration Aspirations: Western Scholars in China and the Navigation of Aspirational Possibilities". Journal of Ethnic and Migration Studies, 13 May. http://doi.org/10.1080/13691 83X.2020.1764841.

Witze, A. (2020). "Universities Will Never be the Same After the Coronavirus Crisis". Nature, 582, 162-4. http://doi.org/10.1038/d41586-020-01518-y.

Zweig, D.; Kang, S.; Wang, H. (2020). “'The Best are yet to Come': State Programs, Domestic Resistance and Reverse Migration of High-Level Talent to China". Journal of Contemporary China, 16 January. http://doi.org/10. 1080/10670564.2019.1705003. 

Part 10

Al and Big Data 



\title{
Artificial Intelligence and Data Analytics in Digital Business Transformation Before, During and Post COVID-19
}

\author{
Kecheng Liu \\ Informatics Research Centre, Henley Business School, University of Reading, UK \\ Hua Guo \\ Informatics Research Centre, Henley Business School, University of Reading, UK
}

\begin{abstract}
Business activities have become highly dependent on the functions that digital technologies offer. The role and critical value of digital technologies such as artificial intelligence and data analytics are clearly witnessed during the COVID-19 pandemic. It is hard to just imagine what the world would become if there were no Internet and digital technologies during these times. The trend and potential value of artificial intelligence and data analytics to leverage and transform organisations are explored, with challenges identified and directions offered to make businesses ready to embrace future unknowns.
\end{abstract}

Keywords Artificial intelligence. Data analytics. Digital transformation. Technology impact. Technology in pandemic.

Summary 1 Artificial Intelligence and Big Data Before and During COVID-19 Pandemic. -2 The Trend of AI \& Big Data Development in Post-Pandemic. - 3 The Challenges in Using Data Effectively for Social and Economic Analyses.

Innovation in Business, Economics \& Finance 1

ISBN [ebook] 978-88-6969-442-4 


\section{Artificial Intelligence and Big Data Before and During COVID-19 Pandemic}

Data has become one of the most valuable assets to determine the success of businesses and public sector institutions globally. Artificial intelligence (AI) and data analytics are the key factors to unlock the value of data assets. Data has played a vital role in the battle against COVID-19. From predicting epidemic progression, detecting infections and diagnosis, accelerating clinical discovery, optimising resource allocation, and supporting public policymaking, in almost every aspect of the epidemic response, AI and big data have made a positive contribution to strategic decision-making and operational measures.

From the perspective of different beneficiaries, with the help of $\mathrm{AI}$ and big data applications, data-driven pandemic responses have taken many forms:

- The public can access the latest statistics to understand the dynamic of the pandemic (WHO 2020b); get information on prevention (WHO 2020a; NHS 2020); receive notifications on the potential risk of infection - contact tracing (Google 2020); and get diagnostics or treatment advice from doctors (GSMA 2020; Ghosh, Gupta, Misra 2020). Transparent and sufficient information exchange avoids unnecessary panic among the public and helps cooperation.

- AI and big data modelling help governments to improve virus surveillance and responses via outbreak predictions (Ardabili et al. 2020; Strzelecki 2020), spread tracking (Zhou et al. 2020), resource allocation (Morariu et al. 2020; Ibrain, Salluh 2020), and policy decisions support (Gao et al. 2020; Gatto et al. 2020).

- AI empowered health institutions and agencies with quick computed tomography (CT) scan image recognition systems (Huang et al. 2020; Mei et al. 2020). In China, more than 100 hospitals employed AI image recognition in lung CT identification which helps with large-scale infection testing (Cheng 2020). Biomedical research might be the one that benefits the most from AI and big data technology (Mamoshina et al. 2016). The vast amount of biomedical data forms the foundation of genomic sequence analysis, drug discovery and vaccine development (Stebbing et al. 2020; Beck et al. 2020). The global race for coronavirus vaccine is essentially a competition to leverage the advantage of $\mathrm{AI}$ and big data in bioscience (Magar, Yadav, Farimani 2020). 
With regard to the accelerated adoption of AI and big data, we recognise three trends that are likely to influence the post-pandemic period.

The first trend is an accelerated digital transformation in various industries with the purpose to compete or even survive through digitisation of the production and delivery of products and services by deployment of technologies such as AI and data analytics. During the lockdown period, the digitisation in enterprise activities and virtual business grew fast, partly driven by the restrictions on the traditional way of conducting business. The increased mode of digital business processes may become the new normal for enterprises, public sectors and individuals. Therefore, traditional enterprises face an urgent necessity for digital transformation to servitise their offerings (Tien 2015) and use technical platforms to conduct business in digital business ecosystems (Liu, Guo, forthcoming). To a large extent, as commented by Atkins (2020), "COVID has been the catalyst for digital transformation at scale". However, enterprises should maintain a balance between their long-term strategic targets and the immediate company benefits that come from technological solutions, which may pose organisational challenges. In a recent survey (NewVantage Partners 2019) administered to 65 Fortune 1000 leading firms, about one third reckoned that they are not data-driven companies yet even though they have already adopted big data and AI and would still increase their investment in those areas. It follows that the journey of digital transformation for organisations is a long-term commitment that will require a radical shift of the mindset of the leadership and changes in business operations and culture across the firm (Liu, Li 2015).

The second trend is an increased exploitation of big data which bears broad implications for all sectors. Data harnessing involves a wide scope of activities starting from the ownership of data or digital sovereignty, to data collection, storage, management and utilisation. This raises a number of challenges. For instance, digital sovereignty is a highly debated issue that is still under the spotlight (Pinto 2019). When organisations grapple with increasingly larger data sets, they gradually improve their ability to change the landscape of business competition. Therefore, enhancing the ability of harnessing big data is critical to a company's long-term development.

The third trend is an easing of the bottleneck due to algorithm maturity. In a review conducted by Bullock et al. (2020), a broad range of AI-driven applications which are used against COVID-19 have been examined. The disappointing finding is that few of the current AI systems are mature enough to make a substantial operational impact in the fields of epidemiology, diagnosis and therapy. A conclusion derived from the study is that "AI systems are still at a preliminary stage, and it will take time before the results of such AI measures 
are visible" (Petropoulos 2020). The constrains mainly come from the lack of solid historical training data and the lack of quality data without noise and outliers (Naudé 2020).

These three trends are interrelated as progress in one area accelerates the advancement of others. The development of technological capabilities and the penetration of technologies to business practices and people's lives will bring profound changes in the years to come.

\section{The Challenges in Using Data Effectively for Social and Economic Analyses}

The need for and benefit from collaborative work in science and technology across disciplines and geographic boundaries have been recognised and even amplified during the COVID-19 pandemic. For example, since the National Oceanic and Atmospheric Administration (NOAA) has made their dataset open access, 68,000 other datasets have become publicly available (NOAA 2018). Those datasets have promoted innovations in weather applications and promoted scientific research in related fields. Other examples are the MIMIC open dataset, which was developed by the MIT Lab for Computational Physiology (Moody, Mark 1996) and the datasets of the Beth Israel Deaconess Medical Center (BIDMC) (Johnson et al. 2016). After more than 20 years of continuous maintenance and updating, BIDMC continues to make the datasets open to researchers as a comprehensive clinical and physiologic data source, which has led to significant contributions to research in the medical field.

Although great advantages are reaped in technological innovations from data openness, potential concerns relate to data misuse and the consequences of breaching data security. As new privacy and data protection laws are gradually put in place in many jurisdictions, the possible conflicts of interests between data openness and privacy become a significant factor in preventing the adoption of big data technology and AI. In order to solve privacy and security issues, researchers have attempted to train AI algorithms without using sensitive data. Federated learning (Konečný et al. 2016a, 2016b; McMahan et al. 2016) is one of the promising solutions which adopts decentralised collaborative machine learning and have been applied in retail, healthcare, and fintech (Yang et al. 2019). Due to differences in cultural backgrounds and strategies in the development and application of new technologies, different geographical regions have put different emphasis on data privacy. This represents a challenge for data re-use and sharing across industries and countries.

AI ethics is a topic that is much debated in academic and industry circles. Due consideration on AI ethics is needed during the process of system development. Dignum (2018) classifies AI ethics into 
three levels: ethics by design, ethics in design and ethics for design. These focus, respectively, on 1) AI's capabilities in ethical reasoning, 2) the methods of analysis and evaluation of AI's ethical implications, and 3) the code that should be adopted to ensure the ethical integrity of developers and users. AI ethics is not just a technical issue. Rather, it is a social concern with broad implications. The European Union published the first draft of ethics guidelines for trustworthy AI (HLEG) in December 2018 with the purpose of leading the discussion. Although there is still a long way to go before key regulations are in place, we believe that researchers in the relevant fields have a critical role to play for the safe and ethical deployment of AI in business, government sectors and society at large.

\section{Bibliography}

Ardabili, S.F.; Mosavi, A.; Ghamisi, P.; Ferdinand, F.; Varkonyi-koczy, A.R.; Reuter, U.; Rabczuk, T.; Atkinson, P.M. (2020). "Covid-19 Outbreak Prediction with Machine Learning". https://dx.doi.org/10.2139/ssrn.3580188.

Atkins, O. (2020). "Why the Covid-19 Pandemic Could Kick-Start Digital Transformation at Scale". The Drum, 18 May. https://bit.ly/3jE3N4c.

Beck, B.R.; Shin, B.; Choi, Y.; Park, S.; Kang, K. (2020). "Predicting Commercially Available Antiviral Drugs that May Act on the Novel Coronavirus (SARSCoV-2) through a Drug-Target Interaction Deep Learning Model". Computational and Structural Biotechnology Journal, 18, 784-90. https://doi. org/10.1016/j.csbj.2020.03.025.

Bullock, J.; Luccioni, A.; Pham, K.H.; Lam, C.S.N.; Luengo-Oroz, M. (2020). "Mapping the Landscape of Artificial Intelligence Applications against COVID-19". arXiv preprint. https://arxiv.org/abs/2003.11336.

Cheng, M.-M. (2020). "Al System in Expediting Diagnosis of COVID-19". https://bit.ly/20UfmGp.

Coeckelbergh, M. (2020). Al Ethics. Cambridge (MA): MIT Press.

Dignum, V. (2018). "Ethics in Artificial Intelligence: Introduction to the Special Issue". Ethics and Information Technology, 20, 1-3. https://doi. org/10.1007/s10676-018-9450-z.

Gao, S.; Rao, J.; Kang, Y.; Liang, Y.; Kruse, J. (2020). "Mapping County-Level Mobility Pattern Changes in the United States in Response to COVID-19". SIGSPATIAL Special, 12, 16-26.

Gatto, M.; Bertuzzo, E.; Mari, L.; Miccoli, S.; Carraro, L.; Casagrandi, R.; Rinaldo, A. (2020). "Spread and Dynamics of the COVID-19 Epidemic in Italy: Effects of Emergency Containment Measures". Proceedings of the National Academy of Sciences, 117, 10484-91. https://doi.org/10.1073/pnas.2004978117.

Ghosh, A.; Gupta, R.; Misra, A. (2020). "Telemedicine for Diabetes Care in India during COVID19 Pandemic and National Lockdown Period: Guidelines for Physicians". Diabetes \& Metabolic Syndrome: Clinical Research \& Reviews, 14(4) 273-6. https://dx.doi.org/10.1016\%2Fj.dsx.2020.04.001.

Google (2020). "COVID-19 Exposure Notifications System”. https://support. google.com/android/answer/9888358?hl=en-GB. 
GSMA (Global System for Mobile Communications) (2020). The Role of Al for Impact in the Fight against COVID-19. https://bit.ly/3jnw3be.

HLEG, A. (2018). Ethics Guidelines for Trustworthy Al. European Commission. https://bit.ly/3jkDjEx.

Huang, L.; Han, R.; Ai, T.; Yu, P.; Kang, H.; Tao, Q.; Xia, L. (2020). "Serial Quantitative Chest CT Assessment of COVID-19: Deep-learning Approach". Radiology: Cardiothoracic Imaging, 2(2), e200075. https://doi.org/10.1148/ ryct. 2020200075.

Ibrain, J.; Salluh, F. (2020). "A COVID-19 Dashboard: Data Analytics to Aid Resource Allocation in Intensive Care Units". ICU Management \& Practice, 20(1), 36-7. https://bit.ly/2ZKHtOj.

Johnson, A.e.; Pollard, T.J.; Shen, L.; Li-Wei, H.L.; Feng, M.; Ghassemi, M.; Moody, B.; Szolovits, P.; Celi, L.A.; Mark, R.G. (2016). "MIMIC-III, a Freely Accessible Critical Care Database". Scientific Data, 3, 1-9. https://doi. org/10.1038/sdata.2016.35.

Konečný, J.; McMahan, H.B.; Ramage, D.; Richtárik, P. (2016a). "Federated Optimization: Distributed Machine Learning for On-Device Intelligence". arXiv preprint. https://arxiv.org/abs/1610.02527.

Konečný, J.; Mcmahan, H.B.; Yu, F.X.; Richtárik, P.; Suresh, A.T.; Bacon, D. (2016b). "Federated Learning: Strategies for Improving Communication Efficiency". arXiv preprint. https://arxiv.org/abs/1610.05492.

Liu, K.; Guo, H. (forthcoming). "Digital Innovation and Transformation to Business Ecosystems". Filipe, J.; Smialek, M.; Brodsky, A.; Hammoudi, S. (eds), Enterprise Information Systems: 22th International Conference, ICEIS 2020. Springer Nature Switzerland AG.

Liu, K.; Li, W. (2015). Organisational Semiotics for Business Informatics. London: Routledge Abingdon.

Magar, R.; Yadav, P.; Farimani, A.B. (2020). "Potential Neutralizing Antibodies Discovered for Novel Corona Virus Using Machine Learning". arXiv preprint. https://arxiv.org/abs/2003.08447.

Mamoshina, P.; Vieira, A.; Putin, E.; Zhavoronkov, A. (2016). "Applications of Deep Learning in Biomedicine". Molecular Pharmaceutics, 13(5), 1445-54. https://doi.org/10.1021/acs.molpharmaceut.5b○0982.

McMahan, H.B.; Moore, E.; Ramage, D.; Arcas, B.A. (2016). "Federated Learning of Deep Networks using Model Averaging". arXiv preprint. https://arxiv.org/abs/1602.05629v1.

Mei, X.; Lee, H.-C.; Diao, K.-Y.; Huang, M.; Lin, B.; Liu, C.; Xie, Z.; Ma, Y.; Robson, P. M.; Chung, M. (2020). "Artificial Intelligence-Enabled Rapid Diagnosis of Patients with COVID-19". Nature Medicine. https://doi.org/10.1038/ s41591-020-0931-3.

Moody, G.B.; Mark, R.G. (1996). "A Database to Support Development and Evaluation of Intelligent Intensive Care Monitoring". Computers in Cardiology 1996. Indianapolis: ISEE, 657-60. https://doi.org/10.1109/ CIC.1996.542622.

Morariu, C.; Morariu, O.; Răileanu, S.; Borangiu, T. (2020). "Machine Learning for Predictive Scheduling and Resource Allocation in Large Scale Manufacturing Systems". Computers in Industry, 120, 103244. https://doi. org/10.1016/j.compind.2020.103244.

Naudé, W. (2020). "Artificial Intelligence Against COVID-19: An Early Review". IZA Discussion Papers No. 13110. http://ftp.iza.org/dp13110.pdf. 
NewVantage Partners, L. (2019). Big Data and Al Executive Survey 2019: Data and Innovation How Big Data and Al are Accelerating Business Transformation. Boston; New York; San Francisco; Austin; Charlotte: NewVantage Partners. https://bit.ly/32DbAsI.

NHS (National Health Service) (2020). Coronavirus (COVID-19). https://www. nhs.uk/conditions/coronavirus-covid-19/.

NOAA (National Oceanic and Atmospheric Administration) (2018). NOAA EXpands Public Access to Big Data. https://www.ncei.noaa.gov/news/ noaa-expands-big-data-access.

Petropoulos, G. (2020). "Artificial Intelligence in the Fight against COVID-19". Bruegel, 23 March. https://www.bruegel.org/2020/03/artificialintelligence-in-the-fight-against-covid-19/.

Pinto, R.A. (2019). “Digital Sovereignty or Digital Colonialism?”. Sur International Journal on Human Rights, 27. https://sur.conectas.org/en/digital-sovereignty-or-digital-colonialism/.

Stebbing, J.; Phelan, A.; Griffin, I.; Tucker, C.; Oechsle, O.; Smith, D.; Richardson, P. (2020). "COVID-19: Combining Antiviral and Anti-Inflammatory Treatments". The Lancet Infectious Diseases, 20(4), 400-2. https://doi. org/10.1016/s1473-3099(20)30132-8.

Stone, P.; Brooks, R.; Brynjolfsson, E.; Calo, R.; Etzioni, O.; Hager, G.; Hirschberg, J.; Kalyanakrishnan, S.; Kamar, E.; Kraus, S. (2016). Artificial Intelligence and Life in 2030. One Hundred Year Study on Artificial Intelligence: Report of the 2015-2016 Study Panel. Stanford (CA): Stanford University. http://ai100. stanford.edu/2016-report.

Strzelecki, A. (2020). "The Second Worldwide Wave of Interest in Coronavirus since the COVID-19 Outbreaks in South Korea, Italy and Iran: A Google Trends Study". arXiv preprint. https://arxiv.org/abs/2003.10998.

Tien, J.M. (2015). "Internet of Connected ServGoods: Considerations, Consequences and Concerns". Journal of Systems Science and Systems Engineering, 24, 130-67. https://doi.org/10.1007/s11518-015-5273-1.

WHO (World Health Organization) (2020a). Coronavirus disease (COVID-19) Pandemic. https://www.who.int/emergencies/diseases/novel-coronavirus-2019.

WHO (2020b). WHO Coronavirus Disease (COVID-19) Dashboard. https://bit. ly/2E2yPCt.

Yang, Q.; Liu, Y.; Chen, T.; Tong, Y. (2019). "Federated Machine Learning: Concept and Applications". ACM Transactions on Intelligent Systems and Technology (TIST), 10(2), 1-19. https://doi.org/10.1145/3298981.

Zhou, C.; Su, F.; Pei, T.; Zhang, A.; Du, Y.; Luo, B.; Cao, Z.; Wang, J.; Yuan, W.; Zhu, Y. (2020). "COVID-19: Challenges to GIS with Big Data". Geography and Sustainability, 1(1), 77-87. https://doi.org/10.1016/j.geosus.2020.03.005. 



\title{
Reshaping the Future Unlocking the Potential of Alternative Data for the Post-COVID-19 World
}

Hung-Yi Chen

Zhejiang University International Business School, China

\begin{abstract}
Alternative data has steadily become more mainstream in investment decision-making. These non-traditional datasets provide a channel to draw insights from information as diverse as satellite images, news, tweets, mobile and internet traffic and credit card purchases. While alternative data has become an industry buzzword, making meaningful use of it remains a challenge. The ongoing financial crisis caused by the COVID-19 pandemic poses unprecedented challenges. This chapter explores examples of how alternative data can be used to help economic recovery.
\end{abstract}

Keywords Alternative data. COVID-19. Data interface. Decision-making.

Summary 1 Introduction. - 2 Alternative Data Applications. - 3 Conclusion.

\section{Introduction}

As many countries around the world continue to face unprecedented challenges from COVID-19, the longer-term economic impact of the crisis is uncertain. In the best-case scenario, the path out of the pandemic-induced recession may be 'V-shaped', that is, a quick rebound. But a protracted 'U-shape' or 'L-shape' recession or a 'W-shape' double-dip recession caused by another wave of infections may not be ruled out at present. How should governments respond to this situation? Could technology and alternative data sources be leveraged to correct the current economic contraction and pave the way for a fast recovery? 
Alternative data comprises information as diverse as satellite images, news, tweets, mobile and internet traffic and credit card purchases. For example, Bloomberg, a data provider, offers a Tesla production tracker (Randall, Halford 2019) that monitors the vehicle identification numbers (VINS) registered by Tesla with safety regulators before production and VINS submitted to Bloomberg by Tesla car owners. This enables Bloomberg to provide real time forecasts of Tesla production rather than rely on infrequent (i.e. quarterly) company reports. Other examples are Nasdaq's acquisition of Quandl, one of the largest alternative data platforms, ${ }^{1}$ and Refinitiv's partnership with BattleFin to integrate alternative datasets with Eikon and its quantitative analytics platform. ${ }^{2}$

These non-traditional datasets also provide a channel to draw insights from the financial profile of a consumer or business. These data sources have the potential to overcome barriers to financial inclusion and enable more diversified risk assessment models for marginalised individuals or small and medium-sized enterprises (SMEs). Over the last few months, most SMEs have likely seen their liquidity buffers come under pressure because of the pandemic-induced economic slowdown (OECD 2020). It is therefore necessary to accelerate the digitisation of the financial industry in order to provide new frameworks for credit decisions, as small businesses and the self-employed are extremely vulnerable. While there is still substantial scepticism over how useful this new information will ultimately prove to be, this chapter seeks to review potential solutions and draw early lessons in order to effectively cope with, recover from or adapt to today's challenging situation. For example, in the current context, it is of interest to identify effective ways to exploit alternative datasets to inform prompt corrective actions in response to the global economic recession. This could include, for instance, impact analyses of markets and industry sectors such as healthcare, consumer goods, transportation and utilities.

\section{Alternative Data Applications}

The use of alternative data for trading purposes is not new. Investors have always been adept at using it to gain an informational edge in the market. Venetian traders would use telescopes to inspect the flags of incoming ships in order to derive clues as to the type of car-

1 "Nasdaq Acquires Quandl to Advance the Use of Alternative Data". Nasdaq, 4 December 2018. https://www.nasdaq.com/about/press-center/nasdaq-acquiresquandl-advance-use-alternative-data.

2 "Refinitiv Makes Strategic Investment in BattleFin and Partners to Incorporate Alternative Datasets within Investor Workflow". Refinitiv, 18 June 2019. https://refini.tv/3jeZDQ6. 
go being carried and also what commodities they would buy or sell accordingly (Wigglesworth 2020).

The ongoing financial crisis caused by the COVID-19 pandemic is unconventional, which has led investors to seek alternative data with the purpose of seeing when the market rebound is likely to begin (Georgiadis, Lockett, Wigglesworth 2020). Analysts mine figures from traffic congestion to food-delivery apps. For example, the traffic index provided by Tom Tom employs data from 600 million drivers to gauge the level of congestion in 416 major cities worldwide. It showed that the traffic congestion level of Wuhan, China, during the lockdown, was obviously lower than the previous year. ${ }^{3}$ However, correlation can be misinterpreted as causation. For instance, the travel data provided by the Transportation Security Administration suggests that the number of Americans flying has been gradually increasing since its nadir in mid-April. ${ }^{4}$ Further, data from Apple shows that more drivers have been searching for directions in the US since April, which might suggest that the economy is starting to recover. ${ }^{5}$ Is this the evidence that the economic rebound is beginning? Or is there no relationship and the number is increasing purely because people feel more confident or just tired of the lockdown conditions? Without rigorous research, alternative data does not offer a clear picture of where the economy is heading or how quickly we might be able to go back to pre-crisis conditions.

Traditional monthly economic indicators such as GDP performance are released weeks or months after the events take place, and may be difficult to use for decision-makers to predict new economic trends and make timely decisions. As an economist aptly suggested, "Obviously, slow data is not helping us right now. We need to start looking at fast data: data arriving at a daily or weekly frequency" (McCracken 2020).

How we can access and utilise alternative data efficiently poses a serious challenge to its exploitation. According to Refinitiv, $80 \%$ of data is unstructured and must be processed into structured content (Gaumer 2020). How to use unstructured data? For example, unstructured text analysis via machine learning algorithm can be used to evaluate the credit risk and default potential of a company. To this end, relevant unstructured data sources include conference call transcripts, company filings and related news. However, finding, testing and using data costs considerable time, energy and money. It there-

3 “Coronavirus: Green Shoots?”. Financial Times, 2 March 2020. https://ftalphaville.ft.com/2020/03/02/1583143211000/Coronavirus--green-shoots-/.

4 "TSA Checkpoint Travel Numbers for 2020 and 2019". Transportation Security Administration, 2020. https://www.tsa.gov/coronavirus/passenger-throughput.

5 “COVID-19 Mobility Trends". Apple, 2020. https://www. apple.com/covid19/mobility. 
fore requires time and human resources that may not be affordable to every decision-maker.

Both BattleFin and Quandl, leading financial and alternative data providers, offer a solution for enabling their clients to easily obtain financial data in the form of an Application Programming Interface (API). ${ }^{6}$ This saves people a lot of time in obtaining, cleaning and processing the data. So, access to the data is not enough, but rather how data can be easily utilised to generate meaningful analysis. For example, the New York Federal Reserve's Weekly Economic Indicator $^{7}$ is an example of how high-frequency data was compiled to provide a measure for current economic conditions. In particular, the key question is how to transform unstructured data into structured content, and also whether to encourage the use of APIs as key elements for data integration.

QR codes were used to track the health status of citizens and their movements during the pandemic in several countries. A QR code is an example of how we can build an interface for efficiently utilising alternative data in the digital world. In the last few months, China has rolled out health code systems across cities (Weinland 2020) with the purpose of identifying those who visited areas with high infection rates or who had been diagnosed with the virus, as well as to track whether individuals had completed a mandatory quarantine. Russia, France, Qatar, and many other countries also adopted similar measures to control the spread of the coronavirus.

\section{Conclusion}

The pandemic crisis spread extremely quickly across countries and much of its economic impact is likely yet to be seen. The ongoing financial crisis is, in many ways, atypical. In the face of the unprecedented nature of current challenges, this chapter presented some examples of how alternative data can be used to support decisionmaking. As the pandemic and its effects are likely to linger for some time, it is important that any informational advantage offered by new sources of data to improve our response to new infections and put our economies on a solid path to recovery is utilised to its fullest. Alternative data appear to offer promising solutions to today's world problems. Harnessing their power is the challenge of our current times and an opportunity to increase the resilience of our society.

6 "Financial Data API". Quandl, 2020. https://www.quandl.com/tools/api.

7 “Weekly Economic Index (WEI)". Federal Reserve Bank of New York, 2020. https:// www.newyorkfed.org/research/policy/weekly-economic-index. 


\section{References}

Cong, L.; Li, B.; Zhang, Q. (2019). "Alternative Data for FinTech and Business Intelligence". http://dx.doi.org/10.2139/ssrn.3521349.

Gaumer, T. (2020). "Finding Alpha with Unstructured Data". Refinitiv Perspectives, 29 January. https://refini.tv/2DMRTEN.

Georgiadis, P.; Lockett, H.; Wigglesworth, R. (2020). “Investors Hunt for Alternative Data to Track Coronavirus Shock". Financial Times, 19 February. https://www.ft.com/content/4667b18c-5249-11ea-8841-482eed००38b1.

In, S.Y.; Rook, D.; Monk, A.H.B. (2019). "Integrating Alternative Data (Also Known as ESG Data) in Investment Decision Making". http://dx.doi. org/10.2139/ssrn.3380835.

Jagtiani, J.A.; Lemieux, C. (2019) "The Roles of Alternative Data and Machine Learning in Fintech Lending: Evidence from the Lending Club Consumer Platform". Financial Management, 48(4). https://doi.org/10.1111/fima.12295.

Katona, Z.; Painter, M.; Patatoukas, P.N.; Zeng, J. (2018). On the Capital Market Consequences of Alternative Data: Evidence from Outer Space (July 30, 2018)". 9th Miami Behavioral Finance Conference 2018. http://dx. doi. org/10.2139/ssrn.3222741.

McCracken, M. (2020). "COVID-19: Forecasting with Slow and Fast Data". Federal Reserve Bank of St. Louis, 3 April. https://bit.ly/20VHd98.

Monk, A.H.B.; Prins, M.; Rook, D. (2018). "Rethinking Alternative Data in Institutional Investment". http://dx.doi.org/10.2139/ssrn.3193805.

OECD (Organization for Economic Co-operation and Development) (2020). "Coronavirus (COVID-19): SME Policy Responses". OECD, Updated 19 May 2020. https://bit.ly/2CYKUIh.

Randall, T.; Halford, D. (2019). "Tesla Model 3 Tracker”. Bloomberg, 28 May. https://www.bloomberg.com/graphics/tesla-model-3-vintracker/.

Weinland, D. (2020). "China's Covid-19 QR Code Surveillance State”. Financial Times, 7 May. https://www.ft.com/content/eee43c3e-8f7c11ea-9b25-c36e3584cda8.

Wigglesworth, R. (2020). "Stockpickers Turn to Big Data to Arrest Decline". Financial Times, 11 February. https://on.ft.com/32SW4ta.

Zhang, T. et al. (2020). "Economic Impact Analysis of the Coronavirus, An Alternative Data Perspective". https://dx.doi.org/10.2139/ssrn.3617029.

Zhu, C. (2018). "Big Data as a Governance Mechanism". The Review of Financial Studies, 32(5), 2021-61. https://doi.org/10.1093/rfs/hhy๑81. 



\section{Part 11}

Travel, Tourism and Entertainment 



\title{
Travel and Tourism At the Frontline of COVID-19
}

Adrian Palmer

Henley Business School, University of Reading, UK

\begin{abstract}
The travel and tourism sector was hit more rapidly and deeply by COVID-19 than most other sectors. Recovery to pre-COVID-19 activity levels is likely to be prolonged, and questions are raised whether enforced change in consumer behaviour will have long-term effects. The travel and tourism sector has a history of reinventing itself, and previous predictions of decline following crises have often been short-lived. This chapter reviews historical precedents and theories of consumer behaviour to explore whether recovery will be different this time round, especially given the possible habit breaking effects of online substitutes, and political expediency of reducing causes of climate change.
\end{abstract}

Keywords Tourism. Travel. COVID-19. Festivals. Virtual tourism. Climate change.

Summary 1 COVID-19-A Crisis for Travel and Tourism. - 2 Which Tourism Pioneers Will Lead the Return? - 3 Reality or Virtual Reality? - 4 Festivals Have Been a Growing Sector Within Tourism. -5 Business Tourism. -6 Green Dividends. -7 Reinvention.

\section{COVID-19 - A Crisis for Travel and Tourism}

Tourism has suffered more than most sectors from the COVID-19 pandemic. The World Travel and Tourism Council (WTTC 2020) reported that in 2019, the last full year before the pandemic, the travel and tourism sector globally grew by $3.5 \%$, outpacing overall economic growth of $2.5 \%$. This pattern of tourism growth outpacing general economic growth had also occurred in the 9 preceding years. By 2020, WTTC estimated that the sector accounted for $10.3 \%$ of global GDP and 330 million jobs, or 1 in 10 jobs around the world.

Innovation in Business, Economics \& Finance 1

ISBN [ebook] 978-88-6969-442-4 
The concept of a lockdown, brought on by COVID-19, caused instant harm to the sector, making its impact one of the most immediate and severe of any sector. Condé Nast reported that on 7 April 2020, the total number of U.S. air passengers recorded by the Transportation Security Administration (TSA) fell below 100,000 for the first time in the agency's history - a 95\% drop compared to the passenger numbers on the same day one year earlier. Over half of the world's aircraft fleet was parked up, costing the world's airlines an estimated $\$ 1.6$ billion of lost revenue per day (Condé Nast Traveler 2020).

Inconvenient or annoying to those denied their holiday, lockdown was devastating to communities dependent on tourists' spending. Hotels worldwide closed and some tourist resorts resembled ghost towns, at a time when they should have been buzzing with tourists spending their money. Governments throughout the world intervened with measures to support the sector, especially to counter the social consequences of unemployment, and to preserve supply side flexibility for when the travel and tourism sector got back on its feet again.

But as we start thinking about the post-COVID-19 world, questions have been asked about what the recovery would look like for the tourism sector. A crisis invariably creates opportunities as well as challenges. New forms of virtual substitutes for tourism have appeared. Climate change protesters have celebrated the temporary banishing of aircraft from the skies and saw COVID-19 as a timely opportunity to fix the causes of global warming. Questions were being asked about the process of recovery in the sector. It was easy to impose a lockdown, but much more difficult to manage a return to normal. Indeed what would be the new normal? There has been a lot of crystal ball gazing, but if we draw on fundamental research about consumer behaviour, and reflect on historical precedents, we might get a better picture.

\section{Which Tourism Pioneers Will Lead the Return?}

Tourism will not one day suddenly be switched back on. Tourism will have to re-launch itself, and history tells us that most product launches see buyers segmented into groups of pioneers, early adopters, through to the laggards who will only adopt when everybody else has. Pioneers have always been a feature of tourism - for example the first to visit warfare zones after a ceasefire and the eager pioneers to be the first 'space tourists'. All eyes will be on the pioneers to kickstart the tourism revival. Way behind them will be a mass-market of people who only venture out if everybody else in their peer group is doing so. Many research studies have demonstrated the power of peer group reference in making purchase decisions. So it may take more than the lifting of travel restrictions to entice fearful people 
back, and will need the perception that other people like them are going on holiday. The most difficult thing to predict here is individual's perception of fear - of becoming infected, or of being stranded away from home in a new lockdown. There may be unintended consequences here which are difficult to predict. 'Social distancing' to keep people apart, the use of face masks and the ubiquity of sanitisation stations may be medically correct, but may reassure and create perception of fear in equal measure.

\section{$3 \quad$ Reality or Virtual Reality?}

Every big downturn in tourism leads to predictions that the sector will never be the same again. Dire predictions were made after 9/11, however most indices of tourism are now well above pre-9/11 levels (US Bureau of Transportation Statistics 2005). "But it is different this time round' is a common repost. This time, greater use of the Internet has been claimed to reduce the need for travel. During lockdown, consumers have been forced to break habits and learn to use new video communications, but will these bring about a long-term change in tourism habits?

The tourism literature has for a long time explored the reasons why people travel. Essentially there are push and pull factors at work. Pull factors relate to the inherent attractiveness of a destination - sunshine, scenery, access to friends and relatives, etc. Push factors represent a desire to escape the confines of current life constraints and to live - temporarily at least - an alternative life. A few days sightseeing in a historic city can be a welcome escape from the tedium of everyday life. But can online tourism provide such escape?

In fact, video portrayal of tourism can be both a substitute and a stimulus to seek the real thing. We have been here before. When colour television first appeared and people could enjoy the sights of an African safari from their armchair, the question was asked why would people need to go there? But seeing it on television evoked desire to see the real thing, and instead of being a substitute, television encouraged more people to go on a real safari. Many films and television soap operas have similarly evoked desire to go and see the film location, or a recreation of the film set. Simulated tourism using artificial intelligence may allow us to imagine that we are walking the streets of Paris or New York but, based on historical precedent, the virtual experience may lead us to seek the authentic real thing.

Customer experience and authenticity have become two big drivers of consumption. Customer experience is often defined in terms of the memorability of an event. Tourism on a video screen can only ever be two-dimensional - sound and sight, with none of the smell, taste or touch of actually being there. So online only has two dimen- 
sions for creating memories, compared to five in real life. Consumers seek out more authenticity as they get wealthier, whether it is authenticity in their music, choice of yoghurt, or tourism experiences. This is unlikely to change, so the quest for 'authentic' tourism experiences will continue. Of course, in an increasingly crowded world of tourism, and diverse media images, it can be debated how tourists construct their idea of authenticity.

Another emerging question, especially for millennials, is the distinction between reality and virtual realities. In a world where an individual's work and leisure life is largely spent online, real-world experiences can stand out as a point of difference. So in a world of streamed music, a music festival is a point of difference in life. One of the reasons for recent growth in book festivals may be a desire to bring e-books to life. For an Instagram generation, 'being there' offers an additional sense of identity and group leadership, reinforced by powerful images sent to followers. Again, we see the paradox of virtual realities feeding tourism demand for the real-life tourism related experiences.

\section{Festivals Have Been a Growing Sector Within Tourism}

Festivals are a growing generator of tourism business. They are essentially a coming together of people with a shared interest. We can learn a lot from sociology about the way in which being a member of a group reinforces an identity, distinguishing a 'tribe' of festivalgoers who are the 'in-crowd' from everybody else who is 'out-crowd'. Festivals often involve travel away from home to be with like-minded people, whether it is camping out and sharing music at a music festival, or sharing a love of books at the growing number of book festivals. The Association of Independent Festivals (AIF 2018) has estimated that audiences at AIF Member festivals spent more than £386 million in 2017, with $£ 34.7$ million of that being spent in the local area of the festival they attended. The average festivalgoer spent $£ 483.14$ while attending a festival, leading to local economic suffering where festivals were cancelled due to the COVID-19 pandemic.

Festivals have also put online delivery to the test - is an online format of a festival a substitute or a complement for the real thing? Festivals which had to cancel their summer 2020 events have developed imaginative ways of keeping in touch with their followers, including live streaming of book and music festivals and interactive presentations by science festivals. Festivals that have gone online have made either no charge or only a nominal charge - the main objective has been to retain the loyalty of followers and retain a diary slot for the following year. Organisers have realised that it would be very difficult to charge anything like the normal attendance fee 
for a virtual festival - there is so much free material available online and high charges for an event low in experiential quality may alienate loyal followers.

Online formats of festivals are probably here to stay. But without the experiential qualities of face-to-face, they will probably only ever be complementary. A challenge for organisers is that having a high quality, creative online presence may now have become a basic expectation of followers who - after the creative adaptations associated with COVID-19 - may not be happy with the previous status quo of a basic static website. This follows a pattern in many service sectors where online has not replaced face-to-face, but created duplicated and complementary routes to customers which must both be supported with investment. How should festivals build online into their business models? What will the business models of festivals look like in the 'new normal'?

\section{Business Tourism}

Business tourism is an increasingly important source of tourism revenue, and conference delegates often use resorts to fill off-peak capacity. With so many now using Zoom conferences, surely demand for business tourism will fall sharply post-COVID-19? This is certainly not a foregone conclusion, and the law of unintended consequences may again kick in here. In the early days of the Internet, many predicted that commuting would decline as people worked from home and didn't need to travel to the office. In fact, working from home wasn't a binary home or office choice, but most people typically work part of the time at the office and part at home. If you only need to go to the office twice a week, it doesn't matter too much if you live a lot further away, so commuting distances increased with the appearance of the long-distance commuter. Could something similar happen postCOVID-19? It is quite likely that more people will work from home. But this may spur a need to bring teams together face-to-face so that they can better identify as a team. And with office space cut back, meeting space may be hired in from hotels and conference centres. This is following a well-trodden path, with many conference facilities already filled with salespeople and other professionals who work from their homes scattered through the country, and who meet for regular team meetings at centrally located hotels and conference centres.

We even need to challenge the assumption that business tourism involves a cognitive, rational decision process, and will therefore be replaced by Zoom meetings. Business travel may be important to individuals' self-esteem and self-image, and may be a status symbol which business people will fight to preserve, regardless of the rational benefits of doing business through videoconferencing. The end 
of business tourism has been predicted before, but it remains to be seen whether this time round the combined effects of climate change, lingering virus dangers and greater familiarity with online conferencing will encourage firms to eschew the emotional appeal of the face-to-face meeting and instead opt for the cost saving and socially responsible videoconferencing option.

\section{Green Dividends}

The other great change in tourism 'this time round' is the spectre of climate change. Restricting international travel through COVID-19 may have been disastrous for some tourism communities, but has helped to delay climate change. Will this forced interruption to travel break habits and focus peoples' spending away from long-distance tourism to other leisure activities which are more benign to the planet? This prospect is in itself unlikely.

There has been a lot of research showing holidays being high on households' lists of spending priorities, for example the ABTA Holiday Habits report in 2019 suggested a growing commitment by UK consumers to spending money on holidays, despite a problematic economic outlook (ABTA 2019). There has been much reported hypocrisy of climate campaigners using planes to travel in what they admit would be a harmful way. This is symbolic of a cognitive dissonance between peoples' need to enjoy the benefits of tourism, yet at the same time feel inwardly calm and socially accepted in their support for measures to limit climate change. The tourism sector has been quite astute in tackling this cognitive dissonance. Flying with an airline which uses the most fuel-efficient aircraft and paying to plant trees to offset carbon emissions provides a clear conscience for those who feel guilty about travel.

The great expansion phases in long-distance leisure tourism have been associated with big reductions in the cost of travel - easyJet's early promise of a flight to the Mediterranean for less than the price of a pair of jeans opened new markets for tourism. In the immediate post-COVID-19 scenario, costs of flying are likely to be increased, caused by restricted supply from airlines who have closed down, and possibly lingering measures to reduce the spread of the virus. Cost - including measures to address climate change and virus limitation - is likely to drive or constrain long-distance tourism. And governments may have been emboldened by COVID-19 to further help reduce climate change. Simply not bailing out the airline sector may restrict supply and raise prices, without much cost or effort by governments. Governments may also see the break in consumers' habits as an opportunity for driving through environmental changes which increase the costs of tourism. Demand for long-distance tourism is 
more likely to be influenced by its cost than a general sentiment towards climate change.

\section{Reinvention}

Tourism has had a habit of reinventing itself over many decades. COVID-19 will not destroy it, and if we look at historical precedent, it is unlikely to dampen long-term demand. Fear and cost may in the short-term restrict the resumption of long-distance tourism, and a reinvigorated 'staycation' may lead the way. Climate change may pose a short- to medium-term challenge to the sector, possibly buoyed by experience with the COVID-19 closedown of the sector. But in the longer term, tourism has shown its capacity to adapt. Fear of travel may be a short-term constraint, but in the longer-term, falling costs of new climate friendly travel technologies may help to reinvent the sector again. And in an online world in which consumers seek greater authenticity, constant images of faraway places are likely to further stimulate demand for travel, rather then replace it.

\section{Bibliography}

ABTA (Association of British Travel Agents) (2019). ABTA Holiday Habits report 2019. London: ABTA.

AIF (Association of Independent Festivals) (2018). 10 Year Annual Report 20082018. London: Association of Independent Festivals.

Condé Nast Traveler (2020). Coronavirus Air Travel: These Numbers Show the Massive Impact of the Pandemic. https://www.cntraveler.com/story/coronavirus-air-travel-these-numbers-show-the-massiveimpact-of-the-pandemic?verso=true.

US Bureau of Transportation Statistics (2005). Airline Travel since 9/11. https://www.bts.gov/archive/publications/special_reports_ and_issue_briefs/issue_briefs/number_13/entire.

WTTC (World Travel and Tourism Council) (2020). Economic Impact Reports. https://wttc.org/Research/Economic-Impact. 



\title{
European Football After COVID-19
}

\author{
J. James Reade \\ University of Reading, UK \\ Carl Singleton \\ University of Reading, UK
}

\begin{abstract}
The European football industry has suffered an unprecedented shock from COVID-19. In this chapter, we reflect on how the sport's administrators responded to the initial outbreaks and what lessons can be learned. We also look ahead to what football in the post-COVID-19 era could look like. We conclude that this largely depends on the decisions now facing the sport's administrators and the powerful owners of the biggest football clubs: will they prioritise football as the inclusive and diverse game, at the heart of local communities? Or will their intrinsic financial interests dominate?
\end{abstract}

Keywords Soccer. Sports Economics. Sports Finance. Coronavirus. Sports Management.

Summary 1 Introduction. - 2 Finishing the 2019-20 Season. - 3 How Could Football be Different in the Post-COVID-19 Era? - 4 Concluding Remarks.

\section{Introduction}

A deadly airborne virus means social distancing and threatens the entire business model of European professional football - sport normally involves large gatherings of people, where an airborne virus can spread. ${ }^{1}$ Following the outbreak of COVID-19, by April 2020 practically all major professional sports had ground to a halt worldwide. Football leagues were suspended, ei-

1 See Stoecker, Sanders, Barreca 2016 and Cardazzi et al. 2020 for evidence from North America that sports events can increase the mortality from influenza in local areas. See Parnell et al. 2020 for a discussion of the implications of COVID-19 for mass gatherings and major sports events, such as the previously planned 2020 UEFA European Championship.

Innovation in Business, Economics \& Finance 1

ISBN [ebook] 978-88-6969-442-4 
ther by themselves or by governments, from the elite level, normally played in front of tens of thousands of fans, to the bottom levels, or 'grassroots', played on local parks and recreation grounds.

Football has become an economically important business. In 201819 , the twenty highest earning football clubs in the world, all in Europe and eight of them in England, generated a combined income of $€ 9.3$ billion (see Deloitte 2020). The growth in European football over the past three decades has been remarkable. The most prosperous league over that period, the English Premier League (EPL), had broadcast rights for 2019-22 valued at $£ 9.2$ billion, with around $46 \%$ of that from overseas (see Svenson 2019). Figure 1 shows how the value of the domestic TV rights for the English Premier League increased from $£ 61$ million per season in 1992 to $€ 1.7$ billion by 2016 [fig. 1].

In this chapter, we discuss how this growth industry has been affected by the COVID-19 global pandemic. First, we summarise how European football responded to the initial shock and disruption caused by the outbreak, mainly focusing on what happened in England. Second, we contemplate how football and its business could be different in the post COVID-19 era. Finally, we offer some concluding remarks, suggesting that the immediate future of European football very much depends on the vision and priorities of its principal decision makers.

\section{Finishing the 2019-20 Season}

As COVID-19 spread globally, sports events that could be postponed were postponed, e.g. the Summer Olympic Games and the UEFA European Football Championship. Annual events that couldn't be postponed were cancelled, e.g. the The Championships, Wimbledon, the Boston Marathon and the Formula One Australian Grand Prix.

The wrangling that took place in the suspended European football leagues during the spring of 2020, concerning their resumption or otherwise, has made clear that the two most fundamental influences are government and money. ${ }^{2}$ In France and the Netherlands (both countries with a rich footballing heritage), the football seasons were cut short due to the intervention of the respective governments. The bans on sports in these countries reached far enough into the summer that a resumption would be impractical, without affecting the start of the next season.

2 Safety played a role too, primarily affecting the timing of resumptions though, rather than the decision between cancelling and continuing. In the immediate weeks around the peak levels of infection, leagues determined that they could not justify using scarce national COVID-19 testing resources to ensure the virus was not spreading among the players and other people involved in putting on football matches, even if they were resolved to return. 


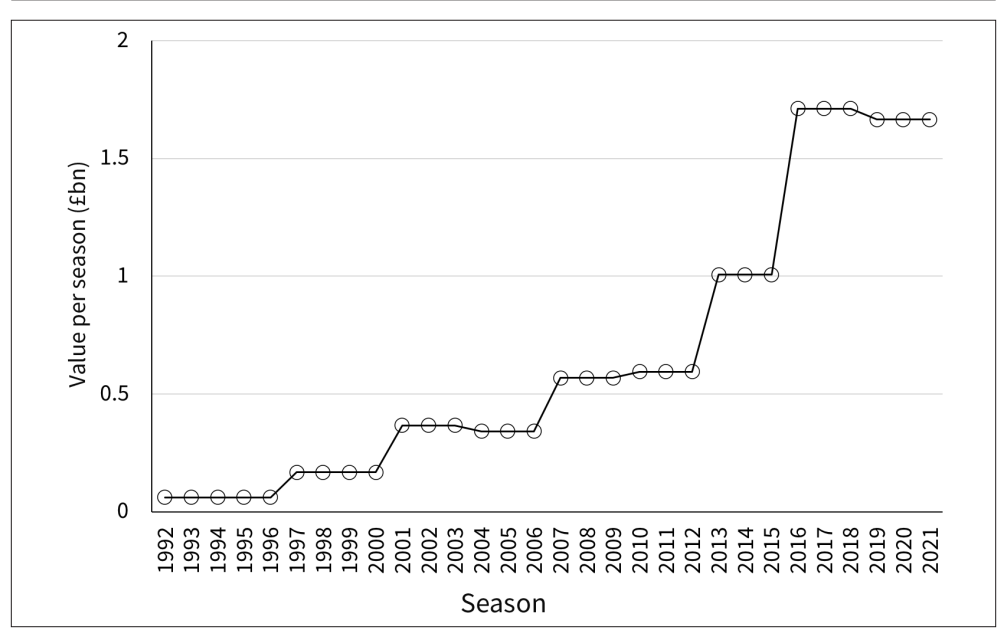

Figure 1 Nominal value of domestic broadcast rights for the English Premier League 1992-92 to 2021-22; author calculations using SportsBusiness Media Rights Tracker, accessed May 2020

Other seasons were cut short, such as in the English lower leagues, arguably because the decision makers were able to impose particular outcomes (usually applying points per game before the season was suspended), to determine the champions, promotion and relegation, without fear of significant adverse financial repercussions from legal action. ${ }^{3}$ Between 2012 and 2015, a club relegated from the EPL, in the best case, suffered a $£ 20$ million loss in revenue, and, in the worst case, $£ 50$ million. ${ }^{4}$ Conversely, the minimum revenue gain to a club from promotion to the EPL in this period was $£ 33$ million, and the maximum gain was $£ 76$ million. Because of these large sums in English football that depend on the outcome of a season, the EPL and the EFL Championship, the second tier, could not be decided in 2019 20 by some arbitrary measure, or even a forecast of likely outcomes.

The financial model of football in Europe, but especially in England, has changed dramatically in the last thirty years, following the formation of the EPL as a breakaway from the English Football League. In 1990, average revenues within the English Fourth Divi-

3 Although not all leagues have avoided this issue. Heart of Midlothian F.C. have begun legal action against the Scottish Professional Football League after they were relegated from the top division when it was cut short (https://www.theguardian.com/football/2020/jun/15/hearts-legal-action-spfl-relegation-scottish-premiership).

4 These and the following financial values are author calculations using the annual reports filed by football clubs at Companies House, the UK's registrar of companies (https://www.gov.uk/government/organisations/companies-house). 
sion (now League 2) were $12 \%$ of those generated by clubs in the First Division (now EPL). But in 2015 the equivalent figure was $2 \%$.

Football has operated on a professional basis for almost a century and a half, and yet at no point in that time has a set of circumstances arisen such as those imposed by COVID-19, where it was financially unviable, and in some cases legally impossible, to complete seasons. One lesson from the crisis is that a set of revised rules and regulations regarding the cutting short of seasons is required. Sports leagues will need procedures in place that determine the exact method by which a season will be cut short, if a particular threshold of matches has been played, or will instead be abandoned, if too few have been played. ${ }^{5}$ If it is known in advance that points per game, weighted or otherwise by other factors (e.g. goals scored, home or away form, uncertainty), will be used to decide the season outcomes, then leagues can be cut short without fear of legal repercussions.

The increased concentration of money at the top of the game has had significant impacts further down the leagues too, since little of the revenues coming into the game make their way down to the grassroots level. Liberalisation of football's labour market has resulted in a larger proportion of immigrant labour at the top of the game over the years, rather than local players making their way up the leagues (see for example the Taylor 2007). Opportunities for local young men and women to succeed in the game are reduced. In England, the Football Association has responsibility for the grassroots, and, along with many small town and village clubs, it has lost out on significant sources of revenues in the summer of 2020 because of COVID-19. Festivals on football pitches and music concerts at stadiums are not only part and parcel of the British summer but also the financial viability of football outside the elite levels. ${ }^{6}$ These patterns are not unique to English football. Without substantial support from governments or a fairer redistribution of wealth in the football pyramid, it seems unlikely that the rich ecology of association football, down to its grassroots, with all its attendant mental and physical health benefits, will look the same post COVID-19.

\section{How Could Football be Different in the Post-COVID-19 Era?}

The future of European football in the post-COVID-19 era largely depends on how soon it will be safe for the fans to return to stadiums, and whether they will come back. To the best of our knowledge, there

5 This happened with the 1939-40 season in England, abandoned after only 3 matches.

6 In June 2020, England's Football Association announced 124 job losses and expected losses of $£ 300$ million (see https://www.bbc.co.uk/sport/football/53222021). 
is not yet any conclusive evidence regarding how easily the virus is transmitted at a large outdoor public gathering such as in a sports stadium. ${ }^{7}$ But regardless, common sense in the ongoing public health emergency dictates that fans should not be returning soon.

A vast literature has looked at the effects of crowds on football match outcomes (e.g. Garicano, Palacios-Huerta, Prendergast 2005; Buraimo, Forrest, Simmons 2010). Along with the familiarity of playing at home and the fatigue from travelling away, the impact of the home crowd has been suggested as a factor in accounting for the substantial home advantage in professional team sports (Schwartz, Barksy 1977), i.e. teams tend to win more often when playing in their own stadiums. Two studies of the rare instances when professional European football was played behind closed doors, before COVID-19, have found evidence that home advantage was disproportionately eroded in these matches (Pettersson-Lidbom, Priks 2010; Reade, Schreyer, Singleton 2020). Figure 2 describes the differences between matches with fans and without in the latter of these studies, showing that on average the normal home advantage was approximately wiped out, accounted for by fewer goals scored by home teams [fig. 2]. Referees also punished players on the away teams significantly less without the pressure from the crowd. However, these results were generally based on one-off games behind closed doors. It is not clear whether they were driven by the familiarity factor rather than reduced referee bias. Further, rules have been changed for the football which has returned since COVID-19, such as an increased number of substitutions, which could also plausibly affect match outcomes.

Nonetheless, it has been widely noted that home advantage has not only disappeared but even reversed in the first major European league to complete its domestic season. ${ }^{8}$ In the German Bundesliga geisterspiele (ghost games), from the post-COVID-19 resumption up to the end of the 2019-20 season, home teams won just $32 \%$ of the matches played (26 of 82, compared with $43 \%$ in the same season before March). Away teams, however, won $45 \%$ (37 of 82 ) of the post-shutdown matches, compared with $35 \%$ in the season beforehand. Figure 3 summarises the trends of home advantage in professional football since 1890, as well as what has happened generally since the European virus-induced social lockdowns [fig. 3]. When football returned behind closed doors in May, home advantage looked to have disappeared, but this has partly

7 There is some preliminary evidence from North American Sports that the different severity in local areas of the initial US outbreak was related to sports events. Ahammer, Halla and Lackner (2020) found that NBA (basketball) and NHL (ice hockey) games in early March 2020 significantly increased the rate of COVID-19 confirmed cases and deaths by the end of April 2020 in the areas surrounding the venues.

8 See for example ESPN, 9th June 2020 (https://www.espn.co.uk/football/germanbundesliga/story/4107639/). 


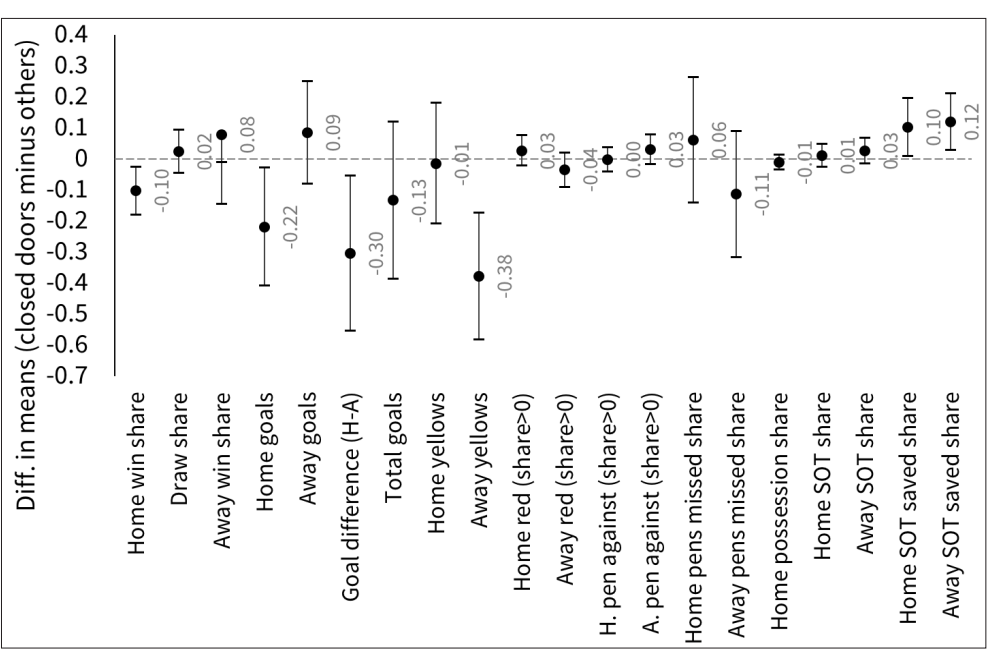

Figure 2 Differences in sample means of football match outcomes: closed doors vs with fans, 2002-03/2019-20. Uses all matches in the UEFA Champions League, Europa League, Italian Serie A, Serie B, Serie C, Coppa Italia and French Ligue 1 since the beginning of the 2002-03 season. SOT is Shots on Target. See details in Reade, Schreyer, Singleton 2020

recovered throughout June, perhaps as teams have become more familiar with the lack of fans in their stadiums.

Why does home advantage matter in football? Home advantage ensures that a weak team in its own stadium has a good chance of beating a strong visiting team (Forrest et al. 2005). If the reduction in home advantage without fans is greater for weaker teams, then stronger teams will win more often, and the competitive balance of leagues will be reduced. Studies have found that the demand for football on television is increased by the uncertainty of the match outcome (e.g. Buraimo, Simmons 2009; Cox 2018; Schreyer, Schmidt, Torgler 2018a, 2018b). This suggests that TV audience demand for European football could be affected if matches remain behind closed doors. Reduced home advantage should increase the attractiveness of matches featuring a strong home team and a weak away team, and vice versa when those relative strengths are reversed. In addition, there could be a second effect on demand, as changes in home advantage that are not equally distributed over team strengths would tend to affect the competitiveness of overall league championships and the interest of fans.

It is also not clear that matchday revenues will recover quickly when fans can return to stadiums. One argument is that there will be a pent-up demand effect, that could offset or override the negative demand effects from any ongoing risk of COVID-19 infection. Two of the most sustained attendance increases in the history of English 


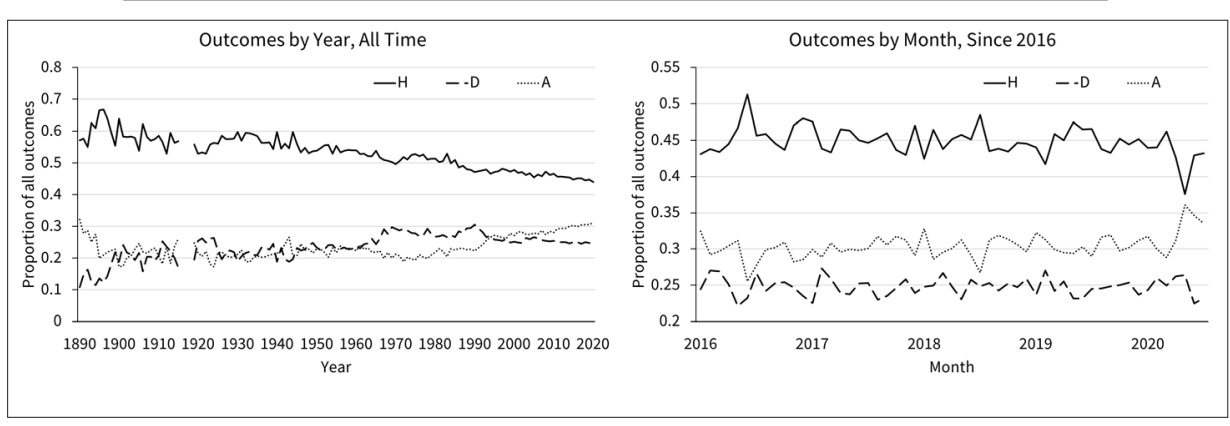

Figure 3 Professional football result outcomes since 1890 (left panel), and between January 2016 to June 2020 (right panel). $\mathrm{H}$ refers to home wins, D refers to draws and A refers to away wins. Uses all matches in the top leagues of 108 countries or regions since 1890, 82 countries since January 2016, and 29 in May and June 2020 Author calculations using https://www.worldfootball.net/

football came after the suspensions brought about by each World War (e.g. Dobson, Goddard 1995). But this is a tentative parallel at best. Reade and Singleton (2020) found that in the initial stages of the European COVID-19 outbreak there were already substantial negative demand responses, suggestively because of the implied risk of infection, even when the significance of the disease and its implications were being widely played down.

The elite European football clubs are likely to survive the outbreak financially, given their continued access to substantial funds besides match-day gate receipts. But professional football below that level still relies on ticket revenues. By studying the 2018-19 accounts of professional football clubs in England and Wales, Szymanski (2020) found that the majority of these businesses were already on the verge of insolvency before the loss of revenues and write-down of assets, i.e. player valuations, due to COVID-19. ${ }^{9}$ If the present structures of professional football are to survive, then some consolidation will be needed. Szymanski (2020) notes that much of football club debt is owed to other clubs, in the form of delayed player transfer payments. Therefore, if any club goes bankrupt it has knock-on effects for others, both domestic and foreign, potentially leading to financial contagion. He suggests that the consolidation of the national football business model should involve assigning the valuable future broadcast rights from the top league to a collective fund, from which those unable to collect unpaid debts can make claims, including for delayed transfer fees and player wages. In other words, the only way to save

9 This research was presented at the Reading Online Sport Economics Seminars (ROSES) on 17 April 2020. See here for a public recording: https://www.youtube.com/ watch?time_continue $=4006 \& v=v i P q e 93 r w 2 c \&$ feature $=$ emb_logo. 
the existing professional football pyramids today is to leverage the future value of football after COVID-19.

\section{Concluding Remarks}

The financial pressures facing most firms in the European football industry will be acute unless drastic collective actions are taken. The benefactor club owners have deep but not bottomless pockets, nor endless patience. Major football clubs and national associations will need to prioritise their resources. The women's game has been an area of substantial growth in participation and interest in recent years. ${ }^{10}$ Given the potential for further growth in this area and others, football's decision makers could find opportunities within any consolidation. By diverting some of the resources held by the powerful elite leagues, which currently feather superstar players' nests and tickle billionaire owners' egos, such as in the EPL, they could make longer-term investments in the health of the European football industry. The football labour market is also overdue for reform. In the 2019-20 season, EPL clubs paid £263 million in fees to the agents representing players. ${ }^{11}$ The influence of these agents should be curtailed, as it represents next to nothing in added value to the sport, but sees large sums of money exiting it, which could be used to prop up the rest of the pyramid and invest in the women's game. Given the public good that football can deliver, in terms of public health and social cohesion, there may be a case for state intervention, not only to support the industry financially but also to force a re-evaluation of whom the beautiful game ultimately serves.

10 For example, in England, 11.7 million watched England's defeat to USA at the 2019 FIFA Women's World Cup, compared with a peak of 2.4 million four years before in the previous World cup (see https://www.theguardian.com/football/blog/2020/jan/02/ womens-football-decade-of-progress-2020).

11 See for example BBC Sport, 24 June 2020; https://www.bbc.co.uk/sport/football/53170215. 


\section{Bibliography}

Ahammer, A.; Halla, M.; Lackner, M. (2020). "Mass Gatherings Contributed to Early COVID-19 Spread: Evidence from US Sports". Covid Economics, Vetted and Real-Time Papers, 30, 44-62. https://cepr.org/file/9200/ download?token=ubiH6c2i.

Buraimo, B.; Forrest, D.; Simmons, R. (2010). "The 12th man?: Refereeing bias in English and German soccer". Journal of the Royal Statistical Society: Series $A$ (Statistics in Society), 173(2), 431-49. https://doi.org/10.1111/ j.1467-985X.2009.00604.x.

Buraimo, B.; Simmons, R. (2009). "A Tale of Two Audiences: Spectators, Television Viewers and Outcome Uncertainty in Spanish Football". Journal of Economics and Business, 61(4), 326-38. https://doi.org/10.1016/j. jeconbus.2008.10.002.

Cardazzi, A.; Humphreys, B.R.; Ruseski, J.E.; Soebbing, B.; Watanabe, N. (2020). "Professional Sporting Events Increase Seasonal Influenza Mortality in US Cities". Working paper. https://dx.doi.org/10.2139/ssrn. 3628649.

Cox, A. (2018). "Spectator Demand, Uncertainty of Results, and Public Interest". Journal of Sports Economics, 19(1), 3-30. https://doi. org/10.1177/1527002515619655.

Deloitte (2020). "Deloitte Football Money League: Eye on the Prize”. January. https://www2.deloitte.com/uk/en/pages/sports-businessgroup/articles/deloitte-football-money-league.html.

Dobson, S.M.; Goddard, J.A. (1995). "The Demand for Professional League Football in England and Wales, 1925-92". Journal of the Royal Statistical Society. Series D (The Statistician), 44(2), 259-77. https://www.jstor.org/ stable/2348449.

Forrest, D.; Beaumont, J.; Goddard, J.; Simmons, R. (2005). "Home Advantage and the Debate About Competitive Balance in Professional Sports Leagues". Journal of Sports Sciences, 23(4), 439-45. https://doi. org/10.1080/02640410400021641.

Garicano, L.; Palacios-Huerta, I.; Prendergast, C. (2005). "Favouritism Under Social Pressure". The Review of Economics and Statistics, 87(2), 208-16. https://doi.org/10.1162/0034653053970267.

Parnell, D.; Widdop, P.; Bond, A.; Wilson, R. (2020). "COVID-19, Networks and Sport”. Managing Sport and Leisure. https://doi.org/10.1080/237504 72.2020.1750100.

Pettersson-Lidbom, P.; Priks, M. (2010). "Behavior Under Social Pressure: Empty Italian Stadiums and Referee Bias”. Economics Letters, 108(2), 212-14. https://doi.org/10.1016/j.econlet.2010.04.023.

Taylor, G. (2007). Meltdown: The Nationality of Premier League Players and the Future of English Football. Manchester: Professional Footballers Association.

Reade, J.J.; Schreyer, D.; Singleton, C. (2020). "Echoes: What Happens When Football is Played Behind Closed Doors?". Economics Discussion Papers em-dp2020-14, Department of Economics, Reading University. https:// ideas.repec.org/p/rdg/emxxdp/em-dp2020-14.html.

Reade, J.J.; Singleton, C. (2020). "Demand for Public Events in the COVID-19 Pandemic: A Case Study of European Football". Economics Discussion Papers em-dp2020-09, Department of Economics, Reading University. https://ideas.repec.org/p/rdg/emxxdp/em-dp2020-09.html. 
Schreyer, D.; Schmidt, S.L.; Torgler, B. (2018a). "Game Outcome Uncertainty and Television Audience Demand: New Evidence from German football”. German Economic Review, 19(2), 140-61. https://doi.org/10.1111/geer.12120.

Schreyer, D.; Schmidt, S.L.; Torgler, B. (2018b). "Game Outcome Uncertainty in the English Premier League: Do German Fans Care?". Journal of Sports Economics, 19(5), 625-44. https://doi.org/10.1177/1527002516673406.

Schwartz, B.; Barsky, S. (1977). "The Home Advantage". Social Forces, 55(3), 641-61. https://www.jstor.org/stable/2577461.

Stoecker, C.; Sanders, N.J.; Barreca, A. (2016). "Success /s Something to Sneeze At: Influenza Mortality in Cities that Participate in the Super Bowl". American Journal of Health Economics, 2(1), 125-43. https://doi.org/10.1162/ AJHE_a_00036.

Svenson, D. (2019). "English Premier League Data Report, 2019”. SportBusiness Media, 18 September. https://media.sportbusiness.com/2019/09/ free-english-premier-league-data-report-2019/.

Szymanski, S. (2020). "Covid-19 and Football Club Insolvency". mimeo. 


\section{Part 12}

Politics: Protectionism and Populism 



\title{
Why Collaboration Needs to Win Over Protectionism
}

Benjamin Laker

Henley Business School, University of Reading, UK

\begin{abstract}
The COVID-19 virus is severely affecting international trade, creating a negative fiscal outlook. Consequently, the global economy is receiving its sharpest reversal since the Great Depression. As such, we are seeing several countries invoke restrictions or taking action to secure medical supplies. A by-product of this is protectionism. One should worry most about developing countries without any domestic suppliers, who also need critical medical supplies, and who will be locked out, and not access essential equipment, medicines, and basic foodstuffs because of export restrictions set by developed nations. Therefore, collaboration is needed more than ever to ensure economic and societal prosperity throughout the world, rather than within a small number of isolated, prosperous regions.
\end{abstract}

Keywords Informal economy. Protectionism. Trade. Xenophobia. Collaboration.

In response to the coronavirus crisis, there are many examples of co-operation and collaboration, from communities coming together to Clap for Carers in the UK to Federal Reserve loans to other central banks. But in emotive, uncertain times, the instinct to wind up the drawbridge and look after your own is strong and playing out across societies, nations, and communities. The pandemic is politicising travel and migration and driving self-reliance and protectionism. Some view this as a much-needed retraction from the upper limits of globalisation, shortening supply chains, and reducing exposure to risk in an unstable world. Others fear a dampening down of trade will leave economies vulnerable and heighten instability, leading to more risk aversion and inward focus.

A particular issue concerning the informal economy is intangibility: things which are not measured are not known to legislators, meaning, unfortu- 
nately, that over two billion workers from the informal sector, are threatened. Narula (2020) suggests that those affected account for $70 \%$ of employment in the Middle East and North Africa, and 80\% in both South Asia and sub-Saharan Africa (ILO 2020). Somewhat concerningly, these people will, according to Narula (2020) not receive government aid in relation to the COVID-19 pandemic. For example, within the nation of India, 63 million micro-enterprises represent $99 \%$ of all enterprises and comprise 107 million people - who are not known to legislators because they are unregistered. As a result, they are not accounted for on government data - though the number may be closer to 300 million (Jayaram et al 2020).

The COVID-19 pandemic has sparked a radical reordering of business ecosystems, suggest several business historians, such as Rita Trehan, CEO of global transformation consultancy Dare Worldwide (Laker et al. 2020). She considers the need for a collaborative approach to be crucial to success when new networks are built as lockdown eases. But these networks should look to contain within them, informal workers because businesses, both foreign and domestic, are responding to the slowdown by reducing employment, hence there will be a sharp upwards increase in those below the poverty line.

Narula (2020) suggests that informal workers typically live from hand to mouth. This means that, without paid work, a person cannot purchase essential supplies such as food - let alone apparent desirables such as medication. One recent example of this transactionary relationship occurred within India, where earlier this year, millions of informal workers walked home from big cities to return to ancestral villages. Even if the pandemic subsides concludes Narula (2020), it is naive to believe activities can ever return to their pre-pandemic state. Economically weak countries will already have suffered from declining revenues from almost all sources, also as the pandemic raises emergency spending to mitigate the immediate challenges. Countries dependent on primary sector exports are notoriously volatile, especially in the extractive sector. Other primary good exports will likely be affected not by price volatility, but due to logistical challenges and restrictions, while imports are likely to cost more. The reduction of fiscal performance may lead to an increase in borrowing and, most certainly, a requirement for aid. There will be a number of nations that rely heavily upon remittances for their foreign exchange (Narula 2020). As a result, these nations will quite likely suffer a shock: Arabic counties will consider returning their migrant workers, who are primarily engaged informally and in receipt of limited, sometimes nonexistent labour rights, both at home and abroad, to their home countries (Narula 2020).

That being said, there is an immediate short-term opportunity from the COVID-19 pandemic. With items from ventilators to masks in seriously short supply and prices soaring, those trying to source goods complained of a bidding war with other buyers, involving a 
web of brokers and suppliers. Shipments destined for multiple countries were diverted elsewhere - often to the US ILO (2020). German officials accused the US of 'confiscating' a consignment of respirators en route from China to the Berlin city police during a stopover in Bangkok ILO (2020).

There is somewhat of a critical opportunity for developing nations to enable and even support informal workers to help contribute to the gap of supply. This could occur through subsidies provided to local suppliers to help maintain import prices. One striking example that has already implemented such a concept is apparent within the global shortage of personal protective equipment for hospitals (Narula 2020). Medical institutions are struggling to acquire specialist items because prices the world over have increased. As a result, many small enterprises are beginning to manufacture and sell items locally, and in some cases, the central government holds the responsibility for sterilising and deep cleaning the final product (Narula 2020).

It is not just the US that has veered into protectionism. According to the Global Trade Alert team at Switzerland's University of St Gallen, 75 countries have introduced some export curbs on medical supplies, equipment, or medicines this year (ESCAP 2020). They include most EU countries, India, China, Brazil, and Russia. But the team also found that 79 countries have liberalised trade in medical supplies this year. Clearly, governments and public authorities have a duty to show responsibility and restraint when it comes to facilitating the flow of supplies, treatments, and testing equipment needed to tackle the coronavirus beyond their borders.

So how will global co-operation play out as lockdown eases? The danger is that the movement of people, goods, and capital curtailed during lockdown is all in danger of being politicised by agendas that existed long before the crisis hit. Regarding the movement of people, the Trump administration used the pretext of the 'Chinese virus' to curtail immigration further, arguing that jobs should go to Americans instead. He will likely be able to maintain anti-immigration policies long after the virulent phase of the epidemic because public concerns will make it easier for him to retain them.

In an atmosphere of mistrust and suspicion, there has been an increase in displays of xenophobia against Chinese and East Asian persons in many countries across the world, fuelled by provocative newspaper headlines like 'Yellow Alert' (France) and 'China Kids Stay at Home' (Australia). Indian health authorities have campaigned to spread awareness that not all people who are from China have COVID-19. Pointing the finger and blaming other ethnic groups for the disease is one response. But public opinion on immigration is often more nuanced than politicians give people credit for. In Europe, the crisis has highlighted the reliance societies have on informal workers in food production and the care system, with many risking their 
lives during the crisis. It is becoming harder than ever to see the world in black and white.

International tourism is set to plunge by $80 \%$ this year, but some regions will recover more quickly than others. Less developed countries will be hit particularly hard, but experts say this is an opportunity to rebuild the industry to be more sustainable. Countries with pre-existing links and similar health protocols are coming together to create 'travel bubbles' as lockdown eases. Australia-New Zealand, Taiwan-Singapore and Greece-Cyprus-Israel are looking to collaborate and set up safe tourist zones to allow movement between countries.

In terms of the flow of capital, the crisis will accelerate an alreadyexisting trend of financial de-globalisation. State ownership of private companies is on the increase, with the nationalization of Italy's airline, Alitalia, the UK government taking control of rail companies, and Spain nationalizing all of its hospitals and healthcare providers to combat the spread of the virus. Nations looking inward are seeking to shorten their supply chains and decrease reliance on overseas manufacturing. The global trade system that has dominated the world for decades is under threat from protectionist thinking, with WTO predicting that world trade could reduce by up to a third (Joyce, Xu 2020). Economists argue that the way to make supply chains more resilient is not to domesticate them but to diversify them ESCAP (2020).

More than ever, there is a need for firms to cultivate adaptive - rather than hierarchical - structures that support rapid change, refocusing, and reallocation of resources. Those organisations that can leverage their network and work together will come out ahead as lockdown eases. There is a need to integrate data from a wide range of sources to innovate and connect. Those companies that are in touch with their core purpose beyond making money will have better clarity on the way forward.

The coronavirus crisis has shown that the global economy's governance is made up of international institutions and informal collaborations that are shaped by individual nations' willingness to cooperate. For the sake of the world's economic and physical health, collaboration needs to win over protectionism. 


\section{Bibliography}

ESCAP (Economic and Social Commission for Asia and the Pacific) (2020). The Impact and Policy Responses for COVID-19 in Asia and the Pacific. https:// bit.ly/2ZK4X6h.

ILO (International Labour Organization) (2020). ILO Monitor 2nd edition: COVID-19 and The World of Work: Updated Estimates and Analysis. https:// bit.ly/2WFR72V.

Jayaram, K.; Leke, A.; Ooko-Ombaka, A.; Ying, S.S. (2020). "Finding Africa's path: Shaping Bold Solutions to Save Lives and Livelihoods in the COVID-19 crisis". McKinsey Institute, 17 April. https://mck.co/20ITwp7.

Joyce, R.; Xu, X. (2020). "Sector Shutdowns During the Coronavirus Crisis: which Workers are Most Exposed?". Institute for Fiscal Studies Briefing Note BN278. https://doi.org/10.1920/BN.IFS.2020.BN0278.

Laker, B.; Cobb, D.; Trehan, R. (2020). "Too Proud to Lead: How Hubris can Destroy Effective Leadership and What to Do About It". Bloomsbury.

Narula, R (2020). "Policy Opportunities and Challenges from the Covid-19 Pandemic for Economies with Large Informal Sectors". Journal of International Business Policy. https://doi.org/10.1057/s42214-020-00059-5 



\title{
The Political Implications of COVID-19 What Now for Populism?
}

Daphne Halikiopoulou University of Reading, UK

\begin{abstract}
This chapter briefly examines the political implications of COVID-19, focusing on the potential constraints and opportunities it poses for populism. Some initial comparative observations suggest the following patterns. First, populists in opposition are likely to be weakened electorally in the short-run, as voters support non-populists on the basis of valence voting. Second, this may not apply to populists in power, who may use emergency measures for democratic backsliding. Third, in the long-run, a potential economic crisis as a result of the pandemic may benefit populist parties, especially those in opposition as discontent voters may punish those in government for the poor managing of the health/economy trade-off. In sum, what will determine the direction of future political developments is the extent to which governments can balance the trade-offs involved in the COVID-19 crisis, including effective health management versus economic growth and individual freedoms versus collective security.
\end{abstract}

Keywords COVID-19. Populism. Far right parties.

Summary 1 Introduction. - 2 COVID-19 Trade-offs. - 3 What Now for Populism? 4 Conclusion.

\section{Introduction}

The exponential spread of COVID-19 in early 2020 placed governments around the world under severe strain. Despite the global reach of the virus, nationstates responded primarily as individual actors, seeking to contain the virus and ensure the resilience of their national health systems. Part of this response was the closure of borders and the grounding of airlines confirm-

Innovation in Business, Economics \& Finance 1

ISBN [ebook] 978-88-6969-442-4 
ing that, although a global phenomenon, COVID-19 required first and foremost a national response. Besides the health dimension, this is also interesting from a political perspective as COVID-19 emerged at a time when the retreat of the nation-state and the restoration of sovereignty were relevant political trends: for example Brexit and the rise of right-wing populist parties that pledge to restrict immigration and challenge EU expansion. How may we assess the political implications of this global crisis, especially given that it comes at a time when populists, who thrive on the tensions between international initiatives and the 'national preference', are either in charge, or the main opposition party, in many countries?

This chapter briefly examines the political implications of COVID-19, focusing on the potential constraints and opportunities it poses for populism. This is a new and fluid situation that is fast evolving. While data is novel and relatively untested, we may still draw some (cautious) preliminary conclusions by comparing cases in an attempt to identify broad patterns and exceptions. What follows is a brief sketch of patterns from which we may identify certain policy implications and lessons learned. The chapter first outlines a series of trade-offs with regard to the COVID-19 situation. It then proceeds to examine the political implications of these trade-offs, before briefly discussing the challenges and opportunities they represent for populist actors. Distinguishing between populists in opposition and populists in power, it concludes with lessons learned and avenues for future research.

\section{COVID-19 Trade-offs}

According to the 2019 Global Health Security (GHS) Index, fewer than $5 \%$ of countries included in the index scored highly, suggesting that the majority of countries were poorly prepared to respond to, and mitigate the effect of, a pandemic. The emergence of COVID-19 confirmed this overall lack of preparedness, but also revealed a paradox: on the one hand, some of the world's most stable democracies that scored highly in the GHS, such as the UK and the US, performed particularly poorly. On the other hand, developing authoritarian countries, such as Vietnam, and smaller democracies fatigued by economic and political upheaval in recent years, such as Greece, outperformed advanced Western democracies in the handling of the pandemic.

In order to explain this variation, preliminary research on this topic has examined short-term indicators such as the speed with which distancing measures were introduced, quarantine effectiveness and willingness to comply (see e.g. Brouard, Vasilopoulos, Becher 2020; Hale et al. 2020; Fenner 2020). This research suggests 
that along with long-term infrastructural capacity, short-term political decisions have played a very important role in the containment and mitigation of COVID-19. Responding early is key to responding effectively, so for example tracking, testing and containing infection clusters is of paramount importance. Countries that introduced lockdown measures early tended to have better results, again Greece being a prime example, though some preliminary work has noted inconsistencies with this broad pattern (see Born et al 2020 on Sweden).

This reality highlighted that addressing the pandemic is all about trade-offs and presented both governments and citizens with some important dilemmas: does effective health management occur at the expense of economic growth? Should we introduce - and adhere - to strict lockdown measures at the expense of our personal liberties? Should we trade-off these individual liberties for our collective security? These trade-offs, in turn, have important political implications given the delicate political climate - rise of populism, euroscepticism, Brexit - at the time of the emergence of COVID-19.

\section{What Now for Populism?}

Far right populist parties, which utilise a rhetoric that combines nationalism and the 'Popular Will', have significantly increased their electoral performance since the 2010s. Examples abound: the French Front National (FN) (now Rassemblement National), the Dutch Freedom Party (PVV), the Austrian Party for Freedom (FPÖ), the Norwegian Progress Party (FrP) and the German Alternative for Germany (AfD) have all mobilised voters on their populist-nationalist platforms. Their electoral success has been the focus of a substantial body of literature in the fields of party politics and voting behaviour (see Mudde, Rovira Kaltwasser 2018; Stockemer, Lentz, Mayer 2018). Different explanations place varying emphasis on factors including immigration and cultural insecurity (Inglehart, Norris 2016), economic deprivation, both actual and relative (Colantone 2018; Fetzer 2019; Adler, Ansell 2019; Engler, Weisstanner 2020; Halikiopoulou, Vlandas 2020), societal decline and status anxiety (Gest 2016; Gidron, Hall 2019) as well as institutional mistrust and poor evaluations of governance quality (Hooghe, Marien, Pauwels 2011; Agerberg 2017). While scholars disagree about the source of the grievance that prompts voters to opt for far right populism, at the core of the debate is the impact of globalisation (Kriesi et al 2006) that divides societies between winners and losers, thus incentivizing the discontent to vote for parties that place blame on the establishment.

Populism posits that only decisions made from below are legitimate - and indeed morally superior (Riker 1982), because only these decisions reflect the will of the people (Mudde 2004). As such, pop- 
ulists tend to be sceptical of intermediary institutions, elites and experts, who they try to discredit. They thrive on an emotive but often empty rhetoric, aimed at voters motivated by the need to protest their social, economic and/or cultural discontent. Far right populism merges this narrative with nationalism. These parties pledge to speak on behalf of the 'pure people', restore national sovereignty, 'take back control' from supranational institutions and promote the 'national preference' through strict immigration and citizenship policies (Halikiopoulou, Vlandas 2019). This suggests competing expectations regarding the electoral fortunes of far right populist parties in light of the COVID-19 pandemic. On the one hand, the limits placed on globalisation by the pandemic could reduce the attractions of populists. In addition, the need to manage the pandemic requires effective government, expertise and efficient democratic institutions providing the organisational and infrastructural support that determines state effectiveness. In this respect, COVID-19 could pose a significant challenge to populists by exposing their lack of competence, and placing them under scrutiny. In accordance to the valence model of voting (Evans, Chzhen 2016), which suggests that party performance evaluations affect voter choices, voters may increasingly prioritise competence over emotive narratives. Populist parties in opposition may become weakened electorally as non-populists in power have tended to consolidate their support during the pandemic (Bayerlin, Gyongyosi 2020).

On the other hand, potential 'austerity' strategies resulting from the health crisis could exacerbate those voters' insecurities that prompt them to support far right populist parties. In addition, populists in power could benefit from the crisis by blaming immigrants and refugees for the spread of the pandemic, using them as an opportunity for power abuse and an excuse to attack freedom of movement. Indeed far right populism is compatible with some of the COVID-19 blame-patterns: closure of borders, exclusion of immigrants and an emphasis on restricting health services for natives. In a number of cases this has helped populists - or rather right-wing nationalist authoritarians - in power to use the COVID-19 crisis to extend their powers in the political system. Autocratic-minded leaders, for example Orban in Hugary, Modi in India and Bolsonaro in Brazil, have rallied around the flag to increase support at a time of heightened insecurity. One important lesson from the past is that, in similar crisis situations, authoritarian and/or nationalist leaders have taken advantage of emergencies to consolidate power (Levitsky, Ziblatt 2018). This suggests that there is a substantial danger of further democratic backsliding by suspending democratic institutions through emergency laws, for example suspending parliament and ruling by decree.

This raises questions about the utility of the term populism to describe the challenges to democratic politics both prior to, and after 
the emergence of COVID-19. One of the most concerning political developments regarding actors described as 'populist' is not actually their populism - referred to above as an ideology that draws on a distinction between the good people and the bad elites (Mudde 2004) - but rather their nationalist, authoritarian and/or a far right agenda. The coronavirus pandemic has highlighted the extent to which the term 'populism' itself is inflated, overused and too broad to be analytically useful. Conflating the terms nationalism, rightwing extremism or authoritarianism, i.e. grouping any party that has these attributes in the populist category because of these attributes, means that populism is superfluous and what really matters is the other attribute: nationalist, far right, or authoritarian for example (Halikiopoulou, Vlandas 2019). Orban was able to impose undemocratic measures in Hungary not because he is a populist but because he is authoritarian. Marine Le Pen and Matteo Salvini blame immigrants for the pandemic not because they are populists, but because they are nationalists.

The long-term political consequences of this are significant. In cases where democratic institutions are weak there is a serious risk of further democratic backsliding. The long-term economic costs of the pandemic can only serve to exacerbate this. As a large body of literature suggests, wealth inequalities, decline of social status, and limited access to compensation can serve to drive voters closer to extremism (Adler, Ansell 2019; Gidron, Hall 2019; Halikiopoulou, Vlandas 2016).

\section{Conclusion}

In sum, what will determine the direction of future political developments is the extent to which governments can balance the trade-offs involved and exit this crisis having simultaneously protected society's most vulnerable and retained its democratic institutions and values.

Future research can delve into these dynamics in greater detail. Comparative research across cases and across time can identify further patterns with regard to which populist actors are more likely to be weakened and why. In the short term, health policies and stringency measures will affect a government's popularity. But longer term factors, such as state capacity and the strength and impartiality of a country's democratic institutions, will determine the extent to which democracy can withstand the COVID-19 shock. While the current pandemic may be unique in its specificities, it is not unprecedented in terms of what it represents: an emergency situation that exposes systemic weaknesses and threatens the stability of democratic societies. Lessons learned from parallel historical precedents may offer us the benefit of hindsight. 


\section{Bibliography}

Adler, D.; Ansell, B. (2019). "Housing and Populism". West European Politics. https://doi.org/10.1080/01402382.2019.1615322.

Agerberg, M. (2017). "Failed Expectations: Quality of Government and Support for Populist Parties in Europe". European Journal of Political Research, 56, 578-600. https://doi.org/10.1111/1475-6765.12203.

Bayerlein, M.; Gyongyozi, G. (2020). "The Impact of Covid-19 on Populism: Will It be Weakened?". Kieler beiträge zur wirtschaftspolitik. https://bit. ly/2ZPZAXY.

Born, B.; Dietrich, A.; Müller, G. (2020). "Do Lockdowns Work? A Counterfactual for Sweden, CEPR Centre for Economic Policy Research". https://cepr.org/active/publications/discussion_papers/ dp.php?dpno=14744.

Brouard, S.; Vasilopoulos, P.; Becher, M. (2020). "Sociodemographic and Psychological Correlates of Compliance with the Covid-19 Public Health Measures in France". Canadian Journal of Political Science, 1-8. https://doi. org/10.1017/s0008423920000335.

Colantone, I.S.P. (2018). "The Trade Origins of Economic Nationalism: Import Competition and Voting Behavior in Western Europe." American Journal of Political Science, 62(4), 936-53. https://doi.org/10.1111/ajps.12358.

Engler, S.; D. Weisstanner. 2020. "The Threat of Social Decline: Income Inequality and Radical Right Support". Journal of European Public Policy, 1-21. https://doi.org/10.1080/13501763.2020.1733636.

Evans, G.; Chzhen, K. (2016). "Re-Evaluating the Valence Model of Political Choice". Political Science Research and Methods, 4(1), 199-220. https:// doi.org/10.1017/psrm.2013.11.

Fenner, S. (2020). "State, Regime, Government and Society in COVID-19 Response: Establishing Baseline Expectations". Duck of Minerva. https:// bit.ly/20VqLW8.

Fetzer, T. (2019). "Did Austerity Cause Brexit?". American Economic Review, 109(11), 3849-86. https://doi.org/10.1257/aer.20181164.

Gest, J. (2016). The New Minority. Oxford: Oxford University Press.

Gidron, N.; Hall, P. (2019). "Populism as a Problem of Social Integration". Comparative Political Studies. https://doi.org/10.1177\%2F0010414019879947.

Hale, T.; Petherick, A.; Phillips, T.; Webster, S. (2020). "Variation in Government Responses to COVID-19". Version 4.0. Blavatnik School of Government Working Paper. April 7, 2020. https://www.bsg.ox.ac.uk/research/publications/variation-government-responses-covid-19.

Halikiopoulou, D. ; Vlandas, T. (2016). "Risks, Costs and Labour Markets: Explaining Cross-National Patterns of Far Right Party Success in European Parliament Elections". Journal of Common Market Studies, 54(3), 636-55. https://doi.org/10.1111/jcms.12310.

Halikiopoulou, D.; Vlandas, T. (2019). "What is New and What is Nationalist About Europe's New Nationalism? Explaining the Rise of the Far Right in Europe". Nations and Nationalism, 25, 409-34. https://doi.org/10.1111/ nana.12515.

Halikiopoulou, D.; Vlandas, T. (2020). "When Economic and Cultural Interests Align: The Anti-Immigration Voter Coalitions Driving far Right Party Success in Europe". European Political Science Review. https://doi.org/10.1017/ S175577392000020X. 
Hooghe M.; Marien, S.; Pauwels, T. (2011). "Where Do Distrusting Voters Turn if There is No Viable Exit or Voice Option? The Impact of Political Trust on Electoral Behaviour in the Belgian Regional Elections of June 2009". Government and Opposition, 46(2), 245-73. https://doi.org/10.1111/j.14777053.2010.01338.x.

Inglehart, R.; Norris, P. (2016). "Trump, Brexit, and the Rise of Populism: Economic Have-Nots and Cultural Backlash". Harvard JFK School of Government Faculty Working Paper Series, 1-52. https://dx.doi.org/10.2139/ ssrn.2818659.

Kriesi, H.; Grande, E.; Lachat, R.; Dolezal, M.; Bornschier, S.; Frey, T. (2006). "Globalization and the Transformation of the National Political Space: Six European Countries Compared". European Journal of Political Research, 45, 92156. https://doi.org/10.1111/j.1475-6765.2006.00644.x.

Levitsky, S.; Ziblatt, D. (2018). How Democracies Die. New York: Penguin Random House.

Mudde, C. (2004). "The Populist Zeitgeist". Government and Opposition, 39, 4, 542-63.

Mudde, C.; Rovira Kaltwasser, C. (2018). "Studying Populism in Comparative Perspective: Reflections on the Contemporary and Future Research Agenda". Comparative Political Studies, 51(13), 1667-93. https://doi. org/10.1177\%2F0010414018789490.

Nuclear Threat Initiative; Johns Hopkins Center for Health Security; The Economist Intelligence Unit (2019). Global Health Security Index. Baltimore and London. https://www.ghsindex.org/.

Riker, W. (1982). Liberalism against Populism: A Confrontation between the Theory of Democracy and the Theory of Social Choice. Illinois: Waveland Press.

Stockemer, D.; Lentz, T.; Mayer, D. (2018). "Individual Predictors of the Radical Right-Wing Vote in Europe: A Meta-Analysis of Articles in Peer-Reviewed Journals (1995-2016)". Government and Opposition, 53(3), 569-93. https:// doi.org/10.1017/gov.2018.2. 
Pandemics are disruptive events that have profound consequences for society and the economy. This volume aims to present an analysis of the economic impact of COVID-19 and its likely consequences for our future. This is achieved by drawing from the expertise of authors who specialise in a wide range of fields including fiscal and monetary policy, banking, financial markets, pensions and insurance, artificial intelligence and big data, climate change, labour market, travel, tourism and politics, among others. We asked contributing authors to write their chapters for a non-technical audience so that their message could reach beyond academia and professional economists to policy makers and the wider society. The material in this volume draws from the latest research and provides a wealth of ideas for further investigations and opportunities for reflection. This also makes it an ideal learning tool for economics and finance students wishing to gain a deeper understanding of how COVID-19 could influence their disciplines.
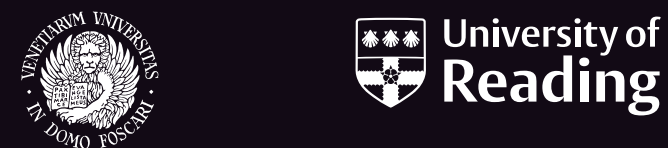

$\begin{array}{lllllll}* & \text { Henley } & & \text { I } & \text { C } & \text { M } & \text { A } \\ \text { Business School } \\ \text { UNIVERSITY OF READING }\end{array}$

Università

Ca'Foscari

Venezia 